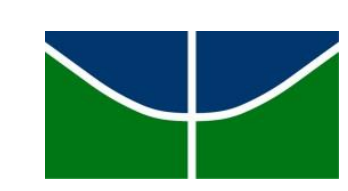

UNIVERSIDADE DE BRASÍLIA - UnB

INSTITUTO DE RELAÇÕES INTERNACIONAIS (IREL)

PROGRAMA DE PÓS-GRADUAÇÃO EM RELAÇÕES INTERNACIONAIS (PPGRI)

DO JULGAMENTO À JUSTIÇA: DETERMINANTES DA IMPLEMENTAÇÃO DE MEDIDAS DO SISTEMA INTERAMERICANO DE DIREITOS HUMANOS PELO ESTADO BRASILEIRO

HELVISNEY DOS REIS CARDOSO

Brasília - DF

Julho de 2016 
HELVISNEY DOS REIS CARDOSO

\title{
DO JULGAMENTO À JUSTIÇA: DETERMINANTES DA IMPLEMENTAÇÃO DE MEDIDAS DO SISTEMA INTERAMERICANO DE DIREITOS HUMANOS PELO ESTADO BRASILEIRO
}

\begin{abstract}
Dissertação com Concentração em Política Internacional e Comparada apresentado à banca de qualificação do Programa de Pós-graduação do Instituto de Relações Internacionais da Universidade de Brasília como requisito parcial para obtenção do título de Mestre em Relações Internacionais.
\end{abstract}

Orientadora: Profa. Dra. Maria Helena de Castro Santos

Brasília - DF

Julho de 2016 
HELVISNEY DOS REIS CARDOSO

DO JULGAMENTO À JUSTIÇA: DETERMINANTES DA IMPLEMENTAÇÃO DE MEDIDAS DO SISTEMA INTERAMERICANO DE DIREITOS HUMANOS PELO ESTADO BRASILEIRO

Comissão Examinadora:

Profa. Dra. Maria Helena de Castro Santos

Universidade de Brasília - IREL/UnB

Orientadora

Prof. Dr. Fúlvio Eduardo Fonseca

Controladoria Geral da União

Examinador

Prof. Dr. Pio Penna Filho

Universidade de Brasília - IREL/UnB

Examinador 
À minha amada irmã, que sempre acreditou nos meus sonhos. 


\section{AGRADECIMENTOS}

Agradeço ao destino e ao universo favorável que me proporcionaram mais essa vitória; uma grande oportunidade de amadurecimento e crescimento acadêmico e pessoal. Brasília me abriu $360^{\circ}$ de céu desde o primeiro dia.

Decidir por continuar na mesma Universidade e prosseguir com o mestrado logo em seguida a minha graduação foi uma das decisões mais difíceis dos últimos dois anos. Amigos partiram na busca de seus sonhos e, de repente, a cidade mudou. Pela primeira vez, me senti sozinho. Brasília se tornou vastidão, infinito, asas de sofrimento e eixos de solidão.

Devo agradecer muito aos meus amigos Robert Lee, Rafael Stucchi, Patrícia Vitorino e Juliana Cristina com quem eu dividi muito dos meus desabafos e anseios sobre a vida. Foram eles que me acolheram em um momento tão especial e me deram raízes novamente no Planalto Central. Muito devo a esses grandes amigos, com quem eu aprendi não só a ser profissional e academicamente melhor, mas também mais seguro e carinhoso. Agradeço enormemente a todos que cruzaram o meu caminho em Brasília, especialmente os frequentadores da 103 sul e as paixões súbitas, idílicas e avassaladoras de todos os setores e superquadras do plano piloto.

Aos mestres, agradeço à professora Maria Helena, pela fiel disponibilidade em me ajudar, pela paciência e empenho na revisão desta dissertação e, mais ainda, pelo modelo de excelência e conhecimento que o presente trabalho me deu a chance de conhecer mais de perto; e agradeço, ainda, aos professores Pio e Fúlvio pela grande disponibilidade em participar da defesa desta dissertação.

Foi com a minha irmã que eu aprendi a ter força. Ela é o meu mais importante exemplo de bom humor e leveza, mesmo durante as adversidades, no qual eu posso me espelhar. Obrigado, Barriguda, pela integral confiança em mim e nos meus sonhos, pela presença durante todos os acidentes ocorridos e por alegrar os dias de descompasso.

Deixo uma homenagem aos meus amigos de outro mar e à Caroline Caldeira, Larissa Araújo e Lorenna Vieira pela fiel amizade, como diz Drummond, desde tempos imemoriáveis. Por fim, agradeço do fundo do meu coração aos meus queridos pais, brasileiros e noruegueses, por me ensinarem a lição mais importante da minha vida: que o mundo é algo que eu posso carregar dentro de mim. 
Sentir tudo de todas as maneiras,

Viver tudo de todos os lados,

Ser a mesma cousa de todos os modos possíveis ao mesmo tempo, Realizar em si toda a humanidade de todos os momentos Num só momento difuso, profuso, completo e longínquo. 


\section{RESUMO}

Este é um estudo das determinantes que afetam o processo de tomada de decisão no que se refere ao cumprimento das resoluções e recomendações do Sistema Interamericano de Direitos Humanos (SIDH) pelo Governo brasileiro (state compliance) entre 1988 e 2014. Utilizou-se compliance como uma variável contínua neste trabalho, explorando o meio termo do cumprimento parcial. Almejou-se produzir uma análise de política governamental que leve em conta todos os aspectos importantes de um processo de decisão. Buscou-se também coletar, consolidar e sistematizar dados empíricos sobre as principais determinantes que afetam o cumprimento dos instrumentos do SIDH pelo Brasil. A partir de uma abordagem que se centrou na compliance como um fator engendrado pela política doméstica dos Estados e nos fatores internos pré-existentes que levam os Estados a se comportarem de acordo com normas internacionais, testei hipóteses sobre como a existência de políticas públicas do Estado referentes às medidas específicas proferidas pelo SIDH, assim como a própria violação de direitos humanos decorrente de uma agenda de política pública do Estado e a dependência de poderes autônomos, como governos locais, Ministério Público e Judiciário, afetam o grau de compliance do Estado brasileiro. Buscou-se, assim, colocar em questão algumas concepções das principais teorias da literatura especializada.

Palavras-chave: Compliance (implementação); Direitos Humanos; Sistema Interamericano de Direitos Humanos; Processo decisório. 


\begin{abstract}
This is a study of the determinants that affect the decision-making process regarding the state compliance with resolutions and recommendations of the Inter-American System of Human Rights (ISHR) by the Brazilian government between 1988 and 2014. Compliance is used as a continuum in this research, exploring the partial term of the concept. It aims at producing a governmental policy analysis that takes into account all important aspects of a decision process and that also collects, consolidates and systematizes empirical data to observe the main determinants that affect the Brazilian compliance with the ISHR' instruments. Using an approach based on compliance resulting from domestic politics and from pre-existing internal factors that lead States to behave in accordance with international rules, assumptions will be tested on how the existence of a public policy agenda specifically addressing the remedies issued by the ISHR, as well as the dependence of autonomous powers, as local governments, prosecutors and judiciary power, and violations that arise from state policy agendas affect the Brazilian degree of compliance with the ISHR' instruments. Hence, this study seeks to question concepts of the main specialized theory.
\end{abstract}

Key-words: Compliance, Human Rights, Inter-American System of Human Rights, Decisionmaking process 


\section{LISTA DE FIGURAS}

Figura 1: Número de petições por país enviadas ao SIDH entre 1999 e 2014

Figura 2: Petições contra o Brasil no SIDH entre 1999 e 2014

Figura 3: Procedimentos contra o Brasil classificados por órgão do SIDH

Figura 4: Procedimentos na $\mathrm{CmDH}$ por fase de tramitação

Figura 5: Procedimentos na $\mathrm{CrDH}$ por fase de tramitação

Figura 6: Procedimentos contra o Brasil no SIDH classificados por região do país em que a violação de direitos humanos foi engendrada

Figura 7: Procedimentos contra o Brasil no SIDH classificadas pela unidade federativa em que a violação de direitos humanos foi engendrada

Figura 8: Temas dos procedimentos contra o Brasil no SIDH

Figura 9: Temas dos procedimentos contra o Brasil no SIDH classificados por região em que as violações foram engendradas

Figura 10: Proporção dos peticionários em procedimentos contra o Brasil no SIDH

Figura 11: Artigos da CADH mais invocados pelos peticionários em procedimentos contra o Brasil no SIDH

Figura 12: Casos contra o Brasil no SIDH em que foram outorgadas recomendações e resoluções classificados pela região do País em que as violações foram engendradas

Figura 13: Casos contra o Brasil no SIDH em que foram outorgadas recomendações e resoluções classificados pela unidade federativa em que as violações foram engendradas

Figura 14: Temas dos casos contra o Brasil no SIDH em que foram outorgadas recomendações e resoluções classificados por unidade federativa em que as violações foram engendradas

Figura 15: Recomendações e Resoluções outorgadas contra o Brasil no SIDH classificadas por seus objetivos

Figura 16: Recomendações e Resoluções outorgadas contra o Brasil no SIDH classificadas por seu tipo

Figura 17: Graus de compliance do Brasil com as medidas outorgadas pelo SIDH

Figura 18: Graus de compliance do Brasil com as recomendações, resoluções e medidas acordadas em solução amistosa do SIDH

Figura 19: Graus de compliance do Brasil com as medidas outorgadas pelo SIDH classificadas por seu tipo 
Figura 20: Graus de compliance do Brasil às recomendações, resoluções e medidas acordadas em solução amistosa outorgadas pelo SIDH classificadas por seu objetivo

Figura 21: Graus de compliance do Brasil com as medidas outorgadas pelo SIDH classificadas pelo tema das violações que as originaram.

Figura 22: Graus de compliance do Brasil com os casos do SIDH

Figura 23: Média de duração em anos dos casos contra o Brasil no SIDH em que foram outorgadas recomendações, resoluções e medidas acordadas em solução amistosa

Figura 24: Média de duração em anos para a compliance do Estado brasileiro com as recomendações, resoluções e medidas acordadas em solução amistosa pelo SIDH

Figura 25: Média de duração em anos para a compliance do Estado brasileiro com as recomendações, resoluções e medidas acordadas em solução amistosa pelo SIDH classificadas por seu tipo

Figura 26: Média de duração em anos para a compliance do Estado brasileiro com as recomendações, resoluções e medidas acordadas em solução amistosa pelo SIDH classificadas por seu objeto

Figura 27: Grau de compliance das medidas outorgadas contra o Brasil no SIDH a partir de seus litigantes

Figura 28: Principais funções das organizações governamentais centrais nas defesas brasileiras e implementação das medidas do SIDH

Figura 29: Compliance como uma resultante política doméstica

Figura 30: Média de duração em anos para o cumprimento das medidas do SIDH categorizadas por variáveis de política doméstica 


\section{LISTA DE TABELAS}

Tabela 1: Número de procedimentos por órgão e fase de tramitação contra o Brasil no SIDH

Tabela 2: Temas dos procedimentos contra o Brasil no SIDH classificados região em que as violações foram engendradas

Tabela 3: Principais temas dos procedimentos contra o Brasil no SIDH classificadas pela unidade federativa em que a violação foi engendrada

Tabela 4: Casos e petições contra o Brasil no SIDH com violação contínua de Direitos Humanos

Tabela 5: Casos contra o Brasil no SIDH em que foram emitidas recomendações, resoluções e acordos de solução amistosa

Tabela 6: Decisões outorgadas contra o Brasil no SIDH classificadas pelos os seus objetivos e tipos

Tabela 7: Compliance do Brasil com recomendações da $\mathrm{CmDH}$ classificadas por seu tipo

Tabela 8: Compliance do Brasil com resoluções da $\mathrm{CrDH}$ classificadas por seu tipo

Tabela 9: Compliance do Brasil com medidas acordadas em solução amistosa no SIDH classificadas por seu tipo

Tabela 10: Casos contra o Estado brasileiro no SIDH em que já foram outorgadas medidas classificados por períodos de interação entre instituições governamentais

Tabela 11: Graus de compliance do Estado brasileiro com medidas proferidas pelo SIDH relacionadas à reparação econômica monetária de vítimas.

Tabela 12: Compliance como resultante de agendas de políticas públicas do Estado 


\section{LISTA DE SIGLAS E ABREVIATURAS}

AGU Advocacia-Geral da União

CADH Convenção Americana de Direitos Humanos

$\mathrm{CEDH}$ Corte Europeia de Direitos Humanos

CPJI Corte Permanente de Justiça Internacional

CIJ Corte Internacional de Justiça

$\mathrm{CmDH}$ Comissão Interamericana de Direitos Humanos

CPT Comissão Pastoral da Terra

CIMI Conselho Indigenista Missionário

CNMP Conselho Nacional do Ministério Público

CNJ Conselho Nacional de Justiça

$\mathrm{CrDH} \quad$ Corte Interamericana de Direitos Humanos

CVDT Convenção de Viana sobre o Direito dos Tratados

DHs Direitos Humanos

DHDT Programa Direitos Humanos, Direitos de Todos

EUA Estados Unidos da América

MCs Medidas Cautelares

MJ Ministério da Justiça

MPs Medidas Provisórias

MRE Ministério das Relações Exteriores

MST Movimento dos Trabalhadores Rurais Sem Terra

OAB Ordem dos Advogados do Brasil

OEA Organização dos Estados Americanos

OIT Organização Internacional do Trabalho

ONG Organização Não Governamental

ONU Organização das Nações Unidas

PFDC Procuradoria Federal dos Direitos do Cidadão

PNDH1 I Plano Nacional de Direitos Humanos

PNDH2 II Plano Nacional de Direitos Humanos

PNDH3 III Plano Nacional de Direitos Humanos

PPA Plano Plurianual

PR Presidência da República

PT Partido dos Trabalhadores 
SAPRS Sistema de Acompanhamento de Processos de Relevância Social

SDH Secretaria de Direitos Humanos da Presidência da República

SIDH Sistema Interamericano de Direitos Humanos

STF Supremo Tribunal Federal

UE União Europeia

UF Unidade federativa 


\section{Sumário}

Introdução.

1. Capítulo 1: Direito Internacional, Sistema Interamericano de Direitos Humanos e o conceito de compliance ..... .22

1.1. Direito Internacional: definição e concepções .......................................................23

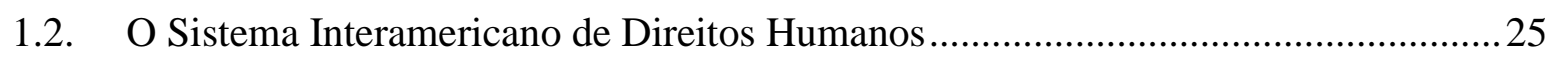

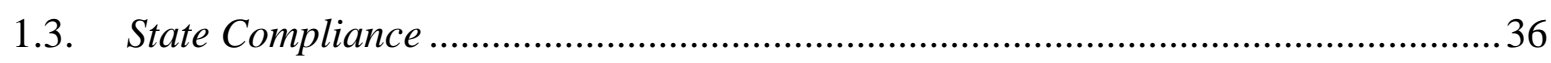

2. Capítulo 2: A inserção do Brasil no Sistema Interamericano de Direitos Humanos: características das petições, casos, medidas de urgência e processo decisório .........................47

2.1. O Brasil e o Sistema Interamericano de Direitos Humanos ......................................... 48

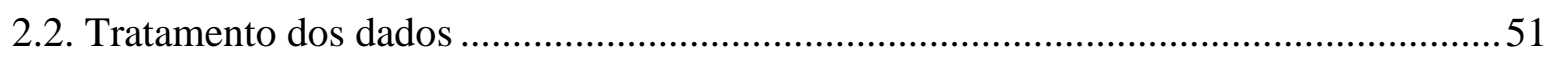

2.3. Procedimentos contra o Brasil no Sistema Interamericano de Direitos Humanos:

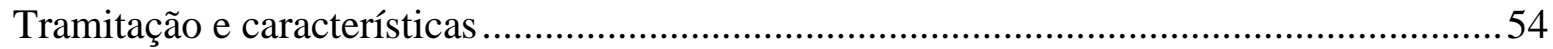

2.4. Graus de state compliance do Brasil para com procedimentos do Sistema

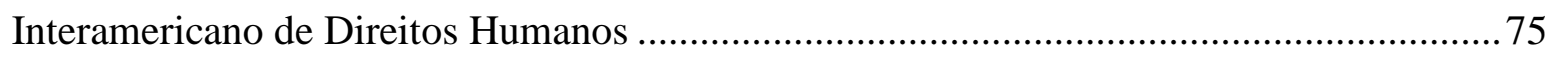

3. Capítulo 3: Processo decisório brasileiro na internalização de sentenças e recomendações do Sistema Interamericano de Direitos Humanos

3.1. O processo decisório de implementação das medidas do SIDH no Brasil

3.2. Evolução da estrutura decisória referente à internalização de medidas do SIDH: conflito e aprendizagem.

3.3. Indenização pecuniária das vítimas

3.4. Implementação das medidas de garantia e acesso à justiça e o Programa Justiça Plena

Capítulo 4: Compliance como uma resultante política doméstica: teste de hipóteses

4.1. Hipóteses

4.2. Tratamento dos dados e procedimentos.

4.3. Resultados

Considerações finais

Referências bibliográficas:

Anexo 1 - Dados fornecidos pelo Ministério das Relações Exteriores

Anexo 2 - Dados fornecidos pela Secretaria de Direitos Humanos da Presidência da República

Anexo 3 - Temas dos procedimentos contra o Brasil no SIDH categorizados por unidade federativa.

Apêndice A - Informações divergentes sobre os casos contra o Brasil no SIDH fornecidos pelo MRE e SDH. 
Apêndice B - Tabela consolidada com os Resultados Gerais .............................................267

Apêndice C - Tabela consolidada com os Resultados Específicos ........................................313 


\section{Introdução}

Este é um estudo das determinantes que afetam o processo de tomada de decisão referente ao cumprimento das resoluções e recomendações do Sistema Interamericano de Direitos Humanos (SIDH) pelo Governo brasileiro (state compliance). O período qualitativo analisado é desde 1988, ano da promulgação da Constituição Federal vigente que marca o final da transição democrática, e 2014, ano do último relatório anual do SIDH divulgado antes do final desta pesquisa.

A expressão "cumprimento", ou compliance na língua inglesa, é usada neste estudo com o significado de adimplemento de medidas, implementação, e diz respeito aos esforços dos diferentes atores para que as determinações dos instrumentos do SIDH fossem consideradas cumpridas na avaliação de cumprimento de recomendações e sentenças realizada pelo SIDH. Compliance é muitas vezes tratada como uma variável dicotômica, mas aqui será tratada como uma variável contínua, explorando o meio termo do cumprimento parcial.

O Brasil é Estado signatário original da Declaração Universal dos Direitos Humanos e da Declaração Americana dos Direitos e Deveres do Homem, ambas de 1948 e pode ser considerado como um dos Estados percursores históricos do que veio a se tornar o SIDH. De fato, na IX Conferência Internacional Interamericana em 1948, em Bogotá, Colômbia, foi proposta a criação de um órgão judicial internacional, que promovesse os direitos humanos no continente, e ao explicitar também a tese que sustentou. Na X Conferência Interamericana, em 1954, na cidade de Caracas, Venezuela, sustentou-se a tese em favor do reconhecimento da personalidade jurídica do indivíduo no plano internacional (TRINDADE, 1991). "Porém, nas décadas seguintes, o regime ditatorial então vigente (1964-1985) impingiu um grave retrocesso às posições brasileiras" (VENTURA; CETRA, 2013, p.2). Após o retorno à democracia,

[f]oi com significativa lentidão que [...] o Brasil buscou resgatar sua atuação em matéria de direitos humanos no âmbito das Américas, principalmente por meio da ratificação da Convenção Americana de Direitos Humanos [CADH] (Pacto de San José da Costa Rica), em 1992, e da aceitação da jurisdição obrigatória da Corte Interamericana de Direitos Humanos, em 1998 (VENTURA; CETRA, 2013, p.2).

De acordo com Santos (2007), mesmo com o estabelecimento do regime democrático "juntamente com uma legislação progressiva e a ratificação de diversas normas internacionais e regionais de direitos humanos, que garantem novos direitos a grupos frequentemente excluídos, tais como prisioneiros, trabalhadores rurais, crianças de rua, populações indígenas, negros, mulheres, homossexuais e travestis práticas 
sistemáticas de violação de direitos humanos contra esses grupos sociais persistem no Brasil” (SANTOS, 2007, p.33).

O objetivo deste estudo é duplo. De um lado, produzir uma análise de política governamental que leve em conta todos os aspectos importantes de um processo de decisão. Assim, no caso em questão, após a identificação e mapeamento das principais questões, problemas, gargalos, conflitos, soluções, atores envolvidos $e$ mecanismos causais, o processo de construção da estrutura decisória do cumprimento de instrumentos do SIDH pelo Brasil (state compliance) é revelado. Munido de tais informações, coletei, consolidei e sistematizei diferentes tipos de dados sobre a inserção do Estado brasileiro no SIDH, assim como dados sobre o seu grau de compliance para com as medidas proferidas pelo sistema, que apontaram as principais determinantes que afetam o cumprimento dos instrumentos da Comissão e Corte Interamericana de Direitos Humanos pelo Brasil.

Por outro lado, o processo de decisão no cumprimento de instrumentos do SIDH se desenvolve em determinado contexto político, com determinados padrões de representação de interesses e mecanismos de tomada de decisão, bem como outros aspectos gerais que caracterizam as relações entre Estado e sociedade. Ao reconstruir empiricamente tais padrões por meio da análise do processo de decisão da política brasileira de cumprimento de resoluções de uma corte internacional, estou, na verdade, $a$ fortiori, desvendando os diferentes padrões e variáveis presentes no cumprimento das resoluções de Cortes Internacionais pelos Estados, especialmente de direitos humanos ( $c f$ CASTRO SANTOS, 1985). Apontar os principais determinantes deste processo é, pois, o segundo objetivo deste estudo.

Nesse marco, a unidade de análise deste trabalho será, em um primeiro momento, as resultantes políticas engendradas dentro do processo decisório de cumprimento dos instrumentos do SIDH e, em um segundo momento, as recomendações e resoluções do SIDH endereçadas ao Brasil.

Para tanto, o universo empírico será composto por todos os relatórios finais de admissibilidade e mérito dos dois órgãos do SIDH, a Comissão Interamericana de Direitos Humanos (CmDH) e Corte Interamericana de Direitos Humanos (CrDH) (art. 51, $\mathrm{CADH}$ ), todos os relatórios da $\mathrm{CmDH}$ e $\mathrm{CrDH}$ de aprovação de acordos de solução amistosa (art. 49, CADH), todas as medidas de urgências outorgadas pela $\mathrm{CmDH}$ e $\mathrm{CrDH}$, todos os relatórios anuais da $\mathrm{CmDH}$ e, por fim, todos os relatórios de 
acompanhamento de implementação da sentença da $\mathrm{CrDH}$ entre 1988 e a 2014. O universo empírico estudado soma mais de 300 documentos.

Tendo como variável dependente o state compliance, determinado pela política doméstica do Estado e pelos fatores internos relacionados ao comportamento estatal balizado pelas normas internacionais, e munidos de dados coletados, consolidados e sistematizados sobre a inserção do Brasil no SIDH, testarei as seguintes hipóteses lançadas por Oscar Vilhena Vieira (2013):

i) A existência de uma agenda de política pública o Estado em andamento ao tempo da decisão afeta positivamente o grau de compliance do Estado brasileiro no SIDH;

ii) A dependência do governo federal de poderes autônomos, como governos locais, Ministério Público e Judiciário, para implementar as políticas públicas necessárias para o cumprimento dos instrumentos do SIDH afeta negativamente o grau de compliance do Estado brasileiro no SIDH; e

iii) Violações de direitos humanos engendradas como consequência de políticas públicas do Estado afetam negativamente o grau de compliance do Estado brasileiro no SIDH.

\section{Nota metodológica}

Para a reconstrução do processo decisório relacionado à implementação das medidas proferidas outorgadas pelo SIDH contra o Brasil, será utilizado o método de process tracing. De acordo com Bennett e Elman (2006), process tracing é um método que rastreia a trajetória de determinado caso para compreender interferências causais entre variáveis contextualizadas historicamente. É apropriada para pesquisas cujos objetos de estudo envolvam padrões complexos de interação entre variáveis múltiplas e interferentes (BERTALANFFY, 2009; GEORGE, L e BENNET, A, 2005, p. 32).

A contribuição do método está no fato de evidenciar a existência de um processo que conecta a causa e o seu resultado ou efeito e, sobretudo, no fato de descobrir as interveniências, processos e causalidade que ligam a variável independente principal e a variável dependente, considerando o contexto em que estão inseridos. Esse método, ao trabalhar com a ideia de que vários eventos podem levar a um mesmo resultado (equifinalidade), assim como resultados idênticos podem advir de variáveis diferentes (multifinalidade), aceita explicitamente que há debilidade na aplicação de qualquer 
metodologia isoladamente e que o diálogo metodológico que conjugue várias técnicas potencializa a força de cada uma delas, alargando-lhes os limites (GEORGE, L e BENNET, A, 2005, p. 27). Não obstante, utilizar-se-á outras ferramentas para complementar, alimentar, o método de process tracing, como elite interviewing ${ }^{l} \mathrm{e}$ pesquisa documental.

Além de Bennett, Rezende compreende que a identificação da equifinalidade nos fenômenos políticos impacta diretamente o método e o desenho da pesquisa.

A equifinalidade importa de modo decisivo para a análise dos fenômenos políticos, dado que estes são sensíveis ao contexto, aos agentes, às instituições, aos processos históricos, e à agência (humana ou não humana). A necessidade crescente de compreensão das configurações causais e da análise dos processos que produzem os fenômenos necessariamente exige que as concepções tradicionais de homogeneidade causal supostas na análise quantitativa não sejam adequadas para a produção de inferências. Estas importantes condições criam limites consideráveis aos métodos quantitativos na ciência politica. (REZENDE, 2011, p. 318)

$\mathrm{Na}$ primeira etapa da pesquisa serão estudados o processo decisório de internalização das recomendações e sentenças do SIDH pelo Estado brasileiro entre 1988 e 2014. Optou-se por estudar a totalidade dos casos no período para se evitar um viés de seleção.

Para acompanhar o processo e reconstruir a trajetória da proposição objeto do estudo, serão analisados dados provenientes dos relatórios anuais do SIDH, de documentos governamentais, de atas de reuniões e notas de grupos de trabalhos. A reconstrução da história e o mapeamento do trajeto permitirão identificar atores-chave para as fases cruciais de discussão sobre a internalização das recomendações do SIDH.

A página oficial da $\mathrm{CmDH}$ e da $\mathrm{CrDH}$ na internet disponibilizam pronunciamentos oficiais (fontes primárias) sobre os casos que lhe chegam, sendo tais documentos fontes de dados essenciais para esta pesquisa. Por essas ferramentas é possível ter acesso aos documentos oficiais: decisões de admissibilidade, acordos de solução amistosa e pronunciamentos de mérito dos casos, além dos relatórios anuais da Comissão e Corte. Por meio desses instrumentos, será possível a análise dos argumentos apresentados pelas instâncias decisórias, possibilitando o entendimento acerca dos posicionamentos e manifestações do Estado. Embora, os relatórios oficiais do Estado não estejam disponíveis, esta lacuna será suprida por meio da análise dos documentos oficiais da Comissão que sempre apresentam resumo das argumentações de ambas as partes

\footnotetext{
1 "Discussions with people who are chosen because of who they are or what position they occupy. That is, by "elite" I do not necessarily mean someone of high social, economic, or political standing; the term indicates a person who is chosen by name or position for a particular reason, rather than randomly or anonymously" (HOCHSCHILD, 2009, p.1).
} 
(peticionários e Estado). Daniela Rodrigues Valentim e Roberto Mendes Mandelli Júnior (1998) ressaltam a importância dos relatórios: “este relatório tem o papel de servir como um retrato do Estado-membro quanto à prática e respeito dos direitos humanos, tendo estes interesse em evitar tais condenações públicas" (VALENTIM; MANDELLI Jr., 1998, p.335).

Com os principais atores identificados serão realizadas entrevistas e lançar-se-á mão da técnica de elite interviewing que, de acordo com Tansey (2007), é recurso complementar para sofisticar dados advindos de outras fontes em pesquisas, como o process tracing. Tansey (TANSEY apud JÚNIOR, 2013, p.4) afirma que este tipo de entrevista intensiva permite o acesso a decisões e ações que estão por trás de eventos ou séries de eventos, colaborando para a reconstrução do processo e identificação de seus pontos críticos.

"Recortes metodológicos são opções do pesquisador que devem estar alinhados aos objetivos da pesquisa e à natureza do fenômeno" (JÚNIOR, 2013, p.44). O método de process tracing requer a coleta de grande quantidade de dados provenientes de diferentes fontes (BENNETT; ELMAN, 2006). Assim, para realizar a pesquisa, serão seguidos os seguintes passos:

1. Identificação dos atores chave;

2. Entrevistas com atores chave;

3. Busca, em discursos e notas das reuniões de grupos de trabalho, de fragmentos para complementar as informações obtidas nos documentos e nas entrevistas;

4. Identificação de momentos críticos do percurso histórico, sequências, do processo decisório;

E a partir dessas etapas:

5. Identificação, reconstrução, do processo decisório da internalização das resoluções a partir de base documental.

Foram entrevistados integrantes de órgãos governamentais responsáveis pela defesa do Estado brasileiro frente ao SIDH e pela implementação de suas decisões no País, como o Ministério das Relações Exteriores (MRE), a Secretaria de Direitos Humanos (SDH/MJ), a Advocacia-Geral da União (AGU). A seleção dos entrevistados ocorreu devido ao fato de estarem diretamente envolvidos nos casos ou com a temática dentro de suas instituições. A maioria dos entrevistados foi indicada pelas suas próprias instituições. Para resguardar a identidade de todos os entrevistados, indicou-se apenas o local e a data das entrevistas. No total, foram entrevistadas cinco pessoas ao longo de um 
ano. Todas as entrevistas seguiram um roteiro semiestruturado específico para cada instituição, levando-se em conta:

1. O contexto político no qual se insere o caso em que o entrevistado atuou;

2. As funções institucionais da respectiva entidade na implementação do caso; e

3. Os obstáculos enfrentados no processo de implementação.

A pesquisa se divide em quatro capítulos. No primeiro capítulo, os conceitos principais utilizados neste trabalho serão discutidos. No segundo capítulo, será traçada uma visão geral da inserção do Estado brasileiro no Sistema Interamericano de Direitos Humanos, assim como será apresentada a metodologia da coleta de dados e os resultados da identificação, classificação e sistematização destes. No terceiro capítulo, será analisado o processo de tomada de decisão referente à internalização de recomendações e decisões do SIDH.

Finalmente, vale observar que, o capítulo quatro do estudo é destinado ao teste das hipóteses relacionadas à compliance e a política doméstica brasileira. Os resultados obtidos a partir da coleta e sistematização dos dados, assim como as determinantes que afetam o processo de tomada de decisão identificado, serão discutidos nas considerações finais desta dissertação. 


\section{Capítulo 1: Direito Internacional, Sistema Interamericano de Direitos Humanos e o conceito de compliance}

Acima dos Estados estão os seres humanos que os compõem Antônio Augusto Cançado Trindade

Parte-se do pressuposto de que a estrutura internacional se altera quando os Estados mudam, por meio de suas práticas, as regras e normas constitutivas da interação internacional. Logo, dada a relação constitutiva ente agente e estrutura, quando as regras e normas que constituem as práticas políticas dos atores se alteram, as crenças e identidades dos atores domésticos, consequentemente, modificam-se.

Este processo impacta diretamente o processo de tomada de decisão interno, como mostrado pela teoria refinada por Robert Putnam (PUTNAM, 1988) com base no modelo dos jogos de dois níveis. O modelo de jogo de dois níveis argumenta que ações do Sistema Internacional impactam as tomadas de decisões no ambiente político doméstico, assim como as decisões políticas internas afetam fortemente o Sistema Internacional. O principal problema do Estado seria, portanto, a busca de uma estratégia de negociação que seja politicamente viável nas ordens interna e externa (LIMA, 1994).

Não obstante, assume-se que o indivíduo é um fim em si mesmo: apesar de os Estados serem importantes na criação do Direito Internacional, o objetivo último deste é a proteção dos indivíduos (URUEÑA, 2012, p. 101). Para Rosalyn Higgins, os indivíduos devem ser entendidos como participantes do Direito Internacional, da mesma forma que os governos e as organizações internacionais o são (HIGGINS, 1978).

Por um sujeito de direito, entende-se uma entidade dotada de direitos e deveres (responsabilidades) em um determinado sistema jurídico (KRENZ, 1966, p. 93). Reconhecer a personalidade jurídica dos indivíduos é admitir que o Direito Internacional atribui direitos e deveres de forma direta às pessoas, e não pela intermediação dos Estados (KRENZ, 1966, pp. 95-96). Para Hugo Grotius, por exemplo, o Estado não é um fim em si mesmo, mas um meio para assegurar a ordem social e aperfeiçoar a sociedade comum, que abarca toda a humanidade (GROTIUS apud TRINDADE, 2006, p. 119).

Nesse marco, o objetivo deste capítulo inicial é clarificar as relações existentes entre as diferentes concepções de direito internacional, como surgiram os Sistemas de Proteção de Direitos Humanos, em especial o Sistema Interamericano de Direitos Humanos (SIDH), e como os Estados buscam cumprir normas jurídicas internacionais 
(State Compliance with international legal rules) relacionadas a direitos humanos haja vista o ambiente político doméstico e externo. Para atingir esse objetivo, serão definidos os conceitos de Direito Internacional e State Compliance utilizados neste trabalho, assim como será investigado o funcionamento do Sistema Interamericano de Direitos Humanos e seus órgãos.

\subsection{Direito Internacional: definição e concepções}

Neste trabalho, usarei a definição de Hedley Bull sobre o Direito Internacional. Para o autor, Direito Internacional é "a body of rules which binds states and other agents in world politics in their relations with one another and is considered to have the status of law" (BULL, 2002, p.127).

Ao considerar o Direito Internacional como um conjunto de regras, Bull deixa de lado a visão de outros teóricos que consideram o Direito Internacional não como regras, mas sim como processos sociais (HIGGINS, 1994). Para Higgins (1994), por exemplo, o Direito Internacional é caracterizado como um processo, pois é determinado por um processo de tomada de decisão autoritário e efetivo, que não compreende apenas a aplicação de um conjunto de regras antigo, mas é determinado também por considerações sociais, morais e políticas.

Contudo, para Bull (2002), é inegável que o direito é criado por meio de um processo político suscetível às influências morais e sociais. Entretanto, o direito não é um processo em si, pois alguns conjuntos de regras jurídicas podem ser definidos em um certo espaço temporal. Bull (2002) explica que:

If we are to recognize legal decision-making as a distinct social process and distinguish it from other process of decision-making, it can only be by recognizing that it is a process whose central and distinguishing feature is the attempt to shape decision in relation to an agreed body of legal rules (BULL, 2002, p.129)

Igualmente, é importante notar que uma das principais características para que atores internacionais acreditem que certas regras internacionais sejam regras jurídicas internacionais, que sejam parte de um Direito Internacional, que promovam direitos e obrigações, é que estes mesmos atores a percebam como tal. Bull (2002) nota que "the activity of those who are concerned with international law, public and private - statesman and their legal advisers, national and international courts, and international assemblies is carried on in terms of the assumption that the rules with which they are dealing are rules of law" (BULL, 2002, p.136). 
David Kennedy (1988), concordando com o argumento de Bull (2002), afirma que o direito não é "a stable domain which relates in some complicated way to society or political economy or class [instead law is] the practice and the argument about the relationship between something posited as law and something posited as society" (KENNEDY, 1988, p.8). Assim, o Direito Internacional poderia ser considerado como "a method of conversation that states have chosen to follow" (PURVIS, 1991, p.115).

Como define Jean-Louis Bergel (2001), o fenômeno jurídico é essencialmente relativo: sua concepção e suas manifestações variam no tempo e no espaço, conforme os sistemas de direito, e são, portanto, dependentes de seu meio ambiente (BERGEL, 2001, p.1). Nesse sentido, há que se afirmar que o direito é um fenômeno eminentemente humano, o qual toma por base o homem, não como um ser isolado, mas socialmente considerado. Assim, "se o direito só se verifica, pois, em sociedade, o fenômeno social aparece-nos desde logo como condicionante do fenômeno jurídico" (ASCENÇÃO, 1987, p.18).

O Direito Internacional não é mais criado unicamente por atores estatais (BERMAN, 2005). Ao contrário, hoje, presencia-se um mundo no qual "transnational law-making [and] crossborder interaction, where state and non-state actors together disseminate alternative normative systems across a diffuse and constantly shifting global landscape.”(BERMAN, 2005, p.492). Esse fenômeno inclui a multiplicação de atores, regras, fontes e organizações no Direito Internacional, assim como a expansão dos princípios jurisdicionais tradicionais (BERMAN, 2005).

Tradicionalmente, o Direito Internacional era baseado nas relações entre atores estatais $^{2}$. Indivíduos, organizações internacionais, organizações não governamentais, e outros tantos atores não estavam dentro do escopo do Direito Internacional. A Corte Internacional de Justiça (CIJ) assim como a sua predecessora Corte Permanente de Justiça Internacional (CPJI) eram e continuam sendo reservadas apenas para querelas estatais. Hoje, o Direito Internacional absorve uma miríade de novos atores e governa múltiplos tipos de relações (BERMAN, 2005).

Thus, it is no longer true that international law represents a body of law that solely governs relations among states; on the contrary, it is a complex web of treaties, regulations, customary norms, and codes of conduct that shapes relationships among state as well as non-state actors along horizontal and vertical axes of power (BERMAN, 2005, p.311-312)

\footnotetext{
${ }^{2}$ Em uma visão mais tradicional da academia, Direito Internacional poderia ser "located international law in the acts of official governmental bureaucratic entities, such as the treaties and agreements entered into by nation states, the declarations and protocols of the United Nations [...] or other affiliated bodies, and the rulings of international courts and tribunals" (CARTER et TRIMBLE, 1999)
} 
Desse modo, o Direito Internacional adapta-se de forma contínua para conservar sua própria existência, em face das transformações sociais. Um exemplo dessa adaptação é o próprio Sistema Interamericano de Direitos Humanos que será visto a seguir.

\subsection{O Sistema Interamericano de Direitos Humanos}

A internacionalização dos direitos humanos consiste, segundo o juiz da Corte Internacional de Justiça (CIJ), A. A. Cançado Trindade, no processo de construção de um conjunto de regras sociais, reconhecidas pelos atores políticos internacionais, de proteção e de promoção da dignidade da pessoa humana (TRINDADE, 2006, p.91). Em meados do século XX, reconheceu-se a necessidade de reconstrução do direito internacional com atenção aos direitos do ser humano, presente na Declaração Universal de 1948, seguida, ao longo de cinco décadas, por mais de setenta tratados de proteção vigentes nos planos global e regional ${ }^{3}$.

O processo de internacionalização dos direitos humanos, desse ângulo, consistiu na construção de uma tutela universal, homologadora do ponto de vista da humanidade, do essencial e elementar "direito a ter direitos" a que faz referência Hannah Arendt (ARENDT, 1985, p. 293-296). Houve, assim, a construção de uma consciência jurídica universal (TRINDADE, 2001) subjacente a essa evolução normativa do Direito Internacional. O despertar desta consciência, que é fonte material de todo o Direito, leva ao reconhecimento inequívoco de que nenhum Estado pode considerar-se acima do Direito, uma vez que as normas têm como destinatários últimos os seres humanos.

Nesse marco, surge o sistema internacional de proteção aos direitos humanos que é composto pelo sistema global, representado pela Organização das Nações Unidas (ONU), e pelos sistemas regionais: europeu, interamericano e africano. Essa divisão tem como escopo fortalecer os direitos humanos em dois níveis: aquele abrange todas as nações, enquanto esse solidifica suas bases por meio da homogeneidade cultural e institucional de seus membros (CORREIA, 2008).

O sistema interamericano de promoção e proteção dos direitos fundamentais do
homem teve seu início formal em 1948, com a Declaração Americana dos
Direitos e Deveres do Homem, aprovada pela IX Conferência Internacional
Americana, em Bogotá. Nesta Conferência, também foi criada a Organização
dos Estados Americanos, cuja Carta proclama os 'direitos fundamentais da
pessoa humana' como um dos princípios fundamentais da Organização. A
forma de concretização deste princípio encontra-se definida no documento
constituinte, mediante o reconhecimento de que 'as finalidades do Estado não
se cumprem apenas com o reconhecimento dos direitos do cidadão' mas

\footnotetext{
${ }^{3}$ Disponível em: http://dai-mre.serpro.gov.br/ Acesso em: 16 junho 2016
} 
também 'com a preocupação pelo destino dos homens e das mulheres, considerados como não cidadãos, mas como pessoas'; consequentemente, deve-se garantir 'simultaneamente tanto o respeito às liberdades políticas e do espírito, como a realização dos postulados da justiça social' (JAYME, 2005, p.64) ${ }^{4}$.

O Sistema Interamericano de Direitos Humanos (SIDH) é composto por quatro principais instrumentos normativos: 1) a Carta da Organização dos Estados Americanos (OEA) (1948); 2) a Declaração Americana dos Direitos e Deveres do Homem (1948), que mesmo não sendo tecnicamente um tratado, explicita os direitos apontados na Carta da OEA (MORAES, 2008, p.11); 3) a Convenção Americana sobre Direitos Humanos (CADH) (1969), ou Pacto de São José da Costa Rica, e 4) o Protocolo Adicional à Convenção Americana em Matéria de Direitos Econômicos Sociais e Culturais, conhecido como Protocolo de San Salvador (1988) ${ }^{5}$. O SIDH é composto ainda por dois órgãos, a Comissão Interamericana de Direitos Humanos $(\mathrm{CmDH})$ e a Corte Interamericana de Direitos Humanos $(\mathrm{CrDH})$, sob a égide da Organização dos Estados Americanos (OEA) (MORAES, 2008), e "teve sua inspiração no modelo do Sistema Europeu" (PASQUALUCCI, 1994/1995, p. 309).

\section{A Comissão Interamericana de Direitos Humanos}

À Comissão Interamericana de Direitos Humanos $(\mathrm{CmDH})$ compete o registro de petições, a verificação de sua admissibilidade, a determinação factual, a tentativa de conciliação (acordo de solução amistosa entre as partes), a emissão de relatórios de recomendações e a submissão de relatório anual à Assembleia Geral da Organização dos

\footnotetext{
${ }^{4}$ A criação da Organização dos Estados Americanos (OEA) ocorreu durante a IX Conferência Internacional Interamericana, em Bogotá, por 21 Estados, entre eles o Brasil. Neste ponto, é preciso diferenciar dois movimentos: a integração interamericana e o pan-americanismo, que se distinguem não apenas temporalmente, mas também quanto ao conteúdo e à participação. $\mathrm{O}$ segundo compreende a América do Norte e foi criado dentro da esfera de interesse dos Estados Unidos. Logo," "a OEA representa a forma institucionalizada do pan-americanismo no pós-Segunda Guerra Mundial” (SEITENFUS, 2012, p.274).

5 Os demais instrumentos normativos do SIDH são: O Protocolo adicional à Convenção Americana sobre Direitos Humanos relativo à Abolição da Pena de Morte (1990); a Convenção Interamericana para Prevenir, Punir e Erradicar a Violência contra a Mulher - Convenção de Belém do Pará (1994); a Convenção Interamericana sobre Desaparecimento Forçado de Pessoas (1994); a Convenção Interamericana para a Eliminação de Todas as Formas de Descriminação contra Pessoas com Deficiência (1999); a Carta Democrática Interamericana (2001); a Declaração de Princípios sobre Liberdade de Expressão (2000); e os Princípios e Boas Práticas sobre a Proteção das Pessoas Privadas de Liberdade nas Américas (2008). Disponível em: www.oas.org/es/cidh/mandato/fuentes.asp Acesso em: 16 junho 2016
} 
Estados Americanos. Criada por Resolução da Assembleia Geral da OEA em $1959^{6}$, a Comissão iniciou seus trabalhos em 1960 com sede em Washington, Estados Unidos da América (EUA).

Sofreu diversas modificações em sua estrutura e competências com a assinatura do Protocolo de Reforma da Carta da OEA, firmado em Buenos Aires em 1967 e em vigor a partir de 1970, sendo uma das principais mudanças a integração do estatuto da $\mathrm{CmDH}$ à Carta da OEA, assumindo assim, personalidade de órgão institucional da OEA com base convencional. O Estatuto que rege atualmente o funcionamento da Comissão foi aprovado no Nono Período Ordinário de Sessões da Assembleia Geral da OEA (La Paz, Bolívia, 1979). "Ele reflete as importantes inovações introduzidas pela Convenção Americana com relação à Comissão" (ORGANIZAÇÃO DOS ESTADOS AMERICANOS, n/d).

“A competência da Comissão Interamericana de Direitos Humanos alcança todos os Estados-parte da Convenção Americana, em relação a todos os direitos nela previstos. Além disso, também alcança todos os Estados participantes da Organização dos Estados Americanos (OEA), em relação aos direitos presentes na Declaração Universal dos Direitos Humanos, de 1948" (PIOVESAN, 2011, p.129) ${ }^{7}$. A CmDH é composta por sete membros, eleitos dentre os Estados-membros da OEA para um mandato de quatro anos, sendo possível uma reeleição (ADVOCACIA GERAL DA UNIÃO, n/d).

A Comissão funciona em parte como órgão político e em parte como órgão quase judicial. Sua natureza política é engendrada pelas "visitas in loco ou a elaboração de relatórios sobre a situação dos direitos humanos nos Estados-membros" (VENTURA; CETRA, 2013, p.2). Já sua função quase judicial é devido ao fato da Comissão exercer "o juízo de admissibilidade de denúncias relativas a violações de direitos humanos e, se for o caso, conduz[ir] um procedimento que pode chegar, por exemplo, a uma solução amigável ou ao encaminhamento do caso ao órgão jurisdicional” (VENTURA; CETRA, 2013, p.2). A CmDH é assim "encarregada do controle do comportamento dos Estados,

\footnotetext{
${ }^{6}$ Declaração de Santiago do Chile adotada na Quinta Reunião de Consulta dos Ministros das Relações Exteriores, Santiago do Chile, de 12 a 18 de agosto de 1959, Ata Final, Doc. OEA/Ser.C/II.5, págs. 4-6; disponível em espanhol em http://www.oas.org/consejo/sp/RC/RCatas.asp.

${ }^{7}$ Até o dia 16 de junho de 2016, os 25 Estados Membros da OEA que ratificaram a Convenção Americana são: Argentina, Barbados, Bolívia, Brasil, Chile, Colômbia, Costa Rica, Dominica, Equador, El Salvador, Granada, Guatemala, Haiti, Honduras, Jamaica, México, Nicarágua, Panamá, Paraguai, Peru, República Dominicana, Suriname, Trinidade e Tobago, Uruguai e Venezuela. Disponível em: https://www.cidh.oas.org/basicos/portugues/d.Convencao_Americana_Ratif..htm Acesso em: 16 junho 2016.
} 
aos quais pode endereçar recomendações" (VENTURA; CETRA, 2013, p.2) não vinculantes.

\title{
Corte Interamericana de Direitos Humanos
}

A Corte Interamericana de Direitos Humanos $(\mathrm{CrDH})$ foi criada pela Convenção Americana sobre Direitos Humanos em 1969 e só pôde ser estabelecida e organizada depois que esse tratado entrou em vigor. Foi instalada "oficialmente em sua sede em São José, Costa Rica, em 3 de setembro de 1979, e seu Estatuto foi aprovado pela Assembleia Geral da OEA de La Paz, Bolívia, em outubro de 1979, mediante a Resolução No 448"8 (ORGANIZAÇÃO DOS ESTADOS AMERICANOS, n/d).

É composta por sete juízes, indicados e eleitos pelos Estados-parte da $\mathrm{CADH}$, que exercem um mandato de seis anos, sendo possível uma reeleição. Suas competências e atividades são reguladas tanto pela CADH como por seu Estatuto e Regulamento próprio (BUERGENTHAL, 1982, pp. 231-232). Para que um Estado aceite a jurisdição da CrDH, não é suficiente que este apenas ratifique a $\mathrm{CADH}$, é necessário ainda que manifeste o reconhecimento da atribuição adicional da cláusula facultativa da competência contenciosa da Corte presente na CADH por meio de declaração específica que ateste esta submissão (BUERGENTHAL, 1982, p. 236). "Dos 25 estados pertencentes à Convenção, 22 declararam reconhecer a jurisdição da Corte até novembro de 2002"9

O primeiro Regulamento da $\mathrm{CrDH}$ foi aprovado em 1980 e se baseava no Regulamento então vigente da Corte Europeia de Direitos Humanos, inspirado no Regulamento da Corte Internacional de Justiça (CIJ). Devido à necessidade de agilizar seu processo, a CrDH aprovou modificações no seu Regulamento em 1991, 1996, 2000 e 2009. Uma das principais modificações foi no seu art.23, que

\begin{abstract}
outorgava aos representantes das vítimas ou de seus familiares a faculdade de apresentar, independentemente, seus próprios argumentos e provas na etapa de reparações do processo. Essa reforma, que entrou em vigor em $1^{\circ}$ de junho de 2001, introduziu diversas medidas para conceder às supostas vítimas, a seus familiares ou a seus representantes devidamente credenciados a participação direta em todas as etapas do processo iniciado com a apresentação de uma demanda ao Tribunal (ORGANIZAÇÃO DOS ESTADOS AMERICANOS, $\mathrm{n} / \mathrm{d})$.
\end{abstract}

Nas diversas alterações que o Regulamento da Corte Interamericana de Direitos Humanos sofreu nos últimos anos fica clara a aplicação de uma lógica que dá uma maior autonomia às vítimas das supostas violações de direitos humanos, uma vez iniciado a

\footnotetext{
${ }^{8}$ Resolução AG/RES. 448 (IX-O/79), Disponível em http://www.cidh.oas.org/basicos/portugues/v.Estatuto.Corte.htm

${ }^{9}$ Disponível em: http://www.dhnet.org.br/dados/cursos/dh/cc/1/sisint.htm Acesso em: 16 junho 2016
} 
litigância de um caso contencioso na CrDH. Em 2004, por exemplo, uma alteração introduzida no seu Regulamento de 2004 dispôs que as vítimas podem apresentar diretamente à Corte o pedido de Medidas Provisórias ${ }^{10}$, sem a necessidade de ter de passar pela CmDH (GONZÁLEZ, 2010, pp.54-55).

A última mudança no Regulamento da CrDH aconteceu em 2010, no seu LXXXV Período Ordinário de Sessões, realizado entre os dias 16 e 28 de novembro de 2009.

O principal aspecto dessa reforma são as modificações introduzidas no papel da
Comissão e dos representantes das vítimas no processo perante a Corte. Em
suas disposições transitórias, o Regulamento da Corte estabelece: (1) que os
casos contenciosos submetidos à Corte antes de $1^{\circ}$ de janeiro de 2010
continuarão sendo tramitados, até a emissão da sentença, em conformidade
com o Regulamento anterior; e (2) que a apresentação dos casos encaminhados
à Corte cujos relatórios tiverem sido adotados pela Comissão em conformidade
com o artigo 50 da Convenção antes de $1^{\circ}$ de janeiro de 2010 é regida pelos
artigos 33 e 34 do Regulamento anterior (ORGANIZAÇÂO DOS ESTADOS
AMERICANOS, n/d)

De acordo com o artigo $1^{\circ}$ do seu Estatuto, “a Corte é uma instituição judicial autônoma cujo objetivo é a aplicação e interpretação da Convenção Americana sobre Direitos Humanos" (ORGANIZAÇÃO DOS ESTADOS AMERICANOS, n/d) ${ }^{12}$. Para cumprir este objetivo, a $\mathrm{CrDH}$ possui uma jurisdição contenciosa (pode julgar litígios) sobre as violações de direitos humanos garantidos na $\mathrm{CADH}$, regida pelos artigos 61, $62 \mathrm{e}$ 63 da Convenção; e outra consultiva (pode emitir pareceres) regida pelas disposições do artigo 64 da Convenção. Sua jurisdição consultiva permite-lhe interpretar a CADH, assim como outros instrumentos em matéria de direitos humanos, conforme a solicitação de um Estado-membro da OEA ou de órgãos da mesma instituição (BUERGENTHAL, 1982, p. 235). Segundo o artigo 45 da CADH, a Corte ainda possui a jurisdição para julgar casos interestatais, caso ambos os Estados litigantes tenham feito anteriormente uma declaração em separado reconhecendo a competência da Corte para tanto (BUERGENTHAL, 1982, p. 236).

As sentenças e resoluções da Corte são vinculantes e obrigatórias para todos os Estados que aceitaram sua jurisdição. O que possibilita a responsabilização internacional do Estado caso não cumpra com a sentença proferida. Observa-se, contudo, que o cumprimento de uma decisão de uma Corte Internacional ao qual o Estado aderiu faz parte de conceito basilar do Direito Internacional. Segundo os termos do pact sunt

\footnotetext{
${ }^{10}$ A definição de Medidas Provisórias será vista em detalhe a seguir.

${ }^{11}$ Disponível em: http://www.oas.org/pt/cidh/mandato/Basicos/introduccion.asp Acesso em: 6 jun 2016

${ }^{12}$ Disponível em: https://www.cidh.oas.org/basicos/portugues/v.Estatuto.Corte.htm Acesso em: 16 jun 2016
} 
servanda, previsto no artigo 27 da Convenção de Viena sobre o Direito dos Tratados (CVDT) de 1969, as obrigações internacionais devem ser cumpridas de boa-fé.

Para que um caso seja avaliado pela $\mathrm{CrDH}$, é preciso que primeiro ele tenha sido admitido pela $\mathrm{CmDH}$, que não tenha ocorrido uma conciliação durante a fase de tentativa de uma solução amistosa entre as partes e que a $\mathrm{CmDH}$ já tenha emitido seu relatório ou recomendações para o(s) Estado(s) acusado(s) (BUERGENTHAL, 1982, pp. 237-238).

Segundo Jo Pasqualucci (1994/1995, p. 323), a $\mathrm{CrDH}$ foi o primeiro tribunal internacional a abordar o problema dos desaparecimentos forçados, dos direitos indígenas e fazer avanços nos mecanismos e modalidades de reparação das vítimas. Além disso, Pasqualucci também afirma que a $\mathrm{CrDH}$ defende que a $\mathrm{CADH}$ deve ser interpretada em favor dos indivíduos, "recusando-se a tomar uma visão estritamente formalista dos requerimentos procedimentais, de modo a não sacrificar a justiça por formalidades" (RIBEIRO, 2013, p.41) - obedecendo ao ordenamento jurídico existente, haja vista o princípio da segurança jurídica (PASQUALUCCI, 1994/1995, pp. 340-342).

Se compararmos o número de petições recebidas pela $\mathrm{CmDH}$ com o número de casos que a $\mathrm{CrDH}$ recebe, fica evidente pela quantidade pequena de casos que chegam à Corte que o órgão não é um tribunal que busca ter uma abrangência continental, que busca resolver todas as supostas violações de direitos humanos do continente, mas um órgão que amplifica questões políticas a partir de um universo pequeno de casos. Portanto, é importante que cada um dos casos que chegue até a Corte consiga ultrapassar a si mesmo, de modo a criar efeitos em situações que sejam semelhantes em diferentes Estados (CAVALLARO; BREWER, 2008b, pp. 87-88) e assim criar uma jurisprudência de âmbito continental.

"Um número muito grande de litígios na Corte, se não articulados da forma correta, são incapazes de promover justiça social ou a eficácia do SIDH" (CAVALlARO; SCHAFFER, 2006/2007, p. 350). Nesse sentido, fica claro que a compliance estatal para com os instrumentos do Sistema Interamericano de Direitos Humanos também depende da capacidade operacional do próprio SIDH.

Medidas de Urgência do Sistema Interamericano de Direitos Humanos

A $\mathrm{CmDH}$ e a $\mathrm{CrDH}$ "possuem um sistema de medidas de urgência" (GONZÁLEZ, 2010, p.51), denominadas, respectivamente, "medidas cautelares" (MCs) e "medidas provisórias" (MPs). Ambas tem como escopo, se o caso for de gravidade ou 
urgência, impor ao Estado adoção de medidas que façam cessar a violação de Direitos Humanos (DHs), ou que impeçam a ocorrência de danos irreparáveis à(s) suposta(s) vítimas. Além disso, “a Comissão pode solicitar à Corte medidas de urgência, seja no sentido de preservar algum direito lesado, ou seja, no sentido de evitar algum dano irreparável à pessoa, em matéria ainda não discutida pela Corte" (PIOVESAN apud SCHNEIDER; BEDIN, 2012, p,16).

Sobre as Medidas Cautelares (MCs) é necessário afirmar que

\begin{abstract}
[e]mbora a prática da Comissão em matéria de medidas cautelares identificasse várias causas para sua concessão, estas vieram a ser reguladas recentemente de forma expressa por meio das reformas introduzidas ao Regulamento da CIDH, as quais entraram em vigor em 31 de dezembro de 2009. Dessa forma, podem ser diferenciadas três hipóteses para a outorga das medidas: [1] uma de caráter geral, referente à prevenção de danos irreparáveis às pessoas no contexto de casos em trâmite na CIDH; [2] uma concernente à salvaguarda do objeto de um processo ante a própria Comissão; e [3] uma terceira relativa a evitar danos irreparáveis independentemente do sistema de casos. Para todas essas hipóteses, uma alteração regulamentar recente sinaliza que será considerado, além disso, o contexto da situação (GONZÁLEZ, 2010, pp.54-55).
\end{abstract}

Já sobre as Medidas Provisórias (MPs), nota-se que elas se encontram expressamente previstas na $\mathrm{CADH}$ e apenas se aplicam aos Estados-parte de tal instrumento. Tais medidas procedem "[e]m casos de extrema gravidade e urgência, e quando se fizer necessário evitar danos irreparáveis às pessoas" (TRINDADE; ROBLES, 2003 , p. 164), de acordo com o artigo 63.2 do referido tratado. "Sua consagração no tratado não deixa nenhuma margem de dúvida sobre o caráter obrigatório das medidas provisórias" (GONZÁLEZ, 2010, pp.54-55). Em termos de fases processuais, o mesmo artigo define que as MPs podem ser emitidas em duas situações: "[1] sobre assuntos dos quais estiver conhecendo a Corte, [2] e quando se tratar de assuntos que ainda não estiverem submetidos a seu conhecimento, [em cujo caso] poderá atuar a pedido da Comissão" (GONZÁLEZ, 2010, pp.54-55).

\title{
Acordos de solução amistosa
}

Há também no Sistema Interamericano de Direitos Humanos a possibilidade das partes, peticionários e Estados, chegarem a um acordo de solução amistosa. Previsto no artigo 49 da Convenção Americana, o acordo de solução amistosa pode ser feito em qualquer fase do processo. Caso aconteça, a Comissão redigirá um relatório vinculante e os encaminhará para ambas as partes e, posteriormente, para o Secretário Geral da Organização dos Estados Americanos para publicação. 
Desse modo, pode-se considerar como instrumentos, medidas de ação do Sistema Interamericano de Direitos Humanos tanto as recomendações e medidas cautelares da Comissão Interamericana de Diretos Humanos como as sentenças e medidas provisórias da Corte Interamericana de Direitos Humanos e ainda os acordos de solução amistosa.

\section{Tramitação de uma petição no Sistema Interamericano de Direitos Humanos}

Segundo o artigo 44 da $\mathrm{CADH}$, "qualquer pessoa ou grupo de pessoas, ou entidade não-governamental legalmente reconhecida em um ou mais Estados-membros da Organização, pode apresentar à Comissão petições que contenham denúncias ou queixas de violação desta Convenção por um Estado-parte" (CADH, art. 44). Os Estados-parte também podem denunciar supostas violações de direitos humanos realizadas por outros Estados-parte desde que ambos reconheçam a competência da Comissão para tanto (artigo 45, CADH).

À Comissão Interamericana de Direitos Humanos cabe a análise de admissibilidade da petição no SIDH. Os artigos que tratam especificamente dos requisitos de admissibilidade de uma petição são os artigos 46 e 47 da CADH. Segundo estes artigos, para que a petição seja aceita é necessário:

\footnotetext{
a. que hajam sido interpostos e esgotados os recursos da jurisdição interna, de acordo com os princípios de direito internacional geralmente reconhecidos;

b. que seja apresentada dentro do prazo de seis meses, a partir da data em que o presumido prejudicado em seus direitos tenha sido notificado da decisão definitiva;

c. que a matéria da petição ou comunicação não esteja pendente de outro processo de solução internacional; e

d. que, no caso do artigo 44, a petição contenha o nome, a nacionalidade, a profissão, o domicílio e a assinatura da pessoa ou pessoas ou do representante legal da entidade que submeter a petição (CADH, artigo 46)
}

Há, contudo, algumas exceções sobre a regra de esgotamento de recursos internos, isto é, "um Estado não pode ser acionado perante a jurisdição internacional sem que lhe seja permitido resolver a questão internamente" (ADVOCACIA GERAL DA UNIÃO, $\mathrm{n} / \mathrm{d}$ ). A regra se baseia no fato de que soluções internas efetivas estejam de fato disponíveis.

Entre as exceções, estão as seguintes situações: (1) locais onde não existe o direito ao devido processo legal; (2) nas ocasiões em que autoridades negam o acesso ou não permitem que a parte consiga recorrer a todas as soluções internas possíveis; (3) ou onde há um atraso injustificado sobre esses procedimentos (PASQUALUCCI, 1994/1995, p. 
338). Quando se é alegado que os recursos internos ainda não foram exauridos, o Estado fica com o ônus da prova para si (PASQUALUCCI, 1994/1995, pp. 335-336).

Não obstante, a Comissão poderá declarar inadmissível toda petição ou comunicação apresentada quando:
a. não preencher algum dos requisitos estabelecidos no artigo 46 ;
b. não expuser fatos que caracterizem violação dos direitos garantidos por esta Convenção;
c. pela exposição do próprio peticionário ou do Estado, for manifestamente infundada a petição ou comunicação ou for evidente sua total improcedência; ou
d. for substancialmente reprodução de petição ou comunicação anterior, já examinada pela Comissão ou por outro organismo internacional (CADH, artigo 47).

Quando a petição é admitida, ela se transforma em um caso do Sistema Interamericano de Direitos Humanos. A Comissão, assim, enviará os trechos da petição que achar necessário ao Estado em que ocorreu a suposta violação de direitos humanos. A partir dessa data, o Estado terá dois meses para apresentar uma resposta. Este período de dois meses pode ser prorrogados por mais um (CADH, artigo 30).

A próxima fase é a apreciação do mérito do caso. A CmDH poderá, então, dar a oportunidade para o peticionário se manifestar sobre o seu caso e para o Estado de apresentar a sua defesa (CADH, artigo 48). Se o caso for grave ou urgente ${ }^{13}$, a Comissão poderá investigar in loco imediatamente a denúncia de violação de direitos humanos (CADH, artigo 38). Em posse de novas informações, a $\mathrm{CmDH}$ poderá arquivar ou continuar com a tramitação do caso (CADH, artigo 48). Também há a possibilidade de que a qualquer momento do processo de tramitação novas provas e informações sejam apresentadas pelas partes de maneira superveniente (CADH, artigo 48). Lembra-se que a qualquer momento do processo, tanto na Comissão quanto na Corte, há a possibilidade de um acordo de solução amistosa entre as partes (CADH, artigo 49), caso este não seja possível, o processo procede normalmente.

Após a apreciação de todas as informações apresentadas por ambas as partes e não havendo um acordo de solução amistosa, a Comissão publica seu relatório de fundo do caso. Esse relatório contém os votos divergentes dos membros da Comissão, as exposições escritas e verbais de ambas as partes do processo e o conjunto de

\footnotetext{
${ }^{13}$ Casos graves e urgentes são aqueles em que a Comissão acredita que deva agir imediatamente para prevenir danos irreparáveis às pessoas ou ao objeto de uma petição (Art. 25 do Regulamento da $\mathrm{CmD}$ ). Disponível em: http://www.oas.org/es/cidh/mandato/Basicos/reglamentoCIDH.asp Acesso em: 16 junho 2016
} 
recomendações que o Estado deve cumprir para reparar os direitos humanos violados apresentados no caso (CADH, artigo 50).

A Comissão, então, envia o relatório aos interessados. Ao final de no máximo três meses por maioria absoluta, a Comissão julgará se o Estado remediou a situação de violação de direitos humanos de acordo com o conjunto de recomendações proferidas. Se a Comissão verificar que o caso não foi solucionado, ela publicará o relatório. Uma vez que a situação de não cumprimento continue, a Comissão Interamericana de Direitos Humanos poderá decidir por encaminhar o caso à Corte Interamericana de Direitos Humanos, exceto se a maioria absoluta de seus membros se opuser (CADH, artigo 44).

Além da Comissão, podem submeter um caso à Corte apenas os Estados-parte da CADH. Contudo, os peticionários podem participar do caso com voz ativa uma vez iniciada o julgamento na Corte Interamericana de Direitos Humanos (REGULAMENTO $\mathrm{CrDH}$, artigo 23), assim como podem solicitar medidas provisórias (MPs).

“A litigância na Corte começa com as considerações sobre objeções preliminares à admissibilidade. Se admitido, o caso é analisado em seu mérito, seguido de uma fase de reparação" (RIBEIRO, 2013, pp.40-41). A Corte possui, em qualquer uma dessas fases, a discricionariedade de convocar audiências públicas para poder colher o testemunho das vítimas. Caso o Estado seja condenado, a $\mathrm{CrDH}$ publica uma resolução vinculante, uma sentença, indicando as violações de direitos humanos encontradas e ordenando as medidas de reparação (CAVALLARO; BREWER, 2008a, p. 781). Nota-se que todas as decisões da $\mathrm{CrDH}$ são adotadas por meio do seu Plenário.

\section{Cumprimento das medidas do Sistema Interamericano de Direitos Humanos}

As medidas proferidas pela $\mathrm{CmDH}$ e pela $\mathrm{CrDH}$ são consideradas como cumpridas no momento em que as suas resoluções são executadas e implementadas em sua totalidade pelo Estado. A $\mathrm{CmDH}$ e a $\mathrm{CrDH}$ tem como prática determinar ao final de todas as suas sentenças que dará por concluído o caso "uma vez que o Estado tenha dado cabal cumprimento ao disposto na mesma" (CrDH, 2010, p.115). Uma vez que as resoluções são dadas como totalmente cumpridas, a Comissão é responsável por emitir resolução que dê como encerrado o processo ou se o caso já tiver sido encaminhado à Corte, esta responsabilidade fica sob sua égide, segundo o artigo 31 de seu Regulamento (2009). 
"[O] cumprimento das sentenças proferidas pela Corte IDH se depara com um desafio atrelado à própria natureza do direito internacional: a falta de poder coercitivo das normas internacionais" (FRANCO, 2014, p.75). Para poder modificar esse quadro, a $\mathrm{CrDH}$ possui mecanismos que buscam compelir os Estados sob sua jurisdição a cumprir suas resoluções em seus âmbitos internos. Os seus mecanismos são: (1) supervisão do cumprimento de sentenças: pedido para as partes para a elaboração de relatório anual sobre o cumprimento da sentença e sua publicação; (2) pressão política: caracterizada pela outorga de medidas de acompanhamento da decisão e reiteração do pedido de apresentação de relatórios; e (3) relatório anual: apresentado à Assembleia Geral da OEA com a análise do avanço do cumprimento da sentença pelo Estado.

A supervisão do cumprimento de sentenças por parte da Corte Interamericana
de Direitos Humanos [...] é inerente ao exercício de sua função jurisdicional, e
encontra seu fundamento normativo nos artigos 33, 62.1, 62.3 e 65 da
Convenção Americana sobre Direitos Humanos, além do artigo 30 do Estatuto
da própria Corte. Já o seu procedimento vem estabelecido no artigo 69 do
Regulamento da Corte, e por esta via objetiva-se monitorar o cumprimento das
sentenças mediante a apresentação de relatórios por parte dos Estados
condenados, e das correspondentes observações a esses relatórios, elaboradas
por parte dos representantes das vítimas, em atenção ao relatório veiculado por
parte do Estado, e da Comissão Interamericana, que nesse caso, apresentará
observações tanto quanto ao relatório do Estado como às observações tecidas
pelas vítimas ou seus representantes (FRANCO, 2014, p.76).

No artigo 69 do Regulamento da $\mathrm{CrDH}$ se estabelece ainda que os relatórios de supervisão do cumprimento de sentenças devem ser publicados a fim de declarar o cumprimento, mesmo que parcial, das resoluções outorgadas na sentença.

Nota-se que a Comissão também possui a competência de emitir relatórios de supervisão do cumprimento de suas recomendações. Como explicado, o Estado litigante deve de boa-fé cooperar com o envio dos relatórios de cumprimento de recomendações. Contudo, devido ao caráter não vinculante de suas recomendações a compliance com essas se torna mais difícil. Um dos mecanismos da $\mathrm{CmDH}$ que busca compelir os Estados sob sua jurisdição a cumprir suas recomendações e, portanto, implementá-las em âmbito interno é a sua discricionariedade de poder enviar o caso para Corte, caso ache necessário para o pleno cumprimento de suas recomendações.

Nesse sentido, os relatórios "funcionam como verdadeiro instrumento processual de ação, e seu objetivo não é outro senão conduzir o Estado ao status de cumprimento de suas decisões, ou seja, ao cumprimento das medidas prolatadas pelo tribunal internacional" (FRANCO, 2014, pp.76-77). Logo, conclui-se que a supervisão do cumprimento das sentenças é importante elemento da jurisdição da $\mathrm{CrDH}$ para compelir os Estados a cumprir suas determinações, perfazendo uma verdadeira estratégia jurídica frente à falta de meios de coerção para a implementação de suas decisões. 
As diferentes definições e concepções de state compliance, assim como as principais teorias que abarcam a questão do processo decisório de internalização de normas jurídicas internacionais, serão vistas na próxima seção.

\subsection{State Compliance}

O problema fundamental que surge no campo dos direitos humanos não é mais declarar ou justificar a sua existência, uma vez que uma agenda internacional de promoção e defesa de direitos humanos já foi consolidada. O desafio, atualmente, consiste em transpor discussões acadêmicas sobre o assunto e torna-las efetivas, a fim de desenvolver maneiras de proteger, assegurar e prevenir que violações aconteçam (BOBBIO, 2004; TRINDADE, 2002). Nessa perspectiva, o impacto do Direito Internacional e o efeito de normas jurídicas internacionais sob o comportamento estatal é analisada pela academia a partir do conceito de compliance.

“Originário do verbo em inglês to comply, compliance expressa o agir de acordo com determinada normativa, daí normalmente ser definido como o estado de conformidade ou identidade entre o comportamento de um ator e uma regra específica" (FRANCO, 2014, p.69). Neste trabalho, o conceito será usado com o significado de adimplemento de medidas, implementação, cumprimento, e diz respeito aos esforços dos diferentes atores para que as determinações dos instrumentos do SIDH fossem consideradas cumpridas pelos próprios requisitos do SIDH.

A origem de estudos sobre o tema data do período do pós-guerra fria, em que compliance era apenas estudado com o objetivo de demonstrar a importância do Direito Internacional (FALK, 1968; HENKIN, 1979). No período, a maioria das pesquisas era advinda do eixo euro-atlântico. Os anos 80 e 90 foram marcados pelo desenvolvimento de estudos teóricos sobre o tema (ABBOT, 1989; SLAUGHTER, 1993; RAUSTIALA; SLAUGHTER, 2002). Recentemente, desde o ano 2000, pesquisadores sobre o tema têm direcionado suas pesquisas para estudos empíricos (MCCLENDON, 2009; HILLEBRECHT, 2009a; PAULSON, 2004; WRIGHT-SMITH, 2009).

\section{Compliance e a efetividade de regras jurídicas internacionais}

É importante fazer distinção entre state compliance e efetividade de regras jurídicas internacionais. Para Kal Raustiala (2000), compliance é a conformidade entre 
um comportamento e um padrão jurídico esperado. $O$ cumprimento de regras internacionais pode ser o resultado da existência da própria regra e de mecanismos cogentes ou apenas simplesmente coincidência. Dizer que um ator cumpre uma normativa jurídica internacional não significa que tal regra tenha gerado determinado comportamento. Efetividade de uma Corte Internacional, ao contrário, é o grau em que uma regra jurídica internacional induz a mudança desejada no comportamento. Logo, regras jurídicas internacionais podem ser efetivas até mesmo quando o grau de compliance é baixa (ao induzir uma mudança comportamental em alguns atores e não em outros) e terem um alto grau de compliance mesmo não sendo efetivas (porque foram criadas com bases em regras costumeiras pré-existentes) (RAUSTIALA, 2000, p.388).

Embora conceitualmente muito útil, essa distinção coloca enormes demandas por dados aos pesquisadores, quando, no curso normal dos acontecimentos, eles tentam distinguir casos de compliance de os de efetividade. Há, no entanto, um conjunto de circunstâncias em que, sem hipóteses muito exigentes, podemos obter uma classe de casos em que é possível eliminar a categoria de comportamentos pré-existentes e, assim, tratar compliance e efetividade como equivalentes. Essa classe de casos é formada pelas decisões de Cortes Internacionais contra Estados por violar as suas obrigações acordadas em tratados.

A pergunta principal dos estudos que concernem o tema de compliance é: Por que Estados cumprem (comply) normas jurídicas internacionais? Respostas podem ser dividas em três grandes abordagens: 1) international enforcement; 2) gestão; e 3) política doméstica.

\section{Primeira abordagem: International Enforcement}

International enforcement se refere à imposição de sanções ou recompensas, tanto materiais como sociais, embora os autores que se concentram nessa linha de pensamento tendam a enfatizar e priorizar o uso de sanções (SIMMONS 2000; CORTRIGHT; LOPEZ 2002; KELLEY 2004; VACHUDOVA 2005). Em uma obra influente, Beth Simmons (2000) sugere que os Estados tendem a respeitar os compromissos internacionais a fim de manter sua boa reputação internacional de um comportamento previsível e de cumpridores de normas.

Estados que gozam de tal reputação tendem a serem recompensados por meio de mecanismos, como o aumento do investimento externo direto, enquanto Estados que não 
possuem tal reputação tendem a serem punidos de forma oposta. No artigo de Simmons (2000), estas punições e recompensas não são explicitamente ligadas ao cumprimento de normas jurídicas internacionais por um Estado, mas poderiam ser. $\mathrm{Na}$ área dos direitos humanos, Emilie Hafner-Burton (2005) argumenta que os acordos internacionais de direitos humanos são mais eficazes quando os Estados relacionam o cumprimento de normas com incentivos materiais específicos, como a integração comercial. Muitos autores com foco em enforcement tendem a combinar a utilização desse mecanismo com aqueles que focam em gestão (TALLBERG, 2002) ou em política interna (SCHIMMELFENNIG, 2005; KELLEY, 2004) e, portanto, são analisados mais detalhadamente abaixo.

Vale a pena notar que mesmo que os próprios tribunais internacionais geralmente não possuam meios de coerção para o cumprimento de suas decisões, Estados ou atores privados podem premiar ou penalizar Estados pelos seus comportamentos. Isto inclui estar em consonância com as decisões de Cortes Internacionais.

\section{Segunda abordagem: Gestão}

Outra abordagem, associada aos escritos de Abram Chayes e Antonia Chayes (1993, 1995), enfatiza as maneiras pelas quais a gestão influencia o cumprimento de decisões internacionais. Problemas de gestão dizem respeito à natureza das normas internacionais e a capacidade estatal em cumpri-las. Logo, vão além dos interesses, recompensas e sanções relacionadas ao seu cumprimento, atuando sobre a própria capacidade estatal em cumprir as sentenças de Cortes Internacionais.

Em alguns casos em que o descumprimento aparece de forma generalizada, um exame mais atento pode mostrar que normas jurídicas internacionais podem ser bastante ambíguas, o que torna difícil para os Estados cumprir uma determinada interpretação dessas normas. Outro problema relacionado à gestão ocorre quando há a falta de especialização técnica ou capacidade econômica para implementar resoluções internacionais.

Por fim, o descumprimento pode ser simplesmente uma questão de tempo: muitas decisões jurídicas internacionais são muito difíceis de serem implementadas e exigem uma quantidade razoável de tempo. Chayes e Chayes (1993) explicitamente identificam tratados de direitos humanos nesta categoria. 
Ao aplicar a abordagem gerencial às Cortes Internacionais, Laurence Helfer e Anne-Marie Slaughter (1997) e Robert Keohane, Andrew Moravcsik e Anne-Marie Slaughter (2000) argumentaram que o desenho institucional dos tribunais influencia o grau de cumprimento de suas resoluções. Helfer e Slaughter (1997), por sua vez, sugerem que instituições jurídicas internacionais são efetivas quando são relativamente independentes (livres de interferência estatal), têm uma autoridade legal obrigatória e envolvem-se em processos e fundamentações jurídicas de alta qualidade.

Keohane, Moravcsik e Slaughter (2000) afirmam que Cortes Internacionais podem variar ao longo de uma importante dimensão transnacional-internacional. Segundo esses autores, três fatores compreendem a dimensão transnacional-internacional de uma Corte Internacional: 1) a independência do tribunal de pressões do Estado; 2) grau de acesso de indivíduos e ONGs ao tribunal, e 3) grau de vinculação dos tribunais nacionais aos tribunais internacionais. Níveis mais elevados dessas características significam que o tribunal tem níveis mais altos de transnacionalismo. Os autores esperam que o cumprimento seja positivamente relacionado com o transnacionalismo.

Eric Posner e John Yoo (2005), ao contrário, são profundamente céticos quanto aos tribunais independentes serem bons gestores. Os autores argumentam que os tribunais independentes são mais propensos a emitir mais decisões altamente controversas em que o Estado é menos propenso a cumprir:

Tribunals composed of dependent members have a strong incentive to serve the
joint interests of the disputing states. Tribunals composed of independent
members have a weaker incentive to serve those states' interests and are more
likely to allow moral ideals, ideological imperatives, or the interests of other
states to influence their judgments (POSNER; YOO, 2005, p.27).

Uma debilidade nesse argumento é que Posner e Yoo (2005) não conseguem explicar, contudo, por que juízes independentes estariam propensos a emitir decisões que os Estados possam ignorar. Segundo o argumento de Posner e Yoo (2005), parece razoável supor que os juízes tentarão impor suas próprias opiniões sobre os Estados, sem considerar se os Estados estão propensos a ouvir as suas opiniões. Entretanto, muitas evidências da Corte Europeia de Direitos Humanos (CEDH) sugerem o contrário: que o Tribunal está bastante preocupado com a inclinação e capacidade de cumprir decisões judiciais dos Estados e agora está dedicando recursos significativos para ajudar Estados especialmente Itália e Turquia - a superarem velhos obstáculos para o cumprimento de suas sentenças (HAWKINS; JACOBY, 2008) 
Terceira abordagem: Política Doméstica

Uma terceira abordagem para compliance se concentra mais diretamente na política doméstica dos Estados. Para alguns autores, compliance é relacionada ao cálculo de custos e benefícios da mudança da política governamental. Onde as mudanças de políticas são relativamente difíceis, o grau de cumprimento de normas jurídicas internacionais é provavelmente baixo (DOWNS; ROCKE; BARSOOM 1996).

De um modo semelhante, compliance pode ser o resultado de fatores domésticos que são difíceis de serem observados, como vontade política (VON STEIN, 2005). Na visão desses autores, o cumprimento de normas jurídicas internacionais é provável que seja o resultado de fatores domésticos pré-existentes que levaram Estados a se comprometerem com normas internacionais em primeiro lugar. Assim, a compliance não é apenas o resultado de normas jurídicas internacionais, mas sim do fato de que Estados que queiram se comportar de uma maneira particular são mais susceptíveis a criar e aceitar regras jurídicas internacionais que codificam esse comportamento.

No contexto brasileiro, essa abordagem é exemplificada pela pesquisa de Oscar Vilhena Vieira (2013) que busca esclarecer as razões pelas quais "o sistema político brasileiro não foi capaz de conceber um mecanismo sólido e eficiente para a implementação das decisões do Sistema Interamericana de Direitos Humanos" (VIEIRA ET AL, 2013, p.6).

Segundo o autor, existem três situações que afetam a compliance do Estado brasileiro para com os instrumentos do SIDH. Elas são: (i) a existência de uma agenda de política pública em andamento ao tempo da decisão; (ii) a dependência do governo de poderes autônomos, como governos locais, Ministério Público e Judiciário, para implementar as políticas públicas necessárias para a compliance do Estado com os instrumentos do SIDH; e (iii) violações de direitos humanos engendradas como consequência de políticas do Estado. Em sua pesquisa, Vieira (2013) afirma que a variável existência de uma agenda pública em andamento ao tempo da decisão afeta positivamente o grau de compliance pelo Brasil e as outras duas a afetam de maneira negativa. Essas hipóteses serão testadas no capítulo quatro desta dissertação.

No contexto europeu, Gerda Falkner e Oliver Treib (2008) sugerem a importância de uma cultura de conformidade interna. Os Estados membros da União Europeia (UE) poderiam ser divididos em quatro grupos: 1) um mundo de observância e cumprimento às leis, onde as culturas de compliance são sólidas e o cumprimento de normas jurídicas 
internacionais é quase sempre rápido e real. Este mundo seria composto por Dinamarca, Finlândia e Suécia; 2) um mundo da política interna, em que há uma inclinação para cumprir, mas apenas em casos onde os custos internos não são muito elevados. Este é o padrão modal na antiga UE-15, exemplificado pela Alemanha, Áustria, Bélgica, Alemanha, Holanda, Espanha e Reino Unido; 3) um mundo de transposição de negligências, no qual os Estados são muito lentos em tomar a tarefa de transposição de diretivas da UE para o direito nacional, exemplificadas pela França, Grécia, Luxemburgo e Portugal; 4) um world of dead letters no qual os Estados são rápidos para aprovar as leis, mas depois não as implementam na prática - todos os novos Estados-membros pós2004, bem como Itália e Irlanda.

Uma abordagem mais dinâmica e centrada no papel do ator sugere que a compliance é mais provável quando atores domésticos que favorecem o cumprimento de normas jurídicas internacionais ganham maior influência no governo. Keohane, Moravcsik e Slaughter (2000) se movem nessa direção com o seu conceito de embeddedness, ou a natureza das relações entre os tribunais internacionais e sistemas judiciais domésticos. Para os autores, normas jurídicas de Tribunais internacionais que são incorporados internamente criam vários links entre atores domésticos que favorecem o respeito ao Estado de Direito. Analogamente, o trabalho recente sobre reformas de políticas transnacionais baseia-se em abordagens de coalizão, em que funcionários de organismos internacionais tentam fornecer uma base duradoura para reformas ao trabalhar em estreita colaboração com os atores nacionais para pender a balança a favor do respeito dos direitos humanos em árduos debates de reforma interna (JACOBY 2006; SCHIMMELFENNIG 2005; KELLEY 2004; ORENSTEIN; BLOOM; LINDSTROM 2008).

A literatura recente sobre compliance com normas de direitos humanos também enfatiza essa abordagem nacional orientada para o papel do indivíduo como ator. Alguns estudos mostram que recentemente a compliance com os tratados de direitos humanos é maior em países com sociedades civis mais robustas, embora haja dúvidas sobre como medir a capacidade da sociedade civil. Além disso, o grau de causalidade entre essas duas variáveis permanece difícil de ser medido (LANDMAN 2005; NEUMAYER 2005). 
Compliance e a socialização de regras jurídicas internacionais

Expectativas sobre o grau de cumprimento (state compliance) de regras jurídicas internacionais ${ }^{14}$, dentre elas as normativas de Cortes Internacionais, relacionadas aos direitos humanos pelos Estados variam enormemente, mas tendem a focar em dois opostos: ou se espera um alto ou um baixo grau de cumprimento. Juristas como Louis Henkin (1979) e Abram Chayes e Antonia Chayes (1993) sugerem que a maioria dos Estados obedece à maioria das normas jurídicas internacionais na maioria das vezes.

Na mesma linha, alguns cientistas políticos sugerem que quando há a socialização de regras jurídicas internacionais por meio de instituições o resultado é um maior cumprimento por parte dos Estados dessas regras ou até mesmo transformações nos próprios interesses dos Estados para fazê-las cumprir (CHECKEL, 2005). Em contraste, outros autores sugerem que instituições internacionais apenas refletem interesses e preferências pré-existentes dos Estados e por isso não representam uma variável importante no processo de state compliance, uma vez que o cumprimento de qualquer norma jurídica internacional é o resultado da criação de regras de fácil cumprimento pelos Estados ou de regras costumeiras já existentes (DOWNS; ROCKE; BARSOON, 1996). Igualmente, outros acreditam em grandes lacunas entre a criação de normativas jurídicas internacionais e o seu cumprimento pelos Estados, especialmente em áreas idealistas do Direito Internacional como os direitos humanos, sendo insignificante o efeito independente de instituições internacionais sob este processo (HAFNER-BURTON; TSUTSUI 2005).

À primeira vista, Estados têm uma grande variedade de ferramentas que podem ser usadas para o cumprimento das resoluções de Cortes Internacionais, assim como para o seu cumprimento parcial. Alguns destes mecanismos são intuitivos: Estados-membros podem ratificar um tratado, mas depois não aprovar em seus congressos nacionais a

\footnotetext{
${ }^{14}$ Uma das características principais das regras legais é que, tanto a parte que as cria e aquela para qual elas foram criadas, as enxerguem como lei. Este argumento tautológico, uma regra legal é considerada uma regra legal porque ela é vista como uma regra legal é uma de suas características mais importantes. Os agentes acreditam que uma regra legal possui uma característica normativa fundamentalmente diferente de uma regra moral, que a primeira é legalmente obrigatória (AREND, 1999). Como argumenta o professor D'Amato (1971) "there must be a characterization of 'legality' [...] an explicit characterization enables states to distinguish legal actions from social habit, courtesy, comity, moral requirements, political expediency, plain 'usage' or other norm" (D'AMATO, 1971, p.76). Pode-se definir, segundo Anthony Arend (1999), que as regras legais são compostas de cinco características fundamentais: 1) são obrigatórias; 2) são produzidas por um processo político; 3) são mandatórias por meio de um processo político; 4) sua aplicação é de responsabilidade de uma autoridade política; e 5) ambos os agentes que criam as regras legais como aqueles para os quais elas foram criadas devem percebê-la como uma regra legal.
} 
legislação pertinente para a implementação das medidas oriundas de Cortes Internacionais; podem aprovar legislação que implementa parte do tratado, mas não o todo; podem implementar a legislação, porém não implementar uma legislação complementar que, por exemplo, financie agências que monitorem e promovam o cumprimento de tais resoluções; Estados-membros podem falhar em fazer cumprir (enforcement) a legislação ou falhar em treinar atores domésticos-chave para que a legislação seja aplicada de fato.

Enquanto alguns estudiosos estão bem cientes da onipresença desses mecanismos e estágios intermediários do cumprimento de normas jurídicas internacionais, muitos escrevem como se o cumprimento parcial das resoluções de Cortes Internacionais fossem estações no caminho para o pleno cumprimento destas (RISSE; SIKKINK, 1977). Muitas vezes, os estudiosos sugerem que a socialização de regras jurídicas internacionais é uma experiência bastante transformadora, no sentido que ao mesmo tempo em que foi criada por Estados para um determinado fim ainda assim conseguem moldar e mudar os interesses iniciais destes, levando os Estados a uma convergência de interesses (BEARCE; BONDANELLA, 2007).

Quando um Estado persiste em um comportamento tempo suficiente para que uma Corte Internacional possa julgar as práticas do país e subsequentemente o Estado mude suas práticas, pode ser assumido que as decisões judiciais da Corte ajudaram a desencadear a mudança de comportamento. Do mesmo modo, quando uma Corte exige um padrão específico de comportamento, como, por exemplo, o pagamento de reparações econômicas monetárias a um indivíduo particular, e o Estado o cumpre, é possível assumir que a decisão da Corte tenha influenciado essa mudança.

Devido ao fato de que processos judiciais internacionais levam muitos anos para serem finalizados e custam aos Estados uma grande quantia de dinheiro e de tempo, é razoável assumir que o Estado prefere persistir no comportamento sendo julgado na Corte. Desprende-se, assim, que todas as mudanças comportamentais resultantes de uma decisão desfavorável no tribunal para o país sugerem que há uma efetividade das regras jurídicas internacionais em questão e cria uma classe de casos em que podemos razoavelmente tratar de compliance e efetividade como a mesma coisa. Ao se fazer esta suposição explícita, não acredito que esta seja terrivelmente controversa. Alguns autores, como Eric Posner e John Yoo (2005), estudam o cumprimento de resoluções de Cortes internacionais e também tratam compliance como parâmetro de efetividade. 
Compliance e tipos de regimes

Outro fator importante que afeta o grau de compliance dos Estados é o tipo de regime a que estes estão expostos. Estudos quantitativos recentes (SIMMONS, 2009; SIMMONS, 2013) demonstram que Estados com regimes democráticos estão mais propensos a cumprir normas jurídicas internacionais ligadas aos direitos humanos que Estados com regimes autoritários (RISSE ET BÖRZEL, 2012, p.7). Nesses casos, há uma série de mecanismos sociais capazes de induzir o cumprimento das normas jurídicas ${ }^{15}$ (RISSE; ROPP; SIKKINK, 1999; BÖRZEL ET AL, 2010; HURD, 1999; CHECKEL, 2001; TALLBERG, 2002; SIMMONS, 2009). No entanto, em áreas de limited statehood $^{16}$, devido à falta de capacidade dos governos de fazer cumprir tais normas, esses mecanismos podem não funcionar. Assim, a falta de estruturas administrativas e instituições capazes de internalizar e implementar normas jurídicas internacionais se tornam fator importante para o grau de compliance dos Estados e deve ser tratada como uma variável ao invés de uma constante (ROTBERG, 2003; ROTBERG, 2004; SCHNECKENER, 2004).

Compliance: uma variável contínua

Esta é uma literatura grande e complexa, mas mesmo assim falta uma conceituação clara da variável dependente principal, a natureza do cumprimento. Compliance é muitas vezes tratada como um termo bastante dicotômico, mas quero conceituá-lo de forma mais explícita como uma variável contínua neste trabalho, explorando o meio termo do cumprimento parcial. Como as várias teorias deixam claro, uma variedade de mecanismos pressiona os Estados para o cumprimento de decisões

\footnotetext{
${ }^{15}$ Alguns mecanismos sociais capazes de induzir o cumprimento de normas jurídicas internacionais são: 1) coerção; 2) incentivos; 3) sanções; 4) recompensas; 5) persuasão; 6) discurso; e 7) desenvolvimento de capacidades internas. Cada um destes mecanismos é relacionado à uma das três principais abordagens ligadas à compliance, como veremos posteriormente (RISSE ET BÖRZEL, 2012).

16 "In short, while areas of limited statehood belong to internationally recognized states (even Somalia still commands international sovereignty), it is their domestic sovereignty which is severely circumscribed. In other words, areas of limited statehood concern those parts of a country in which central authorities (governments) lack the ability to implement and enforce rules and decisions and/or in which the legitimate monopoly over the means of violence is lacking, at least temporarily. Areas of limited statehood can be parts of the territory (e.g. provinces far away from the national capital), but they can also be policy areas (e.g. the inability to implement and enforce environmental laws). In this understanding, areas of limited statehood are not confined to fragile, failing, or failed states the latter having completely lost their domestic sovereignty. Rather, this conceptualization implies that even otherwise fully consolidated states might contain areas of limited statehood in which they do not enjoy domestic sovereignty, at least temporarily (New Orleans shortly after the hurricane Kathrina being an example)" (RISSE, 2010, p.5).
} 
jurídicas internacionais. Dadas estas influências concorrentes, parece improvável que Estados vão acabar em ambas as extremidades de um espectro da compliance (não cumpriu, cumpriu totalmente). Nesse marco, Oona Hathaway afirma que "compliance is not an on-off switch; it is an elastic concept that allows for different gradations" (HATHAWAY, 2002, p.1964)

Portanto, para fins metodológicos, utilizarei neste trabalho três níveis diferentes para a compliance com decisões jurídicas internacionais. São eles: (1) não cumpriu; (2) parcialmente cumprido; e (3) totalmente cumprido.

Utilizando a terceira abordagem que se centra na política doméstica dos Estados e nos fatores internos pré-existentes que levam os Estados a se comportarem de acordo com normas internacionais, munidos de dados coletados, consolidados e sistematizados sobre a inserção do Brasil no SIDH e a partir da identificação do processo decisório do Estado brasileiro junto ao SIDH, testar-se-á, no capítulo quatro, as hipóteses de Vieira (2013) de que:

i) A existência de uma agenda de política pública o Estado em andamento ao tempo da decisão afeta positivamente o grau de compliance do Estado brasileiro no SIDH;

ii) A dependência do governo de poderes autônomos, como governos locais, Ministério Público e Judiciário, para implementar as políticas públicas necessárias para o cumprimento dos instrumentos do SIDH afeta negativamente o grau de compliance do Estado brasileiro no SIDH; e

iii) Violações de direitos humanos engendradas como consequência de políticas públicas do Estado afetam negativamente o grau de compliance do Estado brasileiro no SIDH.

\section{Conclusão}

Segundo Claudio Grossman (1998, p.187), no ensejo de criação do Sistema Interamericano de Direitos Humanos, os seus principais desafios a serem enfrentados nos anos vindouros foram expandir direitos e liberdades dos indivíduos e evitar regressões aos autoritarismos vividos na região. Por isso, a CADH é um instrumento amplo de direito internacional que protege 26 direitos substantivos, incluindo direitos civis, políticos, econômicos, sociais e culturais (PASQUALUCCI, 1994/1995, p. 305). Todos 
os Estados que ratificam a Convenção, assumem a obrigação de cumprir as sentenças em qualquer caso que sejam parte (BUERGENTHAL, 1982, p. 240).

Os tratados de direitos humanos consagram, principalmente, direitos para as pessoas e obrigações para os Estados, todos os quais tem validez no âmbito internacional e podem ser protegidos e supervisionados no mesmo âmbito por meio de normas jurídicas internacionais e pela existência de uma consciência jurídica universal, materializada no próprio direito internacional. Eles respondem à ideia de que a comunidade internacional entendera a transcendência que importa para a paz e para a segurança de todos o estabelecimento de uma ordem mundial que tenha como um eixo central a ideia de que todos os seres humanos são iguais em dignidade e direitos.

Uma ordem internacional de proteção dos direitos humanos, sem embargo, pretende como fim último o fortalecimento dos direitos no âmbito nacional, em seu ordenamento jurídico e em suas práticas. Este é o objetivo principal do Sistema Interamericano de Direitos Humanos.

A partir desse último ponto de vista, é importante que os Estados conheçam com exatidão o alcance de suas obrigações nesta matéria, a sua inserção dentro do Sistema Interamericano de Direitos Humanos e como estes cumprem com as suas medidas. O próximo capítulo deste trabalho trata sobre essas três questões e explicita a inserção do Brasil no Sistema Interamericano de Direitos Humanos, o que implica diretamente sobre o seu processo de tomada de decisão relacionado ao cumprimento de normas jurídicas internacionais. 


\section{Capítulo 2: A inserção do Brasil no Sistema Interamericano de Direitos} Humanos: características das petições, casos, medidas de urgência e processo decisório

"O atraso do Brasil em entrar no SIDH e o desrespeito às normas procedimentais do Sistema até hoje dificultam o engajamento eficaz do país no SIDH” (CAVALLARO, 2002, p. 485). Foi apenas após o início da sua redemocratização em 1985 que o Estado brasileiro começou a ratificar os principais instrumentos de direitos humanos ${ }^{17}$, sendo a Constituição de 1988 um marco do reconhecimento da importância desses direitos e da dignidade humana.

Em 3 de dezembro de 1992, o Estado brasileiro ratifica a Convenção Americana pelo Decreto no 678/1992 que determina que a CADH seja integralmente cumprida pelo Brasil. Contudo, o Brasil manifesta o aceite da cláusula facultativa da competência contenciosa da Corte apenas em 1998, sendo a declaração de aceite da competência do tribunal promulgada apenas no dia 8 de novembro de 2002, pelo Decreto Executivo $4.463 / 2002^{18}$.

Conhecer melhor a prática estatal brasileira no Sistema Interamericano de Direitos Humanos, os procedimentos e medidas contra o Brasil se torna vital para que tanto o Estado como peticionários e litigantes possam melhor atuar para a defesa e promoção dos direitos humanos no País. O objetivo deste capítulo é analisar quais são as características e tramitação, assim como os graus de compliance do Estado brasileiro para com as medidas do SIDH em que foram proferidas recomendações e sentenças ou foram base de acordos de solução amistosa. Munidos desses dados, será possível analisar quais características e como essas afetam o processo decisório brasileiro de implementação das

\footnotetext{
17 "Desde a promulgação da CF/88, o Brasil ratificou os principais tratados de direitos humanos. Alguns deles são: a Convenção Interamericana para Prevenir e Punir a Tortura (20 de julho de 1989); Convenção Contra a Tortura e Outros Tratamentos Cruéis, Desumanos e Degradantes (28 de setembro de 1989); Convenção sobre os Direitos das Crianças (24 de setembro de 1990); Pacto Internacional sobre os Direitos Civis e Políticos (24 de janeiro de 1992); Pacto Internacional sobre os Direitos Econômicos, Sociais e Culturais (24 de janeiro de 1992); Convenção Americana de Direitos Humanos (25 de setembro de 1992); Convenção Interamericana para Prevenir, Punir e Erradicar a Violência contra as Mulheres (27 de novembro de 1995); Protocolo à Convenção Americana relativo à Abolição da Pena de Morte (13 de agosto de 1996); Protocolo à Convenção Americana na área de Direitos Econômicos, Sociais e Culturais Protocolo de San Salvador (21 de agosto de 1996); Estatuto de Roma do Tribunal Penal Internacional (20 de junho de 2002); Protocolo Opcional à Convenção sobre a Eliminação de Todas as Formas de Discriminação contra as Mulheres (28 de junho de 2002); Protocolo Opcional à Convenção sobre os Direitos da Criança sobre o Envolvimento de Crianças em Conflitos Armados (27 de janeiro de 2004); e o Protocolo Opcional à Convenção sobre os Direitos das Crianças sobre a Venda de Crianças, Prostituição Infantil e Pornografia Infantil (27 de janeiro de 2004)" (RIBEIRO, 2013, p.47)

${ }^{18}$ Lembra-se que apenas "Estados que, além de serem Partes na Convenção, aceitaram expressamente a competência jurisdicional da Corte podem ser nela acionados" (FRANCO, 2014, p.83)
} 
medidas proferidas pelo SIDH, assim como a extensão da adesão do Brasil às regras procedimentais do SIDH.

Primeiramente, buscar-se-á clarificar qual a inserção do Estado brasileiro no Sistema Interamericano de Direitos Humanos em comparação com os outros países da região. Em seguida, será apresentado o tratamento dos dados empíricos coletados e as principais características dos procedimentos e medidas contra o Brasil assim como tramitação no SIDH. Por fim, serão analisados os diferentes graus de compliance do Estado brasileiro para com as medidas proferidas pelo Sistema Interamericano de Direitos Humanos contra o Brasil para que seja possível observar as principais variáveis que afetam o total cumprimento das medidas pelo País.

\subsection{O Brasil e o Sistema Interamericano de Direitos Humanos}

Até novembro de 2015, dos 35 países do continente americano, apenas dez nunca ratificaram a $\mathrm{CADH}$ e 21 reconheceram a competência jurisdicional da $\mathrm{CrDH}^{19}$. Os Estados que são parte de todos os principais instrumentos do SIDH são apenas 11. São eles: Argentina, Brasil, Chile, Costa Rica, Equador, Honduras, México, Nicarágua, Panamá, Paraguai e Uruguai. A Argentina, por exemplo, "é um dos países que mais utiliza o SIDH, revelando o amplo conhecimento de advogados e organizações da sociedade civil sobre o funcionamento dessa plataforma" (BORGES, 2008, p. 133).

A figura 1, abaixo, mostra o número de petições enviadas ao SIDH por país nos últimos 14 anos, entre 1999 e 2014. Os dez Estados mais demandados são em ordem decrescentes: 1) Argentina (5.833); 2) México (3.673); 3) Peru (3.499); 4) Colômbia (3.065); 5) Chile (1.163); 6) Estados Unidos da América $(1.140)^{20}$; 7) Brasil (985); 8) Equador (963); 9) Costa Rica (942); e 10) Venezuela (662).

\footnotetext{
${ }^{19}$ Os Estados que reconhecem a competência jurisdicional da CrDH são: Argentina, Barbados, Bolívia, Brasil, Chile, Colômbia, Costa Rica, El Salvador, Equador, Guatemala, Haiti, Honduras, México, Nicarágua, Panamá, Paraguai, Peru, República Dominicana, Suriname, Trinidad e Tobago e Uruguai. Disponível em: http://www.cidh.oas.org/basicos/portugues/d.Convencao_Americana_Ratif..htm. Acesso em: 07 nov. 2015 20 "[O]s Estados Unidos assinaram apenas a Declaração Americana dos Direitos e Deveres do Homem, de 1948. O país não é parte na Convenção Americana sobre Direitos Humanos, de 1969, que oferece o marco jurídico para o funcionamento da CIDH, e não reconhecem a jurisdição da Corte Interamericana. A partir de 1971, a CIDH passou a receber petições individuais contra os Estados Unidos e a emitir recomendações a esse país, com base na Carta da OEA, dado que esse instrumento incorporou a Declaração Americana dos Direitos e Deveres do Homem e instituiu a CIDH" (MACIEL, 2003, p.274-275).
} 
Figura 1: Número de petições por país enviadas ao SIDH entre 1999 e 2014

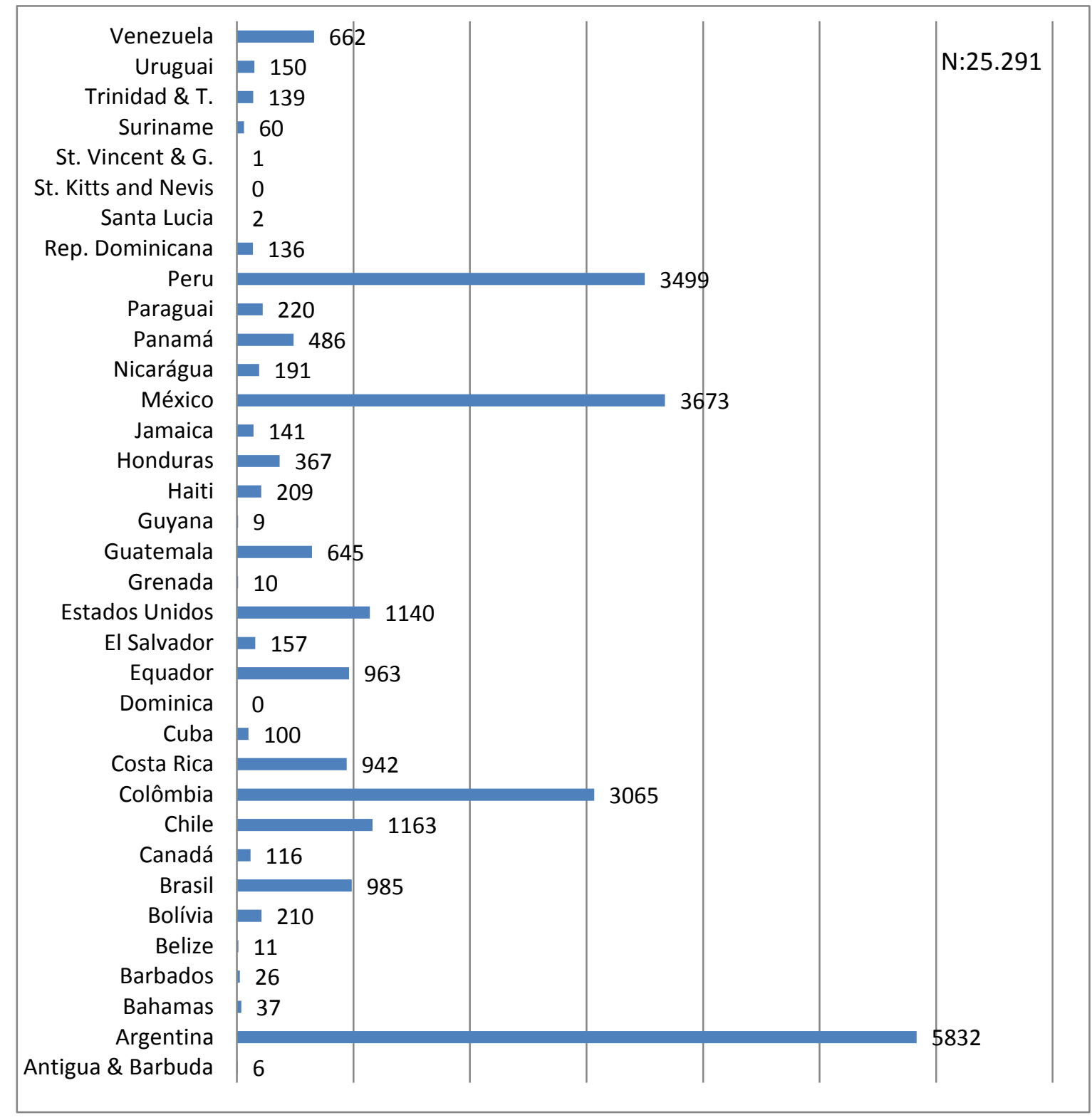

Fonte: Elaboração própria. Dados da CmDH (disponível em: http://www.oas.org/pt/cidh/ Acesso em: 07 nov. 2015).

Lembra-se que nem todas as petições que chegam à SIDH são aceitas para a abertura do trâmite no Sistema, assim como nem todas as aceitas têm sua admissibilidade confirmada pela Comissão.

“Antes de 1994, o Brasil só tinha dois casos na CIDH” (CAVALLARO, 2002, p. 483). Nesse mesmo ano, a CmDH abriu sete casos contra o Estado brasileiro. Já de 1995 em diante, a $\mathrm{CmDH}$ abriu cada vez mais casos contra o Estado brasileiro. Para Nadine Borges (2008), "o aumento das denúncias se deveu à visita da CIDH ao Brasil em 1995" (BORGES, 2008, p. 133). Contudo, "somente em 1996 é retomada, com mais frequência, 
a utilização de denúncias à Comissão Interamericana" (BORGES, 2008, p. 146) por organizações da sociedade civil.

Entre 1999 e 2014, das 985 petições recebidas contra o Estado brasileiro apenas 139 tiveram seu trâmite iniciado. Destas, apenas 63 foram consideradas admitidas e tornaram-se casos do SIDH. Dos 63 casos admitidos contra o Estado brasileiro no SIDH, apenas 16 tiveram seus relatórios de fundo ${ }^{21}$ apresentados pela Comissão. Destes 16 casos em que a Comissão proferiu recomendações, sete (7) foram encaminhados à Corte Interamericana de Direitos Humanos. $\mathrm{Na} \mathrm{CrDH}$, um (1) caso foi arquivado, quatro (4) foram julgados e estão em fase de cumprimento de resoluções e dois (2) se encontram no início do procedimento escrito no Tribunal. ${ }^{22}$ "Um número menor que muitos outros Estados da América Latina inferiores em tamanho e proporção" (CAVALLARO, 2002, p. 484-485).

Figura 2: Petições contra o Brasil no SIDH entre 1999 e 2014

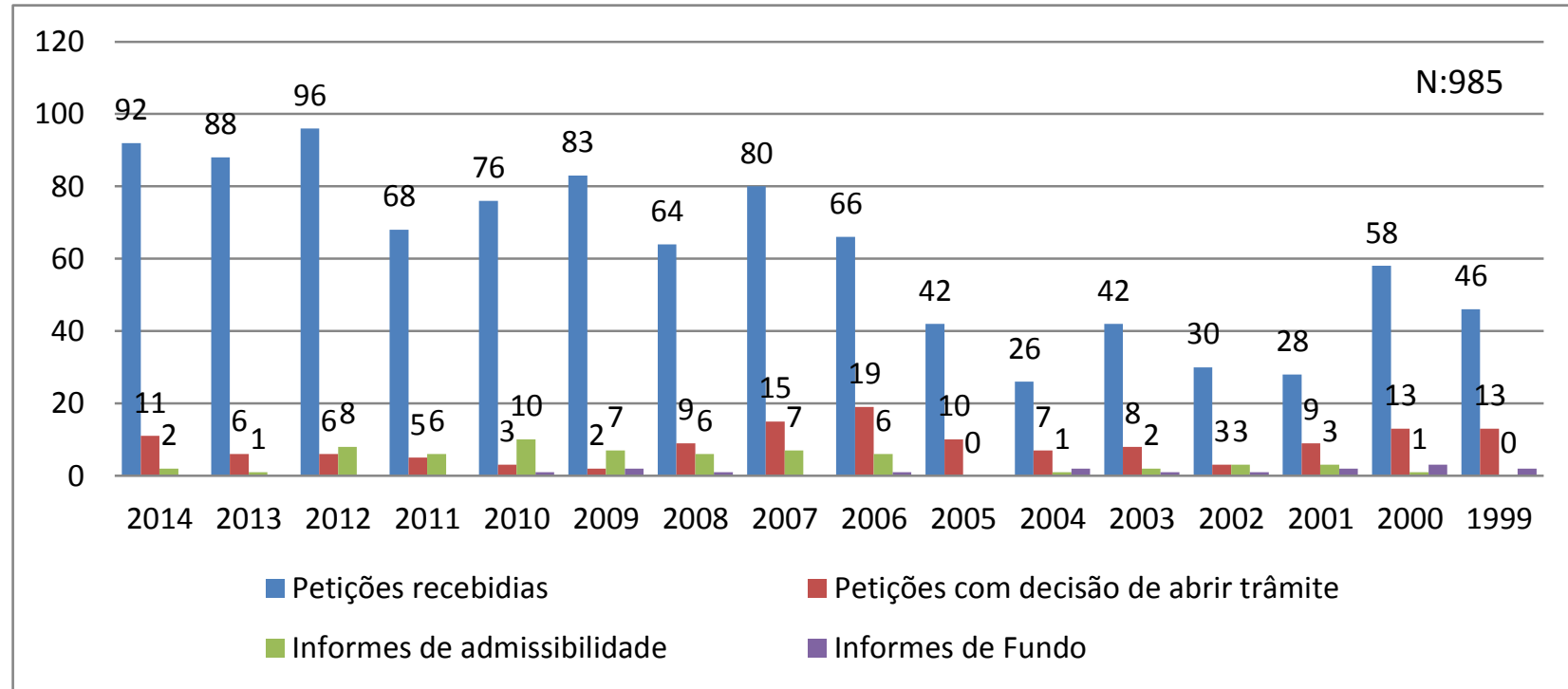

*Informes de fundo: Relatório pelo qual a Comissão apresenta sua decisão sobre o caso com os direitos violados pelo Estado e as suas recomendações.

Fonte: Elaboração própria. Dados da CmDH (disponível em: http://www.oas.org/pt/cidh/ Acesso em: 07 nov. 2015).

Com o intuito de analisar a inserção do Brasil no Sistema Interamericano de Direitos Humanos, busco, a seguir, identificar, classificar e sistematizar os casos contra o Brasil tanto na Comissão como na Corte Interamericana de Direitos Humanos, assim

\footnotetext{
${ }^{21}$ Relatório pelo qual a Comissão apresenta sua decisão sobre o caso com os direitos violados pelo Estado e as suas recomendações.

${ }^{22}$ Todos os casos serão vistos em detalhes na próxima seção.
} 
como suas recomendações, resoluções e medidas de urgência para gerar dados empíricos e, assim, observar as principais variáveis que afetam o cumprimento dos instrumentos do SIDH pelo Brasil.

\subsection{Tratamento dos dados}

Identificar-se-á, primeiramente, todos os casos contra o Brasil no SIDH e, em seguida, aqueles nos quais a Comissão ou Corte proferiram suas recomendações e sentenças e aqueles em que houve uma solução amistosa entre as partes.

Todos os casos serão sistematizados e categorizados por: 1) Região em que as violações foram cometidas; 2) Unidade federativa em que as violações foram cometidas; 3) Em qual órgão do SIDH o caso se encontra; 4) Fase da sua tramitação no órgão identificado; 5) Data de início da tramitação na $\mathrm{CmDH}$; 6) Data em que a violação foi cometida; 7) Quem são os peticionários do caso; 8) Qual o tipo de peticionário; 9) Quais foram os artigos e quais instrumentos do SIDH foram invocados na petição; 10) Quais os temas da violações cometidas.

Os casos em que a Comissão ou a Corte outorgaram recomendações e resoluções e os casos de solução amistosa entre as partes serão ainda classificados em oito categorias. São elas: 1) Data do veredicto da Comissão; 2) Data de envio à Corte; 3) Data da sentença da Corte ${ }^{23}$; 4) Artigos violados pelo Estado e em qual instrumento; 5) Quais foram as recomendações e resoluções outorgadas ou medidas acordadas em solução amistosa; 6) Quais os objetos das recomendações e resoluções outorgadas ou medidas acordadas em solução amistosa; 7) A compliance do Estado brasileiro com tais medidas; e 8) A data em que a compliance com tais medidas foi avaliada pelo SIDH.

Assim, os dados utilizados incluíram todos os 63 relatórios de admissibilidade dos casos; os 16 relatórios de fundo publicados pela $\mathrm{CmDH}$; as 48 medidas cautelares outorgadas contra o Brasil pela $\mathrm{CmDH} ; 27$ relatórios anuais da $\mathrm{CmDH}$ encaminhados à Secretaria Geral da $\mathrm{OEA}^{24}$; cinco (5) sentenças da Corte; cinco (5) medidas provisórias outorgadas pela Corte contra o Estado brasileiro; oito (8) relatórios de supervisão de cumprimento de sentença publicados pela $\mathrm{CrDH}$; dois (2) acordos de solução amistosa; duas (2) notas de remissão de casos da $\mathrm{CmDH}$ para a Corte; e 106 manifestações de

\footnotetext{
${ }^{23}$ Nos casos de solução amistosa, a data usada será aquela em que a Corte reconheceu o acordo entre as partes.

${ }^{24}$ Os relatórios de supervisão de cumprimento das resoluções da CmDH estão inclusos em seus relatórios anuais.
} 
defesa do Estado brasileiro no SIDH entre 1988 e $2014^{25}$. Os dados coletados ${ }^{26}$ nos documentos foram comparados com as informações fornecidas pelo Ministério das Relações Exteriores (MRE) e pela Secretaria de Direitos Humanos da Presidência da República $(\mathrm{SDH})^{27}$.

Nota-se que, algumas vezes, informações fornecidas pelo MRE e pela SDH sobre o mesmo caso divergem entre si. Além disso, as listas de todos os casos do Brasil no SIDH fornecidas pelos dois órgãos são diferentes em termos do seu número. Com o objetivo de sanar este problema, todas as informações do MRE e da SDH foram verificadas novamente e comparadas com os dados e documentos disponíveis nos sítios da Comissão e da Corte. Os casos que não estavam nas duas listas, mas encontram-se registrados na Comissão e na Corte Interamericana de Direitos Humanos podem ser consultados no "Apêndice A (Informações divergentes sobre os casos contra o Brasil no SIDH fornecidos pelo MRE e SDH, p.240)".

Observa-se que os dados fornecidos pelo MRE e pela SDH incluem informações sobre acordos de solução amistosa em processo de negociação e petições em avaliação de admissibilidade. Estas informações são consideradas como confidenciais pelo SIDH e, por isso, não são publicadas em sua página da internet para consulta. Por isso, não fazem parte deste estudo.

\section{Graus de compliance}

Como mencionado anteriormente, para fins metodológicos, utilizarei neste trabalho três níveis diferentes para a compliance com as decisões do SIDH. São eles: (1) aguardando cumprimento; (2) parcialmente cumprido; e (3) totalmente cumprido. A mesma diferenciação é usada pela Comissão e Corte em seus relatórios de supervisão de cumprimento. Segundo o Relatório de 2014 da $\mathrm{CmDH}$ (CmDH, 2014, pp82-83), as categorias são definidas por:

\footnotetext{
${ }^{25}$ Nota-se que em muitos casos o Estado brasileiro não manifesta formalmente sua defesa no Sistema Interamericano de Direitos Humanos. Isto faz com que o número de manifestações de defesa do Brasil seja diferente do total de medidas contra ele no SIDH.

${ }^{26}$ Fornecidos por meio da Lei de Acesso à Informação, Lei no 12.527/2011, pelos protocolos 09200000096201519 e 09200000719201553 (MRE) e 00083000104201536 (SDH).

${ }^{27}$ Os dados fornecidos pelos dois órgãos estão em anexo a este trabalho como "Anexo 1 - Dados fornecidos pelo Ministério das Relações Exteriores" e "Anexo 2 - Dados fornecidos pela Secretaria de Direitos Humanos da Presidência da República", exclui-se desses anexos todas as manifestações de defesa do Estado brasileiro no SIDH por se tratar de arquivos extremamente longos.
} 
- Cumprimento total: aqueles casos em que o Estado cumpriu em totalidade com todas as recomendações e resoluções formuladas pela $\mathrm{CmDH}$ e CrDH. Dado os princípios de efetividade e reparação integral, os dois órgãos consideram como cumpridas totalmente aquelas recomendações e resoluções que o Estado tenha iniciado e concluído satisfatoriamente a tramitação para o seu cumprimento;

- Cumprimento parcial: aqueles casos em que o Estado cumpriu parcialmente com as recomendações formuladas pelo SIDH, seja por cumprir apenas algumas das recomendações e resoluções ou por cumprilas de maneira incompleta;

- Aguardando cumprimento: aqueles casos em que a Comissão e a Corte consideram que não houve cumprimento das recomendações ou resoluções devido ao fato de não se ter iniciado nenhuma ação para tal fim, assim como aquelas ações iniciadas que ainda não produziram resultados concretos, as resoluções e recomendações que o Estado explicitamente indica que não cumprirá ou não cumpriu e aquelas que o Estado não informou ao SIDH sobre seu cumprimento e este não conte com informações de outras fontes que indique uma conclusão contrária.

Em seus relatórios de supervisão de cumprimento tanto a $\mathrm{CmDH}$ quanto a $\mathrm{CrDH}$ avaliam o grau de compliance com as medidas outorgadas de duas formas: 1) Coletivamente, em que a compliance com as medidas proferidas é analisada por caso, ou seja, o caso é avaliado como um todo e classificado em uma das três categorias acima; 2) Individualmente, em que a compliance de cada caso é analisada por meio de cada uma das recomendações ou resoluções pela $\mathrm{CmDH}$ ou $\mathrm{CrDH}$, sendo que cada uma das medidas é classificada no final em uma das três categorias de compliance mencionadas acima. Neste estudo, uso a classificação individual de compliance utilizado pelo SIDH.

Os casos em que os órgãos do SIDH ainda não emitiram nenhum relatório de supervisão de cumprimento foram categorizados como "sem informação". São eles: 1) Caso $n^{\circ} 11.405$ Newton Coutinho Mendes e outros; 2) Caso no 11.516 Ovelário Tames; 3) Caso no 11.598 Alonso Eugênio da Silva; e 4) Caso no 11.599 Marcos Aurélio de Oliveira.

Por fim, as datas em que os relatórios anuais da $\mathrm{CmDH}$ e relatórios de supervisão de cumprimento da Corte foram publicados são consideradas como a data em que o Estado cumpriu com as recomendações e resoluções parcialmente ou totalmente, caso 
tenham sido categorizados como tal. Por isso, os resultados relativos ao tempo de cumprimento das medidas devem ser lidos em termos aproximados e relativos.

\subsection{Procedimentos contra o Brasil no Sistema Interamericano de Direitos Humanos: Tramitação e características}

Nesta seção serão apresentadas as principais características das medidas contra o Brasil no Sistema Interamericano de Direitos Humanos. O universo da amostra é composto por todos os casos contra o Brasil no SIDH, o que inclui tanto aqueles casos em processo de admissão, as petições admitidas, os casos em que foram proferidos relatórios de fundo pela Comissão, os acordos de solução amistosa em negociação e finalizados, os casos na Corte, as Medidas Cautelares e Medidas Provisórias. A tabela consolidada com todos os resultados pode ser vista no "Apêndice B (tabela geral com informações consolidadas, p.267)".

Os resultados referentes aos casos contra o Brasil em que o SIDH outorgou recomendações e resoluções, assim como acordos de solução amistosa finalizados, serão analisados abaixo. A tabela consolidada com todas as informações específicas pode ser vista no "Apêndice C (Tabela com informações consolidadas sobre graus de compliance do Brasil no SIDH, p.313)".

Casos e petições por órgão e fase de tramitação no Sistema Interamericano de Direitos Humanos

Como resultado da pesquisa, descobriu-se que, ao todo, o Brasil possui 196 procedimentos ativos perante o SIDH, a partir do período temporal estudado. Por procedimentos se entende todas as petições admitidas, todos os casos (tanto na Comissão quanto na Corte), medidas de urgência e acordos de solução amistosa ainda em tramitação. Desses 196 procedimentos, 184 estão na $\mathrm{CmDH}$ e apenas 12 na $\mathrm{CrDH}$. 
Figura 3: Procedimentos contra o Brasil classificados por órgão do SIDH

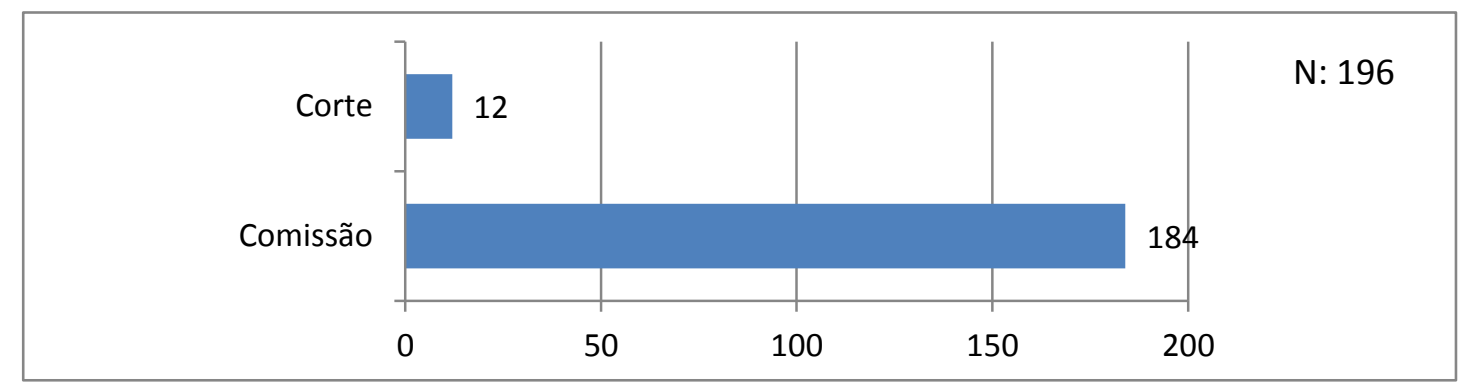

Fonte: Elaboração própria. Dados da $\mathrm{CmDH}$, da $\mathrm{CrDH}$, do MRE e da $\mathrm{SDH}$ (disponível em: http://www.oas.org/pt/cidh/ Acesso em: 07 nov. 2015 e no Apêndice B).

A maioria dos casos e petições que se encontram na $\mathrm{CmDH}$ estão em fase de análise de mérito (33\%), seguidos por medidas cautelares outorgadas $(25 \%)$ e petições em fase de admissibilidade (24\%). Casos de solução amistosa entre as partes representam 9\% e casos em que a Comissão já emitiu relatórios de fundo também representam 9\% dos casos no órgão.

Figura 4: Procedimentos na $\mathrm{CmDH}$ por fase de tramitação

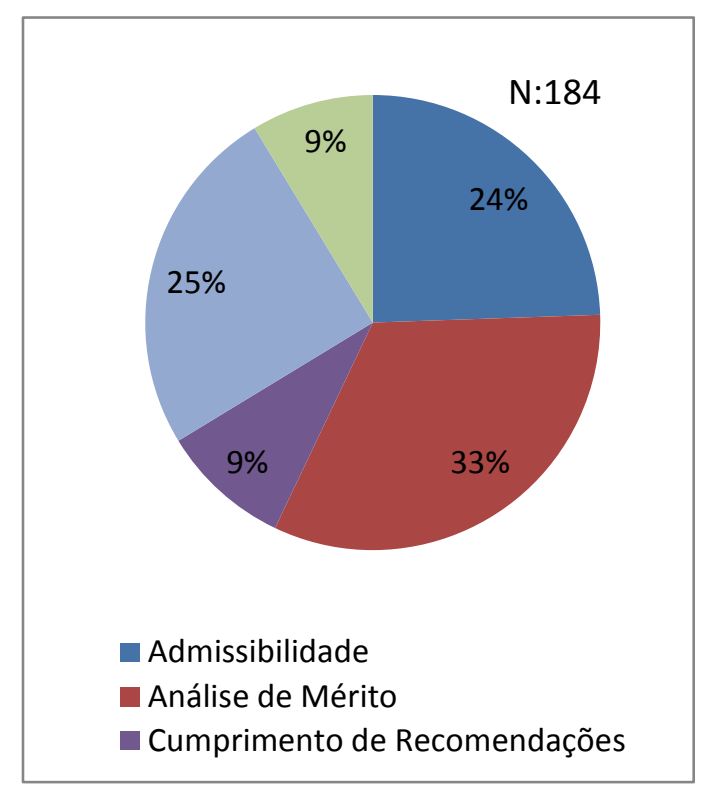

Fonte: Elaboração própria. Dados da $\mathrm{CmDH}$, da $\mathrm{CrDH}$, do MRE e da $\mathrm{SDH}$ (disponível em: http://www.oas.org/pt/cidh/ Acesso em: 07 nov. 2015 e no Apêndice B).
Figura 5: Procedimentos na $\mathrm{CrDH}$ por fase de tramitação

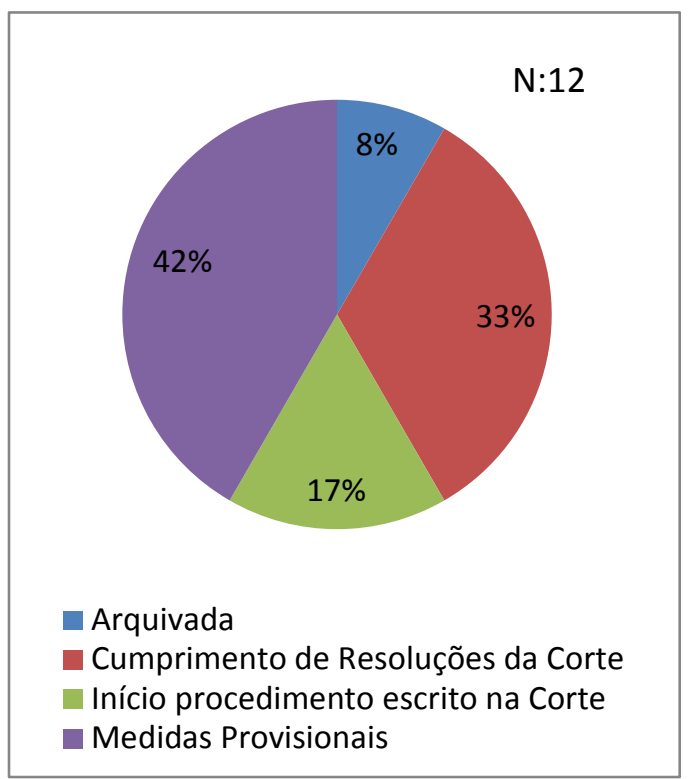

Fonte: Elaboração própria. Dados da $\mathrm{CmDH}$, da $\mathrm{CrDH}$, do MRE e da SDH (disponível em http://www.oas.org/pt/cidh/Acesso em: 07 nov. 2015 e no Apêndice B). 
Os casos brasileiros já julgados pela Corte Interamericana de Direitos Humanos e na fase de cumprimento de sua sentença representam $33 \%$ dos casos no órgão. $17 \%$ iniciaram seus procedimentos na Corte e estão aguardando julgamento e $8 \%$ foram arquivados. As medidas de urgência da Corte representam $42 \%$ dos procedimentos contra o Brasil na $\mathrm{CrDH}$.

Os números referentes a cada uma das fases de tramitação por órgão do SIDH podem ser vistos na tabela abaixo:

Tabela 1: Número de procedimentos por órgão e fase de tramitação contra o Brasil no SIDH

\begin{tabular}{l|c|c}
\hline \multicolumn{1}{c|}{ Fase de tramitação } & Comissão & Corte \\
\hline Admissibilidade & 45 & \\
\hline Análise de Mérito & 60 & 1 \\
\hline Arquivada & & \\
\hline Cumprimento de Recomendações da Comissão & 17 & 2 \\
\hline Cumprimento de Resoluções da Corte & & 5 \\
\hline Início procedimento na Corte & 46 & 12 \\
\hline Medidas Cautelares & 16 & \\
\hline Medidas Provisórias & 184 & \\
\hline Solução Amistosa & & 196 \\
\hline
\end{tabular}

Fonte: Elaboração própria. Dados da $\mathrm{CmDH}$, da $\mathrm{CrDH}$, do MRE e da SDH (disponível em: http://www.oas.org/pt/cidh/ Acesso em: 07 nov. 2015 e no Apêndice B).

Os dados coletados demonstram que há uma deficiência do Sistema Interamericano de Direitos Humanos em analisar uma grande quantidade de petições e casos admitidos. Acredita-se que isto é devido ao fato da Comissão buscar julgar casos expressivos que possam criar uma jurisprudência continental sobre o objeto julgado e também pelo caráter político do órgão. Nota-se também que há um grande número de medidas de urgência contra o Estado brasileiro no SIDH. O que pode vir a demostrar que a capacidade do Estado brasileiro em lidar com situações de violações de direitos 
humanos que possam causar danos irreparáveis às vítimas não é suficiente para remediar tais situações.

Observa-se que poucos casos contra o Brasil foram encaminhados à Corte Interamericana de Direitos Humanos, o que demonstra que depois de analisados pela Comissão há um grande período para que o Estado brasileiro possa cumprir com as recomendações da $\mathrm{CmDH}$ antes que sejam encaminhados à Corte. Contudo, dos casos enviados à $\mathrm{CrDH}$, nota-se que nenhuma das sentenças proferidas pelo tribunal foram totalmente cumpridas pelo Brasil. Por isso, todos os casos do País na Corte Interamericana de Direitos Humanos continuam na fase de cumprimento de resoluções.

Não obstante, é importante notar que há um grande número de acordos de solução amistosa sendo negociadas pelas partes. Isto demonstra que o Estado brasileiro tem agido de boa fé para remediar as situações de violações de direitos humanos quando possível.

\section{Procedimentos contra o Brasil no SIDH por região e unidade federativa}

Nota-se que $48 \%$ dos procedimentos contra o Brasil no SIDH são provenientes da Região Sudeste do País. As outras regiões mais demandadas são: 1) Norte e Nordeste (17\% dos procedimentos cada uma); 2) Sul (10\%); e 3) Centro-Oeste (8\%). Isto pode demonstrar tanto que a situação dos direitos humanos na Região Sudeste é mais precária em relação às outras regiões do País como as vítimas e peticionários da Região possuem maior conhecimento sobre o Sistema Interamericano de Direitos Humanos e, por isso, usam-no com mais frequência para relatar violações de direitos. 
Figura 6: Procedimentos contra o Brasil no SIDH classificados por região do país em que a violação de direitos humanos foi engendrada

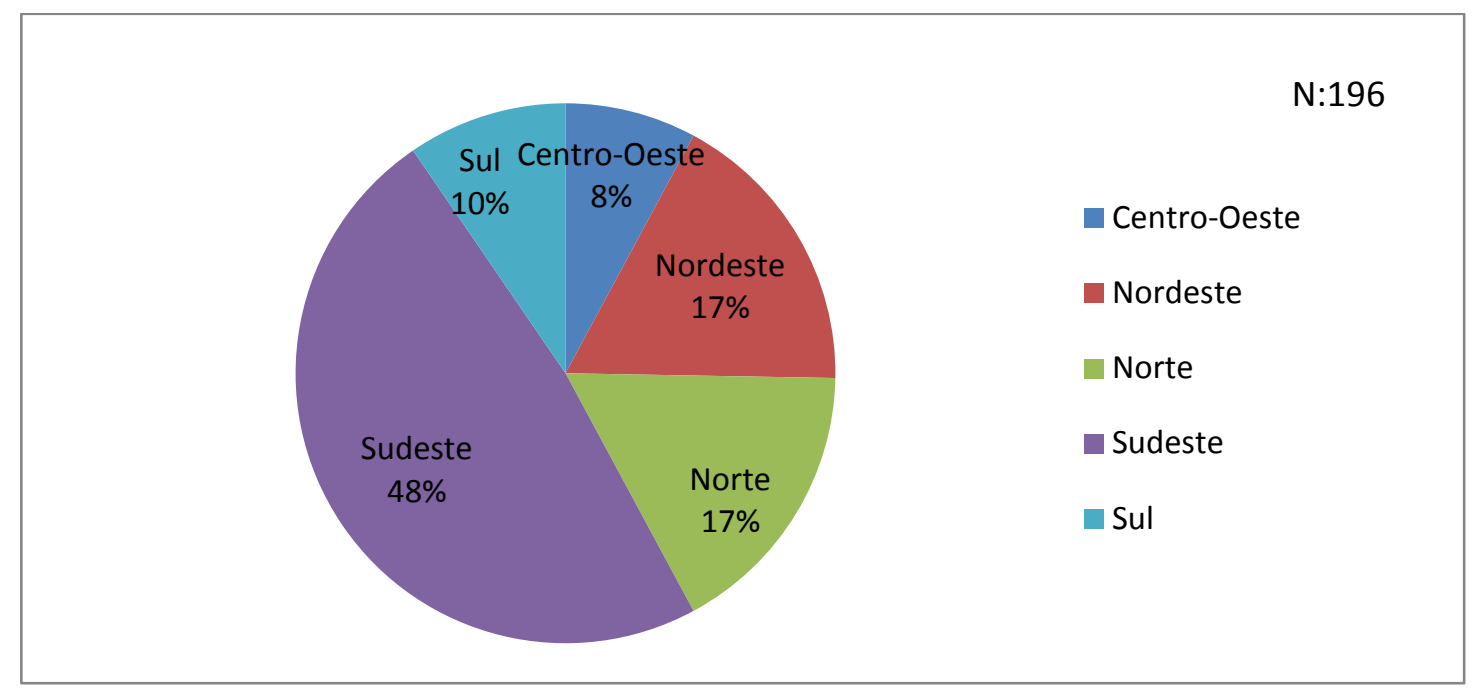

Fonte: Elaboração própria. Dados da $\mathrm{CmDH}$, da $\mathrm{CrDH}$, do MRE e da $\mathrm{SDH}$ (disponível em: http://www.oas.org/pt/cidh/ Acesso em: 07 nov. 2015 e no Apêndice B).

Quando as unidades federativas são analisadas individualmente, percebe-se que a grande maioria dos casos e petições contra o Estado brasileiro no Sistema Interamericano de Direitos Humanos são provenientes de violações de direitos humanos cometidas nos estados de São Paulo (22\%) e do Rio de Janeiro (20,80\%), valor que totaliza $42 \%$ de todos os procedimento contra o País no Sistema Interamericano de Direitos Humanos ${ }^{28}$.

A seguir, encontra-se gráfico demonstrativo dos dados coletados sobre o tópico:

\footnotetext{
${ }^{28}$ Os estados brasileiros, incluindo o Distrito Federal, mais demandados no SIDH são em ordem crescente: 1) São Paulo (22\%); 2) Rio de Janeiro (20,80\%); 3) Pará (9\%); 4) Paraná (5,60\%); 5) Pernambuco $(5,60 \%)$; 6) Maranhão (4\%); 7) Rio Grande do Sul (4\%); 8) Rondônia (3,40\%); 9) Ceará (2,80\%); 10) Espírito Santo $(2,80 \%) ; 11)$ Minas Gerais $(2,80 \%) ; 12)$ Roraima $(2,80 \%) ; 13)$ Tocantins $(2,30 \%) ; 14)$ Bahia $(2,20 \%) ; 15)$ Distrito Federal $(2,20 \%)$; 16) Mato Grosso do Sul $(2,20 \%) ; 17)$ Paraíba $(2,20 \%) ; 18)$ Mato Grosso $(1,80 \%)$; 19) Amazonas (0,5\%); 20) Goiás $(0,5) \%$; e 21$)$ Rio Grande do Norte $(0,5 \%)$. Os estados do Acre, Alagoas, Amapá, Santa Catarina, Sergipe e Piauí não são demandados em nenhum procedimento perante o SIDH no espaço temporal analisado.
} 
Figura 7: Procedimentos contra o Brasil no SIDH classificadas pela unidade federativa em que a violação de direitos humanos foi engendrada

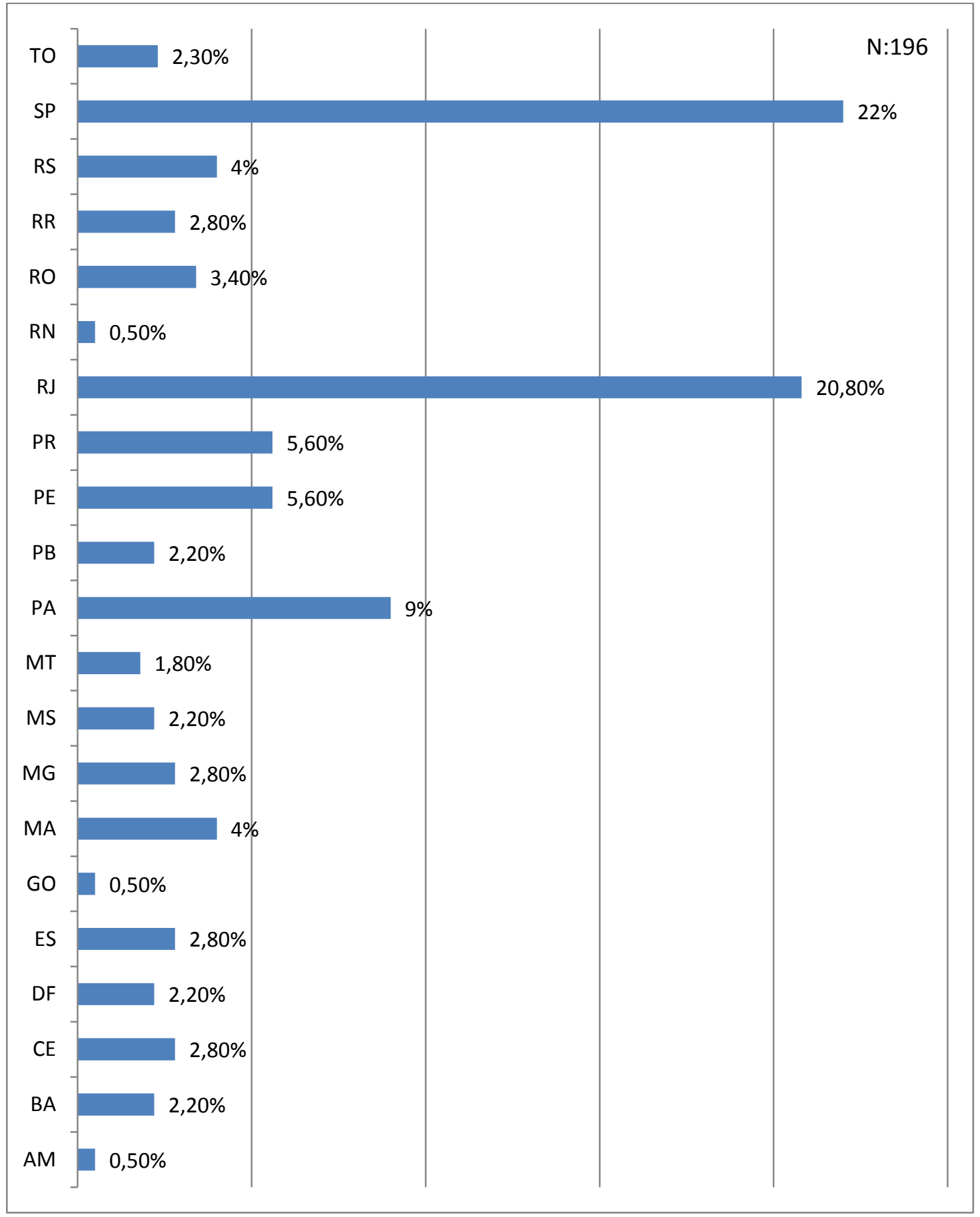

Fonte: Elaboração própria. Dados da $\mathrm{CmDH}$, da $\mathrm{CrDH}$, do MRE e da $\mathrm{SDH}$ (disponível em: http://www.oas.org/pt/cidh/ Acesso em: 07 nov. 2015 e no Apêndice B). 
Temas dos procedimentos contra o Brasil no Sistema Interamericano de Direitos Humanos

Todos os procedimentos contra o Brasil no Sistema Interamericano de Direitos Humanos foram classificados, a partir dos temas das violações de direitos humanos cometidas, em uma ou mais das categorias criadas abaixo ${ }^{29}$ :

- Crimes do período da ditadura: Diz respeito às violações de direitos humanos perpetradas durante o período da ditadura militar no Brasil, entre 1964 e 1988. Em sua maioria, violações de caráter contínuo como o desaparecimento forçado;

- Prestação de Justiça: Diz respeito às violações ao direito a um devido processo legal nos procedimentos judiciais ${ }^{30}$;

- Racismo: A discriminação racial é definida pelo artigo 1 da Convenção Internacional sobre a Eliminação de todas as Formas de Discriminação Racial de 1966 como “qualquer distinção, exclusão restrição ou preferência baseadas em raça, cor, descendência ou origem nacional ou étnica que tem por objetivo ou efeito anular ou restringir o reconhecimento, gozo ou exercício num mesmo plano,( em igualdade de condição), de direitos humanos e liberdades fundamentais no domínio político econômico, social, cultural ou em qualquer outro domínio de vida pública" (ONU, 1966);

- Tortura: O crime de tortura foi tipificado no artigo 1 da Convenção contra a Tortura e Outros Tratamentos ou Penas Cruéis, Desumanos ou Degradantes de 1984 como "O termo tortura designa qualquer ato pelo qual dores ou sofrimentos agudos, físicos ou mentais, são infligidos intencionalmente a uma pessoa a fim de obter, dela ou de uma terceira pessoa, informações ou confissões; de castigá-la por ato que ela ou uma terceira pessoa tenha cometido ou seja suspeita de ter cometido; de intimidar ou coagir esta pessoa ou outras pessoas; ou por qualquer motivo baseado em discriminação de qualquer natureza, quando tais dores ou sofrimentos são infligidos por um funcionários público ou outra pessoa no exercício de funções públicas, ou por sua instigação, ou com o seu consentimento ou aquiescência" (ONU, 1984). Crimes relacionados à tortura dentro do período temporal da ditadura (1964-1988) foram considerados dentro da categoria “crimes

\footnotetext{
${ }^{29}$ Elaboração própria da classificação

${ }^{30}$ Comissão Interamericana de Direitos Humanos. El acceso a la justicia como garantía de los derechos económicos, sociales y culturales. Estudio de los estándares fijados por el sistema interamericano de derechos humanos. Disponível em:

http://www.cidh.org/countryrep/AccesoDESC07sp/Accesodesciv.sp.htm Acesso em: 14 nov. 2015
} 
do período da ditadura", já as demais violações de direitos humanos relacionados à tortura cometidas fora do período ditatorial foram classificados nesta categoria;

- Violência contra defensores de Direitos Humanos: Diz respeito a qualquer ato de violência perpetrado contra defensores de Direitos Humanos. Segundo a Declaração dos Direitos e Responsabilidades dos Indivíduos, Grupos e Órgãos da Sociedade para Promover e Proteger os Direitos Humanos e Liberdades Individuais Universalmente Reconhecidos, adotada pela Assembleia Geral da ONU em 1998, "Defensores dos direitos humanos são todos os indivíduos, grupos e órgãos da sociedade que promovem e protegem os direitos humanos e as liberdades fundamentais universalmente reconhecidos" (ONU, 1998);

- Violência contra indígenas: Diz respeito a qualquer ato de violência perpetrado contra indígenas. Indígenas são definidos pelo artigo 1 da Convenção 169 da OIT como "[...] povos tribais em países independentes, cujas condições sociais, culturais e econômicas os distingam de outros setores da coletividade nacional, e que estejam regidos, total ou parcialmente, por seus próprios costumes ou tradições ou por legislação especial; [...] povos em países independentes, considerados indígenas pelo fato de descenderem de populações que habitavam o país ou uma região geográfica pertencente ao país na época da conquista ou da colonização ou do estabelecimento das atuais fronteiras estatais e que, seja qual for sua situação jurídica, conservam todas as suas próprias instituições sociais, econômicas, culturais e políticas, ou parte delas" (OIT, 1989);

- Violência contra menores: Diz respeito a qualquer ato de violência perpetrado contra crianças e adolescente menores de 18 anos;

- Violência contra mulheres: Diz respeito a qualquer ato de violência perpetrado contra mulheres e meninas;

- Violência no campo: Diz respeito a qualquer ato de violência perpetrado no meio rural, incluindo trabalho forçado ou obrigatório. Trabalho forçado ou obrigatório é defino no artigo 2 da Convenção 29 sobre Trabalho Forçado ou Obrigatório da Organização Internacional do Trabalho (OIT) como "todo trabalho ou serviço exigido de uma pessoa sob a ameaça de sanção e para o qual não se tenha oferecido espontaneamente" (OIT, 1930);

- Violência institucional contra privados de liberdade (sistema prisional e socioeducativo): Violência institucional é aquela praticada nas instituições prestadoras de serviços públicos como hospitais, postos de saúde, escolas, 
delegacias, prisões, judiciário, instituições socioeducativas, entre outros, perpetrada por agentes do Estado. Assim, classifico violência institucional contra privados de liberdade, como violência perpetrada por agentes do Estado contra aquelas pessoas sob a custódia do Estado, incluindo presos em delegacias, prisões, sistema socioeducativo, etc.

- Violência policial: Diz respeito a qualquer ato de violência perpetrado por policiais, sejam eles civis ou militares;

- Outros: Aqueles temas que não se enquadram nas definições citadas acima.

Figura 8: Temas dos procedimentos contra o Brasil no SIDH

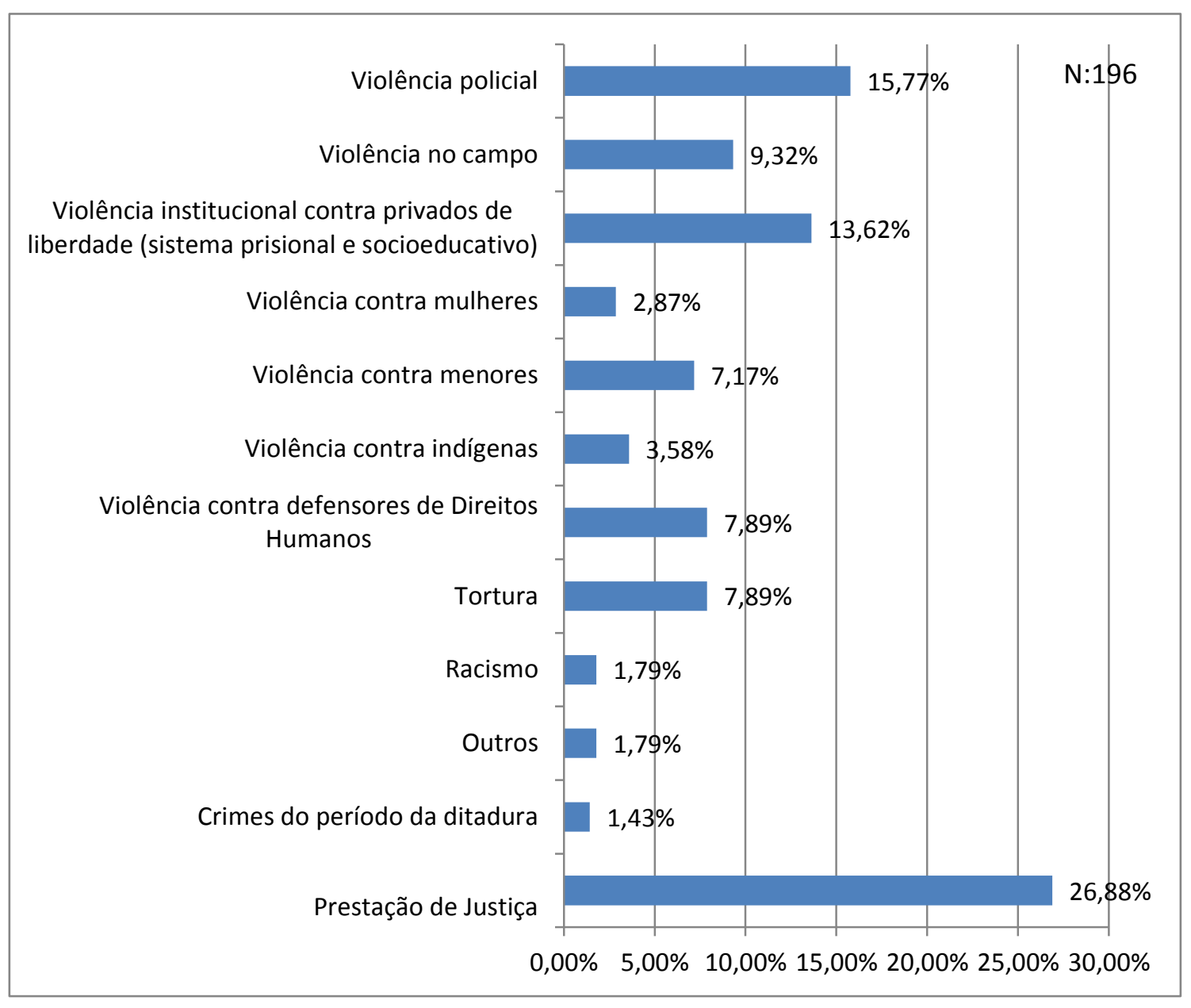

Fonte: Elaboração própria. Dados da $\mathrm{CmDH}$, da $\mathrm{CrDH}$, do MRE e da $\mathrm{SDH}$ (disponível em: http://www.oas.org/pt/cidh/ Acesso em: 07 nov. 2015 e no Apêndice B).

Como mostra a figura 8 acima, verificou-se que, em ordem decrescente, os temas das violações de direitos humanos dos procedimentos contra o Brasil no SIDH são: 1) Prestação de Justiça (26,88\%); 2) Violência policial (15,77\%); 3) Violência institucional 
contra privados de liberdade (sistema prisional e socioeducativo) (13,62\%); 4) Violência no campo $(9,32 \%) ; 5)$ Violência contra defensores de Direitos Humanos (7,89\%); 6) Tortura $(7,89 \%)$; 7) Violência contra menores $(7,17 \%)$; 8) Violência contra indígenas (3,58\%); 9) Violência contra mulheres (2,87\%); 10) Racismo (1,79\%); e 11) Crimes do período da ditadura $(1,43 \%)$. Aqueles temas que não se enquadram nas definições citadas acima, categorizados como "outros", somaram 1,79\% dos casos, petições e medidas de urgência do espaço amostral desta pesquisa.

Isto demonstra que a maioria dos procedimentos contra o Estado brasileiro no Sistema Interamericano Direitos Humanos é engendrada por violações de direitos humanos relacionadas às deficiências do Poder Judiciário, ou seja, a (in)capacidade do Estado em prestar o devido acesso à justiça ou ao devido processo jurisdicional às vítimas. Acredita-se que este fenômeno pode estar relacionado tanto à independência jurídica dos juízes, "a qual retira o magistrado de qualquer subordinação hierárquica no desempenho de suas atividades funcionais; o juiz subordina-se somente à lei" (CARVALHO, 2015, n/d), e o fato da falta de conhecimento sobre os temas relacionados aos direitos humanos, como à prolongada tramitação dos casos no sistema judiciário brasileiro.

Lembra-se que esses três itens listados acima são parte das exceções à regra do esgotamento de recursos internos para a admissão do caso no SIDH e estão diretamente relacionadas ao conceito de prestação de justiça. Logo, a inexistência de um devido processo legal, o fato de autoridades negarem o acesso a um devido processo legal e o atraso injustificado dos procedimentos no sistema judiciário é em parte uma proxy da capacidade do Poder Judiciário de um país em lidar com violações relacionadas a direitos humanos. No caso brasileiro, a capacidade do Poder Judiciário se mostra insuficiente para lidar com as situações de violações de direitos humanos no País.

“A violência em nosso país assume diversas facetas, mas uma das mais preocupantes é a institucional, aquela cometida justamente pelos órgãos e agentes públicos que deveriam se esforçar para proteger e defender os cidadãos" (UNICEF, 2006, p.117). Neste estudo, a violência institucional foi dividida em duas classificações: 1) Violência Policial; e 2) Violência contra Privados de Liberdade (Sistema Prisional e Sistema Socioeducativo).

A questão da violência policial continua sendo um dos principais temas de violações de direitos humanos no Brasil, como mostrado pela figura 10. A atuação arbitrária das forças policiais demonstra o papel antagônico do órgão responsável e 
garantidor da segurança publica como violador de direitos dentro no ordenamento social. "A violência policial é um fato concreto ligado à justiça e segurança e deve ser encarado como um grave problema a ser solucionado" (OLIVEIRA et al, 2011, n/d). Igualmente, a questão da violência institucional perpetrada contra privados de liberdade e da prática da tortura, em sua grande maioria praticada por agentes estatais nos procedimentos contra o Brasil no SIDH, assumem a mesma magnitude.

Essa é "uma discussão importantíssima porque, apesar de contarmos com uma Constituição democrática, o Estado brasileiro continua a fazer uso de práticas autoritárias herdadas do período da ditadura militar, em nome da manutenção da lei e da ordem portanto, do controle social" (UNICEF, 2006, p.117). Essas práticas sistemáticas de violações de direitos humanos afetam principalmente grupos vulneráveis e marginalizados da sociedade, os quais deveriam receber atenção específica do Estado devido às suas particularidades.

Por não prover essa proteção especial, o Estado brasileiro acaba mantendo
inalterado o status quo dessa população marginalizada e excluída. Soma-se a
isso a não internalização da prática democrática (também) pela população em
geral, que quando tem seus direitos desrespeitados desconhece os mecanismos
legais para os fazer valer. Se os conhece, não tem fácil acesso à Justiça ou não
acredita nas instituições jurídicas como meio de resoluções de conflitos
(UNICEF, 2006, p.117).

Outrossim, é importante notar que tanto as violações de direitos humanos engendradas por violência no campo e aquelas perpetradas contra defensores de direitos humanos estão intrinsicamente relacionadas no contexto brasileiro. Segundo a ONG internacional Global Witness, o Brasil liderou a lista de países que mais tiveram ativistas ambientais e agrários assassinados entre 2010 e 2014 ${ }^{31}$. Em 2014, “das 29 mortes de líderes e militantes de causas ambientais ou agrárias registradas [...], 26 delas estavam ligadas a conflitos de terra, segundo a Comissão Pastoral da Terra (CPT)" (BBC, n/d) ${ }^{32}$, que monitora a violência no campo no País desde 1985. O que coloca o Brasil à frente de países com históricos de conflitos internos como Colômbia, Filipinas e Honduras.

A taxa correspondente à violência contra menores $(7,17 \%$ dos procedimentos contra o Brasil no SIDH) "nos deixa distantes da ideia de um Estado democrático" (UNICEF, 2011, p.138), já que violações de direitos humanos contra crianças e adolescentes ainda são corriqueiras no País. "Reconhecer que nos últimos 15 anos avançamos muito ao ratificar convenções e tratados internacionais de direitos humanos, inclusive tendo internalizado formalmente a doutrina de proteção integral à criança e ao

\footnotetext{
${ }^{31}$ Disponível em https://www.globalwitness.org/en/about-us/annual-reviews/ Acesso em: 25 jun 2016.

${ }^{32}$ Disponível em http://www.bbc.com/portuguese/noticias/2015/04/150419 relatorio_mortes_ativistas rm Acesso em 25 jun 2016.
} 
adolescente da ONU, não é suficiente para assegurar a dignidade humana, em especial a integridade física e psicológica, dos nossos adolescentes" (UNICEF, 2011, p.138).

Ao analisar a taxa referente à violência contra indígenas, deve-se frisar que a maioria dos procedimentos relacionados a este tema é composta por medidas de urgência. Esta característica vai ao encontro dos dados do último relatório do Conselho Indigenista Missionário, ONG vinculada à Confederação Nacional de Bispos do Brasil que busca litigar a favor dos indígenas brasileiros. Os dados "expõe[m] responsabilidades específicas dos poderes públicos, especialmente do Executivo, que tem se mostrado omisso diante dos conflitos e não cumpre suas atribuições constitucionais de demarcar as terras indígenas, protegê-las e fiscalizá-las, bem como de executar políticas públicas específicas e diferenciadas de atenção aos povos indígenas" (CIMI, 2014, p.18), fazendo com que a população indígena seja frequentemente posta em situação de risco de violação de direitos humanos.

Os resultados pouco expressivos para os procedimentos contra o Brasil no Sistema Interamericano de Direitos Humanos relacionados à violência contra mulheres, racismo e outros pode estar relacionado ao fato do SIDH buscar casos relevantes que possam gerar uma jurisprudência a ser aplicada em todo o continente, como explicado anteriormente. Lembra-se que um caso emblemático contra o Brasil na Comissão Interamericana de Direitos Humanos é o Caso ${ }^{\circ} 12051$ Maria da Penha ${ }^{33}$. Esse foi um caso de violência contra mulher que engendrou mudanças importantes no ordenamento jurídico brasileiro a partir de recomendações da $\mathrm{CmDH}$, como a Lei nº11.340/2006 (conhecida como lei Maria da Penha) que visa aumentar o rigor das punições de violência doméstica e familiar contra mulheres.

\footnotetext{
33 “Em 1983, a biofarmacêutica Maria da Penha Maia Fernandes, sofreu dupla tentativa de homicídio por parte de seu então marido dentro de sua casa, em Fortaleza, Ceará. O agressor, Marco Antonio Heredia Viveiros, colombiano naturalizado brasileiro, economista e professor universitário, atirou contra suas costas enquanto ela dormia, causando-lhe paraplegia irreversível. Posteriormente, tentou eletrocutá-la no banho.Passados mais de 15 anos do crime, apesar de haver duas condenações pelo Tribunal do Júri do Ceará (1991 e 1996), ainda não havia uma decisão definitiva no processo e o agressor permanecia em liberdade, razão pela qual Maria da Penha, o CEJIL-Brasil (Centro para a Justiça e o Direito Internacional) e o CLADEM-Brasil (Comitê Latino-Americano e do Caribe para a Defesa dos Direitos da Mulher) enviaram o caso à CIDH/OEA (Comissão Interamericana de Direitos Humanos da Organização dos Estados Americanos). Em 2001, a CIDH responsabilizou o Estado brasileiro por omissão, negligência e tolerância. Considerou que neste caso se davam as condições de violência doméstica e de tolerância pelo Estado definidas na Convenção de Belém do Pará [Convenção Interamericana para Prevenir, Punir e Erradicar a Violência Contra a Mulher]" Disponível em: http://www.compromissoeatitude.org.br/o-casomaria-da-penha-na-oea/ Acesso: 26 jun 2016.
} 
Já sobre os temas de procedimentos relacionados a crimes do período da ditatura, nota-se que seu número pouco expressivo é devido ao fato da Lei da Anistia do Brasil (Lei $n^{\circ}$ 6.683/1979), promulgada pelo Presidente Figueiredo ainda durante o período ditatorial, dar anistia

a todos quantos, no período compreendido entre 02 de setembro de 1961 e 15 de agosto de 1979, cometeram crimes políticos ou conexo com estes, crimes eleitorais, aos que tiveram seus direitos políticos suspensos e aos servidores da Administração Direta e Indireta, de fundações vinculadas ao poder público, aos Servidores dos Poderes Legislativo e Judiciário, aos Militares e aos dirigentes e representantes sindicais, punidos com fundamento em Atos Institucionais e Complementares (BRASIL, Lei n ${ }^{\circ} 6.683 / 1979$, art. 1)

Contudo, os casos classificados como crimes do período da ditadura são em sua maioria casos de desaparecimento forçado ${ }^{34}$, característica que faz com que a violação de direitos humanos seja contínua. Isso faz com que o crime em si ultrapasse o limite legal estipulado pela Lei da Anistia e possa assim ser base de um procedimento no Sistema Interamericano de Direitos Humanos.

A figura 9 e a tabela 2 nos mostram que quando os temas dos procedimentos contra o Brasil no SIDH são divididas pelas regiões do País, observa-se a seguinte predominância dos temas:

- Centro-Oeste: Responsável por 50\% dos procedimentos categorizados como "Crimes do período da Ditadura";

- Nordeste e Sul: Responsável por 37,50\% cada dos procedimentos categorizados como "Violência contra a Mulher";

- Norte: Responsável por 53,80\% dos procedimentos categorizados como "Violência no campo"; e

- Sudeste: Responsável por $80 \%$ dos procedimentos categorizados como "Violência contra Menores"; 72,70\% dos procedimentos categorizados como "Tortura"; 65,85\% dos procedimentos categorizados como "Violência Policial"; 65,75\% dos procedimentos categorizados como "Violência institucional contra privados de liberdade (sistema prisional e socioeducativo)"; 50\% dos procedimentos categorizados como "Crimes do Período da Ditadura"; 41,34\% dos procedimentos categorizados como "Prestação de Justiça"; e 40,90\% dos procedimentos categorizados como "Violência contra Defensores de Direitos Humanos"

\footnotetext{
${ }^{34}$ Segundo o artigo $2^{\circ}$ da Convenção, entende-se por desaparecimento forçado: "a prisão, a detenção, o sequestro ou qualquer outra forma de privação de liberdade que seja perpetrada por agentes do Estado ou por pessoas ou grupos de pessoas agindo com a autorização, apoio ou aquiescência do Estado, e a subsequente recusa em admitir a privação de liberdade ou a ocultação do destino ou do paradeiro da pessoa desaparecida, privando-a assim da proteção da lei”.
} 
Figura 9: Temas dos procedimentos contra o Brasil no SIDH classificados por região em que as violações foram engendradas

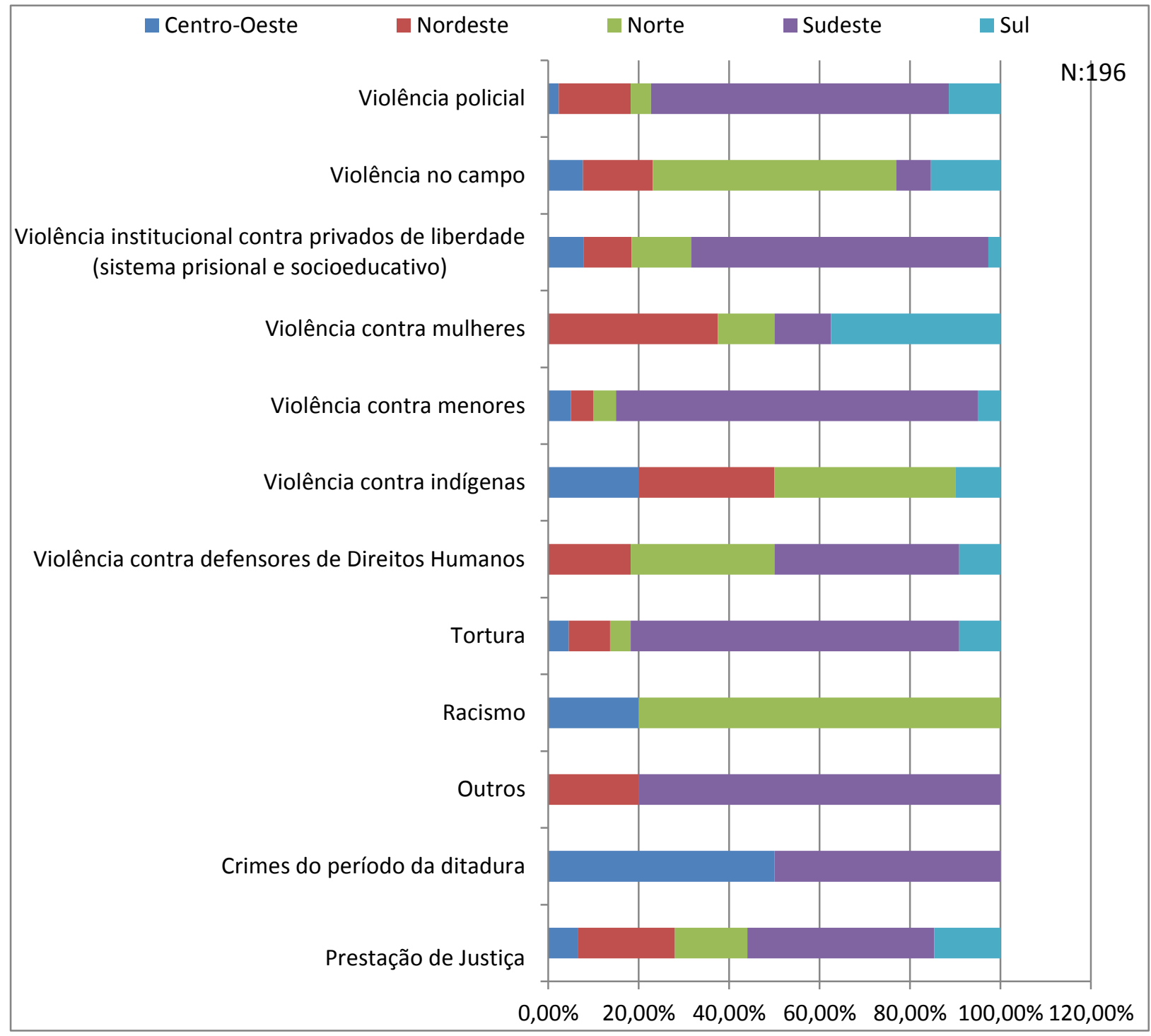

Fonte: Elaboração própria. Dados da $\mathrm{CmDH}$, da $\mathrm{CrDH}$, do MRE e da $\mathrm{SDH}$ (disponível em: http://www.oas.org/pt/cidh/ Acesso em: 07 nov. 2015 e no Apêndice B). 
Tabela 2: Temas dos procedimentos contra o Brasil no SIDH classificados região em que as violações foram engendradas

\begin{tabular}{|c|c|c|c|c|c|c|}
\hline & Centro-Oeste & Nordeste & Norte & Sudeste & Sul & Total \\
\hline Prestação de Justiça & $6,66 \%$ & $21,34 \%$ & $16 \%$ & $41,34 \%$ & $14,66 \%$ & $100 \%$ \\
\hline $\begin{array}{l}\text { Crimes do período da } \\
\text { ditadura }\end{array}$ & $50 \%$ & - & - & $50 \%$ & - & $100 \%$ \\
\hline Outros & - & $20 \%$ & - & $80 \%$ & - & $100 \%$ \\
\hline Racismo & $20 \%$ & - & $80 \%$ & - & - & $100 \%$ \\
\hline Tortura & $4,55 \%$ & $9,10 \%$ & $4,55 \%$ & $72,70 \%$ & $9,10 \%$ & $100 \%$ \\
\hline $\begin{array}{l}\text { Violência contra defensores } \\
\text { de Direitos Humanos }\end{array}$ & - & $18,20 \%$ & $31,80 \%$ & $40,90 \%$ & $9,10 \%$ & $100 \%$ \\
\hline Violência contra indígenas & $20 \%$ & $30 \%$ & $40 \%$ & - & $10 \%$ & $100 \%$ \\
\hline Violência contra menores & $5 \%$ & $5 \%$ & $5 \%$ & $80 \%$ & $5 \%$ & $100 \%$ \\
\hline Violência contra mulheres & - & $37,50 \%$ & $12,50 \%$ & $12,50 \%$ & $37,50 \%$ & $100 \%$ \\
\hline $\begin{array}{l}\text { Violência institucional contra } \\
\text { privados de liberdade } \\
\text { (sistema prisional e } \\
\text { socioeducativo) }\end{array}$ & $7,90 \%$ & $10,55 \%$ & $13,15 \%$ & $65,75 \%$ & $2,65 \%$ & $100 \%$ \\
\hline Violência no campo & $7,70 \%$ & $15,40 \%$ & $53,80 \%$ & $7,70 \%$ & $15,40 \%$ & $100 \%$ \\
\hline Violência policial & $2,30 \%$ & $15,90 \%$ & $4,55 \%$ & $65,85 \%$ & $11,40 \%$ & $100 \%$ \\
\hline & & & & & & $\mathrm{N}: 196$ \\
\hline
\end{tabular}

Fonte: Elaboração própria. Dados da $\mathrm{CmDH}$, da $\mathrm{CrDH}$, do MRE e da $\mathrm{SDH}$ (disponível em: http://www.oas.org/pt/cidh/ Acesso em: 07 nov. 2015 e no Apêndice B).

Os dados refletem as diferentes características das violações de direitos humanos por região no País. A predominância de crimes relacionados ao período da ditatura na Região Centro-Oeste se dá devido ao fato da intensa luta de movimentos sociais organizados contra a ditadura na região. Esses grupos foram vítimas de desaparecimento forçado por agentes estatais da época. Na Região Norte, a predominância de procedimentos com a temática de violência no campo é vista com naturalidade, haja vista a diversidade camponesa da região. Muitos dos grupos camponeses da região são 
classificados como comunidades tradicionais ${ }^{35}$, sendo "uma das características que os distingue é o uso comum da terra onde vivem e trabalham" (CPT, n/d) ${ }^{36}$.

Nas Regiões Nordeste e Sul há a predominância de procedimentos contra o Brasil no SIDH ligados à violência contra a mulher. Fato o qual vai ao encontro de dados coletados no Mapa da Violência 2015 - Homicídio de Mulheres no Brasil, que demonstra que há um maior crescimento nessas duas regiões de violência contra a mulher no País (WAISELFISZ, 2015). Na Região Sudeste há a predominância de crimes cometidos por agentes estatais, tais como violência contra menores, tortura, violência policial, violência institucional contra privados de liberdade, violência contra Defensores de Direitos Humanos e prestação de justiça. Acredita-se que a principal razão disso é a concentração populacional presente na região em comparação com o resto do País, assim como o fato de organizações de litigância e de proteção de direitos humanos na região conhecerem melhor como ter acesso ao Sistema Interamericano de Direitos Humanos para defenderem os direitos das vítimas.

Se os temas dos procedimentos contra o Brasil no SIDH são analisados por unidade federativa (UF), observa-se que em 13 das 27 UFs a maioria dos procedimentos está relacionada à prestação de justiça. Nota-se que não há nenhuma violação de direitos humanos objeto de procedimentos do SIDH contra o Brasil que tenha ocorrido nas seguintes unidades federativas: Acre, Alagoas, Amapá, Goiás, Piauí, Santa Catarina e Sergipe. Igualmente, nota-se que a predominância dos temas dos procedimentos contra o Brasil no SIDH por unidade federativa é, na maioria das vezes, igual ao tema da região do país que a unidade está inserida. A seguir, encontra-se tabela com resumo dos principais temas dos procedimentos contra o Brasil no SIDH por UF. A relação completa pode ser vista no Anexo 3 (Temas dos procedimentos contra o Brasil no SIDH categorizados por unidade federativa, p.230).

\footnotetext{
35 Povos e Comunidades Tradicionais são "grupos culturalmente diferenciados e que se reconhecem como tais, que possuem formas próprias de organização social, que ocupam e usam territórios e recursos naturais como condição para sua reprodução cultural, social, religiosa, ancestral e econômica, utilizando conhecimentos, inovações e práticas gerados e transmitidos pela tradição" (Decreto Federal N ${ }^{\circ} 6.040$ de 7 de fevereiro de 2000, Disponível em: http://www.planalto.gov.br/ccivil_03/_ato20072010/2007/decreto/d6040.htm Acesso: 26 jun 2016).

${ }^{36}$ Disponível em: http://www.cptnacional.org.br/index.php/sobre-nos/historico Acesso: 26 jun 2016
} 
Tabela 3: Principais temas dos procedimentos contra o Brasil no SIDH classificadas pela unidade federativa em que a violação foi engendrada

\begin{tabular}{|c|c|c|}
\hline$U F$ & Tema 1 & Tema 2 \\
\hline Amazonas & $\begin{array}{l}\text { Violência contra defensores de } \\
\text { direitos humanos }(100 \%)\end{array}$ & - \\
\hline Bahia & Prestação de Justiça (40\%) & $\begin{array}{c}\text { Violência contra Defensores de } \\
\text { Direitos Humanos (40\%) }\end{array}$ \\
\hline Ceará & Prestação de Justiça (50\%) & Tortura $(25 \%)$ \\
\hline Distrito Federal & Prestação de Justiça (30\%) & Violência Policial (14\%) \\
\hline Espírito Santo & $\begin{array}{c}\text { Violência contra Defensores de } \\
\text { Direitos Humanos (37\%) }\end{array}$ & $\begin{array}{l}\text { Violência Institucional contra } \\
\text { Privados de Liberdade (27\%) }\end{array}$ \\
\hline Maranhão & Prestação de Justiça (30\%) & Violência no Campo (20\%) \\
\hline Mato Grosso & Prestação de Justiça (60\%) & Violência no Campo (40\%) \\
\hline Mato Grosso do Sul & Violência contra Indígenas (67\%) & $\begin{array}{l}\text { Violência Institucional contra } \\
\text { Privados de Liberdade (33\%) }\end{array}$ \\
\hline Minas Gerais & Prestação de Justiça (40\%) & Tortura $(20 \%)$ \\
\hline Pará & Violência no Campo (42\%) & Prestação de Justiça (23\%) \\
\hline Paraíba & Prestação de Justiça (25\%) & Violência contra Mulheres (25\%) \\
\hline Paraná & Prestação de Justiça (35\%) & Violência Policial (23\%) \\
\hline Pernambuco & Prestação de Justiça (34\%) & Violência Policial (34\%) \\
\hline Rio de Janeiro & Violência Policial (27\%) & Prestação de Justiça (24\%) \\
\hline Rio Grande do Norte & $\begin{array}{c}\text { Violência contra Defensores de } \\
\text { Direitos Humanos (50\%) }\end{array}$ & Prestação de Justiça (50\%) \\
\hline Rio Grande do Sul & Prestação de Justiça (40\%) & Violência contra Mulheres (30\%) \\
\hline Rondônia & $\begin{array}{l}\text { Violência Institucional contra } \\
\text { Privados de Liberdade (49\%) }\end{array}$ & Violência no Campo (17\%) \\
\hline Roraima & Violência contra Indígenas (43\%) & Prestação de Justiça (29\%) \\
\hline São Paulo & Prestação de Justiça (23\%) & $\begin{array}{l}\text { Violência Institucional contra } \\
\text { Privados de Liberdade (20\%) }\end{array}$ \\
\hline Tocantins & Prestação de Justiça (40\%) & $\begin{array}{l}\text { Crimes do Período da Ditadura } \\
\qquad(40 \%)\end{array}$ \\
\hline
\end{tabular}

Fonte: Elaboração própria. Dados da $\mathrm{CmDH}$, da $\mathrm{CrDH}$, do MRE e da $\mathrm{SDH}$ (disponível em: http://www.oas.org/pt/cidh/ Acesso em: 07 nov. 2015 e no Anexo 3). 
Diferença temporal entre a violação de direitos humanos e o início da tramitação do procedimento no Sistema Interamericano de Direitos Humanos

No cálculo do período temporal entre a violação de direitos humanos cometida e o início da tramitação do procedimento no Sistema Interamericano de Direitos Humanos da petição, verificou-se que há uma diferença média de sete anos e um mês. Isso demonstra que há uma ineficiência do Poder Judiciário brasileiro em lidar com casos de violações de direitos humanos de maneira célere, fato que faz com que a regra de exceção ao esgotamento de recursos internos para a admissibilidade do procedimento no Sistema Interamericano de Direitos Humanos seja amplamente reivindicada pelos peticionários.

Quando o procedimento não expressava a data completamente (dia, mês e ano), decidi que: 1) Caso a informação faltante fosse apenas o dia, consideraria como se a violação tivesse acontecido no dia primeiro; 2) Caso não fosse informado, além do dia, o mês, consideraria como se a violação tivesse acontecido no dia $1^{\circ}$ de janeiro. A única petição dentro do espaço amostral em que fiz a consideração conforme o item dois acima foi a P-1122-07 Eliane Ortiz e Murilo Alcaide que iniciou sua tramitação em 2011. Os casos considerados conforme o item dois foram: 1) Caso n ${ }^{\circ} 12.838$ Hildebran da Silva de Freitas de 1997; 2) Caso nº 12.876 Moradores do Conjunto Habitacional Barão de Mauá de 2001; 3) Caso n 12.654 Pessoas privadas de liberdade na Cadeia Pública do Guarujá; 4) Caso no 12.728 Povo Indígena Xucuru de 1989; 5) Caso no 12.781 Povos Indígenas da Raposa Serra do Sol de 2004; 6) Caso no 12.461 Rafael Lozano de 2003; 7) Caso $\mathrm{n}^{\circ}$ 12.200 Juvenal e José Henrique Trindade. Essas decisões foram tomadas para que o cálculo mais aproximado da diferença temporal entre violação e início da tramitação fosse possível.

Se há mais de uma violação de direitos humanos em um mesmo procedimento cometida em períodos diferentes, foi considerada a data da primeira violação haja vista termos como objetivo calcular a diferença temporal entre o início da tramitação do procedimento e a violação de direitos humanos. Os únicos casos nessa categoria são: 1) Caso n 12.837 Clélia Lourdes Goldenberg e Rita de Cássia Rosa, em que as violações de direitos humanos aconteceram entre 1997 e 1998; 2) Caso no 12.675 Gabriel Sales Pimenta, em que as violações de direitos humanos aconteceram em 1982 e 2006; e 3) Caso no 12.907 M.V.M. e P.S.R. entre 1996 e 1997. 
Nos casos de desaparecimento forçado ${ }^{37}$, assim como quando a violação direitos humanos é continua, utilizei como data da violação aquela alegada pelos peticionários como início da violação. Os casos e petições em que a violação é tida como continua contra o Brasil no SIDH são:

Tabela 4: Casos e petições contra o Brasil no SIDH com violação contínua de Direitos Humanos

Casos e petições contra o Brasil no SIDH com violação contínua de Direitos Humanos

$N: 7$

\begin{tabular}{|c|c|c|c|c|c|c|c|}
\hline$U F$ & $\begin{array}{c}\text { N. do } \\
\text { Processo }\end{array}$ & Órgão & Fase & Nome do Caso & $\begin{array}{l}\text { Data de } \\
\text { Início do } \\
\text { Trâmite }\end{array}$ & $\begin{array}{l}\text { Data da } \\
\text { Alegada } \\
\text { Violação }\end{array}$ & Tema das violações \\
\hline RS & P-1140-04 & $\mathrm{CmDH}$ & Admissibilidade & $\begin{array}{c}\text { Felipe Néri } \\
\text { Dresch da } \\
\text { Silveira e outros }\end{array}$ & $12 / 10 / 2006$ & $\begin{array}{c}\text { 22/05/2006 } \\
\text { até o } \\
\text { presente }\end{array}$ & Prestação de Justiça \\
\hline PE & 12.875 & $\mathrm{CmDH}$ & $\begin{array}{l}\text { Análise de } \\
\text { Mérito }\end{array}$ & $\begin{array}{l}\text { Pedro Augusto } \\
\text { da Silva e outros }\end{array}$ & $27 / 10 / 2007$ & $\begin{array}{c}\text { 05/06/1997 } \\
\text { até o } \\
\text { presente }\end{array}$ & Prestação de Justiça \\
\hline SP & 12.654 & $\mathrm{CmDH}$ & $\begin{array}{l}\text { Análise de } \\
\text { Mérito }\end{array}$ & $\begin{array}{c}\text { Pessoas privadas } \\
\text { de liberdade na } \\
\text { Cadeia Pública } \\
\text { do Guarujá }\end{array}$ & $18 / 04 / 2007$ & $\begin{array}{c}\text { 01/01/1999 } \\
\text { até o } \\
\text { presente }\end{array}$ & $\begin{array}{c}\text { Violência } \\
\text { institucional contra } \\
\text { privados de } \\
\text { liberdade (sistema } \\
\text { prisional e } \\
\text { socioeducativo) } \\
\text { Tortura }\end{array}$ \\
\hline PE & 12.728 & $\mathrm{CmDH}$ & $\begin{array}{c}\text { Análise de } \\
\text { Mérito }\end{array}$ & $\begin{array}{c}\text { Povo Indígena } \\
\text { Xucuru } \\
\text { (Município de } \\
\text { Pesqueira) }\end{array}$ & $16 / 10 / 2002$ & $\begin{array}{c}\text { 01/01/1989 } \\
\text { até o } \\
\text { presente }\end{array}$ & $\begin{array}{l}\text { Violência contra } \\
\text { Indígenas } \\
\text { Prestação de Justiça }\end{array}$ \\
\hline SP & 12.461 & $\mathrm{CmDH}$ & $\begin{array}{l}\text { Análise de } \\
\text { Mérito }\end{array}$ & Rafael Lozano & $24 / 04 / 2003$ & $\begin{array}{c}\text { 01/01/2003 } \\
\text { até o } \\
\text { presente }\end{array}$ & Prestação de Justiça \\
\hline
\end{tabular}

${ }^{37}$ Segundo o artigo $2^{\circ}$ da Convenção, entende-se por desaparecimento forçado: "a prisão, a detenção, o sequestro ou qualquer outra forma de privação de liberdade que seja perpetrada por agentes do Estado ou por pessoas ou grupos de pessoas agindo com a autorização, apoio ou aquiescência do Estado, e a subsequente recusa em admitir a privação de liberdade ou a ocultação do destino ou do paradeiro da pessoa desaparecida, privando-a assim da proteção da lei”. 


\begin{tabular}{|c|c|c|c|c|c|c|c|}
\hline RR & 12.567 & $\mathrm{CmDH}$ & $\begin{array}{c}\text { Em negociacão } \\
\text { de acordo de } \\
\text { solução } \\
\text { amistosa }\end{array}$ & $\begin{array}{c}\text { Comunidade } \\
\text { Indígena Ananás } \\
\text { e outros }\end{array}$ & $30 / 01 / 2002$ & $\begin{array}{c}\text { 01/02/2000 } \\
\text { até o } \\
\text { presente }\end{array}$ & $\begin{array}{c}\text { Violência contra } \\
\text { defensores de } \\
\text { Direitos Humanos } \\
\text { Violência contra } \\
\text { Indígenas } \\
\text { Prestação de Justiça }\end{array}$ \\
\hline TO & & $\mathrm{CrDH}$ & $\begin{array}{c}\text { Cumprimento } \\
\text { de Resoluções } \\
\text { da Corte }\end{array}$ & $\begin{array}{c}\text { Caso Julia } \\
\text { Gomes Lund e } \\
\text { outros (Guerrilha } \\
\text { do Araguaia) vs. } \\
\text { Brasil }\end{array}$ & 07/08/1995 & $\begin{array}{c}\text { 01/01/1972 } \\
\text { até o } \\
\text { presente }\end{array}$ & $\begin{array}{c}\text { Crimes do período } \\
\text { da ditadura }\end{array}$ \\
\hline
\end{tabular}

Fonte: Elaboração própria. Dados da $\mathrm{CmDH}$, da $\mathrm{CrDH}$, do MRE e da SDH (disponível em: http://www.oas.org/pt/cidh/ Acesso em: 07 nov. 2015 e no Apêndice B).

Foram excluídas do cálculo todas as medidas de urgência outorgados contra o Brasil no período temporal estudado, uma vez que por sua definição as medidas de urgência buscam proteger as vítimas de violações de direitos humanos que se realizam no presente ou estão sob a sua iminência.

\section{Tipos de peticionários}

Ao analisar o perfil dos peticionários em procedimentos contra o Brasil no Sistema Interamericano de Direitos Humanos, verificou-se que a diferença entre as proporções dos diferentes tipos de peticionários não é muito expressiva. Isso indica que o trabalho de organizações de advocacy e litigância domésticos assim como internacionais têm feito um trabalho em prol da defesa dos direitos humanos na mesma ordem de magnitude (respectivamente $22 \%$ e $18 \%$ do total de peticionários), assim como a parceria entre organizações nacionais e internacionais para a defesa dos direitos humanos no Brasil também é comum (20\%). Igualmente, pode-se concluir que o conhecimento do Sistema Interamericano de Direitos Humanos por indivíduos, tanto vítimas como representantes de vítimas (advogados), mostra-se expressivo (18\% do total de peticionários). Procedimentos em que indivíduos em parceria com organizações internacionais e nacionais apresentaram o procedimento perante o SIDH (3\%), do mesmo modo quando o procedimento é apresentado por ouvidorias ou defensorias (2\%) ou em 
parceria com ONGs nacionais (2\%) mostraram não ter um perfil expressivo nos casos contra o Brasil no SIDH.

Figura 10: Proporção dos peticionários em procedimentos contra o Brasil no SIDH

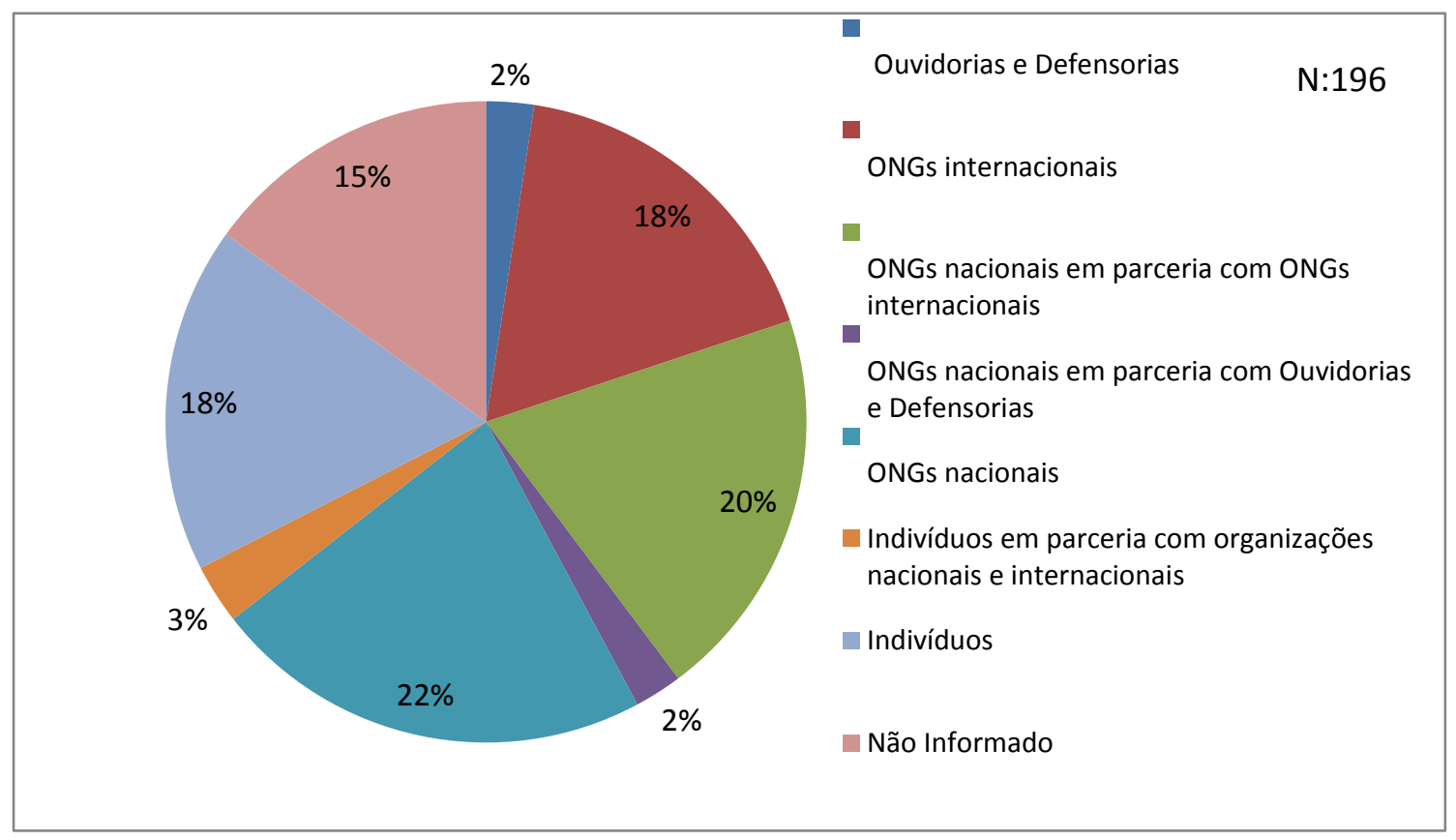

Fonte: Elaboração própria. Dados da $\mathrm{CmDH}$, da $\mathrm{CrDH}$, do MRE e da $\mathrm{SDH}$ (disponível em: http://www.oas.org/pt/cidh/ Acesso em: 07 nov. 2015 e no Apêndice B).

Artigos da Convenção Americana de Direitos Humanos mais invocados pelos peticionários em procedimentos contra o Brasil no Sistema Interamericano de Direitos Humanos

Quando analisado quais foram os artigos da CADH mais invocados pelos peticionários em procedimentos contra o Brasil entre 1988 e 2014, verificou-se que o artigo 25 sobre direito à proteção judicial é o mais invocado (21,43\%), seguidos pelo artigo 8 sobre direito às garantias judiciais $(18,65 \%)$ e o artigo 4 que diz respeito ao direito à vida $(12,50 \%)^{38}$. Isso corrobora com o fato de que a maioria dos procedimentos contra o Brasil no Sistema Interamericano de Direitos Humanos tem como tema a prestação de justiça $(26,88 \%)$ e indica mais uma vez que a capacidade do Poder Judiciário

\footnotetext{
38 1)Art.25: direito à proteção judicial $(21,43 \%)$; 2)Art.8: direito às garantias judiciais $(18,65 \%)$; 3)Art.4: direito à vida $(12,50 \%)$; 4)Art.1: obrigação de respeitar os direitos (12,30); 5)Art.5: direito à integridade pessoal (10,32\%); 6)Art.24: igualdade perante a lei (3,57\%); 7)Art.19: direito das crianças $(3,37 \%)$; 8)Art.2: obrigação de adotar disposições de direito interno (3,37\%); 9)Art.11: proteção da honra e da dignidade $(2,78 \%)$; 10)Art.7: direito à liberdade pessoal $(2,38 \%)$; 11)Art.13: liberdade de pensamento e de expressão $(2,18 \%)$. Outros artigos invocados representam $7,14 \%$ dos resultados.
} 
brasileiro é uma das grandes causas das violações de direitos humanos contra o Brasil no SIDH.

Figura 11: Artigos da CADH mais invocados pelos peticionários em procedimentos contra o Brasil no SIDH

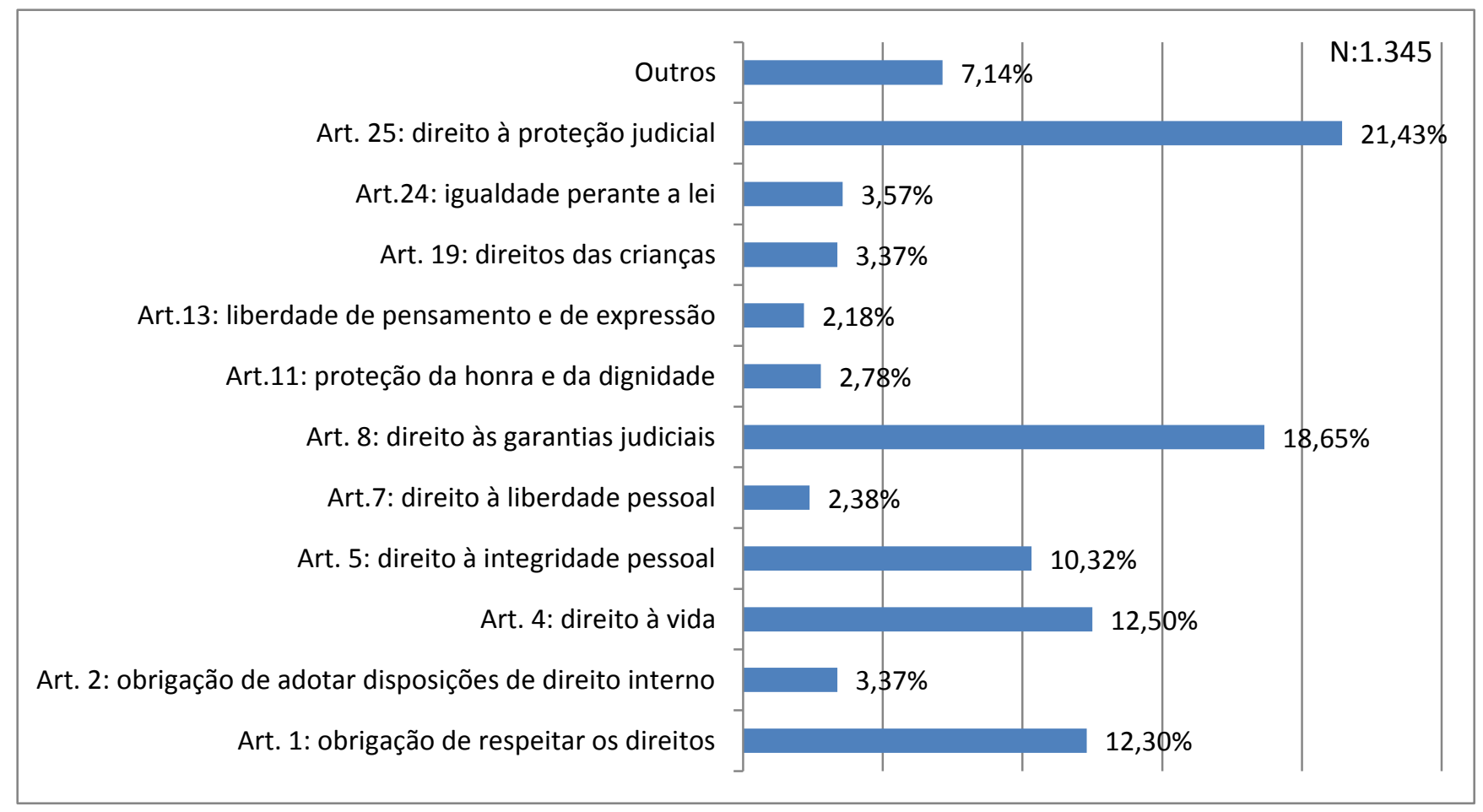

Fonte: Elaboração própria. Dados da $\mathrm{CmDH}$, da $\mathrm{CrDH}$, do MRE e da $\mathrm{SDH}$ (disponível em: http://www.oas.org/pt/cidh/ Acesso em: 07 nov. 2015 e no Apêndice B).

\subsection{Graus de state compliance do Brasil para com procedimentos do Sistema Interamericano de Direitos Humanos}

Nesta seção serão apresentados os resultados da pesquisa em que o universo da amostra é composto por todos os casos contra o Brasil em que a SIDH outorgou recomendações e resoluções, assim como acordos de solução amistosa finalizados. A tabela consolidada com todos os resultados apresentados nesta seção pode ser vista no “Apêndice C (Tabela com informações consolidadas sobre graus de compliance do Brasil no SIDH, p.313)”. Quando se falar em recomendações e resoluções fica subentendido a inclusão das medidas acordadas nos acordos de solução amistosa.

Dentro de nosso universo de estudo, verificou-se que há 26 casos em que o SIDH outorgou recomendações ou resoluções contra o Estado brasileiro. Dos 26 casos, 21 cumprem recomendações da Comissão, sendo que dois deles são acordos de solução 
amistosa finalizados e dois deles foram remitidos à Corte. Os outros cinco casos do Brasil são provenientes de decisão da $\mathrm{CrDH}$. Destes cinco casos, o Brasil cumpre resoluções apenas de quatro, uma vez que um dos casos contra o Estado brasileiro foi arquivado pela Corte por falta de provas (Caso Nogueira de Carvalho e outro vs. Brasil). Abaixo, encontra-se a lista de casos e acordos de solução amistosa analisados nesta seção:

Tabela 5: Casos contra o Brasil no SIDH em que foram emitidas recomendações, resoluções e acordos de solução amistosa

Casos contra o Brasil no SIDH em que foram emitidas recomendações, resoluções e acordos de solução amistosa

\begin{tabular}{|c|c|c|c|c|c|}
\hline & & & & & $N: 26$ \\
\hline$U F$ & N. Processo & Órgão & Fase & $\begin{array}{l}\text { Nome do } \\
\text { Caso }\end{array}$ & Resumo \\
\hline SP & 11.286 & Comissão & $\begin{array}{l}\text { Cumprimento de } \\
\text { Recomendações } \\
\text { da CmDH }\end{array}$ & $\begin{array}{c}\text { Aluísio } \\
\text { Cavalcanti e } \\
\text { outros }\end{array}$ & $\begin{array}{c}\text { Denúncia sobre diversos casos de } \\
\text { assassinato de jovens por forças } \\
\text { policiais }\end{array}$ \\
\hline $\mathrm{CE}$ & 12.019 & Comissão & $\begin{array}{l}\text { Cumprimento de } \\
\text { Recomendações } \\
\text { da CmDH } \\
\end{array}$ & $\begin{array}{c}\text { Antônio } \\
\text { Ferreira } \\
\text { Braga } \\
\end{array}$ & $\begin{array}{l}\text { Denúncia sobre detenção ilegalmente } \\
\text { feita pela polícia civil, inclusive com } \\
\text { tortura da vítima }\end{array}$ \\
\hline RO & 11.556 & Comissão & $\begin{array}{l}\text { Cumprimento de } \\
\text { Recomendações } \\
\text { da CmDH }\end{array}$ & $\begin{array}{l}\text { Massacre de } \\
\text { Corumbiara }\end{array}$ & $\begin{array}{l}\text { Denúncia sobre mortes de trabalhadores } \\
\text { rurais em ação da polícia para } \\
\text { reintegração de posse de terreno }\end{array}$ \\
\hline PR & 11.517 & Comissão & $\begin{array}{l}\text { Cumprimento de } \\
\text { Recomendações } \\
\text { da CmDH }\end{array}$ & $\begin{array}{l}\text { Diniz Bento } \\
\text { da Silva } \\
\text { (Teixeirinha) }\end{array}$ & $\begin{array}{l}\text { Denúncia sobre execução sumária de } \\
\text { membro do Movimento dos } \\
\text { Trabalhadores Rurais Sem Terra (MST) } \\
\text { por forças policiais }\end{array}$ \\
\hline RJ & 11.566 & Corte & $\begin{array}{l}\text { Início } \\
\text { procedimento na } \\
\text { Corte }\end{array}$ & $\begin{array}{l}\text { Favela Nova } \\
\text { Brasília } \\
\text { (Evandro } \\
\text { Oliveira e } \\
\text { outros) }\end{array}$ & $\begin{array}{l}\text { Denúncia sobre execuções extrajudiciais } \\
\text { de } 26 \text { pessoas - incluindo seis crianças - } \\
\text { no âmbito das incursões policiais feitas } \\
\text { pela Polícia Civil do Rio de Janeiro na } \\
\text { Favela Nova Brasília. Estas mortes } \\
\text { foram justificadas pelas autoridades } \\
\text { policiais mediante o levantamento de } \\
\text { "atas de resistência à prisão". }\end{array}$ \\
\hline PA & 12.066 & Corte & $\begin{array}{l}\text { Início } \\
\text { procedimento na } \\
\text { Corte }\end{array}$ & $\begin{array}{c}\text { Fazenda } \\
\text { Brasil Verde }\end{array}$ & $\begin{array}{l}\text { Denúncia sobre a situação de trabalho } \\
\text { escravo de milhares de trabalhadores em } \\
\text { fazenda no Pará, desaparecimento de } \\
\text { menores e denegação de justiça pelo } \\
\text { Estado } \\
\end{array}$ \\
\hline RJ & 11.634 & Comissão & $\begin{array}{l}\text { Cumprimento de } \\
\text { Recomendações } \\
\text { da CmDH }\end{array}$ & $\begin{array}{l}\text { Jaílton Néri } \\
\text { da Fonseca }\end{array}$ & $\begin{array}{l}\text { Denúncia sobre execução sumária de } \\
\text { menor por forças policiais em favela da } \\
\text { cidade do Rio de Janeiro }\end{array}$ \\
\hline PA & 11.287 & Comissão & $\begin{array}{l}\text { Cumprimento de } \\
\text { Recomendações } \\
\text { da CmDH }\end{array}$ & $\begin{array}{c}\text { João Canuto } \\
\text { de Oliveira }\end{array}$ & $\begin{array}{c}\text { Denúncia sobre a falta de investigação e } \\
\text { punição dos responsáveis pelo } \\
\text { homicídio de líder de trabalhadores } \\
\text { rurais no Pará }\end{array}$ \\
\hline
\end{tabular}




\begin{tabular}{|c|c|c|c|c|c|}
\hline PA & 11.289 & Comissão & $\begin{array}{l}\text { Cumprimento de } \\
\text { Acordo de } \\
\text { Solução } \\
\text { Amistosa } \\
\end{array}$ & $\begin{array}{l}\text { José Pereira e } \\
\text { outros }\end{array}$ & $\begin{array}{c}\text { Denúncia sobre redução de } \\
\text { trabalhadores a condições análogas à } \\
\text { escravidão e de demora e negligência no } \\
\text { processamento da ação criminal. }\end{array}$ \\
\hline MA & 12.426 & Comissão & $\begin{array}{l}\text { Cumprimento de } \\
\text { Acordo de } \\
\text { Solução } \\
\text { Amistosa } \\
\end{array}$ & $\begin{array}{l}\text { Meninos } \\
\text { Emasculados } \\
\text { do Maranhão }\end{array}$ & $\begin{array}{l}\text { Denúncia sobre caso de violência } \\
\text { doméstica com demora e negligência no } \\
\text { processamento da ação criminal }\end{array}$ \\
\hline BA & 12.308 & Comissão & $\begin{array}{l}\text { Cumprimento de } \\
\text { Recomendações } \\
\text { da CmDH }\end{array}$ & $\begin{array}{l}\text { Manoel Leal } \\
\text { de Oliveira }\end{array}$ & $\begin{array}{l}\text { Denúncia sobre assassinato de jornalista } \\
\text { após publicação de escândalo de } \\
\text { corrupção no jornal de que era editor }\end{array}$ \\
\hline $\mathrm{CE}$ & 12.051 & Comissão & $\begin{array}{l}\text { Cumprimento de } \\
\text { Recomendações } \\
\text { da CmDH }\end{array}$ & $\begin{array}{l}\text { Maria da } \\
\text { Penha } \\
\text { Fernandes }\end{array}$ & $\begin{array}{l}\text { Denúncia sobre caso de violência } \\
\text { doméstica com demora e negligência no } \\
\text { processamento da ação criminal }\end{array}$ \\
\hline PA & 11.405 & Comissão & $\begin{array}{l}\text { Cumprimento de } \\
\text { Recomendações } \\
\text { da CmDH }\end{array}$ & $\begin{array}{l}\text { Newton } \\
\text { Coutinho } \\
\text { Mendes }\end{array}$ & $\begin{array}{l}\text { Denúncia sobre mortes e ameaças de } \\
\text { mortes sofridas por defensores de } \\
\text { direitos humanos e pessoas ligadas à } \\
\text { ocupação de terras em razão de grupo de } \\
\text { extermínio formado por proprietários }\end{array}$ \\
\hline RR & 11.516 & Comissão & $\begin{array}{l}\text { Cumprimento de } \\
\text { Recomendações } \\
\text { da CmDH }\end{array}$ & $\begin{array}{l}\text { Ovelário } \\
\text { Tames }\end{array}$ & $\begin{array}{l}\text { Denúncia sobre detenção arbitrária da } \\
\text { vítima, que foi morta depois de } \\
\text { torturada por agentes de segurança }\end{array}$ \\
\hline SP & 10.301 & Comissão & $\begin{array}{l}\text { Cumprimento de } \\
\text { Recomendações } \\
\text { da CmDH } \\
\end{array}$ & $\begin{array}{l}\text { Parque São } \\
\text { Lucas }\end{array}$ & $\begin{array}{l}\text { Denúncia sobre tortura de presos no } \\
\text { distrito policial Parque São Lucas em } \\
\text { São Paulo } \\
\end{array}$ \\
\hline PR & 12.310 & Comissão & $\begin{array}{l}\text { Cumprimento de } \\
\text { Recomendações } \\
\text { da CmDH }\end{array}$ & $\begin{array}{l}\text { Sebastião } \\
\text { Camargo } \\
\text { Filho }\end{array}$ & $\begin{array}{l}\text { Denúncia sobre assassinato de membro } \\
\text { do MST no Paraná sem investigação e } \\
\text { indenização }\end{array}$ \\
\hline SP & 12.001 & Comissão & $\begin{array}{l}\text { Cumprimento de } \\
\text { Recomendações } \\
\text { da CmDH }\end{array}$ & $\begin{array}{c}\text { Simone } \\
\text { André Diniz }\end{array}$ & $\begin{array}{l}\text { Denúncia sobre discriminação racial } \\
\text { sofrida por empregada doméstica que } \\
\text { não foi contratada por ser negra }\end{array}$ \\
\hline RJ & 12.440 & Comissão & $\begin{array}{l}\text { Cumprimento de } \\
\text { Recomendações } \\
\text { da CmDH }\end{array}$ & $\begin{array}{l}\text { Wallace de } \\
\text { Almeida }\end{array}$ & $\begin{array}{c}\text { Denúncia sobre assassinato da vítima } \\
\text { em razão de abuso em operação policial, } \\
\text { inclusive com indícios de discriminação } \\
\text { racial }\end{array}$ \\
\hline SP & 11.291 & Comissão & $\begin{array}{l}\text { Cumprimento de } \\
\text { Recomendações } \\
\text { da CmDH }\end{array}$ & Carandiru & $\begin{array}{c}\text { Denúncia sobre o massacre promovido } \\
\text { por forças policiais ao invadirem o } \\
\text { presídio do Carandiru para debelar uma } \\
\text { rebelião }\end{array}$ \\
\hline RJ & 11.598 & Comissão & $\begin{array}{l}\text { Cumprimento de } \\
\text { Recomendações } \\
\text { da CmDH }\end{array}$ & $\begin{array}{l}\text { Alonso } \\
\text { Eugénio da } \\
\text { Silva }\end{array}$ & $\begin{array}{l}\text { Denúncia sobre homicídio de menor por } \\
\text { policial militar durante detenção por } \\
\text { suposto assalto }\end{array}$ \\
\hline RJ & 11.599 & Comissão & $\begin{array}{l}\text { Cumprimento de } \\
\text { Recomendações } \\
\text { da CmDH }\end{array}$ & $\begin{array}{l}\text { Marcos } \\
\text { Aurelio de } \\
\text { Oliveira }\end{array}$ & $\begin{array}{l}\text { Denúncia sobre execução sumária de } \\
\text { criança de rua por policial civil }\end{array}$ \\
\hline TO & - & Corte & $\begin{array}{l}\text { Cumprimento de } \\
\text { Resoluções da } \\
\text { Corte }\end{array}$ & $\begin{array}{l}\text { Caso Julia } \\
\text { Gomes Lund } \\
\text { e outros } \\
\text { (Guerrilha do } \\
\text { Araguaia) vs. } \\
\text { Brasil } \\
\end{array}$ & $\begin{array}{c}\text { Denúncia sobre o desaparecimento } \\
\text { forçado de militantes que participaram } \\
\text { da "Guerrilha do Araguaia", } \\
\text { combatendo o regime ditatorial } \\
\text { brasileiro, e sobre a falta de investigação } \\
\text { sobre os fatos }\end{array}$ \\
\hline PR & - & Corte & $\begin{array}{l}\text { Cumprimento de } \\
\text { Resoluções da } \\
\text { Corte }\end{array}$ & $\begin{array}{c}\text { Caso } \\
\text { Garibaldi vs. } \\
\text { Brasil }\end{array}$ & $\begin{array}{l}\text { Denúncia sobre assassinato de membro } \\
\text { do MST e sobre a falta de investigações. }\end{array}$ \\
\hline
\end{tabular}




\begin{tabular}{c|c|c|c|c|c}
\hline CE & - & Corte & $\begin{array}{c}\text { Cumprimento de } \\
\text { Resoluções da } \\
\text { Corte }\end{array}$ & $\begin{array}{c}\text { Caso Damião } \\
\text { Ximenes } \\
\text { Lopes vs. } \\
\text { Brasil }\end{array}$ & $\begin{array}{c}\text { Denúncia sobre a morte de portador de } \\
\text { deficiência mental internado em clínica, } \\
\text { em razão de maus-tratos e das condições } \\
\text { do local, sem a devida investigação }\end{array}$ \\
\hline PR & - & Corte & $\begin{array}{c}\text { Cumprimento de } \\
\text { Resoluções da } \\
\text { Corte }\end{array}$ & $\begin{array}{c}\text { Caso Arley } \\
\text { José Escher e } \\
\text { outros vs. } \\
\text { Brasil }\end{array}$ & $\begin{array}{c}\text { Denúncia sobre grampos telefônicos } \\
\text { feitos irregularmente pela polícia e } \\
\text { autorizados pelo poder judiciário, com } \\
\text { posterior divulgação das gravações e } \\
\text { dano à imagem das vítimas }\end{array}$ \\
\hline RN & - & Corte & Arquivada & $\begin{array}{c}\text { Caso } \\
\text { Nogueira de } \\
\text { Carvalho e } \\
\text { outro vs. } \\
\text { Brasil }\end{array}$ & Denúncia sobre assassinato não \\
investigado
\end{tabular}

Fonte: Elaboração própria. Dados da $\mathrm{CmDH}$, da $\mathrm{CrDH}$, do MRE e da SDH (disponível em: http://www.oas.org/pt/cidh/ Acesso em: 07 nov. 2015 e no Apêndice C).

Casos contra o Brasil no SIDH em que foram outorgadas recomendações e resoluções classificados por região, unidade federativa e tema das violações

Quando analisado a região em que cada uma das violações de direitos humanos foi cometida nos casos contra o Brasil no SIDH em que foram proferidas recomendações e sentenças, temos que, em ordem decrescente, eles tiveram origem em: 1) Sudeste (35\%); 2) Norte $(23 \%) ; 3)$ Nordeste $(23 \%)$; 4) Sul (15\%); e Centro-Oeste (4\%). O resultado é consoante com os dados apresentados em relação a todos os procedimentos contra o Brasil no SIDH, exceto pelo fato da Região Sul ultrapassar a Região Centro-Oeste nas taxas específicas sobre os casos em que houveram recomendações e sentenças do SIDH.

Figura 12: Casos contra o Brasil no SIDH em que foram outorgadas recomendações e resoluções classificados pela região do País em que as violações foram engendradas

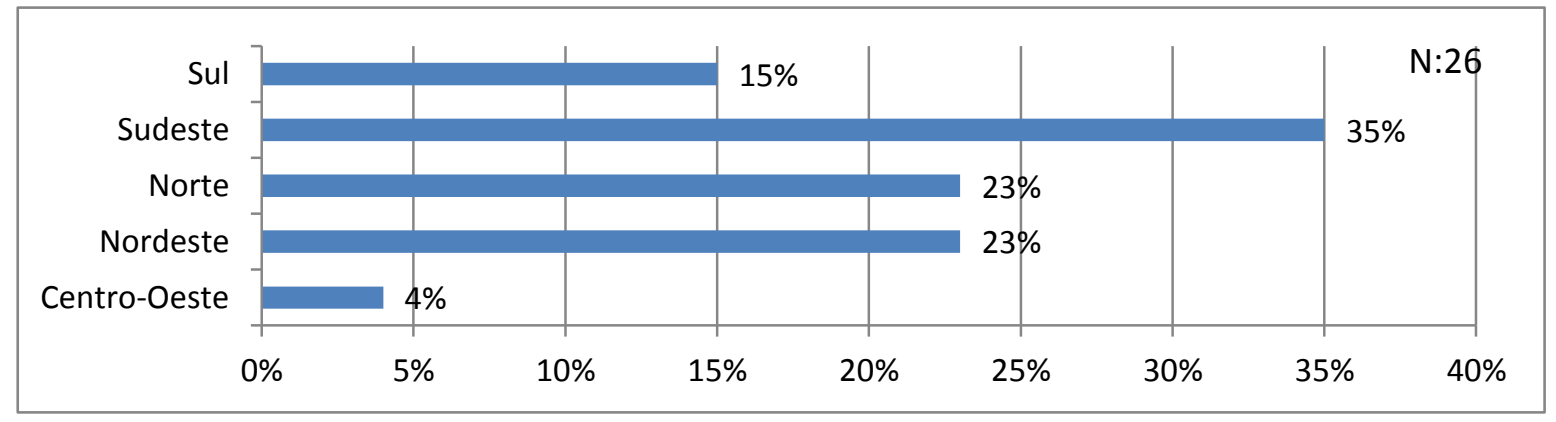

Fonte: Elaboração própria. Dados da $\mathrm{CmDH}$, da $\mathrm{CrDH}$, do MRE e da $\mathrm{SDH}$ (disponível em: http://www.oas.org/pt/cidh/ Acesso em: 07 nov. 2015 e no Apêndice C).

Se classificados por unidade federativa, observa-se que o universo de dados estudado é originário, em ordem decrescente, nos seguintes estados: 1) 19\% são 
originários do Rio de Janeiro; 2) 15\% de São Paulo; 3) 15\% do Paraná; 4) 15\% do Pará; 5) $12 \%$ do Ceará; 6) 4\% do Tocantins; 7) 4\% de Roraima; 8) 4\% de Rondônia; 9) 4\% do Rio Grande do Norte; 10) 4\% do Maranhão; e 11) 4\% da Bahia. Logo, apenas em 11 unidades federativas aconteceram violações de direitos humanos que foram objeto de recomendações e sentenças do $\mathrm{SIDH}$, sendo que a maioria dos casos se concentram apenas quatro estados. São eles: Rio de Janeiro, São Paulo, Pará e Paraná.

Figura 13: Casos contra o Brasil no SIDH em que foram outorgadas recomendações e resoluções classificados pela unidade federativa em que as violações foram engendradas

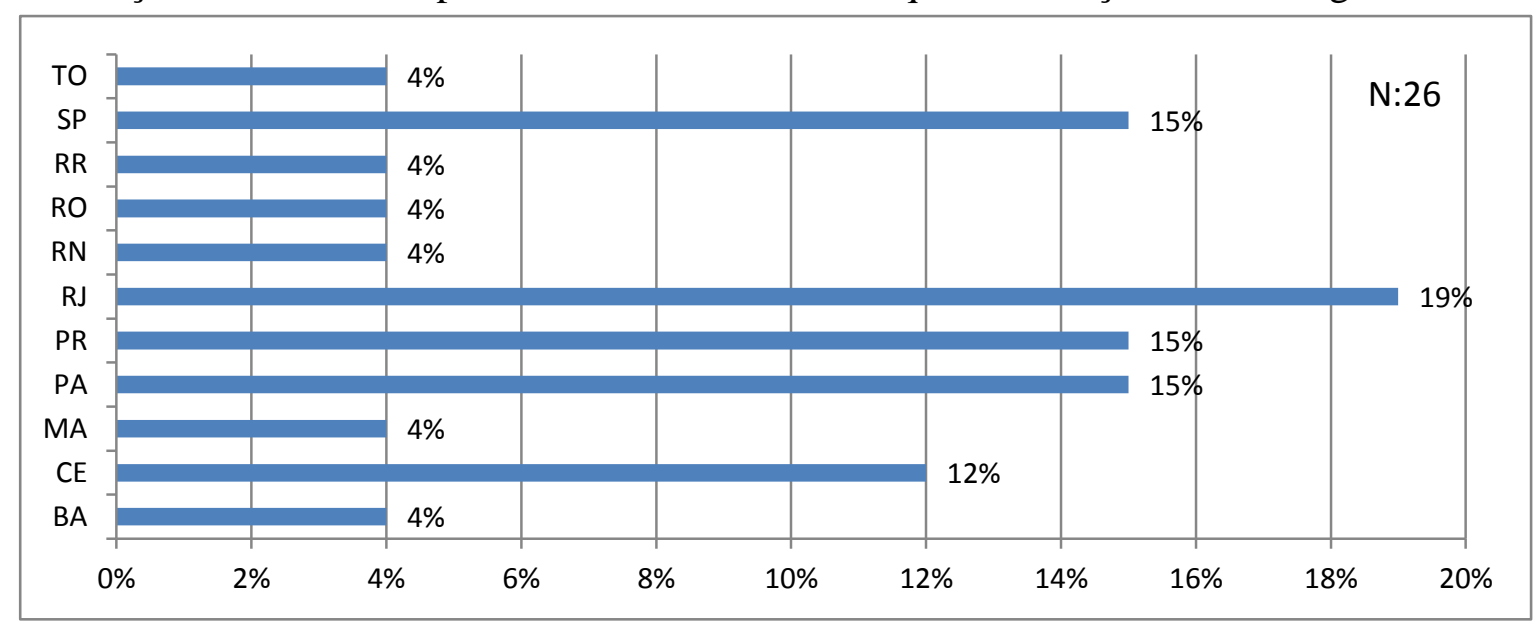

Fonte: Elaboração própria. Dados da $\mathrm{CmDH}$, da $\mathrm{CrDH}$, do MRE e da $\mathrm{SDH}$ (disponível em: http://www.oas.org/pt/cidh/ Acesso em: 07 nov. 2015 e no Apêndice C).

Ao se observar o tema dos casos contra o Brasil no SIDH em que foram outorgadas recomendações e resoluções tem que, em ordem decrescente, eles são compostos por: 1) Prestação de Justiça (34\%); 2) Violência policial (23\%); 3) Violência no campo (17\%); 4) Violência contra menores $(6 \%)$; 5) Tortura (6\%); 6) Racismo (4\%); 7) Violência contra defensores de Direitos Humanos (2\%); 8) Violência institucional contra privados de liberdade (sistema prisional e socioeducativo) (2\%); 9) Violência contra mulheres $(2 \%)$; 10) Violência contra indígenas (2\%); e 11) Crimes do período da ditadura $(2 \%)$.

Esses resultados indicam que tanto em todos os procedimentos contra o Brasil no SIDH como naqueles em que a Comissão e Corte proferiram recomendações e sentenças há a predominância de violações de direitos humanos relacionadas à prestação de justiça e à violência policial. Há também uma diminuição expressiva da relação de casos que tem como temática a violência contra privados de liberdade em que foram outorgadas recomendações e sentenças. Isto pode vir a demostrar que o SIDH ainda não foi capaz de analisar um caso expressivo o suficiente para que seja possível a criação de uma 
jurisprudência continental. Nota-se que a maioria dos procedimentos relacionados à violência contra privados de liberdade é composta por medidas de urgência, isso é uma das causas para a diminuição das taxas desse tipo específico de violência nos casos em que foram proferidas recomendações e sentenças pelo SIDH.

Igualmente, observa-se que há um aumento nas taxas relacionadas à violência no campo entre todos os procedimentos contra o Brasil no SIDH e aqueles apenas em que foram proferidas recomendações e sentenças. Os outros temas dos casos contra o Brasil no SIDH em que foram outorgadas recomendações e resoluções mostram não ser expressivos.

Figura 14: Temas dos casos contra o Brasil no SIDH em que foram outorgadas recomendações e resoluções classificados por unidade federativa em que as violações foram engendradas

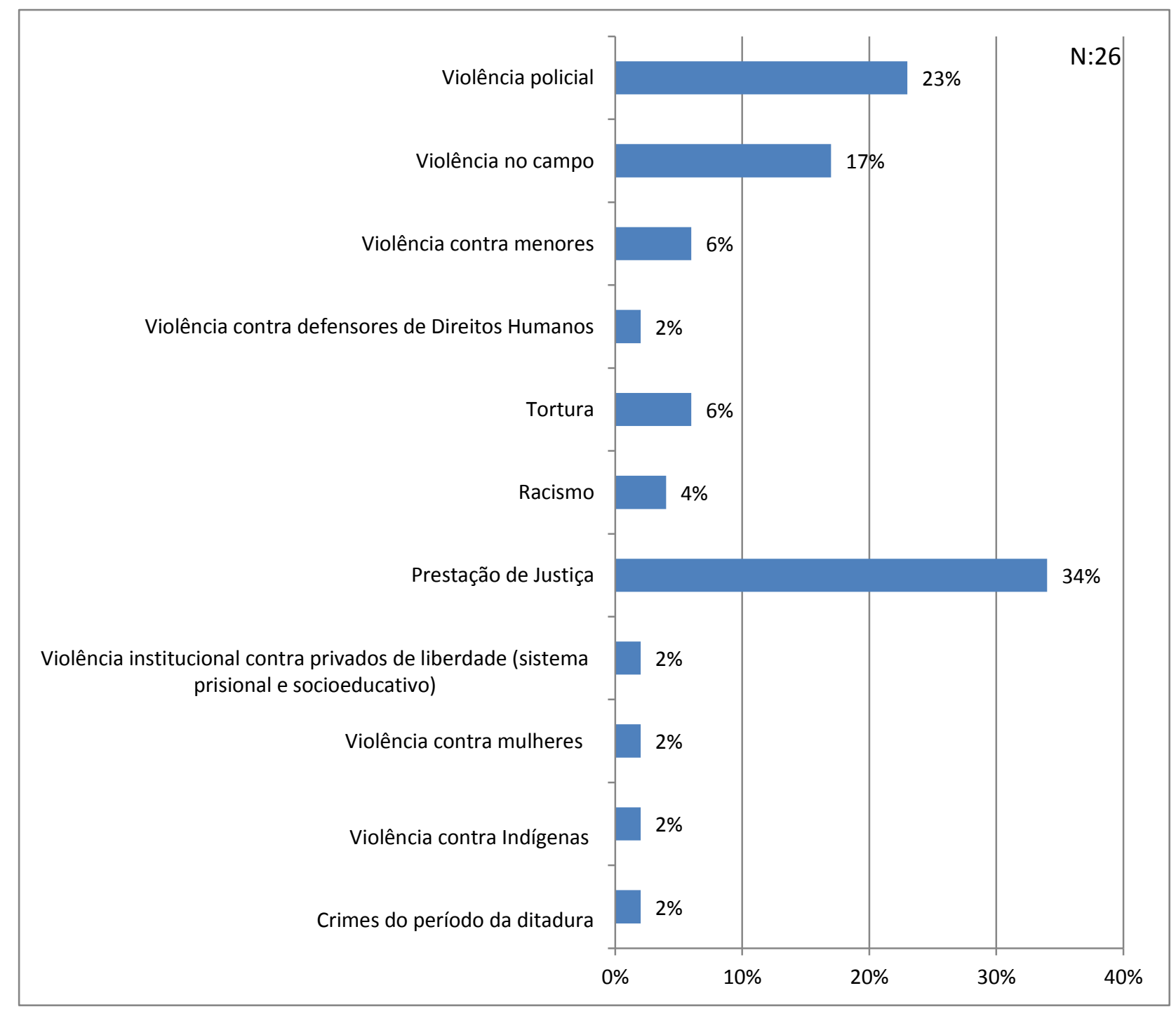

Fonte: Elaboração própria. Dados da $\mathrm{CmDH}$, da $\mathrm{CrDH}$, do MRE e da $\mathrm{SDH}$ (disponível em: http://www.oas.org/pt/cidh/ Acesso em: 07 nov. 2015 e no Apêndice C). 
Recomendações, resoluções e seus objetivos

A partir da nossa amostra do universo estudado, verifica-se que dos 26 casos contra o Brasil no SIDH, incluindo-se também os acordos de solução amistosa finalizados, a Comissão e a Corte outorgaram juntas 161 medidas contra o Estado brasileiro, sendo 136 recomendações da Comissão e 25 resoluções da Corte.

Usarei neste estudo as categorias utilizadas por Basch et al (2010, p.13), em que as recomendações e resoluções regularmente adotadas pelo SIDH são classificadas a partir de seus objetivos individuais. São eles:

- Recompensação de pessoas ou grupos: Compensações econômicas monetárias, compensações econômicas não monetárias, reparações simbólicas, restituição de direitos.

- Prevenção de futuras violações de direitos: Reformas jurídicas; treinamento de funcionários; aumentar a consciência da sociedade civil; fortalecimento, criação e reforma de instituições públicas, outros meios preventivos.

- Investigação e responsabilização de violações de direitos humanos: Com reformas jurídicas e sem reformas jurídicas.

- Proteção de vítimas e testemunhas e outros.

Observa-se que quando as 161 recomendações e resoluções outorgadas contra o Brasil pelo SIDH são categorizadas por seus objetivos temos que em ordem decrescente eles representam: 1) Prevenção de futuras violações de direitos (39\%); 2) Recompensação de pessoas ou grupos (32\%); 3) Investigação e responsabilização de violações de direitos humanos (22\%); e 4) Proteção de vítimas e testemunhas e outros (7\%).

Isso indica que o Sistema Interamericano de Direitos Humanos ao outorgar suas medidas para remediar a violação de direitos humanos e as suas consequências no Brasil tem como principal objetivo fazer com que o Estado adote medidas para prevenir futuras violações de direitos, tanto a partir da mudança do ordenamento jurídico interno como a partir da capacitação de agentes estatais, reforma de instituições públicas e outros. O resultado é consoante com um dos objetivos principais do SIDH: a criação de uma jurisprudência continental de proteção dos direitos humanos na América. 
Figura 15: Recomendações e Resoluções outorgadas contra o Brasil no SIDH classificadas por seus objetivos

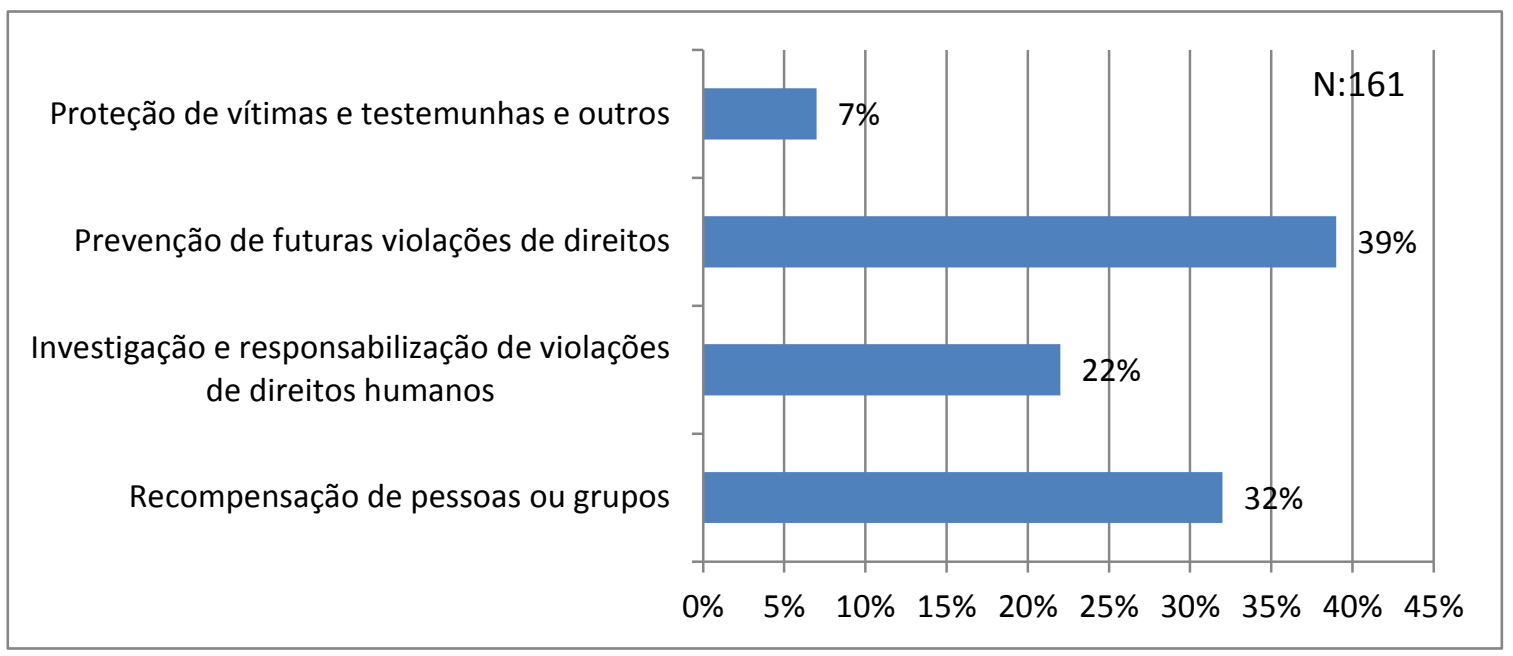

Fonte: Elaboração própria. Dados da $\mathrm{CmDH}$, da $\mathrm{CrDH}$, do MRE e da SDH (disponível em: http://www.oas.org/pt/cidh/ Acesso em: 07 nov. 2015 e no Apêndice C).

Por meio da mesma classificação, Basch et al (2010, p.14), também categoriza as recomendações e resoluções em 13 tipos diferentes de medidas, que podem ser distinguidas ambos pelo tipo de ação requerida pelo Estado para o seu cumprimento como em termos das ações em prol dos beneficiários. São eles:

- Reparação econômica monetária: Medida requerida aos Estados que consiste no pagamento de quantias em dinheiro a indivíduos ou grupos;

- Reparação econômica não monetária: Medida que visa fornecer acesso a algum serviço ou bem específico, ou para destinar recursos para sua provisão ou compra. Por exemplo, bolsas de estudo e assistência médica, criação de fundos para o desenvolvimento produtivo comunitário ou à implementação de programas de saúde, moradia e educação, ou a entrega de terras ou imóveis;

- Reparação simbólica: Medida dirigida a restaurar a dignidade e reparar moralmente as vítimas e para tornar público o reconhecimento do Estado de sua responsabilidade. Esta categoria inclui: colocar placas; realizar eventos públicos; dar o nome de vítimas a estabelecimentos, ruas, bolsas de estudos ou espaços públicos; divulgar publicamente sentenças da Corte ou relatórios da CIDH e outras formas de homenagem ou memória das violações e de suas vítimas. Como reparação simbólica se incluem também a restituição e a transferência dos restos mortais das vítimas a seus familiares;

- Reparação por restituição de direitos: Medida para restituir às vítimas no gozo dos direitos violados quando a ação necessária não seja de eminente conteúdo 
econômico. Por exemplo, a redesignação de um funcionário para a posição da qual ele foi demitido, a readmissão de funcionários do Poder Judiciário que tenham sido ilegitimamente demitidos, a libertação de pessoas detidas, a anulação de condenações, a realização de novos julgamentos com as devidas garantias processuais, a exclusão da vítima de registros de antecedentes criminais, a reinserção de uma pessoa no sistema de pensões ou o fornecimento de medidas de segurança para que pessoas despejadas possam voltar a habitar suas terras;

- Prevenção por meio da formação de agentes públicos: Capacitação ou educação, em determinados temas vinculados com a proteção de direitos humanos, de agentes e funcionários públicos, tais como membros de forças de segurança policial ou militares, da administração pública ou do Poder Judiciário;

- Prevenção por meio da conscientização da população: Lançamento de programas ou campanhas de difusão ou educação pública, a fim de gerar consciência da sociedade sobre questões necessárias para o exercício dos direitos humanos. Estas medidas superam a simples celebração da memória da violação ou de homenagem à vítimas, visando divulgar e promover direitos humanos em geral;

- Prevenção por meio de reformas jurídicas: Reformas legislativas, de decretos, ou de procedimentos administrativos para implementar novas políticas públicas ou reformar as já existentes. Foram excluídos dessa categoria as recomendações, compromissos ou ordens para adotar lei ou sancionar um decreto com a única finalidade de criar uma determinada instituição pública;

- Prevenção por meio do fortalecimento, criação, ou reforma de instituições públicas: Por exemplo, aqui se incluem recomendações, compromissos e ordens para fazer o necessário para cumprir com o que a lei estatal dispõe e cuja infração propiciou a violação de direitos;

- Prevenção sem especificar medidas: Recomendação ou compromisso de fazer o necessário para evitar a repetição de violações de direitos como as ocorridas no caso. Foram incluídas somente as recomendações que não especificam de nenhuma maneira quais ações devem ser adotadas pelo Estado para o cumprimento da sua obrigação perante o Sistema;

- Investigação e sanção com reforma legal: Recomendações, compromissos ou ordens de investigar e sancionar as violações de direitos humanos que exigem, para seu cumprimento, que o Estado execute reformas jurídicas (em sentido amplo) ou em seu sistema de justiça. Por exemplo, a anulação de leis de anistia, 
ou de indultos, ou a modificação de critérios normativos ou jurisprudenciais relativos à aplicação da coisa julgada ou à prescrição da ação;

- Investigação e sanção sem reforma legal: Investigar e sancionar as violações de direitos humanos identificadas, cujo cumprimento não requer modificação da lei. Trata-se de casos nos quais a justiça pode atuar sem a necessidade de superar obstáculos normativos;

- Proteção de vítimas e testemunhas: Medidas específicas de proteção de vítimas ou testemunhas baseadas no risco de que sejam perseguidas, ou por terem comparecido ao Sistema Interamericano de Direitos Humanos ou por terem participado dos processos nacionais de investigação das violações de direitos humanos. Foi decidido analisar tais medidas em uma categoria independente porque essas medidas exigem ações distintas e autônomas do processo principal e porque pode haver casos em que o Estado cumpra plenamente com a investigação e a sanção das violações sem cumprir com a proteção de testemunhas e vice-versa. Além disso, essas medidas não visam à reparação e nem apontam para a prevenção de violações de direitos humanos de modo genérico. Restringem-se à proteção de pessoas específicas indicadas pela Corte ou pela Comissão; e

- Outros: Todas as medidas recomendadas, acordadas ou ordenadas ao Estado que não podem ser classificadas em uma das 12 categorias anteriores.

$\mathrm{Na}$ figura 16, a seguir, é possível analisar a representação gráfica das taxas de incidência de cada um dos tipos de medidas aplicadas pelo Sistema Interamericano contra o Estado brasileiro ${ }^{39}$.

\footnotetext{
${ }^{39}$ Observa-se que, em ordem decrescente, elas representam: 1) Reparação econômica monetária (18\%); 2) Investigação e sanção sem reforma legal (15\%); 3) Prevenção por meio do fortalecimento, criação, ou reforma de instituições públicas (14\%); 4) Reparação simbólica (12\%); 5) Prevenção por meio de reformas jurídicas (11\%); 6) Prevenção por meio da formação de agentes públicos (8\%); 7) Investigação e sanção com reforma legal (7\%); 8) Prevenção por meio da conscientização da população (4\%); 9) Prevenção sem especificar medidas $(2 \%)$; 10) Reparação econômica não monetária $(2 \%)$; e Proteção de vítimas e testemunhas (1\%). Outros representam $6 \%$ das resoluções e medidas contra o Estado brasileiro no SIDH.
} 
Figura 16: Recomendações e Resoluções outorgadas contra o Brasil no SIDH classificadas por seu tipo

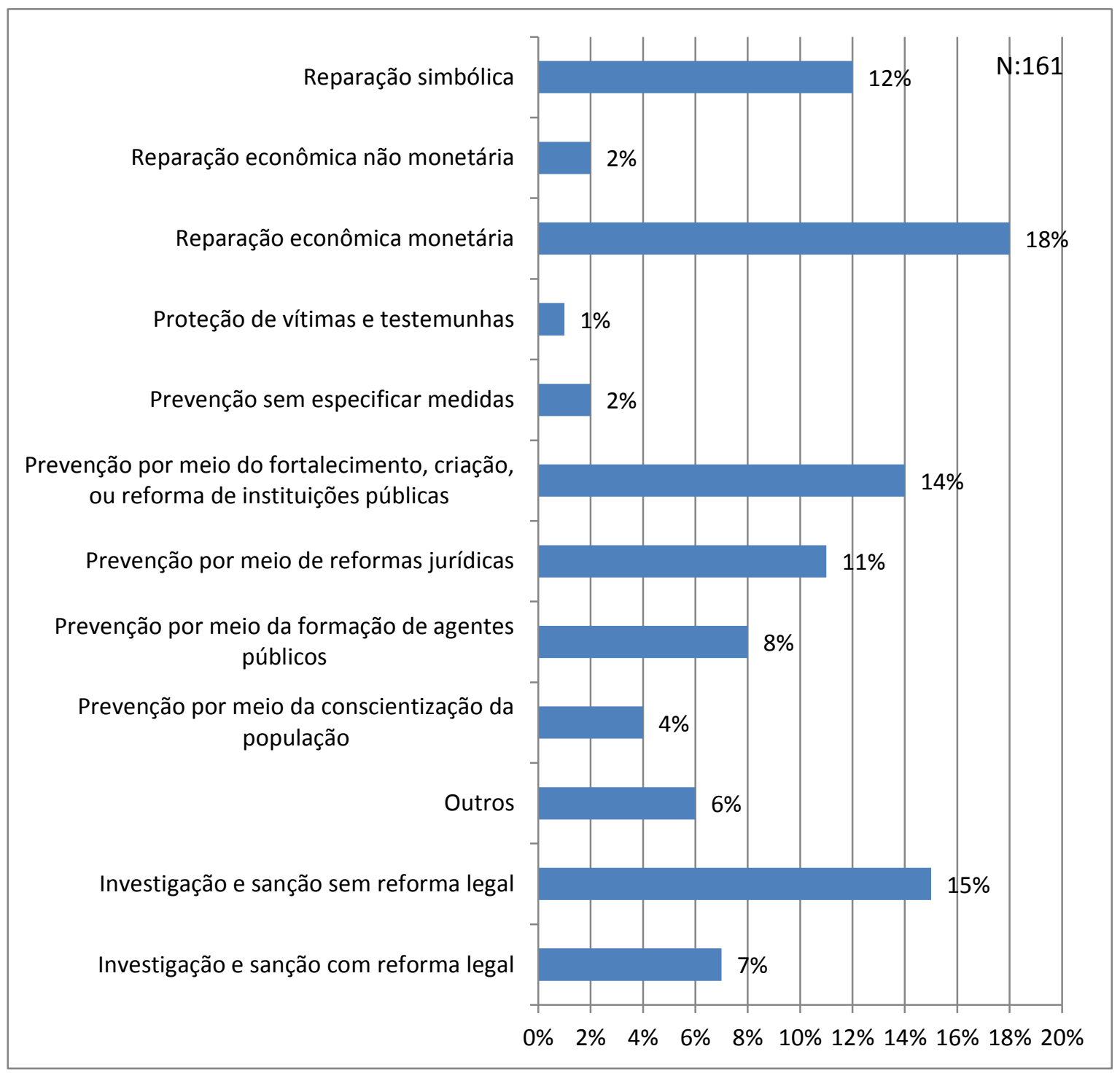

Fonte: Elaboração própria. Dados da $\mathrm{CmDH}$, da $\mathrm{CrDH}$, do MRE e da $\mathrm{SDH}$ (disponível em: http://www.oas.org/pt/cidh/ Acesso em: 07 nov. 2015 e no Apêndice C).

Ao se atentar para qual órgão emitiu cada medida, Comissão ou Corte, de acordo com a classificação acima, observa-se que a maioria das recomendações emitidas pela Comissão Interamericana de Direitos Humanos visa à prevenção de futuras violações de direitos (34\%), entre elas: prevenção por meio de reformas jurídicas (12\%), prevenção por meio da formação de agentes públicos (9\%), prevenção por meio do fortalecimento, criação, ou reforma de instituições públicas (7\%), prevenção sem especificar medidas (4\%) e prevenção por meio da conscientização da população (2\%). A seguir, estão as medidas que visam à reparação econômica monetária (20\%) e à investigação e sanção sem reforma legal (20\%). Logo depois aparecem a investigação e sanção com reforma 
legal (11\%), outros (8\%), reparação simbólica (6\%), e Proteção de vítimas e testemunhas $(1 \%)$.

De maneira geral, os resultados demonstram que há uma tentativa da Comissão de além de gerar uma jurisprudência continental de proteção dos direitos humanos também fazer com que as vítimas tenham acesso à justiça de forma integral, seja por meio de reparação econômica, de investigação e sanção de violações de direitos humanos com ou sem reformas jurídicas no ordenamento interno. De maneira secundária, os resultados refletem que a Comissão não possui como principal foco em suas medidas a mudança de instituições públicas ou a capacitação de agentes estatais como forma de prevenção de futuras violações. Geralmente, essas medidas são proferidas quando o caso específico fora causado por uma instituição específica do Estado, como a Polícia Militar de uma unidade federativa.

Quando analisamos os acordos de solução amistosa, observa-se que $82 \%$ do total das medidas acordadas visam à prevenção de futuras violações de direitos: 1) medidas de prevenção por meio do fortalecimento, criação, ou reforma de instituições públicas representam $47 \%$ do total das medidas acordadas; 2) $16 \%$ prevenção por meio de reformas jurídicas; 3) 13\% prevenção por meio da conscientização da população; 4) 6\% prevenção por meio da formação de agentes públicos; 5) $6 \%$ reparação econômica não monetária; 6) 3\% reparação econômica monetária; 7) 3\% reparação simbólica; e 8) 3\% investigação e sanção sem reforma legal.

Diferentemente das medidas proferidas pela Comissão, os casos em que as partes entraram em acordo de solução amistosa demostram que há uma grande preocupação das vítimas e peticionários de incluírem medidas que façam com que as violações de direitos humanos não aconteçam novamente pelo fortalecimento, criação ou reforma de instituições públicas. Isso demostra que os peticionários e vítimas possuem um grande poder de barganha vis-à-vis o Estado nessa matéria.

Observa-se que há certa reticência do Estado brasileiro a aprovar medidas que envolvam reformas do ordenamento jurídico interno em acordos de solução amistosa. Lembra-se que o Estado busca acordar apenas medidas em que este tenha a certeza que poderá cumpri-las, uma vez que se não cumprir as medidas do acordo de solução amistosa, o caso ainda poderá ser encaminhado à Corte Interamericana de Direitos Humanos e continuar sua tramitação no SIDH. Logo, medidas que envolvem reformas jurídicas são mais difíceis de serem cumpridas e, por isso, não são expressivas em 
acordos de solução amistosa. Medidas relacionadas à reparação das vítimas (monetária, não monetária e simbólica) também não são expressivas.

Verifica-se ao analisar as resoluções emitidas por sentenças da Corte Interamericana de Direitos Humanos que sua maioria corresponde à recompensação de pessoas ou grupos (73\%). As medidas em ordem decrescente visam: 1) reparação simbólica $(41 \%)$; 2) reparação econômica monetária (28\%); 3) investigação e sanção sem reforma legal (14\%); 4) prevenção por meio da formação de agentes públicos (7\%); 5) reparação econômica não monetária $(4 \%)$; 6) prevenção por meio de reformas jurídicas $(3 \%)$; e 7$)$ outros $(3 \%)$.

Os dados coletados sobre os tipos de medidas outorgadas contra o Brasil no Sistema Interamericano de Direitos Humanos classificadas por seus objetivos e órgão de emissão podem ser vistos na tabela seis a seguir.

Isso demostra que as medidas emitidas pela Comissão e Corte, assim como aquelas acordadas em solução amistosa, possuem escopos diferentes. Enquanto a Comissão se preocupa com a criação de uma jurisprudência continental de proteção dos direitos humanos por meio de medidas que visam à prevenção de futuras violações de direitos por meio de reformas jurídicas internas, as medidas emitidas pela Corte Interamericana de Direitos Humanos têm como objetivo o acesso à justiça de forma integral pelas vítimas. Já as medidas acordadas em solução amistosa buscam em sua maioria a prevenção de futuras violações de direitos humanos por meio do fortalecimento, criação ou reforma de instituições públicas.

Essa diferença de escopo das medidas emitidas pelo Sistema Interamericano de Direitos Humanos pode ser explicada pela diferença de mandato de cada órgão. Lembrase que a Comissão é um órgão político com características de um órgão jurisdicional encarregada do controle do comportamento dos Estados, sendo este comportamento regrado por normas jurídicas tanto nacionais como internacionais. Logo, a busca da mudança da prática estatal por meio de reformas jurídicas está em uma de suas principais ações. Não obstante, a Corte Interamericana de Direitos Humanos é um tribunal internacional que além de se mostrar preocupado com a mudança da prática estatal também se mostra preocupado com a violação de direitos humanos em si e em como é possível fazer com que as vítimas e peticionários possam ter acesso à justiça de maneira integral.

Já os acordos de solução amistosa são um caso a parte. Eles demostram que os peticionários, vítimas e o Estado brasileiro possuem um processo de negociação em que 
ambas as partes buscam deixar claro quais são seus interesses e limites de ação. Nesse sentido, os peticionários e vítimas buscam acordar medidas que previnam a repetição das violações de direitos humanos por meio do fortalecimento, reforma e criação de instituições públicas, enquanto o Estado busca acordar medidas que sejam de fácil cumprimento.

Tabela 6: Decisões outorgadas contra o Brasil no SIDH classificadas pelos os seus objetivos e tipos

\begin{tabular}{|c|c|c|c|c|c|c|c|c|}
\hline $\begin{array}{c}\text { Tipos de Recomendações e } \\
\text { Resoluções }\end{array}$ & $\begin{array}{l}\text { Recomendações } \\
\quad(\text { Comissão })\end{array}$ & $\%$ & $\begin{array}{l}\text { Acordo de } \\
\text { Solução } \\
\text { Amistosa } \\
\end{array}$ & $\%$ & $\begin{array}{l}\text { Resoluções } \\
\text { (Corte) }\end{array}$ & $\%$ & Total & $\%$ \\
\hline \multicolumn{9}{|c|}{ Recompensação de pessoas ou grupos } \\
\hline Reparação econômica monetária & 20 & $20 \%$ & 1 & $3 \%$ & 8 & $28 \%$ & 29 & $18 \%$ \\
\hline $\begin{array}{c}\text { Reparação econômica não } \\
\text { monetária }\end{array}$ & - & - & 2 & $6 \%$ & 1 & $4 \%$ & 3 & $2 \%$ \\
\hline Reparação simbólica & 6 & $6 \%$ & 1 & $3 \%$ & 12 & $41 \%$ & 19 & $12 \%$ \\
\hline \multicolumn{9}{|c|}{ Investigação e responsabilização de violações de direitos humanos } \\
\hline $\begin{array}{l}\text { Investigação e sanção com } \\
\text { reforma legal }\end{array}$ & 11 & $11 \%$ & - & - & - & - & 11 & $7 \%$ \\
\hline $\begin{array}{l}\text { Investigação e sanção sem } \\
\text { reforma legal }\end{array}$ & 20 & $20 \%$ & 1 & $3 \%$ & 4 & $14 \%$ & 25 & $15 \%$ \\
\hline \multicolumn{9}{|c|}{ Prevenção de futuras violações de direitos } \\
\hline $\begin{array}{c}\text { Prevenção por meio da } \\
\text { conscientização da população }\end{array}$ & 2 & $2 \%$ & 4 & $13 \%$ & - & - & 6 & $4 \%$ \\
\hline $\begin{array}{l}\text { Prevenção por meio da } \\
\text { formação de agentes públicos }\end{array}$ & 9 & $9 \%$ & 2 & $6 \%$ & 2 & $7 \%$ & 13 & $8 \%$ \\
\hline $\begin{array}{c}\text { Prevenção por meio de reformas } \\
\text { jurídicas }\end{array}$ & 12 & $12 \%$ & 5 & $16 \%$ & 1 & $3 \%$ & 18 & $11 \%$ \\
\hline $\begin{array}{l}\text { Prevenção por meio do } \\
\text { fortalecimento, criação, ou } \\
\text { reforma de instituições públicas }\end{array}$ & 7 & $7 \%$ & 15 & $47 \%$ & - & - & 22 & $14 \%$ \\
\hline $\begin{array}{c}\text { Prevenção sem especificar } \\
\text { medidas }\end{array}$ & 4 & $4 \%$ & - & - & - & - & 4 & $2 \%$ \\
\hline \multicolumn{9}{|c|}{ Proteção de vítimas e testemunhas e outros } \\
\hline Outros & 8 & $8 \%$ & 1 & - & 1 & $3 \%$ & 10 & $6 \%$ \\
\hline $\begin{array}{l}\text { Proteção de vítimas e } \\
\text { testemunhas }\end{array}$ & 1 & $1 \%$ & - & - & - & & 1 & $1 \%$ \\
\hline Total & 100 & $\begin{array}{c}100 \\
\%\end{array}$ & 32 & $\begin{array}{c}100 \\
\%\end{array}$ & 29 & $\begin{array}{c}100 \\
\%\end{array}$ & 161 & $100 \%$ \\
\hline & & & & & & & & $\mathrm{N}: 161$ \\
\hline
\end{tabular}

Fonte: Elaboração própria. Dados da $\mathrm{CmDH}$, da $\mathrm{CrDH}$, do MRE e da $\mathrm{SDH}$ (disponível em: http://www.oas.org/pt/cidh/ Acesso em: 07 nov. 2015 e no Apêndice C). 
Lembra-se que a maioria dos procedimentos contra o Brasil no SIDH, incluindo as medidas de urgência, diz respeito à prestação de justiça e à violência institucional cometida por agentes de Estado. Por isso, a busca dos peticionários e vítimas pelo fortalecimento, reforma e criação de instituições públicas pode vir a indicar que estes acreditam que a melhor forma de mudar a prática estatal é a partir da mudança de suas instituições e não simplesmente pela mudança de seu ordenamento jurídico. Ainda assim, lembra-se que organizações da sociedade civil que lutam pelo respeito dos direitos humanos conhecem melhor a realidade do País e sabem quais são as medidas que terão melhor efetividade na prática. Por exemplo, as organizações peticionárias nos casos em que houve acordos de solução amistosa entre as partes possuem cada uma cerca de 30 anos de trabalho com a proteção e promoção dos direitos humanos e o fortalecimento da sociedade civil e da democracia no Brasil, articulando estratégias de pesquisa e documentação, litigância, advocacy, comunicação e formação sobre direitos humanos.

Graus de compliance do Estado brasileiro para com as medidas do Sistema Interamericano de Direitos Humanos

Ao analisar os graus de compliance com as recomendações, resoluções e medidas acordadas em solução amistosa, identifica-se que não há informações sobre o cumprimento de 12 recomendações (8\%) outorgadas contra o Brasil no Sistema Interamericano de Direitos Humanos. Os casos em que não há o acompanhamento do cumprimento das recomendações são: 1) Caso $n^{\circ} 11.045$ Newton Coutinho Mendes e outros; 2) Caso n ${ }^{\circ} 11.516$ Ovelário Tames; 3) Caso nº 11.598 Alonso Eugénio da Silva; e 4) Caso no 11.599 Marcos Aurélio de Oliveira.

Desse modo, utiliza-se para analisar a compliance do Estado brasileiro apenas as 149 recomendações, resoluções e medidas acordadas em solução amistosa em que se pode averiguar o seu grau de compliance por meio dos relatórios de supervisão de cumprimento emitidos pela Comissão e Corte. Nesse universo reduzido, observa-se que $48 \%$ das medidas não foram cumpridas, $33 \%$ foram cumpridas totalmente e $19 \%$ foram cumpridas parcialmente. 
Figura 17: Graus de compliance do Brasil com as medidas outorgadas pelo SIDH

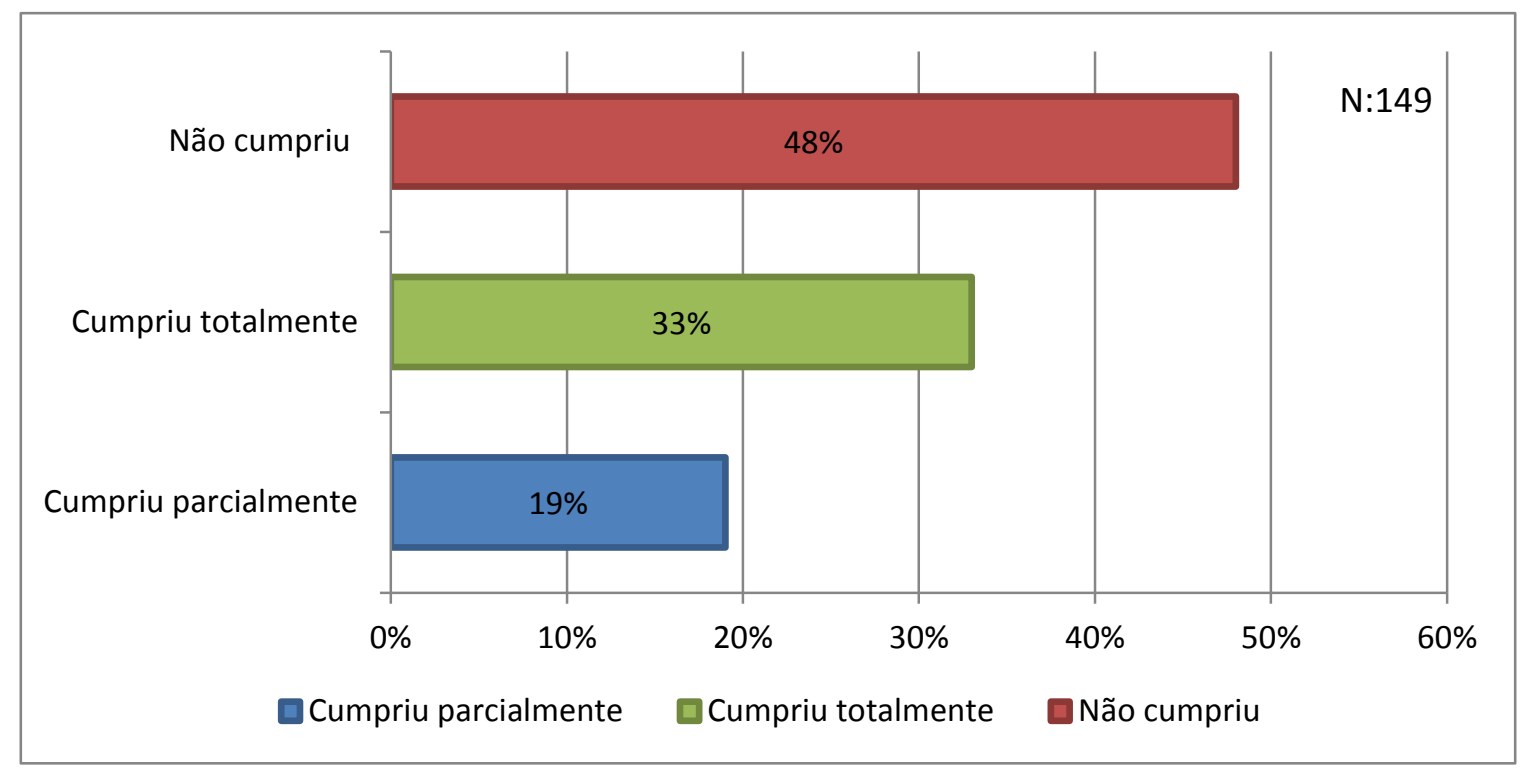

*Os dados referem-se às 149 recomendações e resoluções para as quais existem informações

Fonte: Elaboração própria. Dados da $\mathrm{CmDH}$, da $\mathrm{CrDH}$, do MRE e da $\mathrm{SDH}$ (disponível em: http://www.oas.org/pt/cidh/ Acesso em: 07 nov. 2015 e no Apêndice C).

Ao analisar as medidas outorgadas contra o Brasil pelo SIDH a partir do órgão em que elas foram emitidas, atribuindo as medidas acordadas em solução amistosa uma categoria específica, verifica-se que na $\mathrm{CrDH}:$ 1) $59 \%$ das resoluções foram totalmente cumpridas; 2) $27 \%$ não foram cumpridas; e 3) $14 \%$ foram parcialmente cumpridas. Na $\mathrm{CmDH}$, observa-se que: 1) 64\% das recomendações não foram cumpridas; 2) 21\% foram parcialmente cumpridas; e 3) 15\% foram totalmente cumpridas. Já nos acordos de solução amistosa, verifica-se que: 1) 59\% das medidas acordadas foram totalmente cumpridas; 2) $22 \%$ não foram cumpridas; e 3) 19\% foram parcialmente cumpridas. Os resultados podem ser vistos na figura 18 a seguir.

Os dados indicam que há uma clara evidência que o Estado brasileiro é mais propício a cumprir totalmente medidas proferidas pela Corte Interamericana de Direitos Humanos e aquelas acordadas em solução amistosa (59\% das medidas foram cumpridas em cada uma das classificações). Isso se deve em parte pelo fato de que as medidas proferidas pela Corte são vinculantes e têm peso de norma internacional e porque os acordos de solução amistosa passam por um intenso processo de negociação que culmina com um conjunto de medidas de fácil implementação pelo Estado. 
No entanto, observa-se que uma das razões para o total cumprimento das medidas proferidas tanto pela Corte como aquelas acordadas em solução amistosa pode estar ligada ao seu escopo. Como visto anteriormente, a maioria das medidas outorgadas pela Corte visa à recompensação de pessoas ou grupos e a maioria das medidas acordadas em solução amistosa buscam o fortalecimento, reforma e criação de instituições públicas com o fim de prevenir futuras violações de direitos humanos. Esses tipos de medidas são mais "facilmente" implementadas pelo Estado brasileiro, uma vez que dependem, geralmente, apenas da ação do Poder Executivo. Já a Comissão busca na maioria de suas medidas a mudança da prática estatal por meio de reformas jurídicas. Medidas que para serem implementadas necessitam do trabalho conjunto de diferentes instâncias e Poderes do Estado $^{40}$.

Figura 18: Graus de compliance do Brasil com as recomendações, resoluções e medidas acordadas em solução amistosa do SIDH

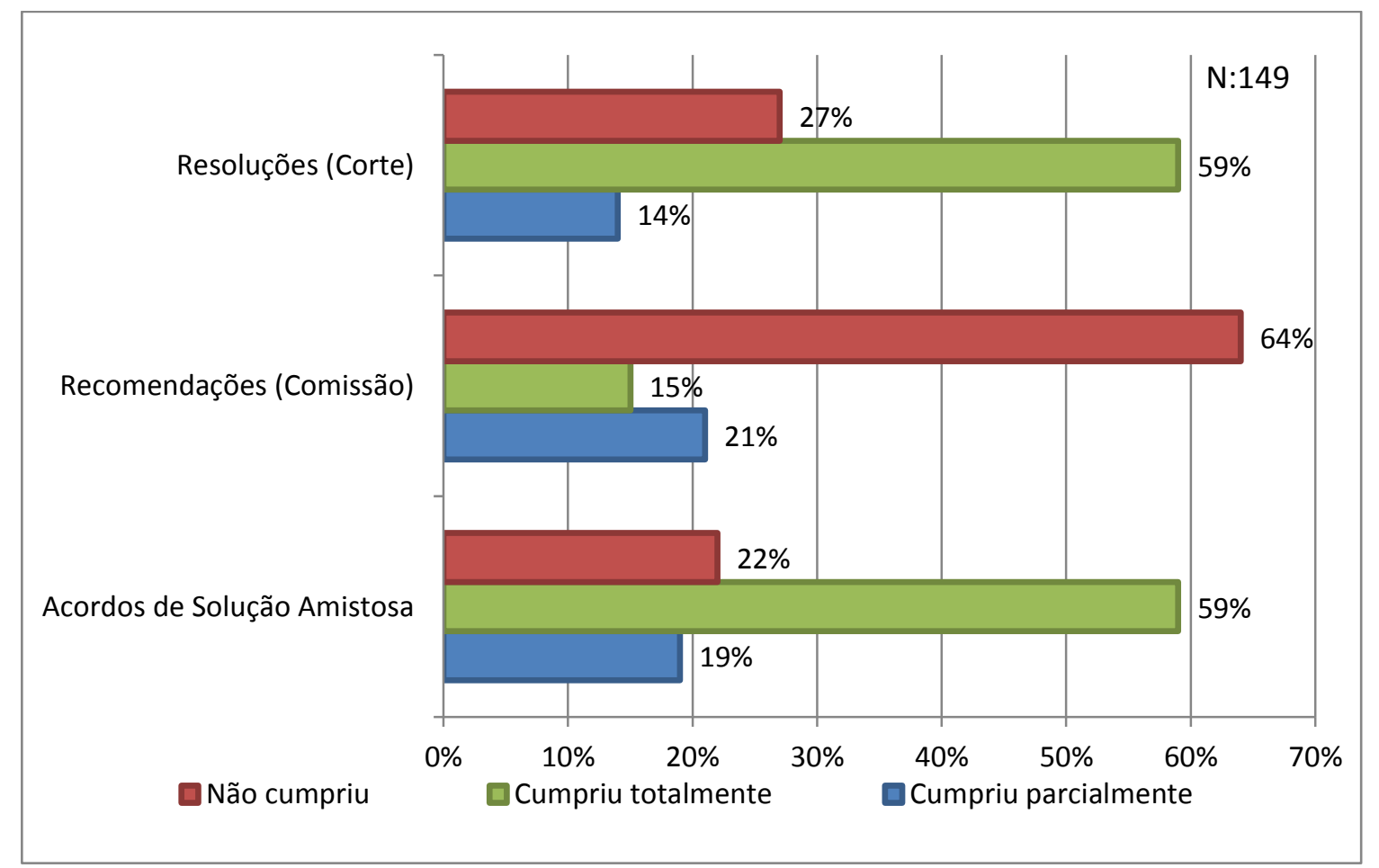

Fonte: Elaboração própria. Dados da $\mathrm{CmDH}$, da $\mathrm{CrDH}$, do MRE e da SDH (disponível em: http://www.oas.org/pt/cidh/ Acesso em: 07 nov. 2015 e no Apêndice C).

\footnotetext{
${ }^{40}$ Mais detalhes sobre o processo decisório da implementação das medidas outorgadas contra o Brasil pelo SIDH serão vistos no próximo capítulo.
} 
A afirmação pode ser comprovada a partir de um olhar mais detalhado ao conjunto de dados contidos na tabela. Ao analisar a compliance do Estado brasileiro para com as recomendações da Comissão Interamericana de Direitos Humanos classificadas por seu tipo, observa-se que a maioria das que não foram cumpridas diz respeito à proteção de vítimas e testemunhas $(100 \%)$ e, em seguida, aquelas que envolvem algum tipo de reforma legal. Nota-se ainda que as medidas totalmente implementadas pelo Brasil têm como seu objetivo a reparação simbólica das vítimas (60\%) e a reparação econômica monetária (35\%). Uma das razões para que isso aconteça é o fato do Governo federal destinar uma alíquota específica de seu orçamento plurianual para o pagamento de indenizações pecuniárias proferidas por órgãos internacionais de direitos humanos ${ }^{41}$.

Tabela 7: Compliance do Brasil com recomendações da $\mathrm{CmDH}$ classificadas por seu tipo

\begin{tabular}{l|c|c|c}
\hline \multicolumn{4}{c}{ Recomendações da Comissão } \\
\hline \multicolumn{1}{c}{ Tipos de recomendações } & $\begin{array}{c}\text { Cumpriu } \\
\text { parcialmente }\end{array}$ & $\begin{array}{c}\text { Cumpriu } \\
\text { totalmente }\end{array}$ & Não cumpriu \\
\hline Investigação e sanção com reforma legal & $10 \%$ & - & $90 \%$ \\
\hline Investigação e sanção sem reforma legal & $13 \%$ & $20 \%$ & $67 \%$ \\
\hline Outros & $43 \%$ & - & $57 \%$ \\
\hline $\begin{array}{l}\text { Prevenção por meio da conscientização da } \\
\text { população }\end{array}$ & $50 \%$ & - & $50 \%$ \\
$\begin{array}{l}\text { Prevenção por meio da formação de } \\
\text { agentes públicos }\end{array}$ & $22 \%$ & - & $78 \%$ \\
\hline $\begin{array}{l}\text { Prevenção por meio de reformas jurídicas } \\
\text { Prevenção por meio do fortalecimento, } \\
\text { criação, ou reforma de instituições públicas }\end{array}$ & $25 \%$ & $8 \%$ & $67 \%$ \\
\hline Prevenção sem especificar medidas & $67 \%$ & - & $71 \%$ \\
\hline Proteção de vítimas e testemunhas & - & - & $100 \%$ \\
\hline Reparação econômica monetária & $18 \%$ & $35 \%$ & $47 \%$ \\
\hline Reparação simbólica & - & $60 \%$ & $40 \%$ \\
\hline
\end{tabular}

Fonte: Elaboração própria. Dados da $\mathrm{CmDH}$, da CrDH, do MRE e da SDH (disponível em: http://www.oas.org/pt/cidh/ Acesso em: 07 nov. 2015 e no Apêndice C).

Esse mecanismo orçamentário é também uma das razões para que as medidas emitidas pela Corte Interamericana de Direitos Humanos que buscam a reparação

\footnotetext{
${ }^{41}$ Mais detalhes sobre o desenvolvimento desse mecanismo de pagamento de reparações econômicas monetárias serão vistos no próximo capítulo.
} 
econômica monetária sejam totalmente cumpridas pelo Estado brasileiro ( $88 \%$ das medidas desse tipo na $\mathrm{CrDH}$ foram totalmente cumpridas pelo Brasil). Outrossim, encontra-se que o cumprimento total das medidas outorgadas pelo tribunal é mais propício quando a sentença contra o Estado brasileiro não envolve nenhuma reforma jurídica. Qualquer outro tipo de resolução tem difícil implementação pelo Estado brasileiro. Isso reforça o argumento de que as medidas outorgadas pelo Sistema Interamericana de Direitos Humanos contra o Brasil possui como maior empecilho para a sua total implementação o processo decisório interno do País. O conjunto de dados sobre o grau de compliance do Brasil com resoluções da Corte, classificadas por seu tipo, pode ser visto abaixo:

Tabela 8: Compliance do Brasil com resoluções da CrDH classificadas por seu tipo

\begin{tabular}{l|c|c|c}
\hline \multicolumn{1}{c}{ Resoluçães da Corte } \\
\hline \multicolumn{1}{c}{ Tipos de Resoluções } & $\begin{array}{c}\text { Cumpriu } \\
\text { parcialmente }\end{array}$ & $\begin{array}{c}\text { Cumpriu } \\
\text { totalmente }\end{array}$ & Não cumpriu \\
\hline Investigação e sanção sem reforma legal & - & $50 \%$ & $50 \%$ \\
\hline Outros & - & - & $100 \%$ \\
\hline $\begin{array}{l}\text { Prevenção por meio da formação de } \\
\text { agentes públicos }\end{array}$ & - & - & $100 \%$ \\
\hline $\begin{array}{l}\text { Prevenção por meio de reformas jurídicas } \\
\text { Reparação econômica monetária }\end{array}$ & - & - & $100 \%$ \\
\hline Reparação econômica não monetária & - & - & $100 \%$ \\
\hline Reparação simbólica & $25 \%$ & $67 \%$ & $8 \%$ \\
\hline
\end{tabular}

Fonte: Elaboração própria. Dados da $\mathrm{CmDH}$, da $\mathrm{CrDH}$, do MRE e da $\mathrm{SDH}$ (disponível em: http://www.oas.org/pt/cidh/ Acesso em: 07 nov. 2015 e no Apêndice C).

As medidas que visam qualquer tipo de reparação às vítimas também são mais propícias a serem cumpridas pelo Estado brasileiro quando há um acordo de solução amistosa (100\% dessas medidas foram cumpridas pelo Brasil). O mesmo acontece quando as medidas acordadas em solução amistosa visam à previsão de futuras violações de direitos humanos, exceto quando há a necessidade de reformas jurídicas (apenas 20\% são totalmente cumpridas pelo Estado brasileiro). Isso reforça o argumento de que o processo decisório da implementação das medidas do SIDH tem implicações diretas sobre o grau de compliance do Estado brasileiro, uma vez que espera-se que todas as medidas acordadas em solução amistosa sejam implementadas de boa-fé pelo Estado brasileiro, 
representado pelo Poder Executivo. O conjunto de dados sobre a compliance do Estado brasileiro com as medidas acordadas em solução amistosa pode ser visto na tabela nove a seguir:

Tabela 9: Compliance do Brasil com medidas acordadas em solução amistosa no SIDH classificadas por seu tipo

\begin{tabular}{|c|c|c|c|}
\hline \multicolumn{4}{|c|}{ Acordos de Solução Amistosa } \\
\hline Tipos de medidas acordadas & $\begin{array}{c}\text { Cumpriu } \\
\text { parcialmente }\end{array}$ & $\begin{array}{l}\text { Cumpriu } \\
\text { totalmente }\end{array}$ & Não cumpriu \\
\hline Investigação e sanção sem reforma legal & $100 \%$ & - & - \\
\hline Outros & - & $100 \%$ & - \\
\hline $\begin{array}{l}\text { Prevenção por meio da conscientização da } \\
\text { população }\end{array}$ & $25 \%$ & $25 \%$ & $50 \%$ \\
\hline $\begin{array}{l}\text { Prevenção por meio da formação de } \\
\text { agentes públicos }\end{array}$ & - & $100 \%$ & - \\
\hline Prevenção por meio de reformas jurídicas & $40 \%$ & $20 \%$ & $40 \%$ \\
\hline $\begin{array}{l}\text { Prevenção por meio do fortalecimento, } \\
\text { criação, ou reforma de instituições públicas }\end{array}$ & $13 \%$ & $67 \%$ & $20 \%$ \\
\hline Reparação econômica monetária & - & $100 \%$ & - \\
\hline Reparação econômica não monetária & - & $100 \%$ & - \\
\hline Reparação simbólica & - & $100 \%$ & - \\
\hline & & & $\mathrm{N}: 32$ \\
\hline
\end{tabular}

Fonte: Elaboração própria. Dados da $\mathrm{CmDH}$, da $\mathrm{CrDH}$, do MRE e da SDH (disponível em: http://www.oas.org/pt/cidh/ Acesso em: 07 nov. 2015 e no Apêndice C).

A figura 19 nos mostra que ao analisar o universo de pesquisa pelos tipos de medidas outorgadas pelo SIDH contra o Estado brasileiro como um todo, sem distinção entre qual órgão a emitiu, observa-se que os temas das recomendações, resoluções e medidas acordadas em solução amistosa que o Brasil não cumpriu 50\% ou mais destas são: 1) Prevenção por meio da conscientização da população (50\%); 2) Outros (56\%); 3) Investigação e sanção sem reforma legal (60\%); Prevenção por meio de reformas jurídicas (61\%); 4) Prevenção por meio da formação de agentes públicos (68\%); 5) Investigação e sanção sem reforma legal (90\%); e 6) Prevenção de vítimas e testemunhas $(100 \%)$. 
Figura 19: Graus de compliance do Brasil com as medidas outorgadas pelo SIDH classificadas por seu tipo

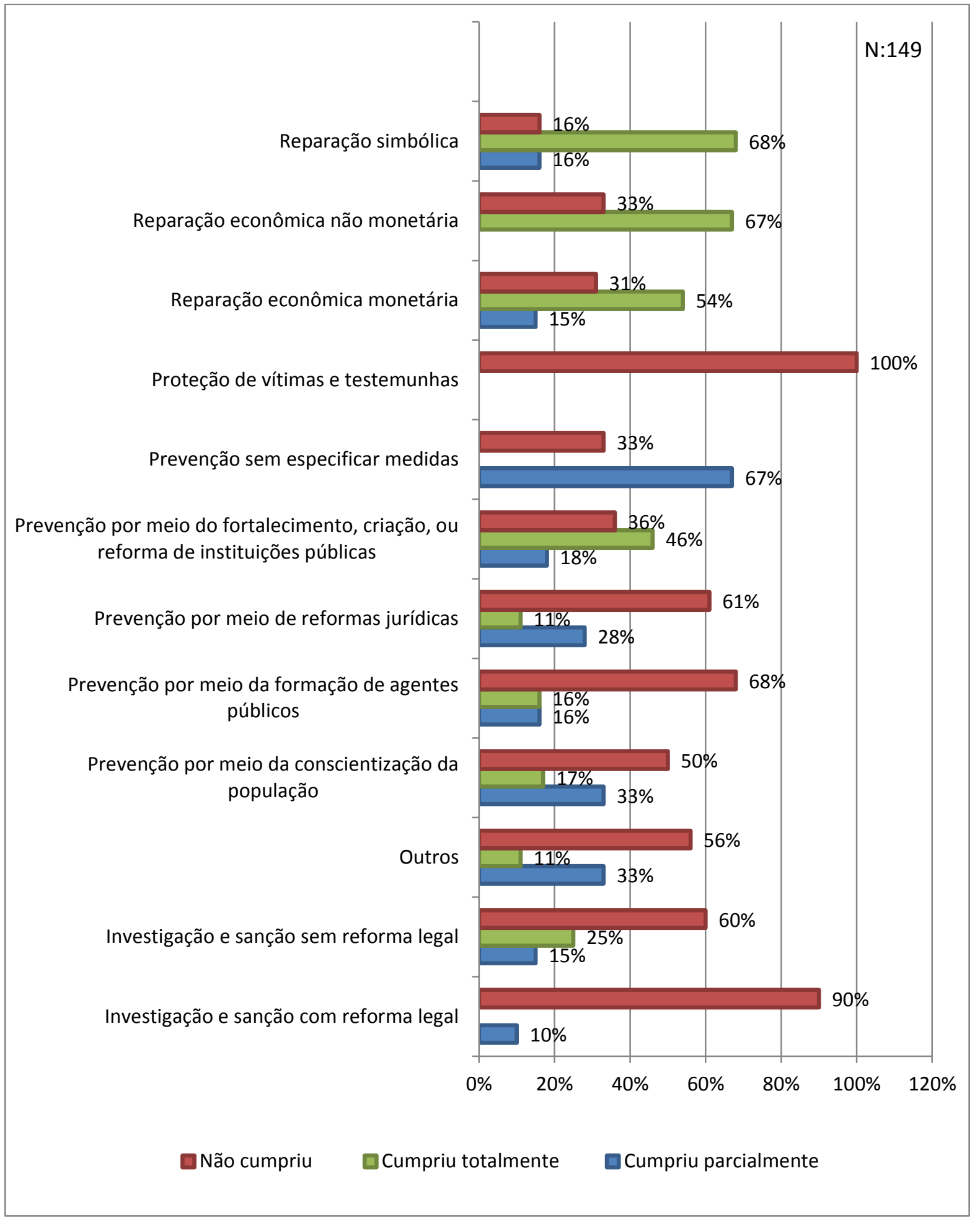

Fonte: Elaboração própria. Dados da $\mathrm{CmDH}$, da $\mathrm{CrDH}$, do MRE e da SDH (disponível em: http://www.oas.org/pt/cidh/ Acesso em: 07 nov. 2015 e no Apêndice C).

Quando se analisa aqueles tipos de medidas em que se verifica maior índice de compliance, temos, em ordem decrescente, que eles são: 1) Reparação simbólica (68\%); 
2) Reparação econômica não monetária (67\%); 3) Reparação econômica monetária (54\%); e 4) Prevenção por meio do fortalecimento, criação ou reforma de instituições públicas (46\%). Há apenas um tipo de medida em que se verifica o cumprimento parcial como principal grau de compliance, ele é: 1) Prevenção sem especificar medidas com $67 \%$ das medidas parcialmente cumpridas pelo Estado brasileiro.

A figura 20, a seguir, demonstra que quando analisados de forma geral, a compliance do Brasil para com as medidas proferidas pelo SIDH classificadas pelo seu objetivo segue o mesmo padrão estabelecido na classificação pelos seus diferentes tipos. Nota-se que há uma predominância do não cumprimento de medidas que tem como objetivo a responsabilização e investigação de direitos humanos (70\% não cumpridas) e a proteção de vítimas e testemunhas e outros (60\% não cumpridas). Medidas que visam a recompensação de vítimas e pessoas, assim como a prevenção de futuras violações de direitos humanos, apresentam uma taxa de cumprimento parcial maior do que as demais medidas, respectivamente $60 \%$ e $52 \%$ de cumprimento parcial.

Figura 20: Graus de compliance do Brasil às recomendações, resoluções e medidas acordadas em solução amistosa outorgadas pelo SIDH classificadas por seu objetivo

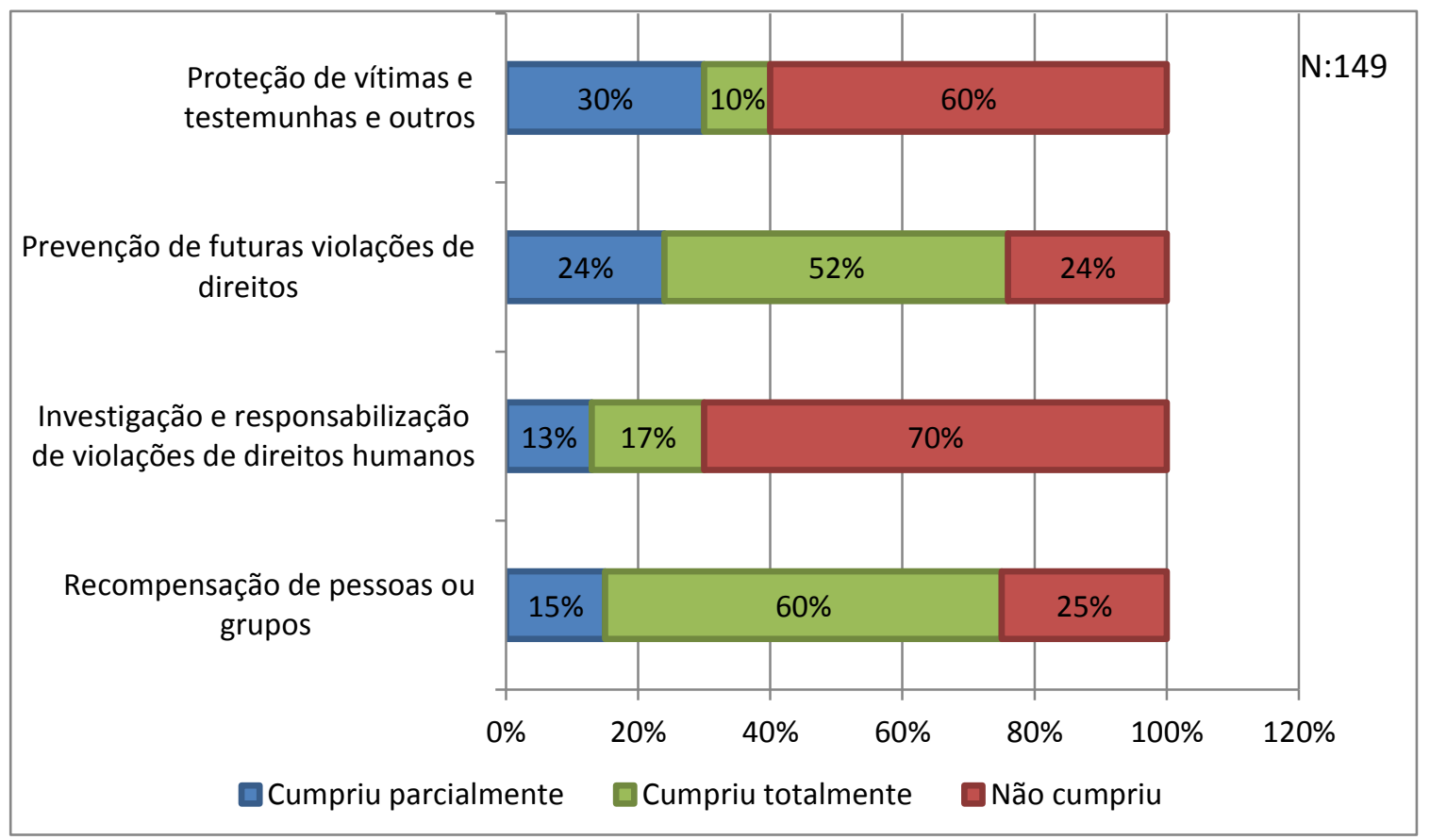

Fonte: Elaboração própria. Dados da $\mathrm{CmDH}$, da $\mathrm{CrDH}$, do MRE e da $\mathrm{SDH}$ (disponível em: http://www.oas.org/pt/cidh/ Acesso em: 07 nov. 2015 e no Apêndice C).

Os resultados são condizentes com aqueles analisados em cada órgão e demonstram que há uma clara deficiência do Estado brasileiro em cumprir totalmente com medidas que envolvam mudanças no ordenamento jurídico interno e que há uma 
melhor ação do Estado quando a medida é relacionada à reparação das vítimas, principalmente reparações monetárias. Isso contribui para o argumento de que o processo decisório da implementação das medidas outorgadas pelo Sistema Interamericano de Direitos Humanos contra o Brasil é uma variável importante para a state compliance brasileira.

Quando se analisa o grau de compliance brasileiro com as medidas outorgadas pelo Sistema Interamericano de Direitos humanos, classificadas pelo tema da violação de direitos humanos que engendrou o início da tramitação do procedimento no SIDH, verifica-se que as medidas com maior propensão ao não cumprimento são: 1) Racismo (75\%); 2) Violência policial (70\%); 3) Tortura (53\%); 4) Crimes do período da ditadura; $52 \%$ ) Prestação de justiça (50\%); 6) Violência institucional contra privados de liberdade (sistema prisional e socioeducativo) (50\%); e 7) Violência no campo (40\%).

Os temas dos casos em que as medidas outorgadas contra o Brasil tiveram um cumprimento parcial maior são apenas dois: 1) Violência contra mulheres (80\%); e 2) Violência institucional contra privados de liberdade (sistema prisional e socioeducativo) $(50 \%)$. Verificou-se ainda que somente em um tema específico de violação de direitos humanos o grau de cumprimento das medidas outorgadas é maior do que os demais. $\mathrm{O}$ tema é violência contra menores, em que $64 \%$ das recomendações, resoluções ou medidas acordadas em solução amistosa foram cumpridas totalmente. O conjunto de dados na figura 21, a seguir, ilustra os resultados.

Essa diferença de prática estatal de acordo com o tema da violação de direitos humanos que originou o envio do caso ao Sistema Interamericano de Direitos Humanos pode ser explicada pelo fato de que alguns temas são mais sensíveis do que outros perante a opinião pública doméstica e, por isso, causariam ao Estado brasileiro, na figura de seu Poder Executivo, grande desgaste político e perca de prestígio. Enquadram-se nessa análise aquelas violações relacionadas à violência contra mulheres e menores. Não obstante, quando a violação de direitos humanos é causada por agentes do Estado se verifica que a maioria das medidas proferidas pelo Sistema Interamericano de Direitos Humanos não é cumprida pelo Estado brasileiro. Observa-se, assim, uma clara dificuldade do Brasil em lidar com as violações de direitos humanos que são perpetradas pelos próprios agentes de Estado. 
Figura 21: Graus de compliance do Brasil com as medidas outorgadas pelo SIDH classificadas pelo tema das violações que as originaram.

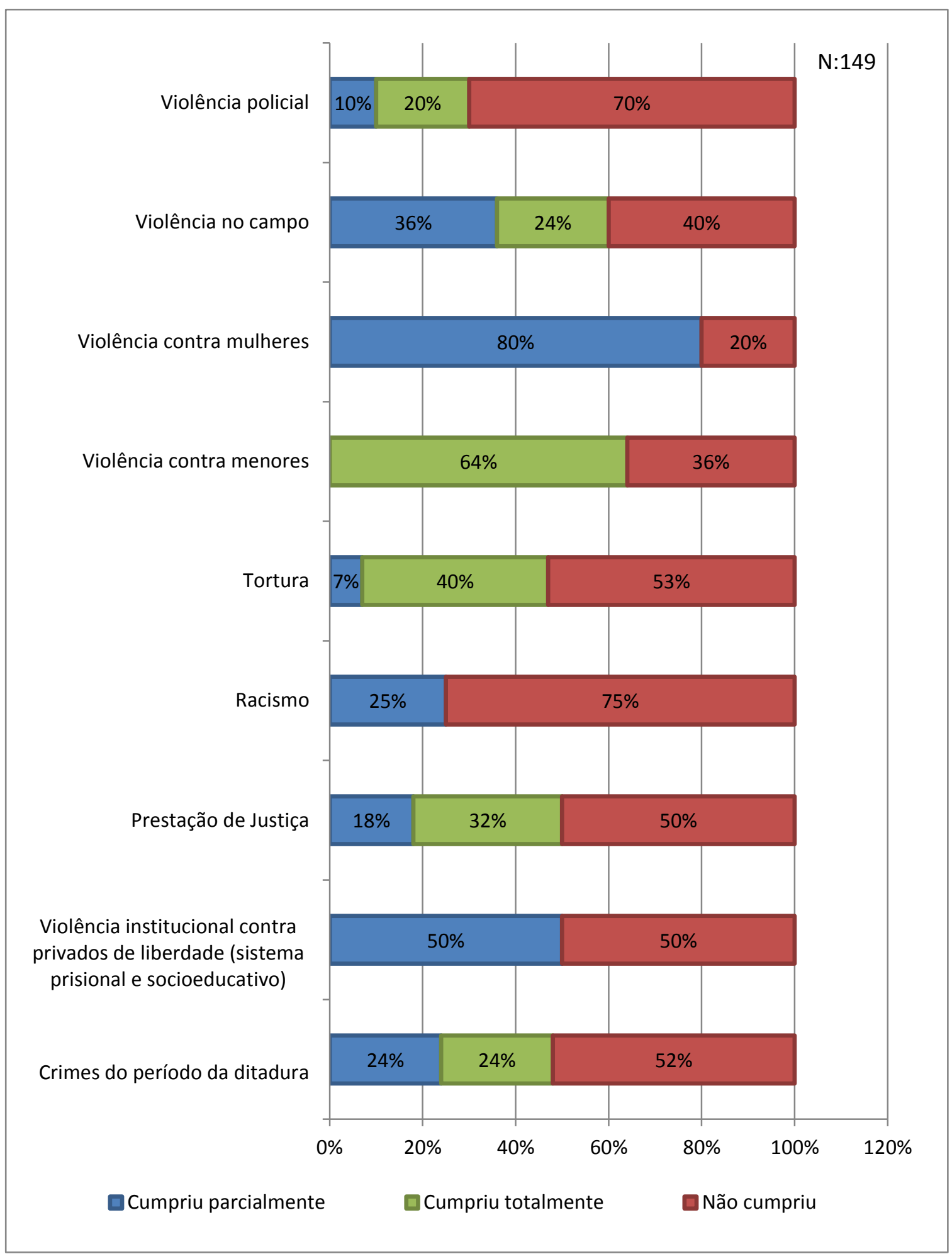

Fonte: Elaboração própria. Dados da $\mathrm{CmDH}$, da $\mathrm{CrDH}$, do MRE e da SDH (disponível em: http://www.oas.org/pt/cidh/ Acesso em: 07 nov. 2015 e no Apêndice C). 
Ao analisar a compliance do Estado brasileiro a partir de cada caso, temos que o Brasil cumpriu totalmente com todas as medidas outorgadas contra si pelo SIDH em apenas três casos: 1) Caso Arley José e outros vs. Brasil (Corte); 2) Caso no 12.426 Meninos Emasculados do Maranhão (Acordo de Solução Amistosa); e 3) Caso no 11.287 João Canuto de Oliveira (Comissão). Os casos em que o Estado brasileiro cumpriu com $50 \%$ ou mais das medidas outorgadas são dois e ambos da $\mathrm{CrDH}$. São eles: 1) Caso Damião Ximenes Lopes vs. Brasil (71\%); e 2) Caso Sétimo Garibaldi vs. Brasil (80\%).

O Brasil não cumpriu com nenhuma das recomendações ou resoluções do SIDH em dois casos. São eles: 1) Caso no 11.566 Favela Nova Brasília (Evandro Oliveira e outros) (Comissão); e 2) Caso nº 12.066 Fazenda Brasil Verde (Comissão).

Os casos em que o Estado brasileiro não cumpriu com $50 \%$ ou mais das medidas outorgadas são 10. Dentre eles, um da $\mathrm{CrDH}$ : 1) $50 \%$ das resoluções do Caso Julia Gomes Lund e outros (Guerrilha do Araguaia). Um caso em acordo de solução amistosa: 1) $54 \%$ das medidas acordadas no Caso $n^{\circ} 11.289$ José Pereira e outros. Por fim, oito casos em cumprimento de recomendações outorgadas pela CmDH. São eles: 1) $50 \%$ das recomendações outorgadas no Caso $\mathrm{n}^{\circ} 11.556$ Massacre de Corumbiara; 2) 50\% das medidas do Caso no 10.301 Parque São Lucas; 3) 58\% das medidas do Caso $\mathrm{n}^{\circ} 12.001$ Simone André Diniz; 4) 60\% das medidas do Caso nº 12.310 Sebastião Camargo; 5) $67 \%$ das medidas do Caso $n^{\circ} 11.634$ Jailton Néri da Fonseca; 6) 75\% das medidas do Caso $\mathrm{n}^{\circ}$ 11.291 Carandiru; 7) 75\% das medidas do Caso $\mathrm{n}^{\circ} 12.440$ Wallace de Almeida; e 8) $86 \%$ das medidas do Caso no 11.286 Aluísio Cavalcanti e outros .

O Estado brasileiro cumpriu parcialmente com 50\% ou mais das medidas outorgadas em três casos. São eles: 1) 50\% das medidas do Caso nº 10301 Parque São Lucas; 2) 67\% das medidas do Caso no 11.517 Diniz Bento da Silva (Teixeirinha); e 3) $80 \%$ das medidas do Caso $n^{\circ} 12.051$ Maria da Penha Fernandes.

Os resultados demonstram que a maioria dos casos em que SIDH proferiu medidas contra o Brasil enfrentam dificuldades para que suas recomendações e resoluções sejam cumpridas, independentemente do tipo e objeto da medida, seu objetivo ou tema que tenha originado a violação de direitos humanos alvo do procedimento no SIDH. Acredita-se que há uma necessidade de se analisar melhor os casos em que há uma polarização do grau compliance, casos em que todas as medidas foram totalmente cumpridas ou não, para entender melhor o processo de implementação das medidas do SIDH. Contudo, o estudo específico desses casos não é tema deste trabalho. Atentar-se-á no próximo capítulo para a reconstrução do processo decisório interno relacionado à 
implementação das medidas proferias pelo Sistema Interamericano de Direitos Humanos como um todo.

Figura 22: Graus de compliance do Brasil com os casos do SIDH

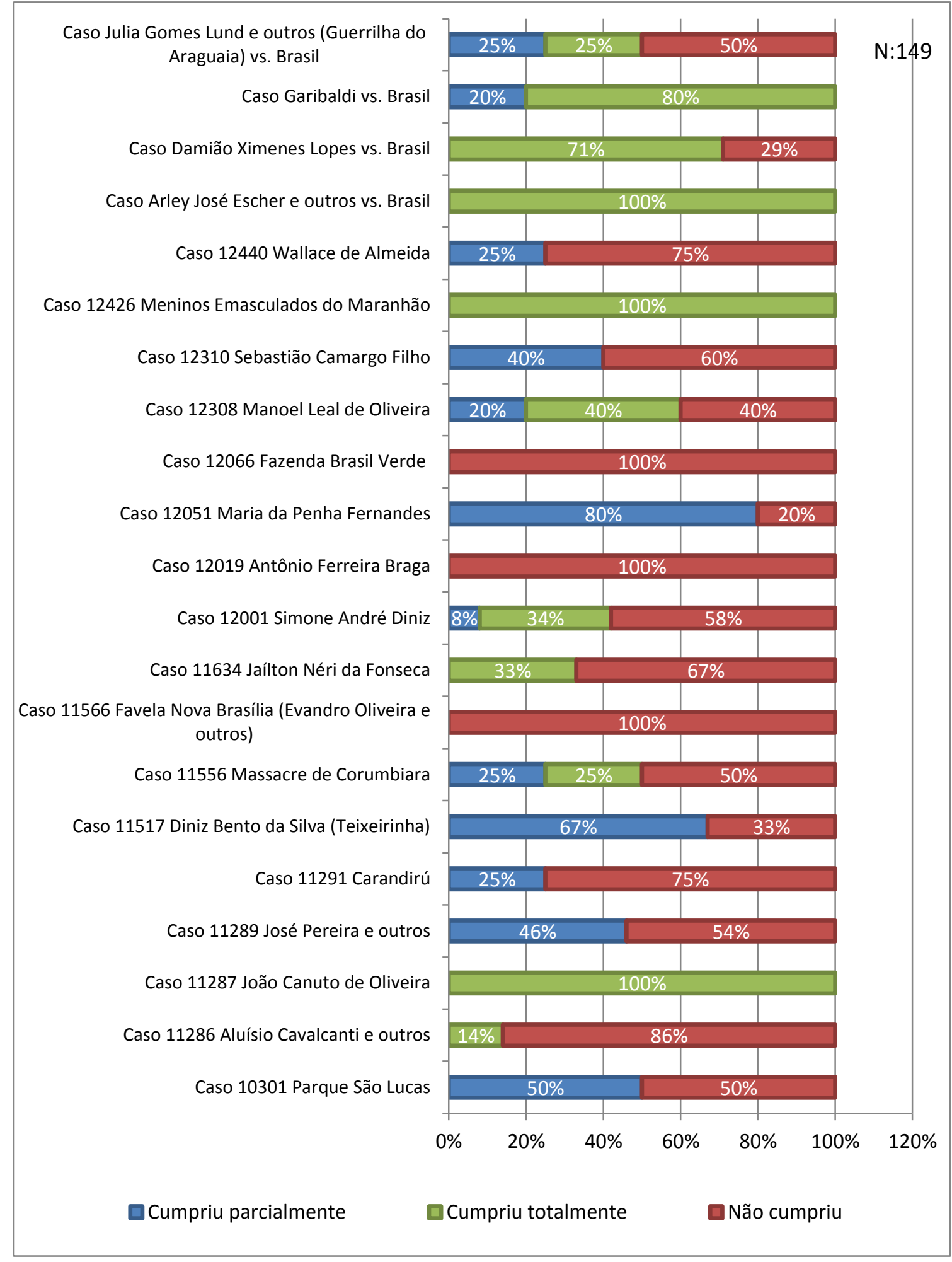

Fonte: Elaboração própria. Dados da $\mathrm{CmDH}$, da $\mathrm{CrDH}$, do MRE e da $\mathrm{SDH}$ (disponível em: http://www.oas.org/pt/cidh/ Acesso em: 07 nov. 2015 e no Apêndice C). 
State Compliance e a duração dos procedimentos contra o Brasil no Sistema Interamericano de Direitos Humanos

Ao analisar a quantidade média de dias entre a violação de direitos humanos e o início da tramitação do caso no Sistema Interamericano de Direitos Humanos daqueles procedimentos em que o SIDH outorgou recomendações, resoluções ou medidas de acordo de solução amistosa, observa-se que a média é de quatro anos e dez meses $(4,85$ anos). O período de tempo médio entre o início da tramitação e a publicação do relatório de fundo pela Comissão Interamericana de Direitos Humanos é de sete anos e quatro meses (7,34 anos).

Quando se analisa o período de tempo médio transcorrido entre a publicação do relatório de fundo da $\mathrm{CmDH}$ e o envio do caso à Corte, situação que engloba os cinco casos contra o Brasil na $\mathrm{CrDH}$ já julgados e dois que iniciaram sua tramitação na $\mathrm{CrDH}$, observa-se que a quantidade média de tempo gasto é de um ano e nove meses (1,76 anos). Esse é o tempo médio em que a $\mathrm{CmDH}$ percebe que o Estado não está cumprindo ou dá sinais que não cumprirá com as recomendações outorgadas e acredita ser necessário o envio do Caso para ser julgado na Corte Interamericana de Direitos Humanos. Verificase ainda que há em média um período de um ano e quatro meses (1,34 anos) entre o envio do caso à $\mathrm{CrDH}$ pela $\mathrm{CmDH}$ e a publicação da sentença da Corte Interamericana de Direitos Humanos com as suas resoluções vinculantes.

A partir dos resultados descritos, é possível afirmar que o período médio de dias entre o início da tramitação de um caso no SIDH e a publicação de sua sentença pela Corte, analisando os quatro casos contra o Brasil que foram julgados pelo tribunal, é de aproximadamente nove anos (9,06 anos). Isso demonstra que tanto peticionários como vítimas enfrentam um longo período de espera para que as violações de direitos humanos sejam remediadas. Igualmente, observa-se que o SIDH não responde com rapidez as petições e casos que lhes são encaminhadas, colocando a prova a sua capacidade como órgão regional de proteção e promoção dos direitos humanos. 
Figura 23: Média de duração em anos dos casos contra o Brasil no SIDH em que foram outorgadas recomendações, resoluções e medidas acordadas em solução amistosa

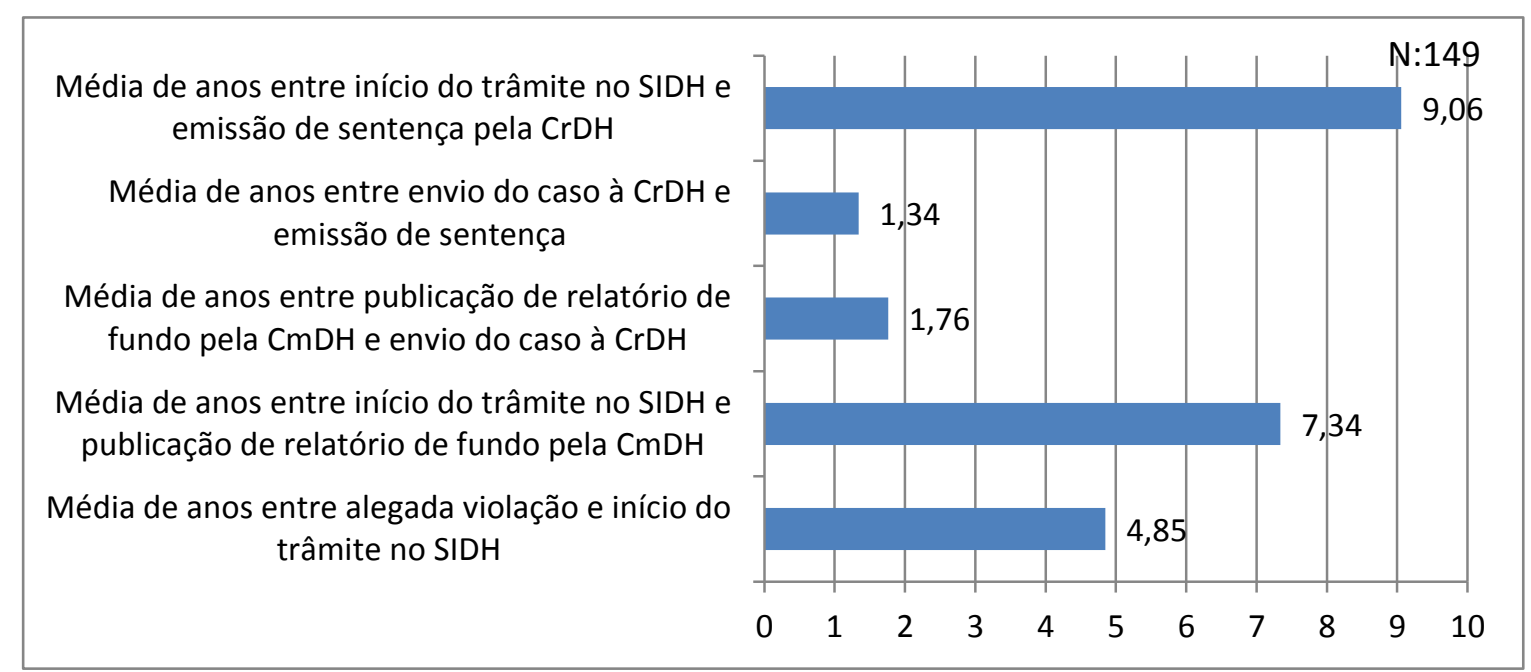

Fonte: Elaboração própria. Dados da $\mathrm{CmDH}$, da $\mathrm{CrDH}$, do MRE e da $\mathrm{SDH}$ (disponível em: http://www.oas.org/pt/cidh/ Acesso em: 07 nov. 2015 e no Apêndice C).

Quando se verifica o período de tempo transcorrido entre a emissão das recomendações, resoluções e medidas acordadas em solução amistosa e a compliance com cada uma das medidas, observa-se que há em média um período de três anos e dois meses (3,22 anos) para que o SIDH considere que o Estado brasileiro cumpriu totalmente as medidas outorgadas e de nove anos e 11 meses (9,93 anos) para que a SIDH considere as medidas como parcialmente cumpridas.

Ao analisar individualmente o período de tempo médio para a compliance com cada uma das medidas, temos que: 1) Para o cumprimento total das recomendações outorgadas pela $\mathrm{CmDH}$ há em média um período de tempo de quatro anos e seis meses (4,56 anos), já para o cumprimento parcial com recomendações outorgadas pela $\mathrm{CmDH}$ há em média um período de 10 anos e seis meses (10,54 anos); 2) Para o cumprimento total das medidas acordadas em solução amistosa há em média um período de dois anos e 11 meses (2,95 anos) e para o cumprimento parcial de 11 anos e dois meses (11,23 anos); e 3) Para o cumprimento total das resoluções outorgadas pela $\mathrm{CrDH}$ há em média um período de tempo de dois anos e seis meses (2,51 anos), já para o seu cumprimento parcial o período médio de tempo é de cinco anos (5,07 anos). 
Figura 24: Média de duração em anos para a compliance do Estado brasileiro com as recomendações, resoluções e medidas acordadas em solução amistosa pelo SIDH

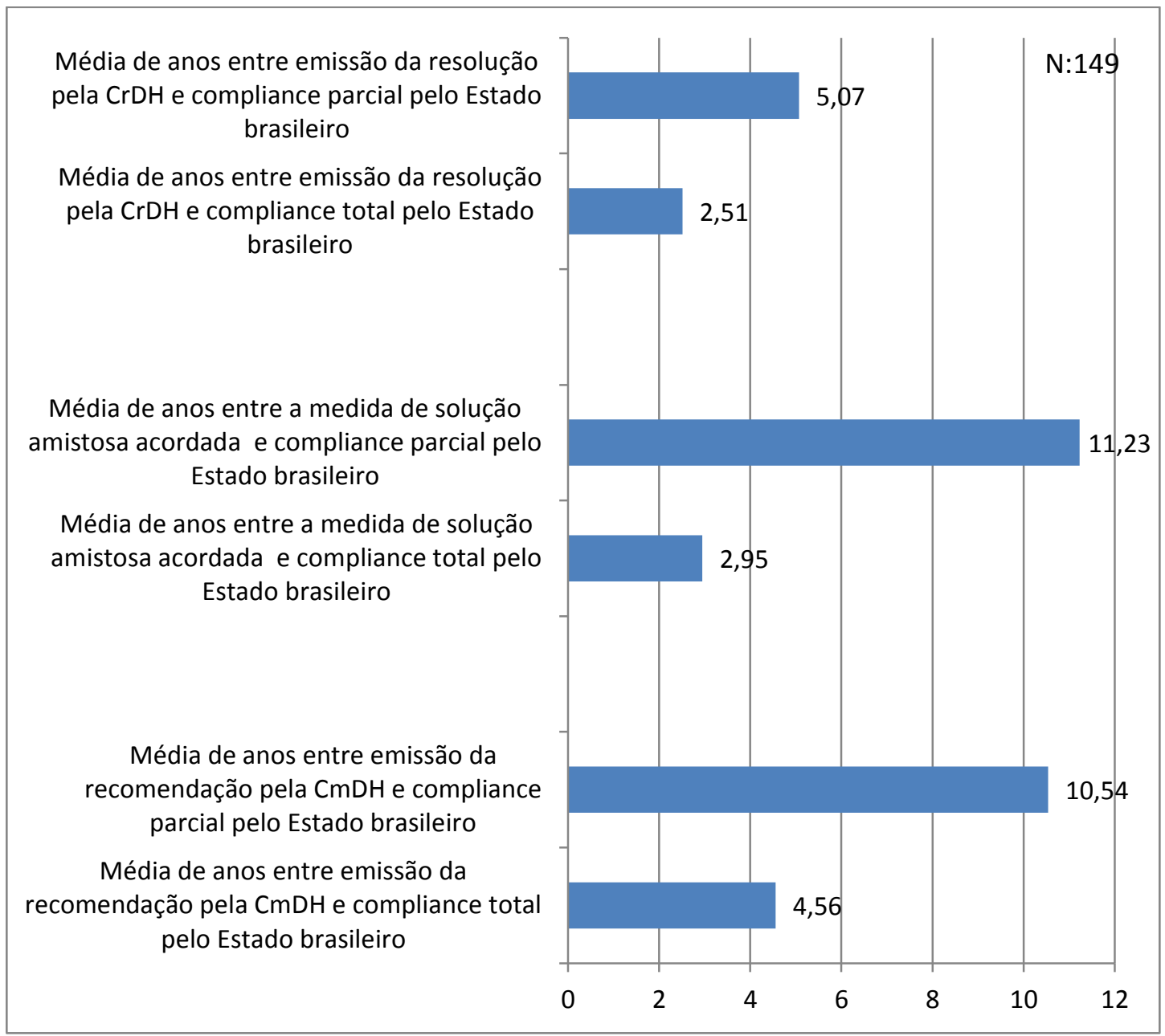

Fonte: Elaboração própria. Dados da $\mathrm{CmDH}$, da $\mathrm{CrDH}$, do MRE e da $\mathrm{SDH}$ (disponível em: http://www.oas.org/pt/cidh/ Acesso em: 07 nov. 2015 e no Apêndice C).

Os dados demonstram que o Estado brasileiro cumpre totalmente com mais celeridade medidas proferidas pela Corte Interamericana de Direitos Humanos e aquelas acordadas em solução amistosa entre as partes. Uma das razões para tanto é o caráter vinculante das decisões da Corte e o fato de que as medidas acordadas em solução amistosa passaram por um amplo processo de barganha entre Estado e peticionários e vítimas. Logo, como visto anteriormente, as medidas resultantes desse processo possuem características de fácil implementação pelo Estado $^{42}$ e de grande significância para às vítimas que buscam a prevenção de novas violações de direitos humanos. Isto faz com que as medidas acordadas em solução amistosa tenham um grau de cumprimento total maior e sejam implementadas com maior rapidez.

\footnotetext{
${ }^{42}$ Por exemplo: a não necessidade de mudanças jurídicas ou não dependência do Executivo de outros Poderes para a criação de políticas públicas que visem a implementação das medidas do SIDH.
} 
Ao classificar o conjunto de dados a partir do tipo de medida outorgada pelo Sistema Interamericano de Direitos Humanos e o tempo utilizado pelo Estado brasileiro para cumpri-las totalmente, obtém-se que o período de tempo médio em anos para o cumprimento total das medidas por seu tipo, em ordem decrescente é: 1) Investigação e sanção sem reforma legal (5,68 anos); 2) Reparação econômica monetária (3,21 anos); 3) Reparação econômica não monetária (2,95 anos); 4) Prevenção por meio do fortalecimento, criação ou reforma de instituições públicas (2,95 anos); 5) Prevenção pela formação de agentes públicos (2,95 anos); 6) Prevenção por meio da conscientização da população (2,95 anos); 7) Outros (2,95 anos); 8) Reparação simbólica (2,71 anos); e 9) Prevenção por meio de reformas jurídicas (2,48 anos).

Figura 25: Média de duração em anos para a compliance do Estado brasileiro com as recomendações, resoluções e medidas acordadas em solução amistosa pelo SIDH classificadas por seu tipo

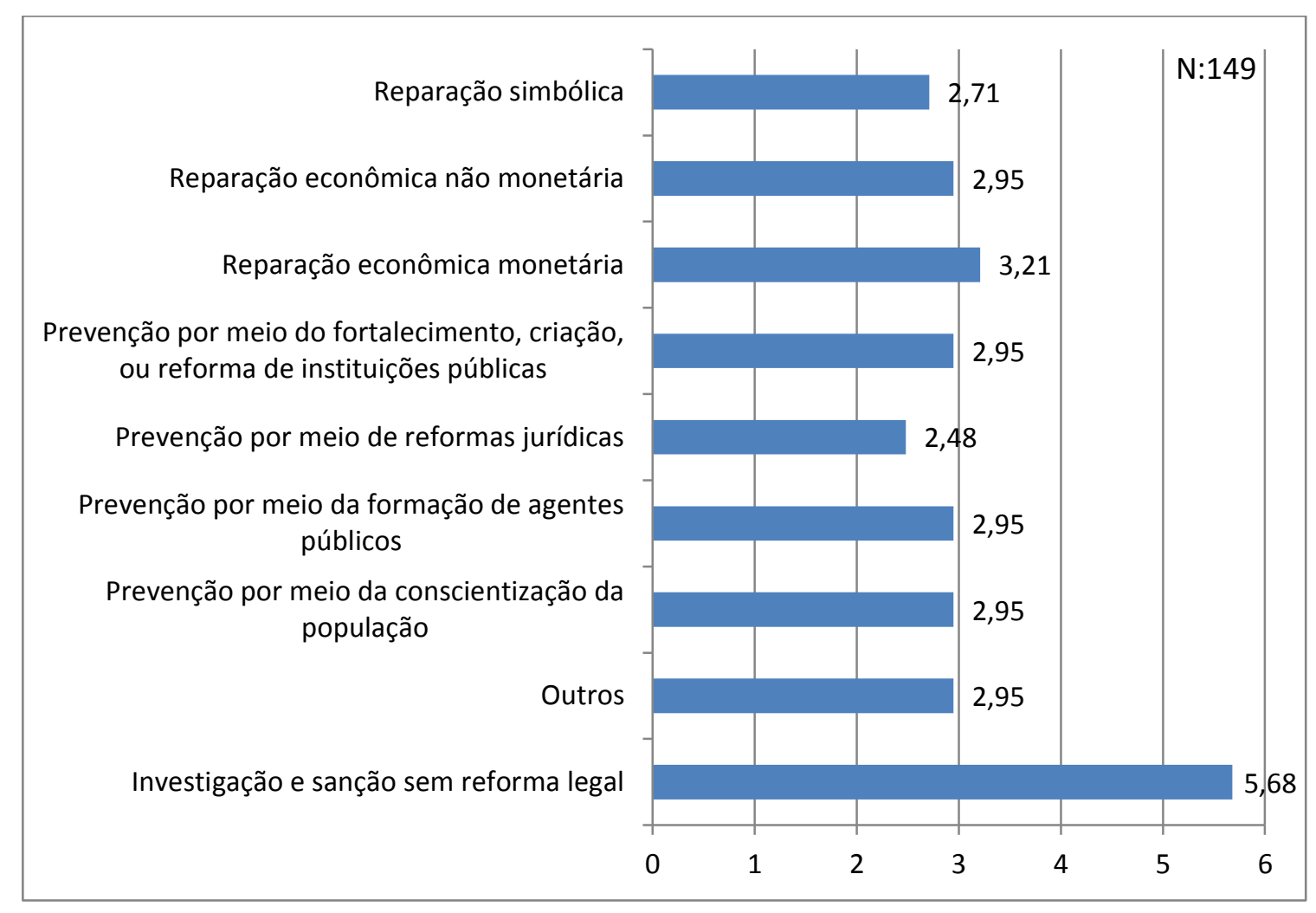

Fonte: Elaboração própria. Dados da $\mathrm{CmDH}$, da $\mathrm{CrDH}$, do MRE e da $\mathrm{SDH}$ (disponível em: http://www.oas.org/pt/cidh/ Acesso em: 07 nov. 2015 e no Apêndice C).

Os resultados demonstram que o Estado brasileiro requer um maior período temporal para implementar totalmente medidas relacionadas à investigação das violações 
de direitos humanos e para a reparação das vítimas. Já os outros tipos de medidas possuem um período médio semelhante para serem cumpridas pelo Brasil.

Observa-se que aquelas medidas relacionadas à prevenção de futuras violações por meio de reformas jurídicas são cumpridas totalmente pelo Estado brasileiro em um curto período de tempo, cerca de dois anos e seis meses (2,48 anos). Lembra-se, contudo, que medidas que envolvem a reforma jurídica são aquelas mais propícias a não serem implementadas pelo País (90\% das medidas desse tipo não foram cumpridas pelo Brasil). Nota-se ainda que essas medidas cumpridas rapidamente pelo Estado brasileiro foram engendradas por meio de acordos de solução amistosa entre as partes. Esse processo dá ao Estado a possibilidade de negociar internamente entre os outros Poderes e agências intergovernamentais as melhores formas de cumprir com as medidas estabelecidas. Assim, medidas que envolvam qualquer tipo de mudança no ordenamento jurídico interno já possuem, de certa forma, o respaldo governamental para serem implementadas e, por isso, são mais propícias a serem implementadas.

Ao analisar o conjunto de dados a partir do objeto das medidas e o período utilizado pelo Estado brasileiro para o seu total cumprimento, temos, em ordem decrescente, os seguintes resultados: 1) Investigação e responsabilização de violações de direitos humanos (5,68 anos); 2) Recompensação de pessoas ou grupos (2,97 anos); 3) Proteção de vítimas e testemunhas e outros (2,95 anos); e 4) Prevenção de futuras violações de direitos (2,89 anos). A figura 26, a seguir, nos mostra graficamente as diferenças de tempo médio em anos para o cumprimento total das medidas emitidas pelo SIDH contra o Brasil.

Pode-se afirmar, a partir dos dados coletados, que a dependência do Poder Executivo de outros poderes autônomos, como poder Judiciário, e de diferentes agências intergovernamentais faz com que até mesmo as medidas totalmente implementadas pelo País proferidas pelo SIDH relacionadas à investigação e responsabilização de violações de direitos humanos utilizem um período temporal maior do que outras medidas. Isso reflete como o processo decisório interno para a implementação de medidas do Sistema Interamericano de Direitos Humanos implica diretamente no grau de compliance do Brasil. 
Figura 26: Média de duração em anos para a compliance do Estado brasileiro com as recomendações, resoluções e medidas acordadas em solução amistosa pelo SIDH classificadas por seu objeto

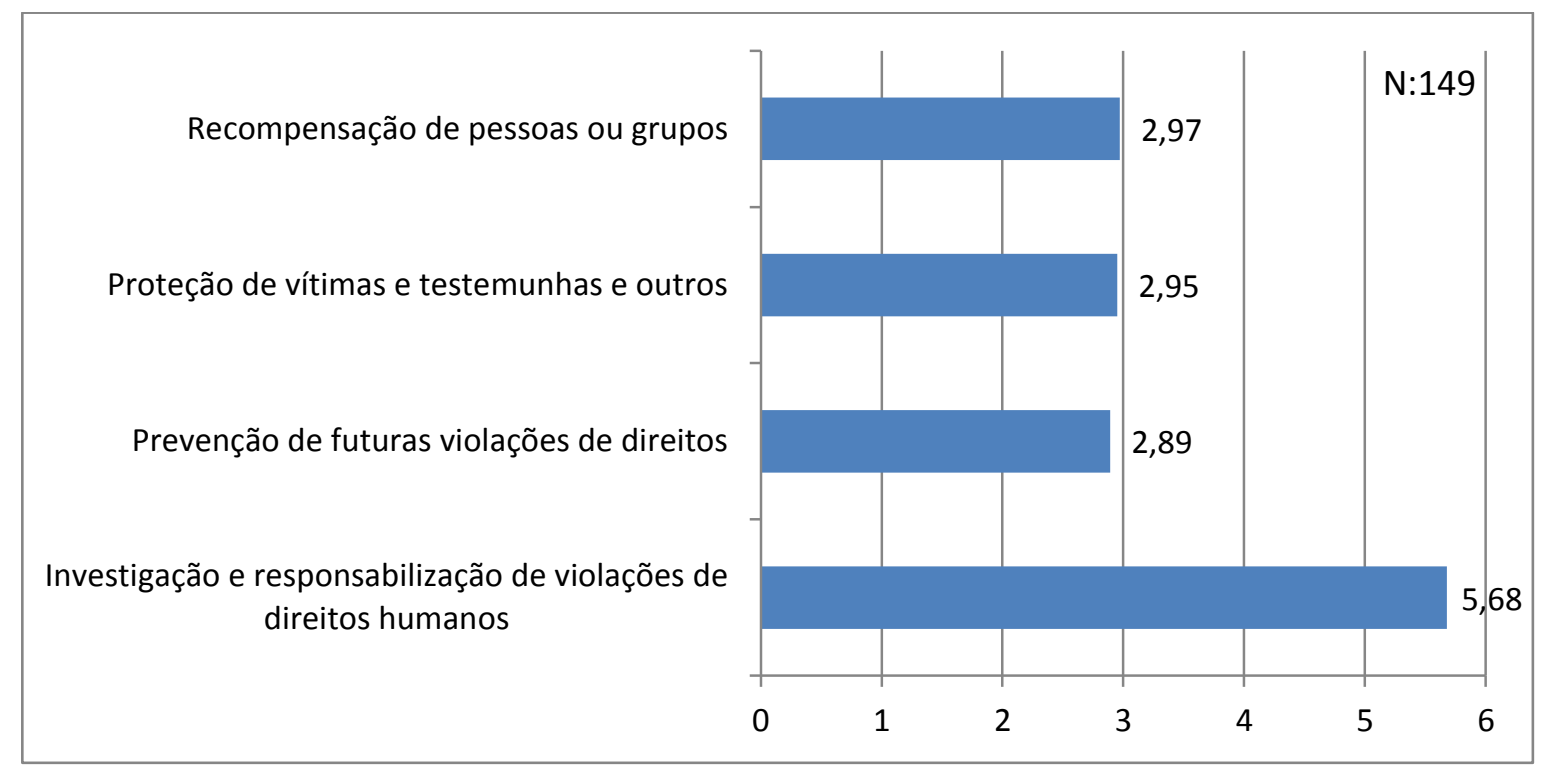

Fonte: Elaboração própria. Dados da $\mathrm{CmDH}$, da $\mathrm{CrDH}$, do MRE e da SDH (disponível em: http://www.oas.org/pt/cidh/ Acesso em: 07 nov. 2015 e no Apêndice C).

Tipos de peticionários e graus de compliance

Das sete classificações de peticionários usadas nesta pesquisa, apenas três estão presentes naqueles casos em que o SIDH outorgou recomendações, resoluções ou medidas de solução amistosa contra o Estado brasileiro. A proporção dos diferentes tipos de peticionários nesses casos não é expressiva ${ }^{43}$. Ao analisar as medidas outorgadas contra o Brasil no SIDH que foram totalmente cumpridas pelo País a partir de seus tipos de peticionários, verifica-se que há uma predominância do trabalho de litigância de ONGs nacionais $(28 \%)$ e do seu trabalho conjunto com ONGs internacionais (25\%). Nota-se ainda que as medidas de casos em que peticionários são formados por ONGs internacionais são menos propícias a não serem cumpridas pelo Brasil, 37\% dessas medidas não foram cumpridas.

\footnotetext{
${ }^{43}$ Em ordem decrescente, é: 1) ONGS nacionais em parceria com ONGS internacionais (41\%); 2) ONGS internacionais (32\%); e 3) ONGS nacionais (27\%). A figura 47 ilustra graficamente a proporção de litigantes encontradas nos casos em que o SIDH outorgou recomendações, resoluções ou medidas de solução amistosa contra o Estado brasileiro.
} 
Figura 27: Grau de compliance das medidas outorgadas contra o Brasil no SIDH a partir de seus litigantes

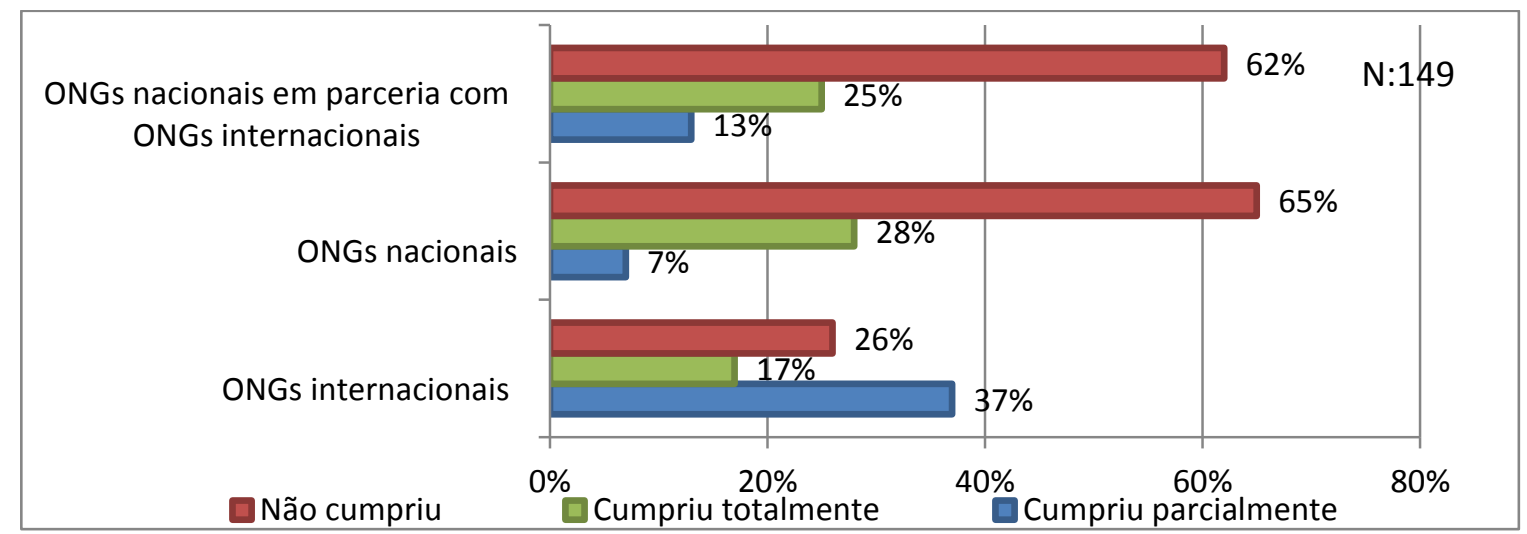

Fonte: Elaboração própria. Dados da $\mathrm{CmDH}$, da $\mathrm{CrDH}$, do MRE e da SDH (disponível em: http://www.oas.org/pt/cidh/ Acesso em: 07 nov. 2015 e no Apêndice C).

De maneira geral, o conjunto de dados analisado não dá indicações expressivas que tipos distintos de peticionários influenciam de maneira diferente a compliance do Estado brasileiro com medidas outorgadas pelo Sistema Interamericano de Direitos Humanos $^{44}$.

Conclusão

Este capítulo teve como objetivo clarificar a inserção do Estado brasileiro no Sistema Interamericano de Direitos Humanos a partir de sua prática e das características dos procedimentos contra o País no Sistema, assim como analisar os graus de compliance do Brasil para com as medidas do SIDH em que foram proferidas recomendações e sentenças ou foram base de acordos de solução amistosa.

Observou-se que mesmo o País sendo um dos mais demandados no Sistema Interamericano de Direitos Humanos ( $7^{\circ}$ posição), há apenas 196 procedimentos ativos contra o Estado brasileiro perante o SIDH, a partir do período temporal estudado. Desses 196 procedimentos, 184 estão na $\mathrm{CmDH}$ e apenas 12 na $\mathrm{CrDH}$.

\footnotetext{
${ }^{44}$ Verifica-se ao que aquelas cumpridas totalmente, em ordem decrescente, por tipo de peticionário são: 1) ONGs nacionais (28\%); 2) ONGs nacionais em parceria com ONGs internacionais (25\%); e 3) ONGs internacionais $(17 \%)$. Quando se analisa o perfil dos litigantes das medidas que foram cumpridas parcialmente, obtêm-se que: 1) ONGs internacionais (37\%); 2) ONGs nacionais em parceria com ONGs internacionais $(13 \%)$; e 3) ONGs nacionais (7\%). Já quando se observa as medidas que não foram cumpridas a partir do tipo de litigante, verifica-se, em ordem decrescente, que sua proporção é: 1) ONGs nacionais (65\%); 2) ONGs nacionais em parceria com ONGs internacionais (62\%); e 3) ONGs internacionais $(26 \%)$.
} 
Notou-se que $48 \%$ dos procedimentos contra o Brasil no SIDH são provenientes da Região Sudeste do País, sendo $22 \%$ do total advindos do estado de São Paulo e $20 \%$ do Rio de Janeiro. Já quando analisado o tema das violações de direitos humanos que originaram o procedimento no SIDH, verificou-se que a maioria dos procedimentos contra o Estado brasileiro no Sistema Interamericano Direitos Humanos é engendrada por violações de direitos humanos relacionadas às deficiências do Poder Judiciário e diretamente relacionadas ao conceito de prestação de justiça.

Igualmente, observou-se que a questão da violência policial continua sendo um dos principais temas de violações de direitos humanos no Brasil, demonstrando a atuação arbitrária das forças policiais e seu papel antagônico de órgão responsável e garantidor da segurança pública como violador de direitos. Ademais, notou-se que violência institucional perpetrada pelo Estado brasileiro, em suas diferentes facetas, é um fato concreto ligado à justiça e segurança e deve ser encarado como um grave problema a ser solucionado.

Quando analisado o tema da violação de direitos humanos por região, observou-se que na Região Centro-oeste é uma predominância de procedimentos ligados a crimes do período da ditadura, devido ao fato da intensa luta de movimentos sociais organizados contra a ditadura na região. Na Região Norte, há a predominância de procedimentos com a temática de violência no campo, haja vista a diversidade camponesa da região e suas comunidades tradicionais. Nas Regiões Nordeste e Sul, há a predominância de procedimentos contra o Brasil no SIDH ligados à violência contra a mulher. Já na Região Sudeste, há a predominância de crimes cometidos por agentes estatais, tais como violência contra menores, tortura, violência policial, violência institucional contra privados de liberdade, violência contra Defensores de Direitos Humanos e prestação de justiça.

No cálculo do período temporal entre a violação de direitos humanos cometida e o início da tramitação do procedimento no Sistema Interamericano de Direitos Humanos da petição, verificou-se que há uma diferença média de sete anos e um mês. Isso demonstra que há uma ineficiência do Poder Judiciário brasileiro em lidar com casos de violações de direitos humanos de maneira célere, fato que faz com que a regra de exceção ao esgotamento de recursos internos para a admissibilidade do procedimento no Sistema Interamericano de Direitos Humanos seja amplamente reivindicada pelos peticionários.

Ao analisar o perfil dos peticionários, verificou-se que a diferença entre as proporções dos diferentes tipos de peticionários (ONGs nacionais, ONGs internacionais, 
parceria entre ONGs nacionais e internacionais, vítimas e representantes de vítimas) nos procedimentos contra o Brasil no SIDH não é muito expressiva.

Dentro de nosso universo de estudo, verificou-se que há 26 casos em que o SIDH outorgou recomendações ou resoluções contra o Estado brasileiro. Dos 26 casos, 21 cumprem recomendações da Comissão, sendo que dois deles são acordos de solução amistosa finalizados e dois deles foram remitidos à Corte. Os outros cinco casos do Brasil são provenientes de decisão da $\mathrm{CrDH}$. Destes cinco casos, o Brasil cumpre resoluções apenas de quatro, uma vez que um dos casos contra o Estado brasileiro foi arquivado pela Corte por falta de provas (Caso Nogueira de Carvalho e outro vs. Brasil).

Nesses casos, há a predominância de violações de direitos humanos relacionadas à prestação de justiça e à violência policial. Há também uma diminuição expressiva da relação de casos que tem como temática a violência no campo e contra privados de liberdade, em comparação com o total geral de procedimentos contra o País. Isso ocorre devido ao fato da maioria desses procedimentos serem compostos por medidas de urgência.

A partir da nossa amostra, verificou-se que dos 26 casos contra o Brasil no SIDH, incluindo-se também os acordos de solução amistosa finalizados, a Comissão e a Corte outorgaram juntas 161 medidas contra o Estado brasileiro, sendo 136 recomendações da Comissão e 25 resoluções da Corte. Contudo, há registros sobre o grau de compliance do Estado brasileiro apenas sobre 149 das 161 medidas. Esse é o número final da amostra utilizado para o estudo dos graus de compliance do Brasil para com medidas do Sistema Interamericano de Direitos Humanos.

Quando analisado o objeto das medidas outorgadas contra o Brasil pelo SIDH, ficou claro que medidas emitidas pela Comissão e Corte, assim como aquelas acordadas em solução amistosa, possuem escopos diferentes. Enquanto a Comissão se preocupa com a criação de uma jurisprudência continental de proteção dos direitos humanos por meio de medidas que visam à prevenção de futuras violações de direitos por meio de reformas jurídicas internas, as medidas emitidas pela Corte Interamericana de Direitos Humanos têm como objetivo o acesso à justiça de forma integral pelas vítimas. Já as medidas acordadas em solução amistosa buscam em sua maioria a prevenção de futuras violações de direitos humanos por meio do fortalecimento, criação ou reforma de instituições públicas.

Essa diferença de escopo das medidas emitidas pelo Sistema Interamericano de Direitos Humanos pode ser explicada pela diferença de mandato de cada órgão. Já os 
acordos de solução amistosa são um caso a parte. Eles demostram que os peticionários, vítimas e o Estado brasileiro possuem um processo de negociação em que ambas as partes buscam deixar claro quais são seus interesses e limites de ação. Nesse sentido, os peticionários e vítimas buscam acordar medidas que previnam a repetição das violações de direitos humanos por meio do fortalecimento, reforma e criação de instituições públicas, enquanto o Estado busca acordar medidas que sejam de fácil cumprimento.

No universo reduzido 149 recomendações, resoluções e medidas acordadas em solução amistosa em que se pode verificar o grau de compliance do Estado brasileiro, observou-se que $48 \%$ das medidas não foram cumpridas, $33 \%$ foram cumpridas totalmente e $19 \%$ foram cumpridas parcialmente. Os dados indicam que há uma clara evidência que o Estado brasileiro é mais propício a cumprir totalmente medidas proferidas pela Corte Interamericana de Direitos Humanos e aquelas acordadas em solução amistosa (59\% das medidas foram cumpridas em cada uma das classificações).

Isso se deve em parte pelo fato de que as medidas proferidas pela Corte são vinculantes e têm peso de norma internacional e porque os acordos de solução amistosa passam por um intenso processo de negociação que culmina com um conjunto de medidas de fácil implementação pelo Estado. Igualmente, observa-se que uma das razões para o total cumprimento das medidas proferidas tanto pela Corte como aquelas acordadas em solução amistosa pode estar ligada ao próprio escopo das medidas, como citado anteriormente.

Ao analisar a compliance do Estado brasileiro para com as recomendações da Comissão Interamericana de Direitos Humanos classificadas por seu tipo, observou-se que a maioria das que não foram cumpridas diz respeito à proteção de vítimas e testemunhas (100\%) e, em seguida, aquelas que envolvem algum tipo de reforma legal. Notou-se ainda que as medidas totalmente implementadas pelo Brasil têm como seu objetivo a reparação simbólica das vítimas $(60 \%)$ e a reparação econômica monetária (35\%). Uma das razões para que isso aconteça é o fato do Governo federal destinar uma alíquota específica de seu orçamento plurianual para o pagamento de indenizações pecuniárias proferidas por órgãos internacionais de direitos humanos.

Esse mecanismo orçamentário é também uma das razões para que as medidas emitidas pela Corte Interamericana de Direitos Humanos que buscam a reparação econômica monetária sejam totalmente cumpridas pelo Estado brasileiro ( $88 \%$ das medidas desse tipo na $\mathrm{CrDH}$ foram totalmente cumpridas pelo Brasil). Outrossim, observou-se que o cumprimento total das medidas outorgadas pelo tribunal é mais 
propicio quando a sentença contra o Estado brasileiro não envolve nenhuma reforma jurídica. Qualquer outro tipo de resolução tem difícil implementação pelo Estado brasileiro. Isso reforça o argumento de que as medidas outorgadas pelo Sistema Interamericana de Direitos Humanos contra o Brasil possui como maior empecilho para a sua total implementação o processo decisório interno do País.

Quando as medidas outorgadas contra o Brasil no SIDH foram classificadas por seu objetivo, notou-se que há uma predominância do não cumprimento de medidas que tem como objetivo a responsabilização e investigação de direitos humanos (70\% não cumpridas) e a proteção de vítimas e testemunhas e outros (60\% não cumpridas). Medidas que visam a recompensação de vítimas e pessoas, assim como a prevenção de futuras violações de direitos humanos, apresentaram uma taxa de cumprimento parcial maior do que as demais medidas, respectivamente $60 \%$ e $52 \%$ de cumprimento parcial.

Os resultados são condizentes com aqueles analisados em cada órgão e demonstram que há uma clara deficiência do Estado brasileiro em cumprir totalmente com medidas que envolvam mudanças no ordenamento jurídico interno e que há uma melhor ação do Estado quando a medida é relacionada à reparação das vítimas, principalmente reparações monetárias. Isso contribui para o argumento de que o processo decisório da implementação das medidas outorgadas pelo Sistema Interamericano de Direitos Humanos contra o Brasil é uma variável importante para a state compliance brasileira.

Quando se analisou o grau de compliance brasileiro com as medidas outorgadas pelo Sistema Interamericano de Direitos humanos, classificadas pelo tema da violação de direitos humanos que engendrou o início da tramitação do procedimento no SIDH, verificou-se que as medidas com maior propensão ao não cumprimento são: 1) Racismo (75\%); 2) Violência policial (70\%); 3) Tortura (53\%); 4) Crimes do período da ditadura; 5) Prestação de justiça (50\%); 6) Violência institucional contra privados de liberdade (sistema prisional e socioeducativo) (50\%); e 7) Violência no campo (40\%).

Os temas dos casos em que as medidas outorgadas contra o Brasil tiveram um cumprimento parcial maior são apenas dois: 1) Violência contra mulheres (80\%); e 2) Violência institucional contra privados de liberdade (sistema prisional e socioeducativo) $(50 \%)$. Há uma clara diferença de prática estatal se o tema da violação de direitos humanos que originou o envio do caso ao Sistema Interamericano de Direitos Humanos é sensível perante a opinião pública doméstica, afetando positivamente a compliance do 
Estado brasileiro, ou se a violação foi perpetrada pelos próprios agentes de Estado, afetando negativamente o grau de compliance do Brasil.

Quando o grau de compliance do Estado brasileiro para com as medidas proferidas pelo SIDH é analisado por cada caso, verificou-se que a maioria dos casos em que SIDH proferiu medidas contra o Brasil enfrentam dificuldades para que suas recomendações e resoluções sejam cumpridas, independentemente do tipo e objeto da medida, seu objetivo ou tema que tenha originado a violação de direitos humanos alvo do procedimento no SIDH.

Observou-se que há em média um período de três anos e dois meses (3,22 anos) para que o SIDH considere que o Estado brasileiro cumpriu totalmente as medidas outorgadas e de nove anos e 11 meses (9,93 anos) para que a SIDH considere as medidas como parcialmente cumpridas. Os dados demonstram que o Estado brasileiro cumpre totalmente com mais celeridade medidas proferidas pela Corte Interamericana de Direitos Humanos e aquelas acordadas em solução amistosa entre as partes. Os resultados demonstram que o Estado brasileiro requer um maior período temporal para implementar totalmente medidas relacionadas à investigação das violações de direitos humanos e para a reparação das vítimas. Já os outros tipos de medidas possuem um período médio semelhante para serem cumpridas pelo Brasil.

A proporção dos diferentes tipos de peticionários nesses casos não é expressiva. Ao analisar as medidas outorgadas contra o Brasil no SIDH que foram totalmente cumpridas pelo País a partir de seus tipos de peticionários, verifica-se que há uma predominância do trabalho de litigância de ONGs nacionais (28\%) e do seu trabalho conjunto com ONGs internacionais (25\%). Não há indicações expressivas que tipos de peticionários diferentes influenciam de alguma forma nos graus de compliance do Estado brasileiro com medidas proferidas pelo SIDH.

Pode-se afirmar, a partir dos dados coletados, que a dependência do Poder Executivo de outros poderes autônomos, como poder Judiciário, e de diferentes agências intergovernamentais faz com que até mesmo as medidas totalmente implementadas pelo País proferidas pelo SIDH relacionadas à investigação e responsabilização de violações de direitos humanos utilizem um período temporal maior do que outras medidas. Isso reflete como o processo decisório interno para a implementação de medidas do Sistema Interamericano de Direitos Humanos implica diretamente no grau de compliance do Brasil. Reconstruir esse processo de tomada de decisão será o objetivo do próximo capítulo. 


\section{Capítulo 3: Processo decisório brasileiro na internalização de sentenças e recomendações do Sistema Interamericano de Direitos Humanos}

Buscar-se-á neste capítulo analisar o processo de tomada de decisão referente à implementação das sentenças e recomendações do Sistema Interamericano de Direitos Humanos contra o Estado brasileiro. Primeiramente, serão identificados quais são as regulações formais e tentativas de regulação que envolve o processo no ordenamento jurídico brasileiro para assim identificar os momentos críticos do percurso histórico, sequências do processo decisório, que afetam a implementação das medidas do SIDH.

Igualmente, buscar-se-á, a partir da identificação e entrevistas com atores-chave e de fontes primárias, reconstruir o processo decisório de internalização das medidas do SIDH, atentando-se para as singularidades da implementação das diferentes medidas e os esforços das diferentes organizações governamentais envolvidas.

\subsection{O processo decisório de implementação das medidas do SIDH no Brasil}

Não há qualquer tipo de regulação formal e abrangente da internalização das medidas do SIDH no Estado brasileiro. Dentre os diversos projetos legislativos votados sobre a matéria, nenhum foi aprovado.

O Projeto de Lei n. 3.214/2000, de autoria do Deputado Marcos Rolim do Partido dos Trabalhadores do Rio Grande do Sul (PT/RS), foi apresentado em 13 de junho de 2000 e foi o primeiro a tratar sobre o tema. Segundo a sua ementa, dispunha sobre "os efeitos jurídicos das decisões da Comissão Interamericana de Direitos Humanos e da Corte Interamericana de Direitos Humanos e dava outras providências" (cf. Projeto de Lei n. 3214, de 2000, Diário da Câmara dos Deputados, 17 de junho de 2000). O projeto abordava de maneira sintética as recomendações e sentenças do SIDH de caráter indenizatório, de maneira a lhes conferir título executivo judicial direto contra a União. $\mathrm{O}$ Deputado Marcos Rolim afirmava que "o projeto procurava suprir a deficiência de legislação nacional sobre o tema e possibilitar à União pagar as indenizações, sem prejuízo de reaver o valor posteriormente do responsável pela violação de direitos humanos" (cf. Projeto de Lei n. 3214, de 2000, Diário da Câmara dos Deputados, 17 de junho de 2000). O projeto recebeu duras críticas pela comissão que o analisou por considerar inconstitucional a execução de uma decisão sem que esta fosse homologada pelo órgão brasileiro competente e foi arquivado sem ter ido à votação na Câmara dos Deputados. 
O segundo projeto apresentado sobre a temática foi o Projeto de Lei n. 4.667/2004, do Deputado José Eduardo Cardozo do Partido dos Trabalhadores de São Paulo (PT/SP). O projeto foi apresentado em 15 de dezembro de 2004 e dispunha "sobre os efeitos jurídicos das decisões dos Organismos Internacionais de Proteção aos Direitos Humanos" (cf. Projeto de Lei n. 4.667, de 2004, Diário da Câmara dos Deputados, 15 de dezembro de 2004). Em seu projeto, o deputado Cardozo reafirma os pontos do projeto anterior e dá especial atenção ao fato de que "apesar da ratificação, as decisões dessas instâncias não estão sendo respeitadas pelo Brasil. O Poder Executivo manifesta interesse no cumprimento das decisões dos organismos de proteção, seja no âmbito regional ou global, porém alega a inexistência de legislação ordinária nacional destinada a disciplinar a matéria" (cf. Projeto de Lei n. 4.667, de 2004, Diário da Câmara dos Deputados, 15 de dezembro de 2004, p.7-10). O projeto ainda está em tramitação e encontra-se parado no Senado Federal desde 2011. Alvo de críticas, o projeto não cobre todas as diferentes hipóteses de condenações internacionais por organismos internacionais e não trata de alguns dos óbices internos que podem influenciar o não cumprimento das recomendações e sentenças, como a demora na tramitação dos processos.

Não obstante, o III Programa Nacional de Direitos Humanos (PNDH3), lançado em 2009 e posteriormente alterado em 2010, trouxe um objetivo específico relacionado ao tema com o título de "Monitoramento dos compromissos internacionais assumidos pelo Estado brasileiro em matéria de Direitos Humanos”. Algumas das ações são:

a) Elaborar relatório anual sobre a situação dos Direitos Humanos no Brasil, em diálogo participativo com a sociedade civil. Responsáveis: Secretaria Especial dos Direitos Humanos da Presidência da República; Ministério das Relações Exteriores. [...]

e) Definir e institucionalizar fluxo de informações, com responsáveis em cada órgão do Governo Federal referentes aos relatórios da Comissão Interamericana de Direitos Humanos e às decisões da Corte Interamericana de Direitos Humanos. Responsáveis: Secretaria Especial dos Direitos Humanos da Presidência da República; Ministério das Relações Exteriores.

f) Criar banco de dados público sobre todas as recomendações dos sistemas ONU e OEA feitas ao Brasil, contendo as medidas adotadas pelos diversos órgãos públicos para seu cumprimento. Responsáveis: Secretaria Especial dos Direitos Humanos da Presidência da República; Ministério das Relações Exteriores. (PNDH3, 2010, p.36-37).

O principal resultado do PNDH3 é fixar um roteiro de atuação para o Poder Público em matéria de Direitos Humanos. Buscou-se institucionalizar, por exemplo, os procedimentos internos do Estado brasileiro para a implementação de recomendações e sentenças oriundas do SIDH.

Devido à falta de uma clareza institucional e jurídica sobre quais órgãos governamentais deveriam ser responsáveis pelos casos do Brasil no Sistema Interamericano de Direitos Humanos, ocorreu uma divisão de tarefas pelos próprios 
órgãos, ao longo do tempo, baseando-se nas suas funções prévias e nos envolvimentos ocasionais com a temática. Neste marco, o Ministério das Relações Exteriores (MRE), a Secretaria de Direitos Humanos (SDH/MJ) ${ }^{45}$ e a Advocacia-Geral da União (AGU) formam o grupo de organizações governamentais centrais nas defesas brasileiras e na implementação das medidas do SIDH. Igualmente, o pagamento de indenizações pecuniárias pelo Brasil se desenvolveu de maneira específica, uma vez que sua concretização foi realizada a partir de rubricas específicas do Orçamento da União. Processo que foi institucionalizado pela União para atender às reparações engendradas por decisões e recomendações do Sistema Interamericano de Direitos Humanos.

O MRE “é o órgão da administração pública federal responsável pelas relações do Brasil com os demais países e pela participação brasileira em organizações internacionais, além disso, executa a política externa definida pela Presidência da República conforme os princípios estabelecidos no art. $4^{\circ}$ da Constituição Federal"46 (MRE, 2016). É a Divisão de Direitos Humanos do MRE responsável por realizar a comunicação com o SIDH em todas as fases do caso.

A SDH/MJ é responsável pelas políticas de implementação dos direitos humanos no governo. De maneira geral, o comunicado da denúncia da suposta violação de direitos humanos pelo Estado Brasileiro é recebido pelo MRE e encaminhado à SDH/MJ. Na Secretaria, sua Assessoria Internacional é responsável por buscar contato e envolver os atores relacionados ao caso em questão.

Já a AGU tem como competência a "representação judicial, extrajudicial da União e as atividades de consultoria e assessoramento jurídicos do Poder Executivo"47 (AGU, 2016). Seu papel dentro do processo de decisão relacionado ao SIDH é, a partir dos trabalhos de seu Departamento Internacional, auxiliar a Secretaria de Direitos Humanos e o MRE tanto na defesa brasileira quanto na implementação das decisões do SIDH. Atualmente, o órgão auxilia principalmente a defesa brasileira nas fases iniciais dos casos no SIDH.

\footnotetext{
${ }^{45}$ A Secretaria de Direitos Humanos foi criada em 17 de abril de 1997 pelo presidente Fernando Henrique Cardoso com o nome de Secretaria Especial de Direitos Humanos, parte do Ministério de Justiça. Durante o governo Lula, obteve status de Ministério e passou a ser parte da estrutura da Presidência da República. A pasta foi anexada com as secretarias de Políticas de Promoção da Igualdade Racial e de Políticas para as Mulheres na reforma ministerial pela presidente Dilma Rousseff formando o Ministério das Mulheres, da Igualdade Racial e dos Direitos Humanos. Em 12 de maio de 2016, o Ministério foi unificado ao Ministério de Justiça pelo governo interino de Michel Temer (Diário Oficial da União, 12 de maio de 2016).

${ }^{46}$ Disponível em: http://www.itamaraty.gov.br/pt-BR/perguntas-frequentes\#I.1 Acesso em: 22 de maio de 2016

${ }^{47}$ Disponível em: http://www.agu.gov.br/faq Acesso em: 22 de maio de 2016
} 
Quando o caso já se encontra na fase de recomendações na Comissão Interamericana de Direitos Humanos, é a SDH/MJ quem coordena internamente o conteúdo da defesa do Estado brasileiro. Nesse momento, são feitos diversos intentos de contato com o ente federativo no qual a suposta violação teria ocorrido com o objetivo de fomentar o início de um processo de solução amistosa entre os peticionários e/ou vítimas com os entes governamentais.

Uma vez que o caso avança para a Corte, os três órgãos (MRE, SDSH/MJ e AGU) atuam conjuntamente na defesa do Estado, buscando incluir outros órgãos e atores relevantes, dependendo de cada caso concreto.

Figura 28: Principais funções das organizações governamentais centrais nas defesas brasileiras e implementação das medidas do SIDH

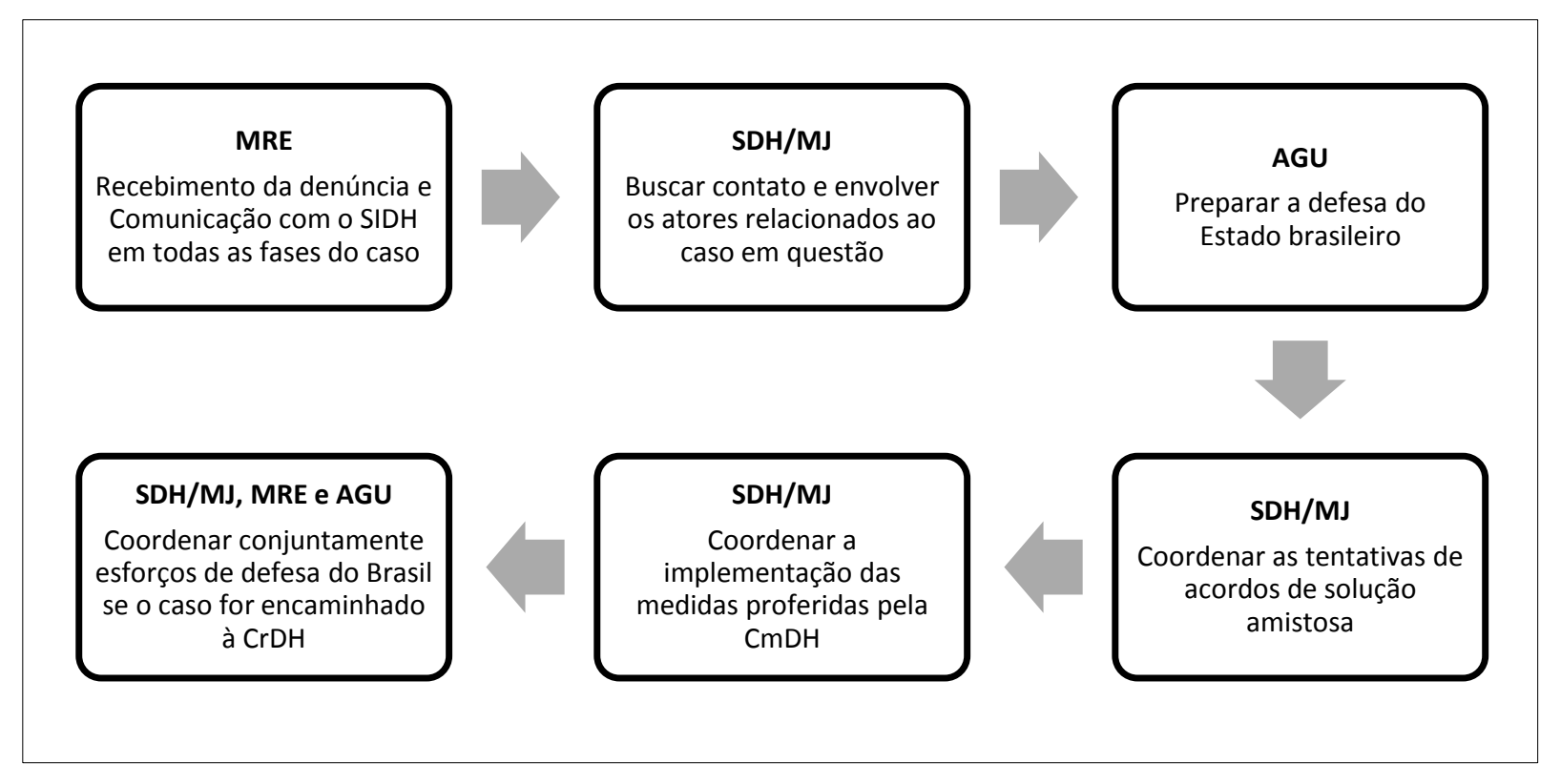

Fonte: Elaboração própria.

A figura 28 acima ilustra as principais funções elencadas das organizações governamentais centrais no processo decisório brasileiro relacionado ao Sistema Interamericano de Direitos Humanos. 


\subsection{Evolução da estrutura decisória referente à internalização de medidas do SIDH: conflito e aprendizagem}

Durante o período analisado, houve um processo de modificação nas responsabilidades de cada instituição governamental envolvida no processo decisório de implementação das recomendações e decisões do SIDH. Essa modificação pode ser vista como resultante política da interação entre as diferentes organizações que compõem o Estado, culminando a um processo de aprendizado institucional.

Pode-se identificar três grandes períodos de interação entre as instituições devido a modificações significativas na estrutura do processo decisório. O primeiro compreende os dois primeiros casos do Estado brasileiro na $\mathrm{CrDH}$ : casos Damião Ximenes Lopes e Gilson Nogueira de Carvalho, respetivamente de 2005 e 2006. O segundo período diz respeito às sentenças dos casos Escher e Garibaldi de 2009. Já o terceiro período se refere ao período entre os casos Julia Gomes Lund (2010) e Belo Monte (2012) (VIEIRA ET $\mathrm{AL}, 2013)$.

A tabela 10 a seguir ilustra a divisão dos casos contra o Brasil no Sistema Interamericano de Direitos Humanos em que já foram proferidas medidas ao Estado brasileiro pelos períodos citados acima:

Tabela 10: Casos contra o Estado brasileiro no SIDH em que já foram outorgadas medidas classificados por períodos de interação entre instituições governamentais

\begin{tabular}{|c|c|c|c|c|c|c|}
\hline $\begin{array}{l}\text { Período de } \\
\text { interação }\end{array}$ & $\begin{array}{l}\text { N. do } \\
\text { caso }\end{array}$ & Nome do Caso & $\begin{array}{l}\text { Data do } \\
\text { relatório de } \\
\text { fundo da } \\
\text { CmDH }\end{array}$ & $\begin{array}{l}\text { Data da } \\
\text { sentença da } \\
\quad \text { CrDH }\end{array}$ & Tipos de decisão & Resumo dos fatos \\
\hline \multirow{5}{*}{ 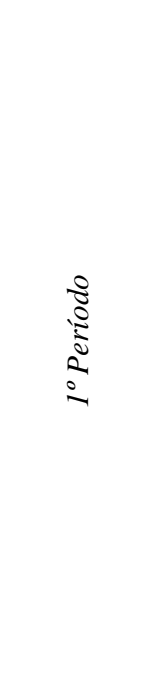 } & 11.287 & $\begin{array}{l}\text { João Canuto de } \\
\text { Oliveira }\end{array}$ & 07/04/1998 & N/A & $\begin{array}{l}\text { Recomendações da } \\
\mathrm{CmDH}\end{array}$ & $\begin{array}{l}\text { Denúncia sobre a falta de investigação e } \\
\text { punição dos responsáveis pelo homicídio de } \\
\text { líder de trabalhadores rurais no Pará }\end{array}$ \\
\hline & 11.516 & Ovelário Tames & 13/04/1999 & N/A & $\begin{array}{l}\text { Recomendações da } \\
\mathrm{CmDH}\end{array}$ & $\begin{array}{l}\text { Denúncia sobre detenção arbitrária da vítima, } \\
\text { que foi morta depois de torturada por agentes } \\
\text { de segurança }\end{array}$ \\
\hline & 11.405 & $\begin{array}{l}\text { Newton Coutinho } \\
\text { Mendes e outros }\end{array}$ & 13/04/1999 & N/A & $\begin{array}{l}\text { Recomendações da } \\
\mathrm{CmDH}\end{array}$ & $\begin{array}{c}\text { Denúncia sobre mortes e ameaças de morte } \\
\text { sofridas por defensores de direitos humanos e } \\
\text { pessoas ligadas à ocupação de terras em razão } \\
\text { de grupo de extermínio formado por } \\
\text { proprietários }\end{array}$ \\
\hline & 11.598 & $\begin{array}{c}\text { Alonso Eugénio da } \\
\text { Silva }\end{array}$ & $24 / 02 / 2000$ & N/A & $\begin{array}{l}\text { Recomendações da } \\
\mathrm{CmDH}\end{array}$ & $\begin{array}{l}\text { Denúncia sobre homicídio de menor por } \\
\text { policial militar durante detenção por suposto } \\
\text { assalto. }\end{array}$ \\
\hline & 11.599 & $\begin{array}{l}\text { Marcos Aurelio de } \\
\text { Oliveira }\end{array}$ & $24 / 02 / 2000$ & N/A & $\begin{array}{l}\text { Recomendações da } \\
\text { CmDH }\end{array}$ & $\begin{array}{l}\text { Denúncia sobre execução sumária de criança } \\
\text { de rua por policial civil }\end{array}$ \\
\hline
\end{tabular}




\begin{tabular}{|c|c|c|c|c|c|c|}
\hline \multirow{12}{*}{$\begin{array}{c}-1 \\
0 \\
0 \\
0 \\
0 \\
0 \\
0 \\
0\end{array}$} & 11.291 & Carandirú & $13 / 04 / 2000$ & N/A & $\begin{array}{l}\text { Recomendações da } \\
\text { CmDH }\end{array}$ & $\begin{array}{l}\text { Denúncia sobre o massacre promovido por } \\
\text { forças policiais ao invadirem o presídio do } \\
\text { Carandiru para debelar uma rebelião }\end{array}$ \\
\hline & 12.051 & $\begin{array}{l}\text { Maria da Penha } \\
\text { Fernandes }\end{array}$ & $16 / 04 / 2001$ & N/A & $\begin{array}{l}\text { Recomendações da } \\
\text { CmDH }\end{array}$ & $\begin{array}{l}\text { Denúncia sobre caso de violência doméstica } \\
\text { com demora e negligência no processamento } \\
\text { da ação criminal }\end{array}$ \\
\hline & 11.286 & $\begin{array}{l}\text { Aluísio Cavalcanti } \\
\text { e outros }\end{array}$ & $16 / 04 / 2001$ & N/A & $\begin{array}{l}\text { Recomendações da } \\
\text { CmDH }\end{array}$ & $\begin{array}{c}\text { Denúncia sobre diversos casos de assassinato } \\
\text { de jovens por forças policiais }\end{array}$ \\
\hline & 11.517 & $\begin{array}{l}\text { Diniz Bento da } \\
\text { Silva (Teixeirinha) }\end{array}$ & $28 / 02 / 2002$ & N/A & $\begin{array}{l}\text { Recomendações da } \\
\text { CmDH }\end{array}$ & $\begin{array}{c}\text { Denúncia sobre execução sumária de membro } \\
\text { do movimento dos trabalhadores rurais sem } \\
\text { terra por forças policiais }\end{array}$ \\
\hline & 11.289 & $\begin{array}{l}\text { José Pereira e } \\
\text { outros }\end{array}$ & $02 / 10 / 2003$ & N/A & $\begin{array}{l}\text { Cumprimento de } \\
\text { Acordo de Solução } \\
\text { Amistosa }\end{array}$ & $\begin{array}{c}\text { Denúncia sobre redução de trabalhadores a } \\
\text { condições análogas à escravidão e de demora } \\
\text { na tomada de providências. }\end{array}$ \\
\hline & 10.301 & Parque São Lucas & $08 / 10 / 2003$ & N/A & $\begin{array}{l}\text { Recomendações da } \\
\text { CmDH }\end{array}$ & $\begin{array}{l}\text { Denúncia sobre tortura de presos no distrito } \\
\text { policial parque são lucas, em São Paulo }\end{array}$ \\
\hline & N/A & $\begin{array}{l}\text { Caso Damião } \\
\text { Ximenes Lopes vs. } \\
\text { Brasil }\end{array}$ & $08 / 10 / 2003$ & $30 / 11 / 2005$ & Sentença da Corte & $\begin{array}{l}\text { Denúncia sobre a morte de portador de } \\
\text { deficiência mental internado em clínica, em } \\
\text { razão de maus-tratos e das condições do local, } \\
\text { sem a devida investigação }\end{array}$ \\
\hline & N/A & $\begin{array}{l}\text { Caso Nogueira de } \\
\text { Carvalho e outro } \\
\text { vs. Brasil }\end{array}$ & $10 / 03 / 2004$ & $28 / 11 / 2006$ & $\begin{array}{l}\text { Arquivada pela } \\
\text { Corte }\end{array}$ & Denúncia sobre assassinato não investigado. \\
\hline & 11.556 & $\begin{array}{l}\text { Massacre de } \\
\text { Corumbiara }\end{array}$ & $11 / 03 / 2004$ & N/A & $\begin{array}{l}\text { Recomendações da } \\
\text { CmDH }\end{array}$ & $\begin{array}{l}\text { Denúncia sobre mortes de trabalhadores } \\
\text { rurais em ação da polícia para reintegração de } \\
\text { posse de terreno }\end{array}$ \\
\hline & 11.634 & $\begin{array}{l}\text { Jaílton Néri da } \\
\text { Fonseca }\end{array}$ & $11 / 03 / 2004$ & N/A & $\begin{array}{l}\text { Recomendações da } \\
\text { CmDH }\end{array}$ & $\begin{array}{c}\text { Denúncia sobre execução sumária de menor } \\
\text { por forças policiais em favela do rio de } \\
\text { janeiro }\end{array}$ \\
\hline & 12.426 & $\begin{array}{l}\text { Meninos } \\
\text { Emasculados do } \\
\text { Maranhão }\end{array}$ & $15 / 03 / 2006$ & N/A & $\begin{array}{l}\text { Cumprimento de } \\
\text { Acordo de Soluçãa } \\
\text { Amistosa }\end{array}$ & $\begin{array}{l}\text { Denúncia sobre caso de violência doméstica } \\
\text { com demora e negligência no processamento } \\
\text { da ação criminal. }\end{array}$ \\
\hline & 12.001 & $\begin{array}{l}\text { Simone André } \\
\text { Diniz }\end{array}$ & $21 / 10 / 2006$ & N/A & $\begin{array}{l}\text { Recomendações da } \\
\text { CmDH }\end{array}$ & $\begin{array}{c}\text { Denúncia Sobre Discriminação Racial Sofrida } \\
\text { Por Empregada Doméstica Que Não Foi } \\
\text { Contratada Por Ser Negra }\end{array}$ \\
\hline \multirow{3}{*}{ 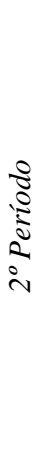 } & N/A & $\begin{array}{l}\text { Caso Arley José } \\
\text { Escher e outros vs. } \\
\text { Brasil }\end{array}$ & 08/03/2007 & 06/07/2009 & Sentença da Corte & $\begin{array}{l}\text { Denúncia sobre grampos telefônicos feitos } \\
\text { irregularmente pela polícia e autorizados pelo } \\
\text { judiciário, com posterior divulgação das } \\
\text { gravações e dano à imagem das vítimas. }\end{array}$ \\
\hline & N/A & $\begin{array}{l}\text { Caso Garibaldi vs. } \\
\text { Brasil }\end{array}$ & $27 / 03 / 2007$ & $23 / 09 / 2009$ & Sentença da Corte & $\begin{array}{l}\text { Denúncia sobre assassinato de membro do } \\
\text { movimento dos trabalhadores rurais sem terra } \\
\text { (mst) e de falta de investigações. }\end{array}$ \\
\hline & 12.019 & $\begin{array}{l}\text { Antônio Ferreira } \\
\text { Braga }\end{array}$ & $18 / 07 / 2008$ & N/A & $\begin{array}{l}\text { Recomendações da } \\
\text { CmDH }\end{array}$ & $\begin{array}{l}\text { Denúncia sobre detenção ilegalmente feita } \\
\text { pela polícia civil, inclusive com tortura da } \\
\text { vítima }\end{array}$ \\
\hline
\end{tabular}




\begin{tabular}{|c|c|c|c|c|c|c|}
\hline \multirow{6}{*}{ 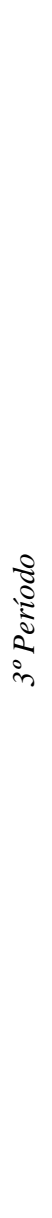 } & N/A & $\begin{array}{l}\text { Caso Julia Gomes } \\
\text { Lund e outros } \\
\text { (Guerrilha do } \\
\text { Araguaia) vs. } \\
\text { Brasil }\end{array}$ & $31 / 10 / 2008$ & 24/11/2010 & Sentença da Corte & $\begin{array}{c}\text { Denúncia sobre o desaparecimento forçado de } \\
\text { militantes que participaram da "Guerrilha do } \\
\text { Araguaia", combatendo o regime ditatorial } \\
\text { brasileiro, e falta de investigação sobre os } \\
\text { fatos. }\end{array}$ \\
\hline & 12.310 & $\begin{array}{c}\text { Sebastião Camargo } \\
\text { Filho }\end{array}$ & $19 / 03 / 2009$ & N/A & $\begin{array}{l}\text { Recomendações da } \\
\text { CmDH }\end{array}$ & $\begin{array}{l}\text { Denúncia sobre assassinato de membro do } \\
\text { movimento dos trabalhadores rurais sem terra } \\
\text { no Paraná sem investigação e indenização }\end{array}$ \\
\hline & 12.440 & $\begin{array}{l}\text { Wallace de } \\
\text { Almeida }\end{array}$ & 20/03/2009 & N/A & $\begin{array}{l}\text { Recomendações da } \\
\mathrm{CmDH}\end{array}$ & $\begin{array}{c}\text { Denúncia sobre assassinato da vítima em } \\
\text { razão de abuso em operação policial, } \\
\text { inclusive com indícios de discriminação } \\
\text { racial }\end{array}$ \\
\hline & 12.308 & $\begin{array}{l}\text { Manoel Leal de } \\
\text { Oliveira }\end{array}$ & $17 / 03 / 2010$ & N/A & $\begin{array}{c}\text { Recomendações da } \\
\text { CmDH }\end{array}$ & $\begin{array}{l}\text { Denúncia sobre assassinato de jornalista após } \\
\text { publicação de escândalo de corrupção no } \\
\text { jornal de que era editor }\end{array}$ \\
\hline & 11.566 & $\begin{array}{l}\text { Favela Nova } \\
\text { Brasília (Evandro } \\
\text { Oliveira e outros) }\end{array}$ & $31 / 10 / 2011$ & N/A & $\begin{array}{l}\text { Recomendações da } \\
\text { CmDH }\end{array}$ & $\begin{array}{l}\text { Denúncia sobre execuções extrajudiciais de } \\
26 \text { pessoas - incluindo seis crianças - no } \\
\text { âmbito das incursões policiais feitas pela } \\
\text { Polícia Civil do Rio de Janeiro na Favela } \\
\text { Nova Brasília. Estas mortes foram } \\
\text { justificadas pelas autoridades policiais } \\
\text { mediante o levantamento de "atas de } \\
\text { resistência à prisão". }\end{array}$ \\
\hline & 12.066 & $\begin{array}{l}\text { Fazenda Brasil } \\
\text { Verde }\end{array}$ & 03/11/2011 & N/A & $\begin{array}{l}\text { Recomendações da } \\
\text { CmDH }\end{array}$ & $\begin{array}{l}\text { Denúncia sobre a situação de trabalho escravo } \\
\text { de milhares de trabalhadores em fazenda no } \\
\text { Pará, desaparecimento de menores e } \\
\text { denegação de justiça pelo Estado }\end{array}$ \\
\hline
\end{tabular}

Fonte: Elaboração própria. Dados da $\mathrm{CmDH}$, da $\mathrm{CrDH}$, do MRE e da $\mathrm{SDH}$ (disponível em: http://www.oas.org/pt/cidh/ Acesso em: 07 nov. 2015 e no Apêndice C).

No caso Damião Ximenes Lopes vs. Brasil se observou os primeiros passos para a institucionalização do processo de defesa do Estado brasileiro e implementação das decisões do SIDH, uma vez que se trata da primeira condenação do Brasil na Corte Interamericana de Direitos Humanos.

\section{Resumidamente, o caso diz respeito ao}

homicídio com sinais de tortura de Damião Ximenes Lopes, portador de deficiência mental, que havia sido internado em $1^{\circ}$ de outubro de 1999 na casa de repouso dos Guararapes, na cidade de Sobral, Ceará, falecendo três dias depois. [...] A ação penal foi ajuizada em 2000, mas o Judiciário brasileiro só se pronunciou com decisão final em 2013. [...] A CIDH apresentou o caso à Corte Interamericana contra o Estado brasileiro em $1^{\circ}$ de outubro de 2004 . A Corte declarou violação dos direitos à vida e à integridade pessoal de Damião Ximenes Lopes e dos demais portadores de deficiência que sofriam com as condições precárias da casa de repouso, à integridade pessoal dos familiares das vítimas pela perda de um ente da família, assim como aos direitos às garantias judiciais e à proteção judicial, diante da demora injustificada do processo criminal e das falhas nas investigações (VIEIRA ET AL, 2013, p.10). 
O Estado brasileiro foi condenado a cumprir uma séria de medidas. Algumas delas foram: "concluir o processo judicial, com eventual responsabilização dos envolvidos na demora; a indenizar a família da vítima; a continuar a desenvolver um programa de formação e capacitação para todas as pessoas vinculadas ao atendimento de saúde mental, em especial sobre os princípios que devem reger o trato das pessoas portadoras de deficiência mental, conforme os padrões internacionais sobre a matéria e aqueles dispostos na decisão" (VIEIRA ET AL, 2013, p.10).

Nesse caso, a defesa do Estado brasileiro perante a $\mathrm{CrDH}$ foi feita por funcionários da Advocacia-Geral da União indicados especialmente para a função. O mesmo voltaria a acontecer no caso Gilson Nogueira de Carvalho. O caso diz respeito ao assassinato do advogado Francisco Gilson Nogueira de Carvalho, defensor de direitos humanos, em 1996 no estado do Rio Grande do Norte. A vítima dedicou parte de seu trabalho profissional a denunciar crimes cometidos pelo grupo de extermínio "meninos de ouro", supostamente formado por policiais e agentes estatais. O caso foi arquivado pela Corte Interamericana de Direitos Humanos por entender que "não ficou demonstrado que o estado tenha violado no presente caso os direitos às Garantias Judiciais e à Proteção Judicial consagrados nos artigos 8 e 25 da Convenção Americana sobre Direitos Humanos" e por falta de $\operatorname{provas}^{48}$.

A representação do Brasil por membros da AGU, assim como a elaboração da defesa, evidenciou uma primeira ruptura nos ritos informais de divisão de trabalhos entre os órgãos governamentais (MRE, SDH/MJ e AGU) no âmbito do SIDH, uma vez que o papel da AGU se restringia agora às fases iniciais dos casos na $\mathrm{CmDH}$ (VIEIRA ET AL, 2013, p.10). Até esse momento, a Secretaria de Direitos Humanos articulava junto com o MRE a defesa dos casos contra o Brasil no SIDH, buscando sempre o fomento de soluções amistosas e fornecendo as informações pedidas dentro dos processos no Sistema Interamericano de Direitos Humanos.

O Departamento Internacional da AGU foi criado em 2000. Assim, quando o caso Damião Ximenes Lopes chegou ao órgão em 2004, esta já estava preparada institucionalmente para realizar a defesa do Estado brasileiro. Dessa maneira, a divisão internacional do órgão passou a ter contato direto com os atores do Poder Judiciário envolvidos no caso, inclusive com visitas à cidade onde aconteceram os fatos (VIEIRA ET AL, 2013). Acredita-se que por ter representado o Estado brasileiro no caso desde o

\footnotetext{
${ }^{48}$ Disponível em: http://www.cnj.jus.br/sobre-o-cnj/quem-somos-visitas-e-contatos Acesso em: 22 de maio de 2016.
} 
seu início, a AGU "assumiu um papel central na fase de implementação das medidas de condenação" (VIEIRA ET AL, 2013, p.21), papel ocupado anteriormente pela SDH/MJ.

Devido ao fato de ser o primeiro caso de condenação do Brasil na Corte Interamericana de Direitos Humanos, o caso Damião Ximenes Lopes também trouxe inovações no que diz respeito às medidas de pagamento de indenização às vítimas. Neste caso, para o cumprimento da sentença da $\mathrm{CrDH}$ referente à indenização da família da vítima se fez necessário uma articulação entre os órgãos governamentais para decidirem como se daria a implementação dessa medida internamente (Entrevista. Brasília, SDH/MJ, dezembro de 2015).

Observou-se no caso que o papel da Secretaria de Direitos Humanos na implementação das medidas oriundas da sentença da $\mathrm{CrDH}$ foi o de tentar convencer os outros órgãos governamentais relacionados ao caso sobre a necessidade da mudança de legislações e políticas públicas ligadas à temática da violação. Não obstante, notou-se que quando "a medida se relacionava às atividades da Justiça brasileira havia dificuldades nesse esforço de convencimento" (VIEIRA ET AL, 2013, p.21).

No caso Damião Ximenes Lopes, isso se tornou ainda mais evidente, uma vez que a questão central do caso é o funcionamento das instituições judiciárias e a necessidade de sua reforma para a implementação das medidas exigidas pela $\mathrm{CrDH}$. Nesse marco, fundou-se a prática de a Advocacia-Geral da União articular diretamente com os atores do Poder Judiciário para facilitar a implementação das recomendações e sentenças do SIDH pelo Estado brasileiro (Entrevista. Brasília, SDH/MJ, dezembro de 2015).

Contudo, mesmo com a atuação mais incisiva da AGU junto aos atores do Poder Judiciário, o tempo de trâmite das ações continuava lento, "em grande parte por causa da ineficácia da abordagem política habitual de convencimento com os atores do Judiciário" (VIEIRA ET AL, 2013, p.21). Foi necessária a inclusão de um quarto ator, o Conselho Nacional de Justiça (CNJ), que "visa aperfeiçoar o trabalho do sistema judiciário brasileiro, principalmente no que diz respeito ao controle e à transparência administrativa e processual ${ }^{49}$ (CNJ, 2016), criado em 2004 e considerado a mais alta instância do Poder Judiciário brasileiro. A atuação do CNJ garantiu que os atores do Poder Judiciário começassem a efetivamente colaborar com a implementação das recomendações e sentenças do SIDH (Entrevista. Brasília, AGU, janeiro de 2016).

Pode-se concluir que ao longo do processo de defesa e implementação das resoluções da primeira condenação do Estado Brasileiro pela Corte Interamericana de

\footnotetext{
${ }^{49}$ Disponível em: http://www.cnj.jus.br/sobre-o-cnj/quem-somos-visitas-e-contatos Acesso em: 22 de maio de 2016.
} 
Direitos Humanos houve uma nova definição de competências e papéis dos atores para a representação da defesa do Brasil na Corte e a elaboração das manifestações brasileiras. Além da entrada do CNJ, mencionada acima, a Advocacia-Geral da União obteve papel de destaque nos âmbitos jurídicos do caso. A Secretaria de Direitos Humanos reforçou seu papel de coordenação entre os órgãos governamentais, principalmente daqueles que envolvem outros entes federativos. Já o Ministério das Relações Exteriores conservou a sua posição de intermediador entre o SIDH e o Estado brasileiro.

De acordo com relatos dos entrevistados, houve no processamento do primeiro caso de condenação brasileira no SIDH uma coordenação e concerto entre as instituições sobre como cada uma deveria atuar no limite das suas funções adquiridas e competências. Essa coordenação e respeito aos seus limites institucionais iria se repetir no caso Gilson Nogueira de Carvalho. Neste caso, “[o]s peticionários alegaram que o Estado havia faltado a sua obrigação de garantir a Gilson Nogueira de Carvalho o direito à vida e de realizar uma investigação séria sobre sua morte, processar os responsáveis e promover os recursos judiciais adequados" ${ }^{, 50}(\mathrm{CrDH}, 2006)$. Ao final, o Estado brasileiro foi absolvido por falta de provas.

O segundo período compreende o caso Escher e outros e o Caso Garibaldi, ambos de 2009. O caso Escher e outros trata de intercepções telefônicas de duas organizações ligadas ao Movimento dos Trabalhadores Rurais Sem Terra (MST) em Querênia do Norte, Paraná, realizadas de maneira irregular pela polícia local com o aval do Poder Judiciário.

\begin{abstract}
As informações resultantes dessa operação foram divulgadas à imprensa e, posteriormente, para o público. Segundo os peticionários, isso teria maculado a imagem das vítimas e do movimento social. A denúncia foi apresentada à Comissão em dezembro de 2000, levada à Corte Interamericana em dezembro de 2007 e julgada pela Corte em julho de 2009. A decisão envolveu as seguintes condenações contra o Brasil: obrigação de publicar as sentenças e de indenizar as vítimas, além da obrigação de investigar adequadamente os fatos e punir os responsáveis pelas violações dos direitos à privacidade, à honra e à liberdade de associação (VIEIRA ET AL, 2013, p.10-11).
\end{abstract}

O caso Garibaldi diz respeito ao homicídio de Sétimo Garibaldi, membro do Movimento dos Trabalhadores Sem Terra (MST) também na mesma cidade de Querênia do Norte, Paraná. O homicídio foi cometido por homens não identificados que atacaram uma ocupação do MST em uma fazenda da região (VIEIRA ET AL, 2013, p.11).

A denúncia foi apresentada em maio de 2003, submetida à Corte Interamericana de Direitos Humanos em março de 2007 e julgada pela Corte

\footnotetext{
${ }^{50}$ Disponível em: http://www.corteidh.or.cr/docs/casos/articulos/seriec_161_por.pdf Acesso em: 22 de maio de 2016.
} 
em setembro de 2009. Envolveu as seguintes condenações contra o Brasil: obrigação de publicar as sentenças, de indenizar as famílias das vítimas e de investigar adequadamente os fatos, além de punir os responsáveis pelas violações de direitos humanos à vida e à proteção judicial (VIEIRA ET AL, 2013, p.11).

Nesse segundo momento, o responsável pela defesa do Estado brasileiro frente à $\mathrm{CrDH}$ passou a ser o Embaixador do Brasil na Costa Rica, sede da Corte, ao invés da AGU. Essa troca marca o diferente tom dado pelo Brasil em suas defesas (Entrevista. Brasília, MRE, abril de 2016). No período passado, as defesas do Estado brasileiro no tribunal interamericano eram permeadas de um discurso de proteção das vítimas quando realizadas pela AGU, com um caráter mais técnico e marcadas por argumentos jurídicos. A maior inserção do MRE no processo mudaria por completo o viés técnico e jurídico do processo decisório do Brasil no SIDH para adquirir um tom político (Entrevista. Brasília, SDH/MJ, dezembro de 2015).

Dessa maneira, a nova reorganização das competências de cada órgão no processo de implementação das decisões oriundas do SIDH passou a representar as próprias dinâmicas dos órgãos entre si. A AGU passou a atuar principalmente nas fases de admissibilidades dos casos tanto na Comissão como na Corte. Enquanto o Ministério das Relações Exteriores se encarregou das outras manifestações do Estado brasileiro frente ao SIDH. A Secretaria de Direitos Humanos passou a atuar apenas como responsável por coordenar os atores internos com o objetivo de recolher informações úteis referentes aos casos e por buscar um diálogo entre vítimas e peticionários com os entes federativos com o objetivo de fomentar a realização de soluções amistosas e facilitar a implementação das recomendações e decisões do SIDH (Entrevista. Brasília, MRE, abril de 2016)

Essa nova organização de competências não era imutável. Segundo relatos dos entrevistados, cada instituição teria a possibilidade de influenciar a atividade da outra por meio da sensibilização de atores-chave (principalmente gestores públicos) de cada órgão. Todavia, era perceptível uma prevalência velada de cada uma das instituições sob as funções especificadas a partir da vigilância realizada pelo MRE para que as instituições governamentais se atentassem às suas competências pré-estabelecidas.

No terceiro período, que compreende o caso Julia Gomes Lund e o caso Belo Monte, há um distanciamento e polarização das posições tomadas internamente pela AGU e SDH. O caso Julia Gomes Lund e outros (caso "Guerrilha do Araguaia") trata da responsabilidade do Estado brasileiro pela 
anos de 1972 e 1975 e da consequente falta de investigação desses atos - o que se relaciona com a edição da Lei federal n. 6.683, de 28 de agosto de 1979 ("Lei da Anistia") e com o sigilo permanente sobre documentos a respeito dessa operação estatal. A denúncia foi apresentada à Comissão em 1995, e a petição foi submetida pela CIDH à Corte em 2009. Em 24 de novembro de 2010, a Corte IDH condenou o Brasil pela falta de investigação dos crimes cometidos por militares durante a "Guerrilha do Araguaia" (VIEIRA ET AL, 2013, p.11-12).

A Corte Interamericana determinou ao Estado brasileiro entre outras medidas: "a condução eficaz da investigação penal a fim de esclarecer os fatos ocorridos no caso, definir as correspondentes responsabilidades penais e aplicar as sanções cabíveis" (VIEIRA ET AL, 2013, p.12). Determinou, ainda, que "o Estado continuasse as iniciativas de busca, sistematização e publicação de toda informação sobre a 'Guerrilha do Araguaia', bem como das violações de direitos humanos ocorridas durante o regime militar" (VIEIRA ET AL, 2013, p.12). Igualmente, a Corte determinou a criação de uma "Comissão da Verdade autônoma, independente e capaz de garantir o direito à verdade sobre o ocorrido" (VIEIRA ET AL, 2013, p.12).

$\mathrm{O}$ caso Comunidades Indígenas da Bacia do rio Xingu vs. Brasil (caso Belo Monte) tem como cerne a construção da Usina Hidrelétrica de Belo Monte, que afetaria dezenas de povos indígenas na região da Volta Grande do Xingu, no centro-norte do Brasil. Desde a década de 1970, o governo brasileiro planeja construir um complexo hidrelétrico na região. Mesmo após diversas tentativas do Ministério Público Federal de suspender a implantação da obra, o licenciamento dessa prosseguiu e ganhou força nos anos $2000 "$ (VIEIRA ET AL, 2013, p.13).

Segundo as entidades peticionárias no SIDH, houve violação aos direitos à vida, à integridade pessoal, à informação e à participação política dos povos indígenas afetados pelo megaempreendimento. Em razão disso, em $1^{\circ}$ de abril de 2011, a CIDH outorgou uma medida cautelar para que o Estado brasileiro suspendesse o processo de licenciamento da obra, impedisse qualquer obra anterior à consulta das populações indígenas e adotasse medidas destinadas a garantir a vida e a integridade pessoal dos envolvidos. Houve reação negativa do governo brasileiro, de um lado, e apoio da sociedade civil organizada à medida cautelar, do outro (VIEIRA ET AL, 2013, p.13-14).

Após grande pressão do governo brasileiro para que a medida cautelar fosse revogada tanto na própria Comissão como na Secretaria Geral da Organização dos Estados Americanos (OEA), a $\mathrm{CmDH}$ alterou a sua decisão para exigir do Estado brasileiro "a adoção de medidas que garantissem o direito à vida e à integridade dos indígenas, que impedissem problemas de saúde nas comunidades e que finalizassem com rapidez a demarcação das terras ancestrais daqueles povos” (VIEIRA ET AL, 2013, p.14). 
Esses dois casos mostram de forma emblemática como a Secretaria de Direitos Humanos se posicionou a favor das vítimas, enquanto a AGU defendeu a posição do governo. No Caso Gomes Lund e outros, por exemplo, a Advocacia-Geral da União defendeu a Lei da Anistia brasileira junto ao Supremo Tribunal Federal (STF). Devido a essa situação divergente entre a SDH/MJ e a AGU, o MRE passou a coordenar todas as manifestações brasileiras no caso em todas as suas fases em diálogo contínuo com a Casa Civil (Entrevista. Brasília, MRE, abril de 2016). Situação análoga aconteceu no caso Belo Monte, no qual as manifestações do Estado brasileiro foram também concentradas no MRE com diálogo contínuo com a Casa Civil, haja vista tamanha sensibilidade do tema para o governo federal (Entrevista. Brasília, MRE, abril de 2016).

Diante do exposto, observa-se que a interação entre os principais atores envolvidos no processo decisório referente à implementação das decisões e recomendações oriundas do SIDH pelo Estado brasileiro se baseia nos interesses políticos-institucionais de cada órgão e em suas capacidades de manobras. Paralelamente, há um processo contínuo de institucionalização e adaptação desses órgãos frente às demandas do SIDH. "Isso se evidencia ainda mais com a sucessão de casos, mediante a maior concentração da defesa brasileira nas mãos do MRE e a colocação da AGU e da SDH em posições novas" (VIEIRA ET AL, 2013, p.23).

\subsection{Indenização pecuniária das vítimas}

O Brasil possui uma rubrica específica do orçamento federal que destina recursos para o pagamento de indenizações que resultam da condenação pela violação de tratados internacionais de direitos humanos. A dotação é denominada "pagamento de indenização a vítimas de violação das obrigações contraídas pela União por meio da adesão a tratados internacionais" (BRASIL, Lei Federal n. 12.798, de 4 de abril de 2013, volume IV, p.603).

No marco da mobilização nacional para a elaboração da agenda brasileira para a Conferência Mundial de Direitos Humanos e como fruto desta e da Declaração e Programa de Ação de Viena de 1993, foi criado o I Programa Nacional de Direitos Humanos (PNDH1). Segundo o programa, os direitos humanos deveriam ser tratados de maneira transversal como objeto de políticas públicas pelos órgãos governamentais (PNDH1, 1996, p.7).

Do ponto de vista orçamentário, o PNDH1 resultou na articulação de distintas propostas de ações governamentais. Criou-se o programa "Promoção e garantia dos 
direitos humanos", entre 1996 e 1999, e posteriormente esse foi substituído e aprimorado pelo programa "Direitos Humanos, Direitos de Todos" (DHDT), ambos ligados ao Ministério da Justiça e com dotação orçamentária desde 1999.

Em 2002, foi lançado II Programa Nacional de Direitos Humanos (PNDH2) no Brasil. Em sua introdução, identifica-se o seguinte trecho:

A criação da Secretaria de Estado dos Direitos Humanos, no âmbito do
Ministerio da Justiça, possibilitou o engajamento efetivo do Governo Federal
em ações voltadas para a proteção e promoção de direitos humanos. As metas
do PNDH foram, em sua maioria, sendo incorporadas aos instrumentos de
planejamento e orçamento do Governo Federal, convertendo-se em programas
e ações específicas com recursos financeiros assegurados nas Leis
Orçamentárias Anuais, conforme determina o Plano Plurianual (PPA) (PNDH2,
2002, p.1).

O PNDH2 tem como um de seus resultados principais a ampliação de programas governamentais que já haviam sido previstos nos orçamentos do governo federal nos anos anteriores, devido tanto ao programa "Promoção e garantia dos direitos humanos" como o DHDT. Todavia, no PNDH2 não foi previsto nenhuma medida para o alcance dos objetivos estratégicos relacionados à diretriz "inserção nos sistemas internacionais de proteção" (PNDH2, 2002, p.32), "tais como a adoção de medidas para cumprimento dos compromissos assumidos em tratados internacionais, o fortalecimento da cooperação com o sistema regional de proteção e a promoção de soluções amistosas no âmbito da Comissão Interamericana de Direitos Humanos” (VIEIRA ET AL, 2013, p.24).

Devido à elaboração do Plano Plurianual de 2004 a 2007 (BRASIL, Lei federal n. 10.933, de 11 de agosto de 2004, Plano Plurianual 2004/2007), foi reconhecida no âmbito do DHDT a necessidade de uma previsão orçamentária clara sobre as indenizações pecuniárias às vítimas e às famílias das vítimas de violações de direitos humanos pelo Estado brasileiro.

Isto ocorreu, principalmente, pelos obstáculos enfrentados pelos órgãos do governo brasileiro na implementação das recomendações oriundas da primeira solução amistosa envolvendo o Brasil e os peticionários do caso José Pereira $(\mathrm{CmDH}$, Informe 95/03) que tratava de matéria de competência da União, combate ao trabalho escravo. Desse modo, retirou-se o dever de indenizar as vítimas da esfera estadual e o passou para a esfera federal (Entrevista. Brasília, SDH/MJ, dezembro de 2015).

Relatos dos entrevistados indicam que foi nesse caso que se percebeu que o pagamento das indenizações pecuniárias por meio de leis consumia muito mais tempo que a destinação exclusiva de uma parte do orçamento federal. Desse modo, a Presidência 
da República poderia cumprir com as recomendações e sentenças indenizatórias "por meio de um simples decreto presidencial" (VIEIRA ET AL, 2013, p.24).

Nessa conjuntura, foi em 2004 que a Lei Orçamentária Anual brasileira previu, pela primeira vez, uma rubrica intitulada "Pagamento de indenização à vítimas de violação das obrigações contraídas pela União por meio da adesão a tratados internacionais de proteção dos direitos humanos" (BRASIL, Lei federal n. 10.933, de 11 de agosto de 2004, Plano Plurianual 2004/2007). Dotação orçamentária dentro do programa DHDT do Ministério da Justiça. Esta ação do governo federal vai ao encontro dos objetivos estratégicos 487 e 489 do PNDH2:

Como resultado da implementação do Programa Nacional de Direitos Humanos - PNDH, o Brasil ampliou sua participação nos sistemas global (da Organização das Nações Unidas - ONU) e regional (da Organização dos Estados Americanos - OEA) de promoção e proteção dos direitos humanos. Em particular, a cooperação com os órgãos de supervisão da OEA tem ensejado a busca de soluções amistosas para casos de violação em exame pela Comissão Interamericana de Direitos Humanos, abrindo a possibilidade de concessão de reparações e indenizações às vítimas dessas violações ou a seus familiares, bem como a adoção de medidas administrativas e legislativas para prevenir a ocorrência de novas violações (PNDH2, 2002, p.32)

Dessa maneira, a previsão orçamentária teve como finalidade não apenas o Sistema Interamericano de Direitos Humanos, mas também o sistema global de proteção dos direitos humanos configurado na Organização das Nações Unidas. A tarefa de coordenar as ações dentro desses dois sistemas foi atribuída ao Gabinete da então Secretaria Especial de Direitos Humanos. Logo, desde 2004, a lei orçamentária brasileira destina um montante para que a SDH/MJ possa arcar com as despesas provenientes das indenizações pecuniárias oriundas de violações de tratados internacionais pelo Estado brasileiro.

Nota-se, contudo, que o orçamento vinculado ao pagamento de indenizações pecuniárias engendradas por medidas oriundas do SIDH é geralmente mobilizado quando há sentenças proferidas pela Corte Interamericana de Direitos Humanos. Desse modo, é sempre a esfera estadual de governo, entre os entes federados, que deve ser o responsável por tal pagamento. Igualmente, é o âmbito estadual de governo que se responsabiliza pela implementação das outras medidas outorgadas pelo SIDH. 
Tabela 11: Graus de compliance do Estado brasileiro com medidas proferidas pelo SIDH relacionadas à reparação econômica monetária de vítimas.

\begin{tabular}{|c|c|c|c|c|}
\hline \multicolumn{5}{|c|}{$\begin{array}{l}\text { Graus de compliance do Estado brasileiro com medidas proferidas pelo SIDH relacionadas à reparação } \\
\text { econômica monetária de vítimas }\end{array}$} \\
\hline & & & & $N: 29$ \\
\hline $\begin{array}{l}\text { N. do } \\
\text { Caso }\end{array}$ & Nome do Caso & Tipos de decisão & Medidas & $\begin{array}{c}\text { Graus de } \\
\text { Compliance }\end{array}$ \\
\hline 12.308 & Manoel Leal de Oliveira & $\begin{array}{l}\text { Recomendações } \\
\text { da } \mathrm{CmDH}\end{array}$ & $\begin{array}{l}\text { Reparação econômica } \\
\text { monetária }\end{array}$ & Cumpriu totalmente \\
\hline 12.310 & Sebastião Camargo Filho & $\begin{array}{l}\text { Recomendações } \\
\text { da } \mathrm{CmDH}\end{array}$ & $\begin{array}{l}\text { Reparação econômica } \\
\text { monetária }\end{array}$ & Não cumpriu \\
\hline 12.440 & Wallace de Almeida & $\begin{array}{l}\text { Recomendações } \\
\text { da CmDH }\end{array}$ & $\begin{array}{l}\text { Reparação econômica } \\
\text { monetária }\end{array}$ & $\begin{array}{c}\text { Cumpriu } \\
\text { parcialmente }\end{array}$ \\
\hline 12.019 & Antônio Ferreira Braga & $\begin{array}{c}\text { Recomendações } \\
\text { da CmDH }\end{array}$ & $\begin{array}{c}\text { Reparação econômica } \\
\text { monetária }\end{array}$ & Não cumpriu \\
\hline \multirow{3}{*}{12.001} & \multirow{3}{*}{ Simone André Diniz* } & \multirow{3}{*}{$\begin{array}{l}\text { Recomendações } \\
\text { da } \mathrm{CmDH}\end{array}$} & $\begin{array}{l}\text { Reparação econômica } \\
\text { monetária }\end{array}$ & Cumpriu totalmente \\
\hline & & & $\begin{array}{l}\text { Reparação econômica } \\
\text { monetária }\end{array}$ & Não cumpriu \\
\hline & & & $\begin{array}{c}\text { Reparação econômica } \\
\text { monetária }\end{array}$ & Cumpriu totalmente \\
\hline 11.556 & Massacre de Corumbiara & $\begin{array}{c}\text { Recomendações } \\
\text { da } \mathrm{CmDH}\end{array}$ & $\begin{array}{c}\text { Reparação econômica } \\
\text { monetária }\end{array}$ & Não cumpriu \\
\hline \multirow{2}{*}{11.634} & \multirow{2}{*}{ Jaílton Néri da Fonseca* } & \multirow{2}{*}{$\begin{array}{c}\text { Recomendações } \\
\text { da } \mathrm{CmDH}\end{array}$} & $\begin{array}{l}\text { Reparação econômica } \\
\text { monetária }\end{array}$ & Cumpriu totalmente \\
\hline & & & $\begin{array}{c}\text { Reparação econômica } \\
\text { monetária }\end{array}$ & Cumpriu totalmente \\
\hline 10.301 & Parque São Lucas & $\begin{array}{c}\text { Recomendações } \\
\text { da } \mathrm{CmDH}\end{array}$ & $\begin{array}{c}\text { Reparação econômica } \\
\text { monetária }\end{array}$ & $\begin{array}{c}\text { Cumpriu } \\
\text { parcialmente }\end{array}$ \\
\hline 11.517 & $\begin{array}{l}\text { Diniz Bento da Silva } \\
\text { (Teixeirinha) }\end{array}$ & $\begin{array}{l}\text { Recomendações } \\
\text { da } \mathrm{CmDH}\end{array}$ & $\begin{array}{l}\text { Reparação econômica } \\
\text { monetária }\end{array}$ & $\begin{array}{c}\text { Cumpriu } \\
\text { parcialmente }\end{array}$ \\
\hline 11.286 & $\begin{array}{c}\text { Aluísio Cavalcanti e } \\
\text { outros } \\
\end{array}$ & $\begin{array}{c}\text { Recomendações } \\
\text { da } \mathrm{CmDH}\end{array}$ & $\begin{array}{c}\text { Reparação econômica } \\
\text { monetária }\end{array}$ & Não cumpriu \\
\hline 11.291 & Carandirú & $\begin{array}{c}\text { Recomendações } \\
\text { da } \mathrm{CmDH}\end{array}$ & $\begin{array}{c}\text { Reparação econômica } \\
\text { monetária }\end{array}$ & Não cumpriu \\
\hline 11.598 & Alonso Eugénio da Silva & $\begin{array}{l}\text { Recomendações } \\
\text { da } \mathrm{CmDH}\end{array}$ & $\begin{array}{l}\text { Reparação econômica } \\
\text { monetária }\end{array}$ & $\begin{array}{l}\text { Informação não } \\
\text { disponível }\end{array}$ \\
\hline 11.599 & $\begin{array}{c}\text { Marcos Aurelio de } \\
\text { Oliveira }\end{array}$ & $\begin{array}{c}\text { Recomendações } \\
\text { da CmDH }\end{array}$ & $\begin{array}{c}\text { Reparação econômica } \\
\text { monetária }\end{array}$ & $\begin{array}{c}\text { Informação não } \\
\text { disponível }\end{array}$ \\
\hline 11.516 & Ovelário Tames & $\begin{array}{c}\text { Recomendações } \\
\text { da } \mathrm{CmDH}\end{array}$ & $\begin{array}{c}\text { Reparação econômica } \\
\text { monetária }\end{array}$ & $\begin{array}{l}\text { Informação não } \\
\text { disponível }\end{array}$ \\
\hline 11.287 & João Canuto de Oliveira & $\begin{array}{c}\text { Recomendações } \\
\text { da } \mathrm{CmDH}\end{array}$ & $\begin{array}{c}\text { Reparação econômica } \\
\text { monetária }\end{array}$ & Cumpriu totalmente \\
\hline 11.566 & $\begin{array}{c}\text { Favela Nova Brasília } \\
\text { (Evandro Oliveira e } \\
\text { outros) }\end{array}$ & $\begin{array}{l}\text { Recomendações } \\
\text { da } \mathrm{CmDH}\end{array}$ & $\begin{array}{c}\text { Reparação econômica } \\
\text { monetária }\end{array}$ & Não cumpriu \\
\hline 12.066 & Fazenda Brasil Verde & $\begin{array}{l}\text { Recomendações } \\
\text { da } \mathrm{CmDH}\end{array}$ & $\begin{array}{l}\text { Reparação econômica } \\
\text { monetária }\end{array}$ & Não cumpriu \\
\hline
\end{tabular}




\begin{tabular}{|c|c|c|c|c|}
\hline 12.426 & $\begin{array}{l}\text { Meninos Emasculados do } \\
\text { Maranhão }\end{array}$ & $\begin{array}{l}\text { Cumprimento de } \\
\text { Acordo de } \\
\text { Solução } \\
\text { Amistosa }\end{array}$ & $\begin{array}{l}\text { Reparação econômica } \\
\text { monetária }\end{array}$ & Cumpriu totalmente \\
\hline N/A & $\begin{array}{c}\text { Caso Julia Gomes Lund e } \\
\text { outros (Guerrilha do } \\
\text { Araguaia) vs. Brasil }\end{array}$ & $\begin{array}{l}\text { Sentença da } \\
\text { Corte }\end{array}$ & $\begin{array}{l}\text { Reparação econômica } \\
\text { monetária }\end{array}$ & $\begin{array}{l}\text { Parcialmente } \\
\text { cumprido }\end{array}$ \\
\hline \multirow{2}{*}{ N/A } & \multirow{2}{*}{ Caso Garibaldi vs. Brasil* } & \multirow{2}{*}{$\begin{array}{l}\text { Sentença da } \\
\text { Corte }\end{array}$} & $\begin{array}{l}\text { Reparação econômica } \\
\text { monetária }\end{array}$ & Cumpriu totalmente \\
\hline & & & $\begin{array}{l}\text { Reparação econômica } \\
\text { monetária }\end{array}$ & Cumpriu totalmente \\
\hline \multirow{3}{*}{ N/A } & \multirow{3}{*}{$\begin{array}{l}\text { Caso Damião Ximenes } \\
\text { Lopes vs. Brasil* }\end{array}$} & \multirow{3}{*}{$\begin{array}{l}\text { Sentença da } \\
\text { Corte }\end{array}$} & $\begin{array}{l}\text { Reparação econômica } \\
\text { monetária }\end{array}$ & Cumpriu totalmente \\
\hline & & & $\begin{array}{c}\text { Reparação econômica } \\
\text { monetária }\end{array}$ & Cumpriu totalmente \\
\hline & & & $\begin{array}{c}\text { Reparação econômica } \\
\text { monetária }\end{array}$ & Cumpriu totalmente \\
\hline \multirow{2}{*}{ N/A } & \multirow{2}{*}{$\begin{array}{c}\text { Caso Arley José Escher e } \\
\text { outros vs. Brasil* }\end{array}$} & \multirow{2}{*}{$\begin{array}{l}\text { Sentença da } \\
\text { Corte }\end{array}$} & $\begin{array}{l}\text { Reparação econômica } \\
\text { monetária }\end{array}$ & Cumpriu totalmente \\
\hline & & & $\begin{array}{l}\text { Reparação econômica } \\
\text { monetária }\end{array}$ & Cumpriu totalmente \\
\hline
\end{tabular}

*Os Casos $n^{\circ} 12.001$ Simone André Diniz e $n^{\circ} 11.634$ Jaílton Néri da Fonseca, ambos em fase de cumprimento de recomendações da $\mathrm{CmDH}$, assim como o Caso Garibaldi vs. Brasil, Caso Damião Ximenes Lopes vs. Brasil e Caso Arley José Escher e outros vs. Brasil, que cumprem resoluções da CrDH, apresentam mais de uma medida relacionada à reparação econômica monetária das vítimas e familiares. Para ter acesso ao teor das medidas, vide Apêndice C.

Fonte: Elaboração própria. Dados da $\mathrm{CmDH}$, da $\mathrm{CrDH}$, do MRE e da $\mathrm{SDH}$ (disponível em: http://www.oas.org/pt/cidh/ Acesso em: 07 nov. 2015 e no Apêndice C).

Os dados contidos na tabela 11 deixam claro que o Estado brasileiro, âmbito federal, cumpre quase totalmente com todas as medidas outorgadas pela Corte Interamericana de Direitos Humanos relacionadas à reparação econômica das vítimas e familiares das vítimas da violação de direitos humanos. A medida referente ao Caso Julia Gomes Lund e outros (Guerrilha do Araguaia) é a única que se encontra parcialmente cumprida, todas as outras medidas da $\mathrm{CrDH}$ referentes à reparação econômica das vítimas e familiares das vítimas foram totalmente cumpridas pelo Brasil.

O mesmo não ocorre com as medidas outorgadas pela Comissão, já que o pagamento das indenizações pecuniárias das medidas proferidas pela $\mathrm{CmDH}$ são responsabilidades dos estados federados e dependem do contexto político de cada caso, assim como dos esforços engendrados pela SIDH para envolver os atores domésticos no processo decisório de implementação das recomendações e resoluções do Sistema Interamericano de Direitos Humanos contra o Brasil, uma vez que a medida não tem caráter jurídico vinculante. 


\subsection{Implementação das medidas de garantia e acesso à justiça e o Programa Justiça Plena}

Como visto na seção 3.2, um dos papéis da Advocacia-Geral da União durante os três grandes períodos identificados de mudanças no processo decisório do Brasil no SIDH é a articulação junto aos atores do Poder Judiciário brasileiro. Contudo, deve-se destacar também o lançamento do programa "Justiça Plena" pelo Conselho Nacional de Justiça, em 2010, como um dos fatores que exercem influência sobre como o Estado brasileiro implementa as decisões e sentenças oriundas do SIDH.

O Programa Justiça Plena monitora e dá transparência ao andamento de
processos de grande repercussão social. Lançada pela Corregedoria Nacional
de Justiça [...], a iniciativa apoia a gestão dessas causas, relacionadas a questões
criminais, ações civis públicas, ações populares, processos em defesa do direito
do consumidor e ambientais. Entre coordenadores e participantes, o Justiça
Plena tem oito protagonistas: o Ministério da Justiça (MJ), o Conselho
Nacional de Justiça (CNJ), a Advocacia- Geral da União (AGU), a Secretaria
de Direitos Humanos (SDH), o Conselho Nacional do Ministério Público
(CNMP), a Ordem dos Advogados do Brasil (OAB), a Defensoria Pública da
União e dos Estados e a Procuradoria Federal dos Direitos do Cidadão (PFDC)
[...] A ferramenta fornece, por exemplo, apoio técnico aos juízes responsáveis
pelas causas publicadas no SAPRS [Sistema de Acompanhamento de Processos
de Relevância Social] ${ }^{51}$ (CNJ, 2016)

Mesmo não vinculado oficialmente ao processo de implementação das decisões oriundas do SIDH no Brasil, na prática, o Programa Justiça Plena é considerado como uma boa prática no monitoramento das ações do Poder Judiciário relacionadas aos casos do Brasil no Sistema Interamericano. Aqueles casos de "grande repercussão social" são indicados pelas organizações participantes do programa para serem objetos de relatórios públicos que apuram o andamento processual e possíveis demoras injustificadas em seus trâmites (CNJ, 2016).

Um dos pontos positivos do programa é dar visibilidade pública aos casos que do contrário ficariam simplesmente limitados às localidades em que as violações de direitos humanos foram cometidas e, portanto, mais suscetíveis à disputas de poder locais e à corrupção, seja no âmbito do Poder Judiciário ou dos outros poderes (Entrevista. Brasília, AGU, janeiro de 2016).

Uma dos órgãos governamentais que tem destaque dentre as atividades do programa é a Secretaria de Direitos Humanos. A SDH/MJ tem como prática solicitar ao CNJ por meio do programa Justiça Plena os processos e ações que, devido ao demasiado

\footnotetext{
${ }^{51}$ Disponível em: http://www.cnj.jus.br/programas-e-acoes/justica-plena Acesso em: 23 de maio de 2016.
} 
tempo de tramitação, poderiam ser ou foram alvos de decisões da Comissão ou Corte Interamericana de Direitos Humanos.

Em 2012, o Programa Justiça Plena lançou seu último relatório de atividades. No total, o programa "conta[va] [...] com 80 processos em andamento e 12 casos já finalizados" em maio de 2012 (CNJ, 2012, p.1), sendo a Secretaria de Direitos Humanos o terceiro órgão governamental que mais incluiu processos no programa. "Todas as suas 16 inclusões se referiam a casos que tramitam ou tramitaram no sistema interamericano" (VIEIRA ET AL, 2013, p.77).

Ainda que houvesse já colaboração entre o CNJ e a SDH anteriormente, este órgão passou a contar com o programa como fator importante no diálogo com o Poder Judiciário, atenuando em parte o problema apontado anteriormente de dificuldade de convencimento dos atores necessários para a implementação das medidas (VIEIRA ET AL, 2013, p.26).

Esse fato fez com que a SDH/MJ ganhasse certa autonomia da AdvocaciaGeral da União para se relacionar com o Poder Judiciário, aumentando assim a sua capacidade de manobra no processo decisório do Estado brasileiro no SIDH (Entrevista. Brasília, SDH/MJ, dezembro de 2015). Observa-se, oportunamente, que as ações judiciais referentes ao caso Damião Ximenes Lopes, ao caso Escher e outros e ao caso Garibaldi, por exemplo, foram incluídas pela Secretaria de Direitos Humanos no programa Justiça Plena $^{52}$.

\section{Conclusão}

O processo de implementação das medidas proferidas pelo Sistema Interamericano de Direitos Humanos contra o Estado brasileiro não é institucionalizado. Por isso, todas as agências governamentais envolvidas nesse processo decisório (AGU, SDH/MJ, MRE) precisam desenvolver um esforço político, a cada caso, para cooperar entre si e com os órgãos locais diretamente relacionados à implementação das medidas específicas a cada uma das violações.

Isso não ocorre apenas quando a medida em questão envolve a reparação econômica monetária da vítima, caso em que houve uma evolução de um mecanismo orçamentário específico pelo Governo federal, ou quando há competência exclusiva do âmbito federal sobre o caso. Ao mesmo tempo, as mesmas organizações governamentais

\footnotetext{
${ }^{52}$ No último relatório do Programa Justiça Plena, publicado em 2012 pelo CNJ, não há indicações das atividades específicas realizadas para a implementação das medidas de garantia de acesso à justiça em cada caso incluído no programa.
} 
disputam entre si espaços de poder dentro do governo, baseados em seus padrões comportamentais historicamente definidos, para obter um maior poder de influência nas partes da implementação das medidas proferidas pelo SIDH que são responsáveis.

Igualmente, a evolução do processo decisório interno de implementação das medidas do SIDH indica que há um aprendizado e conflito contínuo entre as organizações governamentais envolvidas. Os diferentes períodos de interação analisados deixam claro que o poder para esse modelo é fragmentado entre as organizações envolvidas e os próprios processos criados por estas para a implementação das medidas outorgadas pelo SIDH.

Isso demonstra que dentre as três abordagens sobre compliance analisadas no primeiro capítulo (international enforcement, gestão e política doméstica) a que mais se aproxima da realidade brasileira é a que diz respeito à política doméstica dos Estados e aos processos decisórios internos de implementação das medidas outorgadas pelo SIDH. O próximo capítulo analisará mais atentamente quais são as implicações dessa abordagem para o contexto brasileiro a partir das hipóteses relacionadas à compliance do Brasil para com as medidas do SIDH criadas por Oscar Vilhena Vieira (2013). 


\section{Capítulo 4: Compliance como uma resultante política doméstica: teste de} hipóteses

No contexto brasileiro, a abordagem de compliance que foca sua análise na política doméstica do Estado é exemplificada pela pesquisa de Oscar Vilhena Vieira (2013). O autor busca esclarecer como foram implementadas as medidas e decisões do SIDH pelo Brasil e conclui com um conjunto de hipóteses que busca esclarecer quais foram as razões pelas quais "o sistema político brasileiro não foi capaz de conceber um mecanismo sólido e eficiente para a implementação das decisões do Sistema Interamericana de Direitos Humanos" (VIEIRA ET AL, 2013, p.6).

Pesquisas preliminares como a de Vieira (2013) não nos permitem saltar para conclusões rotundas, mas oferecem uma base para que observadores mais atentos possam levantar hipóteses que mobilizem outras linhas de investigação. Por isso, há a necessidade de uma análise mais profunda ao conjunto de dados estudados para que se seja possível testar as hipóteses lançadas por Vieira (2013) e clarificar, com base na realidade empírica, as determinantes que afetam a compliance do Estado brasileiro para com as sentenças oriundas do SIDH a partir da abordagem relacionada à política doméstica. Este será o objetivo deste capítulo e a diferença básica entre este estudo e o de Vieira (2013).

\subsection{Hipóteses}

Em sua pesquisa, Oscar Vilhena Vieira (2013) busca encontrar parâmetros consistentes para aferir a qualidade da implementação das medidas do Sistema Interamericano de Direitos Humanos. Para que se evitasse a escolha aleatória de parâmetros, o autor coletou dados empíricos e normativos domésticos "para desenvolver uma métrica adequada à compreensão do fenômeno, à luz da realidade brasileira" (VIEIRA ET AL, 2013, p.26).

Foram, então, identificadas três variáveis que afetam a compliance do estado brasileiro com os instrumentos do SIDH. As variáveis e seus efeitos estão descritos abaixo:

i) A existência de uma agenda de política pública do Estado em andamento ao tempo da decisão afeta positivamente o grau de compliance do Estado brasileiro no SIDH; 
ii) A dependência do governo de poderes autônomos, como governos locais, Ministério Público e Judiciário, para implementar as políticas públicas necessárias para o cumprimento dos instrumentos do SIDH afeta negativamente o grau de compliance do Estado brasileiro no SIDH; e

iii) Violações de direitos humanos engendradas como consequência de políticas públicas do Estado afetam negativamente o grau de compliance do Estado brasileiro no SIDH.

Segundo o autor, alguns casos estudados em sua pesquisa trazem indícios de que quando há a existência de uma agenda política pública do Estado brasileiro "estabelecida previamente à recomendação ou condenação do SIDH, em qualquer dos níveis federativos, facilitará sua implementação" (VIEIRA ET AL, 2013, p.27). O primeiro caso a ilustrar essa variável é o caso Damião Ximenes Lopes. Desde o início, ficou claro pelas manifestações brasileiras de defesa perante a $\mathrm{CmDH}$ e a $\mathrm{CrDH}$ que havia a existência de uma política interna de reforma do sistema psiquiátrico e de defesa dos direitos das pessoas com deficiência já em andamento no momento de início do trâmite do caso no Sistema Interamericano de Direitos Humanos. "É mencionado nos depoimentos que o fechamento da Casa de Repouso dos Guararapes, onde havia falecido Damião Ximenes, foi um marco que impulsionou essa reforma" (VIEIRA ET AL, 2013, p.38).

Quando o Estado brasileiro promove e/ou apoia o ato que gera a violação de direitos humanos condenada pelo Sistema Interamericano de Direitos Humanos, Vieira (2013) argumenta que o adimplemento das sentenças e recomendações do SIDH se torna mais dificultosa. "Contudo, as medidas nestes casos ainda assim podem ser apropriadas por atores estatais e pela sociedade civil organizada" (VIEIRA ET AL, 2013, p.43). A pressão exercida pela sociedade civil organizada, assim como organizações governamentais envolvidas no processo de tomada de decisão que envolve a implementação das medidas proferidas pelo SIDH, geralmente a SDH/MJ, ao se apropriar do caso pressionaria o Estado brasileiro a ter uma maior compliance com as medidas do SIDH. O autor exemplifica seu argumento a partir da análise dos casos Julia Gomes Lund e outros e o caso Belo Monte.

No caso Julia Gomes Lund e outros, a decisão de não cumprir com a sentença da $\mathrm{CrDH}$ de anular a Lei de Anistia (Lei n 6.683/1979), "ampara-se em um discurso de reconciliação nacional e superação do período ditatorial" (VIEIRA ET AL, 2013, p.36). $\mathrm{O}$ argumento pode ser reforçado pela constitucionalidade da Lei da Anistia confirmada pelo Supremo Tribunal Federal (STF). Já no caso Belo Monte, mesmo depois da 
afirmação da $\mathrm{CmDH}$ de que as comunidades indígenas estavam na iminência de sofrer danos irreparáveis, o Estado brasileiro defendeu sua posição de ir contra a sentença outorgada pela Comissão e prosseguir com a construção das usinas hidrelétricas em terras indígenas na região amazônica ao afirmar que todos os procedimentos internos para resguardar a população local e seu modo de vida e para a preservação da fauna e flora da região foram realizados, projetos e procedimentos os quais já eram estudados desde a década de 1970.

"Um terceiro fator que influencia a implementação é a natureza federal do Estado brasileiro" (VIEIRA ET AL, 2013, p.43). Muitas vezes, há casos em que as sentenças e recomendações oriundas do SIDH envolvem apenas competências exclusivas do Governo federal. Contudo, há alguns casos em que a competência envolvida é dividida entre os entes federativos ou pertence exclusivamente aos estados e/ou municípios.

Normalmente, o Governo federal procura compartilhar, sempre que possível, as responsabilidades com os outros entes federativos para a busca de uma solução amistosa para o caso. Como já visto, esse papel de coordenação e articulação com os atores dos diferentes âmbitos de governo é responsabilidade da Secretaria de Direitos Humanos. Papel valorizado dentro do processo decisório de implementação das decisões do SIDH, uma vez que a maioria das violações de direitos humanos acontece no âmbito local (Entrevista. Brasília, SDH/MJ, dezembro de 2015). Quando o caso é julgado pela $\mathrm{CrDH}$, o Estado brasileiro adota uma posição diferente, haja vista que a União se torna responsável internacionalmente por cumprir com as medidas outorgadas pela Corte Interamericana de Direitos Humanos.

Como identificado, quando não há qualquer tipo de regulação formal e abrangente da internalização das medidas do SIDH no Estado brasileiro e, por isso, esse é um processo eminentemente político. Dessa maneira, por não haver nenhum mecanismo que obrigue os entes federados e outros agentes políticos a cumprir com as decisões outorgadas pelo SIDH, a inclusão desses atores no processo de implementação dos instrumentos do Sistema Interamericano de Direitos Humanos afeta negativamente o grau de compliance do Estado brasileiro (VIEIRA ET AL, 2013). 


\subsection{Tratamento dos dados e procedimentos}

Para testar as hipóteses sugeridas por Vieira (2013) examino todos os 26 casos contra o Estado brasileiro os quais a Comissão ou Corte proferiram suas recomendações e sentenças e aqueles em que houve uma solução amistosa. Lembra-se que o Caso Nogueira de Carvalho e outro foi arquivado pela Corte Interamericana de Direitos Humanos por falta de provas e por atestar que o processo seguiu o devido processo legal no ordenamento jurídico brasileiro. Portanto, o número de casos analisados é 25. Assim, buscar-se-á categorizá-los em cinco categorias diferentes:

(i) Quando há a existência de uma agenda de política pública relativa às questões específicas de direitos humanos objeto de decisão do SIDH;

(ii) Quando há a existência de uma agenda de política pública relativa às questões específicas de direitos humanos objeto de decisão do SIDH e há a dependência de poderes autônomos;

(iii) Quando há violações que decorrem de agendas de políticas públicas do Estado;

(iv) Quando há violações que decorrem de agendas de políticas públicas do Estado e há a dependência de poderes autônomos;

(v) Quando há dependência de poderes autônomos sem a existência de uma agenda política pública a favor ou contra as decisões do SIDH

Preferiu-se conjugar a variável "dependência de poderes autônomos" com as outras duas variáveis devido ao fato da maioria das violações de direitos humanos denunciadas contra o Estado brasileiro no Sistema Interamericano de Direitos Humanos acontecerem no âmbito local e ser de competência, geralmente, compartilhada entre os entes federativos. Assim, poderemos ver o efeito da dependência de poderes autônomos de maneira mais clara sob as outras variáveis.

Para tanto, o universo de estudo é composto por todas as manifestações do Estado brasileiro no SIDH entre 1988 e a 2014. As manifestações foram fornecidas pelo Ministério das Relações Exteriores (MRE) por meio da Lei de Acesso à Informação, Lei ${ }^{\circ} 12.527 / 2011$, pelos protocolos 09200000719201553, e somam o total de 106 relatórios.

Após a sistematização dos casos pelas variáveis dispostas acima, os dados dos casos foram cruzados com aqueles dados que analisam a compliance do Brasil com as sentenças e recomendações oriundas do SIDH presentes no capítulo três desta pesquisa. 
Dessa maneira, será possível analisar os efeitos das variáveis criadas por Vieira (2013) e seus efeitos no cumprimento dos instrumentos do SIDH pelo Estado brasileiro.

\subsection{Resultados}

Nesta seção serão apresentados os resultados da tabulação dos casos contra o Brasil em que o Sistema Interamericano de Direitos Humanos proferiu recomendações ou resoluções contra o Estado brasileiro, assim como os acordos de solução amistosa entre o Brasil e os peticionários e vítimas, a partir das variáveis descritas por Vieira (2013), explicitadas na seção anterior, sobre compliance como uma resultante política doméstica. Logo em seguida, os dados serão cruzados com os resultados da pesquisa empírica conduzida no capítulo dois deste estudo para podermos aferir os seus efeitos sobre a nossa variável dependente, compliance do Estado brasileiro aos instrumentos do SIDH, em seus três níveis (cumpriu totalmente, cumpriu parcialmente e não cumpriu).

Na tabela 12 a seguir, observa-se que nenhum caso foi categorizado como "Quando há violações que decorrem de agendas de políticas públicas do Estado e há a dependência de poderes autônomos". Desse modo, não poderemos comparar o efeito da dependência de poderes autônomos quando há violações que decorrem de agendas políticas do Estado, mas apenas verificar como esta última afeta a implementação das decisões do SIDH referentes ao Estado brasileiro.

Tabela 12: Compliance como resultante de agendas de políticas públicas do Estado

\begin{tabular}{|c|c|c|c|c|c|c|}
\hline \multicolumn{7}{|c|}{ Compliance como resultante de agendas de políticas públicas do Estado } \\
\hline & & & & & & $N: 26$ \\
\hline $\begin{array}{l}\text { N. do } \\
\text { Caso }\end{array}$ & Casos & $\begin{array}{c}\text { Quando há a } \\
\text { existência de uma } \\
\text { agenda de política } \\
\text { pública relativa às } \\
\text { questões específicas de } \\
\text { direitos humanos } \\
\text { objeto de decisão do } \\
\text { SIDH }\end{array}$ & $\begin{array}{l}\text { Quando há a existência } \\
\text { de uma agenda de } \\
\text { política pública relativa } \\
\text { às questões específicas } \\
\text { de direitos humanos } \\
\text { objeto de decisão do } \\
\text { SIDH e há a } \\
\text { dependência de poderes } \\
\text { autônomos }\end{array}$ & $\begin{array}{c}\text { Quando há } \\
\text { violações que } \\
\text { decorrem de } \\
\text { agendas de } \\
\text { políticas públicas } \\
\text { do Estado }\end{array}$ & $\begin{array}{l}\text { Quando há violações } \\
\text { que decorrem de } \\
\text { agendas de políticas } \\
\text { públicas do Estado e } \\
\text { há a dependência de } \\
\text { poderes autônomos }\end{array}$ & $\begin{array}{c}\text { Quando há } \\
\text { dependência de } \\
\text { poderes autônomos } \\
\text { sem a existência de } \\
\text { uma agenda política } \\
\text { pública a favor ou } \\
\text { contra as decisões } \\
\text { do SIDH }\end{array}$ \\
\hline 12.308 & $\begin{array}{c}\text { Manoel Leal } \\
\text { de Oliveira }\end{array}$ & & & & & $\mathrm{X}$ \\
\hline 12.310 & $\begin{array}{c}\text { Sebastião } \\
\text { Camargo } \\
\text { Filho }\end{array}$ & & $\mathrm{x}$ & & & \\
\hline 12.440 & $\begin{array}{c}\text { Wallace de } \\
\text { Almeida }\end{array}$ & & & & & $\mathrm{X}$ \\
\hline
\end{tabular}




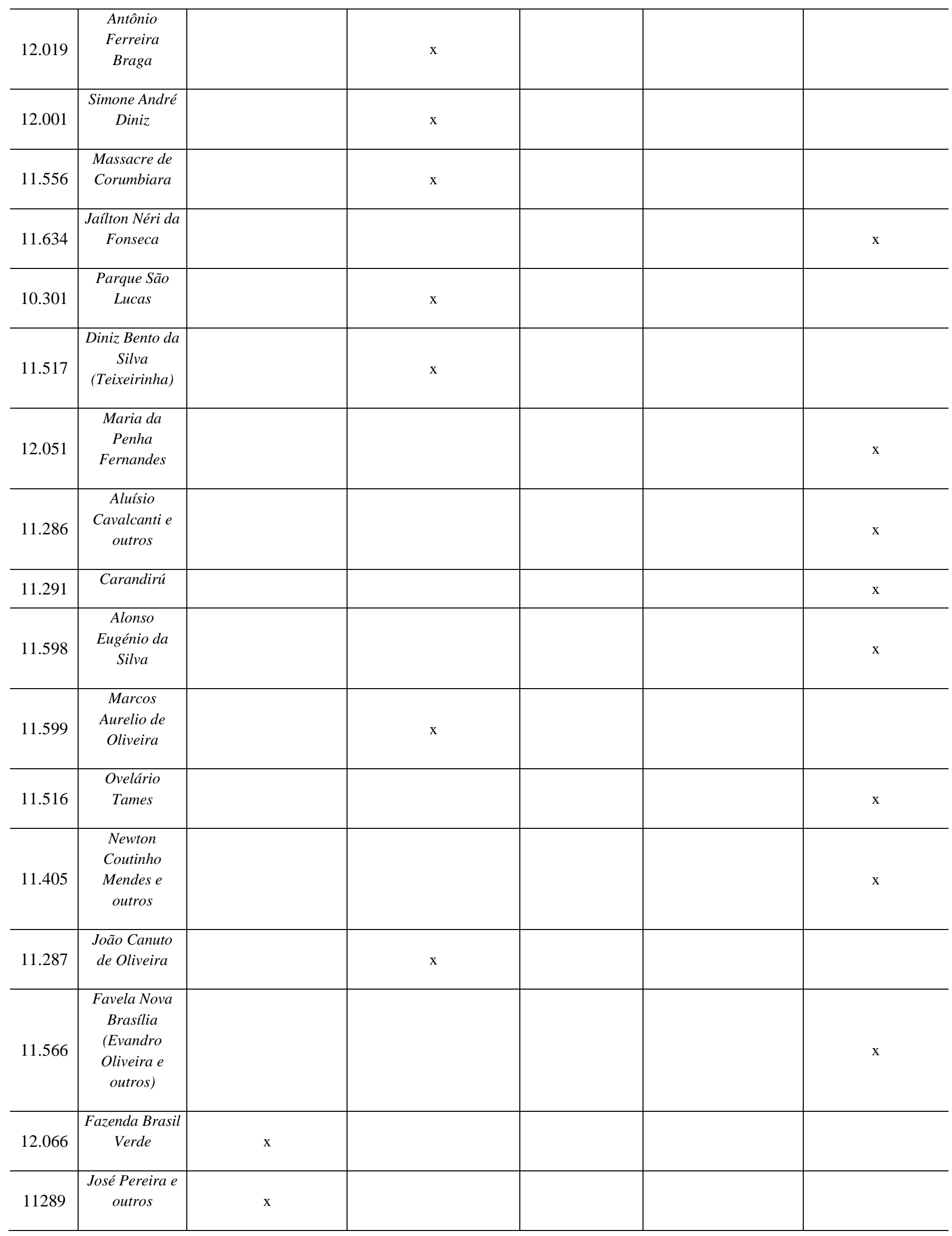




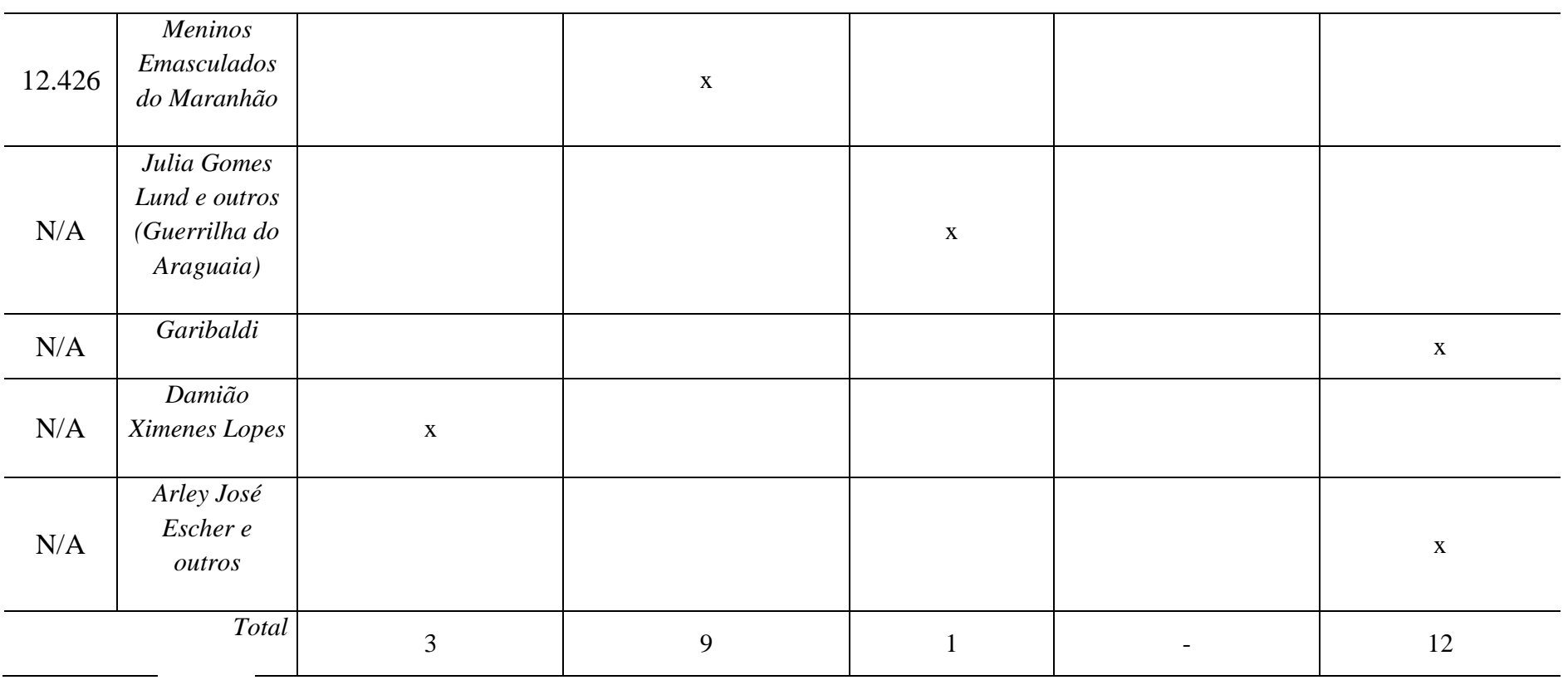

Fonte: Elaboração própria. Dados da $\mathrm{CmDH}$, da $\mathrm{CrDH}$, do MRE e da $\mathrm{SDH}$ (disponível em: http://www.oas.org/pt/cidh/ Acesso em: 07 nov. 2015 e no Apêndice C).

Ao cruzar os casos categorizados com os dados sobre o grau de compliance das resoluções, recomendações e acordos de solução amistosa, observa-se que quando há violações que decorrem de agendas de políticas públicas do Estado já existentes há uma maior probabilidade dos instrumentos do SIDH não serem cumpridos. Neste caso, $50 \%$ das resoluções, recomendações ou acordos de solução amistosa não foram cumpridos pelo Estado brasileiro, 25\% foram parcialmente cumpridos e apenas $25 \%$ cumpridos totalmente. O resultado, assim, está de acordo com a hipótese criada por Vieira (2013) que esta variável afetaria negativamente o grau de compliance do Estado brasileiro com os instrumentos do SIDH.

Quando já existem políticas públicas em andamento referidas ao tema da decisão do SIDH e que não dependam de poderes autônomos há uma maior probabilidade das medidas outorgadas pelo Sistema Interamericano de Direitos Humanos ou acordadas em solução amistosa não serem cumpridas. Nesta situação, observa-se que $62 \%$ das medidas não foram cumpridas, $21 \%$ parcialmente cumpridas e $17 \%$ totalmente cumpridas. Resultado o qual é contrário à hipótese de Vieira (2013) que uma agenda política sendo criada ao tempo da decisão do SIDH poderia facilitar a implementação das medidas outorgadas.

Já quando analisamos o efeito da dependência de poderes autônomos sob o grau de compliance com as medidas proferidas pelo SIDH ou acordadas em solução amistosa, observa-se que quando não há a existência de nenhuma política pública, tanto a favor como contra às medidas outorgas pela Comissão e Corte, concomitante à decisão do 
SIDH há uma probabilidade aproximadamente três vezes maior de que as medidas não sejam cumpridas pelo Estado brasileiro em comparação com a probabilidade seu cumprimento total. Neste caso, $57 \%$ das medidas outorgadas não foram cumpridas, $23 \%$ foram parcialmente cumpridas e $20 \%$ totalmente cumpridas. Fato o qual corrobora com os argumentos de Vieira (2013) que essa variável afeta negativamente o grau de compliance do Estado brasileiro no âmbito do Sistema Interamericano de Direitos Humanos.

Não obstante, verifica-se que quando há uma agenda política em andamento a favor das medidas outorgadas pelo SIDH, ao mesmo tempo em que há uma dependência de poderes autônomos para que o Estado brasileiro possa implementá-las, existe uma probabilidade maior que essas medidas sejam totalmente cumpridas pelo Brasil. Observase que $53 \%$ das medidas foram totalmente cumpridas, $32 \%$ não foram cumpridas e $15 \%$ foram parcialmente cumpridas neste caso.

Os resultados podem ser vistos na figura 29 a seguir:

Figura 29: Compliance como uma resultante política doméstica

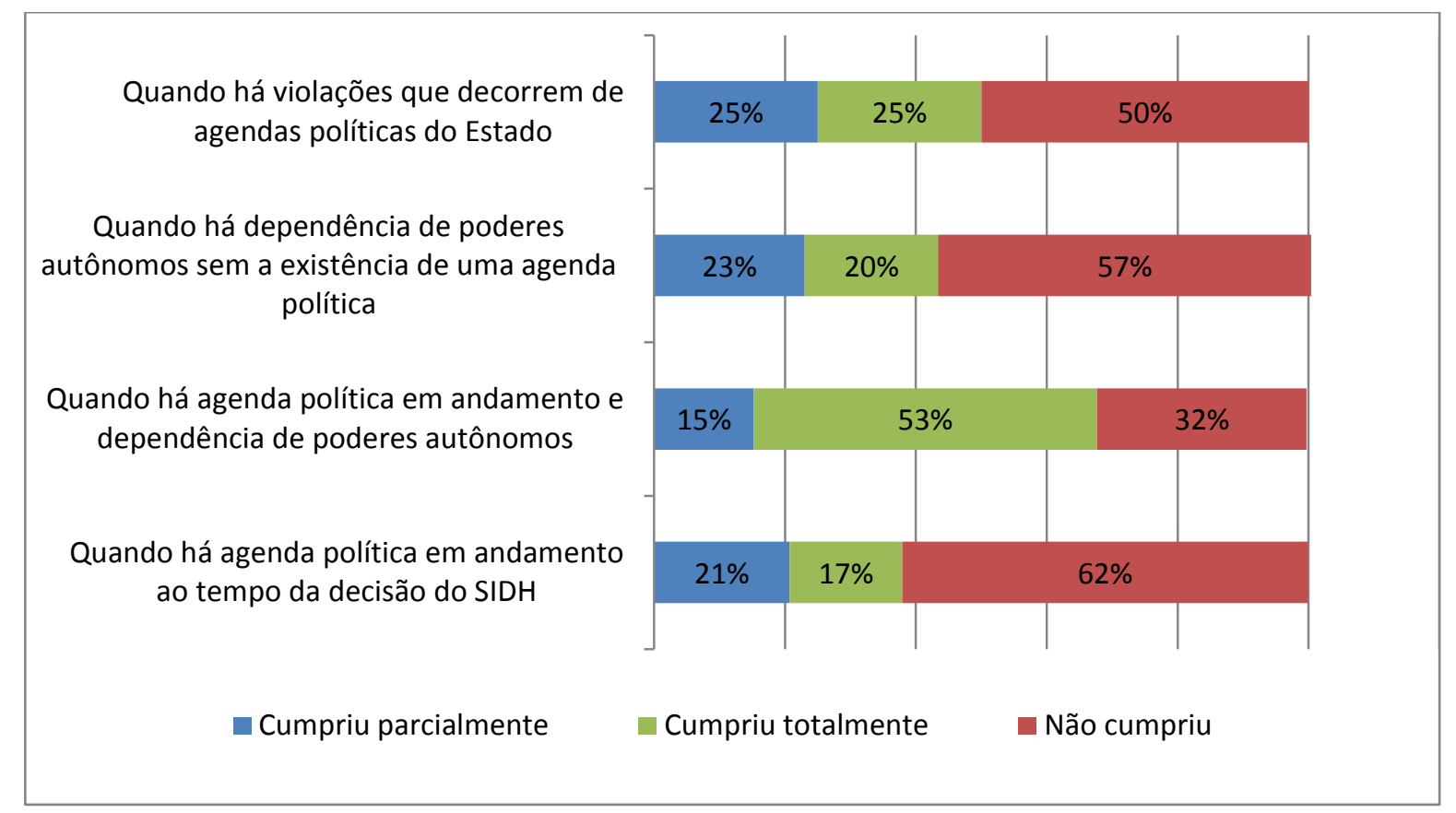

Fonte: Elaboração própria. Dados da $\mathrm{CmDH}$, da $\mathrm{CrDH}$, do MRE e da $\mathrm{SDH}$ (disponível em: http://www.oas.org/pt/cidh/ Acesso em: 07 nov. 2015 e no Apêndice C).

Acredita-se que o resultado dessa última situação comparado com os resultados obtidos na análise da variável "existência de agenda política em andamento ao tempo da decisão do SIDH" é devido ao fato de haver poucos casos que foram categorizados dentro dessa situação. No entanto, fica claro que há existência de uma agenda política do Estado 
a favor das medidas outorgadas pelo SIDH ou acordadas em solução amistosa faz com que haja uma maior probabilidade no seu cumprimento, mesmo que sua implementação dependa de poderes autônomos.

Ao analisar a média de duração em anos para o cumprimento das medidas do SIDH categorizadas pelas variáveis de política doméstica apontadas por Vieira (2013) disponível na figura 30, abaixo, percebe-se que os efeitos positivos e negativos afirmadas se traduzem na quantidade de tempo que cada uma das medidas, recomendações, resoluções e acordos de solução amistosa, demora em ser totalmente cumprida pelo Estado brasileiro. Isto corrobora a afirmação acima de que a existência de uma agenda política em andamento ao tempo da decisão do SIDH tem uma maior probabilidade de ser cumprida, assim como esta probabilisticamente poderá ser cumprida mais rapidamente.

Figura 30: Média de duração em anos para o cumprimento das medidas do SIDH categorizadas por variáveis de política doméstica

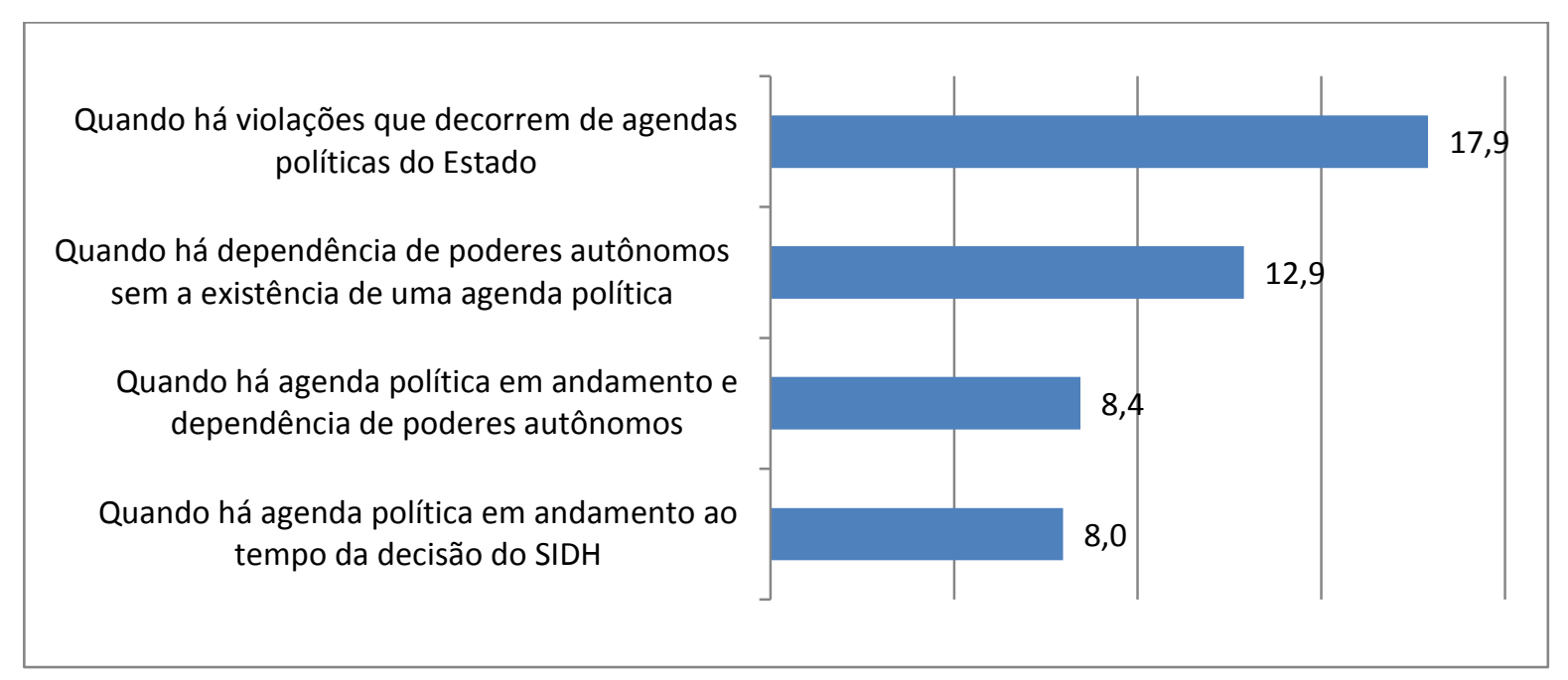

Fonte: Elaboração própria. Dados da $\mathrm{CmDH}$, da $\mathrm{CrDH}$, do MRE e da $\mathrm{SDH}$ (disponível em: http://www.oas.org/pt/cidh/ Acesso em: 07 nov. 2015 e no Apêndice C).

Em ordem crescente, quando há agenda política em andamento ao tempo da decisão do SIDH o Estado brasileiro demora em média oito anos para o cumprimento total das medidas outorgadas pelo SIDH; oito anos e quatro meses quando há agenda política em andamento e dependência de poderes autônomos; aproximadamente 13 anos em média quando há dependência de poderes autônomos sem a existência de uma agenda política, tanto a favor como contra as medidas proferidas pelo SIDH; e uma média de 18 anos aproximadamente quando há violações que decorrem de agendas políticas do Estado. 


\section{Conclusão}

O teste das hipóteses criadas por Vieira (2013) mostrou que os efeitos esperados de suas variáveis sob o grau de cumprimento de recomendações e decisões do Sistema Interamericano de Direitos Humanos pelo Estado brasileiro estão em parte corretos. Ficou claro que:

i) A existência de uma agenda de política pública em andamento ao tempo da decisão afeta negativamente o grau de compliance do Estado brasileiro no SIDH. Neste caso, $57 \%$ das medidas outorgadas não foram cumpridas, $23 \%$ foram parcialmente cumpridas e apenas $20 \%$ totalmente cumpridas, Isto vai contra a hipótese lançada por Vieira (2013);

ii) A dependência do governo de poderes autônomos, como governos locais, Ministério Público e Judiciário, para implementar as políticas públicas necessárias para o cumprimento dos instrumentos do SIDH afeta negativamente o grau de compliance do Estado brasileiro no SIDH. Das Neste caso, $57 \%$ das medidas outorgadas não foram cumpridas, $23 \%$ foram parcialmente cumpridas e $20 \%$ totalmente cumpridas. O que corrobora a hipótese criada por Vieira (2013); e

iii) Violações de direitos humanos engendradas como consequência de políticas públicas do Estado afetam negativamente o grau de compliance do Estado brasileiro no SIDH. Neste caso, 50\% das resoluções, recomendações ou medidas acordadas em solução amistosa não foram cumpridas pelo Estado brasileiro, $25 \%$ foram parcialmente cumpridas e apenas $25 \%$ totalmente cumpridos. Os resultados também estão de acordo com a hipótese criada por Vieira (2013) para essa situação específica.

A análise da média de duração em anos para o cumprimento das medidas proferidas pelo Sistema Interamericano de Direitos Humanos categorizados pelas variáveis de política doméstica utilizadas neste estudo também corroboram ao resultado apresentado acima. Há um clara demora do Estado brasileiro em cumprir com medidas quando há violações de direitos humanos que decorram de agendas de políticas públicas do Estado e quando há a existência de dependência de poderes autônomos. 


\section{Considerações finais}

Este estudo buscou identificar as principais determinantes que afetam o processo de tomada de decisão no cumprimento das resoluções e recomendações do Sistema Interamericano de Direitos Humanos (SIDH) pelo Governo brasileiro (state compliance) entre 1988 e 2014.

Para tanto, a partir da busca por dados empíricos e por inferências descritivas e causais, identifiquei o processo de tomada de decisão do Estado brasileiro com vistas à implementação dos instrumentos do SIDH e as principais variáveis que afetam esse processo. Igualmente, coletei, consolidei e sistematizei dados empíricos para observar as principais determinantes que afetam o cumprimento das medidas do SIDH pelo Brasil. Por fim, testei as hipóteses relacionadas à compliance como uma resultante política doméstica.

A expressão "cumprimento" é usada neste estudo com o significado de adimplemento de medidas, implementação, o mesmo que compliance, e diz respeito aos esforços dos diferentes atores para que as determinações dos instrumentos do SIDH fossem consideradas cumpridas pelos próprios requisitos do SIDH. O termo compliance foi usado fluidamente neste trabalho para além dos valores dicotômicos, explorando o meio termo do cumprimento parcial.

A fim de estudar as medidas proferidas pelo Sistema Interamericano de Direitos Humanos e o processo decisório brasileiro para a implementação destas, foram analisados cerca de 300 documentos oficiais entre relatórios do Sistema Interamericano de Direitos Humanos, manifestações de defesa do Estado brasileiro perante o SIDH e acordos de solução amistosa realizados no período temporal da pesquisa, além de diversas entrevistas realizadas com atores-chave do processo de tomada de decisão relacionado à compliance do Brasil com as medidas do SIDH. Esta forma de trabalho permitiu clarificar o problema da produção de decisões e ações numa estrutura decisória complexa, pela reconstrução das interações organizações governamentais envolvidas na tomada de decisão no cumprimento dos instrumentos do SIDH.

No segundo capítulo, identifiquei a prática estatal brasileira no regime interamericano de proteção e defesa dos direitos humanos e lancei luz sobre as violações sistemáticas de direitos humanos que ocorrem no Brasil. Observou-se que mesmo o País sendo um dos mais demandados no Sistema Interamericano de Direitos Humanos $\left(7^{\circ}\right.$ posição), evidências indicam que ao todo, o Brasil possui 196 procedimentos ativos 
perante o SIDH, durante o período temporal estudado. Desses 196 procedimentos, 184 estão na $\mathrm{CmDH}$ e apenas 12 na $\mathrm{CrDH}$.

Observei que $42 \%$ das petições contra o Estado brasileiro no SIDH advêm da região sudeste do País, sendo que $20 \%$ do total geral de petições são oriundas do estado de São Paulo. No cálculo do período de tempo entre a violação de direitos humanos cometida e o início do trâmite perante o Sistema Interamericano de Direitos Humanos da petição, verificou-se que há uma diferença média de sete anos e um mês. Isso demonstra que há uma ineficiência do Poder Judiciário brasileiro em lidar com casos de violações de direitos humanos de maneira célere, fato que faz com que a regra de exceção ao esgotamento de recursos internos para a admissibilidade do procedimento no Sistema Interamericano de Direitos Humanos seja amplamente reivindicada pelos peticionários.

Ao analisar o perfil dos peticionários, verifiquei que a proporção dos diferentes tipos de peticionários em casos e petições contra o Brasil (ONGs nacionais, ONGs internacionais, parceria entre ONGs nacionais e internacionais, vítimas e representantes de vítimas) não é expressiva: 1) ONGS nacionais (22\%); 2) ONGS nacionais em parceria com ONGS internacionais (20\%). Quando analisado quais foram os artigos da CADH mais invocados pelos peticionários em procedimentos contra o Brasil entre 1988 e 2014, verifiquei que, em ordem decrescente, eles são: 1)Art.25: direito à proteção judicial $(21,43 \%)$; 2)Art.8: direito às garantias judiciais $(18,65 \%)$; e 3)Art.4: direito à vida $(12,50 \%)$.

Verifiquei ainda que, em ordem decrescente, os temas das violações de direitos humanos dos procedimentos contra o Brasil no SIDH são: 1) Prestação de Justiça $(26,88 \%)$; 2) Violência policial $(15,77 \%)$; 3) Violência institucional contra privados de liberdade (sistema prisional e socioeducativo) $(13,62 \%)$; 4) Violência no campo $(9,32 \%)$; 5) Violência contra defensores de Direitos Humanos $(7,89 \%)$; 6) Tortura $(7,89 \%)$; 7) Violência contra menores $(7,17 \%)$; 8) Violência contra indígenas $(3,58 \%)$; 9) Violência contra mulheres $(2,87 \%)$; 10) Racismo (1,79\%); e 11) Crimes do período da ditadura $(1,43 \%)$. Aqueles temas que não se enquadram nas definições citadas acima, categorizados como "outros", somaram 1,79\% dos casos, petições e medidas de urgência do espaço amostral desta pesquisa.

Nesta seção, fica claro que a maioria dos procedimentos contra o Estado brasileiro no Sistema Interamericano Direitos Humanos é engendrada por violações de direitos humanos relacionadas às deficiências do Poder Judiciário e diretamente relacionadas ao conceito de prestação de justiça. Igualmente, observei que a questão da violência policial 
continua sendo um dos principais temas de violações de direitos humanos no Brasil, demonstrando a atuação arbitrária das forças policiais e seu papel antagônico de órgão responsável e garantidor da segurança publica como violador de direitos. Ademais, notouse que violência institucional perpetrada pelo Estado brasileiro, em suas diferentes facetas, é um fato concreto ligado à justiça e segurança e deve ser encarado como um grave problema a ser solucionado.

Apresentei também os dados sobre os temas das violações por estados e regiões. Observei, por exemplo, que a região Centro-Oeste é responsável por $50 \%$ dos procedimentos categorizados como "Crimes do período da Ditadura"; a região Nordeste e Sul é responsável cada uma por $37,50 \%$ dos procedimentos categorizados como "Violência contra a Mulher"; a região Norte é responsável por 53,80\% dos procedimentos categorizados como "Violência no campo"; já na região Sudeste há a predominância de violações de direitos humanos perpetradas por agentes de estatais, a região é responsável por $80 \%$ dos procedimentos categorizados como "Violência contra Menores"; 72,70\% dos procedimentos categorizados como "Tortura"; $65,85 \%$ dos procedimentos categorizados como "Violência Policial"; $65,75 \%$ dos procedimentos categorizados como "Violência institucional contra privados de liberdade (sistema prisional e socioeducativo)".

Quando passei a analisar o grau de compliance do Estado brasileiro com os instrumentos do SIDH, o universo de pesquisa se restringiu a 26 casos e 149 medidas, entre recomendações, resoluções e medidas acordadas em solução amistosa. Dos 26 casos, 21 cumprem recomendações da Comissão, sendo que dois deles são acordos de solução amistosa finalizados e dois deles foram remitidos à Corte. Os outros cinco casos do Brasil são provenientes de decisão da $\mathrm{CrDH}$. Destes cinco casos, o Brasil cumpre resoluções apenas de quatro, uma vez que um dos casos contra o Estado brasileiro foi arquivado pela Corte por falta de provas (Caso Nogueira de Carvalho e outro vs. Brasil).

A partir dessa amostra reduzida, verificou-se que dos 26 casos contra o Brasil no SIDH, incluindo-se também os acordos de solução amistosa finalizados, a Comissão e a Corte outorgaram juntas 161 medidas contra o Estado brasileiro, sendo 136 recomendações da Comissão e 25 resoluções da Corte. Contudo, há registros sobre o grau de compliance do Estado brasileiro apenas sobre 149 das 161 medidas. Esse é o número final da amostra utilizado para o estudo dos graus de compliance do Brasil para com medidas do Sistema Interamericano de Direitos Humanos. Nesse universo reduzido, 
identifiquei que $48 \%$ das medidas não foram cumpridas, $33 \%$ foram cumpridas totalmente e $19 \%$ foram cumpridas parcialmente

Observei também que 50\% dos temas das recomendações, resoluções e medidas acordadas em solução amistosa que o Brasil não cumpriu ou mais são: 1) Prevenção por meio da conscientização da população $(50 \%)$; 2) Outros $(56 \%)$; 3 ) Investigação e sanção sem reforma legal (60\%); Prevenção por meio de reformas jurídicas (61\%); 4) Prevenção por meio da formação de agentes públicos (68\%); 5) Investigação e sanção sem reforma legal (90\%); e 6) Prevenção de vítimas e testemunhas (100\%).

Há nesses casos, mais uma vez, a predominância de violações de direitos humanos relacionadas à prestação de justiça e à violência policial. Há também uma diminuição expressiva da relação de casos que tem como temática a violência no campo e contra privados de liberdade, em comparação com o total geral de procedimentos contra o País. Isso ocorre devido ao fato da maioria desses procedimentos serem compostos por medidas de urgência.

Quando analisei aqueles tipos de medidas em que se verifica maior índice de compliance, temos, em ordem decrescente, que eles são: 1) Reparação simbólica (68\%); 2) Reparação econômica não monetária (67\%); 3) Reparação econômica monetária (54\%); e 4) Prevenção por meio do fortalecimento, criação ou reforma de instituições públicas $(46 \%)$. Há apenas um tipo de medida em que se verifica o cumprimento parcial como principal grau de compliance, ele é: Prevenção sem especificar medidas com $67 \%$ das medidas parcialmente cumpridas pelo Estado brasileiro.

Ao analisar os graus de compliance do Brasil às recomendações, resoluções e medidas acordadas em solução amistosa outorgadas pelo SIDH por seu objetivo, identifiquei que o Estado brasileiro apresenta maior compliance com as medidas que tem como objetivo: 1) Recompensação de pessoas ou grupos (60\%); e 2) Prevenção de futuras violações de direitos (52\%). Os objetivos das medidas em que se verifica um grau de não cumprimento maior são: 1) Investigação e responsabilização de violações de direitos humanos (70\%); e 2) Proteção de vítimas, testemunhas e outros (60\%).

Verifiquei que os graus de cumprimento parcial das medidas quando categorizadas por seus objetivos parcial são: 1) Proteção de vítimas, testemunhas e outros (30\%); 2) Prevenção de futuras violações de direitos (24\%); 3) Recompensação de pessoas ou grupos (15\%); 4) Investigação e responsabilização de violações de direitos humanos $(13 \%)$. 
Identifiquei ao analisar os graus de compliance do Brasil às recomendações, resoluções e medidas acordadas em solução amistosa outorgadas pelo SIDH, a partir do tema dos casos que as geraram, que os temas em que as medidas tiveram um grau de não cumprimento maior, em ordem decrescente, são: 1) Racismo (75\%); 2) Violência policial (70\%); 3) Tortura (53\%); 4) Crimes do período da ditadura (52\%); 5) Prestação de justiça $(50 \%)$; 6) Violência institucional contra privados de liberdade (sistema prisional e socioeducativo) (50\%); e 7) Violência no campo (40\%).

Os temas dos casos em que as medidas outorgadas contra o Brasil tiveram um cumprimento parcial maior são dois: 1) Violência contra mulheres (80\%); e 2) Violência institucional contra privados de liberdade (sistema prisional e socioeducativo) (50\%). Verifiquei que apenas em um tema o grau de cumprimento das medidas outorgadas é maior do que os demais. O tema é violência contra menores com $64 \%$ das recomendações, resoluções ou medidas acordadas em solução amistosa cumpridas totalmente.

Os resultados são condizentes com aqueles analisados em cada órgão e demonstram que há uma clara deficiência do Estado brasileiro em cumprir totalmente com medidas que envolvam mudanças no ordenamento jurídico interno e que há uma melhor ação do Estado quando a medida é relacionada à reparação das vítimas, principalmente reparações monetárias. Isso contribui para o argumento de que o processo decisório da implementação das medidas outorgadas pelo Sistema Interamericano de Direitos Humanos contra o Brasil é uma variável importante para a state compliance brasileira.

Ao analisar as medidas outorgadas ao Brasil pelo SIDH a partir do órgão em que elas foram emitidas, atribuindo as medidas acordadas em solução amistosa uma categoria específica, verifiquei que na $\mathrm{CrDH}$ : 1) 59\% das resoluções foram totalmente cumpridas; 2) $27 \%$ não foram cumpridas; e 3) $14 \%$ foram parcialmente cumpridas. $\mathrm{Na} \mathrm{CmDH}$, observa-se que: 1) $64 \%$ das recomendações não foram cumpridas; 2) $21 \%$ foram parcialmente cumpridas; e 3) 15\% foram totalmente cumpridas. Já nos acordos de solução amistosa, verifica-se que: 1) $59 \%$ das medidas acordadas foram totalmente cumpridas; 2) $22 \%$ não foram cumpridas; e 3) 19\% foram parcialmente cumpridas.

Os dados indicam que há uma clara evidência que o Estado brasileiro é mais propício a cumprir totalmente medidas proferidas pela Corte Interamericana de Direitos Humanos e aquelas acordadas em solução amistosa (59\% das medidas foram cumpridas em cada uma das classificações). Isso se deve em parte pelo fato de que as medidas 
proferidas pela Corte são vinculantes e têm peso de norma internacional e porque os acordos de solução amistosa passam por um intenso processo de negociação que culmina com um conjunto de medidas de fácil implementação pelo Estado. Igualmente, observa-se que uma das razões para o total cumprimento das medidas proferidas tanto pela Corte como aquelas acordadas em solução amistosa pode estar ligada ao próprio escopo das medidas, como citado anteriormente.

Quando analisei o objeto das medidas outorgadas contra o Brasil pelo SIDH, ficou claro que medidas emitidas pela Comissão e Corte, assim como aquelas acordadas em solução amistosa, possuem escopos diferentes. Enquanto a Comissão se preocupa com a criação de uma jurisprudência continental de proteção dos direitos humanos por meio de medidas que visam à prevenção de futuras violações de direitos por meio de reformas jurídicas internas, as medidas emitidas pela Corte Interamericana de Direitos Humanos têm como objetivo o acesso à justiça de forma integral pelas vitimas. Já as medidas acordadas em solução amistosa buscam em sua maioria a prevenção de futuras violações de direitos humanos por meio do fortalecimento, criação ou reforma de instituições públicas.

Essa diferença de escopo das medidas emitidas pelo Sistema Interamericano de Direitos Humanos pode ser explicada pela diferença de mandato de cada órgão. Já os acordos de solução amistosa são um caso a parte. Eles demostram que os peticionários, vítimas e o Estado brasileiro possuem um processo de negociação em que ambas as partes buscam deixar claro quais são seus interesses e limites de ação. Nesse sentido, os peticionários e vítimas buscam acordar medidas que previnam a repetição das violações de direitos humanos por meio do fortalecimento, reforma e criação de instituições públicas, enquanto o Estado busca acordar medidas que sejam de fácil cumprimento.

Ao analisar a compliance do Estado brasileiro para com as recomendações da Comissão Interamericana de Direitos Humanos classificadas por seu tipo, observou-se que a maioria das que não foram cumpridas diz respeito à proteção de vítimas e testemunhas (100\%) e, em seguida, aquelas que envolvem algum tipo de reforma legal. Notou-se ainda que as medidas totalmente implementadas pelo Brasil têm como seu objetivo a reparação simbólica das vítimas $(60 \%)$ e a reparação econômica monetária (35\%). Uma das razões para que isso aconteça é o fato do Governo federal destinar uma alíquota específica de seu orçamento plurianual para o pagamento de indenizações pecuniárias proferidas por órgãos internacionais de direitos humanos por meio de mecanismo específico. 
Esse mecanismo orçamentário é também uma das razões para que as medidas emitidas pela Corte Interamericana de Direitos Humanos que buscam a reparação econômica monetária sejam totalmente cumpridas pelo Estado brasileiro (88\% das medidas desse tipo na $\mathrm{CrDH}$ foram totalmente cumpridas pelo Brasil). Outrossim, observou-se que o cumprimento total das medidas outorgadas pelo tribunal é mais propício quando a sentença contra o Estado brasileiro não envolve nenhuma reforma jurídica. Qualquer outro tipo de resolução tem difícil implementação pelo Estado brasileiro. Isso reforça o argumento de que as medidas outorgadas pelo Sistema Interamericana de Direitos Humanos contra o Brasil possui como maior empecilho para a sua total implementação o processo decisório interno do País.

Quando o grau de compliance do Estado brasileiro para com as medidas proferidas pelo SIDH é analisado por cada caso, verifiquei que a maioria dos casos em que SIDH proferiu medidas contra o Brasil enfrentam dificuldades para que suas recomendações e resoluções sejam cumpridas, independentemente do tipo e objeto da medida, seu objetivo ou tema que tenha originado a violação de direitos humanos alvo do procedimento no SIDH.

Identifiquei ainda que a quantidade média de dias entre a alegada violação e o início do trâmite no Sistema Interamericano de Direitos Humanos daqueles casos em que o Sistema outorgou recomendações, resoluções ou medidas de acordo de solução amistosa, é de quatro anos e 10 meses (4,85 anos). O período de tempo médio entre o início do trâmite e a publicação de sua sentença pela Corte, analisando os quatro casos contra o Brasil que foram julgados pela $\mathrm{CrDH}$, é de nove anos (9,06 anos). Quando se verifica o período de tempo transcorrido entre a emissão das recomendações, resoluções e medidas acordadas em solução amistosa e a compliance com cada uma das medidas, observa-se que há em média um período de três anos e dois meses (3,22 anos) para que o SIDH considere que o Estado brasileiro cumpriu totalmente as medidas outorgadas. Assim, desde o acontecimento da violação de direitos humanos até que o Estado brasileiro possa cumprir totalmente com os instrumentos do SIDH há em média um período de 17 anos.

Os dados demonstram que o Estado brasileiro cumpre totalmente com mais celeridade medidas proferidas pela Corte Interamericana de Direitos Humanos e aquelas acordadas em solução amistosa entre as partes. Os resultados demonstram que o Estado brasileiro requer um maior período temporal para implementar totalmente medidas relacionadas à investigação das violações de direitos humanos e para a reparação das 
vítimas. Já os outros tipos de medidas possuem um período médio semelhante para serem cumpridas pelo Brasil.

Quando analisei o tempo gasto pelo Estado brasileiro para cumprir totalmente as medidas outorgadas pelo SIDH a partir da categorização pelo tipo de medidas, obtêm-se que o período de tempo médio em anos para o cumprimento das medidas por seu tipo, em ordem decrescente, é: 1) Investigação e sanção sem reforma legal (5,68 anos); 2) Reparação econômica monetária (3,21 anos); 3) Reparação econômica não monetária (2,95 anos); 4) Prevenção por meio do fortalecimento, criação ou reforma de instituições públicas (2,95 anos); 5) Prevenção pela formação de agentes públicos (2,95 anos); 6) Prevenção por meio da conscientização da população (2,95 anos); 7) Outros (2,95 anos); 8) Reparação simbólica (2,71 anos); e 9) Prevenção por meio de reformas jurídicas (2,48 anos).

Verifiquei, por fim, ao analisar o grau de compliance das medidas outorgadas contra o Brasil no SIDH a partir de seus litigantes que aquelas cumpridas totalmente, em ordem decrescente, por tipo de peticionário são: 1) ONGs nacionais (28\%); 2) ONGs nacionais em parceria com ONGs internacionais (25\%); e 3) ONGs internacionais (17\%). Não há indicações expressivas que tipos de peticionários diferentes influenciam de alguma forma nos graus de compliance do Estado brasileiro com medidas proferidas pelo SIDH.

No capítulo três, identifiquei que o processo decisório do Brasil junto ao Sistema Interamericano de Direitos Humanos para a implementação de suas sentenças e recomendações não é institucionalizada, sendo por isso eminentemente um processo político. Identifique que todas as agências governamentais envolvidas nesse processo precisam, a cada caso, “desenvolve[r] um esforço político de cooperação com os órgãos locais diretamente relacionados à implementação das medidas específicas a cada uma das violações" (VIEIRA, 2013, p.26). Isto ocorre exceto quando há a necessidade de indenização pecuniária às vítimas ou quando há competência exclusiva do âmbito federal sobre o caso.

Desse modo, a compliance do Estado brasileiro com as decisões oriundas do SIDH se torna dependente da interação entre as diferentes organizações centrais que compõem o Estado e possuem competências sobre a temática. No âmbito federal, elas são: SDH/MJ, MRE e AGU. Já nos outros âmbitos de governo, pode-se destacar legisladores, promotores públicos, membros do poder judiciário e os outros membros federativos como atores relevantes para a concreta implementação dos instrumentos do 
SIDH, sendo a coordenação dos esforços com esses atores responsabilidade da SDH/MJ. Há um delicado equilíbrio das relações institucionais entre esses atores.

Logo, não se pode considerar o Estado como um ator homogêneo; mas sim, como um ator composto por uma série de organizações, que possuem independência em quase todas as suas ações, possuem padrões comportamentais específicos (um modus operandi historicamente determinado) e que focalizam sua atenção apenas na parte do problema na qual são especializadas, interessadas. O poder, para esse modelo, é então fragmentado entre diversas instituições e os processos dos quais são responsáveis.

Baseando-se na identificação e análise do processo decisório brasileiro junto ao SIDH é possível afirmar que das três abordagens que explicam o porquê de Estados cumprem (comply) normas jurídicas internacionais (international enforcement; gestão, e política doméstica) a que mais se aproxima ao caso brasileiro é o modelo que se concentra mais diretamente na política doméstica dos Estados.

Nesse modelo, compliance é relacionada ao cálculo de custos e benefícios da mudança de política pública. Onde as mudanças políticas são relativamente difíceis, o grau de cumprimento de normas jurídicas internacionais é provável que seja baixo (DOWNS; ROCKE; BARSOOM 1996). De um modo semelhante, compliance pode ser o resultado de fatores domésticos que são difíceis de serem observados, como vontade política (VON STEIN, 2005). Na visão desses autores, o cumprimento de normas jurídicas internacionais é provável que seja o resultado de fatores domésticos préexistentes que levaram Estados a se comprometerem com normas internacionais em primeiro lugar.

Afirmo, assim, que uma das variáveis principais para explicar o grau de cumprimento das medidas do SIDH pelo Estado brasileiro é a maneira pela qual o processo decisório referente à sua internalização ocorre. Acredito que o Estado brasileiro hesita entre a indiferença e a tentativa, embora, muitas vezes, formal ou insatisfatória, de atendimento às recomendações do SIDH por não haver um mecanismo institucional que regule o tema. Credita-se isso à coexistência de diferentes lógicas de ação, que são executadas por diferentes instituições do Estado. Essas instituições falham ao implementar as medidas oriundas do SIDH devido especialmente à falta de vontade política dos agentes de Estado e pelos diferentes cálculos políticos das organizações que compõem o grupo responsável pelo processo decisório da internalização das resoluções.

No quarto capítulo deste estudo, pude comprovar que as hipóteses de Vieira (2013) que (i) quando há violações que decorrem de agendas de políticas públicas do 
Estado e (ii) quando há a dependência de poderes autônomos estas afetam negativamente o grau de compliance, sendo que quando não há a existência de nenhuma agenda política, tanto a favor como contra, concomitante à decisão do SIDH há uma probabilidade aproximadamente três vezes maior que as medidas não sejam cumpridas pelo Estado brasileiro do que totalmente cumpridas.

Contudo, ao testar a hipótese (iii) de que quando há agenda de política pública relativa às medidas específicas a serem implementadas pelo Estado brasileiro em andamento ao tempo da decisão do SIDH e que a violação que gerou o caso seja de competência exclusiva do Governo federal, verifiquei que há uma maior probabilidade das medidas outorgadas pelo Sistema Interamericano de Direitos Humanos ou acordadas em solução amistosa não serem cumpridas. Resultado contrário à hipótese de Vieira (2013) que uma agenda política sendo criada ao tempo da decisão do SIDH poderia facilitar a implementação das medidas outorgadas.

Não obstante, verifiquei ainda que quando há uma agenda política em andamento a favor das medidas outorgadas pelo SIDH, ao mesmo tempo em que há uma dependência de poderes autônomos para que o Estado brasileiro possa implementá-las, existe uma probabilidade maior que essas medidas sejam totalmente cumpridas pelo Brasil. Fica claro, assim, que há existência de uma agenda política do Estado a favor das medidas outorgadas pelo SIDH ou acordadas em solução amistosa faz com que haja uma maior probabilidade no seu cumprimento, mesmo que sua implementação dependa de poderes autônomos. Igualmente, qualquer tipo de medida, independentemente de seu objeto ou tema, proferida pela Corte Interamericana de Direitos Humanos possui uma maior probabilidade no seu cumprimento pelo Estado brasileiro.

Ao analisar a média de duração em anos para o cumprimento das medidas do SIDH categorizadas pelas variáveis de política doméstica apontadas por Vieira (2013), percebi que os efeitos positivos e negativos afirmadas se traduzem na quantidade de tempo que cada uma das medidas, recomendações, resoluções e acordos de solução amistosa, demora em ser totalmente cumprida pelo Estado brasileiro. Isto corrobora a afirmação acima de que a existência de uma agenda política em andamento ao tempo da decisão do SIDH tem uma maior probabilidade de ser cumprida, assim como esta probabilisticamente poderá ser cumprida mais rapidamente.

Por fim, afirmo que o esforço científico pretendido com esta pesquisa foi o de clarificar e elucidar quais são as principais determinantes que afetam o cumprimento de 
medidas outorgadas pelo Sistema Interamericano de Direitos Humano pelo Estado brasileiro. São elas:

(i) A falta de um processo decisório institucionalizado para a implementação das medidas proferidas pelo SIDH contra o Brasil, o que torna o processo eminentemente político;

(ii) A disputa de poder, sua fluidez e fragmentação entre as organizações governamentais e poderes autônomos responsáveis pela implementação das medidas específicas proferidas pelo SIDH;

(iii) A deficiência do Poder Judiciário em lidar com casos relacionados a violações de direitos humanos, principalmente de garantia e de acesso à justiça;

(iv) Os próprios temas das violações de direitos humanos que afetam diferentemente a vontade política dos atores para a implementação das medidas proferidas pelo SIDH;

(v) Os diferentes objetivos e objetos das medidas proferidas pelo SIDH que fazem com que o Estado brasileiro desenvolva padrões específicos para a resolução de cada um deles, como por exemplo a criação de um mecanismo orçamentário para o cumprimento de medidas que tenham por objetivo a reparação econômica monetária das vítimas;

(vi) Os diferentes tipos de medidas outorgadas por cada um dos órgãos que compõem o SIDH, a Comissão e Corte, assim como aquelas medidas acordadas em solução amistosa, que fazem com que o Estado brasileiro tenha diferentes motivações para o cumprimento de cada medida;

(vii) A existência de uma agenda de política pública do Estado referente às medidas específicas da decisão do SIDH contra o Brasil;

(viii) A existência de violações de direitos humanos engendradas como consequência de políticas públicas do Estado; e

(ix) Quando a própria violação de direitos humanos é cometida por agentes estatais.

Todas essas determinantes, de uma maneira positiva ou negativa, afetam a compliance do Estado brasileiro para com as sentenças e recomendações do Sistema Interamericano de Direitos Humanos.

Ao tentar sanar um vazio de literatura e dados empíricos sobre a temática, foi criado um rico banco de dados que deve ser explorado por pesquisas quantitativas e qualitativas para que a literatura especializada sobre compliance possa ser refinada e para 
que seja possível entender melhor como o Brasil se insere no Sistema Interamericano de Direitos Humanos.

Nesse sentido, algumas possíveis perguntas para futuros estudos dentro da temática abordada nesta dissertação são: qual seria a razão pela qual o sistema político brasileiro foi incapaz de criar um mecanismo sólido e eficiente para a implementação das medidas oriundas do Sistema Interamericana de Direitos Humanos? Há aqui apenas uma má gestão ou o Estado brasileiro deliberadamente resiste a criar mecanismos mais contundentes de implementação de decisões da jurisdição internacional? Em que medida o pacto federativo do Estado brasileiro é o maior obstáculo para um mecanismo de implementação de medidas do SIDH mais eficiente e institucional? E qual seria o papel da sociedade civil organizada na fiscalização da efetividade desses mecanismos?

Acredito na necessidade de um maior entendimento dentro do debate acadêmico sobre esta temática para ajudar a melhor guiar a estratégia governamental e dos litigantes no âmbito do Sistema Interamericano de Direitos Humanos. Pois, passados quase trinta anos desde o fim da ditadura militar no Brasil, práticas sistemáticas de violação de direitos humanos ainda ocorrem no País. 


\section{Referências bibliográficas:}

ABBOT, Kenneth W. "Modern international relations theory: a prospectus for international lawyers". Yale Journal of International Law, v. 14, n. 2, p. 335-411, 1989.

ADVOCACIA GERAL DA UNIÃO. Comissão Interamericana de Direitos Humanos, n/d. Disponível em < http://tinyurl.com/a7s6h96>. Acesso em 5 out. 2015.

ALLISON, G; ZELIKOW, P. Essence of Decision: Explaining the Cuban Missiles Crisis. Nova York: Logman, 2a ed., 1999.

AREND, A. Legal Rules and International Society. Oxford: Oxford University Press, 1999.

ARENDT, H. The origins of totalitarism. Orlando: Harcourt, 1985.

ASCENÇÃO, José de Oliveira. Direito civil: reais. 4.ed. Coimbra, Coimbra, 1987

BENNETT, Andrew e ELMAN, Colin. Qualitative research: recent developments in case study methods. Annual Review of Polítical Science, n.9, p. 445-476, 2006.

BERGEL, J. Teoria Geral do Direito. São Paulo: Martins Fontes, 2001.

BERMAN, P. From International Law to Law and Globalization, 43 Colum. J.

Transat'1 L. 485, 490 n.11, 2005.

BEARCE, David. BONDANELLA, Stacy. Intergovernmental organizations, socialization, and member-state interest convergence. International Organization 61 (4):703-733, 2007.

BERTALANFFY, Ludwig Von. Teoria geral dos sistemas. 4. ed. Petrópolis: Ed.Vozes, 2009.

BRASIL. I Plano Nacional de Direitos Humanos, anexo ao Decreto Presidencial n. 1.904, de 13 de maio de 1996.

junho de 2000 .

Projeto de Lei n. 3214, de 2000, Diário da Câmara dos Deputados, 17 de

. II Plano Nacional de Direitos Humanos, Anexo ao Decreto

Presidencial n. 4.229, de 13 de maio de 2002. dezembro de 2004.

Projeto de Lei n. 4.667, de 2004, Diário da Câmara dos Deputados, 15 de . Lei federal n. 10.933, de 11 de agosto de 2004, Plano Plurianual

$2004 / 2007$.

. III Plano Nacional de Direitos Humanos, Brasília: SEDH/PR, 2010. 
. Lei Federal n. 12.798, de 4 de abril de 2013, volume IV, p.603.

. Conselho Nacional de Justiça, Relatório do Programa Justiça Plena,

Brasília: CNJ, 2012. Disponível em: http://www.cnj.jus.br/images/programas/justicaplena/relatorio_justicaplena.pdf Acesso em: 23 maio 2016

Diário Oficial da União, 12 de maio de 2016. Disponível em:

http://pesquisa.in.gov.br/imprensa/jsp/visualiza/index.jsp?data=12/05/2016\&jornal $=1000$ $\underline{\text { \&pagina }=3 \& \text { totalArquivos }=10}$ Acesso em: 23 maio 2016

BOBBIO, Norberto. A era dos direitos. Rio de Janeiro: Elsevier, 2004.

BORGES, Nadine M. O Caso Damião Ximenes: Uma análise sócio-jurídica do acesso à Comissão e à Corte Interamericana de Direitos Humanos. Niterói, RJ.

Originalmente apresentada como dissertação de mestrado, Universidade Federal Fluminense, 2008.

BÖRZEL, Tanja A. et al. Obstinate and Inefficient. Why Member States Do Not Comply With European Law, Comparative Political Studies, Vol. 43, No. 11 (November), p. 1363-1390. 2010.

BUERGENTHAL, Thomas. The Inter-American Court of Human Rights. The American Journal of International Law, vol. 76, nº 2, 1982.

BULL, Hedley. A Sociedade Anárquica. São Paulo: Editora Universidade de Brasília, 2002.

CARTER, B. TRIMBLE, P. International Law 2. New York: Wolters Kluwer 3rd ed. 1999.

CARVALHO, Fernando Henrique. A Independência do Poder Judiciário e suas Garantias. Disponível em: http://www.webartigos.com/artigos/a-independencia-dopoder-judiciario-e-suas-garantias/130544/\#ixzz4CbmPP7qU Acesso: 25 jun 2016.

CASTRO SANTOS, Maria Helena de. Alcohol as Fuel in Brazil: An Alternative Energy Policy and Politics, Tese de Doutorado, Massachusetts Institute of Technology, 1985.

CAVALLARO, James L. Toward Fair Play: A Decade of Transformation and Resistance in International Human Rights Advocacy in Brazil. Chicago Journal of International Law, vol. 3, no 2, 2002.

CAVALLARO, James L.; BREWER, Stephanie E. Reevaluating Regional Human Rights Litigation in the Twenty-First Century: The Case of the Inter-American Court. American Society of International Law, vol. 102, $n^{\circ}$ 4, 2008a.

. The Virtue of Following: The Role of Inter-American Litigation in Campaigns for Social Justice. Sur: Revista Internacional de Direitos Humanos, $n^{\circ}$ 8, 2008b.

CAVALLARO, James L.; SCHAFFER, Emily. Justice Before Justiciability: InterAmerican Litigation and Social Change. N.Y.U. Journal of International Law and Politics, vol. 39, 2006/2007. 
CHAYES, Abram. CHAYES, Antonia. On compliance. International Organization 47 (2):175-205, 1993

The New Sovereignty: Compliance with International Regulatory

Agreements. London: Harvard University Press, 1995.

CHECKEL, Jeffrey T. Why Comply? Social Learning and European Identity Change, International Organization, Vol. 55, No. 3 (June), p. 553-588. 2001.

. International institutions and socialization in Europe: Introduction and

framework. International Organization 59 (4):801-826, 2005

CIMI. Violência contra os Povos Indígenas no Brasil - Dados de 2014. Disponível em: http://www.cimi.org.br/pub/Arquivos/Relat.pdf Acesso : 26 jun 2016

COMISIÓN INTERAMERICANA DE DERECHOS HUMANOS. Reglamento de la Comisión Interamericana de Derechos Humanos, aprobado en el $137^{\circ}$ Período

Ordinario de Sesiones de la Comisión, celebrado del 28 de octubre al 13 de noviembre de 2009.

. Annual Report 2014. Disponível em:

http://www.oas.org/es/cidh/informes/anuales.asp Acesso em: 01 nov 2015.

. Annual Report 2013. Disponível em:

http://www.oas.org/es/cidh/informes/anuales.asp Acesso em: 01 nov 2015.

. Annual Report 2012. Disponível em:

http://www.oas.org/es/cidh/informes/anuales.asp Acesso em: 01 nov 2015.

. Annual Report 2011. Disponível em:

http://www.oas.org/es/cidh/informes/anuales.asp Acesso em: 01 nov 2015.

. Annual Report 2010. Disponível em:

http://www.oas.org/es/cidh/informes/anuales.asp Acesso em: 01 nov 2015.

. Annual Report 2009. Disponível em:

http://www.oas.org/es/cidh/informes/anuales.asp Acesso em: 01 nov 2015.

. Annual Report 2008. Disponível em:

http://www.oas.org/es/cidh/informes/anuales.asp Acesso em: 01 nov 2015.

Annual Report 2007. Disponível em:

http://www.oas.org/es/cidh/informes/anuales.asp Acesso em: 01 nov 2015.

. Annual Report 2006. Disponível em:

http://www.oas.org/es/cidh/informes/anuales.asp Acesso em: 01 nov 2015.

Annual Report 2005. Disponível em:

http://www.oas.org/es/cidh/informes/anuales.asp Acesso em: 01 nov 2015. 
. Annual Report 2004. Disponível em:

http://www.oas.org/es/cidh/informes/anuales.asp Acesso em: 01 nov 2015.

. Annual Report 2003. Disponível em:

http://www.oas.org/es/cidh/informes/anuales.asp Acesso em: 01 nov 2015.

. Annual Report 2002. Disponível em:

http://www.oas.org/es/cidh/informes/anuales.asp Acesso em: 01 nov 2015.

Annual Report 2002. Disponível em:

http://www.oas.org/es/cidh/informes/anuales.asp Acesso em: 01 nov 2015.

. Annual Report 2001. Disponível em:

http://www.oas.org/es/cidh/informes/anuales.asp Acesso em: 01 nov 2015.

. Annual Report 2000. Disponível em:

http://www.oas.org/es/cidh/informes/anuales.asp Acesso em: 01 nov 2015.

. Annual Report 1999. Disponível em:

http://www.oas.org/es/cidh/informes/anuales.asp Acesso em: 01 nov 2015.

Annual Report 1998. Disponível em:

http://www.oas.org/es/cidh/informes/anuales.asp Acesso em: 01 nov 2015.

. Annual Report 1997. Disponível em:

http://www.oas.org/es/cidh/informes/anuales.asp Acesso em: 01 nov 2015.

. Annual Report 1996. Disponível em:

http://www.oas.org/es/cidh/informes/anuales.asp Acesso em: 01 nov 2015.

Annual Report 1995. Disponível em:

http://www.oas.org/es/cidh/informes/anuales.asp Acesso em: 01 nov 2015.

Annual Report 1994. Disponível em:

http://www.oas.org/es/cidh/informes/anuales.asp Acesso em: 01 nov 2015.

. Annual Report 1992-1993. Disponível em:

http://www.oas.org/es/cidh/informes/anuales.asp Acesso em: 01 nov 2015.

Annual Report 1991. Disponível em:

http://www.oas.org/es/cidh/informes/anuales.asp Acesso em: 01 nov 2015.

. Annual Report 1990-1991. Disponível em:

http://www.oas.org/es/cidh/informes/anuales.asp Acesso em: 01 nov 2015.

. Annual Report 1989-1990. Disponível em:

http://www.oas.org/es/cidh/informes/anuales.asp Acesso em: 01 nov 2015.

. Annual Report 1988-1989. Disponível em:

http://www.oas.org/es/cidh/informes/anuales.asp Acesso em: 01 nov 2015. 
1996. Apêndice 1.

Informe N. 16/96. 10.301, Parque São Lucas. Brasil, 6 de março de

Informe N. 33/97. Disponível em:

http://www.cidh.oas.org/annualrep/97span/Brasil11.405.htm Acesso em: 15 out 2015.

Informe N. 17/98. Disponível em:

http://www.cidh.oas.org/annualrep/97span/Brasil11.407.htm Acesso em: 15 out 2015.

Informe N. 18/98. Disponível em:

http://www.cidh.oas.org/annualrep/97span/Brasil11.285.htm Acesso em: 15 out 2015.

Informe N. 19/98. Disponível em:

http://www.cidh.oas.org/annualrep/97span/Brasil11.516.htm Acesso em: 15 out 2015.

Informe N. 24/98. Disponível em:

http://www.cidh.oas.org/annualrep/97span/Brasil11.287.htm Acesso em: 15 out 2015.

Informe N. 77/98. Disponível em:

http://www.cidh.oas.org/annualrep/98span/Admisibilidad/Brasil11.556.htm Acesso em: 15 out 2015.

Informe N. 78/98. Disponível em:

http://www.cidh.oas.org/annualrep/98span/Admisibilidad/Brasil11.566.htm Acesso em: 15 out 2015.

Informe N. 79/98. 11.405, Newton Coutinho Mendes e outros. Brasil, 29 de setembro de 1998. Apêndice 1. 1998. Apêndice 1

Informe N. 80/98. 11.516, Ovelário Tames. Brasil, 29 de setembro de

Informe N. 22/99. 11.598, Alonso Eugênio da Silva. Brasil, 24 de março de 1999. Apêndice 1.

Informe N. 23/99. 11.599, Marcos Aurélio de Oliveira. Brasil, 24 de março de 1999, Apêndice 1.

Informe N. 59/99. Disponível em:

http://www.cidh.org/annualrep/98span/Fondo/Brasil\%2011.405.htm Acesso em: 15 out 2015.

Informe N. 60/99. Disponível em:

http://www.cidh.org/annualrep/98span/Fondo/Brasil\%2011.516.htm Acesso em: 15 out 2015.

Apêndice 1.

Informe N. 120/99. 11.291, Carandiru. Brasil, 26 de outubro de 1999. 
Informe N. 09/00. Disponível em:

http://www.cidh.oas.org/annualrep/99span/De\%20Fondo/Brasil11598.htm Acesso em: 15 out 2015.

Informe N. 10/00. Disponível em:

http://www.cidh.oas.org/annualrep/99span/De\%20Fondo/Brasil11599.htm Acesso em: 15 out 2015.

Informe N. 34/00. Disponível em:

http://www.cidh.oas.org/annualrep/99span/De\%20Fondo/Brasil11291.htm Acesso em: 15 out 2015.

Informe N. 61/00. Disponível em:

http://www.cidh.oas.org/annualrep/2000sp/CapituloIII/Admisible/Brasil12.058.htm Acesso em: 15 out 2015.

Informe N. 74/00. 11.286, Aluísio Cavalcante e outros. Brasil, 3 de outubro de 2000. Apêndice 1.

. Informe N.105/00. 12.051, Maria da Penha Maia Fernandes. Brasil, 19 de outubro de 2000. Apêndice 1.

Informe N.33/01. Disponível em:

http://www.cidh.oas.org/annualrep/2000sp/CapituloIII/Admisible/Brasil11.552.htm Acesso em: 15 out 2015.

Informe N.35/01. Disponível em:

http://www.cidh.oas.org/annualrep/2000sp/CapituloIII/Admisible/Brasil11.634.htm Acesso em: 15 out 2015.

Informe N.36/01. Disponível em:

http://www.cidh.oas.org/annualrep/2000sp/CapituloIII/Admisible/Brasil11.694.htm Acesso em: 15 out 2015.

Informe N. 54/01. Disponível em:

http://www.cidh.oas.org/annualrep/2000sp/CapituloIII/Fondo/Brasil12.051.htm Acesso em: 15 out 2015 .

Informe N. 55/01. Disponível em:

http://www.cidh.oas.org/annualrep/2000sp/CapituloIII/Fondo/Brasil11.286.htm Acesso em: 15 out 2015 .

Informe N. 111/01. Disponível em:

https://www.cidh.oas.org/annualrep/2002port/brasil.11517.htm Acesso em: 15 out 2015.

Informe N. 23/02. Disponível em:

http://www.cidh.oas.org/annualrep/2002sp/Brasil.11517.htm Acesso em: 15 out 2015.

Informe N. 37/02. Disponível em:

http://www.cidh.oas.org/annualrep/2002sp/Brasil.12001.htm Acesso em: 15 out 2015. 
Informe N. 38/02. Disponível em:

http://www.cidh.oas.org/annualrep/2002sp/Brasil.12237.htm Acesso em: 15 out 2015.

Informe N. 39/02. Disponível em:

http://www.cidh.oas.org/annualrep/2002sp/Brasil.12328.htm Acesso em: 15 out 2015.

Informe N. 4/03. Disponível em:

http://www.cidh.oas.org/annualrep/2003sp/Brasil.11820.htm Acesso em: 15 out 2015. de 2003. Apêndice 1.

Informe N. 22/03. 11.556, Massacre de Corumbiara. Brasil, 4 de março 2003. Apêndice 1.

Informe N. 23/03. 11.634, Jailton Neri da Fonseca. Brasil, 4 de março de

Informe N. 40/03. Disponível em:

http://www.cidh.oas.org/annualrep/2003sp/Brasil10301.htm Acesso em: 15 out 2015.

Informe N. 43/03. Caso 12.237, Damião Ximenes Lopes, Brasil, 8 de octubre de 2003. Apéndice 2.

Informe N. 73/03. Disponível em:

http://www.cidh.oas.org/annualrep/2003sp/Brasil.12213.htm Acesso em: 15 out 2015.

Informe N. 95/03. Disponível em:

http://www.cidh.oas.org/annualrep/2003sp/Brasil.12289.htm Acesso em: 15 out 2015.

Informe N. 22/04. Caso 12.058, Gilson Nogueira de Carvalho, Brasil, 10 de marzo de 2004. Apéndice 2.

Informe N. 32/04. Disponível em:

http://www.cidh.oas.org/annualrep/2004sp/Brasil.11556.htm Acesso em: 15 out 2015.

Informe N. 33/04. Disponível em:

http://www.cidh.oas.org/annualrep/2004sp/Brasil.11634.htm Acesso em: 15 out 2015.

Informe N. 51/04. Disponível em:

http://www.cidh.oas.org/annualrep/2004sp/Brasil.12198.htm Acesso em: 15 out 2015. 2004. Apêndice 1.

Informe N. 83/04. 12.004, Simone André Diniz. Brasil, 28 de outubro de

Informe N. 18/06. Disponível em:

http://www.cidh.oas.org/annualrep/2006sp/Brasil12353sp.htm Acesso em: 15 out 2015.

Informe N.43/06. Disponível em:

http://www.cidh.oas.org/annualrep/2006sp/Brasil12426sp.htm Acesso em: 15 out 2015.

Informe N. 66/06. Disponível em:

http://www.cidh.oas.org/annualrep/2006sp/Brasil12001sp.htm Acesso em: 15 out 2015. 
. Informe N. 72/06. 12.308, Manoel Leal de Oliveira. Brasil, 17 de outubro de 2006. Apêndice 1.

Informe N.80/06. Disponível em:

http://www.cidh.oas.org/annualrep/2006sp/Brasil62.02sp.htm Acesso em: 15 out 2015.

Informe N.81/06. Disponível em:

http://www.cidh.oas.org/annualrep/2006sp/BRASIL394.02sp.htm Acesso em: 15 out 2015.

Informe N.82/06. Disponível em:

http://www.cidh.oas.org/annualrep/2006sp/Brasil555.01sp.htm Acesso em: 15 out 2015.

Informe N.83/06. Disponível em:

http://www.cidh.oas.org/annualrep/2006sp/Brasil641.03sp.htm Acesso em: 15 out 2015.

Informe N.84/06. Disponível em:

http://www.cidh.oas.org/annualrep/2006sp/Brasil1068.03sp.htm Acesso em: 15 out 2015.

Informe N.13/07 (admisibilidad y fondo), 12.478, Sétimo Garibaldi, Brasil, 27 de marzo de 2007. Apéndice 1.

Informe N.14/07 (fondo), 12.353 Arley José Escher y Otros

(intercepción de líneas telefónicas de organizaciones sociales), Brasil, 8 de marzo de 2007. Apéndice 1.

Informe N.18/07. Disponível em:

http://www.cidh.oas.org/annualrep/2007sp/Brasil.12479sp.htm Acesso em: 15 out 2015.

Informe N.19/07. Disponível em:

http://www.cidh.oas.org/annualrep/2007sp/Brasil.170.02sp.htm Acesso em: 15 out 2015.

Informe N.36/07. Disponível em:

http://www.cidh.oas.org/annualrep/2007sp/Brasil113.06sp.htm Acesso em: 15 out 2015.

Informe N.37/07. Disponível em:

http://www.cidh.oas.org/annualrep/2007sp/Brasil12200sp.htm Acesso em: 15 out 2015.

Informe N.38/07. Disponível em:

http://www.cidh.oas.org/annualrep/2007sp/Brasil.12263p.htm Acesso em: 15 out 2015.

Informe N.40/07. Disponível em:

http://www.cidh.oas.org/annualrep/2007sp/Brasil665.05.sp.htm Acesso em: 15 out 2015.

Informe N.41/07. Disponível em:

http://www.cidh.oas.org/annualrep/2007sp/Brasi1998.05sp.htm Acesso em: 15 out 2015.

Informe N. 84/07. 12.019, Antônio Ferreira Braga. Brasil, 16 de outubro de 2007. Apéndice 1. 
Informe N.9/08. Disponível em:

http://www.cidh.oas.org/annualrep/2008sp/Brasil12332.sp.htm Acesso em: 15 out 2015.

Informe N. 33/08. 12.310, Sebastião Camargo Filho. Brasil, 5 de agosto de 2008. Apêndice 1.

Informe N. 34/08. 12.440, Wallace de Almeida. Brasil, 13 de agosto de 2008. Apêndice 1 .

Informe N. 35/08. Disponível em:

http://www.cidh.oas.org/annualrep/2008sp/Brasil12019.sp.htm Acesso em: 15 out 2015.

Informe N.41/08. Disponível em:

http://www.cidh.oas.org/annualrep/2008sp/Brasil478-07.sp.htm Acesso em: 15 out 2015.

Informe N.70/08. Disponível em:

http://www.cidh.oas.org/annualrep/2008sp/Brasil12242.sp.htm Acesso em: 15 out 2015.

Informe N.71/08. Disponível em:

http://www.cidh.oas.org/annualrep/2008sp/Brasil1290-04.sp.htm Acesso em: 15 out 2015.

Informe N.72/08. Disponível em:

http://www.cidh.oas.org/annualrep/2008sp/Brasil1342-04.sp.htm Acesso em: 15 out 2015.

Informe N.73/08. Disponível em:

http://www.cidh.oas.org/annualrep/2008sp/Brasil1236-06.sp.htm Acesso em: 15 out 2015.

Informe N.91/08 (mérito), 11.552, Julia Gomes Lund e outros (Guerrilha do Araguaia), Brasil, 31 de outubro de 2008. Apéndice 1.

Informe N. 25/09. Disponível em:

http://www.cidh.oas.org/annualrep/2009sp/Brasil12310.sp.htm Acesso em: 15 out 2015.

. Informe N. 26/09. Disponível em:

http://www.cidh.oas.org/annualrep/2009sp/Brasil12440.sp.htm Acesso em: 15 out 2015.

Informe N. 12/09. Disponível em:

http://www.cidh.oas.org/annualrep/2009sp/Brasil4643-02.sp.htm Acesso em: 15 out 2015.

Informe N. 61/09. Disponível em:

http://www.cidh.oas.org/annualrep/2009sp/Brasil373-03.sp.htm Acesso em: 15 out 2015.

Informe N. 62/09. Disponível em:

http://www.cidh.oas.org/annualrep/2009sp/Brasil1173-05.sp.htm Acesso em: 15 out 2015. 
Informe N. 93/09. Disponível em:

http://www.cidh.oas.org/annualrep/2009sp/Brasil337-03.sp.htm Acesso em: 15 out 2015.

Informe N. 94/09. Disponível em:

http://www.cidh.oas.org/annualrep/2009sp/Brasil462-01.sp.htm Acesso em: 15 out 2015.

Informe N. 96/09. Disponível em:

http://www.cidh.oas.org/annualrep/2009sp/Brasil4-04.sp.htm Acesso em: 15 out 2015.

Informe N. 98/09. Disponível em:

http://www.cidh.oas.org/annualrep/2009sp/Brasil4355-02.sp.htm Acesso em: 15 out 2015.

Informe N. 6/10. Disponível em:

http://www.cidh.oas.org/annualrep/2010sp/7.BRAD262-05ES.doc Acesso em: 15 out 2015.

Informe N. 7/10. Disponível em:

http://www.cidh.oas.org/annualrep/2010sp/8.BRAD12378ES.doc Acesso em: 15 out 2015.

Informe N. 37/10. Disponível em:

http://www.cidh.org/annualrep/2010sp/BRPU12308ES.doc Acesso em: 15 out 2015.

Informe N. 38/10. Disponível em:

http://www.cidh.oas.org/annualrep/2010sp/3.BRAD1198-05ES.doc Acesso em: 15 out 2015.

Informe N. 39/10. Disponível em:

http://www.cidh.oas.org/annualrep/2010sp/4.BRAD150-06ES.doc Acesso em: 15 out 2015.

Informe N. 40/10. Disponível em:

http://www.cidh.oas.org/annualrep/2010sp/5.BRAD590-05ES.doc Acesso em: 15 out 2015.

Informe N. 41/10. Disponível em:

http://www.cidh.oas.org/annualrep/2010sp/6.BRAD999-06ES.doc Acesso em: 15 out 2015.

Informe N. 125/10. Disponível em:

http://www.cidh.oas.org/annualrep/2010sp/9.BRAD250-04ES.doc Acesso em: 15 out 2015.

Informe N. 126/10. Disponível em:

http://www.cidh.oas.org/annualrep/2010sp/10.BRAD1448-06ES.DOC Acesso em: 15 out 2015.

Informe N. 127/10. Disponível em:

http://www.cidh.org/annualrep/2010sp/11.BRAD1454-06ES.doc Acesso em: 15 out 2015. 
Informe N. 128/10. Disponível em:

http://www.cidh.org/annualrep/2010sp/BRAD265-05ES.doc Acesso em: 15 out 2015.

Informe N. 5/11. Disponível em:

http://www.oas.org/es/cidh/decisiones/2011/BRAD702-03ES.doc Acesso em: 15 out 2015.

Informe N. 141/11. Disponível em:

http://www.oas.org/es/cidh/decisiones/corte/2015/11566FondoPt.pdf Acesso em: 15 out 2015.

Informe N. 143/11. Disponível em:

http://www.oas.org/es/cidh/decisiones/2011/BRAD303-05ES.doc Acesso em: 15 out 2015.

Informe N. 144/11. Disponível em:

http://www.oas.org/es/cidh/decisiones/2011/BRAD1050-06ES.doc Acesso em: 15 out 2015.

Informe N. 145/11. Disponível em:

http://www.oas.org/es/cidh/decisiones/2011/BRAD1140-04ES.doc Acesso em: 15 out 2015.

Informe N. 146/11. Disponível em:

http://www.oas.org/es/cidh/decisiones/2011/BRAD405-07ES.DOC Acesso em: 15 out 2015.

Informe N. 169/11. Disponível em:

http://www.oas.org/es/cidh/decisiones/corte/2015/12066FondoPt.pdf Acesso em: 15 out 2015.

Informe N. 173/11. Disponível em:

http://www.oas.org/es/cidh/decisiones/2011/BRAD897-04ES.doc Acesso em: 15 out 2015.

Informe N. 9/12. Disponível em:

http://www.oas.org/es/cidh/decisiones/2012/BRAD302-07ES.doc Acesso em: 15 out 2015.

Informe N. 10/12. Disponível em:

http://www.oas.org/es/cidh/decisiones/2012/BRADP341ES.doc Acesso em: 15 out 2015.

Informe N. 11/12. Disponível em:

http://www.oas.org/es/cidh/decisiones/2012/BRADP06-07ES.doc Acesso em: 15 out 2015.

Informe N. 70/12. Disponível em:

http://www.oas.org/es/cidh/decisiones/2012/BRAD1330-07ES.DOC Acesso em: 15 out 2015. 
Informe N. 71/12. Disponível em:

http://www.oas.org/es/cidh/decisiones/2012/BRAD1073-05ES.DOC Acesso em: 15 out 2015.

Informe N. 78/12. Disponível em:

http://www.oas.org/es/cidh/decisiones/2012/BRAD1485-07ES.doc Acesso em: 15 out 2015.

Informe N. 79/12. Disponível em:

http://www.oas.org/es/cidh/decisiones/2012/BRAD342-07ES.DOC Acesso em: 15 out 2015.

Informe N. 80/12. Disponível em:

http://www.oas.org/es/cidh/decisiones/2012/BRAD859-09ES.doc Acesso em: 15 out 2015.

Informe N. 37/13. Disponível em:

http://www.oas.org/es/cidh/decisiones/2013/BRAD1279-04ES.doc Acesso em: 15 out 2015.

Informe N. 70/14. Disponível em:

http://www.oas.org/es/cidh/decisiones/2014/BRAD1453-06ES.pdf Acesso em: 15 out 2015.

Informe N. 74/14. Disponível em:

http://www.oas.org/es/cidh/decisiones/2014/BRAD1294-05ES.pdf Acesso em: 15 out 2015.

Nota de Remisión. Caso 12.066 Fazenda Brasil Verde a la Corte

Interamericana de Derechos Humanos. Disponível em:

http://www.oas.org/es/cidh/decisiones/corte/2015/12066NdeRes.pdf Acesso em: 04 nov 2015.

Nota de Remisión. Caso 11.566 Cosme Rosa Genoveva, Evandro de Oliveira e outros (Favela Nova Brasília) a la Corte Interamericana de Derechos Humanos. Disponível em: http://www.oas.org/es/cidh/decisiones/corte/2015/11566NdeRes.pdf Acesso em: 04 nov 2015.

CONVENÇÃO DE VIENA SOBRE O DIREITO DOS TRATADOS. 22 de maio de 1969. Disponível em: http://dai-mre.serpro.gov.br/legislacao/convencao-de-viena-sobreo-direito-dos-tratados-1/ Acesso em: 06 nov 2015.

CORREIA, T. Corte Interamericana de Direitos Humanos: Repercussão Jurídica das Opiniões Consultivas. Curitiba: Juruá, 2008, p. 69-70.

CORTE INTERAMERICANA DE DIREITOS HUMANOS. Regulamento da Corte Interamericana de Direitos Humanos. Aprovado pela Corte no seu LXXXV Período Ordinário de Sessões, celebrado de 16 a 28 de novembro de 2009. Disponível em: http://www.cidh.oas.org/basicos/portugues/Viejos/w.Regulamento.Corte.htm Acesso em: 06 nov. 2015. 
Case of Ximenes Lopes v. Brazil. Monitoring Compliance with Judgment. Order of the Inter-American Court of Human Rights of May 02, 2008. Disponível em:

http://www.corteidh.or.cr/cf/jurisprudencia2/busqueda_supervision_cumplimiento.cfm?la ng=en Acesso em: 01 nov 2015.

Case of Ximenes Lopes v. Brazil. Monitoring Compliance with

Judgment. Order of the Inter-American Court of Human Rights of September 21, 2009. Disponível em:

http://www.corteidh.or.cr/cf/jurisprudencia2/busqueda_supervision_cumplimiento.cfm?la ng=en Acesso em: 01 nov 2015.

. Case of Ximenes Lopes v. Brazil. Monitoring Compliance with Judgment. Order of the Inter-American Court of Human Rights of May 17, 2010. Disponível em:

http://www.corteidh.or.cr/cf/jurisprudencia2/busqueda_supervision_cumplimiento.cfm?la ng=en Acesso em: 01 nov 2015.

Case of Escher et al. v. Brazil. Monitoring Compliance with Judgment. Order of the Inter-American Court of Human Rights of May 17, 2010. Disponível em: http://www.corteidh.or.cr/cf/jurisprudencia2/busqueda_supervision_cumplimiento.cfm?la $\underline{\text { ng}=e n ~ A c e s s o ~ e m: ~} 01$ nov 2015.

Case of Garibaldi v. Brazil. Monitoring Compliance with Judgment. Order of the Inter-American Court of Human Rights of February 22, 2011. Disponível em:http://www.corteidh.or.cr/cf/jurisprudencia2/busqueda_supervision_cumplimiento.cf m?lang=en Acesso em: 01 nov 2015.

Case of Garibaldi v. Brazil. Monitoring Compliance with Judgment. Order of the Inter-American Court of Human Rights of February 20, 2012. Disponível em:http://www.corteidh.or.cr/cf/jurisprudencia2/busqueda_supervision_cumplimiento.cf m?lang=en Acesso em: 01 nov 2015.

. Case of Escher et al. v. Brazil. Monitoring Compliance with Judgment. Order of the Inter-American Court of Human Rights of June 19, 2012. Disponível em: http://www.corteidh.or.cr/cf/jurisprudencia2/busqueda_supervision_cumplimiento.cfm?la ng=en Acesso em: 01 nov 2015.

Case of Gomes Lund et al. ("Guerrilha do Araguaia") v. Brazil. Monitoring Compliance with Judgment. Order of the Inter-American Court of Human Rights of October 17, 2014. Disponível em:

http://www.corteidh.or.cr/cf/jurisprudencia2/busqueda_supervision_cumplimiento.cfm?la ng=en Acesso em: 01 nov 2015.

Case of Gomes Lund et al. ("Guerrilha do Araguaia") v. Brazil.

Preliminary Objections, Merits, Reparations, and Costs. Judgment of November 24, 2010. Series C No. 219. Disponível em:

http://www.corteidh.or.cr/docs/casos/articulos/seriec_219_ing.pdf Acesso em: 04 nov 2015. 
. Case of Escher et al. v. Brazil. Interpretation of the Judgment on

Preliminary Objections, Merits, Reparations and Costs. Judgment of November 20, 2009. Series C No. 208. Disponível em:

http://www.corteidh.or.cr/docs/casos/articulos/seriec_208_ing.pdf Acesso em: 04 nov 2015.

Case of Garibaldi v. Brazil. Preliminary Objections, Merits,

Reparations, and Costs. Judgment of September 23, 2009. (Spanish and

Portuguese)Versão em português Series C No. 203. Disponível em:

http://www.corteidh.or.cr/docs/casos/articulos/seriec_203_ing.pdf Acesso em: 04 nov

2015.

Case of Nogueira de Carvalho et al. v. Brazil. Preliminary Objections and Merits. Judgment of November 28, 2006. Versão em português. Series C No. 161. Disponível em: http://www.corteidh.or.cr/docs/casos/articulos/seriec_161_ing.pdf Acesso em: 04 nov 2015.

Case of Ximenes Lopes v. Brazil. Merits, Reparations and Costs. Judgment of July 4, 2006. Series C No. 149. Disponível em:

http://www.corteidh.or.cr/docs/casos/articulos/seriec_149_ing.pdf Acesso em: 04 nov 2015.

CORTRIGHT, David. LOPEZ, George. Smart Sanctions: Targeting Economic Statecraft. New York: Rowman and Littlefield, 2002

D'AMATO, A. The concept of Custom in International Law. Ithaca: Cornell University Press, 1971, p.242, n.28, e.74

DIAS, F. As teorias e o papel das ideias nas Relações Internacionais. Dissertação de mestrado, UnB, 2003, 217 fs.

DOWNS, George. ROCKE, David; BARSOOM, Peter. Is the good news about compliance good news about cooperation? International Organization 50 (3):379-406, 1996.

FALK, Richard. The relevance of political context to the nature and functioning of international law: an intermediate review. In: DEUTSCH, Karl W.; HOFFMAN, Stanley (eds.). The relevance of international law: essays in honor of Leo Gross. Cambridge, MA: Schenkman, p. 133-152, 1968.

FALKNER, Gerda; TREIB, Oliver. Three worlds of compliance or four? The EU-15 compared to new member states. Journal of Common Market Studies 46 (2):293-313, 2008.

FRANCA, Luka. Brasil não cumpre recomendações da CIDH sobre Massacre do Carandiru. Brasil, 18 de fevereiro de 2014. Disponível em: http://ultimainstancia.uol.com.br/conteudo/noticias/69238/brasil+nao+cumpre+recomend acoes+da+cidh+sobre+massacre+do+carandiru.shtml Acesso em: 05 nov 2015.

FRANCO, Thalita. Efetividade Das Decisões Proferidas Pela Corte Interamericana De Direitos Humanos: Identificação Dos Marcos Teóricos E Análise Da Conduta Do Estado Brasileiro. São Paulo: USP, 2014. 148f. Dissertação (Mestrado em Relações 
Internacionais) - Instituto de Relações Internacionais, Universidade de São Paulo, São Paulo, 2014.

GEORGE, Alexander and BENNETT, Andrew. Case studies and theory development in the social sciences. Belfer Center for Science and International affairs - BCSIA Haward University, 2005.

GONZÁLEZ, F. As Medidas de Urgência no SIDH, Revista Sur, vol.7, n.13, 2010 p.51.

GROSSMAN, Claudio. Strengthening the Intra-American Human Rights System: The Current Debate. American Society of International Law (Proceedings of the Annual Meeting), vol. 92, The Challenge of Non-State Actors, 1998.

HAFNER-BURTON, Emilie. Trading human rights: How preferential trade agreements influence government repression. International Organization 59 (3):593-629, 2005.

HAFNER-BURTON, Emilie. TSUTSUI, Kiyoteru. Human rights in a globalizing world: The paradox of empty promises. American Journal of Sociology 110 (5):1373-1411, 2005.

HATHAWAY, Oona A. Do human rights make a difference? In: Yale Law Journal, v. 111, pp. 1935-2042, 2002.

HAWKINS, Darren. JACOBY, Wade. Partial Compliance: A Comparison of the European and Inter-American American Courts for Human Rights. Annual Meeting of the American Political Science Association, Boston. 2008.

HELFER, Laurence. SLAUGHTER, Anne-Marie. Why states create international tribunals: A response to professors Posner and Yoo. California Law Review 93 (2):900-957, 2005.

HENKIN, Louis. How Nations Behave: Law and Foreign Policy. 2nd edition ed. New York: Council on Foreign Relations, 1979.

HIGGINS, R. Conceptual Thinking about the Individual in International Law. British Journal of International Studies, vol. 4, $\mathrm{n}^{\circ} 1,1978$.

Problems and Process: International Law and How We Use It. New York: Oxford University Press, 1994. David Kennedy (1988)

HILLEBRECHT, Courtney. "Domestic politics, international human rights adjudication, and the problem of political Will: cases from Inter-American Human Rights system". 65th Annual National Conference of the Midwest Political Science Association, Chicago, IL, USA, april 2-5, 2009a.

HURD, Ian. Legitimacy and Authority in International Politics, International Organization, Vol. 53, No. 2 (Spring), p. 379-408. 1999.

JACOBY, Wade. Inspiration, coalition, and substitution: External influences on post communist transformations. World Politics 58 (4):623-651, 2006. 
JAYME, F. Direitos humanos e sua efetivação pela corte interamericana de direitos humanos. Belo Horizonte: Del Rey, 2005.

JÚNIOR, Nivaldo. Reforma política na Câmara dos Deputados: A rejeição política do modelo de lista fechada e financiamento público exclusivo. 2013. 104 f. Dissertação (Mestrado em Ciência Política) - Instituto de Ciência Política, Universidade de Brasília, Brasília, 2013.

KELLEY, Judith. International actors on the domestic scene: Membership conditionality and socialization by international institutions. International Organization 58 (3):425-457, 2004.

KEOHANE, Robert. MORAVCSIK, Andrew. SLAUGHTER, Anne-Marie. Legalized dispute resolution: Interstate and transnational. International Organization 54 (3):457488, 2000.

KRATOCHWIL, F. Rules, norms and decisions: on the conditions of practical and legal reasoning in International Relations affairs. London: Cambridge University Press, 1989.

KRATOCHWIL, F.; RUGGIE, J. International Organization: a state of art on an art of the state. International Organization, Vol.40, n.40, 1986, pp.753-775.

KRENZ, Frank E. The Refugee as a Subject of International Law. The International and Comparative Law Quarterly, vol. 15, nº 1, 1966.

LANDMAN, Todd. Protecting Human Rights: A Comparative Study. Washington: Georgetown University Press, 2005.

LIMA, Maria Regina Soares de. Ejes Analíticos y Conflicto de Paradigmas en la Política Exterior Brasileña. In: América Latina Internacional, 1994, v.1. n.2, p.27-40.

MACIEL, Débora Alves. Et al. Os Estados Unidos e os mecanismos regionais de proteção dos direitos humanos. Lua Nova, São Paulo, 90: 271-295, 2013. Disponível em: http://www.scielo.br/pdf/ln/n90/a10n90.pdf Acesso em: 16 junho 2016 .

MAZZUOLI, Valerio de Oliveira. Curso de Direito Internacional Público. $2^{\mathrm{a}}$ ed. São Paulo: Editora Revista dos Tribunais, 2007.

McCLENDON, Gwyneth. "Commitment without compliance: settlements and referrals of human right cases in the Inter-American System". International Studies Association Annual Conference, New York, feb. 9, 2009.

MORAES, Marielli. A Corte Interamericana de Direitos Humanos: Uma Análise de suas Decisões no Caso Urso Branco. Revista Eletrônica de Direito Internacional. v.2 (2008- ). Belo Horizonte: CEDIN, 2008.

NEUMAYER, Eric.. Do international human rights treaties improve respect for human rights? Journal of Conflict Resolution 49 (6):925-953, 2005.

OLIVEIRA, Bianca Marques et al. O direito e a violência policial. Revista Âmbito Jurídico, Rio Grande, XIV, n. 88, maio 2011. Disponível em: http://www.ambito- 
juridico.com.br/site/index.php?artigo id=9469\&n link=revista artigos leitura Acesso: 25 jun 2016.

ONUF, N. World of our making: rules and rule in social theory and international relations. Columbia: South Carolina Press, 1989. The constitution of international society. European journal of international law. Vol. 5, n. 1: 1994, p.7.

ORENSTEIN, Mitchell. BLOOM, Stephen. LINDSTROM, Nicole. Transnational Actors in Central and Eastern European Transition. Pittsburgh: University of Pittsburgh Press. 2008.

ORGANIZAÇÃO DAS NAÇÕES UNIDAS. Assembleia Geral. Convenção Internacional sobre a Eliminação de todas as Formas de Discriminação Racial. Nova Iorque, 1966. Disponível em:

http://legis.senado.gov.br/legislacao/ListaTextoIntegral.action?id=94836 Acesso em: 14 nov. 2015

Assembleia Geral. Convenção Internacional contra a Tortura e Outras Penas ou Tratamentos Cruéis, Desumanos e Degradantes. Nova Iorque, 1984. Disponível em: http://www.planalto.gov.br/ccivil_03/_Ato2007-2010/2007/Decreto/D6085.htm Acesso em: 14 nov. 2015

Assembleia Geral. Declaração dos Direitos e Responsabilidades dos Indivíduos, Grupos e Órgãos da Sociedade para Promover e Proteger os Direitos Humanos e Liberdades Individuais Universalmente Reconhecidos. Nova Iorque, 1998. Disponível em:

http://www2.ohchr.org/english/issues/defenders/docs/declaration/declarationPortuguese.d oc Acesso em: 14 nov. 2015.

ORGANIZAÇÃO DOS ESTADOS AMERICANOS. Comissão Interamericana de Direitos Humanos: Mandato, n/d. Disponível em: https://www.oas.org/pt/cidh/mandato/Basicos/intro.pdf. Acesso em: 12 out. 2015

ORGANIZAÇÃO INTERNACIONAL DO TRABALHO. Convenção 29 sobre Trabalho Forçado ou Obrigatório. Genebra, 1930. Disponível em: http://www.oit.org.br/sites/all/forced_labour/oit/convencoes/conv_29.pdf Acesso em: 14 nov. 2015.

Convenção 169 sobre Povos Indígenas e Tribais. Genebra, 1989.

Disponível em: http://www.planalto.gov.br/ccivil_03/_ato20042006/2004/decreto/d5051.htm Acesso em: 14 nov. 2015.

PASQUALUCCI, Jo M. The Inter-American Human Rights System: Establishing Precedents and Procedure in Human Rights Law. The University of Miami InterAmerican Law Review, vol. 26, nº 2, 1994/1995. 
PIOVESAN, F. Direitos humanos e justiça internacional. 2.ed. São Paulo: Saraiva, 2011, p.129

PAULSON, Colter. "Compliance with final judgments of the International Court of Justice since 1987'. American Journal of International Law, v. 98, n. 3, p. 434-461, 2004.

POSNER, Eric. YOO, John. Judicial independence in international tribunals.

California Law Review 93 (1):3-72, 2005.

PURVIS, N. Critical Legal Studies in international Law. Harvard Journal of International Law v.32, n.1, p.81-127, 1991.

PUTNAM, Robert. Diplomacy and Domestic Politics: The Logic of Two-Level Games. In: International Organization. v. 42 (Summer 1988).

RAUSTIALA, Kal. Compliance and effectiveness in international regulatory cooperation. Case Western Reserve Journal of International Law 32:387-440, 2000.

RAUSTIALA, Kal; SLAUGHTER, Anne-Marie. International Law, International Relations and Compliance. In: Handbook of International Relations, p. 538-558, 2002. Available at: <www.law.ucla.edu>. Last login: June, 4th, 2014.

REZENDE, Flávio da Cunha. Razões emergentes para a validade dos estudos de caso em ciência política comparada. Revista Brasileira de Ciência Política, no 06, Brasília: 2011.

RIBEIRO, Cristal. O acesso à justiça pelos indivíduos: $O$ papel da advocacia e litigância internacionais no Sistema Interamericano de Direitos Humanos. Brasília: UnB, 2013. 70f. Monografia (Bacharelado em Relações Internacionais) - Instituto de Relações Internacionais, Universidade de Brasília, Brasília, 2013.

RISSE, Thomas. Governance Under Limited Sovereignty. In: FINNEMORE, Martha. GOLDSTEIN, Judith (ed.) Back to Basics: Rethinking Power in the Contemporary World. Essays in Honor of Stephen D. Krasner (no prelo - forthcomming). Presented at the Annual Convention of the American Political Science Association, Washington DC, Sept. 1 - 5, 2010. Disponível em: https://www.princeton.edu/ pcglobal/conferences/basics/papers/risse_paper.pdf. Acesso em: 25 fev 2015.

RISSE, Thomas. BÖRZEL, Tanja. Human Rights: The New Agenda. TRANSWORLD Consortium, Working paper, v.7, n.2, December, 20p., 2012. Diponível em: http://www.iai.it/sites/default/files/TW_WP_07.pdf. Acesso em: 25 fev 2015.

From Europeanisation to Diffusion: Introduction. West European Politics, v.35, n.1, pp.1-19, 2012.

RISSE, Thomas. ROPP, Stephen C. SIKKINK, Kathryn, eds. The Power of Human Rights. International Norms and Domestic Change, Cambridge, Cambridge University Press. 1999. 
RISSE, Thomas. SIKKINK, Kathryn. The impact of human rights norms on domestic political change: Introduction. Paper read at Annual Convention of the International Studies Association, March 18-22, at Toronto, 1997.

ROTBERG, Robert I., ed. State Failure and State Weakness in a Time of Terror, Washington, Brookings Institution Press. 2003.

ed. When States Fail. Causes and Consequences, Princeton, Princeton University Press. 2004.

SANTOS, C. Ativismo jurídico transnacional e o Estado: reflexões sobre os casos apresentados contra o Brasil na Comissão Interamericana de Direitos Humanos, Revista Sur, n.7, 2007, p. 28.

SCHIMMELFENNIG, Frank. Strategic calculation and international socialization: Membership incentives, party constellations, and sustained compliance in Central and Eastern Europe. International Organization 59 (4):827-860, 2005.

SCHNECKENER, Ulrich, States at Risk - Zur Analyse fragiler Staatlichkeit. In:Ulrich Schneckener, ed., States at Risk. Fragile Staaten als Sicherheits- und Entwicklungsproblem, SWP Studien, No. 43 (November), p. 5-27, 2004. Disponível em : http:// www.swp-berlin.org/de/publikationen/swp-studien-de/swp-studiendetail/article/states_at_risk.html. Acesso em: $24 \mathrm{fev} 2015$

SCHNEIDER, E. BEDIN, G. A Proteção Internacional Dos Direitos Humanos e o Sistema Interamericano. Revista Brasileira de Direito, IMED, Vol. 8, nº 1, jan-jun 2012.

SEITENFUS, R. Manual das Organizações Internacionais. 5.ed. Porto Alegre: Livraria do Advogado, 2012, p. 274

SIMMONS, Beth. International law and state behavior: Commitment and compliance in international monetary affairs. American Political Science Review 94 (4):819-836, 2000

Mobilizing for Human Rights: International Law in Domestic Politics, Cambridge, Cambridge University Press, 2009.

. From Ratification to Compliance: Quantitative Evidence on the Spiral Model, In: Thomas Risse, Stephen C. Ropp and Kathryn Sikkink, eds., The Persistent Power of Human Rights. From Commitment to Compliance, Cambridge, Cambridge University Press, 2013.

SLAUGHTER, Anne-Marie. "International law and international relations theory: a dual agenda”. American Journal of International Law, v. 87, n. 205, p. 205-239, 1993

TALLBERG, Jonas. Paths to Compliance: Enforcement, Management, and the European Union. International Organization 56 (3): 609-643, 2002.

TANSEY, Oisín. Process tracing and the elite interviewing: a case for non-probability sampling. Polítical Science and Politics. Volume 40, n. 4, October, 2007. 
TRINDADE, Antônio Augusto Cançado. Proteção Internacional dos Direitos Humanos: fundamentos jurídicos e instrumentos básicos. São Paulo: Saraiva, 1991.

. Reflexiones sobre el desarraigo como problema de derechos humanos frente a la conciencia jurídica universal. In: La nueva dimensión de las necesidades de protección del ser humano en el inicio del siglo XXI (eds. TRINDADE, A. A. Cançado; DE SANTIAGO, J. Ruiz) San Jose da Costa Rica: ACNUR, 2001, p.19-78.

. A consolidação da capacidade processual dos indivíduos na evolução da proteção internacional dos direitos humanos: quadro atual e perspectivas na passagem do século. In: PINHEIRO, Paulo S.; GUIMARÃES, Samuel P. (orgs.). Direitos humanos no século XXI. Brasília:IPRI, 2002.

Rey, 2006,

A Humanização do Direito Internacional, Belo Horizonte, Edit. Del

TRINDADE, Antônio A. Cançado; ROBLES, Manuel E. Ventura. El Futuro de La

Corte Interamericana de Derechos Humanos. San José: Alto Comissariado das Nações Unidas Para Refugiados, 2003. 


\title{
Anexo 1 - Dados fornecidos pelo Ministério das Relações Exteriores
}

\author{
Lei 12.527, de 18 de novembro de 2011. \\ Solicitação № 09200000718201517
}

\section{RESPOSTA do Ministério das Relações Exteriores}

Em cumprimento ao disposto na Lei 12.527, de 18 de novembro de 2011, e no Decreto 7.724, de 16 de maio de 2012, o Ministério das Relações Exteriores apresenta resposta à solicitação no 09200000718201517, recebida em 5/11/2015, como segue:

\section{SOLICITAÇÃO}

"Gostaria de solicitar informações para dar subsídios à minha dissertação de mestrado. 0 tema específico do projeto de pesquisa é o cumprimento de resoluções de Cortes Internacionais (state compliance). Trata-se do estudo de caso do Brasil e o Sistema Interamericano de Direitos Humanos (SIDH).

Já tinha feito um pedido de informação pelo Protocolo 09200000096201519 de 27/03/2015. Contudo, algumas informações vieram incompletas. Além disso, também fiz o pedido de informações para a Secretaria de Direitos Humanos da Presidência, via SIC (protocolo 00083000104201536), e as informações que a SDH me forneceu contrastam em diversos casos com aquelas apresentadas pelo MRE.

Portanto, gostaria de ter acesso às seguintes informações sobre os casos abaixo contra o Brasil no Sistema Interamericano:

Informações

a) Data de início do trâmite no SIDH;

b) Data da (alegada) violação de direitos humanos;

c) Peticionários do caso;

d) Artigos da jurisprudência competente do SIDH evocados pelos peticionários;

Casos

A lista de casos dos quais se pede informação sobre está no documento em anexo."

Decisão

Este Ministério indefere o pedido de acesso à informação.

Fundamentação

Este Ministério entende que se aplica ao presente pedido o disposto no artigo 13, III do Decreto $\mathrm{n}^{\mathrm{o}}$ 7.724, de 16 de maio de 2012, que regulamenta a Lei de Acesso à Informação. Com efeito, este pedido se enquadra na hipótese de "trabalhos adicionais de análise, interpretação ou consolidação de dados e informações, ou serviço de produção ou tratamento de dados que não seja de competência do órgão ou entidade". Ressalta-se que não se pode transferir ao órgão público o ônus da atividade típica de 
pesquisa como sucedâneo da obrigação legal de dar acesso a informação pública sob a guarda do ente estatal.

Quanto ao disposto no parágrafo único do artigo 13 do mesmo Decreto ("Na hipótese do inciso III do caput, o órgão ou entidade deverá, caso tenha conhecimento, indicar o local onde se encontram as informações a partir das quais o requerente poderá realizar a interpretação, consolidação ou tratamento de dados"), este Ministério considera que trabalho de pesquisa adicional sobre o objeto deste pedido poderá ser feito, por exemplo, por meio de recurso ao sítio eletrônico da Comissão Interamericana de Direitos Humanos - http://www.oas.org/es/cidh/.

\section{Esclarecimentos}

Quanto à data de início do trâmite dos casos, pode haver divergências, tendo em vista que a Secretaria Executiva da CIDH pode demorar anos (de 3 a 5 anos) para, após o procedimento de estudo inicial da petição, comunicá-la ao Estado. O MRE utiliza como data de início do trâmite a data de apresentação da petição à Secretaria Executiva da CIDH, e não a data de comunicação de uma petição ao Estado.

\section{CADASTRO DO SOLICITANTE:}

Nome: Helvisney dos Reis Cardoso

CPF 38427267835

Data de nascimento: 03/05/1990

Sexo: $M$

Escolaridade: Mestrado/Doutorado

Profissão: Pesquisador

E-mail: neyrcd@gmail.com

País: Brasil

Endereço: SQS 103, Bloco A, Apt. 601, Asa Sul,

UF: DF

Cidade: Brasília

CEP 70342-010

Telefone: (61) 95764023

Brasília, 13/11/2015. 


\section{LISTA DE PETIÇÕES, CASOS, MEDIDAS CAUTELARES E MEDIDAS \\ PROVISÓRIAS CONTRA O ESTADO BRASILEIRO NO SISTEMA INTERAMERICANO DE DIREITOS HUMANOS (SIDH) ${ }^{1}$}

\section{Comissão Interamericana de Direitos Humanos (CIDH)}

\begin{tabular}{|c|c|c|c|}
\hline NOME (NÚMERO) & DATA DE INÍCIO & $\begin{array}{l}\text { UNIDADE DA } \\
\text { FEDERAÇÃo (UF) }\end{array}$ & FASE \\
\hline \multicolumn{4}{|c|}{ Petiçṍes (42) } \\
\hline $\begin{array}{l}\text { Adaildo José } \\
\text { Soares, Adair José } \\
\text { da Rocha Alves e } \\
\text { outros (P-1017-08) }\end{array}$ & $29 / 08 / 2008$ & RJ & Admissibilidade \\
\hline $\begin{array}{l}\text { Ailton Vieira (P- } \\
28-06)\end{array}$ & $13 / 01 / 2006$ & $\mathrm{RJ}$ & Admissibilidade \\
\hline $\begin{array}{l}\text { Almir Muniz da } \\
\text { Silva (P-1170-09) }\end{array}$ & $18 / 09 / 2009$ & $\overline{\mathrm{PB}}$ & Admissibilidade \\
\hline $\begin{array}{lr}\text { Almir } & \text { Rodrigues } \\
\text { Ferreira (P-23-10) }\end{array}$ & $06 / 01 / 2010$ & SP & Admissibilidade \\
\hline $\begin{array}{ll}\text { Amaro Rosa } & \text { de } \\
\text { Barros (P-15-08) }\end{array}$ & $03 / 01 / 2007$ & $\mathrm{PE}$ & Admissibilidade \\
\hline $\begin{array}{lr}\text { Antonio } & \text { Reinaldo } \\
\text { Peixoto } & \text { Pereira (P- } \\
384-07) & \\
384 & \end{array}$ & 29/03/2007 & $\overline{D F}$ & Admissibilidade \\
\hline $\begin{array}{lr}\text { Apenados } & \text { do } \\
\text { Sistema } & \text { Prisional } \\
\text { de Ariquemes/RO } \\
(\mathrm{P}-1349-09)\end{array}$ & $27 / 10 / 2009$ & $\mathrm{RO}$ & Admissibilidade \\
\hline $\begin{array}{l}\text { Áureo Neves Filho } \\
\text { (P-1451-06) }\end{array}$ & $27 / 12 / 2006$ & $\mathrm{RJ}$ & Admissibilidade \\
\hline $\begin{array}{l}\text { Brigido Ibanhes e } \\
\text { Elisangela dos } \\
\text { Santos de Souza } \\
\text { Ibanhes(P-1056- } \\
\text { 20) }\end{array}$ & $22 / 07 / 2010$ & MS & Admissibilidade \\
\hline Carlos Eduardo de & $23 / 02 / 2009$ & SP & Admissibilidade \\
\hline
\end{tabular}

\footnotetext{
${ }^{1}$ Levantamento atualizado até o dia 10 de abril de 2015.

${ }^{2}$ A data de início refere-se ao dia, mês e ano que constam da petição inicial.
} 


\begin{tabular}{|c|c|c|c|}
\hline $\begin{array}{l}\text { Oliveira Preti } \\
\text { outros (P-187-09) }\end{array}$ & & & \\
\hline $\begin{array}{l}\text { Célio Márcio Alves } \\
\text { Nogueira (P-271- } \\
\text { 09) }\end{array}$ & $24 / 03 / 2009$ & TO & Admissibilidade \\
\hline $\begin{array}{ll}\text { Cho Bong } & \text { Heang } \\
(\mathrm{P}-690-11) & \end{array}$ & $19 / 02 / 2011$ & SP & Admissibilidade \\
\hline $\begin{array}{l}\text { Claudio Bento de } \\
\text { Oliveira (P-60-09) }\end{array}$ & $20 / 01 / 2009$ & SP & Admissibilidade \\
\hline $\begin{array}{l}\text { Claudio Rogério } \\
\text { Rodrigues da Silva } \\
\text { (P-221-12) }\end{array}$ & $05 / 03 / 2012$ & SP & Admissibilidade \\
\hline $\begin{array}{l}\text { Comunidade } \\
\text { Quilombola de } \\
\text { Saco das Almas (P- } \\
1204-10)\end{array}$ & $28 / 06 / 2010$ & MA & Admissibilidade \\
\hline $\begin{array}{lc}\text { Crianças } & \text { privadas } \\
\text { de liberdade no Rio } \\
\text { de Janeiro e seus } \\
\text { familiares } & \text { (P-607- } \\
06) & \end{array}$ & $11 / 07 / 2006$ & RJ & Admissibilidade \\
\hline $\begin{array}{l}\text { Cristiane Leite de } \\
\text { Souza e outros (P- } \\
1449-06)\end{array}$ & $27 / 12 / 2006$ & $\mathrm{RJ}$ & Admissibilidade \\
\hline $\begin{array}{l}\text { Daliana Kristel } \\
\text { Gonçalves } \\
\text { Camargo (P-1222- } \\
09 \text { ) }\end{array}$ & $30 / 09 / 2009$ & GO & Admissibilidade \\
\hline $\begin{array}{l}\text { Débora Monteiro } \\
\text { Silva (P-1608-07) } \\
\text { Eliane Ortiz } \\
\begin{array}{l}\text { Murilo Alcaide } \\
\text { 1122-07) }\end{array}\end{array}$ & $19 / 12 / 2007$ & MG & \begin{tabular}{|l} 
Admissibilidade \\
\end{tabular} \\
\hline $\begin{array}{lr}\text { Eliane Ortiz } & \mathrm{e} \\
\text { Murilo Alcaide } \\
\text { 1122-07) }\end{array}$ & $29 / 08 / 2007$ & MS & Admissibilidade \\
\hline $\begin{array}{l}\text { Fernando Alcântara } \\
\text { de Freitas Filho e } \\
\text { Laci Marinho de } \\
\text { Araújo }(\mathrm{P}-673-11)\end{array}$ & $17 / 05 / 2011$ & $\mathrm{PE}$ & Admissibilidade \\
\hline $\begin{array}{l}\text { Flávio Mendes de } \\
\text { Morais (P-1277-07) }\end{array}$ & $06 / 08 / 2007$ & SP & Admissibilidade \\
\hline $\begin{array}{ll}\text { Francisco } & \text { Rocha } \\
(\mathrm{P}-1085-11) & \end{array}$ & $17 / 08 / 2011$ & SP & Admissibilidade \\
\hline
\end{tabular}




\begin{tabular}{|c|c|c|c|}
\hline $\begin{array}{l}\text { Francisco de Souza } \\
\text { Geraldo (P-1411- } \\
07)\end{array}$ & $18 / 12 / 2007$ & $\mathrm{CE}$ & Admissibilidade \\
\hline $\begin{array}{l}\text { Gabriel de Matos } \\
\text { Prado (P-950-08) }\end{array}$ & $15 / 08 / 2008$ & SP & Admissibilidade \\
\hline $\begin{array}{ll}\text { Gerson } & \text { Mendonça } \\
\text { de Freitas Filho }(\mathrm{P}- \\
1185-08)\end{array}$ & $09 / 10 / 2008$ & SP & Admissibilidade \\
\hline $\begin{array}{l}\text { Gustavo Magalhães } \\
\text { Pereira (P-176-08) }\end{array}$ & $15 / 02 / 2008$ & SP & Admissibilidade \\
\hline $\begin{array}{ll}\text { Hindenburgh } & \text { de } \\
\text { Mélo Rocha } & (\mathrm{P}- \\
1228-08) & \end{array}$ & $21 / 10 / 2008$ & $\mathrm{CE}$ & Admissibilidade \\
\hline $\begin{array}{lr}\text { Jacqueline } & \text { Simone } \\
\text { de Souza e } & \text { Silva } \\
\text { Ferreira (P-1643- } \\
07)\end{array}$ & $16 / 07 / 2008$ & $\mathrm{RJ}$ & Admissibilidade \\
\hline $\begin{array}{cc}\text { José Rafael } & \text { Brezer } \\
(\mathrm{P}-1174-09) & \end{array}$ & $17 / 09 / 2009$ & $\mathrm{SP}$ & Admissibilidade \\
\hline L.A.B. (P-1178-09) & $18 / 08 / 2010$ & $\overline{\mathrm{PA}}$ & Admissibilidade \\
\hline $\begin{array}{l}\text { Luiza Melinho }(\mathrm{P}- \\
362-09)\end{array}$ & $26 / 03 / 2014$ & SP & Admissibilidade \\
\hline $\begin{array}{l}\text { Luiz José da Cunha } \\
\text { e família (P-858- } \\
\text { 09) }\end{array}$ & $14 / 07 / 2009$ & $\mathrm{SP}$ & Admissibilidade \\
\hline $\begin{array}{l}\text { Luiz } \\
\text { Monteiro (P-90-09) }\end{array}$ & $29 / 01 / 2009$ & $\mathrm{AM}$ & Admissibilidade \\
\hline $\begin{array}{l}\text { Marcelo Henrique } \\
\text { de Freitas (P-1246- } \\
08)\end{array}$ & $23 / 10 / 2008$ & SP & Admissibilidade \\
\hline $\begin{array}{l}\text { Márcio Antonio } \\
\text { Maia de Souza (P- } \\
\text { 32-07) }\end{array}$ & $10 / 12 / 2006$ & RJ & Admissibilidade \\
\hline $\begin{array}{l}\text { Nilson Saldanha (P- } \\
1247-08)\end{array}$ & $23 / 10 / 2008$ & $\mathrm{SP}$ & Admissibilidade \\
\hline $\begin{array}{ll}\text { Paulo César de } \\
\text { Oliveira (P-974-09) }\end{array}$ & $05 / 08 / 2009$ & $\mathrm{MG}$ & Admissibilidade \\
\hline $\begin{array}{l}\text { Paulo Igor do } \\
\text { Nascimento Pinto, } \\
\text { Rafael Carvalho da } \\
\text { Costa e outros (P- } \\
\text { 1116-07) }\end{array}$ & $27 / 08 / 2007$ & RJ & Admissibilidade \\
\hline Pessoas Privadas de & $05 / 10 / 2009$ & MS & Admissibilidade \\
\hline
\end{tabular}




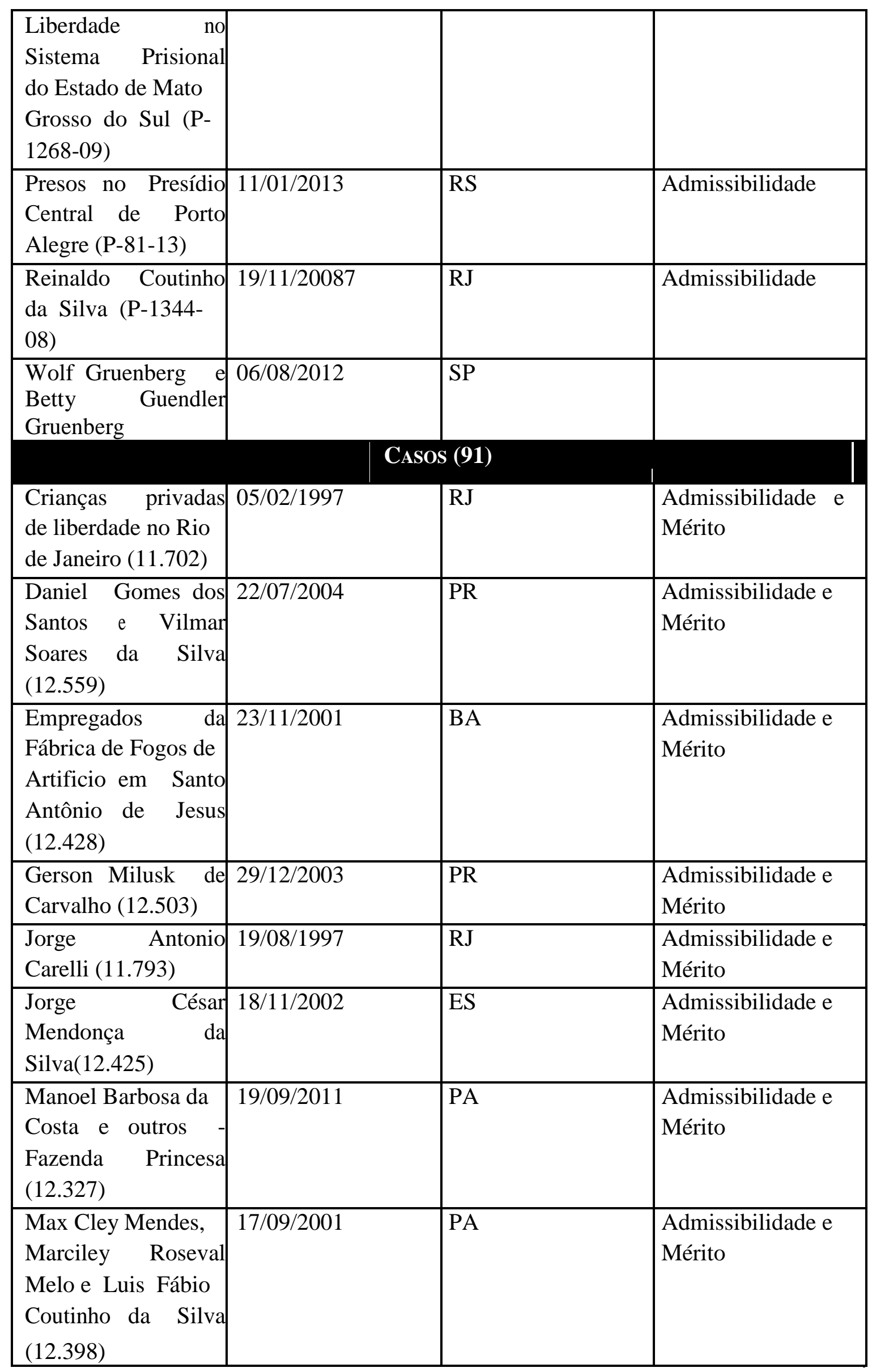




\begin{tabular}{|c|c|c|c|}
\hline $\begin{array}{ll}\text { Rafael } & \text { Lozano } \\
(12.461) & \\
\end{array}$ & $24 / 04 / 2003$ & $\mathrm{SP}$ & $\begin{array}{l}\text { Admissibilidade e } \\
\text { Mérito }\end{array}$ \\
\hline $\begin{array}{l}\text { Ronaldo Santana de } \\
\text { Araújo (12.309) }\end{array}$ & $19 / 05 / 2000$ & $\mathrm{BA}$ & $\begin{array}{l}\text { Admissibilidade e } \\
\text { Mérito }\end{array}$ \\
\hline $\begin{array}{l}\text { Zaqueu de Oliveira } \\
(12.212)\end{array}$ & $03 / 09 / 1999$ & $\mathrm{MG}$ & $\begin{array}{l}\text { Admissibilidade e } \\
\text { Mérito }\end{array}$ \\
\hline $\begin{array}{l}\text { Adão Pereira de } \\
\text { Souza }(12.753)^{3}\end{array}$ & $\begin{array}{l}\text { 19/09/2006 (CIDH } \\
\text { protocola a petição) }\end{array}$ & $\overline{\mathrm{PA}}$ & Mérito \\
\hline $\begin{array}{l}\text { Alan } \\
\text { Silva } \\
(12.615)^{4}\end{array}$ & $01 / 06 / 2005$ & RJ & Mérito \\
\hline 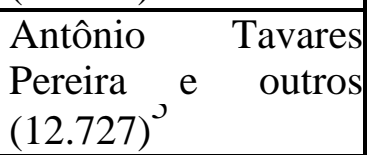 & $01 / 01 / 2004$ & $\overline{\mathrm{PR}}$ & Mérito \\
\hline $\begin{array}{lr}\text { Ariomar } & \text { Oliveira } \\
\text { Rocha, } & \text { Ademir } \\
\text { Federicci e } & \text { Natur } \\
\text { de Assis } & \text { Filho } \\
(12.604)^{\mathrm{O}} & \\
\end{array}$ & $\begin{array}{l}\text { 12/03/2002 (CIDH } \\
\text { protocola a petição) }\end{array}$ & $\overline{\mathrm{PA}}$ & Mérito \\
\hline $\begin{array}{lr}\text { Clélia de } & \text { Lourdes } \\
\text { Goldenberg e } & \text { Rita } \\
\text { de Cassiada } & \text { Rosa } \\
(12.837)^{\prime} & \end{array}$ & $\begin{array}{l}\text { 27/10/2004 (CIDH } \\
\text { protocola a petição) }\end{array}$ & $\mathrm{RS}$ & Mérito \\
\hline $\begin{array}{l}\text { Clínica Pediátrica } \\
\text { da Região dos } \\
\operatorname{Lagos}_{(12.242)^{\circ}}\end{array}$ & $10 / 01 / 2000$ & $\mathrm{RJ}$ & Mérito \\
\hline $\begin{array}{l}\text { Comunidades } \\
\text { Quilombolas } \\
\text { Alcântara } \\
\text { Samucangaua, } \\
\text { Iririzal, Ladeira, Só } \\
\text { Assim, Santa Maria } \\
\text { e outras (12.569) }^{9}\end{array}$ & $17 / 08 / 2001$ & MA & Mérito \\
\hline $\begin{array}{ll}\text { Crianças } & \mathrm{e} \\
\text { Adolescentes }\end{array}$ & $05 / 09 / 2000$ & SP & Mérito \\
\hline
\end{tabular}

${ }^{3}$ Disponível em: < http://www.cidh.oas.org/annualrep/2010sp/6.BRAD999-06ES.doc>. Acesso em: 02 de abril de 2015

${ }^{4}$ Disponível em: < http://www.cidh.oas.org/annualrep/2007sp/Brasil665.05.sp.htm>. Acesso em: 01 de abril de 2015

5 Disponível em: < http://www.cidh.oas.org/annualrep/2009sp/Brasil4-04.sp.htm>. Acesso em: 01 de abril de 2015

${ }^{6}$ Disponível em: < http://www.cidh.oas.org/annualrep/2007sp/Brasil.170.02sp.htm>. Acesso em: 01 de abril de 2015

${ }^{7}$ Disponível em: < http://www.oas.org/es/cidh/decisiones/2011/BRAD1140-04ES.doc>. Acesso em: 02 de abril de 2015

${ }^{8}$ Disponível em: < http://www.cidh.oas.org/annualrep/2008sp/Brasil12242.sp.htm>. Acesso em: 01 de abril de 2015

${ }^{9}$ Disponível em: < http://www.cidh.oas.org/annualrep/2006sp/Brasil555.01sp.htm>. Acesso em: 01 de abril de 2015 


\begin{tabular}{|c|c|c|c|}
\hline $\begin{array}{l}\text { privados de } \\
\text { liberdade }- \text { FEBEM } \\
(12.328)^{1 \mathrm{U}}\end{array}$ & & & \\
\hline $\begin{array}{l}\text { Eldorado dos } \\
\text { Carajás (11.820) }\end{array}$ & 05/09/1996 & PA & Mérito \\
\hline $\begin{array}{lr}\text { Fátima } & \text { Regina } \\
\text { Nascimento } & \text { de } \\
\text { Oliveira e } & \text { Maura } \\
\text { Tatiane } & \text { Ferreira } \\
\text { Alves }(12.378)^{1 L}\end{array}$ & $22 / 03 / 2001$ & $\mathrm{RS}$ & Mérito \\
\hline $\begin{array}{l}\text { Flavio } \quad \text { Mendes } \\
\text { Pontes }(12.857)^{13}\end{array}$ & $\begin{array}{l}14 / 03 / 2007 \text { (CIDH } \\
\text { protocola a petição) }\end{array}$ & RJ & Mérito \\
\hline $\begin{array}{l}\text { Francisco de Assis } \\
\text { Ferreira }(12.726)^{14}\end{array}$ & $19 / 07 / 2010$ & MA & Mérito \\
\hline $\begin{array}{lc}\text { Gabriel } & \text { Sales } \\
\text { Pimenta } & (12.675)^{1 J} \\
\end{array}$ & $09 / 11 / 2006$ & PA & Mérito \\
\hline $\begin{array}{lr}\begin{array}{l}\text { Hildebrando } \\
\text { de }\end{array} & \text { Silva } \\
(12.838)^{10} & \text { Freitas } \\
\end{array}$ & 03/04/2007 & PA & Mérito \\
\hline $\begin{array}{ll}\text { Ivan } \\
(12.806)^{1 \prime} & \text { Rocha } \\
\end{array}$ & $28 / 05 / 2003$ & $\mathrm{BA}$ & Mérito \\
\hline 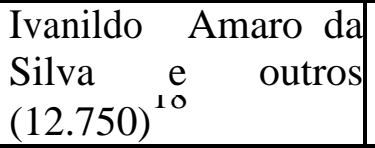 & $\begin{array}{l}\text { 24/10/2005 (CIDH } \\
\text { protocola a petição) }\end{array}$ & SP & Mérito \\
\hline $\begin{array}{l}\text { Ivete Jordani } \\
\text { Demeneck e outros } \\
(12.878)^{1 y}\end{array}$ & $\begin{array}{l}\text { 18/03/2007 (CIDH } \\
\text { protocola a petição) }\end{array}$ & PR & Mérito \\
\hline $\begin{array}{l}\text { José Airton } \\
\text { Honorato e outros - } \\
\text { "Castelinho" } \\
(12.479) \\
\end{array}$ & $\begin{array}{l}\text { 24/04/2003 (dia que } \\
\text { a CIDH protocolou } \\
\text { a denúncia) }\end{array}$ & SP & Mérito \\
\hline José $\quad$ do $\quad$ Egito & 14/03/2005 (CIDH & $\mathrm{RJ}$ & Mérito \\
\hline
\end{tabular}

${ }^{10}$ Disponível em: < http://www.cidh.oas.org/annualrep/2002sp/Brasil.12328.htm>. Acesso em: $01 \mathrm{de}$ abril de 2015

${ }^{11}$ Disponível em: < http://www.cidh.oas.org/annualrep/2003sp/Brasil.11820.htm>. Acesso em: $01 \mathrm{de}$ abril de 2015

${ }^{12}$ Disponível em: < http://www.cidh.oas.org/annualrep/2010sp/8.BRAD12378ES.doc>. Acesso em: 02 de abril de 2015

${ }^{13}$ Disponível em: < http://www.oas.org/es/cidh/decisiones/2012/BRAD302-07ES.doc>. Acesso em: 02 de abril de 2015

${ }^{14}$ Disponível em: < http://www.cidh.oas.org/annualrep/2009sp/Brasil462-01.sp.htm>. Acesso em: $01 \mathrm{de}$ abril de 2015

${ }^{15}$ Disponível em: < http://www.cidh.oas.org/annualrep/2008sp/Brasil1236-06.sp.htm>. Acesso em: $01 \mathrm{de}$ abril de 2015

${ }^{16}$ Disponível em: < http://www.oas.org/es/cidh/decisiones/2011/BRAD405-07ES.DOC>. Acesso em: 02 de abril de 2015

17 Disponível em: < http://www.oas.org/es/cidh/decisiones/2011/BRAD702-03ES.doc>. Acesso em: 02 de abril de 2015

${ }^{18}$ Disponível em: < http://www.cidh.oas.org/annualrep/2010sp/3.BRAD1198-05ES.doc>. Acesso em: 02 de abril de 2015

${ }^{19}$ Disponível em: < http://www.oas.org/es/cidh/decisiones/2012/BRAD342-07ES.DOC>. Acesso em: 02 de abril de 2015 


\begin{tabular}{|c|c|c|c|}
\hline $\begin{array}{ll}\text { Romão } \\
(12.746)\end{array} \quad$ Diniz & protocola a petição) & & \\
\hline $\begin{array}{lr}\text { José } & \text { Laurindo } \\
\text { Soares } & (12.877)^{<1}\end{array}$ & $\begin{array}{l}\text { 16/10/2007 (CIDH } \\
\text { protocola a petição) }\end{array}$ & SP & Mérito \\
\hline $\begin{array}{lr}\text { Josenildo João } & \text { de } \\
\text { Freitas Júnior } & \text { e } \\
\text { outros }(12.707)^{L L} & \end{array}$ & $17 / 05 / 2003$ & $\mathrm{PE}$ & Mérito \\
\hline $\begin{array}{l}\text { Jurandir Ferreira de } \\
\text { Lima (12.859) }\end{array}$ & $03 / 01 / 2007$ & RJ & Mérito \\
\hline $\begin{array}{l}\text { Lazinho Brambilla } \\
\text { da Silva (12.616) }\end{array}$ & $\begin{array}{l}02 / 09 / 2005 \text { (CIDH } \\
\text { protocola a petição) }\end{array}$ & SP & Mérito \\
\hline $\begin{array}{l}\text { Maicon de Souza } \\
\text { Silva e Renato da } \\
\text { Paixão }(12.968)^{\angle 4}\end{array}$ & $\begin{array}{l}\text { 27/12/2006 (CIDH } \\
\text { protocola a petição) }\end{array}$ & RJ & Mérito \\
\hline $\begin{array}{lll}\text { Manoel Luiz } & \text { da } \\
\text { Silva (12.570) } & \\
\end{array}$ & $20 / 08 / 2003$ & $\mathrm{~PB}$ & Mérito \\
\hline $\begin{array}{l}\text { Márcia Barbosa de } \\
\text { Souza }(12.263)\end{array}$ & $28 / 03 / 2000$ & $\mathrm{~PB}$ & Mérito \\
\hline $\begin{array}{ll}\text { Márcio } & \text { Aurélio } \\
\text { Gonçalves } & \\
(12.752)^{<\prime} & \\
\end{array}$ & $\begin{array}{l}\text { 21/05/2005 (CIDH } \\
\text { protocola a petição) }\end{array}$ & $\mathrm{RJ}$ & Mérito \\
\hline $\begin{array}{l}\text { Márcio Manoel } \\
\text { Fraga }(12.858)^{\perp \mathrm{O}}\end{array}$ & $\begin{array}{l}25 / 05 / 2001 \text { (CIDH } \\
\text { protocola a petição) }\end{array}$ & $\mathrm{RJ}$ & Mérito \\
\hline $\begin{array}{l}\text { Margarida Maria } \\
\text { Alves }(12.332)\end{array}$ & $17 / 10 / 2000$ & $\mathrm{~PB}$ & Mérito \\
\hline $\begin{array}{l}\text { Mario de } \begin{array}{r}\text { Almeida } \\
\text { Coelho } \\
(12.970)^{\text {ju }}\end{array} \\
\end{array}$ & $14 / 11 / 2005$ & $\mathrm{RJ}$ & Mérito \\
\hline $\begin{array}{ll}\begin{array}{l}\text { M.V.M. e } \\
(12.907)\end{array} & \text { P.S.R. } \\
\end{array}$ & $30 / 11 / 2004$ & $\mathrm{RJ}$ & Mérito \\
\hline
\end{tabular}

${ }^{20}$ Disponível em: < http://www.cidh.oas.org/annualrep/2010sp/7.BRAD262-05ES.doc>. Acesso em: 02 de abril de 2015

${ }^{21}$ Disponível em: < http://www.oas.org/es/cidh/decisiones/2012/BRAD1485-07ES.doc>. Acesso em: 02 de abril de 2015

${ }^{22}$ Disponível em: < http://www.cidh.oas.org/annualrep/2009sp/Brasil373-03.sp.htm>. Acesso em: $01 \mathrm{de}$ abril de 2015

${ }^{23}$ Disponível em: < http://www.oas.org/es/cidh/decisiones/2012/BRADP06-07ES.doc>. Acesso em: 02 de abril de 2015

${ }^{24}$ Disponível em: < http://www.oas.org/es/cidh/decisiones/2014/BRAD1453-06ES.pdf>. Acesso em: 06 de abril de 2015

25 Disponível em: < http://www.cidh.oas.org/annualrep/2006sp/Brasil641.03sp.htm>. Acesso em: $01 \mathrm{de}$ abril de 2015

${ }^{26}$ Disponível em: < http://www.cidh.oas.org/annualrep/2007sp/Brasil.12263p.htm>. Acesso em: 01 de abril de 2015

27 Disponível em: < http://www.cidh.oas.org/annualrep/2010sp/5.BRAD590-05ES.doc>. Acesso em: 02 de abril de 2015

${ }^{28}$ Disponível em: < http://www.oas.org/es/cidh/decisiones/2012/BRADP341ES.doc>. Acesso em: 02 de abril de 2015

${ }^{29}$ Disponível em: < http://www.cidh.oas.org/annualrep/2008sp/Brasil12332.sp.htmAcesso em: 01 de abril de 2015

${ }^{30}$ Disponível em: < http://www.oas.org/es/cidh/decisiones/2014/BRAD1294-05ES.pdf>. Acesso em: 06 de abril de 2015 


\begin{tabular}{|c|c|c|c|}
\hline $\begin{array}{l}\text { Maurício } \\
\text { Hernández } \\
\text { Norambuena } \\
(12.835)^{J \perp}\end{array}$ & $\begin{array}{l}\text { 18/03/2005 (CIDH } \\
\text { protocola a petição) }\end{array}$ & SP & Mérito \\
\hline $\begin{array}{l}\text { Moradores } \\
\text { conjunto } \\
\text { habitacional } \\
\text { de Marão } \\
\text { de (12.876) }\end{array}$ & $19 / 09 / 2005$ & SP & Mérito \\
\hline $\begin{array}{l}\text { Nélio Nakamura } \\
\text { Brandão } \\
\text { Alexandre Azevedo } \\
(12.751)^{34}\end{array}$ & $\begin{array}{l}\text { 17/02/2006 (CIDH } \\
\text { protocola a petição) }\end{array}$ & $\mathrm{SP}$ & Mérito \\
\hline $\begin{array}{l}\text { Neusa dos Santos } \\
\text { Nascimento } \\
\text { Gisele Ana Ferreira } \\
(12.571)^{\text {JJ }}\end{array}$ & $08 / 12 / 2003$ & SP & Mérito \\
\hline $\begin{array}{l}\text { Ozeas Antonio dos } \\
\text { Santos }(11.414)^{36}\end{array}$ & Setembro/1994 & SP & Mérito \\
\hline $\begin{array}{lr}\text { Pedro } & \text { Augusto da } \\
\text { Silva, Inácio } & \text { José } \\
\text { da Silva e } & \text { outros } \\
(12.875)^{\text {ग }} & \\
\end{array}$ & $\begin{array}{l}\text { 12/10/2007 (CIDH } \\
\text { protocola a petição) }\end{array}$ & $\mathrm{PE}$ & Mérito \\
\hline $\begin{array}{l}\text { Pedro Stábile Neto } \\
\text { e outros }(12.836)^{\text {गo }}\end{array}$ & $29 / 09 / 2006$ & SP & Mérito \\
\hline $\begin{array}{l}\text { Pessoas privadas de } \\
\text { liberdade na Cadeia } \\
\text { Pública do Guarujá } \\
(12.654)^{\text {गy }}\end{array}$ & $18 / 04 / 2007$ & SP & Mérito \\
\hline 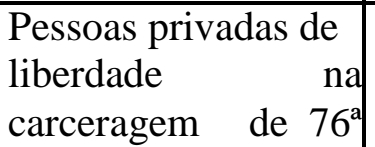 & 14/06/2006 & RJ & Mérito \\
\hline
\end{tabular}

${ }^{31}$ Disponível em: < http://www.oas.org/es/cidh/decisiones/2013/BRAD1279-04ES.doc>. Acesso em: 06 de abril de 2015

32 Disponível em: < http://www.oas.org/es/cidh/decisiones/2011/BRAD303-05ES.doc>. Acesso em: 02 de abril de 2015

33 Disponível em: < http://www.oas.org/es/cidh/decisiones/2012/BRAD1073-05ES.DOC>. Acesso em: 2 de abril de 2015

${ }^{34}$ Disponível em: < http://www.cidh.oas.org/annualrep/2010sp/4.BRAD150-06ES.doc>. Acesso em: 02 de abril de 2015

${ }^{35}$ Disponível em: < http://www.cidh.oas.org/annualrep/2006sp/Brasil1068.03sp.htm>. Acesso em: $01 \mathrm{de}$ abril de 2015

${ }^{36}$ Disponível em: < http://www.cidh.oas.org/annualrep/97span/Brasil11.407.htm>. Acesso em: 06 de abril de 2015

37 Disponível em: < http://www.oas.org/es/cidh/decisiones/2012/BRAD1330-07ES.DOC>. Acesso em: 2 de abril de 2015

38 Disponível em: < http://www.oas.org/es/cidh/decisiones/2011/BRAD1050-06ES.doc>. Acesso em: 02 de abril de 2015

${ }^{39}$ Disponível em: < http://www.cidh.oas.org/annualrep/2008sp/Brasil478-07.sp.htm>. Acesso em: $01 \mathrm{de}$ abril de 2015 


\begin{tabular}{|c|c|c|c|}
\hline \multicolumn{4}{|l|}{$\begin{array}{l}\text { Delegacia } \\
\text { Polícia }(12.613)^{4 \mathrm{v}}\end{array}$} \\
\hline \begin{tabular}{lr}
\multicolumn{2}{|c|}{$\begin{array}{l}\text { ressoas privadas de } \\
\text { liberdade }\end{array}$} \\
Presídio & Urso \\
Branco, & Rondônia \\
$(12.568)^{41}$ & \\
\end{tabular} & $05 / 06 / 2002$ & RO & Mérito \\
\hline $\begin{array}{l}\text { Povo Indígena } \\
\text { Xucuru }(12.728)^{4 \leftarrow}\end{array}$ & $16 / 10 / 2002$ & $\mathrm{PE}$ & Mérito \\
\hline 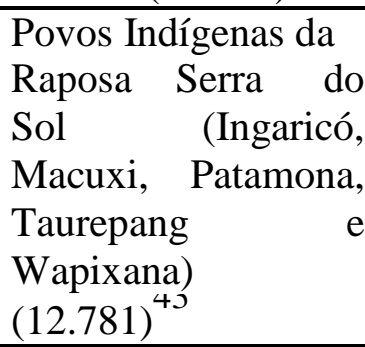 & $29 / 03 / 2004$ & RR & Mérito \\
\hline $\begin{array}{lr}\text { Roberto } & \text { Carlos } \\
\text { Pereira de Souza e } \\
\text { outros }(12.778)^{4+4}\end{array}$ & $\begin{array}{l}\text { 27/12/2006 (CIDH } \\
\text { protocola a petição) }\end{array}$ & RJ & Mérito \\
\hline $\begin{array}{l}\text { Robson William da } \\
\text { Silva Cassiano } \\
\text { outros }(12.198)^{4}\end{array}$ & \begin{tabular}{|l|l|}
$11 / 08 / 1999$ \\
\end{tabular} & RJ & Mérito \\
\hline $\begin{array}{ll}\text { Rosa } & \text { Hernándes } \\
\text { Sundermann e José } \\
\text { Luis } \quad \text { Sundermann } \\
(12.783)^{40}\end{array}$ & $\begin{array}{l}\text { 14/03/2005 (CIDH } \\
\text { protocola a petição) }\end{array}$ & SP & Mérito \\
\hline $\begin{array}{l}\text { Samanta Nunes } \\
\text { Silva }(12.725)^{+1}\end{array}$ & $25 / 04 / 2003$ & RS & Mérito \\
\hline $\begin{array}{lr}\text { Silas Abel da } \\
\text { Conceição } \\
\text { Augusta Tomázia } \\
\text { Inácia }(12.708)^{40} \\
\end{array}$ & $19 / 10 / 2005$ & MG & Mérito \\
\hline
\end{tabular}

${ }^{40}$ Disponível em: < http://www.cidh.oas.org/annualrep/2007sp/Brasil113.06sp.htm>. Acesso em: 01 de abril de 2015

41 Disponível em: < http://www.cidh.oas.org/annualrep/2006sp/BRASIL394.02sp.htm>. Acesso em: 01 de abril de 2015

42 Disponível em: < http://www.cidh.oas.org/annualrep/2009sp/Brasil4355-02.sp.htm>. Acesso em: $01 \mathrm{de}$ abril de 2015

43 Disponível em: < http://www.cidh.oas.org/annualrep/2010sp/9.BRAD250-04ES.doc>. Acesso em: 02 de abril de 2015

Disponível em: < http://www.cidh.oas.org/annualrep/2010sp/10.BRAD1448-06ES.DOC>. Acesso em: 2 de abril de 2015

45 Disponível em: < http://www.cidh.oas.org/annualrep/2004sp/Brasil.12198.htm>. Acesso em: $01 \mathrm{de}$ abril de 2015

${ }^{46}$ Disponível em: < http://www.cidh.org/annualrep/2010sp/BRAD265-05ES.doc>. Acesso em: 02 de abril de 2015

${ }^{47}$ Disponível em: < http://www.cidh.oas.org/annualrep/2009sp/Brasil337-03.sp.htm>. Acesso em: $01 \mathrm{de}$ abril de 2015

${ }^{48}$ Disponível em: < http://www.cidh.oas.org/annualrep/2009sp/Brasil1173-05.sp.htm>. Acesso em: $01 \mathrm{de}$ abril de 2015 


\begin{tabular}{|c|c|c|c|}
\hline \begin{tabular}{l}
\multicolumn{3}{l|}{ Thalita Carvalho do } \\
Mello e eutros \\
$(12.782)$
\end{tabular} & $\begin{array}{l}\text { 27/12/2006 (CIDH } \\
\text { protocola a petição) }\end{array}$ & $\overline{\mathrm{RJ}}$ & Mérito \\
\hline $\begin{array}{l}\text { Vladimir Herzog e } \\
\text { outros }(12.879)\end{array}$ & $\begin{array}{l}\text { 10/07/2009 (CIDH } \\
\text { protocola a petição) }\end{array}$ & SP & Mérito \\
\hline $\begin{array}{lr}\begin{array}{l}\text { Alejandro } \\
\text { Esteve e }\end{array} & \begin{array}{l}\text { Daniel } \\
\text { filhos }\end{array} \\
(12.852) & \end{array}$ & $16 / 09 / 2004$ & RJ & $\begin{array}{l}\text { Solução Amistosa } \\
\text { (Mérito) }\end{array}$ \\
\hline \begin{tabular}{lc|} 
Armand & Lerco e \\
Alain & Rouland \\
$(12.694)$ & \\
\end{tabular} & $18 / 12 / 2002$ & MT & $\begin{array}{l}\text { Solução Amistosa } \\
\text { (Mérito) }\end{array}$ \\
\hline $\begin{array}{ll}\text { La Candelaria } \\
11-993)\end{array}$ & $09 / 03 / 1998$ & RJ & $\begin{array}{l}\text { Solução Amistosa } \\
\text { (Admissibilidade) }\end{array}$ \\
\hline $\begin{array}{l}\text { Comunidade } \\
\text { Indígena de Ananás } \\
(12.567)\end{array}$ & $30 / 01 / 2002$ & RR & $\begin{array}{l}\text { Soluçãa Amistosa } \\
\text { (Mérito) }\end{array}$ \\
\hline $\begin{array}{l}\text { Edson } \quad \text { Damião } \\
\text { Calixto }(11.285)\end{array}$ & $11 / 03 / 1998$ & $\mathrm{PE}$ & $\begin{array}{l}\text { Solução Amistosa } \\
\text { (Mérito) }\end{array}$ \\
\hline $\begin{array}{ll}\text { Fazenda } & \text { Ubá } \\
(12.277) & \\
\end{array}$ & $20 / 12 / 1999$ & $\mathrm{PA}$ & $\begin{array}{l}\text { Solução Amistosa } \\
\text { (Mérito) }\end{array}$ \\
\hline $\begin{array}{l}\text { José Dutra da Costa } \\
(12.673)\end{array}$ & $30 / 11 / 2004$ & PA & $\begin{array}{l}\text { Solução Amistosa } \\
\text { (Mérito) }\end{array}$ \\
\hline $\begin{array}{|lr|}\text { José } & \text { Henrique } \\
\text { Trindade e } & \text { Juvenal } \\
\text { Ferreira } & \text { Trindade } \\
(12.200) & \\
\end{array}$ & $10 / 02 / / 199$ & $\overline{\mathrm{MT}}$ & $\begin{array}{l}\text { Solução Amistosa } \\
\text { (Mérito) }\end{array}$ \\
\hline $\begin{array}{l}\text { Márcio Lapoente da } \\
\text { Silveira (12.674) }\end{array}$ & $08 / 12 / 2004$ & $\overline{\mathrm{RJ}}$ & $\begin{array}{l}\text { Solução Amistosa } \\
\text { (Mérito) }\end{array}$ \\
\hline $\begin{array}{l}\text { Roselândio Borges } \\
\text { Serrano }(11.290)\end{array}$ & $11 / 03 / 1998$ & $\overline{\mathrm{PE}}$ & $\begin{array}{l}\text { Solução Amistosa } \\
\text { (Mérito) }\end{array}$ \\
\hline \begin{tabular}{lll|} 
Vigário & Geral & $(\mathrm{P}-$ \\
$12-008)$ & & \\
\end{tabular} & $19 / 10 / 2005$ & $\overline{\mathrm{MG}}$ & $\begin{array}{l}\text { Solução Amistosa } \\
\text { (Admissibilidade) }\end{array}$ \\
\hline $\begin{array}{l}\text { Wagner dos Santos } \\
\text { (P-11-994) }\end{array}$ & $26 / 03 / 1998$ & RJ & $\begin{array}{l}\text { Solução Amistosa } \\
\text { (Admissibilidade) }\end{array}$ \\
\hline $\begin{array}{l}\text { Aluísio Cavalcanti } \\
\text { e outros }(11.286)^{{ }^{\prime}}\end{array}$ & Fevereiro/1994 & SP & $\begin{array}{l}\text { Cumprimento de } \\
\text { Recomendações }\end{array}$ \\
\hline $\begin{array}{l}\text { Antônio Ferreira } \\
\text { Braga }(12.019)^{J\lrcorner}\end{array}$ & $11 / 06 / 1998$ & $\overline{\mathrm{CE}}$ & $\begin{array}{l}\text { Cumprimento de } \\
\text { Recomendações }\end{array}$ \\
\hline $\begin{array}{ll}\text { Aristeu Guida } & \text { da } \\
\text { Silva (12.213) } & \\
\end{array}$ & $23 / 09 / 1999$ & RJ & $\begin{array}{l}\text { Cumprimento de } \\
\text { Recomendações }\end{array}$ \\
\hline $\begin{array}{l}\text { Corumbiara } \\
(11.556)^{J د}\end{array}$ & $06 / 10 / 1995$ & $\mathrm{RO}$ & $\begin{array}{l}\text { Cumprimento de } \\
\text { Recomendações }\end{array}$ \\
\hline
\end{tabular}

\footnotetext{
${ }^{49}$ Disponível em: < http://www.cidh.org/annualrep/2010sp/11.BRAD1454-06ES.doc>. Acesso em: 02 de abril de 2015

${ }^{50}$ Disponível em: < http://www.oas.org/es/cidh/decisiones/2012/BRAD859-09ES.doc>. Acesso em: 02 de abril de 2015

51 Disponível em: < http://www.cidh.oas.org/annualrep/2000sp/CapituloIII/Fondo/Brasil11.286.htm>. Acesso em: 30 de março de 2015

${ }^{52}$ Disponível em: < http://www.cidh.oas.org/annualrep/2008sp/Brasil12019.sp.htm>. Acesso em: 30 de março de 2015
} 


\begin{tabular}{|c|c|c|c|}
\hline $\begin{array}{l}\text { Diniz } \\
\text { Silva }\end{array}$ & 05/07/1995 & PR & $\begin{array}{l}\text { Cumprimento de } \\
\text { Recomendações }\end{array}$ \\
\hline $\begin{array}{l}\text { Favela } \\
\text { Brasília (11.566) }\end{array}$ & $17 / 01 / 1996$ & RJ & $\begin{array}{l}\text { Cumprimento de } \\
\text { Recomendações }\end{array}$ \\
\hline $\begin{array}{ll}\text { Jailton Neri da } \\
\text { Fonseca }\end{array}$ & $07 / 12 / 1995$ & $\mathrm{RJ}$ & $\begin{array}{l}\text { Cumprimento de } \\
\text { Recomendações }\end{array}$ \\
\hline $\begin{array}{ll}\text { João } & \text { Canuto } \\
(11.287) & \text { jo } \\
\end{array}$ & $27 / 05 / 1994$ & PA & $\begin{array}{ll}\text { Cumprimento de } \\
\text { Recomendações }\end{array}$ \\
\hline $\begin{array}{ll}\text { José } & \text { Pereira } \\
(11.289) & \\
\end{array}$ & $22 / 02 / 1994$ & PA & $\begin{array}{l}\text { Cumprimento de } \\
\text { Recomendações }\end{array}$ \\
\hline $\begin{array}{l}\text { Manoel Leal de } \\
\text { Oliveira (12.308) }\end{array}$ & $22 / 05 / 2000$ & $\mathrm{BA}$ & $\begin{array}{l}\text { Cumprimento de } \\
\text { Recomendações }\end{array}$ \\
\hline $\begin{array}{lll}\text { Maria da } & \text { Penha } \\
(12.051) & \\
\end{array}$ & $20 / 08 / 1998$ & PA & $\begin{array}{l}\text { Cumprimento de } \\
\text { Recomendações }\end{array}$ \\
\hline $\begin{array}{l}\text { Newton Coutinho } \\
\text { Mendes (11.405) }\end{array}$ & $18 / 11 / 1994$ & PA & $\begin{array}{l}\text { Cumprimento de } \\
\text { Recomendações }\end{array}$ \\
\hline $\begin{array}{ll}\text { Ovelário } \\
(11.516)\end{array}$ & Junho/1995 & RR & $\begin{array}{l}\text { Cumprimento de } \\
\text { Recomendações }\end{array}$ \\
\hline $\begin{array}{l}\text { Parque São } \\
(10.301)\end{array}$ & $07 / 02 / 1989$ & SP & $\begin{array}{l}\text { Cumprimento de } \\
\text { Recomendações }\end{array}$ \\
\hline $\begin{array}{l}\text { Sebastião Camargo } \\
\text { Filho (12.310) } \angle\end{array}$ & $30 / 06 / 200$ & $\mathrm{PR}$ & $\begin{array}{l}\text { Cumprimento de } \\
\text { Recomendações }\end{array}$ \\
\hline $\begin{array}{l}\text { Simone André } \\
\text { Diniz }(12.001)\end{array}$ & 7 e 10/10/1997 & SP & $\begin{array}{l}\text { Cumprimento de } \\
\text { Recomendações }\end{array}$ \\
\hline $\begin{array}{l}\text { Wallace } \\
\text { Almeida }(12.440)^{\mathrm{ve}}\end{array}$ & $26 / 12 / 2001$ & $\mathrm{RJ}$ & $\begin{array}{l}\text { Cumprimento de } \\
\text { Recomendações }\end{array}$ \\
\hline \multicolumn{4}{|c|}{ Medidas CauTelares (20) } \\
\hline Adolescentes & $09 / 02 / 2006$ & DF & Ativa $^{\text {oo }}$ \\
\hline
\end{tabular}

53 Disponível em: < http://www.cidh.oas.org/annualrep/2004sp/Brasil.11556.htm>. Acesso em: 30 de março de 2015

${ }^{54}$ Disponível em: < http://www.cidh.oas.org/annualrep/2002sp/Brasil.11517.htm>. Acesso em: 30 de março de 2015

${ }^{55}$ Disponível em: < http://www.cidh.oas.org/annualrep/2004sp/Brasil.11634.htm>. Acesso em: $30 \mathrm{de}$ março de 2015

${ }^{56}$ Disponível em: <http://www.cidh.oas.org/annualrep/97span/Brasil11.287.htm>. Acesso em: 30 de março de 2015

${ }^{57}$ Disponível em: < http://www.cidh.org/annualrep/2010sp/BRPU12308ES.doc>. Acesso em: 30 de março de 2015

58 Disponível em: < http://www.cidh.oas.org/annualrep/2000sp/CapituloIII/Fondo/Brasil12.051.htm>. Acesso em: 30 de março de 2015

${ }^{59}$ Disponível em: < http://www.cidh.org/annualrep/98span/Fondo/Brasil\%2011.405.htm>. Acesso em: 30 de março de 2015

${ }^{60}$ Disponível em: < http://www.cidh.org/annualrep/98span/Fondo/Brasil\%2011.516.htm>. Acesso em: 30 de março de 2015

61 Disponível em: < http://www.cidh.oas.org/annualrep/2003sp/Brasil10301.htm>. Acesso em: $30 \mathrm{de}$ março de 2015

${ }^{62}$ Disponível em: < http://www.cidh.oas.org/annualrep/2009sp/Brasil12310.sp.htm>. Acesso em: 30 de março de 2015

63 Disponível em: < http://www.cidh.oas.org/annualrep/2006sp/Brasil12001sp.htm>. Acesso em: $30 \mathrm{de}$ março de 2015

${ }^{64}$ Disponível em: < http://www.cidh.oas.org/annualrep/2009sp/Brasil12440.sp.htm>. Acesso em: 30 de março de 2015 


\begin{tabular}{|c|c|c|c|}
\hline $\begin{array}{l}\text { internados no CAJE } \\
(\text { MC-14-06) }\end{array}$ & & & \\
\hline 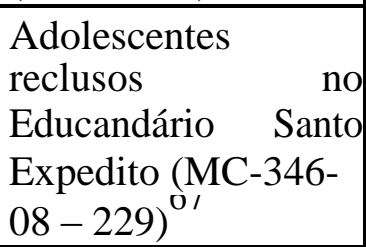 & $10 / 05 / 1996$ & RJ & Inativa $^{\text {Oo }}$ \\
\hline $\begin{array}{l}\text { Airton de Lucena } \\
\text { Dants (MC-233-05) }\end{array}$ & $\begin{array}{l}\text { 19/10/2005 (CIDH } \\
\text { notifica o Estado) }\end{array}$ & Não há registro & Inativa \\
\hline $\begin{array}{lr}\text { Almir Suruí, } & \text { sua } \\
\text { família e seu } & \text { povo } \\
(\mathrm{MC}-250-06) & \end{array}$ & $12 / 10 / 2006$ & RO & Inativa \\
\hline $\begin{array}{l}\text { Célio Márcio Alves } \\
\text { Nogueira (MC-95- } \\
\text { 09) }\end{array}$ & $26 / 05 / 2008$ & TO & Inativa \\
\hline $\begin{array}{l}\text { Comunidades } \\
\text { Esperança, Vitória } \\
\text { e Rosa Leão - BH } \\
(\mathrm{MC}-314-14)\end{array}$ & $17 / 09 / 2014$ & MG & Ativa \\
\hline $\begin{array}{l}\text { Comunidades } \\
\text { Indígenas Guarani- } \\
\text { Kaiowá e Terena, e } \\
\text { suas Lideranças } \\
\text { (MC-5-12) }\end{array}$ & $08 / 02 / 2012$ & MS & Ativa \\
\hline $\begin{array}{l}\text { Comunidades } \\
\text { tradicionais } \\
\text { bacia do rio Xingu, } \\
\text { Pará - Belo Monte } \\
\text { (MC-382-10) }\end{array}$ & \begin{tabular}{|}
$04 / 03 / 2011$ \\
\end{tabular} & $\begin{array}{l}\mathrm{PA} \\
\end{array}$ & Ativa \\
\hline $\begin{array}{lr}\text { Dominici } & \text { Sávio } \\
\text { Ramos } & \text { Coelho } \\
\text { Mororó (MC-1038- } \\
\text { 04) }\end{array}$ & 16/11/2004 & $\overline{P E}$ & Inativa \\
\hline $\begin{array}{l}\text { Eduardo Nuno de } \\
\text { Freitas } \quad \text { Pereira } \\
(\text { MC-251-10) }\end{array}$ & $10 / 05 / 2010$ & $\mathrm{SP}$ & Inativa \\
\hline $\begin{array}{l}\text { Elma Soraya Souza } \\
\text { Novais e filhos } \\
\text { (MC-387-02) }\end{array}$ & $21 / 11 / 2002$ & $\overline{\mathrm{PE}}$ & Ativa \\
\hline $\begin{array}{l}\text { Iolanda Figueiral } \\
\text { (MC-282-05) }\end{array}$ & $01 / 12 / 2005$ & SP & Inativa \\
\hline Pessoas Privadas de & $11 / 02 / 2013$ & $\mathrm{RS}$ & Ativa \\
\hline
\end{tabular}

${ }^{66}$ Classificação feita pela Comissão Interamericana de Direitos Humanos para controle interno de sua Secretaria Executiva.

${ }^{65}$ Disponível em: < http://www.cidh.org/medidas/2006.sp.htm>. Acesso em: 30 de março de 2015

${ }^{67}$ Disponível em: < http://www.crprj.org.br/documentos/2010-nota-cedeca.pdf >. Acesso em: 06 de abril de 2015.

68 Classificação feita pela Comissão Interamericana de Direitos Humanos para controle interno de sua Secretaria Executiva. Ainda assim, o Estado não foi notificado do levantamento das medidas cautelares consideradas "inativas". 


\begin{tabular}{|c|c|c|c|}
\hline 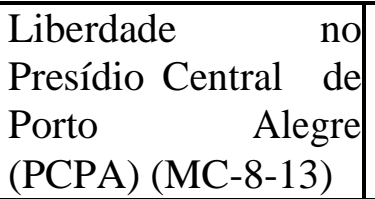 & & & \\
\hline $\begin{array}{l}\text { Presos, agentes } \\
\text { funcionários } \\
\text { unidades } \\
\text { tratamento penal do } \\
\text { Paraná. (MC-366- } \\
14)\end{array}$ & $11 / 09 / 2014$ & PR & Ativa \\
\hline $\begin{array}{lr}\text { Presos } & \text { da } \\
\text { Penitenciária } & \text { do } \\
\text { Monte } & \text { Cristo, } \\
\text { Cidade de } & \text { Boa } \\
\text { Vista, no Estado de } \\
\text { Roraima (MC-438- } \\
\text { 13) }\end{array}$ & $16 / 12 / 2013$ & RR & Ativa \\
\hline $\begin{array}{l}\text { Povo Awá-Guajá } \\
\text { (MC-145-13) }\end{array}$ & $03 / 05 / 2013$ & MA & Ativa \\
\hline $\begin{array}{l}\text { Povos Indígenas } \\
\text { Ingaricó, Macuxi, } \\
\text { Patamona, } \\
\text { Taurepang } \\
\text { Wapixana ("Raposa } \\
\text { Serra do Sol") } \\
(\text { MC-818-04) }\end{array}$ & $06 / 12 / 2004$ & RR & $\overline{\text { Ativa }}$ \\
\hline $\begin{array}{lr}\begin{array}{l}\text { Violência } \\
\text { comunidade }\end{array} & \\
\text { indígena } & \text { Guarani } \\
\text { Pyelito Kuê } & \\
\text { M'barakai, } & \text { Mato } \\
\text { Grosso do } & \text { Sul } \\
(\text { MC-339-11) } & \end{array}$ & $21 / 11 / 2011$ & MS & Ativa \\
\hline 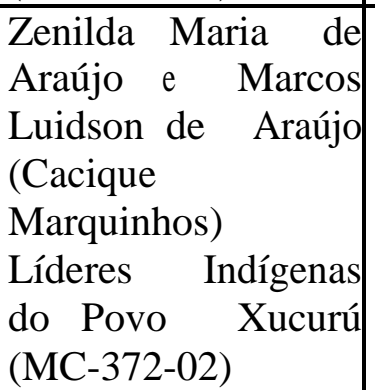 & $16 / 10 / 2002$ & $\mathrm{PE}$ & $\overline{\text { Ativa }}$ \\
\hline
\end{tabular}

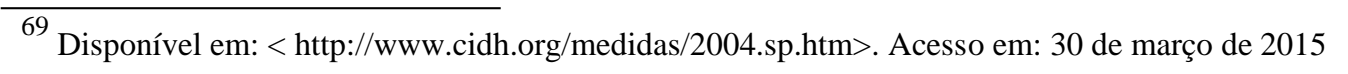




\begin{tabular}{|c|c|c|c|}
\hline NoME & DATA DE INÍCIO $^{\text {/U }}$ & $\begin{array}{l}\text { UNIDADE DA } \\
\text { FEDERAÇÃo (UF) }\end{array}$ & FASE \\
\hline \multicolumn{4}{|c|}{ CASOS (4) } \\
\hline $\begin{array}{lr}\text { Trabalhadores } & \text { da } \\
\text { Fazenda } & \text { Brasil } \\
\text { Verde } & \\
\end{array}$ & $12 / 11 / 1998$ & $\mathrm{PA}$ & $\begin{array}{ll}\text { Início } & \text { do } \\
\text { procedimento } \\
\text { escrito }\end{array}$ \\
\hline \begin{tabular}{llr|}
$\begin{array}{l}\text { Gomes } \\
\text { outros ("Gund }\end{array}$ ("Guerrilha \\
do Araguaia") vs. \\
Brasil
\end{tabular} & $07 / 08 / 1995$ & TO & $\begin{array}{l}\text { Cumprimento de } \\
\text { Sentença }\end{array}$ \\
\hline $\begin{array}{ll}\text { Sétimo } & \text { Garibaldi } \\
\text { vs. Brasil } & \\
\end{array}$ & $06 / 05 / 2003$ & PR & $\begin{array}{l}\text { Cumprimento de } \\
\text { Sentença }\end{array}$ \\
\hline $\begin{array}{l}\text { Ximenes Lopes vs. } \\
\text { Brasil }\end{array}$ & $22 / 11 / 1999$ & $\mathrm{CE}$ & $\begin{array}{l}\text { Cumprimento de } \\
\text { Sentença }\end{array}$ \\
\hline \multicolumn{4}{|c|}{ Medidas Provisórias (3) } \\
\hline $\begin{array}{l}\text { Complexo } \\
\text { Penitenciário } \\
\text { Curado }\end{array}$ & $\begin{array}{lr}31 / 03 / 2014 & \text { CIDH } \\
\text { entra com } & \mathrm{a} \\
\text { solicitação } & \mathrm{de} \\
\text { medidas } & \\
\text { provisórias) } & \end{array}$ & PE & $\begin{array}{l}\text { Cumprimento de } \\
\text { Resolução }\end{array}$ \\
\hline $\begin{array}{l}\text { Complexo } \\
\text { Penitenciário } \\
\text { Pedrinhas }\end{array}$ & $\begin{array}{|lr|}23 / 09 / 2014 & \text { (CIDH } \\
\text { entra com } & \mathrm{a} \\
\text { solicitação } & \mathrm{de} \\
\text { medidas } & \\
\text { provisórias) } & \\
\end{array}$ & MA & $\begin{array}{l}\text { Cumprimento } \mathrm{de} \\
\text { Resolução }\end{array}$ \\
\hline $\begin{array}{ll}\text { Unidade } & \text { de } \\
\text { Internação } & \\
\text { Socioeducativa } & \\
\text { (UNIS) } & \end{array}$ & $\begin{array}{|lr|}30 / 12 / 2010 & \text { (CIDH } \\
\text { entra com } & \mathrm{a} \\
\text { solicitação } & \mathrm{de} \\
\text { medidas } & \\
\text { provisórias) } & \\
\end{array}$ & ES & $\begin{array}{l}\text { Cumprimento } \mathrm{de} \\
\text { Resolução }\end{array}$ \\
\hline
\end{tabular}

${ }^{70}$ A data de início refere-se ao dia, mês e ano que constam da petição inicial. 


\title{
Anexo 2 - Dados fornecidos pela Secretaria de Direitos Humanos da Presidência da República
}

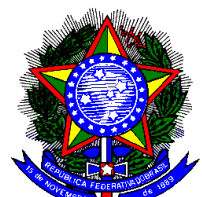 \\ PRESIDÊNCIA DA REPÚBLICA \\ SECRETARIA DE DIREITOS HUMANOS \\ SCS-B Quadra 09, Lote C, Ed. Parque Cidade Corporate, Torre A, $10^{\circ}$ Andar \\ 70308-200 - Brasília-DF
}

\section{Lei 12.527, de 18 de novembro de 2011.}

\section{Solicitação Nº 00083000104201536}

Em cumprimento ao disposto na Lei 12.527, de 18 de novembro de 2011, e no Decreto 7.724, de 16 de maio de 2012, a Secretaria de Direitos Humanos da Presidência da República apresenta resposta à solicitação $n^{\circ} 00083000104201536$, recebida em 27/03/2015, como segue:

SOLICITAÇÃO

\section{Dados do Pedido}

Protocolo

Solicitante

Data de abertura

Orgão Superior Destinatário

Orgão Vinculado Destinatário

Resumo

Detalhamento
00083000104201536

Helvisney dos Reis Cardoso

27/03/2015 17:07

SDH - Secretaria de Direitos Humanos

Pedido de informações sobre os casos contra o Brasil no SIDH, tanto na Comissão quanto na Corte Interamericana de Direitos Humanos, e suas medidas de urgência (medidas cautelares e medidas provisórias)

Gostaria de solicitar informações para dar subsídios à minha dissertação de mestrado. O tema específico deste projeto de pesquisa é o cumprimento de resoluções de Cortes Internacionais (state compliance). Trata-se do estudo de caso do Brasil e o Sistema Interamericano de Direitos Humanos (SIDH). Para tanto, gostaria de ter acesso as seguintes informações: 
1) Lista completa de todos os casos contra o Brasil no SIDH, tanto na Comissão quanto na Corte Interamericana de Direitos Humanos, e suas medidas de urgência (medidas cautelares e medidas provisórias) - sejam os casos arquivados, em fase de mérito, ativos, concluídos, em solução amistosa ou em outra fase do processo nas duas casas - a partir de 1988 até hoje.

2) Informações sobre cada um dos casos e medidas de urgência mencionada acima seguindo os seguintes indicadores:

- Nome;

- Número do caso;

- Data de início do processo;

- Data de conclusão do processo (caso aplicável);

- Fase do processo em que ele se encontra (análise mérito, acordo de solução, cumprimento de recomendações/resoluções, etc.);

- Unidade da Federação em que a suposta violação ocorreu; e

- Recomendações e/ou resoluções proferidas pelo SIDH (caso aplicável);

3) Os memoriais enviados à Comissão e Corte Interamericana de Direitos Humanos pelo Estado brasileiro, resoluções e/ou recomendações proferidas e nome dos funcionários públicos (diplomatas, assessores, analistas, gestores, cargos de confiança e outros possíveis) responsáveis e/ou envolvidos na defesa do Brasil, nos seguintes casos:

a) Caso Damião Ximenes Lopes vs. Brasil:

b) Caso Escher e outros vs. Brasil;

c) Caso Garibaldi vs. Brasil;

d) Caso Julia Gomes Lund e outros vs. Brasil;

e) Caso José Pereira;

f) Caso Meninos emasculados do Maranhão;

g) Caso Maria da Penha vs. Brasil; e

h) Caso Comunidades Indígenas da Bacia do rio Xingu vs.

Brasil;

Origem da Solicitação Internet

\section{DECISÃO:}

Esta Secretaria atende parcialmente aos pedidos 1 e 2.

Esta Secretaria de Direitos Humanos da Presidência da República decidiu disponibilizar acesso à "Planilha dos Casos em Andamento na Comissão Interamericana de Direitos Humanos (CIDH)", elaborada por esta Secretaria para controle interno, contendo planilha, por fase processual, dos casos e petições contra o Estado brasileiro no âmbito da CIDH Admissibilidade, Mérito, Cumprimento de Recomendações, Solução Amistosa, Medidas Cautelares, Arquivamentos. Em cada planilha por fase processual, tem-se a indicação da unidade da federação em que a suposta violação ocorreu, número do processo, nome do caso ou petição, data de início do trâmite, data da alegada violação, organizações peticionárias, 
tema, artigos da Convenção Americana sobre Direitos Humanos invocados e fase processual. Ressalta-se que tais informações já se encontravam sistematizadas e disponíveis por esta Secretaria de Direitos Humanos, ainda que sejam necessárias algumas atualizações.

\section{FUNDAMENTAÇÃO:}

Esta Secretaria de Direitos Humanos da Presidência da República entende que se aplica parcialmente aos pedidos 1 e 2 o disposto no artigo 13, III do Decreto ${ }^{\circ} 7.724$, de 16 de maio de 2012, que regulamenta a Lei de Acesso à Informação. Com efeito, esses pedidos se enquadram, em princípio, na hipótese de "trabalhos adicionais de análise, interpretação ou consolidação de dados e informações, ou serviço de produção ou tratamento de dados que não seja de competência do órgão ou entidade". Ressalta-se que não se pode transferir ao órgão público o ônus da atividade típica de pesquisa como sucedâneo da obrigação legal de dar acesso a informação pública sob a guarda do ente estatal, sob pena de sobrecarregar a máquina pública. Ao mesmo tempo, esta Secretaria considera que deve observar o disposto no parágrafo único do artigo 13 do mesmo Decreto ("Na hipótese do inciso III do caput, o órgão ou entidade deverá, caso tenha conhecimento, indicar o local onde se encontram as informações a partir das quais o requerente poderá realizar a interpretação, consolidação ou tratamento de dados"), além de afastar a aplicação do referido inciso sempre que as informações solicitadas já se encontrem disponíveis, ainda que para referência interna do órgão, hipótese em que a Administração não poderá alegar que a sistematização das informações demandará "trabalhos adicionais de análise".

Tendo em vista que esta Secretaria já dispõe de base de dados sobre casos ativos na Comissão Interamericana de Direitos Humanos (CIDH) para sua referência interna, decidiu-se disponibilizar acesso a essas informações, com relação às quais seria controverso invocar o disposto no artigo 13, III do Decreto $\mathrm{n}^{\circ}$ 7.724, de 16 de maio de 2012. Eventual trabalho de confirmação dessas informações, bem como atualização das mesmas, tendo em vista que estas não constam de documento oficial deste Ministério e foram compiladas para referência interna do órgão, poderá ser feito por meio de recurso ao sítio eletrônico da Comissão Interamericana de Direitos Humanos - http://www.corteidh.or.cr/. Além disso, recomenda-se pesquisa ao sítio eletrônico da Corte Interamericana de Direitos Humanos (Corte IDH) http://www.oas.org/es/cidh/ - para consulta aos dados e documentos referentes aos casos contra o Estado brasileiro em trâmite nesse Tribunal.

A busca e sistematização de informações sobre procedimentos já arquivados na Corte Interamericana e na Comissão Interamericana, remontando ao ano de 1988, incluindo a data de seu arquivamento, como solicitado neste pedido de acesso à informação, demandaria uma pesquisa histórica inédita, que não corresponde à obrigação legal desta Secretaria (artigo 13, III do Decreto $\mathrm{n}^{\circ}$ 7.724, de 16 de maio de 2012). O solicitante poderá recorrer a pesquisa nos sítios eletrônicos mencionados, nos relatórios anuais da Corte IDH e da CIDH, disponíveis nesses mesmos sítios eletrônicos, no acervo de documentos dos órgãos do Sistema Interamericano mediante contato com a Secretaria da Corte IDH e com a Secretaria Executiva da CIDH.

Com relação ao pedido de acesso às "Recomendações elou resoluções proferidas pelo SIDH (caso aplicável)", este Ministério também aplica o disposto no artigo 13, III do Decreto n ${ }^{\circ}$ 7.724, de 16 de maio de 2012. Este Ministério informa o solicitante de que os Relatórios de Admissibilidade e de Inadmissibilidade são publicados pela CIDH, que os inclui em seu Relatório Anual à Assembleia Geral da OEA. Compete à CIDH decidir sobre a publicidade de Relatórios de Mérito, os quais, quando a CIDH decide publicá-los, são incluídos no Relatório 
Anual da Comissão à Assembleia Geral da OEA. As sentenças da Corte IDH e resoluções sobre medidas provisórias referentes a casos brasileiros poderão ser encontradas no sítio eletrônico da Corte Interamericana mediante a ferramenta de pesquisa de jurisprudência desse Tribunal. Relatórios de mérito, Relatórios de Admissibilidade ou de Inadmissibilidade e Relatórios que homologam acordos de solução amistosa referentes a casos brasileiros poderão ser encontrados no sítio eletrônico da CIDH. Resoluções sobre medidas cautelares poderão, também, ser encontradas mediante pesquisa no sítio eletrônico do órgão.

Com relação ao pedido de acesso aos documentos estatais referentes aos casos listados no pedido de número três, esta Secretaria de Direitos Humanos da Presidência da República (SDH/PR) esclarece que não é o órgão responsável pela elaboração dos relatórios oficiais do Estado brasileiro de seguimento das medidas cautelares, medidas provisórias, recomendações e sentenças outorgadas pelos órgãos do Sistema Interamericano de Direitos Humanos, os quais são de competência do Ministério das Relações Exteriores. A SDH/PR é, tão-somente, um dos órgãos de governo envolvidos no processo de construção do documento, o qual, reiteramos, tem a finalidade de relatar aos órgãos do SIDH as ações do Estado brasileiro para o cumprimento de medidas cautelares e de medidas provisórias, bem como recomendações, sentenças e acordos extra-judiciais.

Ressalte-se, nesse sentido, que o órgão responsável pela relação do Estado brasileiro com o SIDH é o Ministério das Relações Exteriores. Assim, de acordo com o Regimento Interno da Secretaria de Estado das Relações Exteriores (RISE), o qual dispõe sobre sua organização geral, anexo à Portaria do Ministério das Relações Exteriores no 212, de 30 de abril de 2008, Artigo $\mathrm{n}^{\circ} 48$, inciso VI, compete à Divisão de Direitos Humanos do MRE, "representar o Ministério junto à Comissão e à Corte Interamericana de Direitos Humanos, bem como acompanhar, supervisionar e coordenar a preparação das respostas do Governo brasileiro aos procedimentos de análise de denúncias de violações de direitos humanos instaurados perante aqueles órgãos e a preparação de visitas de trabalho de seus membros ao país". O contato do Estado brasileiro com a Comissão Interamericana é feito pela Missão Permanente do Brasil junto à Organização dos Estados Americanos, em Washington. No caso da Corte Interamericana, a responsabilidade recai sobre o chefe da Embaixada do Brasil em San José, na Costa Rica.

Especificamente com relação ao pedido do "nome dos funcionários públicos (diplomatas, assessores, analistas, gestores, cargos de confiança e outros possíveis) responsáveis elou envolvidos na defesa do Brasil", esta Secretaria informa de que os nomes dos agentes que tenham atuado em casos ante a Corte Interamericana constam de suas sentenças, disponíveis no sítio eletrônico do referido Tribunal. Quanto à defesa do Estado nos casos da CIDH, em regra, o Departamento Internacional da Advocacia-Geral da União atua na fase de admissibilidade, e a Assessoria Internacional da Secretaria de Direitos Humanos da Presidência da República, na fase de mérito, em coordenação com a Divisão de Direitos Humanos do Ministério das Relações Exteriores. Ante a Corte IDH, em regra, atuam como agentes do Estado brasileiro Advogados da União e diplomatas. Ressalta-se, ainda, que a defesa do Estado brasileiro não é feita em caráter pessoal.

Ainda, quanto ao tema da pesquisa do solicitante ("state compliance"), esta secretaria de Direitos Humanos esclarece que, a partir do Relatório Anual da CIDH à Assembleia Geral da Organização dos Estados Americanos referente ao ano de 2003, a Comissão Interamericana passou a incluir neste documento uma seção sobre o estado de cumprimento de suas 
recomendações aos Estados. Nessa oportunidade, decidiu apresentar o estado de cumprimento de suas recomendações formuladas no marco de casos resolvidos e publicados nos últimos três anos. Dessa forma, os Estados membros da OEA passaram a ter acesso a um quadro de avaliação do cumprimento de recomendações quanto aos relatórios de mérito e relatórios que homologam acordos de solução amistosa, publicados a partir do ano 2000, conforme cumprimento total, parcial ou incumprimento. Relatórios publicados antes de 2000 não contam com um registro público de avaliação da CIDH sobre o estágio de cumprimento das recomendações. Pesquisa quanto a casos decididos antes de 2000 deverá, necessariamente, ser feita com recurso ao arquivo histórico da Comissão Interamericana de Direitos Humanos.

O solicitante encontrará indicação do estágio de cumprimento das decisões da Corte Interamericana de Direitos Humanos nas resoluções sobre supervisão de cumprimento de sentença ou nas resoluções sobre medidas provisórias, disponíveis no sítio eletrônico do Tribunal.

Segue, em anexo, Planilha dos Casos em Andamento na Comissão Interamericana de Direitos Humanos.

Brasília, 04/05/2015. 


\begin{tabular}{|c|c|c|c|c|c|c|c|}
\hline \multicolumn{8}{|c|}{ ADMISSIBILIDADE } \\
\hline UF & $\begin{array}{c}N^{0} \text { do } \\
\text { Processo }\end{array}$ & Caso & $\begin{array}{c}\text { Data de Início do } \\
\text { Trâmite }\end{array}$ & Data da Alegada Violação & Peticionários & Tema & Artigos Invocados \\
\hline RJ & P-1017-08 & $\begin{array}{c}\text { Adaildo José } \\
\text { Soares, Adair } \\
\text { José da Rocha } \\
\text { Alves e } \\
\text { outros }\end{array}$ & $07 / 03 / 2014$ & 02/05/2007 & $\begin{array}{l}\text { Defensoria Pública do } \\
\text { Estado do Rio de Janeiro }\end{array}$ & Sistema prisional & $\begin{array}{c}\text { CADH: } 1^{\circ}, 2^{\circ}, 5^{\circ}, 8^{\circ}, \\
25 .\end{array}$ \\
\hline RJ & P-28-06 & Ailton Vieira & $21 / 10 / 2010$ & & Ailton Vieira & $\begin{array}{l}\text { Indeferimento do } \\
\text { pedido à Comissão } \\
\text { de Anistia }\end{array}$ & \\
\hline $\mathrm{PE}$ & P-15-08 & $\begin{array}{l}\text { Amaro Rosa } \\
\text { de Barros }\end{array}$ & $23 / 08 / 2010$ & & Amaro Rosa de Barros & $\begin{array}{l}\text { Morosidade } \\
\text { processual }\end{array}$ & \\
\hline DF & P-384-07 & $\begin{array}{c}\text { Antonio } \\
\text { Reinaldo } \\
\text { Peixoto } \\
\text { Pereira }\end{array}$ & $29 / 03 / 2007$ & 30 de abril de 2000 (?) & $\begin{array}{l}\text { Sr. Antonio Reinaldo } \\
\text { Peixoto Pereira }\end{array}$ & $\begin{array}{l}\text { Direito de } \\
\text { aposentadoria }\end{array}$ & $\begin{array}{c}\text { Convenção Americana: } \\
\text { arts. } 24 \text { e } 25 . \\
\text { Protocolo Adicional à } \\
\text { Convenção Americana } \\
\text { sobre Direitos } \\
\text { Humanos em Matéria } \\
\text { de Direitos } \\
\text { Econômicos, Sociais e } \\
\text { Culturais - Pacto San } \\
\text { Salvador - arts. } 6 \text { e } 9 .\end{array}$ \\
\hline RJ & P-145-06 & $\begin{array}{l}\text { Áureo Neves } \\
\quad \text { Filho }\end{array}$ & $27 / 12 / 2006$ & 04.01 .2006 & $\begin{array}{c}\text { Organização de Direitos } \\
\text { Humanos PROJETO } \\
\text { LEGAL }\end{array}$ & $\begin{array}{l}\text { Execução por } \\
\text { policiais militares }\end{array}$ & $\begin{array}{l}\text { Convenção Americana: } \\
\text { arts. } 4,5,11 \text { e } 25\end{array}$ \\
\hline
\end{tabular}




\begin{tabular}{|c|c|c|c|c|c|c|c|}
\hline \multicolumn{8}{|c|}{ ADMISSIBILIDADE } \\
\hline UF & $\begin{array}{c}N^{0} \text { do } \\
\text { Processo }\end{array}$ & Caso & $\begin{array}{c}\text { Data de Início do } \\
\text { Trâmite }\end{array}$ & Data da Alegada Violação & Peticionários & Tema & Artigos Invocados \\
\hline TO & P-271-09 & $\begin{array}{l}\text { Célio Márcio } \\
\text { Alves } \\
\text { Nogueira }\end{array}$ & 24/03/2009 & & $\begin{array}{c}\text { Sergio Constantino } \\
\text { Wachelski, Bernardino } \\
\text { Cosobeck da Costa e } \\
\text { Martonio Ribeiro Silva }\end{array}$ & Prisão irregular & CADH: $4^{\circ}$ e $5^{\circ}$ \\
\hline SP & P-221-12 & $\begin{array}{l}\text { Claudio } \\
\text { Rogério } \\
\text { Rodrigues da } \\
\text { Silva }\end{array}$ & $02 / 10 / 2013$ & $18 / 05 / 2009$ & $\begin{array}{l}\text { Cláudio Rogério } \\
\text { Rodrigues da Silva }\end{array}$ & $\begin{array}{l}\text { Acesso à justiça } \\
\text { Discriminação por } \\
\text { orientação sexual }\end{array}$ & $\begin{array}{c}\text { Declaração Americana: } \\
\text { Arts. II, V, XIV, XVII, } \\
\text { XVIII, XXIV, XXVI; } \\
\text { Convenção Americana: } \\
\text { Arts. } 1,5,8,11,14,24 \text {, } \\
25,\end{array}$ \\
\hline RJ & P-607-06 & $\begin{array}{l}\text { Crianças } \\
\text { privadas de } \\
\text { liberdade no } \\
\text { Rio de } \\
\text { Janeiro } \\
\text { (DEGASE) }\end{array}$ & 02/06/2006 & $\begin{array}{l}03.03 .2005 \text { (data de } \\
\text { arquivamento de processo, } \\
\text { impedindo a existência do } \\
\text { devido processo legal) }\end{array}$ & $\begin{array}{c}\text { Organização de Direitos } \\
\text { Humanos PROJETO } \\
\text { LEGAL }\end{array}$ & $\begin{array}{l}\text { Maus-tratos em } \\
\text { instituições sócio } \\
\text { educativas } \\
\text { Tortura }\end{array}$ & $\begin{array}{c}\text { Convenção Americana: } \\
\text { art. } 25\end{array}$ \\
\hline RJ & P-1449-06 & $\begin{array}{l}\text { Cristiane } \\
\text { Leite de } \\
\text { Souza e } \\
\text { outros }\end{array}$ & $11 / 04 / 2011$ & 26.07 .1990 & Projeto Legal & $\begin{array}{l}\text { Violência policial } \\
\text { urbana } \\
\text { Desaparecimento } \\
\text { de pessoas }\end{array}$ & $\begin{array}{c}\text { Convenção: art. } 4,5 \text {, } \\
11, \text { e } 25 .\end{array}$ \\
\hline MG & $\begin{array}{l}P-1608- \\
07\end{array}$ & $\begin{array}{l}\text { Débora } \\
\text { Monteiro } \\
\text { Silva }\end{array}$ & $19 / 12 / 2007$ & 20 de janeiro de 2003 & Pai de Débora & $\begin{array}{l}\text { Morosidade } \\
\text { processual }\end{array}$ & $\begin{array}{l}\text { Não foram citados } \\
\text { artigos }\end{array}$ \\
\hline
\end{tabular}




\begin{tabular}{|c|c|c|c|c|c|c|c|}
\hline \multicolumn{8}{|c|}{ ADMISSIBILIDADE } \\
\hline UF & $\begin{array}{c}N^{\circ} \text { do } \\
\text { Processo }\end{array}$ & Caso & $\begin{array}{c}\text { Data de Início do } \\
\text { Trâmite }\end{array}$ & Data da Alegada Violação & Peticionários & Tema & Artigos Invocados \\
\hline MT & P-1122-07 & $\begin{array}{l}\text { Eliane Ortiz e } \\
\text { Murilo } \\
\text { Alcaide }\end{array}$ & 2011 & 21/06/2005 & $\begin{array}{l}\text { Seccionária de Mato } \\
\text { Grosso do Sul da OAB }\end{array}$ & $\begin{array}{l}\text { Morosidade } \\
\text { processual }\end{array}$ & $\begin{array}{l}\text { Convenção: Art 4; Art. } \\
\text { 5; Art. 8; Art. } 25\end{array}$ \\
\hline DF & P-673-11 & $\begin{array}{l}\text { Fernando } \\
\text { Alcântara de } \\
\text { Freitas Filho } \\
\text { e Laci } \\
\text { Marinho de } \\
\text { Araújo }\end{array}$ & $27 / 01 / 2014$ & & $\begin{array}{c}\text { Centro pela Justiça e o } \\
\text { Direito Internacional } \\
\text { (CEJIL) }\end{array}$ & $\begin{array}{l}\text { Forças Armadas, } \\
\text { tortura, } \\
\text { discriminiação por } \\
\text { orientação sexual, } \\
\text { violação à vida } \\
\text { privada }\end{array}$ & $\begin{array}{c}\text { CADH: } 5,7,8,11,13 \text {, } \\
24 \text { e } 25 \\
\text { Covenção contra a } \\
\text { torutra: } 1,2,6 \text { e } 8\end{array}$ \\
\hline RS & P-1140-04 & $\begin{array}{l}\text { Felipe Néri } \\
\text { Dresch da } \\
\text { Silveira e } \\
\text { outros }\end{array}$ & $12 / 10 / 2006$ & $\begin{array}{l}\text { 22.5.2006, se extendendo } \\
\text { até hoje }\end{array}$ & $\begin{array}{l}\text { Sra. Rita de Cássaia da } \\
\text { Rosa e Sra. Clélia de } \\
\text { Lourdes Goldenberg, } \\
\text { através da representação } \\
\text { de Felipe Néri da Silveira }\end{array}$ & $\begin{array}{l}\text { Não pagamento de } \\
\text { precatórios pelo } \\
\text { Estado }\end{array}$ & $\begin{array}{c}\text { Convenção: arts.: } 8,25 \\
\text { e } 28\end{array}$ \\
\hline SP & $\begin{array}{c}\mathrm{P}-1277- \\
07\end{array}$ & $\begin{array}{l}\text { Flávio } \\
\text { Mendes de } \\
\text { Morais }\end{array}$ & $10 / 04 / 2012$ & & $\begin{array}{l}\text { Socrates Spyros Patseas } \\
\quad \text { (advogado) }\end{array}$ & $\begin{array}{l}\text { Violência em } \\
\text { instituição sócio- } \\
\text { educativa }\end{array}$ & \\
\hline SP & P - 905-08 & $\begin{array}{l}\text { Gabriel de } \\
\text { Matos Prado }\end{array}$ & $18 / 05 / 2012$ & & $\begin{array}{l}\text { Roosevelt de Souza } \\
\text { Bormann (advogado) }\end{array}$ & $\begin{array}{l}\text { Violência policial } \\
\text { em delegacia } \\
\text { Tortura }\end{array}$ & \\
\hline SP & P-1185-08 & $\begin{array}{c}\text { Gerson } \\
\text { Mendonça de } \\
\text { Freitas Filho }\end{array}$ & & $17 / 03 / 2006$ & $\begin{array}{l}\text { Conectas Direitos } \\
\text { Humanos } \\
\text { Sonia Kodaira }\end{array}$ & $\begin{array}{l}\text { Violência policial } \\
\text { Uso excessivo da } \\
\text { força } \\
\text { Homicídio }\end{array}$ & $1.1,4$ e $25(\mathrm{CADH})$ \\
\hline
\end{tabular}




\begin{tabular}{|c|c|c|c|c|c|c|c|}
\hline \multicolumn{8}{|c|}{ ADMISSIBILIDADE } \\
\hline UF & $\begin{array}{c}\mathrm{N}^{\circ} \text { do } \\
\text { Processo }\end{array}$ & Caso & $\begin{array}{c}\text { Data de Início do } \\
\text { Trâmite }\end{array}$ & Data da Alegada Violação & Peticionários & Tema & Artigos Invocados \\
\hline SP & P-176-08 & $\begin{array}{l}\text { Gustavo } \\
\text { Magalhães } \\
\text { Pereira }\end{array}$ & $15 / 02 / 2008$ & 07.09 .2008 & $\begin{array}{l}\text { Sra. Janaira de Fatima } \\
\text { Magalhães }\end{array}$ & $\begin{array}{l}\text { Violações aos } \\
\text { direitos da criança }\end{array}$ & $\begin{array}{l}\text { Não são citados } \\
\text { possíveis artigos } \\
\text { violados }\end{array}$ \\
\hline $\mathrm{CE}$ & P-1228-08 & $\begin{array}{l}\text { Hindenburgh } \\
\text { de Mélo } \\
\text { Rocha }\end{array}$ & $10 / 06 / 2013$ & & & $\begin{array}{c}\text { Morosidade } \\
\text { processual } \\
\text { Denegação de } \\
\text { justiça }\end{array}$ & \\
\hline RJ & P-1643-07 & $\begin{array}{c}\text { Jacqueline } \\
\text { Simone de } \\
\text { Souza e Silva } \\
\text { Ferreira } \\
\end{array}$ & $16 / 07 / 2008$ & & $\begin{array}{l}\text { Jacqueline Simone de } \\
\text { Souza e Silva Ferreira }\end{array}$ & $\begin{array}{l}\text { Morosidade } \\
\text { processual } \\
\text { Inventário }\end{array}$ & Convenção: art. 8 e 25 . \\
\hline PA & P-1178-09 & L. A. B. & $18 / 08 / 2010$ & $31 / 10 / 2007$ & SOS Direitos Humanos & $\begin{array}{l}\text { Estupro em centro } \\
\text { de detenção } \\
\text { Violação dos } \\
\text { direitos da criança } \\
\text { e do adolescente }\end{array}$ & $\begin{array}{c}\text { CADH: } 5^{\circ}, 7^{\circ}, 8^{\circ}, 11, \\
19 ; \\
\text { Convenção } \\
\text { Internacional dos } \\
\text { Direitos da Criança: } 34, \\
36,37 \text { e } 40 ; \\
\text { Convenção de Belém } \\
\text { do Pará: } 1^{\circ}, 2^{\circ}, 3^{\circ}, 4^{\circ}, \\
5^{\circ}, 7^{\circ}, 8^{\circ} \text { e } 10^{\circ}\end{array}$ \\
\hline RJ & P-1453-06 & $\begin{array}{l}\text { Maicon de } \\
\text { Souza Silva }\end{array}$ & $10 / 12 / 2006$ & 15.04.1996 & $\begin{array}{c}\text { Organização de Direitos } \\
\text { Humanos PROJETO } \\
\text { LEGAL }\end{array}$ & $\begin{array}{l}\text { Violência policial } \\
\text { urbana }\end{array}$ & $\begin{array}{l}\text { Convenção Americana: } \\
\text { arts. } 4,5,11 \text { e } 25\end{array}$ \\
\hline SP & P-1246-08 & $\begin{array}{l}\text { Marcelo } \\
\text { Henrique de } \\
\text { Freitas }\end{array}$ & 23/mai/12 & $29 / 08 / 2000$ & & $\begin{array}{l}\text { Violência em } \\
\text { presídio. Tortura. }\end{array}$ & \\
\hline
\end{tabular}




\begin{tabular}{|c|c|c|c|c|c|c|c|}
\hline \multicolumn{8}{|c|}{ ADMISSIBILIDADE } \\
\hline UF & $\begin{array}{c}N^{\circ} \text { do } \\
\text { Processo }\end{array}$ & Caso & $\begin{array}{c}\text { Data de Início do } \\
\text { Trâmite }\end{array}$ & Data da Alegada Violação & Peticionários & Tema & Artigos Invocados \\
\hline RJ & P-32-07 & $\begin{array}{c}\text { Marcio } \\
\text { Antonio Maia } \\
\text { de Souza }\end{array}$ & $10 / 12 / 2006$ & 01.11 .1995 & $\begin{array}{c}\text { Organização de Direitos } \\
\text { Humanos PROJETO } \\
\text { LEGAL }\end{array}$ & $\begin{array}{l}\text { Violência policial } \\
\text { urbana } \\
\text { Execução sumária } \\
\text { por policiais } \\
\text { militares }\end{array}$ & $\begin{array}{c}\text { Convenção Americana: } \\
\text { art. } 25\end{array}$ \\
\hline SP & P-1247-08 & $\begin{array}{l}\text { Nilson } \\
\text { Saldanha }\end{array}$ & $12 / 10 / 2012$ & 09/06/2000 & $\begin{array}{l}\text { Ação dos Cristãos para a } \\
\text { Aboliçãa da Tortura } \\
\text { (ACAT-BRASIL) }\end{array}$ & $\begin{array}{l}\text { Sistema prisional } \\
\text { Tortura }\end{array}$ & \\
\hline MS & P-1268-09 & $\begin{array}{c}\text { Pessoas } \\
\text { Privadas de } \\
\text { Liberdade no } \\
\text { Sistema } \\
\text { Prisional do } \\
\text { Estado de } \\
\text { Mato Grosso } \\
\text { do Sul } \\
\end{array}$ & & & & Sistema prisional & \\
\hline RJ & P-1344-08 & $\begin{array}{l}\text { Reinaldo } \\
\text { Coutinho da } \\
\text { Silva }\end{array}$ & $27 / 01 / 2014$ & 29/08/1995 & $\begin{array}{l}\text { Sociedade Interamericana } \\
\text { de Imprensa (SIP) }\end{array}$ & $\begin{array}{l}\text { Assassinato de } \\
\text { jornalista }\end{array}$ & CADH: $4,8,13,25$ \\
\hline
\end{tabular}

Fonte: Secretaria de Direitos Humanos 


\begin{tabular}{|c|c|c|c|c|c|c|c|c|}
\hline \multicolumn{9}{|c|}{ MÉRITO } \\
\hline UF & $\begin{array}{c}\mathbf{N}^{\circ} \text { do } \\
\text { Processo }\end{array}$ & Caso & $\begin{array}{l}\text { Data de Início } \\
\text { do Trâmite }\end{array}$ & $\begin{array}{l}\text { Data da Alegada } \\
\text { Violação }\end{array}$ & Peticionários & Tema & Artigos Invocados & Fase \\
\hline PA & 12.753 & $\begin{array}{l}\text { Adão Pereira de } \\
\text { Souza }\end{array}$ & 19/07/2006 & 1993 & $\begin{array}{c}\text { Centro pela Justiça e pelo } \\
\text { Direito Internacional (CEJIL) } \\
\text { Sociedade Paraense de Defesa } \\
\text { dos Direitos Humanos } \\
\text { Comissão Pastoral da Terra } \\
\text { (CPT) }\end{array}$ & $\begin{array}{l}\text { Violência policial no } \\
\text { campo } \\
\text { Denegação de Justiça }\end{array}$ & $\begin{array}{c}\text { Convenção: arts. } 4,5 \text {, } \\
7,8 \text { e 25. Convenção } \\
\text { Interamericana para } \\
\text { Prevenir e Erradicar a } \\
\text { Tortura: arts. 1, 2, 3, } \\
\text { 4, 5, } 6 \text { e } 8\end{array}$ & $\begin{array}{c}\text { Informações } \\
\text { Adicionais de } \\
\text { Mérito }\end{array}$ \\
\hline RJ & 12.615 & $\begin{array}{l}\text { Alan Felipe da } \\
\text { Silva e outros }\end{array}$ & 08/06/2005 & $29 / 05 / 2002$ & $\begin{array}{l}\text { Defensores Públicos em } \\
\text { exercício do Núcleo de Defesa } \\
\text { dos Direitos Humanos } \\
\text { (NUDEH) } \\
\text { Coordenadoria de Defesa dos } \\
\text { Direitos da Criança e do } \\
\text { Adolescente da Defensoria } \\
\text { Pública (CDEDICA) }\end{array}$ & $\begin{array}{c}\text { Violência contra } \\
\text { crianças e } \\
\text { adolescentes; } \\
\text { Tortura; } \\
\text { Maus tratos em } \\
\text { instituições sócio- } \\
\text { educativas (Centro de } \\
\text { Triagem de Recepção } \\
\text { do RJ - CTR). }\end{array}$ & $\begin{array}{c}\text { Covenção } \\
\text { Americana: arts. 1.1, } \\
\text { 5, 8.1,19 e 25; } \\
\text { Convenção } \\
\text { Interamericana para } \\
\text { Prevenir e Punir a } \\
\text { Tortura: arts. 6, } 7 \text { e } 8 .\end{array}$ & $\begin{array}{c}\text { Informações } \\
\text { Adicionais de } \\
\text { Mérito }\end{array}$ \\
\hline PR & 12.727 & $\begin{array}{c}\text { Antônio Tavares } \\
\text { Pereira e outros } \\
185 \text { trabalhadores } \\
\text { rurais }\end{array}$ & 01/01/2004 & $02 / 05 / 2000$ & $\begin{array}{c}\text { Justiça Global } \\
\text { Movimento dos Trabalhadores } \\
\text { Rurais Sem Terra (MST) } \\
\text { Comissão Pastoral da Terra } \\
\text { (CPT) } \\
\text { Centro de Justiça Global e } \\
\text { Terra de Direitos }\end{array}$ & $\begin{array}{l}\text { Violência Policial no } \\
\text { campo } \\
\text { Denegação de Justiça: } \\
\text { arquivamento de } \\
\text { investigação }\end{array}$ & $\begin{array}{l}\text { Convenção:arts. } 1.1 \text {, } \\
4,5,8,15,22 \text { e } 25 \text {. }\end{array}$ & $\begin{array}{c}\text { Informações } \\
\text { Adicionais de } \\
\text { Mérito }\end{array}$ \\
\hline PA & 12.604 & $\begin{array}{l}\text { Ariomar Oliveira } \\
\text { Rocha, Ademir } \\
\text { Federicchi e Natur } \\
\text { de Assis Filho }\end{array}$ & $15 / 03 / 2002$ & 22/07/1998 & $\begin{array}{l}\text { Nelson Vicente Portela } \\
\text { Pellegrino, Helio Pereira } \\
\text { Bicudo e Cláudio Grossman }\end{array}$ & Execução extrajudicial & $\begin{array}{c}\text { CADH: } 4,8.1,23 \mathrm{e} \\
25\end{array}$ & \\
\hline
\end{tabular}




\begin{tabular}{|c|c|c|c|c|c|c|c|c|}
\hline \multicolumn{9}{|c|}{ MÉRITO } \\
\hline UF & $\begin{array}{c}\mathrm{N}^{\mathbf{o}} \text { do } \\
\text { Processo }\end{array}$ & Caso & $\begin{array}{l}\text { Data de Início } \\
\text { do Trâmite }\end{array}$ & $\begin{array}{l}\text { Data da Alegada } \\
\text { Violação }\end{array}$ & Peticionários & Tema & Artigos Invocados & Fase \\
\hline RJ & 12.213 & $\begin{array}{l}\text { Aristeu Guida da } \\
\text { Silva }\end{array}$ & 23/09/1999 & $12 / 05 / 1995$ & $\begin{array}{l}\text { Sociedade Interamericana de } \\
\text { Imprensa (SIP) }\end{array}$ & $\begin{array}{c}\text { Violência contra } \\
\text { jornalista } \\
\text { Defensores de direitos } \\
\text { humanos } \\
\text { Liberdade de opinião e } \\
\text { expressão }\end{array}$ & $\begin{array}{l}\text { Convenção: arts. } 1.1, \\
4,8,13 \text { e } 25 .\end{array}$ & $\begin{array}{l}\text { Informações } \\
\text { Adicionais de } \\
\text { Mérito }\end{array}$ \\
\hline RS & 12.837 & $\begin{array}{l}\text { Clélia Lourdes } \\
\text { Goldenberg e Rita } \\
\text { de Cássia Rosa }\end{array}$ & $\begin{array}{l}27.10 .2004 \mathrm{e} \\
3.07 .2006\end{array}$ & $1997-8$ & $\begin{array}{l}\text { Clélia Lourdes Goldenberg e } \\
\text { Rita de Cássia Rosa }\end{array}$ & Precatórios & $\begin{array}{l}\text { Convenção: arts. } 1.1, \\
2,8,25 \text { e } 28 .\end{array}$ & $\begin{array}{c}\text { Pós- } \\
\text { Admissibilidade }\end{array}$ \\
\hline RJ & 12.242 & $\begin{array}{l}\text { Clínica Pediátrica } \\
\text { da Região dos } \\
\text { Lagos }\end{array}$ & $10 / 01 / 2000$ & 1996 & $\begin{array}{c}\text { Projeto Legal } \\
\text { Associação Mães de Cabo } \\
\text { Frio }\end{array}$ & $\begin{array}{c}\text { Negligência em } \\
\text { hospital público } \\
\text { Mortes por infeccção } \\
\text { hospitalar } \\
\text { Denegação de justiça }\end{array}$ & $\begin{array}{l}\text { Convenção: arts. 1.1, } \\
4,8,19 \text { e } 25 .\end{array}$ & $\begin{array}{l}\text { Informações } \\
\text { Adicionais de } \\
\text { Mérito }\end{array}$ \\
\hline MA & 12.569 & $\begin{array}{l}\text { Comunidades } \\
\text { Quilombolas de } \\
\text { Alcântara }\end{array}$ & 17/08/2001 & 1980 & $\begin{array}{l}\text { Centro de Justiça Global } \\
\text { representantes das } \\
\text { Comunidades Samucangaua, } \\
\text { Iririzal, Ladeira, Só Assim, } \\
\text { Santa Maria, Canelatiua, } \\
\text { Itapera e Mamuninha } \\
\text { Centro de Cultura Negra do } \\
\text { Maranhão (CCN) } \\
\text { Associação das Comunidades } \\
\text { Negras Rurais Quilombolas do } \\
\text { Maranhão (ACONERUQ) } \\
\text { Federação dos Trabalhadores } \\
\text { na Agricultura do Estado do } \\
\text { Maranhão (FETAEMA) } \\
\text { Global Exchange }\end{array}$ & $\begin{array}{c}\text { Quilombolas } \\
\text { Violação dos direitos } \\
\text { de propriedade }\end{array}$ & $\begin{array}{l}\text { Declaração: arts. VI, } \\
\text { VIII, XII, XIII, XIV, } \\
\text { XVIII, XXII e XXIII } \\
\text { Convenção: arts. } 1.1 \text {, } \\
2,8,16,17,21,24 \text { e } \\
25\end{array}$ & $\begin{array}{l}\text { Informações } \\
\text { Adicionais de } \\
\text { Mérito. Amicus } \\
\text { Curiae. }\end{array}$ \\
\hline
\end{tabular}




\begin{tabular}{|c|c|c|c|c|c|c|c|c|}
\hline \multicolumn{9}{|c|}{ MÉRITO } \\
\hline UF & $\begin{array}{l}\mathrm{N}^{\circ} \text { do } \\
\text { Processo }\end{array}$ & Caso & $\begin{array}{l}\text { Data de Início } \\
\text { do Trâmite }\end{array}$ & $\begin{array}{l}\text { Data da Alegada } \\
\text { Violação }\end{array}$ & Peticionários & Tema & Artigos Invocados & Fase \\
\hline SP & 12.328 & $\begin{array}{c}\text { Crianças e } \\
\text { Adolescentes } \\
\text { privados de } \\
\text { liberdade, no } \\
\text { complexo } \\
\text { Imigrantes, Centro } \\
\text { de Observações } \\
\text { Criminológicas } \\
\text { (COC), Cadeião } \\
\text { de Santo André, } \\
\text { Cadeião de } \\
\text { Pinheiros, } \\
\text { Presídio de } \\
\text { Parelheiros, } \\
\text { Complexo do } \\
\text { Tatuapé, Franco } \\
\text { da Rocha e } \\
\text { Unidade de } \\
\text { Atendimento } \\
\text { Inicial (UAI) - } \\
\text { FEBEM }\end{array}$ & 04/09/2000 & 2000 & $\begin{array}{l}\text { Centro pela Justiça e o Direito } \\
\text { Internacional (CEJIL) }\end{array}$ & $\begin{array}{l}\text { Violência contra } \\
\text { crianças e } \\
\text { adolescentes; } \\
\text { Tortura; } \\
\text { Maus tratos em } \\
\text { instituições sócio- } \\
\text { educativas. }\end{array}$ & $\begin{array}{c}\text { Convenção: } 1.1,4,5 \text {, } \\
7,8,25 \text { e } 19 ; \\
\text { Protocolo de São } \\
\text { Salvador: } 13\end{array}$ & $\begin{array}{c}\text { Informações } \\
\text { Adicionais de } \\
\text { Mérito }\end{array}$ \\
\hline RJ & 11.702 & $\begin{array}{c}\text { Crianças privadas } \\
\text { de liberdade no } \\
\text { Rio de Janeiro }\end{array}$ & 1996 & 1996 & $\begin{array}{l}\text { Centro pela Justiça e o Direito } \\
\text { Internacional (CEJIL) }\end{array}$ & $\begin{array}{l}\text { Violência contra } \\
\text { crianças e } \\
\text { adolescentes; } \\
\text { Maus tratos em } \\
\text { instituições sócio- } \\
\text { educativas. }\end{array}$ & $\begin{array}{l}\text { Convenção: } 1.1,4,5, \\
\quad 7,8,19 \text { e } 25\end{array}$ & $\begin{array}{c}\text { Informações } \\
\text { Adicionais de } \\
\text { Mérito }\end{array}$ \\
\hline
\end{tabular}




\begin{tabular}{|c|c|c|c|c|c|c|c|c|}
\hline \multicolumn{9}{|c|}{ MÉRITO } \\
\hline UF & $\begin{array}{c}\mathrm{N}^{0} \text { do } \\
\text { Processo }\end{array}$ & Caso & $\begin{array}{l}\text { Data de Início } \\
\text { do Trâmite }\end{array}$ & $\begin{array}{l}\text { Data da Alegada } \\
\text { Violação }\end{array}$ & Peticionários & Tema & Artigos Invocados & Fase \\
\hline PR & 12.569 & $\begin{array}{l}\text { Daniel Gomes dos } \\
\text { Santos e Vilmar } \\
\text { Soares da Silva }\end{array}$ & 2004 & 1991 & $\begin{array}{l}\text { Daniel Gomes dos Santos } \\
\text { Vilmar Soares da Silva }\end{array}$ & $\begin{array}{c}\text { Violência policial } \\
\text { urbana } \\
\text { Tortura } \\
\text { Confissão induzida } \\
\text { Denegação de justiça }\end{array}$ & $\begin{array}{c}\text { Convenção: arts. } 8 \text { e } \\
25\end{array}$ & $\begin{array}{l}\text { Informações } \\
\text { Adicionais de } \\
\text { Mérito }\end{array}$ \\
\hline BA & 12.428 & $\begin{array}{l}\text { Fábrica de fogos } \\
\text { de Artifício em } \\
\text { Santo Antônio de } \\
\text { Jesus }\end{array}$ & & 11/12/1998 & $\begin{array}{l}\text { Justiça Global } \\
\text { Movimento } 11 \text { de Dezembro }\end{array}$ & $\begin{array}{l}\text { Morosidade processual } \\
\text { Denegação de justiça }\end{array}$ & $\begin{array}{l}\text { Declaração: art. XVI } \\
\text { Convenção } \\
\text { Americana: Arts. } 4 \text {, } \\
\text { 5, 18, } 25\end{array}$ & $\begin{array}{l}\text { Informações } \\
\text { Adicionais de } \\
\text { Mérito }\end{array}$ \\
\hline RS & 12.378 & $\begin{array}{c}\text { Fátima Regina } \\
\text { Nascimento de } \\
\text { Oliveira e Maura } \\
\text { Tatiane Ferreira } \\
\text { Alves }\end{array}$ & 22/03/2001 & 23/07/1989 & $\begin{array}{c}\text { Justiça Global } \\
\text { THEMIS - Assessoria Jurídica } \\
\text { e Estudos de Gênero } \\
\text { Comissão de Cidadania e } \\
\text { Direitos Humanos da } \\
\text { Assembléia Legislativa do Rio } \\
\text { Grande do Sul } \\
\text { Subcomissão da Criança e do } \\
\text { Adolescente da Assembléia } \\
\text { Legislativa do Rio Grande do } \\
\text { Sul } \\
\text { Instituto Amigos de Luca }\end{array}$ & $\begin{array}{l}\text { Direito das mulheres } \\
\text { Degenação do direito à } \\
\text { licença maternidade }\end{array}$ & $\begin{array}{l}\text { Convenção: arts. } 1.1 \text {, } \\
8,17,19 \text { e } 24 \text { e } 25.1\end{array}$ & $\begin{array}{c}\text { Pós- } \\
\text { Admissibilidade }\end{array}$ \\
\hline
\end{tabular}




\begin{tabular}{|c|c|c|c|c|c|c|c|c|}
\hline \multicolumn{9}{|c|}{ MÉRITO } \\
\hline UF & $\begin{array}{c}\mathrm{N}^{0} \text { do } \\
\text { Processo }\end{array}$ & Caso & $\begin{array}{l}\text { Data de Início } \\
\text { do Trâmite }\end{array}$ & $\begin{array}{l}\text { Data da Alegada } \\
\text { Violação }\end{array}$ & Peticionários & Tema & Artigos Invocados & Fase \\
\hline RJ & $\begin{array}{c}12.859 \\
(\mathrm{P}-302-07)\end{array}$ & $\begin{array}{l}\text { Flávio Mendes } \\
\text { Pontes }\end{array}$ & 08.05.2007 & 30.03 .2004 & $\begin{array}{l}\text { Sra. Joana D’Arc Mendes } \\
\text { (auxiliada pelo Núcleo de } \\
\text { Defesa de Direitos Humanos } \\
\text { da Defensoría Pública Geral } \\
\text { do Estado do RJ - NUDE - RJ) }\end{array}$ & $\begin{array}{l}\text { Violência policial } \\
\text { urbana }\end{array}$ & $\begin{array}{c}\text { Convençãa } \\
\text { Americana: arts. } 4,5 \text {, } \\
24 \text { e } 25\end{array}$ & $\begin{array}{c}\text { fev/2008: Estado } \\
\text { envia informações } \\
\text { à OEA } \\
\text { abr/2011: } \\
\text { Peticionários } \\
\text { enviam } \\
\text { informaçõos à } \\
\text { CIDH. Apesar da } \\
\text { última } \\
\text { movimentação ter } \\
\text { sido dos } \\
\text { peticionários, não } \\
\text { houve data } \\
\text { definida para } \\
\text { resposta }\end{array}$ \\
\hline MA & 12.726 & $\begin{array}{c}\text { Francisco de Assis } \\
\text { Ferreira }\end{array}$ & $19 / 07 / 2001$ & 05/11/1991 & $\begin{array}{c}\text { Justiça Global } \\
\text { Sociedade Maranhense de } \\
\text { Direitos Humanos e pelo } \\
\text { Centro de Justiça Global }\end{array}$ & $\begin{array}{l}\text { Violência no campo } \\
\text { Denegação de justiça: } \\
\text { impunidade dos } \\
\text { responsáveis }\end{array}$ & $\begin{array}{l}\text { Declaração: arts. I e } \\
\text { XVIII } \\
\text { Convenção: arts. } 4 \text { e } \\
25\end{array}$ & $\begin{array}{l}\text { Informações } \\
\text { Adicionais de } \\
\text { Mérito }\end{array}$ \\
\hline & & & & & & & & \\
\hline
\end{tabular}




\begin{tabular}{|c|c|c|c|c|c|c|c|c|}
\hline \multicolumn{9}{|c|}{ MÉRITO } \\
\hline UF & $\begin{array}{l}\mathrm{N}^{\circ} \text { do } \\
\text { Processo }\end{array}$ & Caso & $\begin{array}{l}\text { Data de Iń́cio } \\
\text { do Trâmite }\end{array}$ & $\begin{array}{l}\text { Data da Alegada } \\
\text { Violação }\end{array}$ & Peticionários & Tema & Artigos Invocados & Fase \\
\hline PA & 12.675 & $\begin{array}{l}\text { Gabriel Sales } \\
\text { Pimenta }\end{array}$ & $09 / 11 / 2006$ & $\begin{array}{c}1982 \text { (assassinato) } \\
2006 \text { (extinção do } \\
\text { processo) }\end{array}$ & $\begin{array}{c}\text { Centro pela Justiça e o Direito } \\
\text { Internacional (CEJIL) } \\
\text { Comissão Pastoral da Terra } \\
\text { (CPT) }\end{array}$ & $\begin{array}{c}\text { Violência no campo } \\
\text { Defensor de direitos } \\
\text { humanos } \\
\text { Denegação de justiça }\end{array}$ & $\begin{array}{c}\text { Declaração: arts. I, } \\
\text { XVIII e XXII. } \\
\text { Convenção: arts. } 1.1, \\
8 \text { e } 25 .\end{array}$ & $\begin{array}{l}\text { Durante a visita do } \\
\text { então Presidente da } \\
\text { Comissão (Felipe } \\
\text { González) ao } \\
\text { Brasil, em junho } \\
\text { de 2010, houve } \\
\text { reunião no CEJIL, } \\
\text { sem êxito quanto à } \\
\text { solução amistosa. } \\
\text { Os peticionários } \\
\text { irão retomar o } \\
\text { trâmite de mérito } \\
\text { normal do caso. 25 } \\
\text { julho/2012: A } \\
\text { CIDH informa que } \\
\text { família da vítima } \\
\text { não tem interesse } \\
\text { em continuar o } \\
\text { processo de } \\
\text { solução amistosa. } \\
\text { O caso continuará } \\
\text { em tramitacãa. }\end{array}$ \\
\hline & & & & & & & & \\
\hline
\end{tabular}




\begin{tabular}{|c|c|c|c|c|c|c|c|c|}
\hline \multicolumn{9}{|c|}{ MÉRITO } \\
\hline UF & $\begin{array}{c}\mathrm{N}^{0} \text { do } \\
\text { Processo }\end{array}$ & Caso & $\begin{array}{l}\text { Data de Início } \\
\text { do Trâmite }\end{array}$ & $\begin{array}{l}\text { Data da Alegada } \\
\text { Violação }\end{array}$ & Peticionários & Tema & Artigos Invocados & Fase \\
\hline PR & 12.503 & $\begin{array}{l}\text { Gerson Minusk de } \\
\text { Carvalho }\end{array}$ & $28 / 03 / 2003$ & 03/02/1995 & Gerson Miluisk de Carvalho & $\begin{array}{l}\text { Violëncia policial } \\
\text { urbana } \\
\text { Tortura }\end{array}$ & $\begin{array}{c}\text { Convenção: Art.5 - } \\
\text { Direito à integridade } \\
\text { pessoal; art.8 - } \\
\text { Garantias judiciais; } \\
\text { art.25 - Proteção } \\
\text { judicial; art. } 4.1 \text { - } \\
\text { Convenção Contra a } \\
\text { Tortura; art. } 2.9 \text { - } \\
\text { Direito à } \\
\text { inviolabilidade do } \\
\text { domicílio. }\end{array}$ & $\begin{array}{l}\text { Informações } \\
\text { Adicionais de } \\
\text { Mérito }\end{array}$ \\
\hline $\mathrm{PA}$ & 12.838 & $\begin{array}{l}\text { Hildebrando Silva } \\
\text { de Freitas }\end{array}$ & 03/04/2007 & 1997 & $\begin{array}{l}\text { Centro pela Justiça e o Direito } \\
\text { Internacional (CEJIL) }\end{array}$ & $\begin{array}{l}\text { Violência policial } \\
\text { urbana }\end{array}$ & $\begin{array}{l}\text { Convenção: arts. 1.1, } \\
5,7,8 \text { e } 25 .\end{array}$ & $\begin{array}{c}\text { Pós- } \\
\text { Admissibilidade }\end{array}$ \\
\hline BA & $\begin{array}{c}12.806 \\
(\mathrm{P}-702-03)\end{array}$ & Ivan Rocha & 28.05 .2003 & 22/04/1991 & $\begin{array}{l}\text { Sociedade Interamericana de } \\
\text { Imprensa (SIP) }\end{array}$ & $\begin{array}{l}\text { Desaparecimento e } \\
\text { suposto assassinato de } \\
\text { radialista }\end{array}$ & $\begin{array}{c}\text { Convenção } \\
\text { Americana: arts. } 4,8, \\
13 \text { e } 25\end{array}$ & $\begin{array}{c}\text { Pós- } \\
\text { Admissibilidade }\end{array}$ \\
\hline SP & 12.750 & $\begin{array}{l}\text { Ivanildo Amaro } \\
\text { da Silva e outros }\end{array}$ & $28 / 10 / 2005$ & $19 / 10 / 2004$ & $\begin{array}{c}\text { Fundação Interamericana de } \\
\text { Direitos Humanos }\end{array}$ & $\begin{array}{l}\text { Violência policial } \\
\text { urbana: moradores de } \\
\text { rua } \\
\text { Denegação de justiça }\end{array}$ & $\begin{array}{c}\text { Convenção: arts. } 1,4, \\
5,25 \text { e } 26\end{array}$ & $\begin{array}{c}\text { Pós- } \\
\text { Admissibilidade }\end{array}$ \\
\hline PR & 12.878 & $\begin{array}{l}\text { Ivete Jordani } \\
\text { Demeneche e } \\
\quad \text { outros }\end{array}$ & 27.07.2008 & 18.07.2004 & Sr. Fábio Demeneche & $\begin{array}{c}\text { Negligência de } \\
\text { profissionais da área } \\
\text { de saúde no tratamento } \\
\text { de idoso, levando a } \\
\text { falecimento do mesmo }\end{array}$ & $\begin{array}{c}\text { Convenção } \\
\text { Americana: art. 1.1, } \\
\text { 4, 5, 8.1 e 25. }\end{array}$ & $\begin{array}{c}\text { Pós- } \\
\text { Admissibilidade }\end{array}$ \\
\hline
\end{tabular}




\begin{tabular}{|c|c|c|c|c|c|c|c|c|}
\hline \multicolumn{9}{|c|}{ MÉRITO } \\
\hline UF & $\begin{array}{c}\mathrm{N}^{\mathbf{o}} \text { do } \\
\text { Processo }\end{array}$ & Caso & $\begin{array}{l}\text { Data de Iń́cio } \\
\text { do Trâmite }\end{array}$ & $\begin{array}{l}\text { Data da Alegada } \\
\text { Violação }\end{array}$ & Peticionários & Tema & Artigos Invocados & Fase \\
\hline RJ & 11.793 & $\begin{array}{l}\text { Jorge Antônio } \\
\quad \text { Carelli }\end{array}$ & 18/05/1999 & 1993 & $\begin{array}{c}\text { Antonio Careli } \\
\text { Maria de Almeirda Careli }\end{array}$ & $\begin{array}{l}\text { Violência policial } \\
\text { urbana } \\
\text { Desaparecimento } \\
\text { forçado } \\
\end{array}$ & $\begin{array}{c}\text { art. } 4^{\circ}, \text { art. } 5^{\circ}, \text { art. } 8^{\circ}, \\
\text { art. } 10, \text { art. } 11 \text { e art. } \\
25 \text { da Convenção } \\
\text { Americana }\end{array}$ & $\begin{array}{l}\text { Informações } \\
\text { Adicionais de } \\
\text { Mérito }\end{array}$ \\
\hline ES & 12.425 & $\begin{array}{l}\text { Jorge César } \\
\text { Mendonça da } \\
\text { Silva }\end{array}$ & $20 / 05 / 2003$ & & Justiça Global & & & $\begin{array}{l}\text { Informações } \\
\text { Adicionais de } \\
\text { Mérito }\end{array}$ \\
\hline SP & 12.479 & $\begin{array}{c}\text { José Airton } \\
\text { Honorato, José } \\
\text { Maria Menezes, } \\
\text { Aleksandro de } \\
\text { Oliveira Araújo e } \\
\text { outros } \\
\text { (Castelinho) }\end{array}$ & $24 / 04 / 2003$ & 05/03/2002 & $\begin{array}{c}\text { Associação Conectas Direitos } \\
\text { Humanos } \\
\text { Instituto Pro Bono } \\
\text { Conselho Comunitário } \\
\text { Penitenciário de Guarujá e } \\
\text { Vicente de Carvalho }\end{array}$ & $\begin{array}{c}\text { Violência policial } \\
\text { urbana } \\
\text { Denegação de justiça. }\end{array}$ & $\begin{array}{c}\text { Convenção: arts. 1.1, } \\
\text { 4, 8.1 e } 25 .\end{array}$ & $\begin{array}{l}\text { Informações } \\
\text { Adicionais de } \\
\text { Mérito }\end{array}$ \\
\hline RJ & 12.746 & $\begin{array}{l}\text { José do Egito } \\
\text { Romão Diniz }\end{array}$ & $14 / 03 / 2005$ & $22 / 08 / 2044$ & $\begin{array}{c}\text { Rogério Nunes de Oliveira e } \\
\text { João Paulo de Aguiar Sampaio } \\
\text { Souza }\end{array}$ & $\begin{array}{l}\text { Violência policial } \\
\text { contra detento } \\
\text { Tortura }\end{array}$ & $\begin{array}{c}\text { Convenção: arts. } 2,3 \\
\text { e } 6 .\end{array}$ & $\begin{array}{c}\text { Pós- } \\
\text { Admissibilidade }\end{array}$ \\
\hline SP & 12.877 & $\begin{array}{l}\text { José Laurindo } \\
\text { Soares }\end{array}$ & $16 / 11 / 2007$ & & José Laurindo Soares & $\begin{array}{l}\text { Atraso processual de } \\
\text { ação civil revisional de } \\
\text { benefício } \\
\text { previdenciário }\end{array}$ & $\begin{array}{l}\text { Convenção: art. } 1.1, \\
2,5,8.1 \text { e } 25 .\end{array}$ & $\begin{array}{c}\text { Pós- } \\
\text { Admissibilidade }\end{array}$ \\
\hline $\mathrm{PE}$ & 12.707 & $\begin{array}{l}\text { Josenildo João de } \\
\text { Freitas Júnior e } \\
\text { familiares }\end{array}$ & $17 / 05 / 2003$ & $15 / 12 / 2009$ & DHInternacional & $\begin{array}{c}\text { Violência policial } \\
\text { urbana } \\
\text { Execução sumária } \\
\text { Denegação de justiça: } \\
\text { demora injustificada }\end{array}$ & $\begin{array}{c}\text { Convenção: arts. 1.1, } \\
2,4,8,24,25\end{array}$ & $\begin{array}{c}\text { Pós- } \\
\text { Admissibilidade }\end{array}$ \\
\hline
\end{tabular}




\begin{tabular}{|c|c|c|c|c|c|c|c|c|}
\hline \multicolumn{9}{|c|}{ MÉRITO } \\
\hline UF & $\begin{array}{l}\mathrm{N}^{\circ} \mathrm{do} \\
\text { Processo }\end{array}$ & Caso & $\begin{array}{c}\text { Data de Início } \\
\text { do Trâmite }\end{array}$ & $\begin{array}{l}\text { Data da Alegada } \\
\text { Violação }\end{array}$ & Peticionários & Tema & Artigos Invocados & Fase \\
\hline RJ & 12.859 & $\begin{array}{l}\text { Jurandir Ferreira } \\
\text { de Lima e outros }\end{array}$ & 03.01 .2007 & 14.03 .1995 & Projeto Legal & $\begin{array}{l}\text { Violência policial } \\
\text { Desaparecimento } \\
\quad \text { forçado }\end{array}$ & $\begin{array}{c}\text { Convenção: artigos } \\
1.1,2,3,4,5,7,8,16 \\
\text { e } 25 .\end{array}$ & $\begin{array}{c}\text { Pós- } \\
\text { Admissibilidade }\end{array}$ \\
\hline SP & 12.616 & $\begin{array}{l}\text { Lazinho } \\
\text { Brambilla da Silva }\end{array}$ & $02 / 09 / 2005$ & $09 / 11 / 2003$ & $\begin{array}{c}\text { Conectas Direitos Humanos } \\
\text { Teresa de Jesús Brambilla } \\
\text { Associação de Mães e Amigos } \\
\text { de Crianças e Adolescentes em } \\
\text { Risco (AMAR) }\end{array}$ & $\begin{array}{l}\text { Violência contra } \\
\text { crianças e } \\
\text { adolescentes; } \\
\text { Maus tratos em } \\
\text { instituições sócio- } \\
\text { educativas. }\end{array}$ & $\begin{array}{l}\text { Convenção: arts. } 1.1 \text {, } \\
\quad 4,8.1,19 \text { e } 25\end{array}$ & $\begin{array}{l}\text { Informações } \\
\text { Adicionais de } \\
\text { Mérito }\end{array}$ \\
\hline $\mathrm{RS}$ & 12.907 & M.V.M. e P.S.R. & 08/01/2010 & 1996 & $\begin{array}{l}\text { THEMIS - Assessoria Jurídica } \\
\text { e Estudos de Gênero } \\
\text { CLADEM } \\
\text { Justiça Global }\end{array}$ & $\begin{array}{c}\text { Estupro } \\
\text { Denegação de justiça } \\
\text { Acesso à justiça }\end{array}$ & $\begin{array}{l}\text { CADH: } 5,8.1,11 \text {, } \\
\text { 19, } 24 \text { e } 25 \\
\text { Art. } 7 \text { da Convenção } \\
\text { de Belém do Pará }\end{array}$ & $\begin{array}{c}\text { Pós- } \\
\text { Admissibilidade }\end{array}$ \\
\hline PA & 12.327 & $\begin{array}{c}\text { Manoel Barbosa } \\
\text { da Costa e outros } \\
\text { (Fazenda } \\
\text { Princesa) }\end{array}$ & 1999 & 27/09/1985 & $\begin{array}{c}\text { Movimento Nacional de } \\
\text { Direitos Humanos } \\
\text { Sociedade Paraense de Defesa } \\
\text { dos Direitos Humanos }\end{array}$ & $\begin{array}{l}\text { Violência no campo } \\
\text { Denegação de justiça }\end{array}$ & CADH: 5,8 e 25 & $\begin{array}{l}\text { Informações } \\
\text { Adicionais de } \\
\text { Mérito }\end{array}$ \\
\hline PB & 12.570 & $\begin{array}{l}\text { Manoel Luiz da } \\
\text { Silva }\end{array}$ & $17 / 02 / 2005$ & $19 / 05 / 1997$ & $\begin{array}{c}\text { Justiça Global, CPT, } \\
\text { Dignitatis }\end{array}$ & $\begin{array}{l}\text { Violência no campo } \\
\text { Execução extrajudicial }\end{array}$ & CADH: $4,5,8$ e 25 & $\begin{array}{l}\text { Informações } \\
\text { Adicionais de } \\
\text { Mérito }\end{array}$ \\
\hline
\end{tabular}




\begin{tabular}{|c|c|c|c|c|c|c|c|c|}
\hline \multicolumn{9}{|c|}{ MÉRITO } \\
\hline UF & $\begin{array}{l}\mathrm{N}^{\circ} \text { do } \\
\text { Processo }\end{array}$ & Caso & $\begin{array}{l}\text { Data de Início } \\
\text { do Trâmite }\end{array}$ & $\begin{array}{l}\text { Data da Alegada } \\
\text { Violação }\end{array}$ & Peticionários & Tema & Artigos Invocados & Fase \\
\hline PB & 12.263 & $\begin{array}{c}\text { Márcia Barbosa } \\
\text { de Souza }\end{array}$ & & 1998 & $\begin{array}{l}\text { Movimento Nacional de } \\
\text { Direitos Humanos (MNDH) } \\
\text { Gabinete de Assessoria } \\
\text { Jurídica às Organizações } \\
\text { Governamentais (GAJOP) } \\
\text { Centro pela Justiça e o Direito } \\
\text { Internacional (CEJIL) }\end{array}$ & $\begin{array}{l}\text { Violência contra as } \\
\text { mulheres; } \\
\text { Imunidade } \\
\text { parlamentar. }\end{array}$ & $\begin{array}{c}\text { Convenção } \\
\text { Americana: arts. 1.1, } \\
\text { 4, 8.1,24 e 25; } \\
\text { Convenção de Belém } \\
\text { do Pará: art. } 7 .\end{array}$ & $\begin{array}{l}\text { jan/2011: Estado } \\
\text { transmite } \\
\text { observações sobre o } \\
\text { caso, informando } \\
\text { sobre reformas } \\
\text { constitucionais para } \\
\text { restringir a } \\
\text { imunidade } \\
\text { parlamentar e sobre } \\
\text { políticas públicas } \\
\text { para coibir violência } \\
\text { de gênero. } \\
\text { Nov/2011: CEJIL } \\
\text { cobra solução } \\
\text { amistosa pro caso. } \\
\text { Out/2012:Comissão } \\
\text { solicita às partes } \\
\text { encaminhar } \\
\text { observações quanto } \\
\text { ao mérito da } \\
\text { questão apresentada } \\
\text { pelo peticionário no } \\
\text { prazo de } 3 \text { meses. } \\
\text { Julho/2013: CIDH } \\
\text { concede } \\
\text { prorrogação de um } \\
\text { mês para o envio de } \\
\text { resposta pelos } \\
\text { peticionários. } \\
\text { Out/2013: } \\
\text { Peticionários } \\
\text { enviam informações } \\
\text { adicionais }\end{array}$ \\
\hline
\end{tabular}




\begin{tabular}{|c|c|c|c|c|c|c|c|c|}
\hline \multicolumn{9}{|c|}{ MÉRITO } \\
\hline UF & $\begin{array}{c}\mathbf{N}^{\circ} \text { do } \\
\text { Processo }\end{array}$ & Caso & $\begin{array}{l}\text { Data de Início } \\
\text { do Trâmite }\end{array}$ & $\begin{array}{l}\text { Data da Alegada } \\
\text { Violação }\end{array}$ & Peticionários & Tema & Artigos Invocados & Fase \\
\hline RJ & 12.752 & $\begin{array}{c}\text { Márcio Aurélio } \\
\text { Gonçalves }\end{array}$ & $21 / 05 / 2005$ & 03/08/2000 & $\begin{array}{c}\text { Centro de Estudos e Defesa da } \\
\text { Cidadania, Direitos Humanos } \\
\text { e Segurança Pública } \\
\text { (CEDESP) }\end{array}$ & $\begin{array}{c}\text { Violência policial } \\
\text { urbana } \\
\text { Denegação de justiça }\end{array}$ & $\begin{array}{c}\text { Convenção: Arts. 1.1, } \\
4,5,8.1 \text { e } 25.1\end{array}$ & $\begin{array}{c}\text { Pós- } \\
\text { Admissibilidade }\end{array}$ \\
\hline RJ & 12.858 & $\begin{array}{l}\text { Marcio Manoel } \\
\text { Fraga }\end{array}$ & 04.06 .2001 & 27.03.1999 & Sra. Nancy Victor da Silva & $\begin{array}{c}\text { Violência contra } \\
\text { detento } \\
\text { Detento morto em } \\
\text { decorrência de pouco } \\
\text { caso e precárias } \\
\text { condições do hospital } \\
\text { e da polícia }\end{array}$ & $\begin{array}{c}\text { Convenção } \\
\text { Americana: arts. } 4,8 \\
\text { e } 25\end{array}$ & $\begin{array}{c}\text { Jun/2010: Estado } \\
\text { brasileio envia } \\
\text { informações à } \\
\text { OEA } \\
\text { Dez/2010: Estado } \\
\text { brasileio envia } \\
\text { informações à } \\
\text { OEA } \\
\text { Jul/2011: OEA } \\
\text { envia informações } \\
\text { ao Estado } \\
\text { brasilerio }\end{array}$ \\
\hline SP & 12.835 & $\begin{array}{l}\text { Maurício } \\
\text { Hernández } \\
\text { Norambuena }\end{array}$ & 11.05 .2005 & 03.02 .2002 & $\begin{array}{l}\text { Sra. Cecilia Adriana } \\
\text { Hernández Norabuena }\end{array}$ & $\begin{array}{l}\text { Detenção, tortura, } \\
\text { tratamento desumano } \\
\text { em penitenciária. }\end{array}$ & $\begin{array}{c}\text { Convenção } \\
\text { Americana: artigos } \\
25.2 \text { e } 33 . \\
\text { Regulamento da } \\
\text { Convenção } \\
\text { Americana: artigos } \\
23 \text { em diante. }\end{array}$ & $\begin{array}{c}\text { Pós- } \\
\text { Admissibilidade }\end{array}$ \\
\hline
\end{tabular}




\begin{tabular}{|c|c|c|c|c|c|c|c|c|}
\hline \multicolumn{9}{|c|}{ MÉRITO } \\
\hline UF & $\begin{array}{l}\mathrm{N}^{\circ} \mathrm{do} \\
\text { Processo }\end{array}$ & Caso & $\begin{array}{l}\text { Data de Início } \\
\text { do Trâmite }\end{array}$ & $\begin{array}{l}\text { Data da Alegada } \\
\text { Violação }\end{array}$ & Peticionários & Tema & Artigos Invocados & Fase \\
\hline RJ & 12.970 & $\begin{array}{l}\text { Mario de Almeida } \\
\text { Coelho Filho }\end{array}$ & $24 / 04 / 2006$ & 16.08 .2001 & $\begin{array}{l}\text { Sociedade Interamericana de } \\
\text { Imprensa (SIP) }\end{array}$ & $\begin{array}{l}\text { Assassinato de } \\
\text { jornalista com suposta } \\
\text { participação de } \\
\text { políticos }\end{array}$ & $\begin{array}{c}\text { Convenção } \\
\text { Americana: arts. } 4,8 \text {, } \\
13 \text { e } 25\end{array}$ & \begin{tabular}{|c} 
Jan/2010: Estado \\
brasileiro envia \\
informações acerca \\
da admissibilidade. \\
Out/2013: \\
Peticionários \\
enviam \\
informações \\
adicionais \\
Set/2014: CIDH \\
aprova o Relatório \\
de Admissibilidade \\
$\mathrm{n}^{\circ} 74 / 14$
\end{tabular} \\
\hline SP & 12.876 & $\begin{array}{l}\text { Moradores do } \\
\text { Conjunto } \\
\text { Habitacional } \\
\text { Barão de Mauá } \\
\text { (CHBM) }\end{array}$ & $21 / 02 / 2006$ & 2001 & $\begin{array}{l}\text { Instituto Barão de Mauá. } \\
\text { Aurélio Alexandre Esteimber } \\
\text { Pereira Okaida, advogado } \\
\text { representando todas as } \\
\text { supostas vítimas }\end{array}$ & $\begin{array}{c}\text { Crime ambiental: } \\
\text { degradação ambiental } \\
\text { e risco de vida humana } \\
\text { e da integridade e } \\
\text { saúde dos moradores } \\
\text { do CHBM }\end{array}$ & $\begin{array}{c}\text { Convenção } \\
\text { Americana: art. } 4, \\
5.1,8,13,21 \text { e } 25\end{array}$ & $\begin{array}{c}\text { Pós- } \\
\text { Admissibilidade }\end{array}$ \\
\hline SP & 12.751 & $\begin{array}{l}\text { Nélio Nakamura } \\
\text { Brandão e } \\
\text { Alexandre } \\
\text { Azevedo }\end{array}$ & $17 / 02 / 2006$ & $13 / 09 / 2004$ & $\begin{array}{c}\text { Fundação Interamericana de } \\
\text { Direitos Humanos }\end{array}$ & $\begin{array}{c}\text { Violência policial } \\
\text { urbana } \\
\text { Execução sumária } \\
\text { Denegação de justiça: } \\
\text { demora excessiva. }\end{array}$ & $\begin{array}{c}\text { Convenção: arts. } 1.1 \text {, } \\
4.1,5.1,5.2,7.1,8.2 \\
\text { e } 24\end{array}$ & $\begin{array}{c}\text { Pós- } \\
\text { Admissibilidade }\end{array}$ \\
\hline
\end{tabular}




\begin{tabular}{|c|c|c|c|c|c|c|c|c|}
\hline \multicolumn{9}{|c|}{ MÉRITO } \\
\hline UF & $\begin{array}{c}\mathrm{N}^{0} \text { do } \\
\text { Processo }\end{array}$ & Caso & $\begin{array}{l}\text { Data de Início } \\
\text { do Trâmite }\end{array}$ & $\begin{array}{l}\text { Data da Alegada } \\
\text { Violação }\end{array}$ & Peticionários & Tema & Artigos Invocados & Fase \\
\hline SP & 12.571 & $\begin{array}{l}\text { Neusa dos Santos } \\
\text { Nascimento e } \\
\text { Gisele Ana } \\
\text { Ferreira }\end{array}$ & $08 / 12 / 2003$ & 26.03 .1998 & $\begin{array}{l}\text { Instituto da Mulher Negra } \\
\text { (Geledés) }\end{array}$ & $\begin{array}{c}\text { Racismo } \\
\text { Discriminação de } \\
\text { gênero } \\
\text { Denegação de justiça }\end{array}$ & $\begin{array}{c}\text { Convenção: arts. } 1,8, \\
24 \text { e } 25 .\end{array}$ & $\begin{array}{l}\text { Informações } \\
\text { Adicionais de } \\
\text { Mérito }\end{array}$ \\
\hline SP & 11.414 & $\begin{array}{l}\text { Ozeas Antônio } \\
\text { dos Santos }\end{array}$ & 13/12/1994 & 01/09/1994 & $\begin{array}{l}\text { Centro de Direitos Humanos } \\
\text { da Arquidiocese de São Paulo }\end{array}$ & $\begin{array}{c}\text { Violência policial } \\
\text { urbana } \\
\text { Homicídio }\end{array}$ & $\begin{array}{c}\text { Declaração: XVIII e } \\
\text { XIX } \\
\text { Convenção: } 8.1 \mathrm{e} \\
25.1\end{array}$ & $\begin{array}{l}\text { Informações } \\
\text { Adicionais de } \\
\text { Mérito }\end{array}$ \\
\hline PE & $\begin{array}{c}12.875 \\
(\mathrm{P}-1330-07)\end{array}$ & $\begin{array}{l}\text { Pedro Augusto da } \\
\text { Silva e outros }\end{array}$ & 27.03.2008 & $\begin{array}{l}05.06 .1997 \text { (data dos } \\
\text { crimes) perdurando } \\
\text { até, no mínimo, a data } \\
\text { de início de trâmite }\end{array}$ & $\begin{array}{l}\text { Rede Social de Justiça } \\
\text { Comissão Pastoral da Terra }\end{array}$ & $\begin{array}{l}\text { Demora na apuração } \\
\text { de casos de homicídio } \\
\text { e tentativa de } \\
\text { homicídio }\end{array}$ & $\begin{array}{c}\text { Convenção } \\
\text { Americana: arts. 4, 5, } \\
\text { 8, } 19 \text { e } 25\end{array}$ & $\begin{array}{c}\text { jul/2008: Estado } \\
\text { brasileiro envia } \\
\text { observações sobre } \\
\text { admissibilidade à } \\
\text { CIDH. } \\
\text { Jul/2012: O } \\
\text { relatório n. } 70 / 12 \\
\text { acata a petição n. } \\
\text { 1330-07 sobre } \\
\text { Pedro Augusto da } \\
\text { Silva, Inácio José } \\
\text { da Silva e outros } \\
\text { sob o número de } \\
\text { Caso } 12.875 .\end{array}$ \\
\hline SP & 12.836 & $\begin{array}{l}\text { Pedro Stábile } \\
\text { Neto e outros }\end{array}$ & 02.10 .2006 & Dezembro de 1999 & Sr. Pedro Stábile Neto & $\begin{array}{l}\text { Não pagamento de } \\
\text { indenização pelo } \\
\text { Estado }\end{array}$ & $\begin{array}{c}\text { Declaração } \\
\text { Americana arts.: XI, } \\
\text { XIV, XVIII. } \\
\text { Convenção arts. 1.1, } \\
2,8,11 \text { e } 25 .\end{array}$ & $\begin{array}{c}\text { Pós- } \\
\text { Admissibilidade }\end{array}$ \\
\hline
\end{tabular}




\begin{tabular}{|c|c|c|c|c|c|c|c|c|}
\hline \multicolumn{9}{|c|}{ MÉRITO } \\
\hline UF & $\begin{array}{c}\mathrm{N}^{\mathbf{o}} \text { do } \\
\text { Processo }\end{array}$ & Caso & $\begin{array}{l}\text { Data de Início } \\
\text { do Trâmite }\end{array}$ & $\begin{array}{l}\text { Data da Alegada } \\
\text { Violação }\end{array}$ & Peticionários & Tema & Artigos Invocados & Fase \\
\hline SP & 12.654 & $\begin{array}{c}\text { Pessoas privadas } \\
\text { de liberdade na } \\
\text { Cadeia Pública do } \\
\text { Guarujá }\end{array}$ & $18 / 04 / 2007$ & 1999 até o presente & $\begin{array}{c}\text { Associação Conectas Direitos } \\
\text { Humanos } \\
\text { Instituto Pro Bono } \\
\text { Conselho Comunitário } \\
\text { Penitenciário de Guarujá e } \\
\text { Vicente de Carvalho } \\
\end{array}$ & $\begin{array}{c}\text { Violência contra } \\
\text { detentos; } \\
\text { Maus-tratos e } \\
\text { condições degradantes } \\
\text { em penitenciárias. }\end{array}$ & $\begin{array}{c}\text { Convenção } \\
\text { Americana: } 1.1,4,5, \\
19 \text { e } 25 . \\
\text { Convençãa de Belém } \\
\text { do Pará: art. } 7 .\end{array}$ & $\begin{array}{c}\text { Informações } \\
\text { Adicionais de } \\
\text { Mérito }\end{array}$ \\
\hline RJ & 12.613 & $\begin{array}{c}\text { Pessoas privadas } \\
\text { de liberdade na } \\
\text { carceragem de } 76^{\mathrm{a}} \\
\text { Delegacia de } \\
\text { Polícia }\left(76^{\circ} \mathrm{DP}\right)\end{array}$ & $14 / 06 / 2006$ & 2006 & $\begin{array}{c}\text { Justiça Global } \\
\text { Associação Pela Reforma } \\
\text { Prisional (ARP) } \\
\text { Grupo Tortura Nunca Mais do } \\
\text { Rio de Janeiro } \\
\text { Associação dos Defensores } \\
\text { Públicos do Estado do Rio de } \\
\text { Janeiro (APDERJ) } \\
\text { Laboratório de Análise de } \\
\text { Violência da Universidade do } \\
\text { Estado do Rio de Janeiro }\end{array}$ & Sistema prisional & $\begin{array}{l}\text { Convenção:arts. } 1.1 \\
2,5,8.1 \text { e } 25 .\end{array}$ & $\begin{array}{c}\text { Informações } \\
\text { Adicionais de } \\
\text { Mérito }\end{array}$ \\
\hline RO & 12.568 & $\begin{array}{c}\text { Pessoas privadas } \\
\text { de liberdade no } \\
\text { Presídio de Urso } \\
\text { Branco } \\
\end{array}$ & 05/06/2002 & 01/01/2002 & $\begin{array}{l}\text { Justiça Global } \\
\text { Comissão de Justiça e Paz da } \\
\text { Arquidiocese de Porto Velho }\end{array}$ & Sistema prisional & $\begin{array}{l}\text { Convenção: arts. } 1.1 \text {, } \\
2,4,5,8 \text { e } 25.1\end{array}$ & $\begin{array}{c}\text { Informações } \\
\text { Adicionais de } \\
\text { Mérito }\end{array}$ \\
\hline $\mathrm{PE}$ & 12.728 & $\begin{array}{l}\text { Povo Indígena } \\
\text { Xucuru } \\
\text { (Município de } \\
\text { Pesqueira) }\end{array}$ & $16 / 10 / 2002$ & 1989 até o momento & $\begin{array}{c}\text { Movimento Nacional de } \\
\text { Direitos Humanos/Regional } \\
\text { Nordeste } \\
\text { Gabinete de Assessoria } \\
\text { Jurídica às Organizações } \\
\text { Populares (GAJOP) } \\
\text { Conselho Indigenista } \\
\text { Missionário (CIMI) }\end{array}$ & $\begin{array}{c}\text { Indígenas } \\
\text { Violação do direito de } \\
\text { propriedade: demora } \\
\text { injustificada na } \\
\text { demarcação de terras }\end{array}$ & $\begin{array}{c}\text { Convenção: Arts. 1.1, } \\
2,8,21 \text { e } 25\end{array}$ & $\begin{array}{c}\text { Informações } \\
\text { Adicionais de } \\
\text { Mérito }\end{array}$ \\
\hline
\end{tabular}




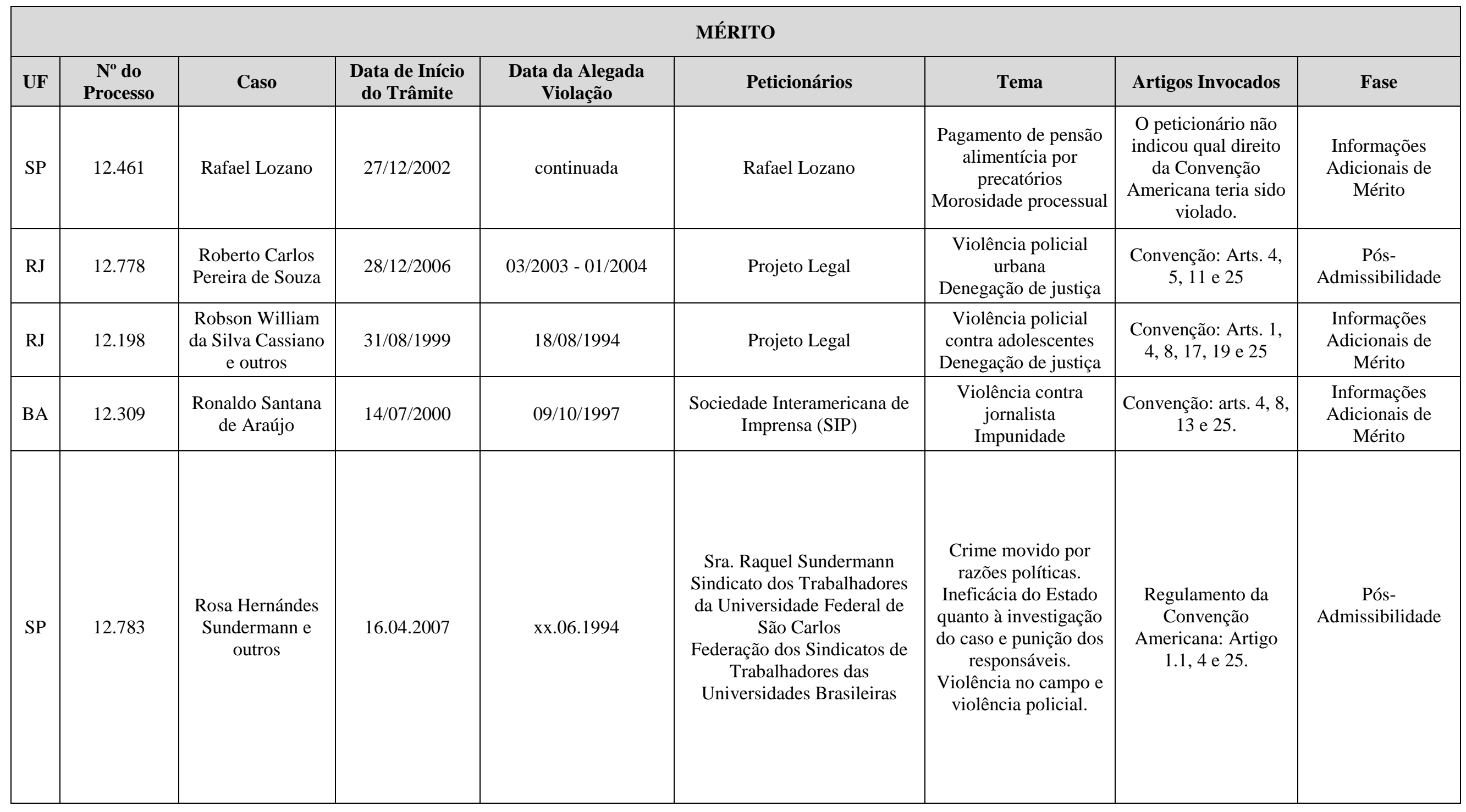




\begin{tabular}{|c|c|c|c|c|c|c|c|c|}
\hline \multicolumn{9}{|c|}{ MÉRITO } \\
\hline UF & $\begin{array}{l}\mathrm{N}^{\circ} \text { do } \\
\text { Processo }\end{array}$ & Caso & $\begin{array}{c}\text { Data de Início } \\
\text { do Trâmite }\end{array}$ & $\begin{array}{c}\text { Data da Alegada } \\
\text { Violação } \\
\end{array}$ & Peticionários & Tema & Artigos Invocados & Fase \\
\hline RS & 12.725 & $\begin{array}{l}\text { Samanta Nunes da } \\
\text { Silva }\end{array}$ & $25 / 04 / 2003$ & 15/10/1997 & $\begin{array}{l}\text { THEMIS - Assessoria Jurídica } \\
\text { e Estudos de Gênero }\end{array}$ & $\begin{array}{l}\text { Violência contra a } \\
\text { mulher } \\
\text { Denegação de justiça: } \\
\text { falhas na investigação } \\
\text { de crime sexual } \\
\text { cometido por médico } \\
\text { no exercício da } \\
\text { profissão contra } \\
\text { vítima, que era menor } \\
\text { e afro-descendente }\end{array}$ & $\begin{array}{c}\text { Convenção de Belém } \\
\text { do Pará: arts. } 1,2,3, \\
4 \text { e } 7 \\
\text { Convenção } \\
\text { Americana: arts. } 8.1, \\
\text { 19, 24, } 25\end{array}$ & $\begin{array}{c}\text { Pós- } \\
\text { Admissibilidade }\end{array}$ \\
\hline RJ & 12.782 & $\begin{array}{l}\text { Thalita Carvalho } \\
\text { de Mello e outros }\end{array}$ & $26 / 12 / 2006$ & 10/10/1998 & Projeto Legal & $\begin{array}{c}\text { Violência policial } \\
\text { urbana } \\
\text { Denegação de justiça }\end{array}$ & $\begin{array}{l}\text { Convenção: Arts. } 4, \\
5,11 \text { e } 25\end{array}$ & $\begin{array}{c}\text { Pós- } \\
\text { Admissibilidade }\end{array}$ \\
\hline SP & 12.879 & Vladimir Herzog & 29.03 .2012 & 25.10 .1985 & $\begin{array}{c}\text { CEJIL, Fundação } \\
\text { Interamericana de Defesa, } \\
\text { Centro Santo Dias de Direitos } \\
\text { Humanos na Arquidiocese de } \\
\text { São Paulo, Grupo Tortura } \\
\text { Nunca Mais }\end{array}$ & $\begin{array}{c}\text { Detenção arbitrária, } \\
\text { Tortura, Execução } \\
\text { Sumária, Lei de } \\
\text { Anistia }\end{array}$ & $\begin{array}{c}\text { Declaração arts: I, } \\
\text { XVIII, XXV, XXVI. } \\
\text { Convenção } \\
\text { Americana art. } 1,2, \\
5,8 \text { e } 25 . \text { Convenção } \\
\text { Interamericana para } \\
\text { previnir e punir a } \\
\text { tortura: art. } 1,6 \text { e } 8 .\end{array}$ & $\begin{array}{c}\text { Pós- } \\
\text { Admissibilidade }\end{array}$ \\
\hline MG & 12.212 & $\begin{array}{l}\text { Zaqueu de } \\
\text { Oliveira }\end{array}$ & 21/10/1999 & 21/03/1995 & $\begin{array}{l}\text { Sociedade Interamericana de } \\
\text { Imprensa (SIP) }\end{array}$ & $\begin{array}{l}\text { Violência contra } \\
\text { jornalista } \\
\text { Impunidade }\end{array}$ & $\begin{array}{c}\text { Convenção: } 4,8,13 \mathrm{e} \\
25\end{array}$ & $\begin{array}{l}\text { Informações } \\
\text { Adicionais de } \\
\text { Mérito }\end{array}$ \\
\hline
\end{tabular}




\begin{tabular}{|c|c|c|c|c|c|c|c|c|}
\hline \multicolumn{9}{|c|}{ MÉRITO } \\
\hline UF & $\begin{array}{c}\mathbf{N}^{0} \text { do } \\
\text { Processo }\end{array}$ & Caso & $\begin{array}{l}\text { Data de Início } \\
\text { do Trâmite }\end{array}$ & $\begin{array}{l}\text { Data da Alegada } \\
\text { Violaçãa }\end{array}$ & Peticionários & Tema & Artigos Invocados & Fase \\
\hline RR & 12.781 & $\begin{array}{l}\text { Povos Indígenas } \\
\text { da Raposa Serra } \\
\text { do Sol }\end{array}$ & $29 / 03 / 2004$ & 2004 & $\begin{array}{c}\text { Conselho Indígena de Roraima } \\
\text { - CIR } \\
\text { Rainforest Foundation US }\end{array}$ & \begin{tabular}{|} 
Indígenas \\
Restrições ao direito \\
de circulação e \\
residência, liberdade \\
de religião e direito a \\
exercer sua cultura \\
Decisão do STF que \\
violou o direito à \\
propriedade comunal e \\
o direito à consulta \\
prévia dos povos \\
indígenas.
\end{tabular} & $\begin{array}{l}\text { Declaração: arts. I, II, } \\
\text { III, VIII, IX, XVIII e } \\
\text { XXIII; } \\
\text { Convenção: arts. } 1.1 \text {, } \\
2,4,5,8,12,21,22, \\
24 \text { e } 25 .\end{array}$ & $\begin{array}{c}8 \text { maio/2012: } \\
\text { Manifestação da } \\
\text { CIDH sobre o } \\
\text { caso. Pede } \\
\text { considerações } \\
\text { brasileiras sobre o } \\
\text { caso até } 18 / 06 \\
\text { Maio/2012: } \\
\text { peticionários } \\
\text { encontram } \\
\text { informação do } \\
\text { Governo de } \\
\text { out/2010 que não } \\
\text { havia sido } \\
\text { transmitida a eles } \\
\text { nem à Comissão. } \\
18 \text { junho/ 2012. } \\
\text { Brasil solicita } \\
\text { prorrogação de } 15 \\
\text { dias para o prazo } \\
\text { de resposta, o que } \\
\text { é acatado pela } \\
\text { CIDH. } 2 \\
\text { julho/2012. CIDH } \\
\text { estabelece novo } \\
\text { prazo para } \\
\text { manifestação } \\
\text { brasileira para } 24 \\
\text { de julho de } 2012 . \\
\text { O Brasil NÃO } \\
\text { RESPONDEU ao } \\
\text { último relatório. }\end{array}$ \\
\hline
\end{tabular}




\begin{tabular}{|c|c|c|c|c|c|c|c|c|}
\hline \multicolumn{9}{|c|}{ MÉRITO } \\
\hline UF & $\begin{array}{l}\mathrm{N}^{\circ} \mathrm{do} \\
\text { Processo }\end{array}$ & Caso & $\begin{array}{l}\text { Data de Início } \\
\text { do Trâmite }\end{array}$ & $\begin{array}{l}\text { Data da Alegada } \\
\text { Violação }\end{array}$ & Peticionários & Tema & Artigos Invocados & Fase \\
\hline PB & 12.332 & $\begin{array}{c}\text { Margarida Maria } \\
\text { Alves }\end{array}$ & 17.11 .2000 & 12.08 .1983 & $\begin{array}{c}\text { Centro pela Justiça e o Direito } \\
\text { Internacional (CEJIL) } \\
\text { Movimento Nacional de } \\
\text { Direitos Humanos (MNDH) } \\
\text { Gabinete da Assessoria } \\
\text { Jurídica às Organizações } \\
\text { Populares (GAJOP) } \\
\text { Comissão Pastoral da Terra } \\
\text { (CPT) } \\
\text { Fundação de Defesa dos } \\
\text { Direitos Humanos Margarida } \\
\text { Maria Alves (FDDH-MMA) }\end{array}$ & $\begin{array}{c}\text { Assassinato de } \\
\text { trabalhadora rural; } \\
\text { Violência do campo; } \\
\text { Violência contra a } \\
\text { mulher; } \\
\text { Impunidade e violação } \\
\text { de garantias judiciais. }\end{array}$ & $\begin{array}{l}\text { Declaração: arts. I e } \\
\text { XII; } \\
\text { Convençãa: arts. 1.1, } \\
\text { 8 e } 25 .\end{array}$ & $\begin{array}{c}\text { 2003: absolvição } \\
\text { do único réu em } \\
\text { julgamento pelo } \\
\text { assassinato, } \\
\text { ocorrido em 1983; } \\
\text { Jun/2008: } \\
\text { Comissão se } \\
\text { coloca à disposição } \\
\text { para solução } \\
\text { amistosa } \\
\text { Nov/2008: } \\
\text { Procuradoria-Geral } \\
\text { do Estado da } \\
\text { Paraíba informa } \\
\text { que ainda há } \\
\text { pendências } \\
\text { processuais } \\
\text { referentes ao caso, } \\
\text { com o processo de } \\
\text { captura de dois } \\
\text { reús acusados do } \\
\text { homicídio; } \\
\text { Nov/2008: SDH } \\
\text { convoca } \\
\text { Procuradoria-Geral } \\
\text { do Estado da } \\
\text { Paraíba para } \\
\text { reunião de trabalho } \\
\text { em Brasília, para } \\
\text { discussão da } \\
\text { possibilidade de } \\
\text { solução amistosa. }\end{array}$ \\
\hline
\end{tabular}




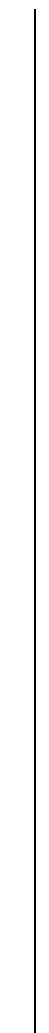

Nov/2011: CEJIL

cobra solução

amistosa para o

caso.

Jul/2012: CIDH

solicitou aos

peticionários suas

observações

adicionais quanto

ao mérito

Out 2012: CEJIL

pronuncia-se sobre

o mérito.

Nov/2012:

Observações dos

peticionários

quanto ao mérito.

Avaliando a

necessidade de

encaminhamentos

substanciais, por

decisão da chefia

da AI/SDH e dep.

jurídico, o Brasil

ainda não enviou à CIDH seu relatório 


\begin{tabular}{|c|c|c|c|c|c|c|c|c|}
\hline \multicolumn{9}{|c|}{ CUMPRIMENTO DE RECOMENDAÇÕES } \\
\hline UF & $\begin{array}{c}\mathbf{N}^{\mathbf{o}} \text { do } \\
\text { Processo }\end{array}$ & Caso & $\begin{array}{l}\text { Data de Iń́cio } \\
\text { do Trâmite }\end{array}$ & $\begin{array}{l}\text { Data da Alegada } \\
\text { Violação }\end{array}$ & Peticionários & Tema & Artigos Invocados & Fase \\
\hline SP & 11.286 & $\begin{array}{l}\text { Aluísio } \\
\text { Cavalcanti e } \\
\text { outros }\end{array}$ & 1994 & 04/03/1987 & $\begin{array}{c}\text { Centro Santos Dias de Direitos } \\
\text { Humanos da Arquidiocese de } \\
\text { São Paulo }\end{array}$ & $\begin{array}{l}\text { Violência policial } \\
\text { urbana } \\
\text { Execução sumária }\end{array}$ & $\begin{array}{c}\text { Declaração: I, XVIII e } \\
\text { XIX } \\
\text { Convenção: } 1.1,8 \text { e } 25\end{array}$ & $\begin{array}{l}\text { Cumprimento de } \\
\text { Recomendações }\end{array}$ \\
\hline $\mathrm{CE}$ & 12.019 & $\begin{array}{c}\text { Antônio Ferreira } \\
\text { Braga }\end{array}$ & $11 / 06 / 1998$ & 1993 & $\begin{array}{l}\text { Centro pela Justiça e o Direito } \\
\text { Internacional (CEJIL) } \\
\text { Centro de Defesa e Promoção } \\
\text { dos Direitos Humanos da } \\
\text { Arquidiocese de Fortaleza } \\
\text { Centro de Defesa da Vida } \\
\text { Herbert de Sousa } \\
\text { Antônio Ferreira Braga }\end{array}$ & $\begin{array}{c}\text { Violência policial } \\
\text { urbana } \\
\text { Tortura } \\
\text { Confissão induzida } \\
\text { Denegação de justiça }\end{array}$ & $\begin{array}{c}\text { Declaração: arts. I, II, } \\
\text { V, IX, XV e XXIII; } \\
\text { Convenção: arts. 4, 5, } 7 \\
\text { e } 11 . \\
\text { Convenção } \\
\text { Interamericana para } \\
\text { Prevenir e Punir a } \\
\text { Tortura: } 1 \text { e } 6 .\end{array}$ & $\begin{array}{l}\text { Cumprimento de } \\
\text { Recomendações }\end{array}$ \\
\hline RO & 11.556 & Corumbiara & $06 / 10 / 1995$ & 1995 & $\begin{array}{l}\text { Centro pela Justiça e o Direito } \\
\text { Internacional (CEJIL) } \\
\text { Centro de Defesa e Promoção } \\
\text { dos Direitos Humanos da } \\
\text { Arquidiocese de Porto Velho } \\
\text { Comissão Teotônio Vilela de } \\
\text { Direitos Humanos } \\
\text { Movimento dos Trabalhadores } \\
\text { Rurais Sem Terra (MST) } \\
\text { Human Rights Watch/Américas }\end{array}$ & $\begin{array}{c}\text { Violência policial no } \\
\text { campo } \\
\text { Tortura } \\
\text { Denegação de justiça }\end{array}$ & $\begin{array}{c}\text { Convenção: arts. } 1.1,4 \text {, } \\
5,8 \text { e } 25 . \\
\text { Convenção } \\
\text { Interamericana para } \\
\text { Prevenir e Punir a } \\
\text { Tortura: arts. } 1,6 \text { e } 8 .\end{array}$ & $\begin{array}{l}\text { Cumprimento de } \\
\text { Recomendações }\end{array}$ \\
\hline
\end{tabular}




\begin{tabular}{|c|c|c|c|c|c|c|c|c|}
\hline \multicolumn{9}{|c|}{ CUMPRIMENTO DE RECOMENDAÇÕES } \\
\hline UF & $\begin{array}{c}N^{\circ} \text { do } \\
\text { Processo }\end{array}$ & Caso & $\begin{array}{c}\text { Data de Início } \\
\text { do Trâmite }\end{array}$ & $\begin{array}{l}\text { Data da Alegada } \\
\text { Violação }\end{array}$ & Peticionários & Tema & Artigos Invocados & Fase \\
\hline PR & 11.517 & $\begin{array}{l}\text { Diniz Bento da } \\
\text { Silva } \\
\text { (Teixeirinha) }\end{array}$ & 05/07/1995 & 1993 & $\begin{array}{l}\text { Centro pela Justiça e o Direito } \\
\text { Internacional (CEJIL) } \\
\text { Human Rights Watch/Americas }\end{array}$ & $\begin{array}{c}\text { Violência policial no } \\
\text { campo } \\
\text { Denegação de justiça }\end{array}$ & $\begin{array}{c}\text { Convenção: arts. } 4,8, \mathrm{e} \\
25 .\end{array}$ & $\begin{array}{l}\text { Cumprimento de } \\
\text { Recomendações }\end{array}$ \\
\hline RJ & 11.566 & $\begin{array}{c}\text { Favela Nova } \\
\text { Brasília (Evandro } \\
\text { Oliveira e outros) }\end{array}$ & $18 / 04 / 2000$ & 08/05/1995 & $\begin{array}{l}\text { Centro pela Justiça e o Direito } \\
\text { Internacional (CEJIL) } \\
\text { Human Rights Watch/Americas }\end{array}$ & $\begin{array}{c}\text { Violência policial } \\
\text { urbana } \\
\text { Denegação de } \\
\text { justiça: impunidade } \\
\text { e arquivamento de } \\
\text { inquérito }\end{array}$ & $\begin{array}{c}\text { Convenção: arts. } 4,8 \text { e } \\
25\end{array}$ & $\begin{array}{l}\text { Cumprimento de } \\
\text { Recomendações }\end{array}$ \\
\hline PA & 12.066 & $\begin{array}{l}\text { Fazenda Brasil } \\
\text { Verde }\end{array}$ & & 1988 & $\begin{array}{l}\text { CEJIL } \\
\text { CPT }\end{array}$ & $\begin{array}{c}\text { Escravidão } \\
\text { Desaparecimento } \\
\text { forçado } \\
\text { Denegação de justiça }\end{array}$ & $\begin{array}{l}\text { Declaração Americana: } \\
\text { arts. I, XIV e XXV. } \\
\text { Convenção: arts. } 6,8, \\
25 .\end{array}$ & $\begin{array}{l}\text { Cumprimento de } \\
\text { Recomendações }\end{array}$ \\
\hline RJ & 11.634 & $\begin{array}{l}\text { Jaílton Néri da } \\
\text { Fonseca }\end{array}$ & $07 / 12 / 1995$ & 1992 & $\begin{array}{l}\text { Centro pela Justiça e o Direito } \\
\text { Internacional (CEJIL) } \\
\text { Centro de Defesa Dom Luciano } \\
\text { Mendes da Associação } \\
\text { Beneficiente São Martinho }\end{array}$ & $\begin{array}{l}\text { Violência policial } \\
\text { contra } \\
\text { criança/adolescente } \\
\text { Execução }\end{array}$ & $\begin{array}{c}\text { Convenção: arts. } 4,8, \\
19 \text { e } 25 .\end{array}$ & $\begin{array}{l}\text { Cumprimento de } \\
\text { Recomendações }\end{array}$ \\
\hline PA & 11.287 & $\begin{array}{l}\text { João Canuto de } \\
\text { Oliveira }\end{array}$ & $27 / 05 / 1994$ & 1985 & $\begin{array}{l}\text { Centro pela Justiça e o Direito } \\
\text { Internacional (CEJIL) }\end{array}$ & Violência no campo & Convenção: 8 e 25. & $\begin{array}{l}\text { Informações } \\
\text { Adicionais de } \\
\text { Mérito }\end{array}$ \\
\hline
\end{tabular}




\begin{tabular}{|c|c|c|c|c|c|c|c|c|}
\hline \multicolumn{9}{|c|}{ CUMPRIMENTO DE RECOMENDAÇÕES } \\
\hline UF & $\begin{array}{c}\mathbf{N}^{0} \text { do } \\
\text { Processo }\end{array}$ & Caso & $\begin{array}{l}\text { Data de Início } \\
\text { do Trâmite }\end{array}$ & $\begin{array}{l}\text { Data da Alegada } \\
\text { Violação }\end{array}$ & Peticionários & Tema & Artigos Invocados & Fase \\
\hline PA & 11.289 & $\begin{array}{l}\text { José Pereira e } \\
\quad \text { outros }\end{array}$ & $16 / 11 / 1994$ & 1989 & $\begin{array}{l}\text { Centro pela Justiça e o Direito } \\
\text { Internacional (CEJIL) } \\
\text { Human Rights Watch/Americas }\end{array}$ & $\begin{array}{l}\text { Violência no campo } \\
\text { Escravidão } \\
\text { Denegação de justiça }\end{array}$ & $\begin{array}{l}\text { Declaração: arts. I, XIV } \\
\text { e XXV. } \\
\text { Convenção: arts. } 1.1,6, \\
\text { 8 e } 25 .\end{array}$ & $\begin{array}{l}\text { Cumprimento de } \\
\text { Recomendações }\end{array}$ \\
\hline BA & 12.308 & $\begin{array}{l}\text { Manoel Leal de } \\
\text { Oliveira }\end{array}$ & $25 / 05 / 2000$ & 14/01/1998 & $\begin{array}{l}\text { Sociedade Interamericana de } \\
\text { Imprensa (SIP) }\end{array}$ & $\begin{array}{l}\text { Violência contra } \\
\text { jornalista por } \\
\text { particulares } \\
\text { Denegação de } \\
\text { justiça: impunidade }\end{array}$ & $\begin{array}{c}\text { Convenção: } 1.1,4,8,13 \\
\text { e } 25 .\end{array}$ & \\
\hline $\mathrm{CE}$ & 12.051 & $\begin{array}{l}\text { Maria da Penha } \\
\text { Fernandes }\end{array}$ & 20/08/1998 & 1983 & $\begin{array}{l}\text { Centro pela Justiça e o Direito } \\
\text { Internacional (CEJIL) } \\
\text { Comitê Latino-Americano de } \\
\text { Defesa dos Direitos da Mulher } \\
\text { (CLADEM) }\end{array}$ & $\begin{array}{l}\text { Violência contra as } \\
\text { mulheres } \\
\text { Impunidade }\end{array}$ & \begin{tabular}{|} 
Declaração: arts. II e \\
XVIII \\
Convenção Americana: \\
1.1, 8,24 e 25. \\
Convenção de Belém do \\
Pará: 7 e 12.
\end{tabular} & $\begin{array}{l}\text { Cumprimento de } \\
\text { Recomendações }\end{array}$ \\
\hline PA & 11.405 & $\begin{array}{l}\text { Newton Coutinho } \\
\text { Mendes }\end{array}$ & 18/11/1994 & 1994 & $\begin{array}{l}\text { Centro pela Justiça e o Direito } \\
\text { Internacional (CEJIL) }\end{array}$ & $\begin{array}{l}\text { Violência no campo } \\
\text { Defensores de } \\
\text { direitos humanos }\end{array}$ & Convenção: $4,5,8$ e 25 & $\begin{array}{l}\text { Cumprimento de } \\
\text { Recomendações }\end{array}$ \\
\hline $\mathrm{RR}$ & 11.516 & Ovelário Tames & 1999 & 1998 & $\begin{array}{l}\text { Centro pela Justiça e o Direito } \\
\text { Internacional (CEJIL) }\end{array}$ & $\begin{array}{l}\text { Violência policial } \\
\text { contra indígenas }\end{array}$ & $\begin{array}{c}\text { Declaração: arts. I, } \\
\text { XVIII e XXV } \\
\text { Convenção: } 1.1,8 \text { e } 25 .\end{array}$ & $\begin{array}{l}\text { Cumprimento de } \\
\text { Recomendações }\end{array}$ \\
\hline
\end{tabular}




\begin{tabular}{|c|c|c|c|c|c|c|c|c|}
\hline \multicolumn{9}{|c|}{ CUMPRIMENTO DE RECOMENDAÇÕES } \\
\hline UF & $\begin{array}{c}N^{\circ} \text { do } \\
\text { Processo }\end{array}$ & Caso & $\begin{array}{l}\text { Data de Início } \\
\text { do Trâmite }\end{array}$ & $\begin{array}{l}\text { Data da Alegada } \\
\text { Violação }\end{array}$ & Peticionários & Tema & Artigos Invocados & Fase \\
\hline SP & 10.301 & Parque São Lucas & 07/02/1989 & 1989 & $\begin{array}{l}\text { Centro pela Justiça e o Direito } \\
\text { Internacional (CEJIL) }\end{array}$ & $\begin{array}{l}\text { Violência contra } \\
\text { detentos }\end{array}$ & $\begin{array}{l}\text { Declaração: arts. I e } \\
\text { XVIII } \\
\text { Convenção: arts. 1, } 8 \text { e } \\
25\end{array}$ & $\begin{array}{l}\text { Cumprimento de } \\
\text { Recomendações }\end{array}$ \\
\hline PR & 12.310 & $\begin{array}{c}\text { Sebastião } \\
\text { Camargo Filho }\end{array}$ & $30 / 06 / 2000$ & 07/02/1998 & $\begin{array}{c}\text { Movimento dos Trabalhadores } \\
\text { Rurais Sem Terra (MST) } \\
\text { Comissão Pastoral da Terra } \\
\text { (CPT) } \\
\text { Rede Nacional Autônoma de } \\
\text { Advogados e Advogadas } \\
\text { Populares (RENAAP) } \\
\text { Centro de Justiça Global (CJG) } \\
\text { International Human Rights Law } \\
\text { Group }\end{array}$ & $\begin{array}{l}\text { Violência no campo } \\
\text { (grupos ilegais } \\
\text { armados) } \\
\text { Assassinato de } \\
\text { trabalhador rural } \\
\text { Denegação de } \\
\text { justiça: impunidade }\end{array}$ & $\begin{array}{c}\text { Convenção: arts. } 1.1,4, \\
8 \text { e } 25 .\end{array}$ & $\begin{array}{l}\text { Cumprimento de } \\
\text { Recomendações }\end{array}$ \\
\hline SP & 12.001 & $\begin{array}{l}\text { Simone André } \\
\text { Diniz }\end{array}$ & $10 / 10 / 1997$ & 1997 & $\begin{array}{l}\text { Centro pela Justiça e o Direito } \\
\text { Internacional (CEJIL) } \\
\text { Subcomissão do Negro da } \\
\text { Comissão de Direitos Humanos } \\
\text { da Ordem dos Advogados do } \\
\text { Brasil (OAB/SP) } \\
\text { Instituto do Negro Padre Batista }\end{array}$ & $\begin{array}{c}\text { Racismo } \\
\text { Denegação de justiça }\end{array}$ & $\begin{array}{l}\text { Convenção: arts. 1.1, } \\
8.1,24 \text { e } 25 .\end{array}$ & $\begin{array}{l}\text { Cumprimento de } \\
\text { Recomendações }\end{array}$ \\
\hline
\end{tabular}




\begin{tabular}{|c|c|c|c|c|c|c|c|c|}
\hline \multicolumn{9}{|c|}{ CUMPRIMENTO DE RECOMENDAÇÕES } \\
\hline UF & $\begin{array}{c}\mathrm{N}^{\circ} \text { do } \\
\text { Processo }\end{array}$ & Caso & $\begin{array}{l}\text { Data de Início } \\
\text { do Trâmite }\end{array}$ & $\begin{array}{l}\text { Data da Alegada } \\
\text { Violação }\end{array}$ & Peticionários & Tema & Artigos Invocados & Fase \\
\hline RJ & 12.440 & $\begin{array}{l}\text { Wallace de } \\
\text { Almeida }\end{array}$ & $26 / 12 / 2001$ & $14 / 09 / 1998$ & $\begin{array}{c}\text { Justiça Global } \\
\text { Núcleo de Estudos Negros }\end{array}$ & \begin{tabular}{|c|} 
Violência policial \\
urbana \\
Execução sumária \\
Racismo \\
Denegação de justiça
\end{tabular} & $\begin{array}{c}\text { Convenção: arts. } 1.1,4, \\
5,8,24 \text { e } 25 .\end{array}$ & $\begin{array}{l}\text { Cumprimento de } \\
\text { Recomendações }\end{array}$ \\
\hline
\end{tabular}




\begin{tabular}{|c|c|c|c|c|c|c|c|}
\hline \multicolumn{8}{|c|}{ SOLUÇÃO AMISTOSA } \\
\hline UF & $\begin{array}{c}\mathrm{N}^{\mathbf{o}} \text { do } \\
\text { Processo }\end{array}$ & Caso & $\begin{array}{l}\text { Data de Início do } \\
\text { Trâmite }\end{array}$ & $\begin{array}{l}\text { Data da Alegada } \\
\text { Violação }\end{array}$ & Peticionários & Tema & Artigos Invocados \\
\hline RJ & 12.852 & $\begin{array}{l}\text { Alejandro Daniel } \\
\text { Esteve }\end{array}$ & 16.09 .2004 & & Sr. Alejandro Daniel Esteve & $\begin{array}{l}\text { Pai extraditado e crianças } \\
\text { deixadas para trás } \\
\text { Restituição internacional de } \\
\text { menores }\end{array}$ & $\begin{array}{c}\text { Convenção Americana: arts. } 1, \\
8.1,17,19 \text { e } 25\end{array}$ \\
\hline MT & 12649 & $\begin{array}{l}\text { Armand Lerco e } \\
\text { Alain Rouland }\end{array}$ & $18 / 12 / 2002$ & 1996 & $\begin{array}{l}\text { Armand Lerco e Alain } \\
\text { Rouland }\end{array}$ & $\begin{array}{l}\text { Invasão às terras e violação do } \\
\text { direito à propriedade; } \\
\text { Grilagem de terras. }\end{array}$ & $\begin{array}{c}\text { Conveção: arts. 1.1, 5, 8, 21 e } \\
25 .\end{array}$ \\
\hline $\mathrm{RJ}$ & P-11993 & $\begin{array}{l}\text { Chacina da } \\
\text { Candelária }\end{array}$ & & & Projeto legal & $\begin{array}{l}\text { Violência policial contra crianças } \\
\text { e adolescentes de rua; }\end{array}$ & \\
\hline RR & 12.567 & $\begin{array}{l}\text { Comunidade } \\
\text { Indígena Ananás } \\
\text { e outros }\end{array}$ & 31.01 .2003 & $\begin{array}{l}\text { Violações do direito à } \\
\text { propriedade e livre } \\
\text { circulação: fev e } \\
\text { mar/200 } \\
\text { Violações dos DESC: } \\
\text { até o presente }\end{array}$ & $\begin{array}{c}\text { Centro pela Justiça e o } \\
\text { Direito Internacional } \\
\text { (CEJIL) } \\
\text { Conselho Indígena de } \\
\text { Roraima (CIR) } \\
\text { Comissão de Direitos } \\
\text { Humanos da Diocese de } \\
\text { Roraima } \\
\text { Conselho Indigenista } \\
\text { Missionário (CIMI) }\end{array}$ & $\begin{array}{c}\text { Invasão às terras e violação do } \\
\text { direito à propriedade; } \\
\text { Violação do direito à livre } \\
\text { circulação e à integridade física e } \\
\text { psíquica de indígenas e } \\
\text { missionários; } \\
\text { DESC: Impedimento ao acesso } \\
\text { de serviços públicos básicos } \\
\text { (educação, saúde). }\end{array}$ & $\begin{array}{c}\text { Convenção: arts. 5, 21, 22, 24, } \\
\text { 8, } 25 \text { e 1.1 } \\
\text { Protocolo San Salvador: 13, } 3 \text { e } \\
1\end{array}$ \\
\hline PE & 11.285 & $\begin{array}{l}\text { Edson Damião } \\
\quad \text { Calixto }\end{array}$ & & 1991 & $\begin{array}{l}\text { Centro pela Justiça e o } \\
\text { Direito Internacional } \\
\text { (CEJIL) }\end{array}$ & Violência Policial urbana & \\
\hline
\end{tabular}




\begin{tabular}{|c|c|c|c|c|c|c|c|}
\hline \multicolumn{8}{|c|}{ SOLUÇÃO AMISTOSA } \\
\hline UF & $\begin{array}{c}\mathbf{N}^{\circ} \text { do } \\
\text { Processo }\end{array}$ & Caso & $\begin{array}{c}\text { Data de Início do } \\
\text { Trâmite }\end{array}$ & $\begin{array}{l}\text { Data da Alegada } \\
\text { Violaçãa }\end{array}$ & Peticionários & Tema & Artigos Invocados \\
\hline PA & 11.820 & $\begin{array}{l}\text { Eldorado dos } \\
\text { Carajás }\end{array}$ & $31 / 10 / 1996$ & $17 / 04 / 1996$ & $\begin{array}{l}\text { Centro pela Justiça e o } \\
\text { Direito Internacional } \\
\text { (CEJIL) } \\
\text { Movimento dos } \\
\text { Trabalhadores sem Terra } \\
\text { (MST) }\end{array}$ & Violência policial no campo & $\begin{array}{c}\text { Convenção: arts. } 4,5,8,25,2 \mathrm{e} \\
1.1\end{array}$ \\
\hline PA & 12.277 & Fazenda Ubá & & 1985 & $\begin{array}{c}\text { Centro pela Justiça e o } \\
\text { Direito Internacional } \\
\text { (CEJIL) }\end{array}$ & $\begin{array}{l}\text { Violência no campo } \\
\text { Denegação de justiça }\end{array}$ & \\
\hline PA & 12673 & $\begin{array}{c}\text { José Dutra da } \\
\text { Costa } \\
\text { ("Dezinho") }\end{array}$ & $09 / 12 / 2004$ & $21 / 11 / 2000$ & $\begin{array}{c}\text { Justiça Global } \\
\text { CPT/Marabá } \\
\text { Terra de Direitos } \\
\text { Sindicato dos Trabalhadores } \\
\text { de Rondon do Pará }\end{array}$ & $\begin{array}{l}\text { Violência no campo; } \\
\text { Denegação de justiça. }\end{array}$ & Convenção: 4, 5, 7, 8 e 25. \\
\hline MT & 12.200 & $\begin{array}{c}\text { Juvenal e José } \\
\text { Henrique } \\
\text { Trindade }\end{array}$ & $10 / 02 / 1999$ & 1982 & $\begin{array}{c}\text { Centro pela Justiça e o } \\
\text { Direito Internacional } \\
\text { (CEJIL) } \\
\text { Comissão Pastoral da Terra }\end{array}$ & $\begin{array}{l}\text { Violência no campo por } \\
\text { particulares } \\
\text { Denegação de justiça: demora } \\
\text { injustificada resultou na } \\
\text { prescrição em } 2006 .\end{array}$ & $\begin{array}{l}\text { Declaração: arts. I, IX e XVIII; } \\
\text { Convenção: arts. 1.1, 8.1 e } 25 .\end{array}$ \\
\hline
\end{tabular}




\begin{tabular}{|c|c|c|c|c|c|c|c|}
\hline \multicolumn{8}{|c|}{ SOLUÇÃO AMISTOSA } \\
\hline UF & $\begin{array}{c}\mathrm{N}^{\circ} \text { do } \\
\text { Processo }\end{array}$ & Caso & $\begin{array}{c}\text { Data de Início do } \\
\text { Trâmite }\end{array}$ & $\begin{array}{l}\text { Data da Alegada } \\
\text { Violação }\end{array}$ & Peticionários & Tema & Artigos Invocados \\
\hline RJ & 12674 & $\begin{array}{l}\text { Márcio Lapoente } \\
\text { da Silveira }\end{array}$ & $08 / 12 / 2004$ & 09/10/1990 & & $\begin{array}{c}\text { Tortura; } \\
\text { Violência perpetrada por } \\
\text { militares (AMAN); } \\
\text { Denegação de justiça e demora } \\
\text { injustificada no pagamento de } \\
\text { indenização. }\end{array}$ & $\begin{array}{c}\text { Declaração: arts. I e XVIII; } \\
\text { Convenção Americana: arts. } \\
\text { 1.1, 8.1 e 25; Convenção } \\
\text { Interamericana para Prevenir e } \\
\text { Punir a Tortura: } 1,6,8 \text { e } 9 .\end{array}$ \\
\hline PE & 11.290 & $\begin{array}{l}\text { Roselândio } \\
\text { Borges }\end{array}$ & & 1991 & $\begin{array}{c}\text { Centro pela Justiça e o } \\
\text { Direito Internacional } \\
\text { (CEJIL) }\end{array}$ & Violência Policial urbana & \\
\hline MG & 12.708 & $\begin{array}{c}\text { Silas Abel da } \\
\text { Conceição e } \\
\text { Augusta Tomázia } \\
\text { Inácia }\end{array}$ & $19 / 10 / 2005$ & 22/09/1988 & $\begin{array}{l}\text { Augusta Tomázia Inácia } \\
\text { Elcio Pacheco } \\
\text { Dionara Amparo dos Anjos }\end{array}$ & $\begin{array}{l}\text { Violência policial urbana } \\
\text { Tortura } \\
\text { Execução sumária }\end{array}$ & $\begin{array}{l}\text { Declaração: arts. I e XVIII } \\
\text { Convenção: arts. } 1.1 \text { e } 25\end{array}$ \\
\hline RJ & P-12008 & Vigário Geral & 1999 & 1993 & & $\begin{array}{l}\text { Violência policial contra crianças } \\
\text { e adolescentes de rua; }\end{array}$ & \\
\hline RJ & 11.994 & $\begin{array}{l}\text { Wagner dos } \\
\text { Santos }\end{array}$ & & 1993 & $\begin{array}{l}\text { Centro pela Justiça e o } \\
\text { Direito Internacional } \\
\text { (CEJIL) }\end{array}$ & $\begin{array}{c}\text { Violência policial contra } \\
\text { crianças/adolescentes } \\
\text { Sobrevivente do "Massacre da } \\
\text { Candelária" }\end{array}$ & $\begin{array}{l}\text { Arts. } 4^{\circ}, 5^{\circ}, 7^{\circ}, 8^{\circ} \text { e } 25, \text { c/c } 1.1, \\
\text { da Convenção Americana }\end{array}$ \\
\hline
\end{tabular}




\begin{tabular}{|c|c|c|c|c|c|}
\hline \multicolumn{6}{|c|}{ MEDIDAS CAUTELARES } \\
\hline UF & $N^{\circ}$ do Processo & Caso & $\begin{array}{l}\text { Data de Início do } \\
\text { Trâmite }\end{array}$ & Peticionários & Tema \\
\hline PE & MC-372-02 & $\begin{array}{l}\text { Zenilda Maria de Araújo e Marcos Luidson de Araújo } \\
\text { (Cacique Marquinhos) Líderes Indígenas do Povo } \\
\text { Xucurú }\end{array}$ & $16 / 10 / 2002$ & $\begin{array}{c}\text { Movimento Nacional de Direitos } \\
\text { Humanos/Regional Nordeste } \\
\text { Gabinete de Assessoria Jurídica às } \\
\text { Organizações Populares (GAJOP) } \\
\text { Conselho Indigenista Missionário (CIMI) }\end{array}$ & $\begin{array}{l}\text { Garantir a vida e a integridade do } \\
\text { chefe do povo indígena Xucuru, } \\
\text { Marcos Luidson de Araújo } \\
\text { (“Cacique Marquinhos”) e sua mãe, } \\
\text { Zenilda Maria de Araújo, em virtude } \\
\text { de várias ameaças de morte } \\
\text { recebidas por ambos. }\end{array}$ \\
\hline PE & MC-387-02 & Elma Soraya Novais e filhos & $05 / 11 / 2002$ & DHInternacional & $\begin{array}{l}\text { Garantir a vida e a integridade da } \\
\text { mãe da suposta vítima, Elma Soraia } \\
\text { Souza Novais. }\end{array}$ \\
\hline $\mathrm{RR}$ & MC-818-04 & $\begin{array}{l}\text { Povos Indígenas Ingaricó, Macuxi, Patamona, } \\
\text { Taurepang e Wapixana (Raposa Serra do Sol) }\end{array}$ & $29 / 03 / 2004$ & $\begin{array}{c}\text { Conselho Indígena de Roraima - CIR } \\
\text { Rainforest Foundation US }\end{array}$ & Violência contra povos indígenas \\
\hline DF & MC-14-06 & Adolescentes Internados no CAJE & 2006 & $\begin{array}{l}\text { Centro de Defesa dos Direitos Humanos da } \\
\text { Criança e do Adolescente - CEDECA/DF }\end{array}$ & $\begin{array}{l}\text { Maus-tratos contra crianças e } \\
\quad \text { adolescentes; } \\
\text { Instituições sócio-educativas. }\end{array}$ \\
\hline PA & MC-382-10 & $\begin{array}{l}\text { Comunidades tradicionais da Bacia do Rio Xingu } \\
\text { (Belo Monte) }\end{array}$ & $01 / 04 / 2011$ & $\begin{array}{c}\text { Movimento Xingu Vivo para Sempre } \\
\text { Coordenação das Organizações Indígenas } \\
\text { da Amazônia Brasileira } \\
\text { Prelazia do Xingu } \\
\text { Conselho Indigenista Missionário } \\
\text { Sociedade Paraense de Direitos Humanos } \\
\text { Justiça Global } \\
\text { Asociacion Interamericana para la Defensa } \\
\text { del Ambiente }\end{array}$ & $\begin{array}{c}\text { Proteção das comunidades indígenas } \\
\text { Juruna, Arara, Xikrin, Asurini, } \\
\text { Kararaô, Kayapó, Parakanã e } \\
\text { Araweté }\end{array}$ \\
\hline
\end{tabular}




\begin{tabular}{|c|c|c|c|c|c|}
\hline \multicolumn{6}{|c|}{ MEDIDAS CAUTELARES } \\
\hline UF & $\mathbf{N}^{\circ}$ do Processo & Caso & $\begin{array}{c}\text { Data de Início do } \\
\text { Trâmite }\end{array}$ & Peticionários & Tema \\
\hline PE & MC-199-11 & Presídio Professor Aníbal Bruno & jun/11 & $\begin{array}{c}\text { Pastoral Carcerária de Pernambuco; } \\
\text { Serviço Ecumênico de Militância } \\
\text { nas Prisões (SEMPRI); Pastoral } \\
\text { Carcerária Nacional; a Justiça } \\
\text { Global e a Clínica Internacional de } \\
\text { Direitos Humanos da Universidade } \\
\text { de Harvard }\end{array}$ & $\begin{array}{l}\text { Violência contra detentos } \\
\text { Maus-tratos em penitenciárias }\end{array}$ \\
\hline MS & MC-339-11 & $\begin{array}{l}\text { Violência contra a Comunidade indígena Guarani } \\
\text { Pyelito Kuê/M'barakai }\end{array}$ & $21 / 11 / 2011$ & Survival International & Violência contra povos indígenas \\
\hline MS & MC-5-12 & Comunidades Indígenas Guarani-Kaiowá e Terena & 08/03/2012 & $\begin{array}{l}\text { Conselho Indigenista Missionário, Justiça } \\
\text { Global, Food First Information and Action } \\
\text { Network, Comissão Regional de Justiça e } \\
\text { Paz de Mato Grosso do Sul e Comitê } \\
\text { Nacional de Defesa dos Povos Indígenas de } \\
\text { Mato Grosso do Sul. }\end{array}$ & Violência contra povos indígenas. \\
\hline RS & MC - $8-13$ & Presídio Central de Porto Alegre & $14 / 02 / 2013$ & $\begin{array}{l}\text { AJURIS; AMPRGS; ADPERGS; IBAPE; } \\
\text { ITEC; Themis Assessoria Jurídica e } \\
\text { Estudos de Gênero. }\end{array}$ & $\begin{array}{l}\text { Superpopulação e estrutura precária } \\
\text { de Penitenciária. Condições } \\
\text { insalubres e falta de assistência } \\
\text { médica para detentos. Precário } \\
\text { controle e supervisão de detentos. }\end{array}$ \\
\hline MA & MC-145-13 & $\begin{array}{c}\text { Povo Awá-Guajá (Comunidades Indígenas Awá- } \\
\text { Guajá dos territórios indígrenas Awá, Alto Turiaçu, } \\
\text { Caru e Araribóia) }\end{array}$ & $23 / 07 / 2013$ & $\begin{array}{l}\text { Conselho Indigenista Missionário (CIMI); } \\
\text { Survival International USA. }\end{array}$ & $\begin{array}{c}\text { Proteção das comunidades indígenas } \\
\text { Awá-Guajá dos territórios indígenas } \\
\text { Awá. Alto Turiaçu, Caru e } \\
\text { Araribóia. }\end{array}$ \\
\hline
\end{tabular}




\begin{tabular}{|c|c|c|c|c|c|}
\hline \multicolumn{6}{|c|}{ MEDIDAS CAUTELARES } \\
\hline UF & $N^{o}$ do Processo & Caso & $\begin{array}{c}\text { Data de Início do } \\
\text { Trâmite } \\
\end{array}$ & Peticionários & Tema \\
\hline MA & MC-367-13 & $\begin{array}{l}\text { Pessoas privadas de liberdade no Complexo } \\
\text { Penitenciário de Pedrinhas }\end{array}$ & $25 / 10 / 2013$ & $\begin{array}{l}\text { Sociedade Maranhense de Direitos } \\
\text { Humanos (SMDH) } \\
\text { Ordem dos Advogados do Brasil - Seção } \\
\text { Maranhão (OAB/MA) }\end{array}$ & $\begin{array}{l}\text { Violência contra detentos } \\
\text { Maus-tratos em penitenciárias } \\
\text { Execuções extrajudiciais }\end{array}$ \\
\hline DF & MC-363-13 & Antônio Pereira de Araújo & $07 / 11 / 2013$ & Lairsson Rodrigues Bueno & Desaparecimento forçado \\
\hline $\mathrm{RR}$ & MC-438-13 & $\begin{array}{l}\text { Pessoas privadas de liberdade na Penitenciária de } \\
\text { Monte Cristo }\end{array}$ & $18 / 02 / 2014$ & $\begin{array}{l}\text { Grupo de Promoção e Proteção } \\
\text { dos Direitos Humanos da Defensoria } \\
\text { Pública do Estado de Roraima }\end{array}$ & Violência contra detentos \\
\hline \multicolumn{6}{|c|}{ INATIVAS } \\
\hline RJ & MC-346-08 & Educandário Santo Expedito & 22.01 .2009 & $\begin{array}{c}\text { Organização de Direitos Humanos Projeto } \\
\text { Legal - ODHPL }\end{array}$ & $\begin{array}{c}\text { Violência contra menores privados } \\
\text { de liberdade } \\
\text { Tortura } \\
\text { Condições de insalubridade no } \\
\text { Educandário Santo Expedito }\end{array}$ \\
\hline TO & MC-95-09 & Célio Nogueira & $29 / 04 / 2009$ & Sérgio Constantino Wacheleski & $\begin{array}{l}\text { Encarceramento ilegal de Célio } \\
\text { Nogueira (detenção arbitrária) }\end{array}$ \\
\hline
\end{tabular}




\section{Anexo 3 - Temas dos procedimentos contra o Brasil no SIDH categorizados por unidade federativa}

Todas as figuras deste anexo são de elaboração própria a partir de dados da $\mathrm{CmDH}$, da $\mathrm{CrDH}$, do MRE e da SDH (disponível em: http://www.oas.org/pt/cidh/ Acesso em: 07 nov. 2015 e no Apêndice B).

Figura 1: Temas dos procedimentos contra o Brasil no SIDH no Amazonas

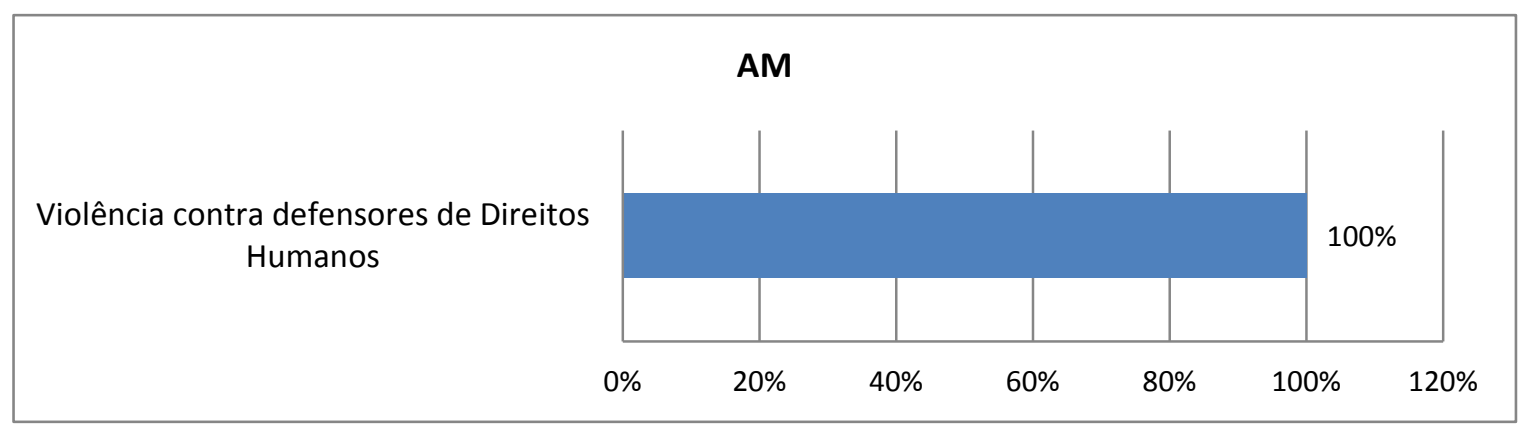

Fonte: Elaborado própria. Dados da $\mathrm{CmDH}$, da $\mathrm{CrDH}$, do MRE e da $\mathrm{SDH}$ (disponível em: http://www.oas.org/pt/cidh/ Acesso em: 07 nov. 2015 e no Apêndice B).

Figura 2: Temas dos procedimentos contra o Brasil no SIDH na Bahia

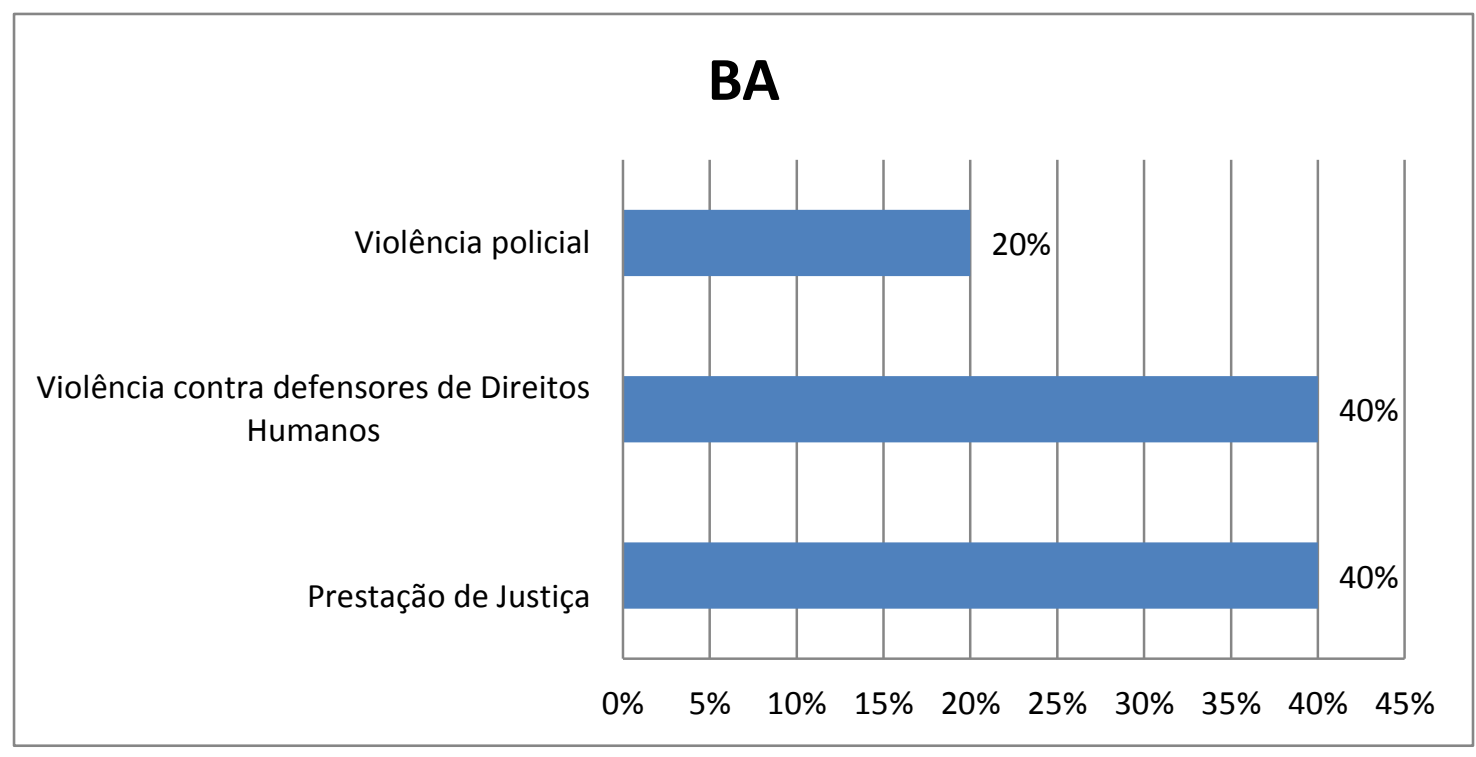

Fonte: Elaborado própria. Dados da $\mathrm{CmDH}$, da $\mathrm{CrDH}$, do MRE e da $\mathrm{SDH}$ (disponível em: http://www.oas.org/pt/cidh/ Acesso em: 07 nov. 2015 e no Apêndice B). 
Figura 3: Temas dos procedimentos contra o Brasil no SIDH no Ceará

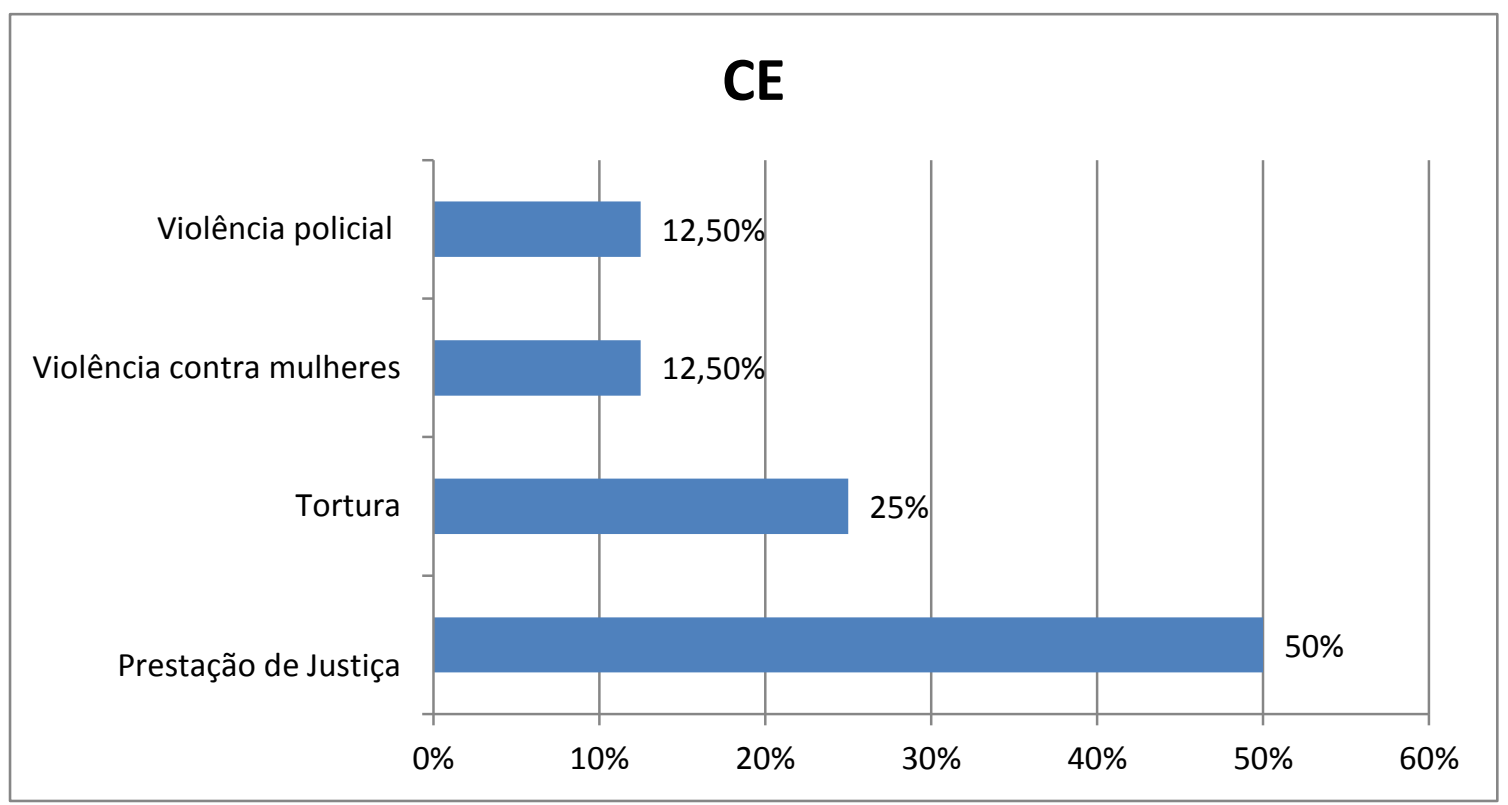

Fonte: Elaborado própria. Dados da $\mathrm{CmDH}$, da $\mathrm{CrDH}$, do MRE e da $\mathrm{SDH}$ (disponível em: http://www.oas.org/pt/cidh/ Acesso em: 07 nov. 2015 e no Apêndice B).

Figura 4: Temas dos procedimentos contra o Brasil no SIDH no Distrito Federal

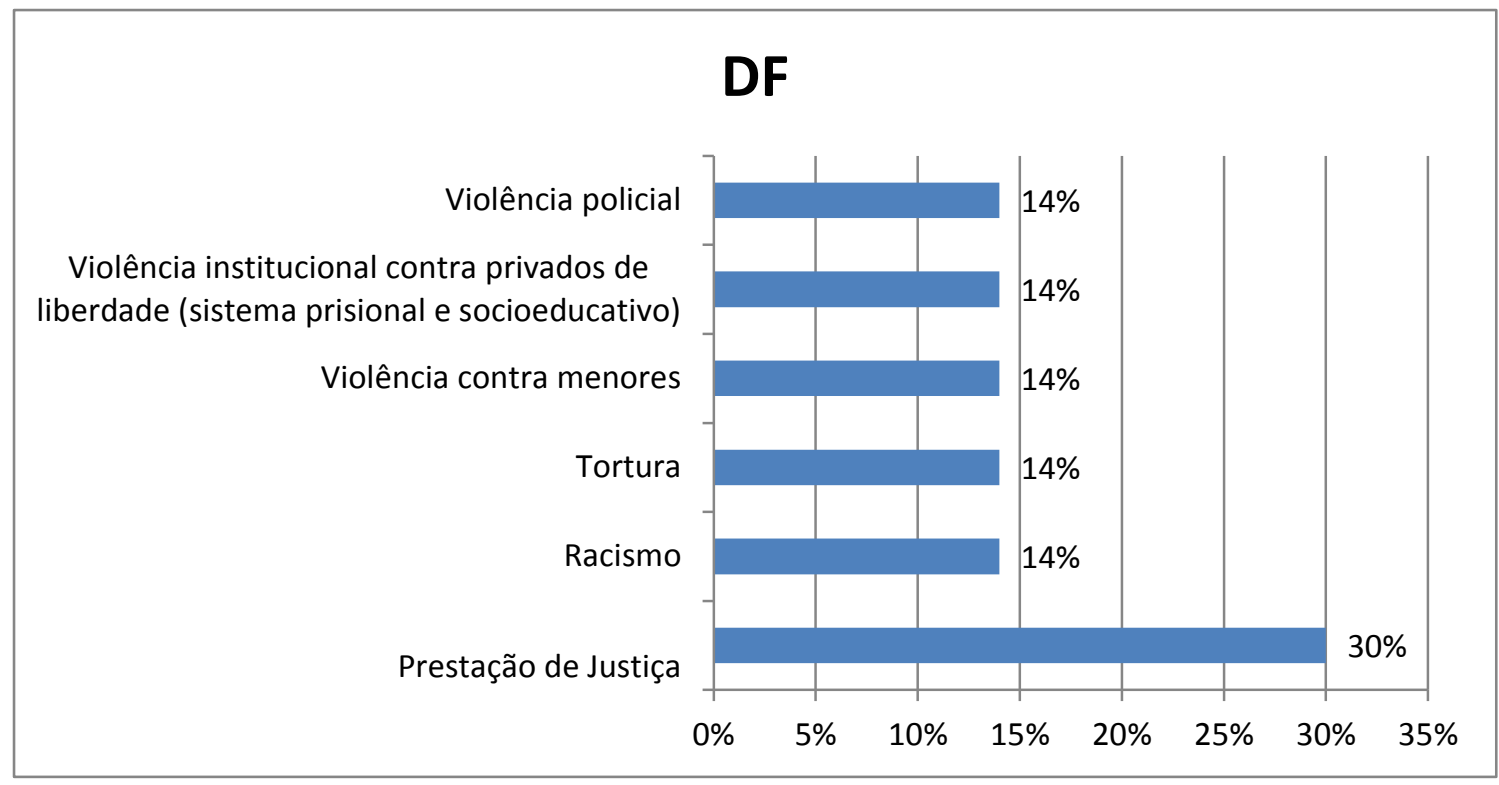

Fonte: Elaborado própria. Dados da $\mathrm{CmDH}$, da $\mathrm{CrDH}$, do MRE e da $\mathrm{SDH}$ (disponível em: http://www.oas.org/pt/cidh/ Acesso em: 07 nov. 2015 e no Apêndice B). 
Figura 5: Temas dos procedimentos contra o Brasil no SIDH no Espírito Santo

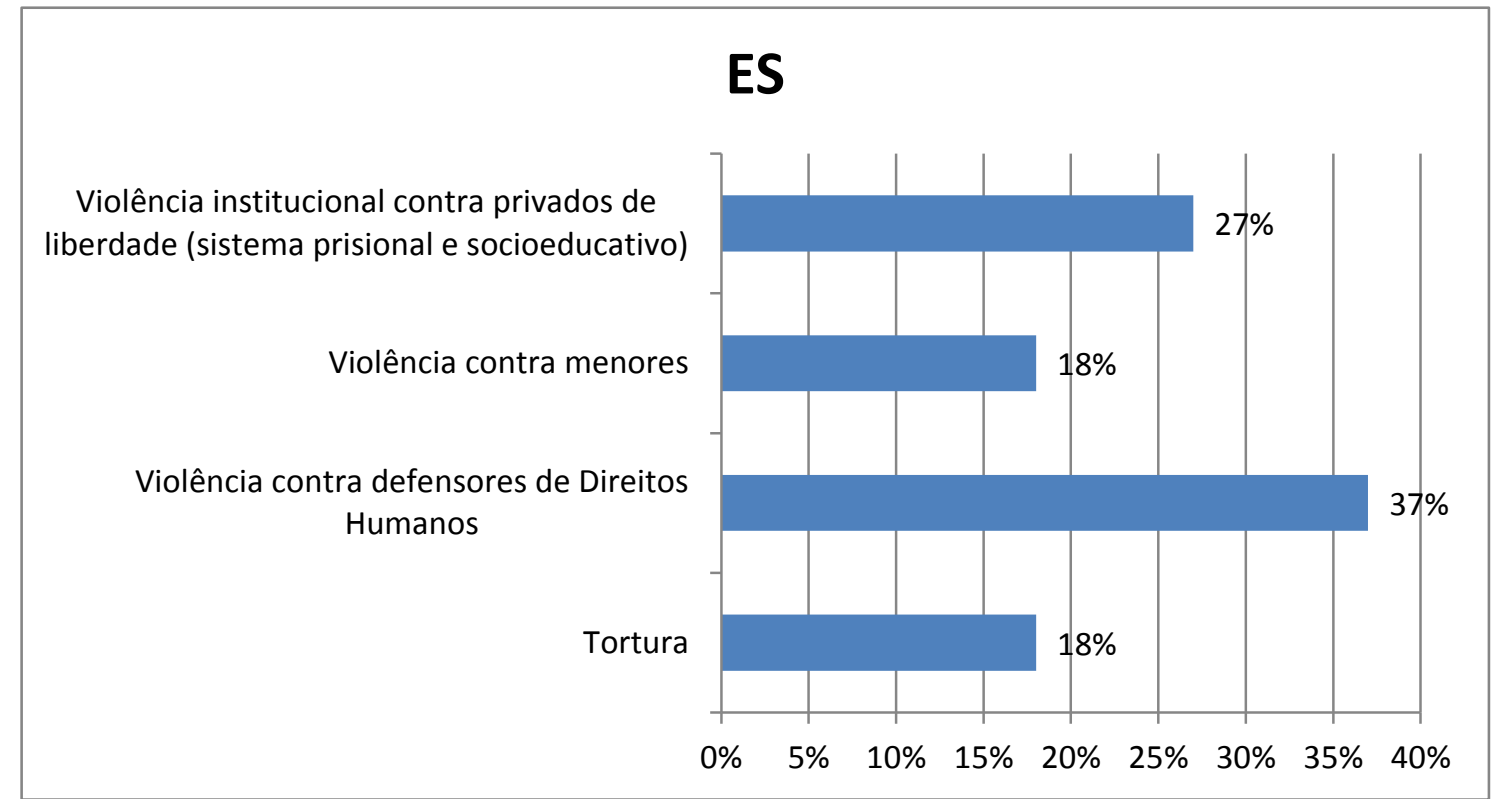

Fonte: Elaborado própria. Dados da $\mathrm{CmDH}$, da $\mathrm{CrDH}$, do MRE e da $\mathrm{SDH}$ (disponível em: http://www.oas.org/pt/cidh/ Acesso em: 07 nov. 2015 e no Apêndice B).

Figura 6: Temas dos procedimentos contra o Brasil no SIDH no Maranhão

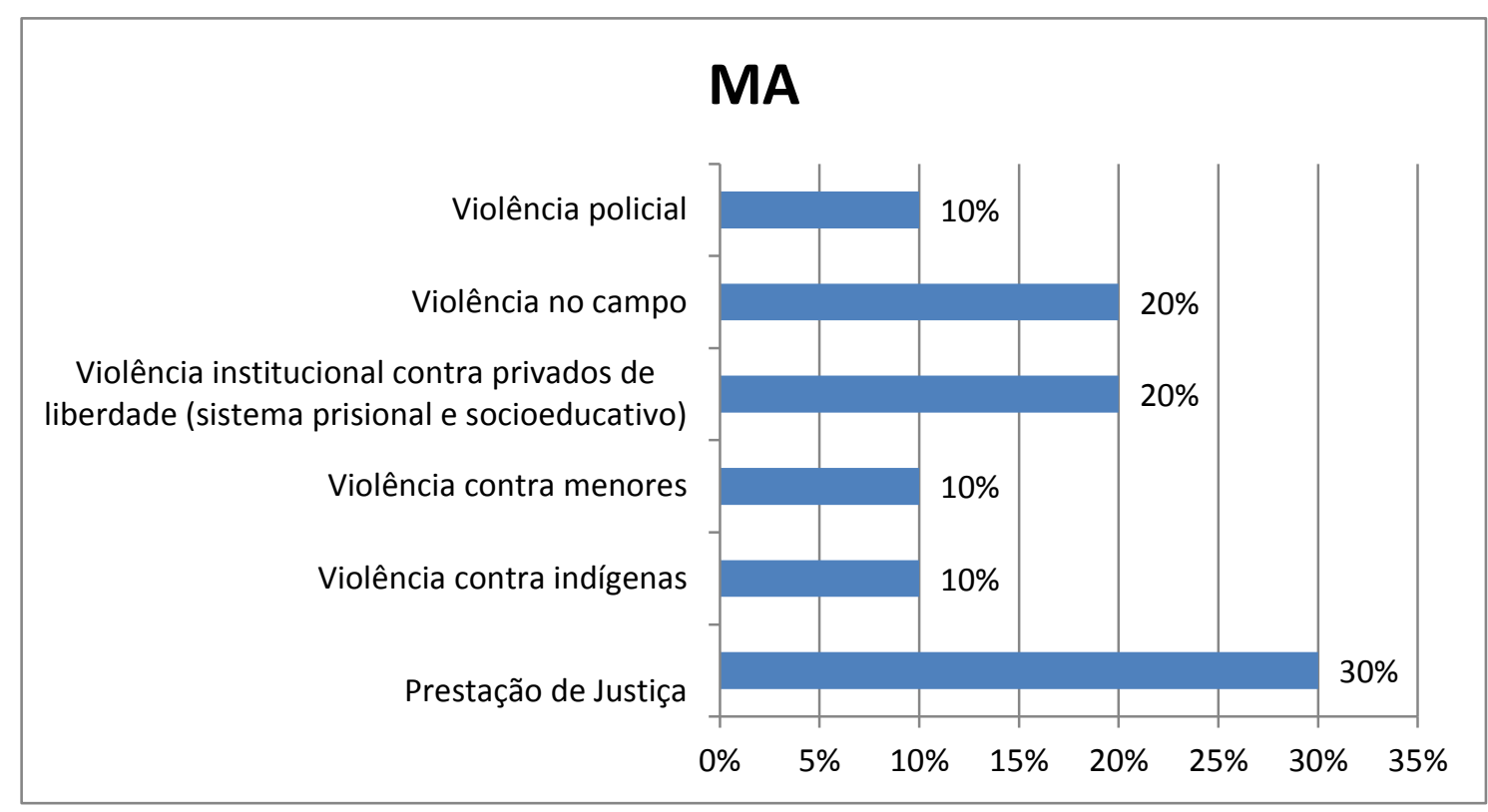

Fonte: Elaborado própria. Dados da $\mathrm{CmDH}$, da $\mathrm{CrDH}$, do MRE e da $\mathrm{SDH}$ (disponível em: http://www.oas.org/pt/cidh/ Acesso em: 07 nov. 2015 e no Apêndice B). 
Figura 7: Temas dos procedimentos contra o Brasil no SIDH em Minas Gerais

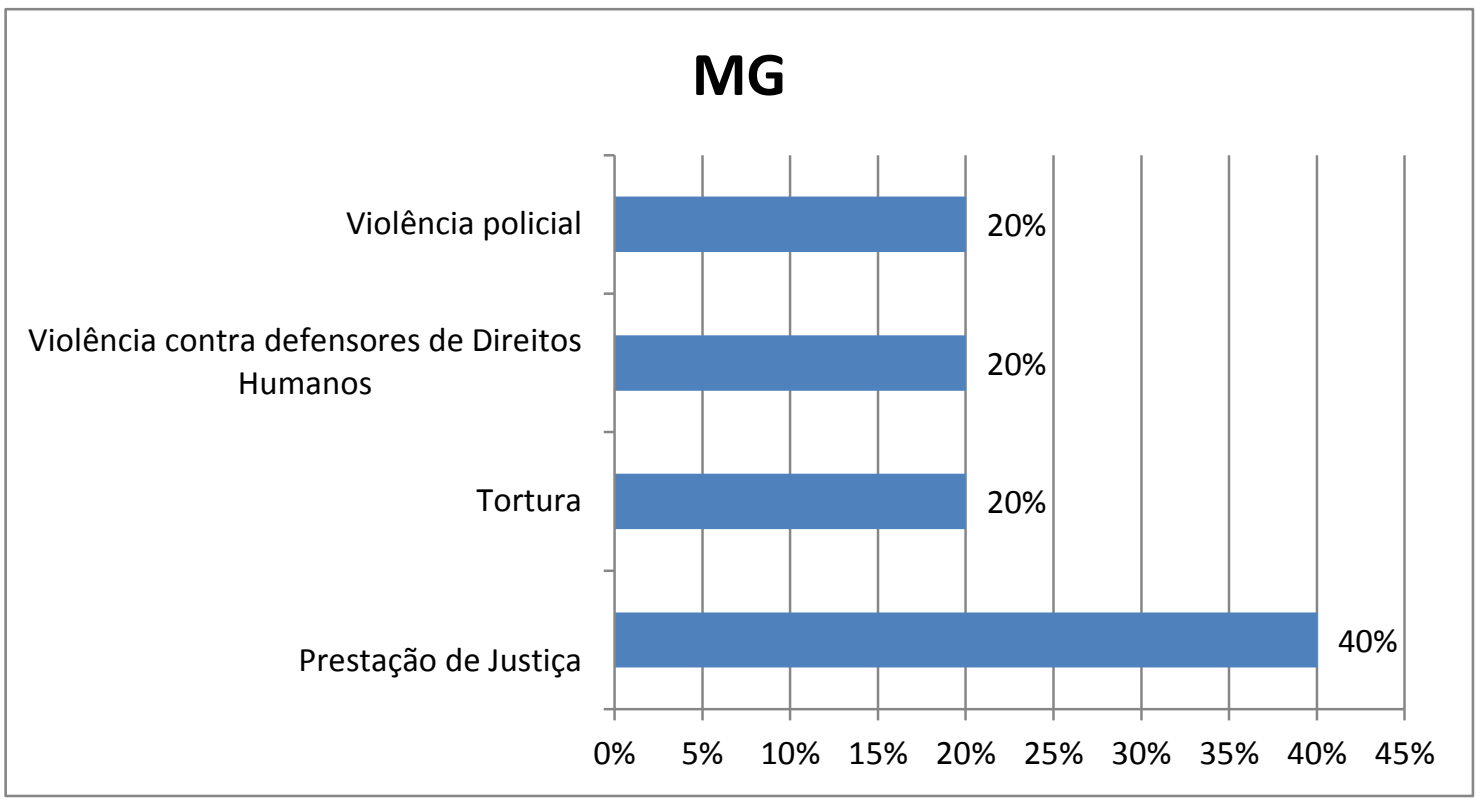

Fonte: Elaborado própria. Dados da $\mathrm{CmDH}$, da $\mathrm{CrDH}$, do MRE e da $\mathrm{SDH}$ (disponível em: http://www.oas.org/pt/cidh/ Acesso em: 07 nov. 2015 e no Apêndice B).

Figura 8: Temas dos procedimentos contra o Brasil no SIDH em Mato Grosso do Sul

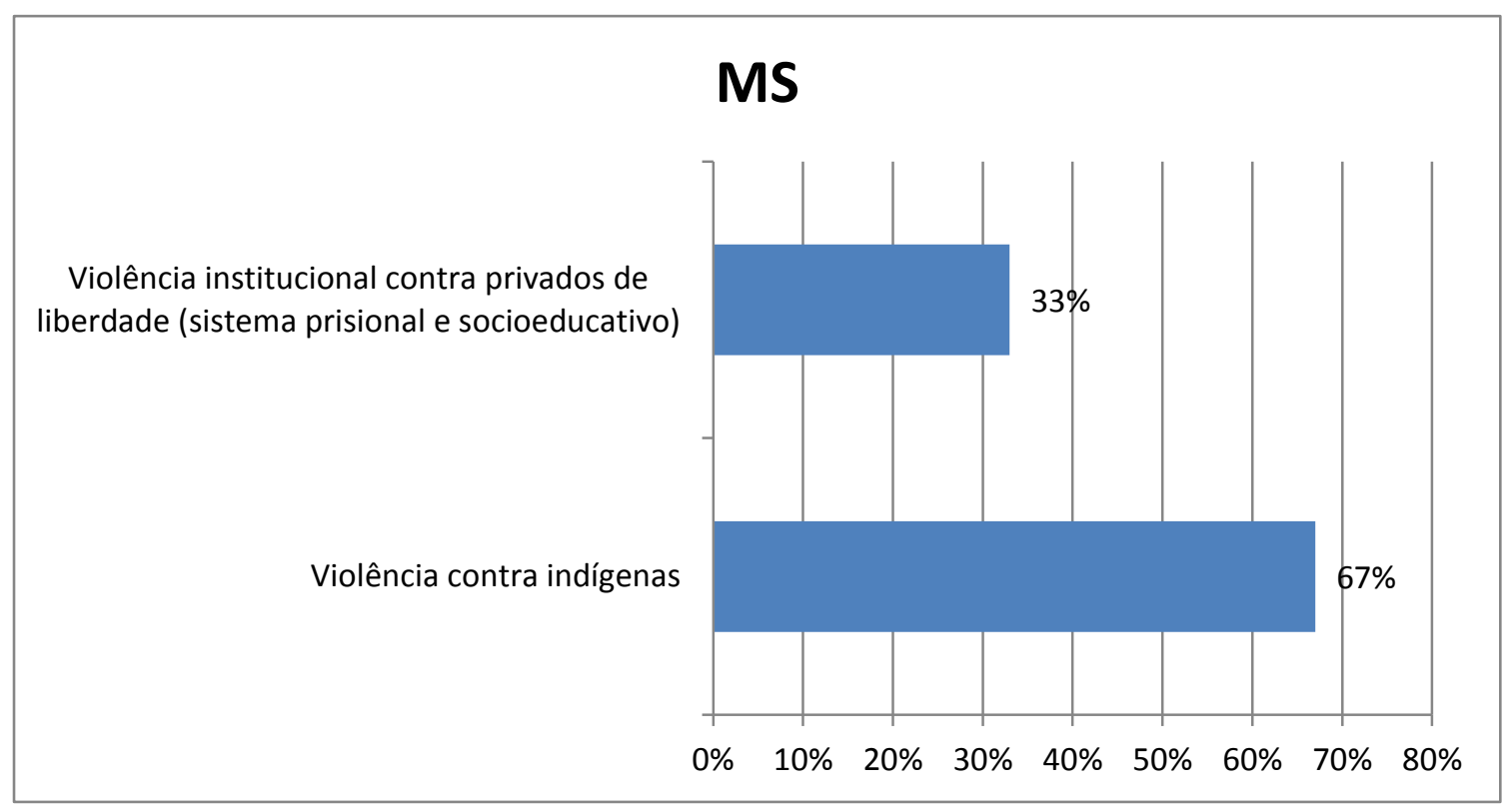

Fonte: Elaborado própria. Dados da $\mathrm{CmDH}$, da $\mathrm{CrDH}$, do MRE e da $\mathrm{SDH}$ (disponível em: http://www.oas.org/pt/cidh/ Acesso em: 07 nov. 2015 e no Apêndice B). 
Figura 9: Temas dos procedimentos contra o Brasil no SIDH em Mato Grosso

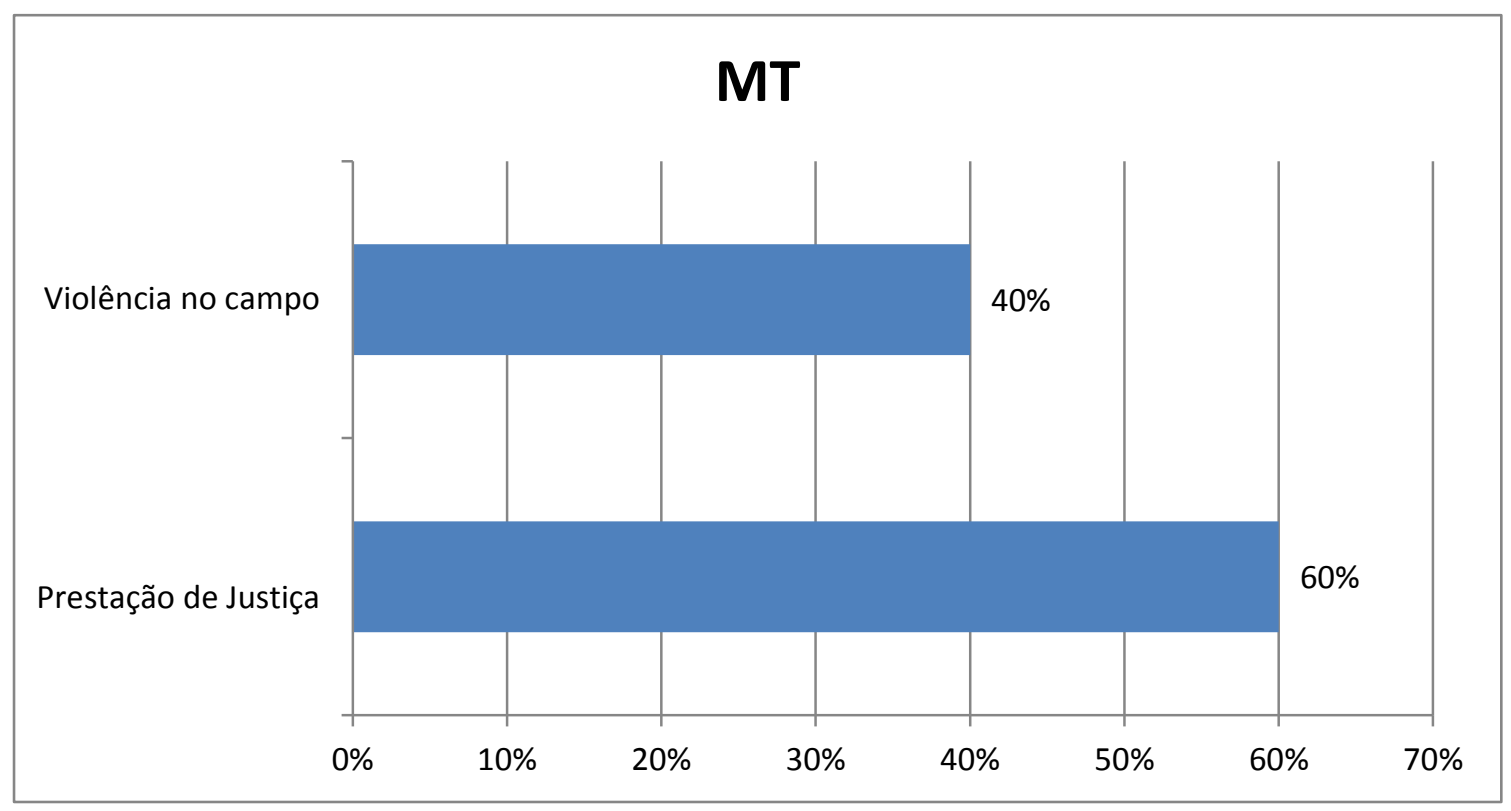

Fonte: Elaborado própria. Dados da $\mathrm{CmDH}$, da $\mathrm{CrDH}$, do MRE e da $\mathrm{SDH}$ (disponível em: http://www.oas.org/pt/cidh/ Acesso em: 07 nov. 2015 e no Apêndice B).

Figura 10: Temas dos procedimentos contra o Brasil no SIDH no Pará

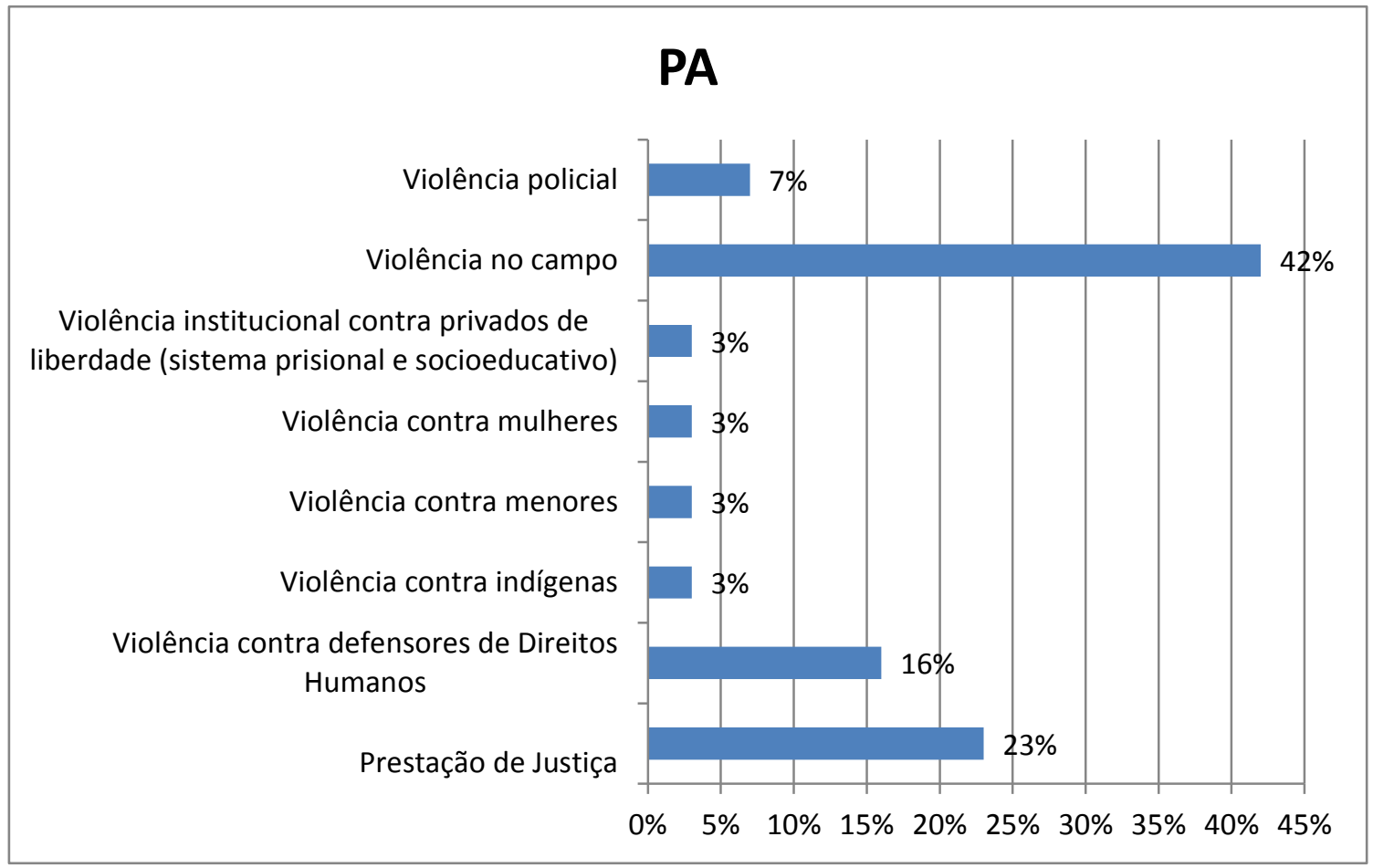

Fonte: Elaborado própria. Dados da $\mathrm{CmDH}$, da $\mathrm{CrDH}$, do MRE e da SDH (disponível em: http://www.oas.org/pt/cidh/ Acesso em: 07 nov. 2015 e no Apêndice B). 
Figura 11: Temas dos procedimentos contra o Brasil no SIDH na Paraíba

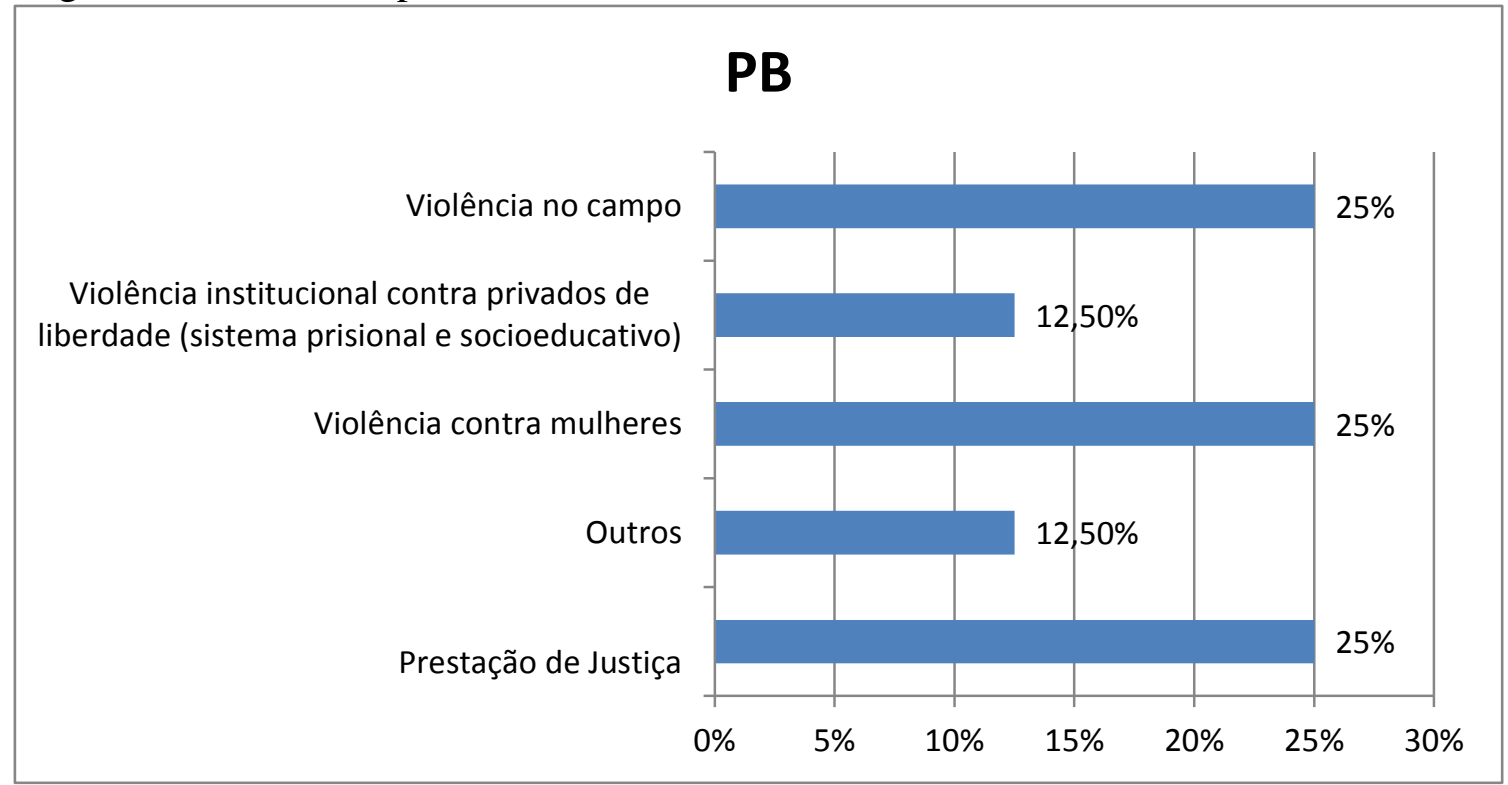

Fonte: Elaborado própria. Dados da $\mathrm{CmDH}$, da $\mathrm{CrDH}$, do MRE e da $\mathrm{SDH}$ (disponível em: http://www.oas.org/pt/cidh/ Acesso em: 07 nov. 2015 e no Apêndice B).

Figura 12: Temas dos procedimentos contra o Brasil no SIDH na Pernambuco

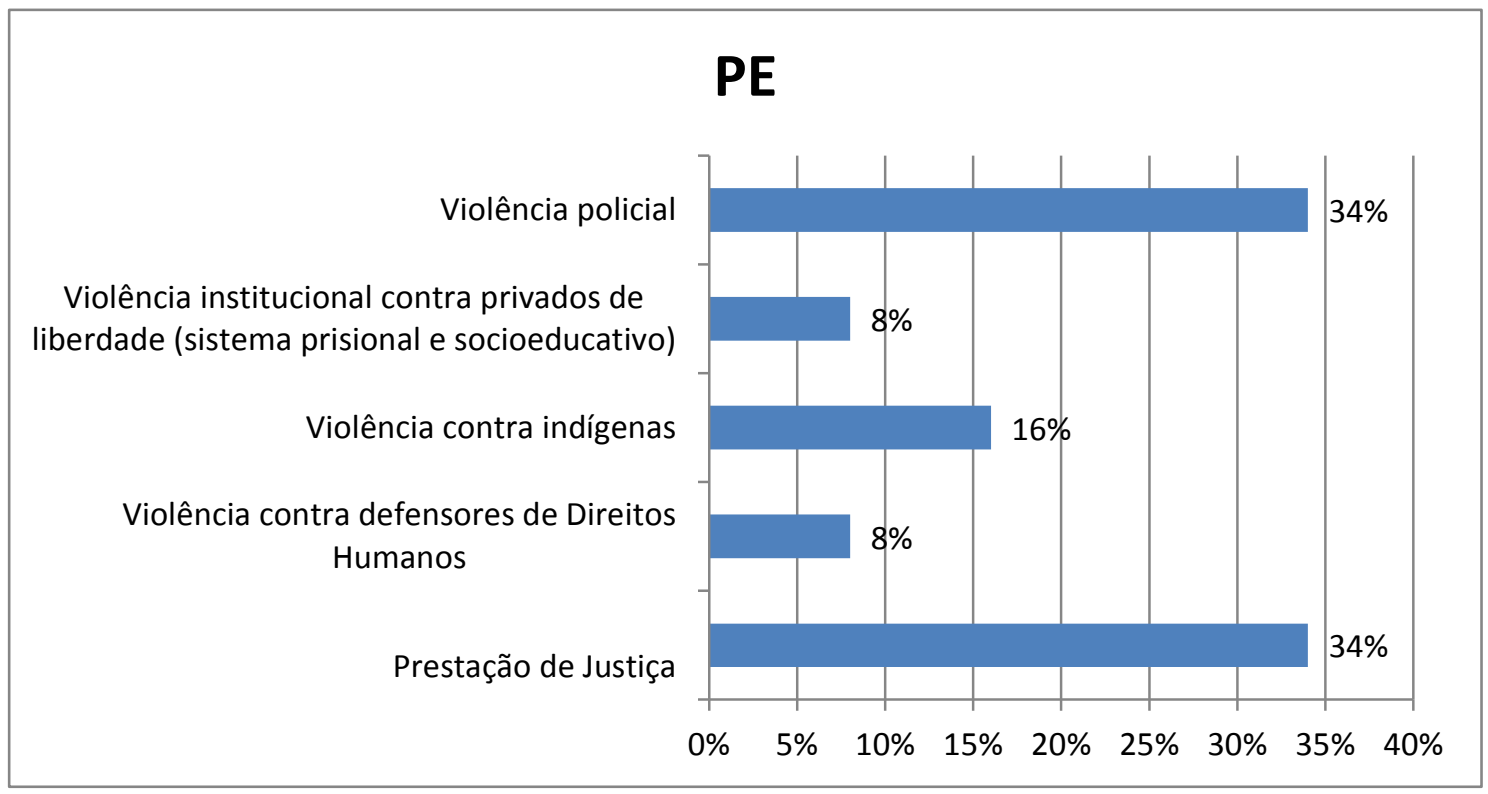

Fonte: Elaborado própria. Dados da $\mathrm{CmDH}$, da $\mathrm{CrDH}$, do MRE e da $\mathrm{SDH}$ (disponível em: http://www.oas.org/pt/cidh/ Acesso em: 07 nov. 2015 e no Apêndice B). 
Figura 13: Temas dos procedimentos contra o Brasil no SIDH no Paraná

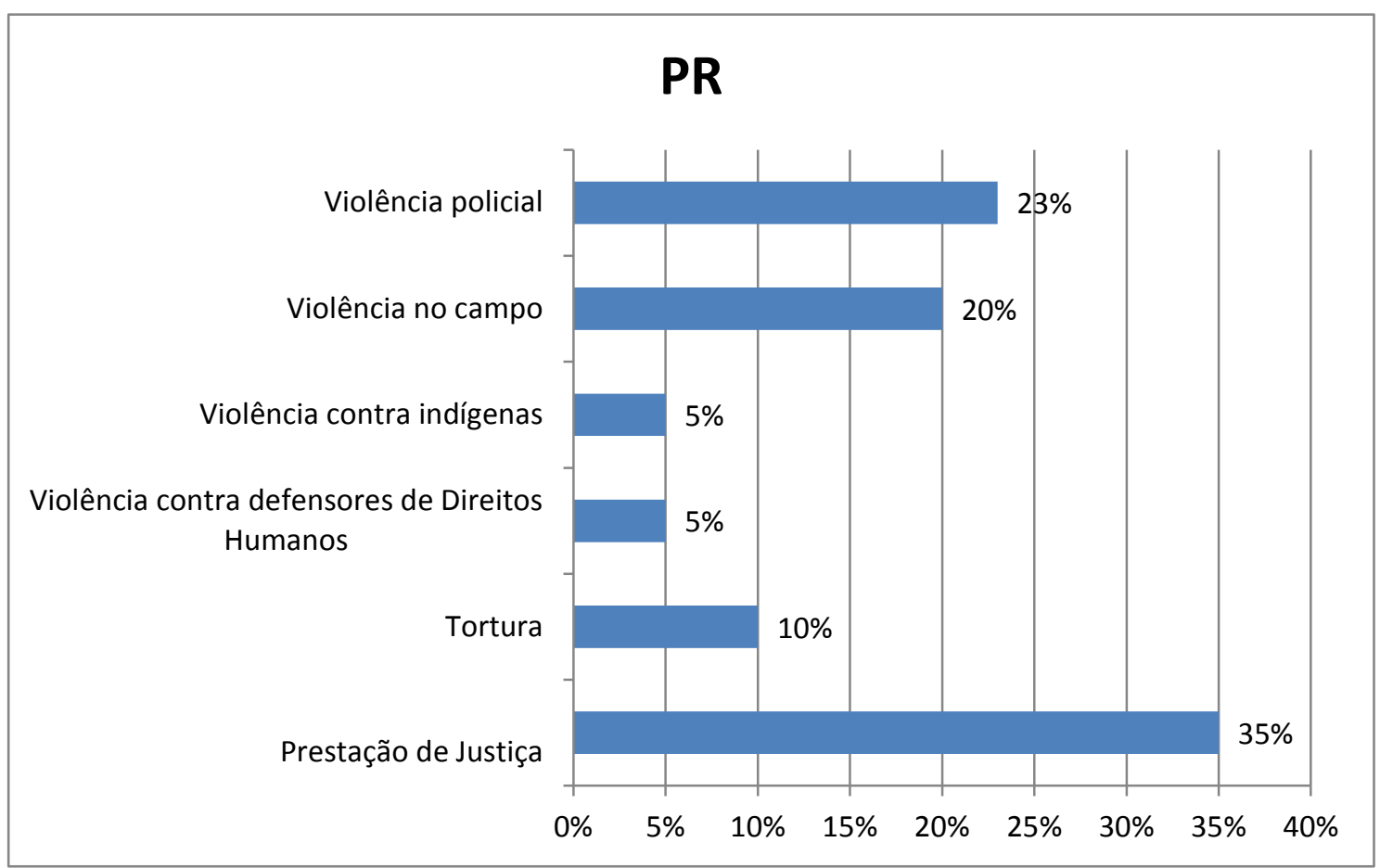

Fonte: Elaborado própria. Dados da $\mathrm{CmDH}$, da $\mathrm{CrDH}$, do MRE e da $\mathrm{SDH}$ (disponível em: http://www.oas.org/pt/cidh/ Acesso em: 07 nov. 2015 e no Apêndice B).

Figura 14: Temas dos procedimentos contra o Brasil no SIDH no Rio de Janeiro

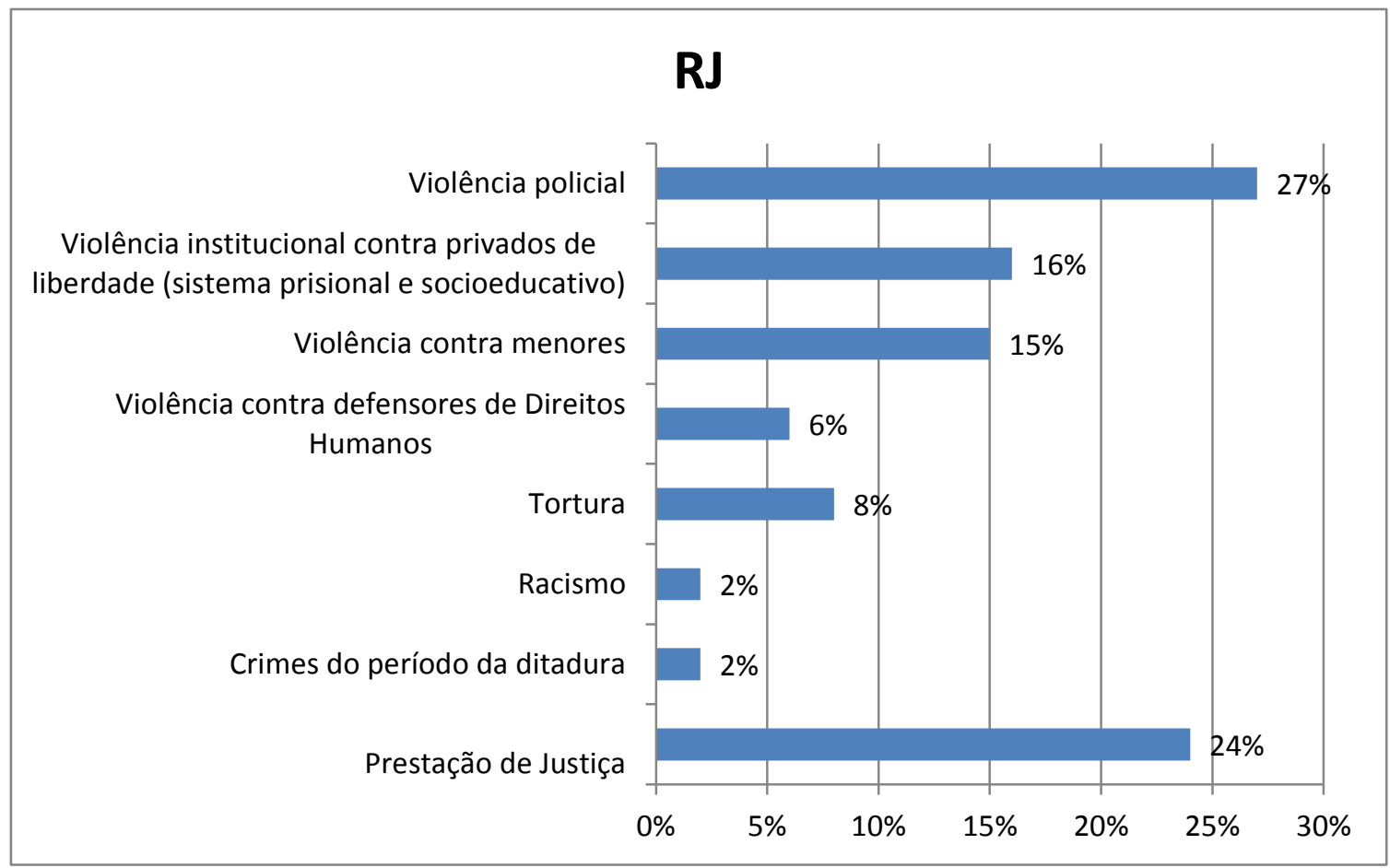

Fonte: Elaborado própria. Dados da $\mathrm{CmDH}$, da $\mathrm{CrDH}$, do MRE e da $\mathrm{SDH}$ (disponível em: http://www.oas.org/pt/cidh/ Acesso em: 07 nov. 2015 e no Apêndice B). 
Figura 15: Temas dos procedimentos contra o Brasil no SIDH no Rio Grande do Norte

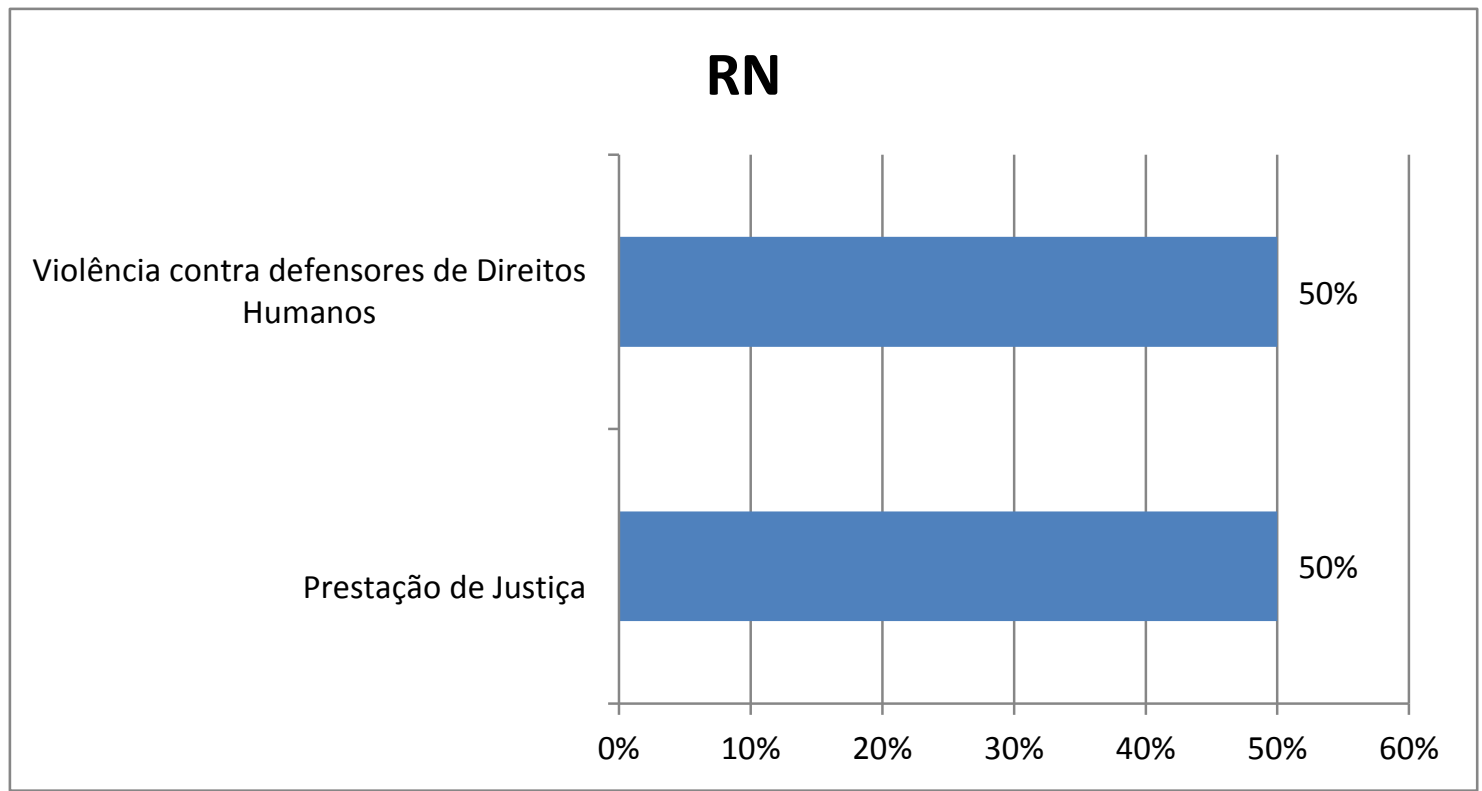

Fonte: Elaborado própria. Dados da $\mathrm{CmDH}$, da $\mathrm{CrDH}$, do MRE e da SDH (disponível em: http://www.oas.org/pt/cidh/ Acesso em: 07 nov. 2015 e no Apêndice B).

Figura 16: Temas dos procedimentos contra o Brasil no SIDH em Rondônia

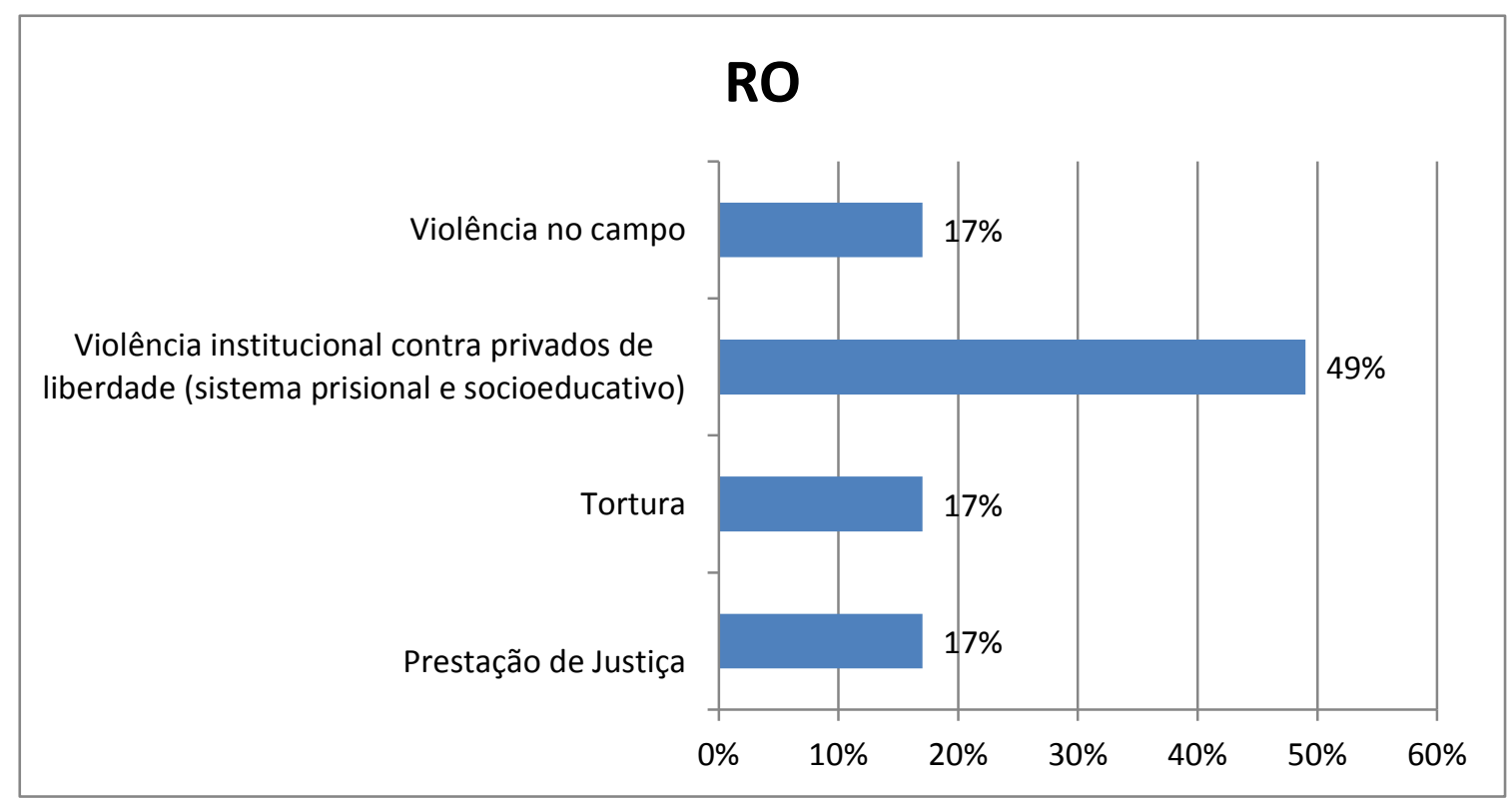

Fonte: Elaborado própria. Dados da $\mathrm{CmDH}$, da $\mathrm{CrDH}$, do MRE e da $\mathrm{SDH}$ (disponível em: http://www.oas.org/pt/cidh/ Acesso em: 07 nov. 2015 e no Apêndice B). 
Figura 17: Temas dos procedimentos contra o Brasil no SIDH em Roraima

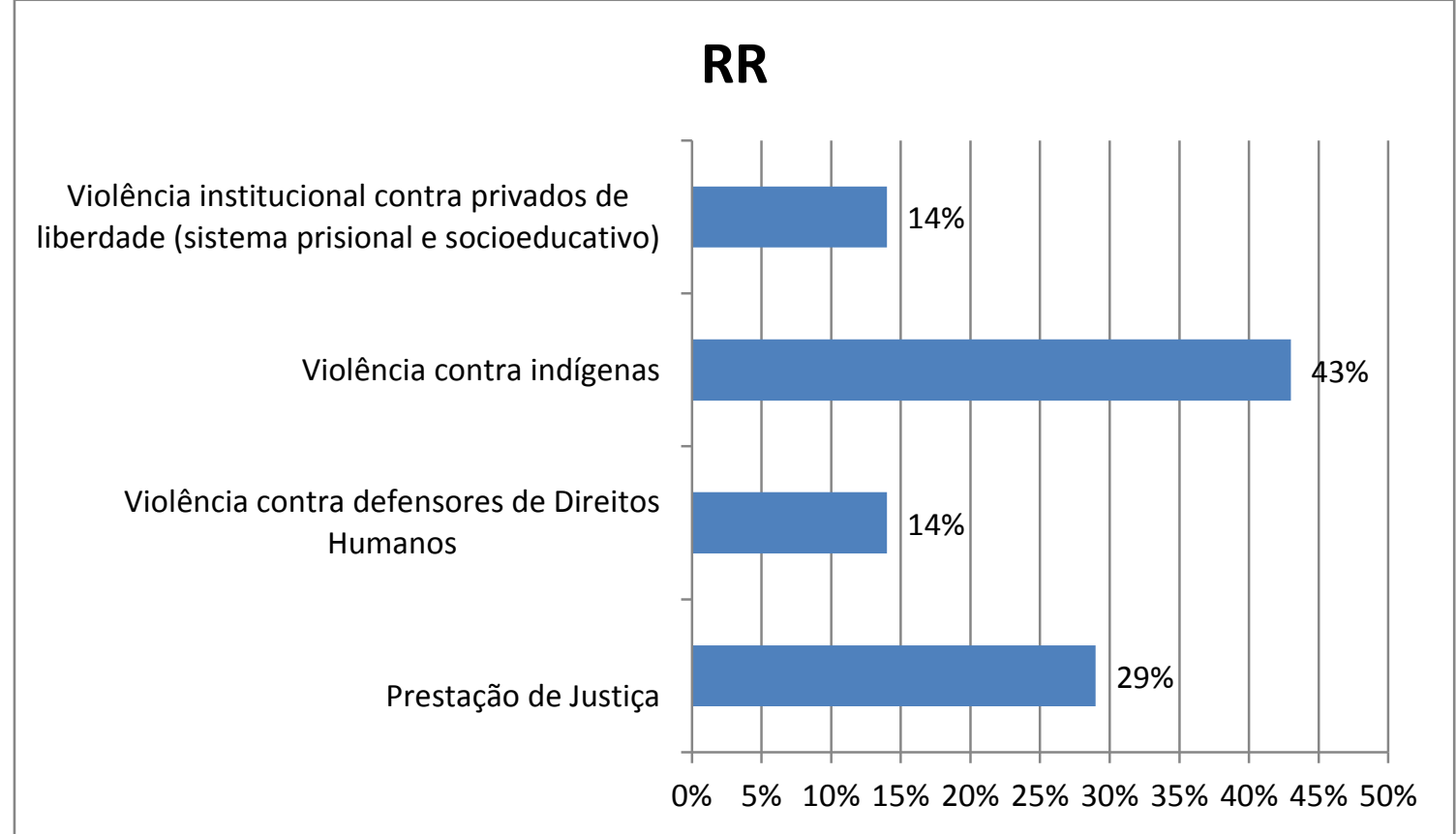

Fonte: Elaborado própria. Dados da $\mathrm{CmDH}$, da $\mathrm{CrDH}$, do MRE e da SDH (disponível em: http://www.oas.org/pt/cidh/ Acesso em: 07 nov. 2015 e no Apêndice B).

Figura 18: Temas dos procedimentos contra o Brasil no SIDH no Rio Grande do Sul

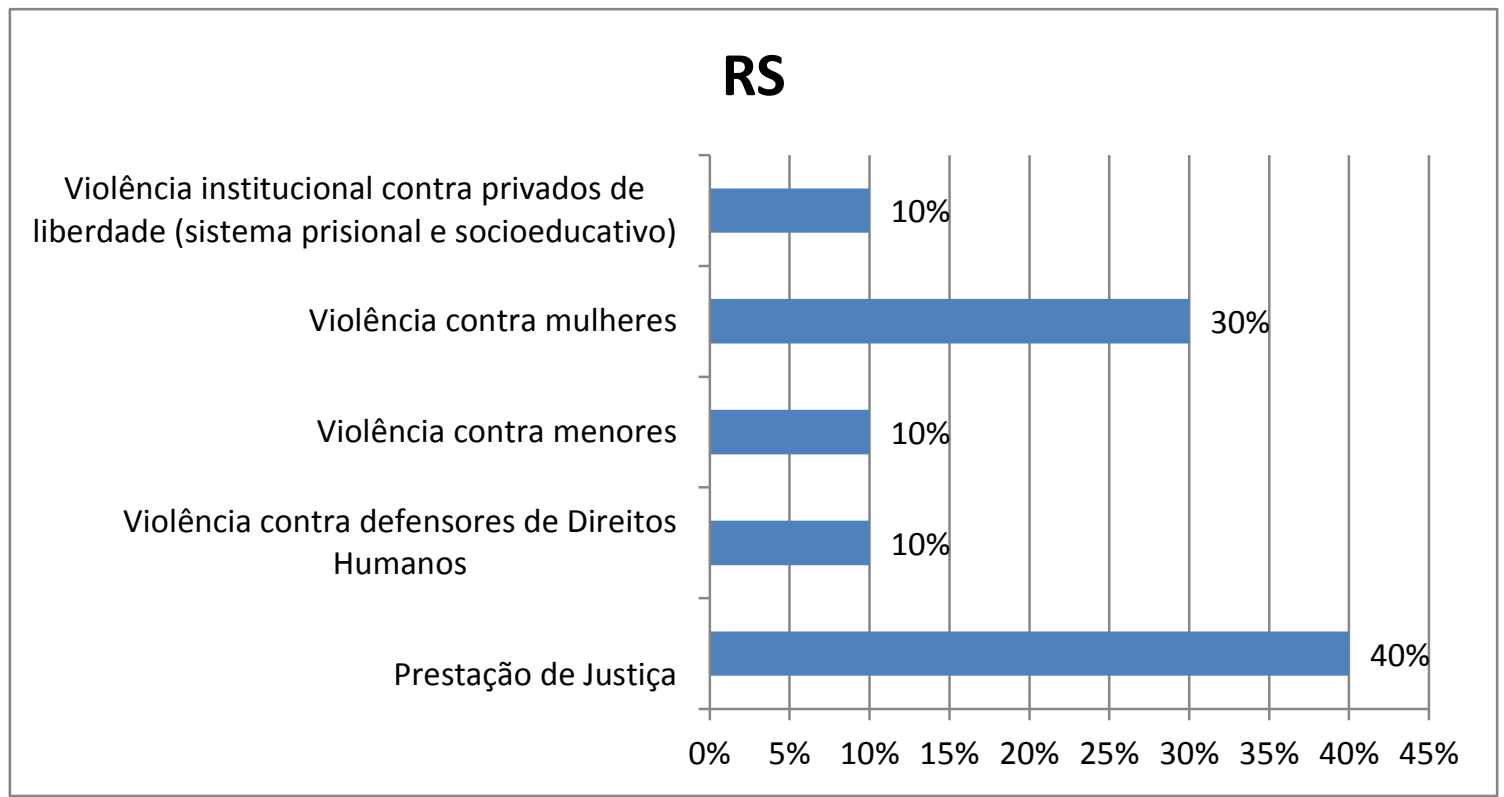

Fonte: Elaborado própria. Dados da $\mathrm{CmDH}$, da $\mathrm{CrDH}$, do MRE e da $\mathrm{SDH}$ (disponível em: http://www.oas.org/pt/cidh/ Acesso em: 07 nov. 2015 e no Apêndice B). 
Figura 19: Temas dos procedimentos contra o Brasil no SIDH em São Paulo

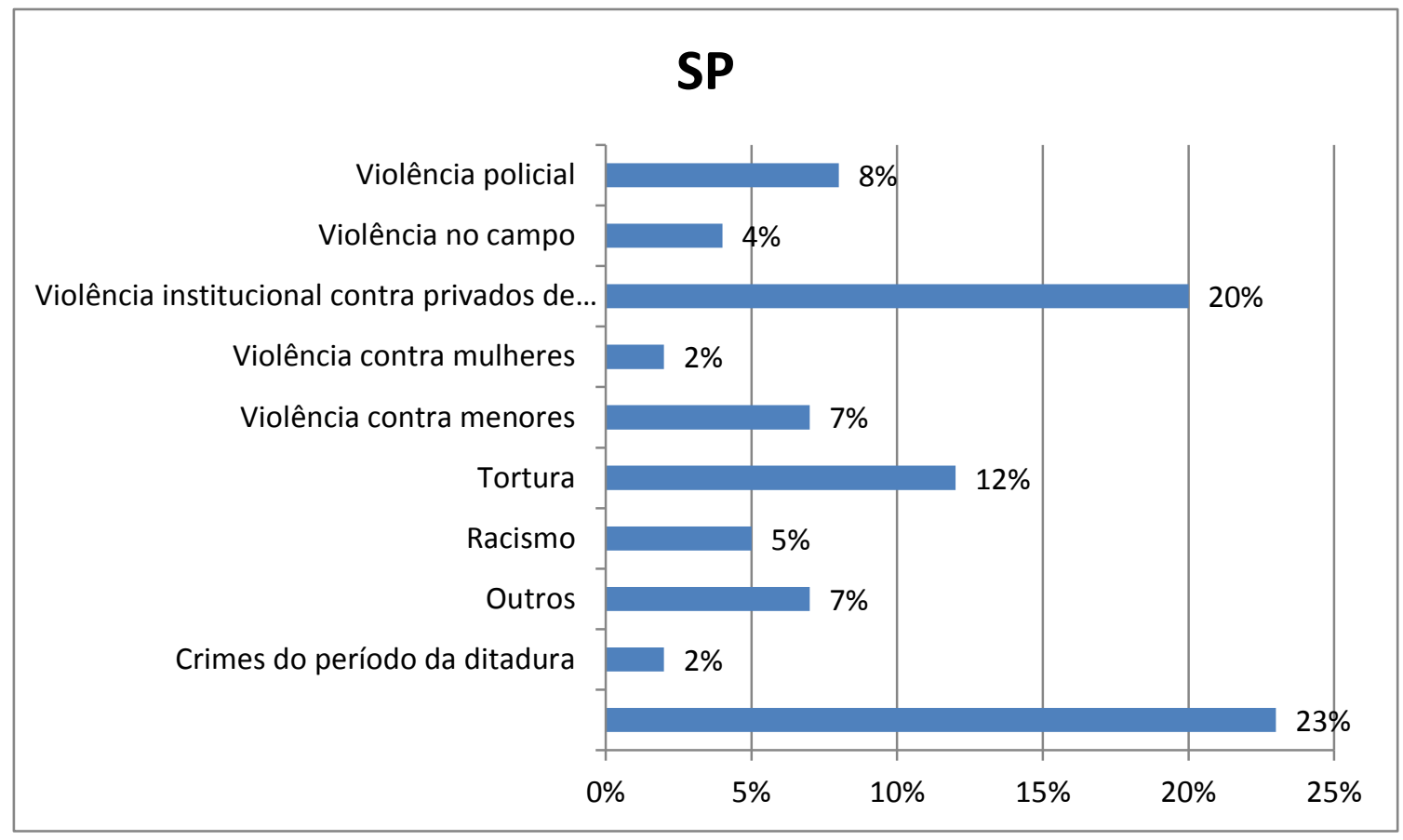

Fonte: Elaborado própria. Dados da $\mathrm{CmDH}$, da $\mathrm{CrDH}$, do MRE e da $\mathrm{SDH}$ (disponível em: http://www.oas.org/pt/cidh/ Acesso em: 07 nov. 2015 e no Apêndice B).

Figura 20: Temas dos procedimentos contra o Brasil no SIDH no Tocantins

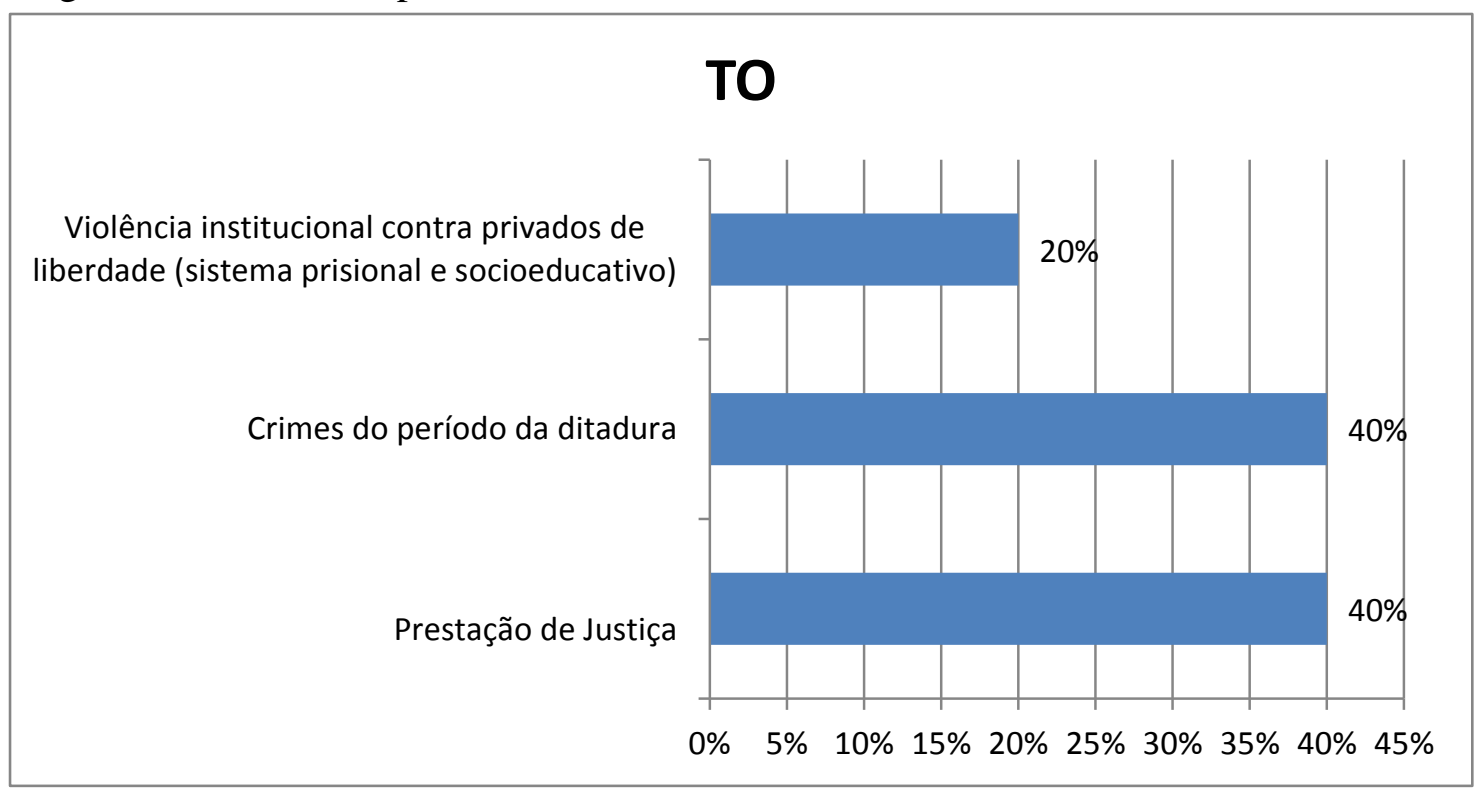

Fonte: Elaborado própria. Dados da $\mathrm{CmDH}$, da $\mathrm{CrDH}$, do MRE e da $\mathrm{SDH}$ (disponível em: http://www.oas.org/pt/cidh/ Acesso em: 07 nov. 2015 e no Apêndice B). 
Apêndice A - Informações divergentes sobre os casos contra o Brasil no SIDH fornecidos pelo MRE e SDH

\begin{tabular}{|c|c|c|c|c|c|c|c|c|c|c|c|c|}
\hline \multicolumn{13}{|c|}{ CASOS QUE NÃO ESTAVAM NA LISTA FORNECIDA PELO MRE } \\
\hline Região & $\mathbf{U F}$ & $\begin{array}{c}\mathrm{N}^{\mathbf{0}} \text { do } \\
\text { Processo }\end{array}$ & Órgão & Fase & $\begin{array}{c}\text { Especificação } \\
\text { da fase }\end{array}$ & $\begin{array}{l}\text { Nome do } \\
\text { Caso }\end{array}$ & $\begin{array}{l}\text { Data de } \\
\text { Início do } \\
\text { Trâmite } \\
\end{array}$ & $\begin{array}{l}\text { Data da } \\
\text { Alegada } \\
\text { Violação } \\
\end{array}$ & Peticionários & $\begin{array}{l}\text { Peticionários } \\
\text { Classificados }\end{array}$ & $\begin{array}{c}\text { Artigos } \\
\text { Invocados }\end{array}$ & $\begin{array}{l}\text { Tema das } \\
\text { violações }\end{array}$ \\
\hline Sul & $\mathrm{RS}$ & P-1140-04 & Comissão & $\begin{array}{c}\text { Admiss } \\
\text { ibilidad } \\
\mathrm{e}\end{array}$ & & $\begin{array}{l}\text { Felipe Néri } \\
\text { Dresch da } \\
\text { Silveira e } \\
\text { outros }\end{array}$ & $12 / 10 / 2006$ & $\begin{array}{l}\text { 22/5/2006 se } \\
\text { estendendo até } \\
\text { hoje }\end{array}$ & $\begin{array}{c}\text { Sra. Rita de } \\
\text { Cássaia da } \\
\text { Rosa e Sra. } \\
\text { Clélia de } \\
\text { Lourdes } \\
\text { Goldenberg, } \\
\text { através da } \\
\text { representação } \\
\text { de Felipe Néri } \\
\text { da Silveira }\end{array}$ & Indivíduos & $\begin{array}{l}\text { CADH: } 8 \\
25 \text { e } 28\end{array}$ & $\begin{array}{l}\text { Prestação de } \\
\text { Justiça }\end{array}$ \\
\hline Sudeste & RJ & P-1453-06 & Comissão & $\begin{array}{c}\text { Admiss } \\
\text { ibilidad } \\
\mathrm{e}\end{array}$ & & $\begin{array}{l}\text { Maicon de } \\
\text { Souza } \\
\text { Silva }\end{array}$ & $10 / 12 / 2006$ & $15 / 04 / 1996$ & $\begin{array}{c}\text { Organização } \\
\text { de Direitos } \\
\text { Humanos } \\
\text { PROJETO } \\
\text { LEGAL }\end{array}$ & $\begin{array}{c}\text { ONGs } \\
\text { nacionais }\end{array}$ & $\begin{array}{l}\text { CADH: } 4, \\
5,11 \text { e } 25\end{array}$ & $\begin{array}{l}\text { Violência } \\
\text { policial }\end{array}$ \\
\hline Nordeste & $\begin{array}{c}\mathrm{M} \\
\mathrm{A}\end{array}$ & 12.426 & Comissão & $\begin{array}{l}\text { Soluçã } \\
\text { o } \\
\text { Amisto } \\
\text { sa }\end{array}$ & $\begin{array}{c}\text { Cumprimento } \\
\text { de Acordo de } \\
\text { Solução } \\
\text { Amistosa }\end{array}$ & $\begin{array}{l}\text { Meninos } \\
\text { Emasculad } \\
\text { os do } \\
\text { Maranhão }\end{array}$ & $27 / 07 / 2001$ & 01/09/1991 & $\begin{array}{c}\text { Centro de } \\
\text { Defensa de los } \\
\text { Derechos del } \\
\text { Niño y del } \\
\text { Adolescente } \\
\text { Padre Marcos } \\
\text { Passerini y } \\
\text { Centro de } \\
\text { Justicia Global } \\
\text { (CJG) }\end{array}$ & $\begin{array}{c}\text { ONGs } \\
\text { nacionais }\end{array}$ & $\begin{array}{c}\text { Declaração } \\
: 1,6,7 \mathrm{e} \\
\text { 18. CADH: } \\
4,8,19 \mathrm{e} \\
25\end{array}$ & $\begin{array}{l}\text { Violência } \\
\text { contra } \\
\text { menores } \\
\text { Prestação de } \\
\text { Justiça }\end{array}$ \\
\hline
\end{tabular}




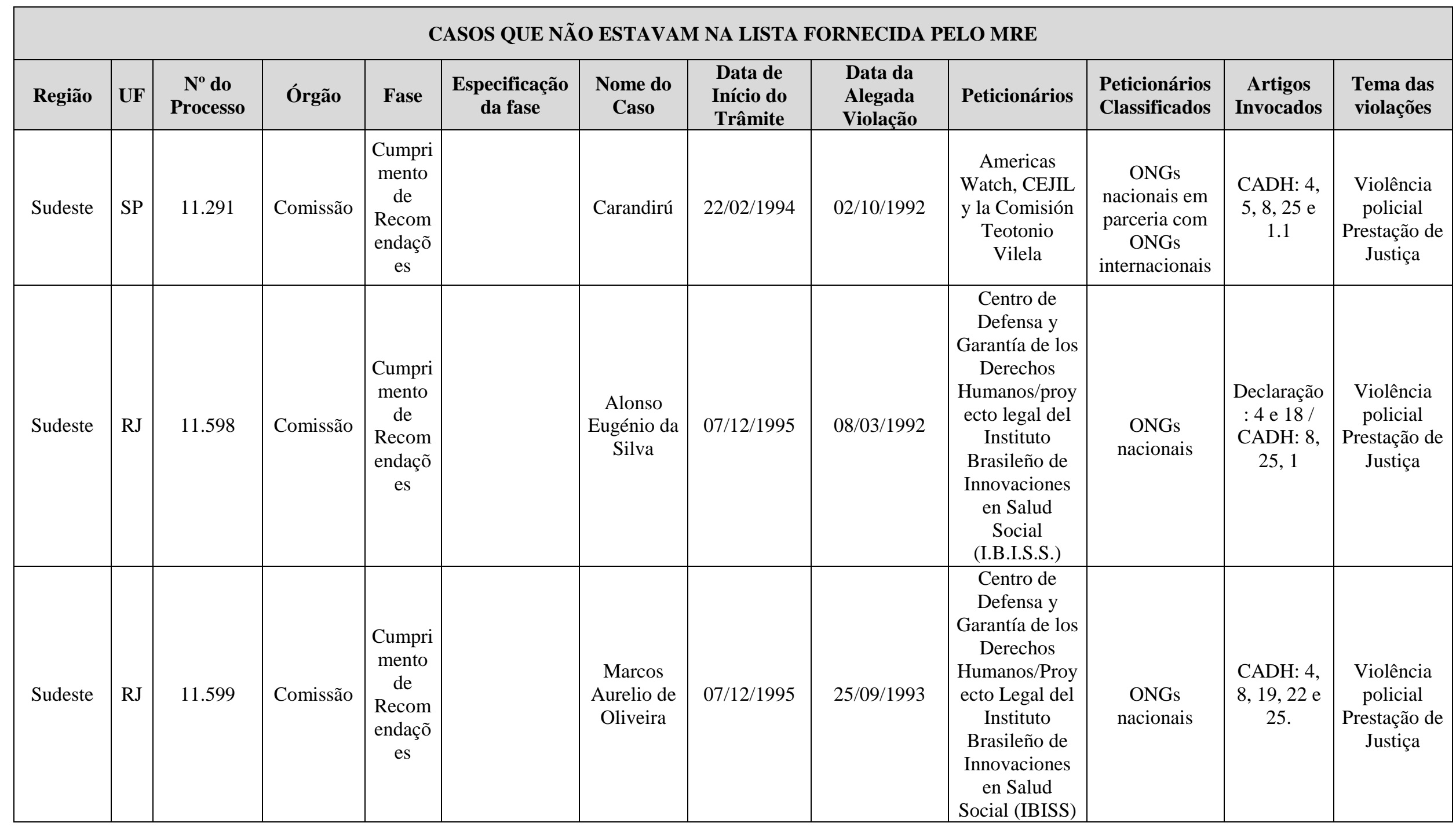




\begin{tabular}{|c|c|c|c|c|c|c|c|c|c|c|c|c|}
\hline \multicolumn{13}{|c|}{ CASOS QUE NÃO ESTAVAM NA LISTA FORNECIDA PELO MRE } \\
\hline Região & UF & $\begin{array}{c}\mathrm{N}^{\circ} \text { do } \\
\text { Processo }\end{array}$ & Órgão & Fase & $\begin{array}{l}\text { Especificação } \\
\text { da fase }\end{array}$ & $\begin{array}{l}\text { Nome do } \\
\text { Caso }\end{array}$ & $\begin{array}{l}\text { Data de } \\
\text { Início do } \\
\text { Trâmite }\end{array}$ & $\begin{array}{l}\text { Data da } \\
\text { Alegada } \\
\text { Violação }\end{array}$ & Peticionários & $\begin{array}{l}\text { Peticionários } \\
\text { Classificados }\end{array}$ & $\begin{array}{c}\text { Artigos } \\
\text { Invocados }\end{array}$ & $\begin{array}{l}\text { Tema das } \\
\text { violações }\end{array}$ \\
\hline Norte & PA & 11.820 & Comissão & $\begin{array}{l}\text { Soluçã } \\
\text { o } \\
\text { Amisto } \\
\text { sa }\end{array}$ & $\begin{array}{l}\text { Mérito (Em } \\
\text { negociacão de } \\
\text { acordo de } \\
\text { solução } \\
\text { amistosa) }\end{array}$ & $\begin{array}{c}\text { Eldorado } \\
\text { dos Carajás }\end{array}$ & $31 / 10 / 1996$ & $17 / 04 / 1996$ & $\begin{array}{l}\text { Centro pela } \\
\text { Justiça e o } \\
\text { Direito } \\
\text { Internacional } \\
\text { (CEJIL) } \\
\text { Movimento } \\
\text { dos } \\
\text { Trabalhadores } \\
\text { sem Terra } \\
\text { (MST) }\end{array}$ & $\begin{array}{c}\text { ONGs } \\
\text { nacionais em } \\
\text { parceria com } \\
\text { ONGs } \\
\text { internacionais }\end{array}$ & $\begin{array}{c}\text { CADH: } 4 \text {, } \\
5,8,25,2 \mathrm{e} \\
1.1\end{array}$ & $\begin{array}{l}\text { Violência no } \\
\text { campo }\end{array}$ \\
\hline Nordeste & $\mathrm{PE}$ & MC-199-11 & Comissão & $\begin{array}{c}\text { Medida } \\
\text { s } \\
\text { Cautela } \\
\text { res }\end{array}$ & & $\begin{array}{c}\text { Presídio } \\
\text { Professor } \\
\text { Aníbal } \\
\text { Bruno }\end{array}$ & jun/11 & jun/11 & $\begin{array}{c}\text { Pastoral } \\
\text { Carcerária de } \\
\text { Pernambuco; } \\
\text { Serviço } \\
\text { Ecumênico de } \\
\text { Militância nas } \\
\text { Prisões } \\
\text { (SEMPRI); } \\
\text { Pastoral } \\
\text { Carcerária } \\
\text { Nacional; a } \\
\text { Justiça Global } \\
\text { e a Clínica } \\
\text { Internacional } \\
\text { de Direitos } \\
\text { Humanos da } \\
\text { Universidade } \\
\text { de Harvard }\end{array}$ & $\begin{array}{c}\text { ONGs } \\
\text { nacionais em } \\
\text { parceria com } \\
\text { ONGs } \\
\text { internacionais } \\
\text { Universidades }\end{array}$ & $\begin{array}{c}\text { DIREITO } \\
\text { À VIDA, À } \\
\text { INTEGRID } \\
\text { ADE } \\
\text { PESSOAL, } \\
\text { À SAÚDE, } \\
\text { À } \\
\text { GARANTI } \\
\text { A } \\
\text { JUDICIAL } \\
\text { E À } \\
\text { PROTEÇÃ } \\
\text { O } \\
\text { JUDICIAL. }\end{array}$ & $\begin{array}{l}\text { Violência } \\
\text { institucional } \\
\text { contra } \\
\text { privados de } \\
\text { liberdade } \\
\text { (sistema } \\
\text { prisional e } \\
\text { socioeducati } \\
\text { vo) }\end{array}$ \\
\hline
\end{tabular}




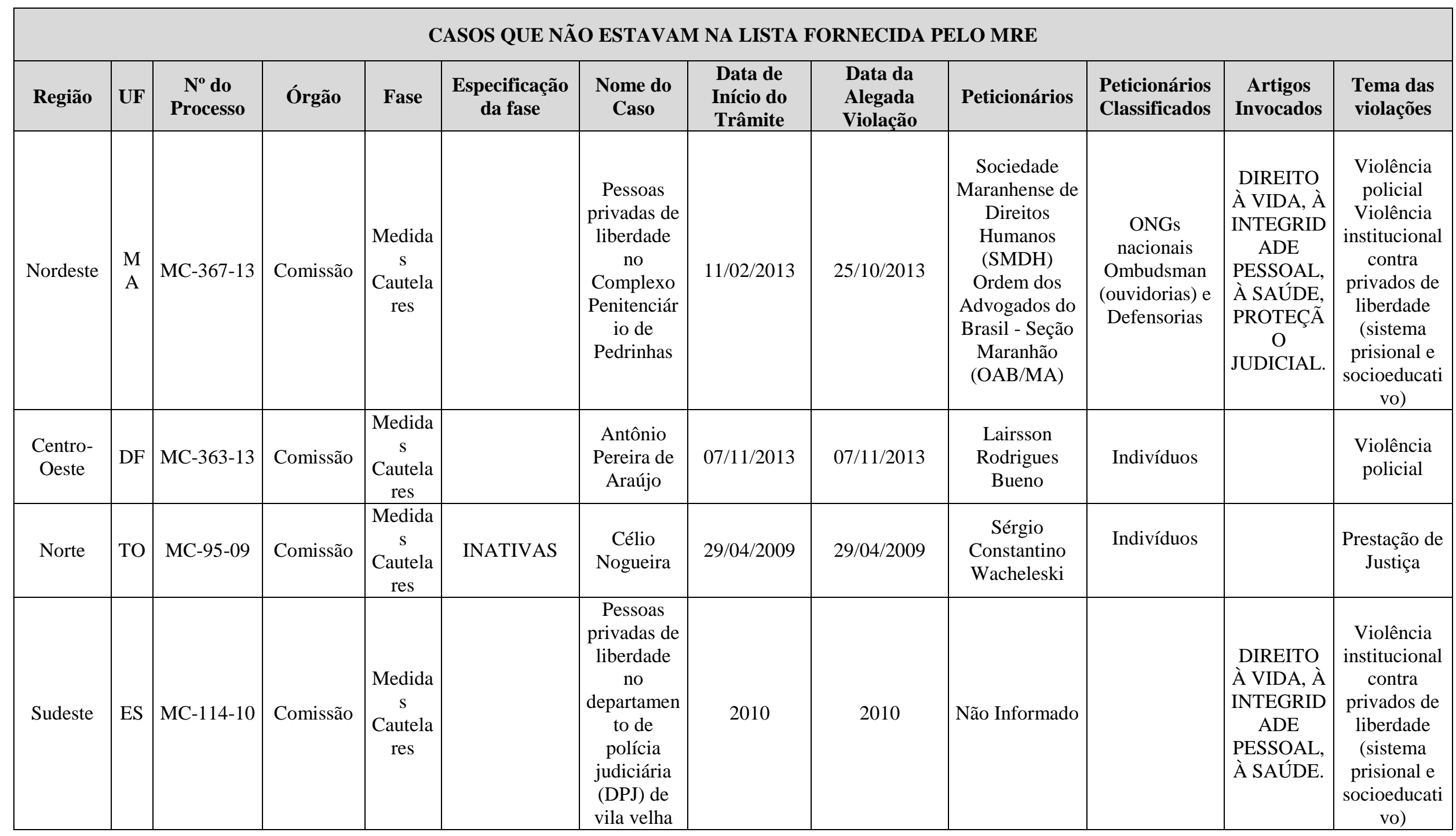




\begin{tabular}{|c|c|c|c|c|c|c|c|c|c|c|c|c|}
\hline \multicolumn{13}{|c|}{ CASOS QUE NÃO ESTAVAM NA LISTA FORNECIDA PELO MRE } \\
\hline Região & UF & $\begin{array}{c}N^{o} \text { do } \\
\text { Processo }\end{array}$ & Órgão & Fase & $\begin{array}{l}\text { Especificação } \\
\text { da fase }\end{array}$ & Nome do Caso & $\begin{array}{l}\text { Data de } \\
\text { Início do } \\
\text { Trâmite }\end{array}$ & $\begin{array}{l}\text { Data da } \\
\text { Alegada } \\
\text { Violação }\end{array}$ & Peticionários & $\begin{array}{l}\text { Peticionários } \\
\text { Classificados }\end{array}$ & $\begin{array}{c}\text { Artigos } \\
\text { Invocados }\end{array}$ & $\begin{array}{l}\text { Tema das } \\
\text { violações }\end{array}$ \\
\hline & & MC 351/02 & Comissão & $\begin{array}{l}\text { Medida } \\
\text { s } \\
\text { Cautela } \\
\text { res }\end{array}$ & & $\begin{array}{c}\text { ROSEMARY } \\
\text { SOUTO } \\
\text { MAIOR E } \\
\text { OUTROS }\end{array}$ & 2010 & 2010 & & & $\begin{array}{c}\text { DIREITO À } \\
\text { VIDA, À } \\
\text { INTEGRIDAD } \\
\text { E PESSOAL E } \\
\grave{A} \\
\text { PROTEÇÃO } \\
\text { JUDICIAL. }\end{array}$ & $\begin{array}{c}\text { Violência } \\
\text { contra } \\
\text { defensores } \\
\text { de Direitos } \\
\text { Humanos }\end{array}$ \\
\hline & & MC 224/09 & Comissão & $\begin{array}{l}\text { Medida } \\
\text { s } \\
\text { Cautela } \\
\text { res }\end{array}$ & & $\begin{array}{c}\text { ADOLESCENT } \\
\text { ES PRIVADOS } \\
\text { DE } \\
\text { LIBERDADE } \\
\text { NA UNIDADE } \\
\text { DE } \\
\text { INTERNAÇÃO } \\
\text { SOCIOEDUCA } \\
\text { TIVA (UNIS) }\end{array}$ & 2009 & 2009 & & & $\begin{array}{c}\text { DIREITO À } \\
\text { VIDA E À } \\
\text { INTEGRIDAD } \\
\text { E PESSOAL }\end{array}$ & $\begin{array}{c}\text { Violência } \\
\text { institucional } \\
\text { contra } \\
\text { privados de } \\
\text { liberdade } \\
\text { (sistema } \\
\text { prisional e } \\
\text { socioeducati } \\
\text { vo) } \\
\text { Violência } \\
\text { contra } \\
\text { menores } \\
\text { Tortura } \\
\end{array}$ \\
\hline & & MC 236/08 & Comissão & $\begin{array}{l}\text { Medida } \\
\text { s } \\
\text { Cautela } \\
\text { res }\end{array}$ & & $\begin{array}{c}\text { "PESSOAS } \\
\text { PRIVADAS DE } \\
\text { LIBERDADE } \\
\text { NA } \\
\text { PENITENCIÁRI } \\
\text { A POLINTER- } \\
\text { NEVES" }\end{array}$ & 2009 & 2009 & & & $\begin{array}{l}\text { DIREITO À } \\
\text { VIDA, À } \\
\text { INTEGRIDADE } \\
\text { PESSOAL, À } \\
\text { SAÚDE. }\end{array}$ & $\begin{array}{c}\text { Violência } \\
\text { institucional } \\
\text { contra } \\
\text { privados de } \\
\text { liberdade } \\
\text { (sistema } \\
\text { prisional e } \\
\text { socioeducati } \\
\text { vo) }\end{array}$ \\
\hline
\end{tabular}




\begin{tabular}{|c|c|c|c|c|c|c|c|c|c|c|c|c|}
\hline \multicolumn{13}{|c|}{ CASOS QUE NÃO ESTAVAM NA LISTA FORNECIDA PELO MRE } \\
\hline Região & $\mathbf{U F}$ & $\begin{array}{c}\mathrm{N}^{\mathrm{o}} \text { do } \\
\text { Processo }\end{array}$ & Órgão & Fase & $\begin{array}{l}\text { Especificação } \\
\text { da fase }\end{array}$ & $\begin{array}{l}\text { Nome do } \\
\text { Caso }\end{array}$ & $\begin{array}{l}\text { Data de } \\
\text { Início do } \\
\text { Trâmite }\end{array}$ & $\begin{array}{l}\text { Data da } \\
\text { Alegada } \\
\text { Violação }\end{array}$ & Peticionários & $\begin{array}{l}\text { Peticionários } \\
\text { Classificados }\end{array}$ & $\begin{array}{c}\text { Artigos } \\
\text { Invocados }\end{array}$ & $\begin{array}{l}\text { Tema das } \\
\text { violações }\end{array}$ \\
\hline & & & Comissão & $\begin{array}{l}\text { Medida } \\
\text { s } \\
\text { Cautela } \\
\text { res }\end{array}$ & & $\begin{array}{c}\text { CASO } \\
\text { ADOLESCE } \\
\text { NTES NA } \\
\text { CADEIA } \\
\text { PÚBLICA } \\
\text { DE } \\
\text { GUARUJÁ }\end{array}$ & 2007 & 2007 & & & \begin{tabular}{|} 
DIREITO \\
À VIDA, À \\
INTEGRID \\
ADE \\
PESSOAL, \\
À \\
PROTEÇÃ \\
O \\
JUDICIAL \\
E \\
DIREITOS \\
DAS \\
CRIANÇA \\
S \\
E \\
ADOLESC \\
ENTES.
\end{tabular} & $\begin{array}{c}\text { Violência } \\
\text { institucional } \\
\text { contra } \\
\text { privados de } \\
\text { liberdade } \\
\text { (sistema } \\
\text { prisional e } \\
\text { socioeducati } \\
\text { vo) }\end{array}$ \\
\hline & & & Comissão & $\begin{array}{l}\text { Medida } \\
\text { s } \\
\text { Cautela } \\
\text { res }\end{array}$ & & $\begin{array}{c}\text { CASO } \\
\text { MARIA } \\
\text { APARECID } \\
\text { A } \\
\text { DENADAI }\end{array}$ & 2006 & 2006 & & & $\begin{array}{c}\text { DIREITO } \\
\text { À VIDA E } \\
\hat{A} \\
\text { INTEGRID } \\
\text { ADE } \\
\text { PESSOAL. }\end{array}$ & $\begin{array}{c}\text { Violência } \\
\text { contra } \\
\text { defensores } \\
\text { de Direitos } \\
\text { Humanos }\end{array}$ \\
\hline & & & & & & & & & & & & \\
\hline
\end{tabular}




\begin{tabular}{|c|c|c|c|c|c|c|c|c|c|c|c|c|}
\hline \multicolumn{13}{|c|}{ CASOS QUE NÃO ESTAVAM NA LISTA FORNECIDA PELO MRE } \\
\hline Região & $\mathbf{U F}$ & $\begin{array}{c}N^{o} \text { do } \\
\text { Processo }\end{array}$ & Órgão & Fase & $\begin{array}{l}\text { Especificação } \\
\text { da fase }\end{array}$ & $\begin{array}{l}\text { Nome do } \\
\text { Caso }\end{array}$ & $\begin{array}{c}\text { Data de } \\
\text { Início do } \\
\text { Trâmite } \\
\end{array}$ & $\begin{array}{l}\text { Data da } \\
\text { Alegada } \\
\text { Violação } \\
\end{array}$ & Peticionários & $\begin{array}{l}\text { Peticionários } \\
\text { Classificados }\end{array}$ & $\begin{array}{c}\text { Artigos } \\
\text { Invocado } \\
\text { S } \\
\end{array}$ & $\begin{array}{l}\text { Tema das } \\
\text { violações }\end{array}$ \\
\hline & & MC 130/06 & Comissão & $\begin{array}{l}\text { Medida } \\
\text { s } \\
\text { Cautela } \\
\text { res }\end{array}$ & & $\begin{array}{c}\text { "PESSOAS } \\
\text { DETIDAS NA } \\
76^{\mathrm{a}} \\
\text { DELEGACIA } \\
\text { DE POLÍCIA }\end{array}$ & 2006 & 2006 & & & $\begin{array}{c}\text { DIREITO } \\
\text { À VIDA } \\
\text { E À } \\
\text { INTEGRI } \\
\text { DADE } \\
\text { PESSOA } \\
\text { L. }\end{array}$ & $\begin{array}{c}\text { Violência } \\
\text { policial } \\
\text { Violência } \\
\text { institucional } \\
\text { contra privados } \\
\text { de liberdade } \\
\text { (sistema } \\
\text { prisional e } \\
\text { socioeducativo } \\
\text { ) } \\
\text { Tortura }\end{array}$ \\
\hline Sudeste & SP & MC 852/04 & Comissão & $\begin{array}{l}\text { Medida } \\
\text { s } \\
\text { Cautela } \\
\text { res }\end{array}$ & & $\begin{array}{c}\text { “CRIANÇAS } \\
\text { PRIVADAS } \\
\text { DE } \\
\text { LIBERDADE } \\
\text { NA } \\
\text { FUNDAÇÃO } \\
\text { ESTADUAL } \\
\text { DO BEM- } \\
\text { ESTAR DO } \\
\text { MENOR } \\
\text { (FEBEM) DO } \\
\text { TATUAPÉ }\end{array}$ & 2004 & 2004 & & & $\begin{array}{c}\text { DIREITO } \\
\text { À VIDA, } \\
\text { À } \\
\text { INTEGRI } \\
\text { DADE } \\
\text { PESSOA } \\
\text { L, À } \\
\text { SAÚDE. }\end{array}$ & $\begin{array}{c}\text { Violência } \\
\text { institucional } \\
\text { contra privados } \\
\text { de liberdade } \\
\text { (sistema } \\
\text { prisional e } \\
\text { socioeducativo } \\
\text { ) } \\
\text { Violência } \\
\text { contra menores }\end{array}$ \\
\hline & & & & & & & & & & & & \\
\hline
\end{tabular}




\begin{tabular}{|c|c|c|c|c|c|c|c|c|c|c|c|c|}
\hline \multicolumn{13}{|c|}{ CASOS QUE NÃO ESTAVAM NA LISTA FORNECIDA PELO MRE } \\
\hline \multirow[t]{2}{*}{ Sul } & PR & & Comissão & $\begin{array}{l}\text { Medida } \\
\text { s } \\
\text { Cautela } \\
\text { res }\end{array}$ & & $\begin{array}{c}\text { “CASO } \\
\text { JORGE } \\
\text { CUSTODIO, } \\
\text { ROSANGEL } \\
\text { A } \\
\text { APARECID } \\
\text { A } \\
\text { SARAIVA } \\
\text { FERREIRA } \\
\text { E } \\
\text { ALESSAND } \\
\text { RA } \\
\text { RODRIGUE } \\
\text { Z } \\
\text { CELESTIN } \\
\text { O }\end{array}$ & 2003 & 2003 & & & $\begin{array}{c}\text { DIREITO } \\
\text { À VIDA E } \\
\text { À } \\
\text { INTEGRID } \\
\text { ADE } \\
\text { PESSOAL. }\end{array}$ & $\begin{array}{c}\text { Violência } \\
\text { contra } \\
\text { defensores } \\
\text { de Direitos } \\
\text { Humanos }\end{array}$ \\
\hline & & & Comissão & $\begin{array}{l}\text { Medida } \\
\text { s } \\
\text { Cautela } \\
\text { res }\end{array}$ & & $\begin{array}{c}\text { "CASO } \\
\text { MARIA } \\
\text { APARECID } \\
\text { A GOMES } \\
\text { DA SILVA } \\
\text { E } \\
\text { SUA } \\
\text { FAMÍLIA E } \\
\text { EDSON } \\
\text { AZAMBUJ } \\
\text { A" }\end{array}$ & 2003 & 2003 & & & $\begin{array}{c}\text { DIREITO } \\
\text { À VIDA E } \\
\text { À } \\
\text { INTEGRID } \\
\text { ADE } \\
\text { PESSOAL. }\end{array}$ & $\begin{array}{c}\text { Violência } \\
\text { contra } \\
\text { defensores } \\
\text { de Direitos } \\
\text { Humanos }\end{array}$ \\
\hline
\end{tabular}




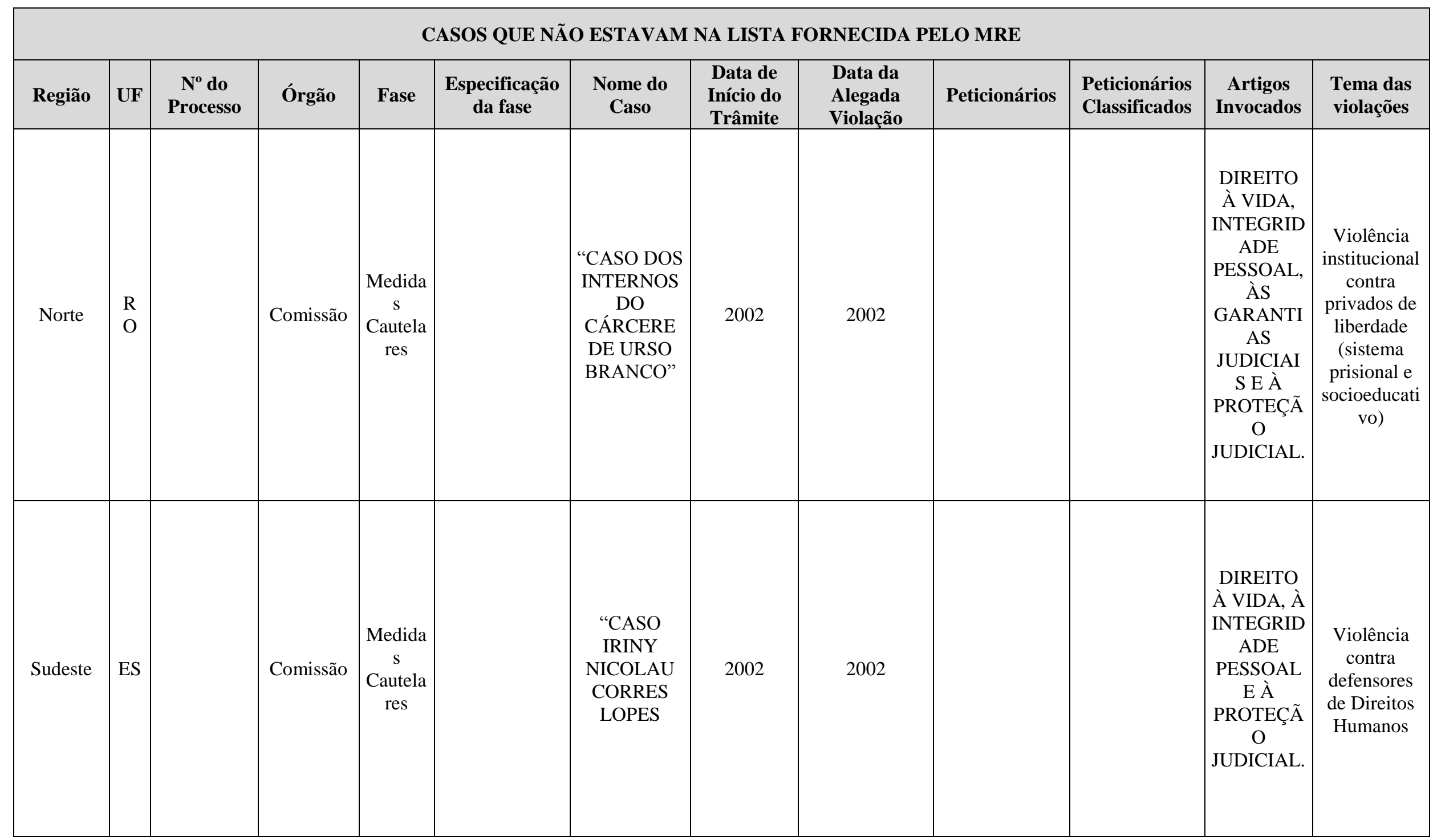




\begin{tabular}{|c|c|c|c|c|c|c|c|c|c|c|c|c|}
\hline \multicolumn{13}{|c|}{ CASOS QUE NÃO ESTAVAM NA LISTA FORNECIDA PELO MRE } \\
\hline Região & UF & $\begin{array}{c}N^{\circ} \text { do } \\
\text { Processo }\end{array}$ & Órgão & Fase & $\begin{array}{l}\text { Especificação } \\
\text { da fase }\end{array}$ & $\begin{array}{l}\text { Nome do } \\
\text { Caso }\end{array}$ & $\begin{array}{c}\text { Data de } \\
\text { Início do } \\
\text { Trâmite }\end{array}$ & $\begin{array}{l}\text { Data da } \\
\text { Alegada } \\
\text { Violação } \\
\end{array}$ & Peticionários & $\begin{array}{l}\text { Peticionários } \\
\text { Classificados }\end{array}$ & $\begin{array}{c}\text { Artigos } \\
\text { Invocados }\end{array}$ & $\begin{array}{l}\text { Tema das } \\
\text { violações }\end{array}$ \\
\hline & & & Comissão & $\begin{array}{c}\text { Medida } \\
\text { s } \\
\text { Cautela } \\
\text { res }\end{array}$ & & $\begin{array}{c}\text { “CASO } \\
\text { RONY } \\
\text { CLAY } \\
\text { CHAVES, } \\
\text { RUBENS } \\
\text { LEONCIO } \\
\text { PEREIRA, } \\
\text { MARCOS } \\
\text { MASSARI E } \\
\text { GILMAR } \\
\text { LEITE } \\
\text { SIQUIERA } \\
\text { (PROTEÇÃ } \\
\text { O DE } \\
\text { TESTEMUN } \\
\text { HAS DA } \\
\text { OPERAÇÃ } \\
\text { O } \\
\text { CASTELIN } \\
\text { HO)” }\end{array}$ & 2002 & 2002 & & & $\begin{array}{c}\text { DIREITO } \\
\text { À VIDA E } \\
\grave{A} \\
\text { INTEGRID } \\
\text { ADE } \\
\text { PESSOAL. }\end{array}$ & Outros \\
\hline & & MC 351/02 & Comissão & $\begin{array}{c}\text { Medida } \\
\text { s } \\
\text { Cautela } \\
\text { res }\end{array}$ & & $\begin{array}{c}\text { "CASO } \\
\text { MANOEL } \\
\text { BEZERRA, } \\
\text { ROSEMAR } \\
\text { Y } \\
\text { SOUTO E } \\
\text { LUIZ DA } \\
\text { SILVA }\end{array}$ & 2002 & 2002 & & & $\begin{array}{c}\text { DIREITO } \\
\text { À VIDA, À } \\
\text { INTEGRID } \\
\text { ADE } \\
\text { PESSOAL } \\
\text { E À } \\
\text { PROTEÇÃ } \\
\text { O } \\
\text { JUDICIAL. }\end{array}$ & Outros \\
\hline
\end{tabular}




\begin{tabular}{|c|c|c|c|c|c|c|c|c|c|c|c|c|}
\hline \multicolumn{13}{|c|}{ CASOS QUE NÃO ESTAVAM NA LISTA FORNECIDA PELO MRE } \\
\hline \multirow[t]{3}{*}{ Sudeste } & \multirow[t]{2}{*}{ SP } & & Comissão & $\begin{array}{l}\text { Medida } \\
\text { s } \\
\text { Cautela } \\
\text { res }\end{array}$ & & $\begin{array}{c}\text { CASO DOS } \\
\text { PROMOTO } \\
\text { RES E DOS } \\
\text { DETENTOS } \\
\text { DA } \\
\text { PRISÃO } \\
\text { PÚBLICA } \\
\text { DE } \\
\text { SOROCAB } \\
\text { A" }\end{array}$ & 2000 & 2000 & & & \begin{tabular}{|} 
DIREITO \\
À VIDA, À \\
INTEGRID \\
ADE \\
PESSOAL \\
E À \\
PROTEÇÃ \\
O \\
JUDICIAL.
\end{tabular} & Outros \\
\hline & & & Comissão & $\begin{array}{l}\text { Medida } \\
\text { s } \\
\text { Cautela } \\
\text { res }\end{array}$ & & $\begin{array}{c}\text { "CASO } \\
\text { BENEDITO } \\
\text { MARIANO" }\end{array}$ & 2000 & 2000 & & & \begin{tabular}{|c|} 
DIREITO \\
À VIDA, À \\
INTEGRID \\
ADE \\
PESSOAL \\
E À \\
PROTEÇÃ \\
O \\
JUDICIAL.
\end{tabular} & Outros \\
\hline & & & Comissão & $\begin{array}{l}\text { Medida } \\
\text { s } \\
\text { Cautela } \\
\text { res }\end{array}$ & & $\begin{array}{c}\text { CASO } \\
\text { CATHERIN } \\
\text { E } \\
\text { HALVEY" }\end{array}$ & 2000 & 2000 & & & \begin{tabular}{|c|} 
DIREITO \\
À VIDA, À \\
INTEGRID \\
ADE \\
PESSOAL \\
E À \\
PROTEÇÃ \\
O \\
JUDICIAL.
\end{tabular} & $\begin{array}{c}\text { Violência } \\
\text { contra } \\
\text { defensores } \\
\text { de Direitos } \\
\text { Humanos }\end{array}$ \\
\hline
\end{tabular}




\begin{tabular}{|c|c|c|c|c|c|c|c|c|c|c|c|c|}
\hline \multicolumn{13}{|c|}{ CASOS QUE NÃO ESTAVAM NA LISTA FORNECIDA PELO MRE } \\
\hline Região & UF & $\begin{array}{c}N^{\circ} \text { do } \\
\text { Processo }\end{array}$ & Órgão & Fase & $\begin{array}{l}\text { Especificação } \\
\text { da fase }\end{array}$ & $\begin{array}{l}\text { Nome do } \\
\text { Caso }\end{array}$ & $\begin{array}{c}\text { Data de } \\
\text { Início do } \\
\text { Trâmite }\end{array}$ & $\begin{array}{l}\text { Data da } \\
\text { Alegada } \\
\text { Violação }\end{array}$ & Peticionários & $\begin{array}{l}\text { Peticionários } \\
\text { Classificados }\end{array}$ & $\begin{array}{c}\text { Artigos } \\
\text { Invocados }\end{array}$ & $\begin{array}{l}\text { Tema das } \\
\text { violações }\end{array}$ \\
\hline & & & Comissão & $\begin{array}{l}\text { Medida } \\
\text { s } \\
\text { Cautela } \\
\text { res }\end{array}$ & & $\begin{array}{c}\text { “CASO } \\
\text { JOAQUIM } \\
\text { MARCELO } \\
\text { DENADAI }\end{array}$ & 1999 & 1999 & & & \begin{tabular}{|c|} 
DIREITO \\
À VIDA, À \\
INTEGRID \\
ADE \\
PESSOAL \\
E À \\
PROTEÇÃ \\
O \\
JUDICIAL.
\end{tabular} & $\begin{array}{c}\text { Violência } \\
\text { contra } \\
\text { defensores } \\
\text { de Direitos } \\
\text { Humanos }\end{array}$ \\
\hline & & & Comissão & $\begin{array}{l}\text { Medida } \\
\text { s } \\
\text { Cautela } \\
\text { res }\end{array}$ & & $\begin{array}{l}\text { "CASO } \\
\text { LUZIA } \\
\text { CANUTO" }\end{array}$ & 1998 & 1998 & & & \begin{tabular}{|c|} 
DIREITO \\
À VIDA, À \\
INTEGRID \\
ADE \\
PESSOAL \\
E À \\
PROTEÇÃ \\
O \\
JUDICIAL.
\end{tabular} & $\begin{array}{c}\text { Violência no } \\
\text { campo } \\
\text { Violência } \\
\text { contra } \\
\text { defensores } \\
\text { de Direitos } \\
\text { Humanos }\end{array}$ \\
\hline & & & Comissão & $\begin{array}{l}\text { Medida } \\
\text { s } \\
\text { Cautela } \\
\text { res }\end{array}$ & & $\begin{array}{l}\text { "2 }{ }^{\circ} \text { CASO } \\
\text { PADRE } \\
\text { RICARDO } \\
\text { REZENDE" }\end{array}$ & 1998 & 1998 & & & \begin{tabular}{|c} 
DIREITO \\
À VIDA, \\
INTEGRID \\
ADE \\
PESSOAL, \\
À \\
GARANTI \\
A \\
JUDICIAL \\
E À \\
PROTEÇÃ \\
O \\
JUDICIAL.
\end{tabular} & $\begin{array}{c}\text { Violência no } \\
\text { campo } \\
\text { Violência } \\
\text { contra } \\
\text { defensores } \\
\text { de Direitos } \\
\text { Humanos }\end{array}$ \\
\hline
\end{tabular}




\begin{tabular}{|c|c|c|c|c|c|c|c|c|c|c|c|c|}
\hline \multicolumn{13}{|c|}{ CASOS QUE NÃO ESTAVAM NA LISTA FORNECIDA PELO MRE } \\
\hline Região & $\mathbf{U F}$ & $\begin{array}{c}\mathrm{N}^{\circ} \text { do } \\
\text { Processo }\end{array}$ & Órgão & Fase & $\begin{array}{l}\text { Especificação } \\
\text { da fase }\end{array}$ & $\begin{array}{l}\text { Nome do } \\
\text { Caso }\end{array}$ & $\begin{array}{c}\text { Data de } \\
\text { Início do } \\
\text { Trâmite }\end{array}$ & $\begin{array}{l}\text { Data da } \\
\text { Alegada } \\
\text { Violação }\end{array}$ & Peticionários & $\begin{array}{l}\text { Peticionários } \\
\text { Classificados }\end{array}$ & $\begin{array}{c}\text { Artigos } \\
\text { Invocados }\end{array}$ & $\begin{array}{l}\text { Tema das } \\
\text { violações }\end{array}$ \\
\hline & & $\begin{array}{l}\text { CASO } \\
12.002\end{array}$ & Comissão & $\begin{array}{l}\text { Medida } \\
\text { s } \\
\text { Cautela } \\
\text { res }\end{array}$ & & $\begin{array}{l}\text { "MARIA } \\
\text { EMILIA DE } \\
\text { MARCHI E } \\
\text { OUTROS" }\end{array}$ & 1998 & 1998 & & & \begin{tabular}{|c|} 
DIREITO \\
À VIDA, À \\
INTEGRID \\
ADE \\
PESSOAL \\
E À \\
PROTEÇÃ \\
O \\
JUDICIAL.
\end{tabular} & $\begin{array}{c}\text { Violência } \\
\text { institucional } \\
\text { contra } \\
\text { privados de } \\
\text { liberdade } \\
\text { (sistema } \\
\text { prisional e } \\
\text { socioeducati } \\
\text { vo) }\end{array}$ \\
\hline Norte & PA & & Comissão & $\begin{array}{l}\text { Medida } \\
\text { s } \\
\text { Cautela } \\
\text { res }\end{array}$ & & $\begin{array}{c}\text { "1 }{ }^{\circ} \text { CASO } \\
\text { PADRE } \\
\text { RICARDO } \\
\text { REZENDE } \\
\text { E OUTROS" }\end{array}$ & $1995 / 1996$ & $1995 / 1996$ & & & $\begin{array}{c}\text { DIREITO } \\
\text { À VIDA, À } \\
\text { INTEGRID } \\
\text { ADE } \\
\text { PESSOAL } \\
\text { E À } \\
\text { PROTEÇÃ } \\
\text { O } \\
\text { JUDICIAL. }\end{array}$ & $\begin{array}{c}\text { Violência } \\
\text { contra } \\
\text { defensores } \\
\text { de Direitos } \\
\text { Humanos }\end{array}$ \\
\hline Sudeste & ES & & Comissão & $\begin{array}{l}\text { Medida } \\
\text { s } \\
\text { Cautela } \\
\text { res }\end{array}$ & & $\begin{array}{c}\text { "CASO DO } \\
\text { ADVOGAD } \\
\text { O OSMAR } \\
\text { BARCELOS } \\
\text { DO } \\
\text { NASCIMEN } \\
\text { TO" }\end{array}$ & 1996 & 1996 & & & \begin{tabular}{|c|} 
DIREITO \\
À VIDA, À \\
INTEGRID \\
ADE \\
PESSOAL \\
E À \\
PROTEÇÃ \\
O \\
JUDICIAL.
\end{tabular} & $\begin{array}{l}\text { Violência } \\
\text { contra } \\
\text { defensores } \\
\text { de Direitos } \\
\text { Humanos }\end{array}$ \\
\hline
\end{tabular}




\begin{tabular}{|c|c|c|c|c|c|c|c|c|c|c|c|c|}
\hline \multicolumn{13}{|c|}{ CASOS QUE NÃO ESTAVAM NA LISTA FORNECIDA PELO MRE } \\
\hline Região & $\mathbf{U F}$ & $\begin{array}{c}\mathrm{N}^{\circ} \text { do } \\
\text { Processo }\end{array}$ & Órgão & Fase & $\begin{array}{l}\text { Especificação } \\
\text { da fase }\end{array}$ & $\begin{array}{l}\text { Nome do } \\
\text { Caso }\end{array}$ & $\begin{array}{l}\text { Data de } \\
\text { Início do } \\
\text { Trâmite }\end{array}$ & $\begin{array}{l}\text { Data da } \\
\text { Alegada } \\
\text { Violação }\end{array}$ & Peticionários & $\begin{array}{l}\text { Peticionários } \\
\text { Classificados }\end{array}$ & $\begin{array}{c}\text { Artigos } \\
\text { Invocados }\end{array}$ & $\begin{array}{l}\text { Tema das } \\
\text { violações }\end{array}$ \\
\hline & & & Comissão & $\begin{array}{l}\text { Medida } \\
\text { s } \\
\text { Cautela } \\
\text { res }\end{array}$ & & $\begin{array}{c}\text { "CASO DOS } \\
\text { MENORES } \\
\text { INTERNOS } \\
\text { DO } \\
\text { INSTITUTO } \\
\text { PADRE } \\
\text { SEVERINO, } \\
\text { DA } \\
\text { ESCOLA } \\
\text { JOÃO LUIS } \\
\text { ALVES } \\
\text { E DA } \\
\text { ESCOLA } \\
\text { SANTOS } \\
\text { DUMONT" }\end{array}$ & 1996 & 1996 & & & $\begin{array}{c}\text { DIREITO } \\
\text { À VIDA, À } \\
\text { INTEGRID } \\
\text { ADE } \\
\text { PESSOAL } \\
\text { E À } \\
\text { PROTEÇÃ } \\
\text { O } \\
\text { JUDICIAL. }\end{array}$ & $\begin{array}{l}\text { Violência } \\
\text { institucional } \\
\text { contra } \\
\text { privados de } \\
\text { liberdade } \\
\text { (sistema } \\
\text { prisional e } \\
\text { socioeducati } \\
\text { vo) }\end{array}$ \\
\hline & & & Comissão & $\begin{array}{l}\text { Medida } \\
\text { s } \\
\text { Cautela } \\
\text { res }\end{array}$ & & $\begin{array}{c}\text { "CASO } \\
\text { AMEAÇAD } \\
\text { OS PELOS } \\
\text { 'MENINOS } \\
\text { DE OURO"” }\end{array}$ & 1996 & 1996 & & & \begin{tabular}{|c|} 
DIREITO \\
À VIDA, À \\
INTEGRID \\
ADE \\
PESSOAL \\
E À \\
PROTEÇÃ \\
O \\
JUDICIAL.
\end{tabular} & $\begin{array}{c}\text { Violência } \\
\text { contra } \\
\text { defensores } \\
\text { de Direitos } \\
\text { Humanos }\end{array}$ \\
\hline
\end{tabular}




\begin{tabular}{|c|c|c|c|c|c|c|c|}
\hline $\begin{array}{l}\text { Centro- } \\
\text { oeste }\end{array}$ & To & Corte & $\begin{array}{c}\text { Medida } \\
\text { s } \\
\text { Provisi } \\
\text { onais }\end{array}$ & $\begin{array}{c}\text { CASO } \\
\text { JULIA } \\
\text { GOMES } \\
\text { LUND E } \\
\text { OUTROS" }\end{array}$ & 2009 & 2009 & \begin{tabular}{c|c} 
DIREITO & \\
À VIDA, À & \\
INTEGRID & \\
ADE & \\
PESSOAL, & \\
À & \\
LIBERDA & \\
DE, AO & \\
TRABALH & \\
O E A & \\
UMA & Crimes do \\
JUSTA & período da \\
REMUNE & ditadura \\
RAÇÃO, & \\
ÅS & \\
GARANTI & \\
AS & \\
JUDICIAI & \\
S E À & \\
PROTEÇÃ & \\
O & \\
JUDICIAL. &
\end{tabular} \\
\hline
\end{tabular}




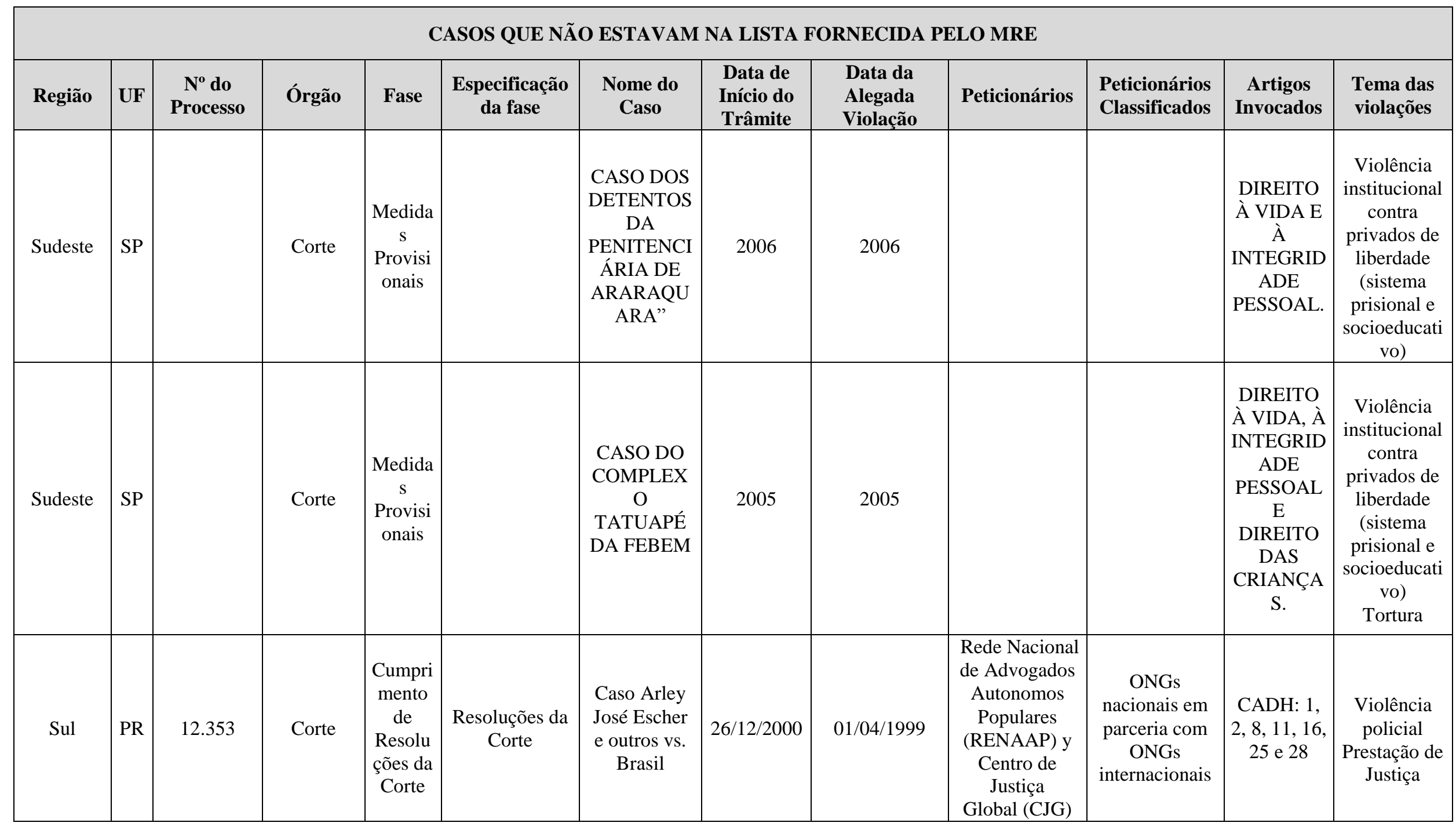




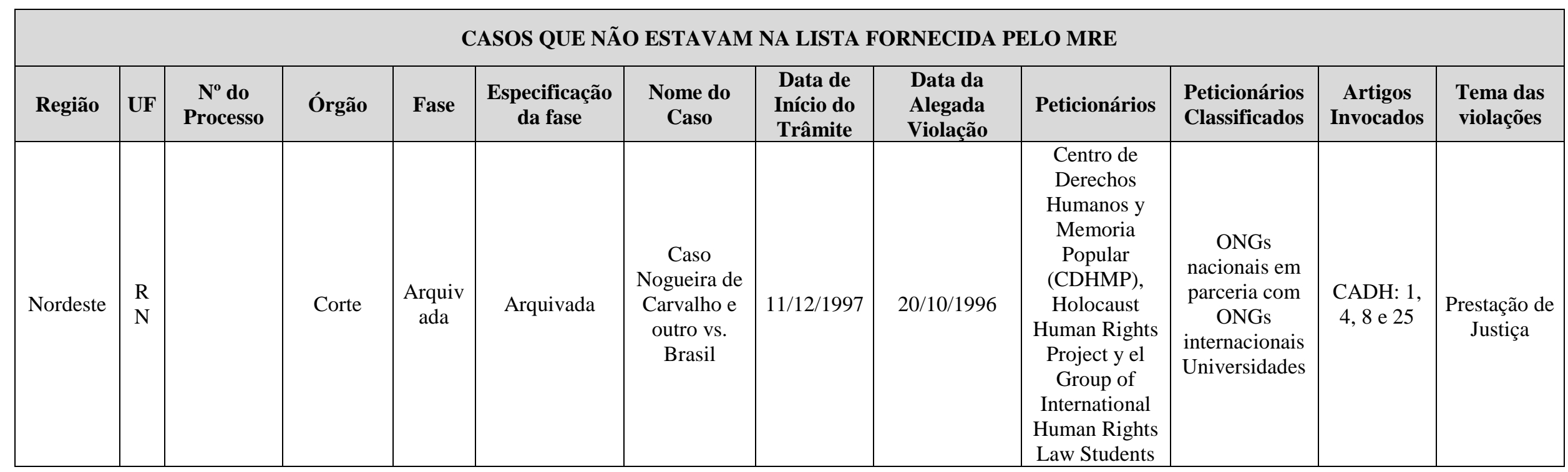




\section{CASOS QUE NÃO ESTAVAM NA LISTA FORNECIDA PELA SDH}

\begin{tabular}{|c|c|c|c|c|c|c|c|}
\hline Região & $\mathbf{U F}$ & $\begin{array}{l}\text { Número do } \\
\text { Processo }\end{array}$ & Órgão & Fase & $\begin{array}{l}\text { Especificação } \\
\text { da fase }\end{array}$ & Nome do Caso & Data de Início do Trâmite \\
\hline Nordeste & PB & P-1170-09 & Comissão & Admissibilidade & & Almir Muniz da Silva & $18 / 09 / 2009$ \\
\hline Sudeste & SP & P-23-10 & Comissão & Admissibilidade & & Almir Rodrigues Ferreira & $06 / 01 / 2010$ \\
\hline Norte & RO & P-1349-09 & Comissão & Admissibilidade & & $\begin{array}{c}\text { Apenados do Sistema Prisional de } \\
\text { Arniqueiras }\end{array}$ & $27 / 10 / 2009$ \\
\hline Centro-Oeste & MS & P-1056-20 & Comissão & Admissibilidade & & $\begin{array}{l}\text { Brigido Ibanhes e Elisangela dos } \\
\text { Santos de Souza Ibanhes }\end{array}$ & $22 / 07 / 2010$ \\
\hline Sudeste & SP & P-187-09 & Comissão & Admissibilidade & & $\begin{array}{c}\text { Carlos Eduardo de Oliveira Preti e } \\
\text { outros }\end{array}$ & $23 / 02 / 2009$ \\
\hline Sudeste & SP & P-690-11 & Comissão & Admissibilidade & & Cho Bong Heang & $19 / 02 / 2011$ \\
\hline Sudeste & SP & P-60-09 & Comissão & Admissibilidade & & Claudio Bento de Oliveira & $20 / 01 / 2009$ \\
\hline Nordeste & MA & P-1204-10 & Comissão & Admissibilidade & & $\begin{array}{c}\text { Comunidade Quilombola de Saco } \\
\text { das Almas }\end{array}$ & $28 / 06 / 2010$ \\
\hline Centro-Oeste & GO & $\mathrm{P}-1222-09$ & Comissão & Admissibilidade & & Daliana Kristel Gonçalves Camargo & $30 / 09 / 2009$ \\
\hline Sudeste & SP & $\mathrm{P}-1085-11$ & Comissão & Admissibilidade & & Francisco Rocha & $17 / 08 / 2011$ \\
\hline Nordeste & $\mathrm{CE}$ & $\mathrm{P}-1411-07$ & Comissão & Admissibilidade & & Francisco de Souza Geraldo & $18 / 12 / 2007$ \\
\hline Sudeste & SP & P-1174-09 & Comissão & Admissibilidade & & José Rafael Brezer & $17 / 09 / 2009$ \\
\hline Sudeste & SP & P-362-09 & Comissão & Admissibilidade & & Luiza Melinho & $26 / 03 / 2014$ \\
\hline Sudeste & SP & P-858-09 & Comissão & Admissibilidade & & Luiz José da Cunha e Família & $14 / 07 / 2009$ \\
\hline Norte & $\mathrm{AM}$ & P-90-09 & Comissão & Admissibilidade & & Luiz Otávio Monteiro & $29 / 01 / 2009$ \\
\hline Sudeste & MG & P-974-09 & Comissão & Admissibilidade & & Paulo Cézar de Oliveira & $05 / 08 / 2009$ \\
\hline Sudeste & $\mathrm{RJ}$ & P-1116-07 & Comissão & Admissibilidade & & $\begin{array}{l}\text { Paulo Igor do Nascimento Filho, } \\
\text { Rafael Carvalho da Costa e outros }\end{array}$ & $27 / 08 / 2007$ \\
\hline Sul & $\mathrm{RS}$ & P-81-13 & Comissão & Admissibilidade & & $\begin{array}{l}\text { Pessoas Privadas de Liberdade no } \\
\text { Presídio Central de Porto Alegre }\end{array}$ & $11 / 01 / 2013$ \\
\hline
\end{tabular}




\begin{tabular}{|c|c|c|c|c|c|c|c|}
\hline \multicolumn{7}{|c|}{ CASOS QUE NÃO ESTAVAM NA LISTA FORNECIDA PELA SDH } \\
\hline Região & UF & $\begin{array}{c}\text { Número do } \\
\text { Processo }\end{array}$ & Órgão & Fase & $\begin{array}{c}\text { Especificação } \\
\text { da fase }\end{array}$ & Nome do Caso & Data de Início do Trâmite \\
\hline Sudeste & SP & & Comissão & Admissibilidade & & Wolf Gruenberg e Betty Guendler \\
Gruenberg & & $06 / 08 / 2012$ \\
\hline Norte & PA & 12.398 & Comissão & Análise de Mérito & & $\begin{array}{c}\text { Max Cley Mendes, Marciley Roseval } \\
\text { Melo e Luis Fábio Coutinho da Silva }\end{array}$ & $17 / 09 / 2001$ \\
\hline Norte & RO & MC-250-06 & Comissão & Medidas Cautelares & INATIVAS & Almir Suruí, sua família e seu povo & $19 / 10 / 2005$ \\
\hline Sudeste & MG & MC-314-14 & Comissão & Medidas Cautelares & Ativa & $\begin{array}{c}\text { Comunidades Esperança, Vitória e } \\
\text { Rosa Leão - BH }\end{array}$ & $12 / 10 / 2006$ \\
\hline Nordeste & PE & MC-1038-04 & Comissão & Medidas Cautelares & INATIVAS & $\begin{array}{c}\text { Dominici Sávio Ramos Coelho } \\
\text { Mororó }\end{array}$ & $17 / 09 / 2014$ \\
\hline Sudeste & SP & MC-251-10 & Comissão & Medidas Cautelares & INATIVAS & Eduardo Nuno de Freitas Pereira & $16 / 11 / 2004$ \\
\hline Sul & PR & MC-366-14 & Comissão & Medidas Cautelares & Ativa & $\begin{array}{c}\text { Presos, agentes e funcionários das } \\
\text { unidades de tratamento penal do } \\
\text { Paraná }\end{array}$ & $10 / 05 / 2010$ \\
\hline
\end{tabular}




\begin{tabular}{|c|c|c|c|c|c|c|c|c|c|c|}
\hline \multicolumn{11}{|c|}{ CASOS QUE NÃO ESTAVAM NOS DOIS PEDIDOS DE INFORMAÇÃO } \\
\hline Região & UF & $\begin{array}{c}\mathrm{N}^{\circ} \text { do } \\
\text { Processo }\end{array}$ & Órgão & Fase & $\begin{array}{l}\text { Especificação } \\
\text { da fase }\end{array}$ & Nome do Caso & $\begin{array}{l}\text { Data de } \\
\text { Início do } \\
\text { Trâmite } \\
\end{array}$ & $\begin{array}{l}\text { Data da } \\
\text { Alegada } \\
\text { Violação } \\
\end{array}$ & Artigos Invocados & $\begin{array}{l}\text { Tema das } \\
\text { violações }\end{array}$ \\
\hline & & MC 351/02 & Comissão & $\begin{array}{l}\text { Medidas } \\
\text { Cautelares }\end{array}$ & & $\begin{array}{l}\text { ROSEMARY } \\
\text { SOUTO MAIOR E } \\
\text { OUTROS }\end{array}$ & 2010 & 2010 & $\begin{array}{l}\text { DIREITO À VIDA, À } \\
\text { INTEGRIDADE } \\
\text { PESSOAL E À } \\
\text { PROTEÇÃO JUDICIAL. }\end{array}$ & $\begin{array}{c}\text { Violência contra } \\
\text { defensores de } \\
\text { Direitos } \\
\text { Humanos }\end{array}$ \\
\hline & & MC 224/09 & Comissão & $\begin{array}{c}\text { Medidas } \\
\text { Cautelares }\end{array}$ & & $\begin{array}{l}\text { ADOLESCENTES } \\
\text { PRIVADOS DE } \\
\text { LIBERDADE NA } \\
\text { UNIDADE DE } \\
\text { INTERNAÇÃO } \\
\text { SOCIOEDUCATI } \\
\text { VA (UNIS) }\end{array}$ & 2009 & 2009 & $\begin{array}{l}\text { DIREITO À VIDA E À } \\
\text { INTEGRIDADE } \\
\text { PESSOAL. }\end{array}$ & $\begin{array}{c}\text { Violência } \\
\text { institucional } \\
\text { contra privados } \\
\text { de liberdade } \\
\text { (sistema } \\
\text { prisional e } \\
\text { socioeducativo) } \\
\text { Violência contra } \\
\text { menores } \\
\text { Tortura } \\
\end{array}$ \\
\hline & & MC 236/08 & Comissão & $\begin{array}{c}\text { Medidas } \\
\text { Cautelares }\end{array}$ & & $\begin{array}{c}\text { "PESSOAS } \\
\text { PRIVADAS DE } \\
\text { LIBERDADE } \\
\text { NA } \\
\text { PENITENCIÁRIA } \\
\text { POLINTER- } \\
\text { NEVES" }\end{array}$ & 2009 & 2009 & $\begin{array}{l}\text { DIREITO À VIDA, À } \\
\text { INTEGRIDADE } \\
\text { PESSOAL, À } \\
\text { SAÚDE. }\end{array}$ & $\begin{array}{c}\text { Violência } \\
\text { institucional } \\
\text { contra privados } \\
\text { de liberdade } \\
\text { (sistema } \\
\text { prisional e } \\
\text { socioeducativo) } \\
\end{array}$ \\
\hline & & & Comissão & $\begin{array}{c}\text { Medidas } \\
\text { Cautelares }\end{array}$ & & $\begin{array}{c}\text { CASO } \\
\text { ADOLESCENTES } \\
\text { NA CADEIA } \\
\text { PÚBLICA DE } \\
\text { GUARUJÁ }\end{array}$ & 2007 & 2007 & $\begin{array}{l}\text { DIREITO À VIDA, À } \\
\text { INTEGRIDADE } \\
\text { PESSOAL, À } \\
\text { PROTEÇÃO JUDICIAL E } \\
\text { DIREITOS DAS } \\
\text { CRIANÇAS } \\
\text { E ADOLESCENTES. }\end{array}$ & \begin{tabular}{|c} 
Violência \\
institucional \\
contra privados \\
de liberdade \\
(sistema \\
prisional e \\
socioeducativo)
\end{tabular} \\
\hline
\end{tabular}




\begin{tabular}{|c|c|c|c|c|c|c|c|c|c|c|}
\hline \multicolumn{11}{|c|}{ CASOS QUE NÃO ESTAVAM NOS DOIS PEDIDOS DE INFORMAÇÃO } \\
\hline Região & UF & $\begin{array}{c}\mathbf{N}^{\circ} \text { do } \\
\text { Processo }\end{array}$ & Órgão & Fase & $\begin{array}{c}\text { Especificação } \\
\text { da fase }\end{array}$ & Nome do Caso & $\begin{array}{l}\text { Data de } \\
\text { Início do } \\
\text { Trâmite }\end{array}$ & $\begin{array}{l}\text { Data da } \\
\text { Alegada } \\
\text { Violação } \\
\end{array}$ & Artigos Invocados & $\begin{array}{l}\text { Tema das } \\
\text { violações }\end{array}$ \\
\hline & & & Comissão & $\begin{array}{c}\text { Medidas } \\
\text { Cautelares }\end{array}$ & & $\begin{array}{l}\text { CASO MARIA } \\
\text { APARECIDA } \\
\text { DENADAI }\end{array}$ & 2006 & 2006 & $\begin{array}{l}\text { DIREITO À VIDA E } \\
\text { À INTEGRIDADE } \\
\text { PESSOAL. }\end{array}$ & $\begin{array}{c}\text { Violência contra } \\
\text { defensores de } \\
\text { Direitos } \\
\text { Humanos }\end{array}$ \\
\hline & & MC 130/06 & Comissão & $\begin{array}{c}\text { Medidas } \\
\text { Cautelares }\end{array}$ & & $\begin{array}{c}\text { "PESSOAS } \\
\text { DETIDAS NA 76a } \\
\text { DELEGACIA DE } \\
\text { POLÍCIA }\end{array}$ & 2006 & 2006 & $\begin{array}{l}\text { DIREITO À VIDA E } \\
\text { À INTEGRIDADE } \\
\text { PESSOAL. }\end{array}$ & $\begin{array}{c}\text { Violência } \\
\text { policial } \\
\text { Violência } \\
\text { institucional } \\
\text { contra privados } \\
\text { de liberdade } \\
\text { (sistema } \\
\text { prisional e } \\
\text { socioeducativo) } \\
\text { Tortura }\end{array}$ \\
\hline Sudeste & SP & MC 852/04 & Comissão & $\begin{array}{l}\text { Medidas } \\
\text { Cautelares }\end{array}$ & & $\begin{array}{l}\text { “CRIANÇAS } \\
\text { PRIVADAS DE } \\
\text { LIBERDADE } \\
\text { NA FUNDAÇÃO } \\
\text { ESTADUAL DO } \\
\text { BEM-ESTAR DO } \\
\text { MENOR (FEBEM) } \\
\text { DO TATUAPÉ }\end{array}$ & 2004 & 2004 & $\begin{array}{l}\text { DIREITO À VIDA, } \\
\text { À INTEGRIDADE } \\
\text { PESSOAL, À } \\
\text { SAÚDE. }\end{array}$ & $\begin{array}{c}\text { Violência } \\
\text { institucional } \\
\text { contra privados } \\
\text { de liberdade } \\
\text { (sistema } \\
\text { prisional e } \\
\text { socioeducativo) } \\
\text { Violência contra } \\
\text { menores }\end{array}$ \\
\hline
\end{tabular}




\begin{tabular}{|c|c|c|c|c|c|c|c|c|c|c|}
\hline \multicolumn{11}{|c|}{ CASOS QUE NÃO ESTAVAM NOS DOIS PEDIDOS DE INFORMAÇÃO } \\
\hline Região & UF & $\begin{array}{c}N^{\circ} \text { do } \\
\text { Processo }\end{array}$ & Órgão & Fase & $\begin{array}{l}\text { Especificação } \\
\text { da fase }\end{array}$ & Nome do Caso & $\begin{array}{c}\text { Data de } \\
\text { Início do } \\
\text { Trâmite } \\
\end{array}$ & $\begin{array}{l}\text { Data da } \\
\text { Alegada } \\
\text { Violação } \\
\end{array}$ & Artigos Invocados & $\begin{array}{l}\text { Tema das } \\
\text { violações }\end{array}$ \\
\hline \multirow[t]{2}{*}{ Sul } & PR & & Comissão & $\begin{array}{l}\text { Medidas } \\
\text { Cautelares }\end{array}$ & & $\begin{array}{l}\text { “CASO JORGE } \\
\text { CUSTODIO, } \\
\text { ROSANGELA } \\
\text { APARECIDA } \\
\text { SARAIVA } \\
\text { FERREIRA E } \\
\text { ALESSANDRA } \\
\text { RODRIGUEZ } \\
\text { CELESTINO }\end{array}$ & 2003 & 2003 & $\begin{array}{l}\text { DIREITO À VIDA E } \\
\text { À INTEGRIDADE } \\
\text { PESSOAL. }\end{array}$ & $\begin{array}{l}\text { Violência contra } \\
\text { defensores de } \\
\text { Direitos } \\
\text { Humanos }\end{array}$ \\
\hline & & & Comissão & $\begin{array}{l}\text { Medidas } \\
\text { Cautelares }\end{array}$ & & $\begin{array}{l}\text { "CASO MARIA } \\
\text { APARECIDA } \\
\text { GOMES DA } \\
\text { SILVAE } \\
\text { SUA FAMÍLIA E } \\
\text { EDSON } \\
\text { AZAMBUJA" }\end{array}$ & 2003 & 2003 & $\begin{array}{l}\text { DIREITO À VIDA E } \\
\text { À INTEGRIDADE } \\
\text { PESSOAL. }\end{array}$ & $\begin{array}{l}\text { Violência contra } \\
\text { defensores de } \\
\text { Direitos } \\
\text { Humanos }\end{array}$ \\
\hline Sudeste & ES & & Comissão & $\begin{array}{l}\text { Medidas } \\
\text { Cautelares }\end{array}$ & & $\begin{array}{l}\text { “CASO IRINY } \\
\text { NICOLAU } \\
\text { CORRES LOPES }\end{array}$ & 2002 & 2002 & $\begin{array}{c}\text { DIREITO À VIDA, } \\
\text { À INTEGRIDADE } \\
\text { PESSOAL E À } \\
\text { PROTEÇÃO } \\
\text { JUDICIAL. }\end{array}$ & $\begin{array}{c}\text { Violência contra } \\
\text { defensores de } \\
\text { Direitos } \\
\text { Humanos } \\
\end{array}$ \\
\hline
\end{tabular}




\begin{tabular}{|c|c|c|c|c|c|c|c|c|c|c|}
\hline \multicolumn{11}{|c|}{ CASOS QUE NÃO ESTAVAM NOS DOIS PEDIDOS DE INFORMAÇÃO } \\
\hline Região & UF & $\begin{array}{c}N^{\circ} \text { do } \\
\text { Processo }\end{array}$ & Órgão & Fase & $\begin{array}{l}\text { Especificação } \\
\text { da fase }\end{array}$ & Nome do Caso & $\begin{array}{l}\text { Data de } \\
\text { Início do } \\
\text { Trâmite }\end{array}$ & $\begin{array}{l}\text { Data da } \\
\text { Alegada } \\
\text { Violação }\end{array}$ & Artigos Invocados & $\begin{array}{l}\text { Tema das } \\
\text { violações }\end{array}$ \\
\hline & & & Comissão & $\begin{array}{l}\text { Medidas } \\
\text { Cautelares }\end{array}$ & & $\begin{array}{c}\text { "CASO RONY } \\
\text { CLAY CHAVES, } \\
\text { RUBENS } \\
\text { LEONCIO } \\
\text { PEREIRA, } \\
\text { MARCOS } \\
\text { MASSARI E } \\
\text { GILMAR LEITE } \\
\text { SIQUIERA } \\
\text { (PROTEÇÃO DE } \\
\text { TESTEMUNHAS } \\
\text { DA } \\
\text { OPERAÇÃO } \\
\text { CASTELINHO)" }\end{array}$ & 2002 & 2002 & $\begin{array}{l}\text { DIREITO À VIDA E À } \\
\text { INTEGRIDADE } \\
\text { PESSOAL. }\end{array}$ & Outros \\
\hline & & MC 351/02 & Comissão & $\begin{array}{l}\text { Medidas } \\
\text { Cautelares }\end{array}$ & & $\begin{array}{l}\text { "CASO MANOEL } \\
\text { BEZERRA, } \\
\text { ROSEMARY } \\
\text { SOUTO E LUIZ } \\
\text { DA SILVA }\end{array}$ & 2002 & 2002 & $\begin{array}{l}\text { DIREITO À VIDA, À } \\
\text { INTEGRIDADE } \\
\text { PESSOAL E À } \\
\text { PROTEÇÃO JUDICIAL. }\end{array}$ & Outros \\
\hline Sudeste & SP & & Comissão & $\begin{array}{l}\text { Medidas } \\
\text { Cautelares }\end{array}$ & & $\begin{array}{c}\text { CASO DOS } \\
\text { PROMOTORES E } \\
\text { DOS DETENTOS } \\
\text { DA } \\
\text { PRISÃO } \\
\text { PÚBLICA DE } \\
\text { SOROCABA" }\end{array}$ & 2000 & 2000 & $\begin{array}{l}\text { DIREITO À VIDA, À } \\
\text { INTEGRIDADE } \\
\text { PESSOAL E À } \\
\text { PROTEÇÃO JUDICIAL. }\end{array}$ & Outros \\
\hline & & & Comissão & $\begin{array}{l}\text { Medidas } \\
\text { Cautelares }\end{array}$ & & $\begin{array}{l}\text { "CASO } \\
\text { BENEDITO } \\
\text { MARIANO" }\end{array}$ & 2000 & 2000 & $\begin{array}{l}\text { DIREITO À VIDA, À } \\
\text { INTEGRIDADE } \\
\text { PESSOAL E À } \\
\text { PROTEÇÃO JUDICIAL. }\end{array}$ & Outros \\
\hline
\end{tabular}




\begin{tabular}{|c|c|c|c|c|c|c|c|c|c|c|}
\hline \multicolumn{11}{|c|}{ CASOS QUE NÃO ESTAVAM NOS DOIS PEDIDOS DE INFORMAÇÃO } \\
\hline Região & $\mathbf{U F}$ & $\begin{array}{c}\mathrm{N}^{\mathrm{o}} \text { do } \\
\text { Processo }\end{array}$ & Órgão & Fase & $\begin{array}{l}\text { Especificação } \\
\text { da fase }\end{array}$ & Nome do Caso & $\begin{array}{c}\text { Data de } \\
\text { Início do } \\
\text { Trâmite }\end{array}$ & $\begin{array}{l}\text { Data da } \\
\text { Alegada } \\
\text { Violação }\end{array}$ & Artigos Invocados & $\begin{array}{l}\text { Tema das } \\
\text { violações }\end{array}$ \\
\hline & & & Comissão & $\begin{array}{l}\text { Medidas } \\
\text { Cautelares }\end{array}$ & & $\begin{array}{c}\text { CASO } \\
\text { CATHERINE } \\
\text { HALVEY" }\end{array}$ & 2000 & 2000 & $\begin{array}{c}\text { DIREITO À VIDA, } \\
\text { Â INTEGRIDADE } \\
\text { PESSOAL E À } \\
\text { PROTEÇÃO } \\
\text { JUDICIAL. }\end{array}$ & $\begin{array}{l}\text { Violência contra } \\
\text { defensores de } \\
\text { Direitos } \\
\text { Humanos }\end{array}$ \\
\hline & & & Comissão & $\begin{array}{c}\text { Medidas } \\
\text { Cautelares }\end{array}$ & & $\begin{array}{l}\text { “CASO JOAQUIM } \\
\text { MARCELO } \\
\text { DENADAI }\end{array}$ & 1999 & 1999 & $\begin{array}{l}\text { DIREITO À VIDA, } \\
\text { Â INTEGRIDADE } \\
\text { PESSOAL E À } \\
\text { PROTEÇÃO } \\
\text { JUDICIAL. }\end{array}$ & $\begin{array}{l}\text { Violência contra } \\
\text { defensores de } \\
\text { Direitos } \\
\text { Humanos }\end{array}$ \\
\hline & & & Comissão & $\begin{array}{c}\text { Medidas } \\
\text { Cautelares }\end{array}$ & & $\begin{array}{l}\text { "CASO LUZIA } \\
\text { CANUTO" }\end{array}$ & 1998 & 1998 & $\begin{array}{l}\text { DIREITO À VIDA, } \\
\text { Â INTEGRIDADE } \\
\text { PESSOAL E À } \\
\text { PROTEÇÃO } \\
\text { JUDICIAL. }\end{array}$ & \begin{tabular}{|} 
Violência no \\
campo \\
Violência contra \\
defensores de \\
Direitos \\
Humanos
\end{tabular} \\
\hline & & & Comissão & $\begin{array}{c}\text { Medidas } \\
\text { Cautelares }\end{array}$ & & $\begin{array}{c}\text { “2 CASO PADRE } \\
\text { RICARDO } \\
\text { REZENDE” }\end{array}$ & 1998 & 1998 & $\begin{array}{c}\text { DIREITO À VIDA, } \\
\text { INTEGRIDADE } \\
\text { PESSOAL, À } \\
\text { GARANTIA } \\
\text { JUDICIAL E À } \\
\text { PROTEÇÃO } \\
\text { JUDICIAL. }\end{array}$ & $\begin{array}{c}\text { Violência no } \\
\text { campo } \\
\text { Violência contra } \\
\text { defensores de } \\
\text { Direitos } \\
\text { Humanos }\end{array}$ \\
\hline
\end{tabular}




\begin{tabular}{|c|c|c|c|c|c|c|c|c|c|c|}
\hline \multicolumn{11}{|c|}{ CASOS QUE NÃO ESTAVAM NOS DOIS PEDIDOS DE INFORMAÇÃO } \\
\hline Região & UF & $\begin{array}{c}N^{0} \text { do } \\
\text { Processo }\end{array}$ & Órgão & Fase & $\begin{array}{l}\text { Especificação } \\
\text { da fase }\end{array}$ & Nome do Caso & $\begin{array}{c}\text { Data de } \\
\text { Início do } \\
\text { Trâmite }\end{array}$ & $\begin{array}{l}\text { Data da } \\
\text { Alegada } \\
\text { Violação } \\
\end{array}$ & Artigos Invocados & $\begin{array}{l}\text { Tema das } \\
\text { violações }\end{array}$ \\
\hline Norte & PA & & Comissão & $\begin{array}{l}\text { Medidas } \\
\text { Cautelares }\end{array}$ & & $\begin{array}{c}\text { “1 CASO PADRE } \\
\text { RICARDO } \\
\text { REZENDE E } \\
\text { OUTROS" }\end{array}$ & 1995/1996 & 1995/1996 & $\begin{array}{l}\text { DIREITO À VIDA, } \\
\text { À INTEGRIDADE } \\
\text { PESSOAL E À } \\
\text { PROTEÇÃO } \\
\text { JUDICIAL. }\end{array}$ & $\begin{array}{c}\text { Violência contra } \\
\text { defensores de } \\
\text { Direitos } \\
\text { Humanos }\end{array}$ \\
\hline \multirow[t]{3}{*}{ Sudeste } & ES & & Comissão & $\begin{array}{l}\text { Medidas } \\
\text { Cautelares }\end{array}$ & & $\begin{array}{c}\text { "CASO DO } \\
\text { ADVOGADO } \\
\text { OSMAR } \\
\text { BARCELOS DO } \\
\text { NASCIMENTO" }\end{array}$ & 1996 & 1996 & $\begin{array}{l}\text { DIREITO À VIDA, } \\
\text { À INTEGRIDADE } \\
\text { PESSOAL E À } \\
\text { PROTEÇÃO } \\
\text { JUDICIAL. }\end{array}$ & $\begin{array}{c}\text { Violência contra } \\
\text { defensores de } \\
\text { Direitos } \\
\text { Humanos }\end{array}$ \\
\hline & & & Comissão & $\begin{array}{c}\text { Medidas } \\
\text { Cautelares }\end{array}$ & & $\begin{array}{l}\text { "CASO DOS } \\
\text { MENORES } \\
\text { INTERNOS DO } \\
\text { INSTITUTO } \\
\text { PADRE } \\
\text { SEVERINO, DA } \\
\text { ESCOLA JOÃO } \\
\text { LUIS ALVES } \\
\text { E DA ESCOLA } \\
\text { SANTOS } \\
\text { DUMONT" }\end{array}$ & 1996 & 1996 & $\begin{array}{l}\text { DIREITO À VIDA, } \\
\text { Â INTEGRIDADE } \\
\text { PESSOAL E À } \\
\text { PROTEÇÃO } \\
\text { JUDICIAL. }\end{array}$ & $\begin{array}{c}\text { Violência } \\
\text { institucional } \\
\text { contra privados } \\
\text { de liberdade } \\
\text { (sistema } \\
\text { prisional e } \\
\text { socioeducativo) }\end{array}$ \\
\hline & & & Comissão & $\begin{array}{l}\text { Medidas } \\
\text { Cautelares }\end{array}$ & & $\begin{array}{c}\text { "CASO } \\
\text { AMEAÇADOS } \\
\text { PELOS } \\
\text { 'MENINOS DE } \\
\text { OURO”" }\end{array}$ & 1996 & 1996 & $\begin{array}{c}\text { DIREITO À VIDA, } \\
\text { À INTEGRIDADE } \\
\text { PESSOAL E À } \\
\text { PROTEÇÃO } \\
\text { JUDICIAL. }\end{array}$ & $\begin{array}{l}\text { Violência contra } \\
\text { defensores de } \\
\text { Direitos } \\
\text { Humanos }\end{array}$ \\
\hline
\end{tabular}




\begin{tabular}{|c|c|c|c|c|c|c|c|c|c|c|}
\hline \multicolumn{11}{|c|}{ CASOS QUE NÃO ESTAVAM NOS DOIS PEDIDOS DE INFORMAÇÃO } \\
\hline Região & $\mathbf{U F}$ & $\begin{array}{c}N^{0} \text { do } \\
\text { Processo }\end{array}$ & Órgão & Fase & $\begin{array}{c}\text { Especificação } \\
\text { da fase }\end{array}$ & Nome do Caso & $\begin{array}{l}\text { Data de } \\
\text { Início do } \\
\text { Trâmite }\end{array}$ & $\begin{array}{l}\text { Data da } \\
\text { Alegada } \\
\text { Violação } \\
\end{array}$ & Artigos Invocados & $\begin{array}{l}\text { Tema das } \\
\text { violações }\end{array}$ \\
\hline $\begin{array}{l}\text { Centro- } \\
\text { oeste }\end{array}$ & To & & Corte & $\begin{array}{l}\text { Medidas } \\
\text { Provisionais }\end{array}$ & & $\begin{array}{l}\text { CASO JULIA } \\
\text { GOMES LUND E } \\
\text { OUTROS" }\end{array}$ & 2009 & 2009 & $\begin{array}{l}\text { DIREITO À VIDA, } \\
\text { À INTEGRIDADE } \\
\text { PESSOAL, À } \\
\text { LIBERDADE, AO } \\
\text { TRABALHO E A } \\
\text { UMA JUSTA } \\
\text { REMUNERAÇÃO, } \\
\text { ÀS GARANTIAS } \\
\text { JUDICIAIS E À } \\
\text { PROTEÇÃO } \\
\text { JUDICIAL. }\end{array}$ & $\begin{array}{l}\text { Crimes do } \\
\text { período da } \\
\text { ditadura }\end{array}$ \\
\hline Sudeste & SP & & Corte & $\begin{array}{l}\text { Medidas } \\
\text { Provisionais }\end{array}$ & & $\begin{array}{c}\text { CASO DOS } \\
\text { DETENTOS DA } \\
\text { PENITENCIÁRIA } \\
\text { DE } \\
\text { ARARAQUARA" }\end{array}$ & 2006 & 2006 & $\begin{array}{l}\text { DIREITO À VIDA E } \\
\text { À INTEGRIDADE } \\
\text { PESSOAL. }\end{array}$ & $\begin{array}{c}\text { Violência } \\
\text { institucional } \\
\text { contra privados } \\
\text { de liberdade } \\
\text { (sistema } \\
\text { prisional e } \\
\text { socioeducativo) }\end{array}$ \\
\hline Sudeste & SP & & Corte & $\begin{array}{l}\text { Medidas } \\
\text { Provisionais }\end{array}$ & & $\begin{array}{c}\text { CASO DO } \\
\text { COMPLEXO } \\
\text { TATUAPÉ DA } \\
\text { FEBEM }\end{array}$ & 2005 & 2005 & $\begin{array}{l}\text { DIREITO À VIDA, } \\
\text { À INTEGRIDADE } \\
\text { PESSOAL E } \\
\text { DIREITO DAS } \\
\text { CRIANÇAS. }\end{array}$ & $\begin{array}{c}\text { Violência } \\
\text { institucional } \\
\text { contra privados } \\
\text { de liberdade } \\
\text { (sistema } \\
\text { prisional e } \\
\text { socioeducativo) } \\
\text { Tortura }\end{array}$ \\
\hline
\end{tabular}


Apêndice B - Tabela consolidada com os Resultados Gerais

\begin{tabular}{|c|c|c|c|c|c|c|c|c|}
\hline Região & UF & $\begin{array}{l}\text { Número do } \\
\text { Processo }\end{array}$ & Órgão & Fase & Especificação da fase & Nome do Caso & $\begin{array}{l}\text { Data de } \\
\text { Início do } \\
\text { Trâmite } \\
\end{array}$ & $\begin{array}{c}\text { Data da } \\
\text { Alegada } \\
\text { Violação }\end{array}$ \\
\hline Sudeste & RJ & 12.970 & Comissão & $\begin{array}{l}\text { Análise de } \\
\text { Mérito }\end{array}$ & $\begin{array}{c}\text { Informações } \\
\text { Adicionais de Mérito }\end{array}$ & $\begin{array}{l}\text { Mário de Almeida Coelho Filho e } \\
\text { família }\end{array}$ & $14 / 11 / 2005$ & $16 / 08 / 2001$ \\
\hline Sul & RS & 12.907 & Comissão & $\begin{array}{l}\text { Análise de } \\
\text { Mérito }\end{array}$ & $\begin{array}{c}\text { Informações } \\
\text { Adicionais de Mérito }\end{array}$ & M.V.M. e P.S.R. & $30 / 11 / 2004$ & 1996-1997 \\
\hline Sudeste & RJ & P-1017-08 & Comissão & Admissibilidade & $\begin{array}{l}\text { Informação não } \\
\text { disponível }\end{array}$ & $\begin{array}{l}\text { Adaildo José Soares, Adair José da } \\
\text { Rocha Alves e outros }\end{array}$ & 07/03/2014 & $02 / 05 / 2007$ \\
\hline Sudeste & RJ & P-28-06 & Comissão & Admissibilidade & $\begin{array}{l}\text { Informação não } \\
\text { disponível }\end{array}$ & Ailton Vieira & $21 / 10 / 2010$ & $13 / 01 / 2206$ \\
\hline Nordeste & PE & P-15-08 & Comissão & Admissibilidade & $\begin{array}{c}\text { Informação não } \\
\text { disponível }\end{array}$ & Amaro Rosa de Barros & $23 / 08 / 2010$ & 03/01/2007 \\
\hline $\begin{array}{l}\text { Centro- } \\
\text { Oeste }\end{array}$ & $\mathrm{DF}$ & P-384-07 & Comissão & Admissibilidade & $\begin{array}{l}\text { Informação não } \\
\text { disponível }\end{array}$ & Antonio Reinaldo Peixoto Pereira & $29 / 03 / 2007$ & $30 / 04 / 2000$ \\
\hline
\end{tabular}




\begin{tabular}{|c|c|c|c|c|c|c|c|c|}
\hline Região & UF & $\begin{array}{l}\text { Número do } \\
\text { Processo }\end{array}$ & Órgão & Fase & Especificação da fase & Nome do Caso & $\begin{array}{l}\text { Data de } \\
\text { Início do } \\
\text { Trâmite }\end{array}$ & $\begin{array}{l}\text { Data da } \\
\text { Alegada } \\
\text { Violação }\end{array}$ \\
\hline Sudeste & RJ & P-145-06 & Comissão & Admissibilidade & $\begin{array}{l}\text { Informação não } \\
\text { disponível }\end{array}$ & Áureo Neves Filho & $27 / 12 / 2006$ & 04/01/2006 \\
\hline Norte & TO & P-271-09 & Comissão & Admissibilidade & $\begin{array}{l}\text { Informação não } \\
\text { disponível }\end{array}$ & Célio Márcio Alves Nogueira & $24 / 03 / 2009$ & $\begin{array}{c}\text { Informação } \\
\text { não disponível }\end{array}$ \\
\hline Sudeste & SP & P-221-12 & Comissão & Admissibilidade & $\begin{array}{l}\text { Informação não } \\
\text { disponível }\end{array}$ & Claudio Rogério Rodrigues da Silva & $02 / 10 / 2013$ & $18 / 05 / 2009$ \\
\hline Sudeste & RJ & P-607-06 & Comissão & Admissibilidade & $\begin{array}{l}\text { Informação não } \\
\text { disponível }\end{array}$ & $\begin{array}{l}\text { Crianças privadas de liberdade no } \\
\text { Rio de Janeiro (DEGASE) }\end{array}$ & 02/06/2006 & 03/03/2005 \\
\hline Sudeste & RJ & P-1449-06 & Comissão & Admissibilidade & $\begin{array}{l}\text { Informação não } \\
\text { disponível }\end{array}$ & Cristiane Leite de Souza e outros & $11 / 04 / 2011$ & 26/07/1990 \\
\hline Sudeste & MG & $\begin{array}{l}P-1608- \\
07\end{array}$ & Comissão & Admissibilidade & $\begin{array}{l}\text { Informação não } \\
\text { disponível }\end{array}$ & Débora Monteiro Silva & $19 / 12 / 2007$ & 20/jan/03 \\
\hline $\begin{array}{l}\text { Centro- } \\
\text { Oeste }\end{array}$ & MT & P-1122-07 & Comissão & Admissibilidade & $\begin{array}{l}\text { Informação não } \\
\text { disponível }\end{array}$ & Eliane Ortiz e Murilo Alcaide & 01/01/2011 & $21 / 06 / 2005$ \\
\hline $\begin{array}{l}\text { Centro- } \\
\text { Oeste }\end{array}$ & DF & P-673-11 & Comissão & Admissibilidade & $\begin{array}{l}\text { Informação não } \\
\text { disponível }\end{array}$ & $\begin{array}{l}\text { Fernando Alcântara de Freitas Filho } \\
\text { e Laci Marinho de Araújo }\end{array}$ & $27 / 01 / 2014$ & $17 / 05 / 2011$ \\
\hline Sul & RS & P-1140-04 & Comissão & Admissibilidade & $\begin{array}{l}\text { Informaçãa não } \\
\text { disponível }\end{array}$ & $\begin{array}{l}\text { Felipe Néri Dresch da Silveira e } \\
\text { outros }\end{array}$ & $12 / 10 / 2006$ & $\begin{array}{l}22 / 5 / 2006 \text { até } \\
\text { o presente }\end{array}$ \\
\hline Sudeste & SP & $\begin{array}{c}P-1277- \\
07\end{array}$ & Comissão & Admissibilidade & $\begin{array}{l}\text { Informação não } \\
\text { disponível }\end{array}$ & Flávio Mendes de Morais & $14 / 03 / 2007$ & $30 / 03 / 2004$ \\
\hline
\end{tabular}




\begin{tabular}{|c|c|c|c|c|c|c|c|c|}
\hline Região & UF & $\begin{array}{l}\text { Número do } \\
\text { Processo }\end{array}$ & Órgão & Fase & Especificação da fase & Nome do Caso & $\begin{array}{l}\text { Data de } \\
\text { Início do } \\
\text { Trâmite } \\
\end{array}$ & $\begin{array}{l}\text { Data da } \\
\text { Alegada } \\
\text { Violação } \\
\end{array}$ \\
\hline Sudeste & SP & P - 905-08 & Comissão & Admissibilidade & $\begin{array}{l}\text { Informação não } \\
\text { disponível }\end{array}$ & Gabriel de Matos Prado & $18 / 05 / 2012$ & $15 / 08 / 2008$ \\
\hline Sudeste & SP & P-1185-08 & Comissão & Admissibilidade & $\begin{array}{l}\text { Informação não } \\
\text { disponível }\end{array}$ & Gerson Mendonça de Freitas Filho & 09/10/2008 & $17 / 03 / 2006$ \\
\hline Sudeste & SP & P-176-08 & Comissão & Admissibilidade & $\begin{array}{l}\text { Informação não } \\
\text { disponível }\end{array}$ & Gustavo Magalhães Pereira & $15 / 02 / 2008$ & $07 / 09 / 2008$ \\
\hline Nordeste & $\mathrm{CE}$ & P-1228-08 & Comissão & Admissibilidade & $\begin{array}{l}\text { Informação não } \\
\text { disponível }\end{array}$ & Hindenburgh de Mélo Rocha & $10 / 06 / 2013$ & $21 / 10 / 2008$ \\
\hline Sudeste & $\mathrm{RJ}$ & P-1643-07 & Comissão & Admissibilidade & $\begin{array}{l}\text { Informação não } \\
\text { disponível }\end{array}$ & $\begin{array}{c}\text { Jacqueline Simone de Souza e Silva } \\
\text { Ferreira }\end{array}$ & $16 / 07 / 2008$ & $\begin{array}{c}\text { Informação } \\
\text { não disponível }\end{array}$ \\
\hline Norte & PA & P-1178-09 & Comissão & Admissibilidade & $\begin{array}{l}\text { Informação não } \\
\text { disponível }\end{array}$ & L. A. B. & $18 / 08 / 2010$ & $31 / 10 / 2007$ \\
\hline Sudeste & $\mathrm{RJ}$ & P-1453-06 & Comissão & Admissibilidade & $\begin{array}{l}\text { Informação não } \\
\text { disponível }\end{array}$ & Maicon de Souza Silva & $10 / 12 / 2006$ & $15 / 04 / 1996$ \\
\hline Sudeste & SP & P-1246-08 & Comissão & Admissibilidade & $\begin{array}{c}\text { Informação não } \\
\text { disponível }\end{array}$ & Marcelo Henrique de Freitas & 23/mai/12 & $29 / 08 / 2000$ \\
\hline Sudeste & RJ & P-32-07 & Comissão & Admissibilidade & $\begin{array}{l}\text { Informação não } \\
\text { disponível }\end{array}$ & Marcio Antonio Maia de Souza & $10 / 12 / 2006$ & $01 / 11 / 1995$ \\
\hline Sudeste & SP & P-1247-08 & Comissão & Admissibilidade & $\begin{array}{l}\text { Informação não } \\
\text { disponível }\end{array}$ & Nilson Saldanha & $12 / 10 / 2012$ & 09/06/2000 \\
\hline
\end{tabular}




\begin{tabular}{|c|c|c|c|c|c|c|c|c|}
\hline Região & UF & $\begin{array}{l}\text { Número do } \\
\text { Processo }\end{array}$ & Órgão & Fase & Especificação da fase & Nome do Caso & $\begin{array}{l}\text { Data de } \\
\text { Início do } \\
\text { Trâmite }\end{array}$ & $\begin{array}{l}\text { Data da } \\
\text { Alegada } \\
\text { Violação }\end{array}$ \\
\hline $\begin{array}{l}\text { Centro- } \\
\text { Oeste }\end{array}$ & MS & P-1268-09 & Comissão & Admissibilidade & $\begin{array}{l}\text { Informação não } \\
\text { disponível }\end{array}$ & $\begin{array}{l}\text { Pessoas Privadas de Liberdade no } \\
\text { Sistema Prisional do Estado de } \\
\text { Mato Grosso do Sul }\end{array}$ & $\begin{array}{c}\text { Informação } \\
\text { não } \\
\text { disponível }\end{array}$ & 05/10/2009 \\
\hline Sudeste & RJ & P-1344-08 & Comissão & Admissibilidade & $\begin{array}{l}\text { Informação não } \\
\text { disponível }\end{array}$ & Reinaldo Coutinho da Silva & $27 / 01 / 2014$ & 29/08/1995 \\
\hline Norte & PA & 12.753 & Comissão & $\begin{array}{l}\text { Análise de } \\
\text { Mérito }\end{array}$ & $\begin{array}{c}\text { Informações } \\
\text { Adicionais de Mérito }\end{array}$ & Adão Pereira de Souza & $19 / 07 / 2006$ & 1993 \\
\hline Sudeste & RJ & 12.615 & Comissão & $\begin{array}{l}\text { Análise de } \\
\text { Mérito }\end{array}$ & $\begin{array}{c}\text { Informações } \\
\text { Adicionais de Mérito }\end{array}$ & Alan Felipe da Silva e outros & 08/06/2005 & $29 / 05 / 2002$ \\
\hline Sul & PR & 12.727 & Comissão & $\begin{array}{l}\text { Análise de } \\
\text { Mérito }\end{array}$ & $\begin{array}{c}\text { Informações } \\
\text { Adicionais de Mérito }\end{array}$ & $\begin{array}{l}\text { Antônio Tavares Pereira e outros } \\
185 \text { trabalhadores rurais }\end{array}$ & 01/01/2004 & $02 / 05 / 2000$ \\
\hline Norte & PA & 12.604 & Comissão & $\begin{array}{l}\text { Análise de } \\
\text { Mérito }\end{array}$ & $\begin{array}{l}\text { Informação não } \\
\text { disponível }\end{array}$ & $\begin{array}{l}\text { Ariomar Oliveira Rocha, Ademir } \\
\text { Federicchi e Natur de Assis Filho }\end{array}$ & $15 / 03 / 2002$ & 22/07/1998 \\
\hline Sudeste & RJ & 12.213 & Comissão & $\begin{array}{l}\text { Análise de } \\
\text { Mérito }\end{array}$ & $\begin{array}{c}\text { Informações } \\
\text { Adicionais de Mérito }\end{array}$ & Aristeu Guida da Silva & 23/09/1999 & $12 / 05 / 1995$ \\
\hline Sul & RS & 12.837 & Comissão & $\begin{array}{l}\text { Análise de } \\
\text { Mérito }\end{array}$ & Pós-Admissibilidade & $\begin{array}{c}\text { Clélia Lourdes Goldenberg e Rita } \\
\text { de Cássia Rosa }\end{array}$ & $27 / 10 / 2004$ & 1997 e 1998 \\
\hline Sudeste & $\mathrm{RJ}$ & 12.242 & Comissão & $\begin{array}{l}\text { Análise de } \\
\text { Mérito }\end{array}$ & $\begin{array}{c}\text { Informações } \\
\text { Adicionais de Mérito }\end{array}$ & $\begin{array}{l}\text { Clínica Pediátrica da Região dos } \\
\text { Lagos }\end{array}$ & $10 / 01 / 2000$ & 01/06/1996 \\
\hline Nordeste & MA & 12.569 & Comissão & $\begin{array}{l}\text { Análise de } \\
\text { Mérito }\end{array}$ & $\begin{array}{l}\text { Informações } \\
\text { Adicionais de Mérito. } \\
\text { Amicus Curiae. }\end{array}$ & $\begin{array}{c}\text { Comunidades Quilombolas de } \\
\text { Alcântara }\end{array}$ & $17 / 08 / 2001$ & $12 / 09 / 1980$ \\
\hline
\end{tabular}




\begin{tabular}{|c|c|c|c|c|c|c|c|c|}
\hline Região & UF & $\begin{array}{l}\text { Número do } \\
\text { Processo }\end{array}$ & Órgão & Fase & Especificação da fase & Nome do Caso & $\begin{array}{l}\text { Data de } \\
\text { Início do } \\
\text { Trâmite }\end{array}$ & $\begin{array}{l}\text { Data da } \\
\text { Alegada } \\
\text { Violação }\end{array}$ \\
\hline Sudeste & SP & 12.328 & Comissão & $\begin{array}{l}\text { Análise de } \\
\text { Mérito }\end{array}$ & $\begin{array}{c}\text { Informações } \\
\text { Adicionais de Mérito }\end{array}$ & $\begin{array}{l}\text { Crianças e Adolescentes privados } \\
\text { de liberdade, no complexo } \\
\text { Imigrantes, Centro de Observações } \\
\text { Criminológicas (COC), Cadeião de } \\
\text { Santo André, Cadeião de Pinheiros, } \\
\text { Presídio de Parelheiros, Complexo } \\
\text { do Tatuapé, Franco da Rocha e } \\
\text { Unidade de Atendimento Inicial } \\
\text { (UAI) - FEBEM }\end{array}$ & 05/09/2000 & 01/08/1999 \\
\hline Sudeste & RJ & 11.702 & Comissão & $\begin{array}{l}\text { Análise de } \\
\text { Mérito }\end{array}$ & $\begin{array}{c}\text { Informações } \\
\text { Adicionais de Mérito }\end{array}$ & $\begin{array}{l}\text { Crianças privadas de liberdade no } \\
\text { Rio de Janeiro }\end{array}$ & 05/02/1997 & 1996 \\
\hline Sul & PR & 12.569 & Comissão & $\begin{array}{l}\text { Análise de } \\
\text { Mérito }\end{array}$ & $\begin{array}{c}\text { Informações } \\
\text { Adicionais de Mérito }\end{array}$ & $\begin{array}{l}\text { Daniel Gomes dos Santos e Vilmar } \\
\text { Soares da Silva }\end{array}$ & 22/07/2004 & 1991 \\
\hline Nordeste & BA & 12.428 & Comissão & $\begin{array}{l}\text { Análise de } \\
\text { Mérito }\end{array}$ & $\begin{array}{c}\text { Informações } \\
\text { Adicionais de Mérito }\end{array}$ & $\begin{array}{l}\text { Fábrica de fogos de Artifício em } \\
\text { Santo Antônio de Jesus }\end{array}$ & $23 / 11 / 2001$ & $11 / 12 / 1998$ \\
\hline Sul & RS & 12.378 & Comissão & $\begin{array}{l}\text { Análise de } \\
\text { Mérito }\end{array}$ & Pós-Admissibilidade & $\begin{array}{c}\text { Fátima Regina Nascimento de } \\
\text { Oliveira e Maura Tatiane Ferreira } \\
\text { Alves }\end{array}$ & $22 / 03 / 2001$ & 23/07/1989 \\
\hline Sudeste & RJ & $\begin{array}{c}12.857 \\
(\mathrm{P}-302-07)\end{array}$ & Comissão & $\begin{array}{l}\text { Análise de } \\
\text { Mérito }\end{array}$ & $\begin{array}{l}\text { fev/2008: Estado envia } \\
\text { informações à OEA } \\
\text { abr/2011: } \\
\text { Peticionários enviam } \\
\text { informações à CIDH. } \\
\text { Apesar da última } \\
\text { movimentação ter sido } \\
\text { dos peticionários, não } \\
\text { houve data definida } \\
\text { para resposta }\end{array}$ & Flávio Mendes Pontes & 08/05/2007 & $30 / 03 / 2004$ \\
\hline
\end{tabular}




\begin{tabular}{|c|c|c|c|c|c|c|c|c|}
\hline Região & UF & $\begin{array}{l}\text { Número do } \\
\text { Processo }\end{array}$ & Órgão & Fase & Especificação da fase & Nome do Caso & $\begin{array}{l}\text { Data de } \\
\text { Início do } \\
\text { Trâmite }\end{array}$ & $\begin{array}{l}\text { Data da } \\
\text { Alegada } \\
\text { Violação }\end{array}$ \\
\hline Nordeste & MA & 12.726 & Comissão & $\begin{array}{l}\text { Análise de } \\
\text { Mérito }\end{array}$ & $\begin{array}{c}\text { Informações } \\
\text { Adicionais de Mérito }\end{array}$ & Francisco de Assis Ferreira & $19 / 07 / 2001$ & 05/11/1991 \\
\hline Norte & PA & 12.675 & Comissão & $\begin{array}{l}\text { Análise de } \\
\text { Mérito }\end{array}$ & $\begin{array}{c}\text { Informações } \\
\text { Adicionais de Mérito }\end{array}$ & Gabriel Sales Pimenta & $09 / 11 / 2006$ & $\begin{array}{c}1982 \\
\text { (assassinato) } \\
2006 \text { (extinção } \\
\text { do processo) }\end{array}$ \\
\hline Sul & PR & 12.503 & Comissão & $\begin{array}{l}\text { Análise de } \\
\text { Mérito }\end{array}$ & $\begin{array}{c}\text { Informações } \\
\text { Adicionais de Mérito }\end{array}$ & Gerson Minusk de Carvalho & $28 / 03 / 2003$ & 03/02/1995 \\
\hline Norte & PA & 12.838 & Comissão & $\begin{array}{l}\text { Análise de } \\
\text { Mérito }\end{array}$ & Pós-Admissibilidade & Hildebrando Silva de Freitas & 03/04/2007 & 1997 \\
\hline Nordeste & BA & $\begin{array}{c}12.806 \\
(\mathrm{P}-702-03)\end{array}$ & Comissão & $\begin{array}{l}\text { Análise de } \\
\text { Mérito }\end{array}$ & Pós-Admissibilidade & Ivan Rocha & 28.05 .2003 & 22/04/1991 \\
\hline Sudeste & SP & 12.750 & Comissão & $\begin{array}{l}\text { Análise de } \\
\text { Mérito }\end{array}$ & Pós-Admissibilidade & Ivanildo Amaro da Silva e outros & $24 / 10 / 2005$ & $19 / 10 / 2004$ \\
\hline Sul & PR & 12.878 & Comissão & $\begin{array}{l}\text { Análise de } \\
\text { Mérito }\end{array}$ & Pós-Admissibilidade & Ivete Jordani Demeneche e outros & $18 / 03 / 2007$ & $18 / 07 / 2004$ \\
\hline Sudeste & RJ & 11.793 & Comissão & $\begin{array}{l}\text { Análise de } \\
\text { Mérito }\end{array}$ & $\begin{array}{c}\text { Informações } \\
\text { Adicionais de Mérito }\end{array}$ & Jorge Antônio Carelli & 19/08/1999 & $10 / 08 / 1993$ \\
\hline Sudeste & ES & 12.425 & Comissão & $\begin{array}{l}\text { Análise de } \\
\text { Mérito }\end{array}$ & $\begin{array}{c}\text { Informações } \\
\text { Adicionais de Mérito }\end{array}$ & Jorge César Mendonça da Silva & $20 / 05 / 2003$ & $18 / 11 / 2002$ \\
\hline Sudeste & SP & 12.479 & Comissão & $\begin{array}{l}\text { Análise de } \\
\text { Mérito }\end{array}$ & $\begin{array}{c}\text { Informações } \\
\text { Adicionais de Mérito }\end{array}$ & $\begin{array}{l}\text { José Airton Honorato, José Maria } \\
\text { Menezes, Aleksandro de Oliveira } \\
\text { Araújo e outros (Castelinho) }\end{array}$ & $24 / 04 / 2003$ & 05/03/2002 \\
\hline
\end{tabular}




\begin{tabular}{|c|c|c|c|c|c|c|c|c|}
\hline Região & UF & $\begin{array}{l}\text { Número do } \\
\text { Processo }\end{array}$ & Órgão & Fase & Especificação da fase & Nome do Caso & $\begin{array}{l}\text { Data de } \\
\text { Início do } \\
\text { Trâmite }\end{array}$ & $\begin{array}{l}\text { Data da } \\
\text { Alegada } \\
\text { Violação }\end{array}$ \\
\hline Sudeste & $\mathrm{RJ}$ & 12.746 & Comissão & $\begin{array}{l}\text { Análise de } \\
\text { Mérito }\end{array}$ & Pós-Admissibilidade & José do Egito Romão Diniz & $14 / 03 / 2005$ & $22 / 08 / 2044$ \\
\hline Sudeste & SP & 12.877 & Comissão & $\begin{array}{l}\text { Análise de } \\
\text { Mérito }\end{array}$ & Pós-Admissibilidade & José Laurindo Soares & $16 / 10 / 2007$ & $21 / 05 / 1986$ \\
\hline Nordeste & PE & 12.707 & Comissão & $\begin{array}{l}\text { Análise de } \\
\text { Mérito }\end{array}$ & Pós-Admissibilidade & $\begin{array}{l}\text { Josenildo João de Freitas Júnior e } \\
\text { familiares }\end{array}$ & $17 / 05 / 2003$ & $15 / 12 / 2009$ \\
\hline Sudeste & $\mathrm{RJ}$ & 12.859 & Comissão & $\begin{array}{l}\text { Análise de } \\
\text { Mérito }\end{array}$ & Pós-Admissibilidade & Jurandir Ferreira de Lima e outros & 03/01/2007 & $14 / 03 / 1995$ \\
\hline Sudeste & SP & 12.616 & Comissão & $\begin{array}{l}\text { Análise de } \\
\text { Mérito }\end{array}$ & $\begin{array}{c}\text { Informações } \\
\text { Adicionais de Mérito }\end{array}$ & Lazinho Brambilla da Silva & 02/09/2005 & $09 / 11 / 2003$ \\
\hline Norte & PA & 12.327 & Comissão & $\begin{array}{l}\text { Análise de } \\
\text { Mérito }\end{array}$ & $\begin{array}{c}\text { Informações } \\
\text { Adicionais de Mérito }\end{array}$ & $\begin{array}{l}\text { Manoel Barbosa da Costa e outros } \\
\text { (Fazenda Princesa) }\end{array}$ & $19 / 09 / 2011$ & $27 / 09 / 1985$ \\
\hline Nordeste & PB & 12.570 & Comissão & $\begin{array}{l}\text { Análise de } \\
\text { Mérito }\end{array}$ & $\begin{array}{c}\text { Informações } \\
\text { Adicionais de Mérito }\end{array}$ & Manoel Luiz da Silva & $20 / 08 / 2003$ & $19 / 05 / 1997$ \\
\hline Nordeste & PB & 12.263 & Comissão & $\begin{array}{l}\text { Análise de } \\
\text { Mérito }\end{array}$ & $\begin{array}{c}\text { Informações } \\
\text { Adicionais de Mérito }\end{array}$ & Márcia Barbosa de Souza & $28 / 03 / 2000$ & $18 / 06 / 1998$ \\
\hline Sudeste & RJ & 12.752 & Comissão & $\begin{array}{l}\text { Análise de } \\
\text { Mérito }\end{array}$ & Pós-Admissibilidade & Márcio Aurélio Gonçalves & $21 / 05 / 2005$ & 03/08/2000 \\
\hline Sudeste & RJ & 12.858 & Comissão & $\begin{array}{l}\text { Análise de } \\
\text { Mérito }\end{array}$ & $\begin{array}{c}\text { Informações } \\
\text { Adicionais de Mérito }\end{array}$ & Marcio Manoel Fraga & $25 / 01 / 2001$ & 27/03/1999 \\
\hline
\end{tabular}




\begin{tabular}{|c|c|c|c|c|c|c|c|c|}
\hline Região & UF & $\begin{array}{l}\text { Número do } \\
\text { Processo }\end{array}$ & Órgão & Fase & Especificação da fase & Nome do Caso & $\begin{array}{l}\text { Data de } \\
\text { Início do } \\
\text { Trâmite }\end{array}$ & $\begin{array}{l}\text { Data da } \\
\text { Alegada } \\
\text { Violação }\end{array}$ \\
\hline Nordeste & PB & 12.332 & Comissão & $\begin{array}{l}\text { Análise de } \\
\text { Mérito }\end{array}$ & $\begin{array}{c}\text { Informações } \\
\text { Adicionais de Mérito }\end{array}$ & Margarida Maria Alves & $17 / 10 / 2000$ & $12 / 08 / 1983$ \\
\hline Sudeste & SP & 12.835 & Comissão & $\begin{array}{l}\text { Análise de } \\
\text { Mérito }\end{array}$ & Pós-Admissibilidade & Maurício Hernández Norambuena & $18 / 03 / 2005$ & $03 / 022002$ \\
\hline Sudeste & RJ & 12.970 & Comissão & $\begin{array}{l}\text { Análise de } \\
\text { Mérito }\end{array}$ & Pós-Admissibilidade & Mario de Almeida Coelho Filho & $24 / 04 / 2006$ & $16 / 08 / 2001$ \\
\hline Sudeste & SP & 12.876 & Comissão & $\begin{array}{l}\text { Análise de } \\
\text { Mérito }\end{array}$ & Pós-Admissibilidade & $\begin{array}{c}\text { Moradores do Conjunto } \\
\text { Habitacional Barão de Mauá } \\
\text { (CHBM) }\end{array}$ & $19 / 09 / 2005$ & 2001 \\
\hline Sudeste & SP & 12.751 & Comissão & $\begin{array}{l}\text { Análise de } \\
\text { Mérito }\end{array}$ & Pós-Admissibilidade & $\begin{array}{l}\text { Nélio Nakamura Brandão e } \\
\text { Alexandre Azevedo }\end{array}$ & $17 / 02 / 2006$ & $13 / 09 / 2004$ \\
\hline Sudeste & SP & 12.571 & Comissão & $\begin{array}{l}\text { Análise de } \\
\text { Mérito }\end{array}$ & $\begin{array}{c}\text { Informações } \\
\text { Adicionais de Mérito }\end{array}$ & $\begin{array}{l}\text { Neusa dos Santos Nascimento e } \\
\text { Gisele Ana Ferreira }\end{array}$ & $08 / 12 / 2003$ & 26/03/1998 \\
\hline Sudeste & SP & 11.414 & Comissão & $\begin{array}{l}\text { Análise de } \\
\text { Mérito }\end{array}$ & $\begin{array}{c}\text { Informações } \\
\text { Adicionais de Mérito }\end{array}$ & Ozeas Antônio dos Santos & $13 / 12 / 1994$ & 01/09/1994 \\
\hline Nordeste & PE & $\begin{array}{l}12.875 \\
(\mathrm{P}-1330- \\
07)\end{array}$ & Comissão & $\begin{array}{l}\text { Análise de } \\
\text { Mérito }\end{array}$ & $\begin{array}{c}\text { Informações } \\
\text { Adicionais de Mérito }\end{array}$ & Pedro Augusto da Silva e outros & $27 / 10 / 2007$ & $\begin{array}{c}05 / 06 / 1997 \\
\text { (data dos } \\
\text { crimes) até o } \\
\text { presente }\end{array}$ \\
\hline Sudeste & SP & 12.836 & Comissão & $\begin{array}{l}\text { Análise de } \\
\text { Mérito } \\
\end{array}$ & Pós-Admissibilidade & Pedro Stábile Neto e outros & 29/09/2006 & 01/12/1999 \\
\hline Sudeste & SP & 12.654 & Comissão & $\begin{array}{l}\text { Análise de } \\
\text { Mérito }\end{array}$ & $\begin{array}{c}\text { Informações } \\
\text { Adicionais de Mérito }\end{array}$ & $\begin{array}{l}\text { Pessoas privadas de liberdade na } \\
\text { Cadeia Pública do Guarujá }\end{array}$ & $18 / 04 / 2007$ & $\begin{array}{l}1999 \text { até o } \\
\text { presente }\end{array}$ \\
\hline
\end{tabular}




\begin{tabular}{|c|c|c|c|c|c|c|c|c|}
\hline Região & UF & $\begin{array}{c}\text { Número do } \\
\text { Processo }\end{array}$ & Órgão & Fase & Especificação da fase & Nome do Caso & $\begin{array}{l}\text { Data de } \\
\text { Início do } \\
\text { Trâmite }\end{array}$ & $\begin{array}{l}\text { Data da } \\
\text { Alegada } \\
\text { Violação }\end{array}$ \\
\hline Sudeste & $\mathrm{RJ}$ & 12.613 & Comissão & $\begin{array}{l}\text { Análise de } \\
\text { Mérito }\end{array}$ & $\begin{array}{c}\text { Informações } \\
\text { Adicionais de Mérito }\end{array}$ & $\begin{array}{l}\text { Pessoas privadas de liberdade na } \\
\text { carceragem de } 76^{\mathrm{a}} \text { Delegacia de } \\
\text { Polícia }\left(76^{\circ} \mathrm{DP}\right)\end{array}$ & $14 / 06 / 2006$ & $26 / 04 / 2006$ \\
\hline Norte & RO & 12.568 & Comissão & $\begin{array}{l}\text { Análise de } \\
\text { Mérito }\end{array}$ & $\begin{array}{c}\text { Informações } \\
\text { Adicionais de Mérito }\end{array}$ & $\begin{array}{l}\text { Pessoas privadas de liberdade no } \\
\text { Presídio de Urso Branco }\end{array}$ & 05/06/2002 & $01 / 01 / 2002$ \\
\hline Nordeste & PE & 12.728 & Comissão & $\begin{array}{l}\text { Análise de } \\
\text { Mérito }\end{array}$ & $\begin{array}{c}\text { Informações } \\
\text { Adicionais de Mérito }\end{array}$ & $\begin{array}{l}\text { Povo Indígena Xucuru (Município } \\
\text { de Pesqueira) }\end{array}$ & $16 / 10 / 2002$ & $\begin{array}{l}1989 \text { até o } \\
\text { presente }\end{array}$ \\
\hline Norte & $\mathrm{RR}$ & 12.781 & Comissão & $\begin{array}{l}\text { Análise de } \\
\text { Mérito }\end{array}$ & $\begin{array}{c}\text { Informações } \\
\text { Adicionais de Mérito }\end{array}$ & $\begin{array}{l}\text { Povos Indígenas da Raposa Serra } \\
\text { do Sol }\end{array}$ & $29 / 03 / 2004$ & 2004 \\
\hline Sudeste & SP & 12.461 & Comissão & $\begin{array}{l}\text { Análise de } \\
\text { Mérito }\end{array}$ & $\begin{array}{c}\text { Informações } \\
\text { Adicionais de Mérito }\end{array}$ & Rafael Lozano & $24 / 04 / 2003$ & até o presente \\
\hline Sudeste & $\mathrm{RJ}$ & 12.778 & Comissão & $\begin{array}{l}\text { Análise de } \\
\text { Mérito }\end{array}$ & Pós-Admissibilidade & Roberto Carlos Pereira de Souza & $27 / 12 / 2006$ & $\begin{array}{l}03 / 2003- \\
01 / 2004\end{array}$ \\
\hline Sudeste & $\mathrm{RJ}$ & 12.198 & Comissão & $\begin{array}{l}\text { Análise de } \\
\text { Mérito }\end{array}$ & $\begin{array}{c}\text { Informações } \\
\text { Adicionais de Mérito }\end{array}$ & $\begin{array}{l}\text { Robson William da Silva Cassiano } \\
\text { e outros }\end{array}$ & 11/08/1999 & 18/08/1994 \\
\hline Nordeste & BA & 12.309 & Comissão & $\begin{array}{l}\text { Análise de } \\
\text { Mérito }\end{array}$ & $\begin{array}{l}\text { Informações } \\
\text { Adicionais de Mérito }\end{array}$ & Ronaldo Santana de Araújo & $19 / 05 / 2000$ & 09/10/1997 \\
\hline Sudeste & SP & 12.783 & Comissão & $\begin{array}{l}\text { Análise de } \\
\text { Mérito }\end{array}$ & Pós-Admissibilidade & $\begin{array}{l}\text { Rosa Hernándes Sundermann e } \\
\text { outros }\end{array}$ & $14 / 03 / 2005$ & 01/06/1994 \\
\hline Sul & RS & 12.725 & Comissão & $\begin{array}{l}\text { Análise de } \\
\text { Mérito }\end{array}$ & Pós-Admissibilidade & Samanta Nunes da Silva & $25 / 04 / 2003$ & $15 / 10 / 1997$ \\
\hline
\end{tabular}




\begin{tabular}{|c|c|c|c|c|c|c|c|c|}
\hline Região & UF & $\begin{array}{l}\text { Número do } \\
\text { Processo }\end{array}$ & Órgão & Fase & Especificação da fase & Nome do Caso & $\begin{array}{l}\text { Data de } \\
\text { Início do } \\
\text { Trâmite }\end{array}$ & $\begin{array}{l}\text { Data da } \\
\text { Alegada } \\
\text { Violação }\end{array}$ \\
\hline Sudeste & RJ & 12.782 & Comissão & $\begin{array}{l}\text { Análise de } \\
\text { Mérito }\end{array}$ & Pós-Admissibilidade & Thalita Carvalho de Mello e outros & $27 / 12 / 2006$ & $10 / 10 / 1998$ \\
\hline Sudeste & SP & 12.879 & Comissão & $\begin{array}{l}\text { Análise de } \\
\text { Mérito }\end{array}$ & Pós-Admissibilidade & Vladimir Herzog & $10 / 07 / 2009$ & $25 / 10 / 1985$ \\
\hline Sudeste & MG & 12.212 & Comissão & $\begin{array}{l}\text { Análise de } \\
\text { Mérito }\end{array}$ & $\begin{array}{c}\text { Informações } \\
\text { Adicionais de Mérito }\end{array}$ & Zaqueu de Oliveira & 03/09/1999 & 21/03/1995 \\
\hline Sudeste & SP & 11.286 & Comissão & $\begin{array}{c}\text { Cumprimento de } \\
\text { Recomendações } \\
\text { da CmDH }\end{array}$ & $\begin{array}{l}\text { Informação não } \\
\text { disponível }\end{array}$ & Aluísio Cavalcanti e outros & 01/02/1994 & 04/03/1987 \\
\hline Nordeste & $\mathrm{CE}$ & 12.019 & Comissão & $\begin{array}{c}\text { Cumprimento de } \\
\text { Recomendações } \\
\text { da CmDH }\end{array}$ & $\begin{array}{l}\text { Informação não } \\
\text { disponível }\end{array}$ & Antônio Ferreira Braga & $11 / 06 / 1998$ & $11 / 03 / 1993$ \\
\hline Norte & RO & 11.556 & Comissão & $\begin{array}{c}\text { Cumprimento de } \\
\text { Recomendações } \\
\text { da CmDH }\end{array}$ & $\begin{array}{l}\text { Informação não } \\
\text { disponível }\end{array}$ & Massacre de Corumbiara & 06/10/1995 & $15 / 07 / 1995$ \\
\hline Sul & PR & 11.517 & Comissão & $\begin{array}{l}\text { Cumprimento de } \\
\text { Recomendações } \\
\text { da CmDH }\end{array}$ & $\begin{array}{l}\text { Informação não } \\
\text { disponível }\end{array}$ & Diniz Bento da Silva (Teixeirinha) & 05/07/1995 & 08/03/1993 \\
\hline Sudeste & RJ & 11.566 & Corte & $\begin{array}{c}\text { Início } \\
\text { procedimento } \\
\text { escrito na Corte }\end{array}$ & $\begin{array}{c}\text { Cumprimento de } \\
\text { Recomendações da } \\
\text { CmDH }\end{array}$ & $\begin{array}{l}\text { Favela Nova Brasília (Evandro } \\
\text { Oliveira e outros) }\end{array}$ & $18 / 04 / 2000$ & $18 / 10 / 1994$ \\
\hline Norte & PA & 12.066 & Corte & $\begin{array}{c}\text { Início } \\
\text { procedimento } \\
\text { escrito na Corte }\end{array}$ & $\begin{array}{c}\text { Cumprimento de } \\
\text { Recomendações da } \\
\text { CmDH }\end{array}$ & Fazenda Brasil Verde & $12 / 11 / 1998$ & $21 / 12 / 1988$ \\
\hline Sudeste & RJ & 11.634 & Comissão & $\begin{array}{l}\text { Cumprimento de } \\
\text { Recomendações } \\
\text { da CmDH }\end{array}$ & $\begin{array}{l}\text { Informação não } \\
\text { disponível }\end{array}$ & Jaílton Néri da Fonseca & 07/12/1995 & $22 / 12 / 1992$ \\
\hline
\end{tabular}




\begin{tabular}{|c|c|c|c|c|c|c|c|c|}
\hline Região & UF & $\begin{array}{l}\text { Número do } \\
\text { Processo }\end{array}$ & Órgão & Fase & Especificação da fase & Nome do Caso & $\begin{array}{l}\text { Data de } \\
\text { Início do } \\
\text { Trâmite } \\
\end{array}$ & $\begin{array}{l}\text { Data da } \\
\text { Alegada } \\
\text { Violação }\end{array}$ \\
\hline Norte & PA & 11.287 & Comissão & $\begin{array}{c}\text { Cumprimento de } \\
\text { Recomendações } \\
\text { da CmDH }\end{array}$ & $\begin{array}{l}\text { Informação não } \\
\text { disponível }\end{array}$ & João Canuto de Oliveira & 27/05/1994 & $18 / 12 / 1985$ \\
\hline Norte & PA & 11.289 & Comissão & $\begin{array}{c}\text { Cumprimento de } \\
\text { Acordo de } \\
\text { Solução } \\
\text { Amistosa } \\
\end{array}$ & $\begin{array}{l}\text { Cumprimento de } \\
\text { Acordo de Solução } \\
\text { Amistosa }\end{array}$ & José Pereira e outros & 22/02/1994 & $01 / 09 / 1989$ \\
\hline Nordeste & MA & 12.426 & Comissão & $\begin{array}{c}\text { Cumprimento de } \\
\text { Acordo de } \\
\text { Solução } \\
\text { Amistosa } \\
\end{array}$ & $\begin{array}{l}\text { Cumprimento de } \\
\text { Acordo de Solução } \\
\text { Amistosa }\end{array}$ & $\begin{array}{l}\text { Meninos Emasculados do } \\
\text { Maranhão }\end{array}$ & 27/07/2001 & 01/09/1991 \\
\hline Nordeste & BA & 12.308 & Comissão & $\begin{array}{c}\text { Cumprimento de } \\
\text { Recomendações } \\
\text { da CmDH }\end{array}$ & $\begin{array}{l}\text { Informação não } \\
\text { disponível }\end{array}$ & Manoel Leal de Oliveira & $22 / 05 / 2000$ & $14 / 01 / 1998$ \\
\hline Nordeste & $\mathrm{CE}$ & 12.051 & Comissão & $\begin{array}{c}\text { Cumprimento de } \\
\text { Recomendações } \\
\text { da CmDH }\end{array}$ & $\begin{array}{l}\text { Informação não } \\
\text { disponível }\end{array}$ & Maria da Penha Fernandes & 20/08/1998 & $29 / 05 / 1993$ \\
\hline Norte & PA & 11.405 & Comissão & $\begin{array}{l}\text { Cumprimento de } \\
\text { Recomendações } \\
\text { da CmDH }\end{array}$ & $\begin{array}{l}\text { Informação não } \\
\text { disponível }\end{array}$ & Newton Coutinho Mendes & $18 / 11 / 1994$ & 01/04/1994 \\
\hline Norte & $\mathrm{RR}$ & 11.516 & Comissão & $\begin{array}{l}\text { Cumprimento de } \\
\text { Recomendações } \\
\text { da CmDH }\end{array}$ & $\begin{array}{l}\text { Informação não } \\
\text { disponível }\end{array}$ & Ovelário Tames & 01/06/1995 & $23 / 10 / 1988$ \\
\hline Sudeste & SP & 10.301 & Comissão & $\begin{array}{l}\text { Cumprimento de } \\
\text { Recomendações } \\
\text { da CmDH }\end{array}$ & $\begin{array}{l}\text { Informação não } \\
\text { disponível }\end{array}$ & Parque São Lucas & 07/02/1989 & 05/021989 \\
\hline Sul & PR & 12.310 & Comissão & $\begin{array}{l}\text { Cumprimento de } \\
\text { Recomendações } \\
\text { da CmDH }\end{array}$ & $\begin{array}{l}\text { Informação não } \\
\text { disponível }\end{array}$ & Sebastião Camargo Filho & $30 / 06 / 2000$ & 07/02/1998 \\
\hline Sudeste & SP & 12.001 & Comissão & $\begin{array}{l}\text { Cumprimento de } \\
\text { Recomendações } \\
\text { da CmDH }\end{array}$ & $\begin{array}{l}\text { Informação não } \\
\text { disponível }\end{array}$ & Simone André Diniz & 07/10/1997 & 02/03/1997 \\
\hline
\end{tabular}




\begin{tabular}{|c|c|c|c|c|c|c|c|c|}
\hline Região & $\mathbf{U F}$ & $\begin{array}{l}\text { Número do } \\
\text { Processo }\end{array}$ & Órgão & Fase & Especificação da fase & Nome do Caso & $\begin{array}{l}\text { Data de } \\
\text { Início do } \\
\text { Trâmite } \\
\end{array}$ & $\begin{array}{l}\text { Data da } \\
\text { Alegada } \\
\text { Violação }\end{array}$ \\
\hline Sudeste & RJ & 12.440 & Comissão & $\begin{array}{l}\text { Cumprimento de } \\
\text { Recomendações } \\
\text { da CmDH }\end{array}$ & $\begin{array}{l}\text { Informação não } \\
\text { disponível }\end{array}$ & Wallace de Almeida & $26 / 12 / 2001$ & $14 / 09 / 1998$ \\
\hline Sudeste & SP & 11.291 & Comissão & $\begin{array}{c}\text { Cumprimento de } \\
\text { Recomendações } \\
\text { da CmDH }\end{array}$ & $\begin{array}{l}\text { Informação não } \\
\text { disponível }\end{array}$ & Carandirú & 22/02/1994 & 02/10/1992 \\
\hline Sudeste & RJ & 11.598 & Comissão & $\begin{array}{l}\text { Cumprimento de } \\
\text { Recomendações } \\
\text { da CmDH }\end{array}$ & $\begin{array}{l}\text { Informação não } \\
\text { disponível }\end{array}$ & Alonso Eugénio da Silva & 07/12/1995 & 08/03/1992 \\
\hline Sudeste & RJ & 11.599 & Comissão & $\begin{array}{l}\text { Cumprimento de } \\
\text { Recomendações } \\
\text { da CmDH }\end{array}$ & $\begin{array}{l}\text { Informação não } \\
\text { disponível }\end{array}$ & Marcos Aurelio de Oliveira & 07/12/1995 & 25/09/1993 \\
\hline Sudeste & RJ & 12.852 & Comissão & $\begin{array}{l}\text { Em negociacão } \\
\text { de acordo de } \\
\text { solução amistosa }\end{array}$ & $\begin{array}{c}\text { Mérito (Em } \\
\text { negociacão de acordo } \\
\text { de solução amistosa) }\end{array}$ & Alejandro Daniel Esteve & $16 / 09 / 2004$ & $28 / 03 / 2003$ \\
\hline $\begin{array}{l}\text { Centro- } \\
\text { Oeste }\end{array}$ & MT & 12.694 & Comissão & $\begin{array}{c}\text { Em negociacão } \\
\text { de acordo de } \\
\text { solução amistosa }\end{array}$ & $\begin{array}{c}\text { Mérito (Em } \\
\text { negociacão de acordo } \\
\text { de solução amistosa) }\end{array}$ & Armand Lerco e Alain Rouland & $18 / 12 / 2002$ & 01/05/1992 \\
\hline Sudeste & RJ & P-11993 & Comissão & $\begin{array}{l}\text { Em negociacão } \\
\text { de acordo de } \\
\text { solução amistosa }\end{array}$ & $\begin{array}{c}\text { Mérito (Em } \\
\text { negociacão de acordo } \\
\text { de solução amistosa) }\end{array}$ & Chacina da Candelária & 09/03/1998 & 23/07/1993 \\
\hline Norte & $\mathrm{RR}$ & 12.567 & Comissão & $\begin{array}{l}\text { Em negociacão } \\
\text { de acordo de } \\
\text { solução amistosa }\end{array}$ & $\begin{array}{c}\text { Mérito (Em } \\
\text { negociacão de acordo } \\
\text { de solução amistosa) }\end{array}$ & $\begin{array}{l}\text { Comunidade Indígena Ananás e } \\
\text { outros }\end{array}$ & $30 / 01 / 2002$ & $\begin{array}{l}01 / 02 / 2000 \text { até } \\
\text { o presente }\end{array}$ \\
\hline Nordeste & PE & 11.285 & Comissão & $\begin{array}{c}\text { Em negociacão } \\
\text { de acordo de } \\
\text { solução amistosa }\end{array}$ & $\begin{array}{c}\text { Mérito (Em } \\
\text { negociacão de acordo } \\
\text { de solução amistosa) }\end{array}$ & Edson Damião Calixto & $11 / 03 / 1998$ & 28/12/1991 \\
\hline Norte & PA & 11.820 & Comissão & $\begin{array}{l}\text { Em negociacão } \\
\text { de acordo de } \\
\text { solução amistosa }\end{array}$ & $\begin{array}{c}\text { Mérito (Em } \\
\text { negociacão de acordo } \\
\text { de solução amistosa) }\end{array}$ & Eldorado dos Carajás & $31 / 10 / 1996$ & 17/04/1996 \\
\hline
\end{tabular}




\begin{tabular}{|c|c|c|c|c|c|c|c|c|}
\hline Região & $\mathbf{U F}$ & $\begin{array}{l}\text { Número do } \\
\text { Processo }\end{array}$ & Órgão & Fase & Especificação da fase & Nome do Caso & $\begin{array}{l}\text { Data de } \\
\text { Início do } \\
\text { Trâmite } \\
\end{array}$ & $\begin{array}{l}\text { Data da } \\
\text { Alegada } \\
\text { Violação }\end{array}$ \\
\hline Norte & PA & 12.277 & Comissão & $\begin{array}{l}\text { Em negociacão } \\
\text { de acordo de } \\
\text { solução amistosa }\end{array}$ & $\begin{array}{c}\text { Mérito (Em } \\
\text { negociacão de acordo } \\
\text { de solução amistosa) }\end{array}$ & Fazenda Ubá & 20/12/1999 & $13 / 06 / 1985$ \\
\hline Norte & PA & 12673 & Comissão & $\begin{array}{l}\text { Em negociacão } \\
\text { de acordo de } \\
\text { solução amistosa }\end{array}$ & $\begin{array}{c}\text { Mérito (Em } \\
\text { negociacão de acordo } \\
\text { de solução amistosa) }\end{array}$ & José Dutra da Costa ("Dezinho") & $30 / 11 / 2004$ & $21 / 11 / 2000$ \\
\hline $\begin{array}{l}\text { Centro- } \\
\text { Oeste }\end{array}$ & MT & 12.200 & Comissão & $\begin{array}{l}\text { Em negociacão } \\
\text { de acordo de } \\
\text { solução amistosa }\end{array}$ & $\begin{array}{c}\text { Mérito (Em } \\
\text { negociacão de acordo } \\
\text { de solução amistosa) }\end{array}$ & Juvenal e José Henrique Trindade & $10 / 02 / 1999$ & 1982 \\
\hline Sudeste & RJ & 12674 & Comissão & $\begin{array}{l}\text { Em negociacão } \\
\text { de acordo de } \\
\text { solução amistosa }\end{array}$ & $\begin{array}{c}\text { Mérito (Em } \\
\text { negociacão de acordo } \\
\text { de solução amistosa) }\end{array}$ & Márcio Lapoente da Silveira & $08 / 12 / 2004$ & 09/10/1990 \\
\hline Nordeste & PE & 11.290 & Comissão & $\begin{array}{l}\text { Em negociacão } \\
\text { de acordo de } \\
\text { solução amistosa }\end{array}$ & $\begin{array}{c}\text { Mérito (Em } \\
\text { negociacão de acordo } \\
\text { de solução amistosa) }\end{array}$ & Roselândio Borges & $11 / 03 / 1998$ & 28/12/1991 \\
\hline Sudeste & MG & 12.708 & Comissão & $\begin{array}{l}\text { Em negociacão } \\
\text { de acordo de } \\
\text { solução amistosa }\end{array}$ & $\begin{array}{c}\text { Mérito (Em } \\
\text { negociacão de acordo } \\
\text { de solução amistosa) }\end{array}$ & $\begin{array}{c}\text { Silas Abel da Conceição e Augusta } \\
\text { Tomázia Inácia }\end{array}$ & $19 / 10 / 2005$ & $22 / 09 / 1988$ \\
\hline Sudeste & RJ & P-12008 & Comissão & $\begin{array}{l}\text { Em negociacão } \\
\text { de acordo de } \\
\text { solução amistosa }\end{array}$ & $\begin{array}{c}\text { Mérito (Em } \\
\text { negociacão de acordo } \\
\text { de solução amistosa) }\end{array}$ & Vigário Geral & $19 / 10 / 2005$ & 29/07/1993 \\
\hline Sudeste & RJ & 11.994 & Comissão & $\begin{array}{l}\text { Em negociacão } \\
\text { de acordo de } \\
\text { solução amistosa }\end{array}$ & $\begin{array}{c}\text { Mérito (Em } \\
\text { negociacão de acordo } \\
\text { de solução amistosa) }\end{array}$ & Wagner dos Santos & 26/03/1998 & 23/07/1993 \\
\hline Nordeste & PE & MC-372-02 & Comissão & $\begin{array}{l}\text { Medidas } \\
\text { Cautelares }\end{array}$ & $\begin{array}{l}\text { Informação não } \\
\text { disponível }\end{array}$ & $\begin{array}{c}\text { Zenilda Maria de Araújo e Marcos } \\
\text { Luidson de Araújo (Cacique } \\
\text { Marquinhos) Líderes Indígenas do } \\
\text { Povo Xucurú } \\
\end{array}$ & $19 / 10 / 2002$ & $19 / 10 / 2002$ \\
\hline Nordeste & PE & MC-387-02 & Comissão & $\begin{array}{l}\text { Medidas } \\
\text { Cautelares }\end{array}$ & $\begin{array}{l}\text { Informação não } \\
\text { disponível }\end{array}$ & Elma Soraya Novais e filhos & $21 / 11 / 2002$ & $21 / 11 / 2002$ \\
\hline
\end{tabular}




\begin{tabular}{|c|c|c|c|c|c|c|c|c|}
\hline Região & UF & $\begin{array}{l}\text { Número do } \\
\text { Processo }\end{array}$ & Órgão & Fase & Especificação da fase & Nome do Caso & $\begin{array}{l}\text { Data de } \\
\text { Início do } \\
\text { Trâmite }\end{array}$ & $\begin{array}{l}\text { Data da } \\
\text { Alegada } \\
\text { Violação }\end{array}$ \\
\hline Norte & $\mathrm{RR}$ & MC-818-04 & Comissão & $\begin{array}{l}\text { Medidas } \\
\text { Cautelares }\end{array}$ & $\begin{array}{l}\text { Informação não } \\
\text { disponível }\end{array}$ & $\begin{array}{l}\text { Povos Indígenas Ingaricó, Macuxi, } \\
\text { Patamona, Taurepang e Wapixana } \\
\text { (Raposa Serra do Sol) }\end{array}$ & $06 / 12 / 2004$ & $06 / 12 / 2004$ \\
\hline $\begin{array}{l}\text { Centro- } \\
\text { Oeste }\end{array}$ & $\mathrm{DF}$ & MC-14-06 & Comissão & $\begin{array}{l}\text { Medidas } \\
\text { Cautelares }\end{array}$ & $\begin{array}{l}\text { Informação não } \\
\text { disponível }\end{array}$ & Adolescentes Internados no CAJE & 09/02/2006 & $09 / 02 / 2006$ \\
\hline Norte & PA & MC-382-10 & Comissão & $\begin{array}{l}\text { Medidas } \\
\text { Cautelares }\end{array}$ & $\begin{array}{l}\text { Informação não } \\
\text { disponível }\end{array}$ & $\begin{array}{l}\text { Comunidades tradicionais da Bacia } \\
\text { do Rio Xingu (Belo Monte) }\end{array}$ & 04/03/2011 & $04 / 03 / 2011$ \\
\hline Nordeste & PE & MC-199-11 & Comissão & $\begin{array}{l}\text { Medidas } \\
\text { Cautelares }\end{array}$ & $\begin{array}{l}\text { Informação não } \\
\text { disponível }\end{array}$ & Presídio Professor Aníbal Bruno & $28 / 06 / 2011$ & $28 / 06 / 2011$ \\
\hline $\begin{array}{l}\text { Centro- } \\
\text { Oeste }\end{array}$ & MS & MC-339-11 & Comissão & $\begin{array}{l}\text { Medidas } \\
\text { Cautelares }\end{array}$ & $\begin{array}{l}\text { Informação não } \\
\text { disponível }\end{array}$ & $\begin{array}{l}\text { Violência contra a Comunidade } \\
\text { indígena Guarani Pyelito } \\
\text { Kuê/M'barakai }\end{array}$ & $21 / 11 / 2011$ & $21 / 11 / 2011$ \\
\hline $\begin{array}{l}\text { Centro- } \\
\text { Oeste }\end{array}$ & MS & MC-5-12 & Comissão & $\begin{array}{c}\text { Medidas } \\
\text { Cautelares }\end{array}$ & $\begin{array}{c}\text { Informação não } \\
\text { disponível }\end{array}$ & $\begin{array}{l}\text { Comunidades Indígenas Guarani- } \\
\text { Kaiowá e Terena }\end{array}$ & 08/02/2012 & $08 / 02 / 2012$ \\
\hline Sul & RS & MC - $8-13$ & Comissão & $\begin{array}{l}\text { Medidas } \\
\text { Cautelares }\end{array}$ & $\begin{array}{l}\text { Informação não } \\
\text { disponível }\end{array}$ & $\begin{array}{l}\text { Pessoas Privadas de Liberdade no } \\
\text { Presídio Central de Porto Alegre }\end{array}$ & $11 / 02 / 2013$ & $11 / 02 / 2013$ \\
\hline Nordeste & MA & MC-145-13 & Comissão & $\begin{array}{l}\text { Medidas } \\
\text { Cautelares }\end{array}$ & $\begin{array}{l}\text { Informação não } \\
\text { disponível }\end{array}$ & $\begin{array}{l}\text { Povo Awá-Guajá (Comunidades } \\
\text { Indígenas Awá-Guajá dos } \\
\text { territórios indígrenas Awá, Alto } \\
\text { Turiaçu, Caru e Araribóia) } \\
\end{array}$ & 03/05/2013 & 03/05/2013 \\
\hline Nordeste & MA & MC-367-13 & Comissão & $\begin{array}{l}\text { Medidas } \\
\text { Cautelares }\end{array}$ & $\begin{array}{l}\text { Informação não } \\
\text { disponível }\end{array}$ & $\begin{array}{c}\text { Pessoas privadas de liberdade no } \\
\text { Complexo Penitenciário de } \\
\text { Pedrinhas }\end{array}$ & 03/05/2013 & $03 / 05 / 2013$ \\
\hline $\begin{array}{l}\text { Centro- } \\
\text { Oeste }\end{array}$ & DF & MC-363-13 & Comissão & $\begin{array}{l}\text { Medidas } \\
\text { Cautelares }\end{array}$ & $\begin{array}{l}\text { Informação não } \\
\text { disponível }\end{array}$ & Antônio Pereira de Araújo & $07 / 11 / 2013$ & $07 / 11 / 2013$ \\
\hline
\end{tabular}




\begin{tabular}{|c|c|c|c|c|c|c|c|c|}
\hline Região & UF & $\begin{array}{l}\text { Número do } \\
\text { Processo }\end{array}$ & Órgão & Fase & Especificação da fase & Nome do Caso & $\begin{array}{l}\text { Data de } \\
\text { Início do } \\
\text { Trâmite }\end{array}$ & $\begin{array}{l}\text { Data da } \\
\text { Alegada } \\
\text { Violação }\end{array}$ \\
\hline Norte & $\mathrm{RR}$ & MC-438-13 & Comissão & $\begin{array}{l}\text { Medidas } \\
\text { Cautelares }\end{array}$ & $\begin{array}{l}\text { Informação não } \\
\text { disponível }\end{array}$ & $\begin{array}{l}\text { Pessoas privadas de liberdade na } \\
\text { Penitenciária de Monte Cristo }\end{array}$ & $16 / 12 / 2013$ & $16 / 12 / 2013$ \\
\hline Sudeste & $\mathrm{RJ}$ & MC-346-08 & Comissão & $\begin{array}{l}\text { Medidas } \\
\text { Cautelares }\end{array}$ & Inativa & Educandário Santo Expedito & $10 / 05 / 1996$ & $10 / 05 / 1996$ \\
\hline Norte & TO & MC-95-09 & Comissão & $\begin{array}{l}\text { Medidas } \\
\text { Cautelares }\end{array}$ & Inativa & Célio Márcio Alves Nogueira & $29 / 04 / 2009$ & $29 / 04 / 2009$ \\
\hline Sudeste & ES & MC-114-10 & Comissão & $\begin{array}{l}\text { Medidas } \\
\text { Cautelares }\end{array}$ & $\begin{array}{l}\text { Informação não } \\
\text { disponível }\end{array}$ & $\begin{array}{l}\text { Pessoas privadas de liberdade no } \\
\text { departamento de polícia judiciária } \\
\text { (DPJ) de vila velha }\end{array}$ & $28 / 04 / 2010$ & $28 / 04 / 2010$ \\
\hline Nordeste & PB & MC 351/02 & Comissão & $\begin{array}{l}\text { Medidas } \\
\text { Cautelares }\end{array}$ & $\begin{array}{l}\text { Informação não } \\
\text { disponível }\end{array}$ & Rosemary Souto Maior e outros & $23 / 09 / 2002$ & $23 / 09 / 2002$ \\
\hline Sudeste & ES & MC 224/09 & Comissão & $\begin{array}{c}\text { Medidas } \\
\text { Cautelares }\end{array}$ & $\begin{array}{l}\text { Informação não } \\
\text { disponível }\end{array}$ & $\begin{array}{l}\text { Adolescentes privados de liberdade } \\
\text { na Unidade de Internação } \\
\text { Socioeducativa (UNIS) }\end{array}$ & $25 / 11 / 2009$ & $25 / 11 / 2009$ \\
\hline Sudesre & $\mathrm{RJ}$ & MC 236/08 & Comissão & $\begin{array}{l}\text { Medidas } \\
\text { Cautelares }\end{array}$ & $\begin{array}{l}\text { Informação não } \\
\text { disponível }\end{array}$ & $\begin{array}{l}\text { Pessoas privadas de liberdade na } \\
\text { penitenciária Polinter-Neves }\end{array}$ & $01 / 06 / 2009$ & 01/06/2009 \\
\hline Sudeste & SP & $\begin{array}{l}\text { Informação } \\
\text { não } \\
\text { disponível }\end{array}$ & Comissão & $\begin{array}{l}\text { Medidas } \\
\text { Cautelares }\end{array}$ & $\begin{array}{l}\text { Informação não } \\
\text { disponível }\end{array}$ & $\begin{array}{c}\text { Caso adolescentes na cadeia pública } \\
\text { de Guarujá }\end{array}$ & $26 / 10 / 2007$ & $26 / 10 / 2007$ \\
\hline Sudeste & ES & $\begin{array}{l}\text { Informação } \\
\text { não } \\
\text { disponível }\end{array}$ & Comissão & $\begin{array}{c}\text { Medidas } \\
\text { Cautelares }\end{array}$ & $\begin{array}{l}\text { Informação não } \\
\text { disponível }\end{array}$ & Caso Maria Aparecida Denadai & $09 / 02 / 2006$ & 09/02/2006 \\
\hline Sudeste & $\mathrm{RJ}$ & MC 130/06 & Comissão & $\begin{array}{l}\text { Medidas } \\
\text { Cautelares }\end{array}$ & $\begin{array}{l}\text { Informação não } \\
\text { disponível }\end{array}$ & $\begin{array}{c}\text { Pessoas detidas na } 76^{\mathrm{a}} \text { Delegacia } \\
\text { de Polícia }\end{array}$ & $19 / 10 / 2006$ & $19 / 10 / 2006$ \\
\hline
\end{tabular}




\begin{tabular}{|c|c|c|c|c|c|c|c|c|}
\hline Região & UF & $\begin{array}{l}\text { Número do } \\
\text { Processo }\end{array}$ & Órgão & Fase & Especificação da fase & Nome do Caso & $\begin{array}{l}\text { Data de } \\
\text { Início do } \\
\text { Trâmite }\end{array}$ & $\begin{array}{l}\text { Data da } \\
\text { Alegada } \\
\text { Violação }\end{array}$ \\
\hline Sudeste & SP & MC 852/04 & Comissão & $\begin{array}{l}\text { Medidas } \\
\text { Cautelares }\end{array}$ & $\begin{array}{l}\text { Informação não } \\
\text { disponível }\end{array}$ & $\begin{array}{l}\text { Crianças privadas de liberdade na } \\
\text { Fundação Estadual do Bem-Estar } \\
\text { do Menor (FEBEM) do Tatuapé }\end{array}$ & $21 / 12 / 2004$ & $21 / 12 / 2004$ \\
\hline Sul & PR & $\begin{array}{c}\text { Informação } \\
\text { não } \\
\text { disponível }\end{array}$ & Comissão & $\begin{array}{l}\text { Medidas } \\
\text { Cautelares }\end{array}$ & $\begin{array}{l}\text { Informação não } \\
\text { disponível }\end{array}$ & $\begin{array}{l}\text { Caso Jorge Custodio, Rosangela } \\
\text { Aparecida Saraiva Ferreira e } \\
\text { Alessandra Rodriguez Celestino }\end{array}$ & $12 / 08 / 2003$ & $12 / 08 / 2003$ \\
\hline Sul & RS & $\begin{array}{l}\text { Informação } \\
\text { não } \\
\text { disponível }\end{array}$ & Comissão & $\begin{array}{l}\text { Medidas } \\
\text { Cautelares }\end{array}$ & $\begin{array}{l}\text { Informação não } \\
\text { disponível }\end{array}$ & $\begin{array}{c}\text { Caso Maria Aparecida Gomes da } \\
\text { Silva e sua família e Edson } \\
\text { Azambuja }\end{array}$ & $29 / 05 / 2003$ & $29 / 05 / 2003$ \\
\hline Norte & RO & $\begin{array}{c}\text { Informação } \\
\text { não } \\
\text { disponível }\end{array}$ & Comissão & $\begin{array}{l}\text { Medidas } \\
\text { Cautelares }\end{array}$ & $\begin{array}{l}\text { Informação não } \\
\text { disponível }\end{array}$ & $\begin{array}{c}\text { Caso dos internos do cárcere de } \\
\text { Urso Branco }\end{array}$ & $14 / 03 / 2002$ & $14 / 03 / 2002$ \\
\hline Sudeste & ES & $\begin{array}{l}\text { Informação } \\
\text { não } \\
\text { disponível }\end{array}$ & Comissão & $\begin{array}{l}\text { Medidas } \\
\text { Cautelares }\end{array}$ & $\begin{array}{l}\text { Informação não } \\
\text { disponível }\end{array}$ & Caso Iriny Nicolau Corres Lopes & 04/06/2002 & $04 / 06 / 2002$ \\
\hline Sudeste & SP & $\begin{array}{c}\text { Informação } \\
\text { não } \\
\text { disponível }\end{array}$ & Comissão & $\begin{array}{l}\text { Medidas } \\
\text { Cautelares }\end{array}$ & $\begin{array}{l}\text { Informação não } \\
\text { disponível }\end{array}$ & $\begin{array}{c}\text { Caso Rony Clay Chaves, Rubens } \\
\text { Leoncio Pereira, Marcos Massari e } \\
\text { Gilmar Leite Siquiera (proteção de } \\
\text { testemunhas da operação } \\
\text { castelinho) } \\
\end{array}$ & $19 / 08 / 2002$ & $19 / 08 / 2002$ \\
\hline Nordeste & PB & MC 351/02 & Comissão & $\begin{array}{l}\text { Medidas } \\
\text { Cautelares }\end{array}$ & $\begin{array}{l}\text { Informação não } \\
\text { disponível }\end{array}$ & $\begin{array}{l}\text { Caso Manoel Bezerra, Rosemary } \\
\text { Souto e Luiz da Silva }\end{array}$ & $23 / 09 / 2002$ & $23 / 09 / 2002$ \\
\hline Sudeste & SP & $\begin{array}{l}\text { Informação } \\
\text { não } \\
\text { disponível }\end{array}$ & Comissão & $\begin{array}{l}\text { Medidas } \\
\text { Cautelares }\end{array}$ & $\begin{array}{l}\text { Informação não } \\
\text { disponível }\end{array}$ & $\begin{array}{l}\text { Caso dos promotores e dos detentos } \\
\text { da prisão pública de Sorocaba }\end{array}$ & $21 / 12 / 2000$ & $21 / 12 / 2000$ \\
\hline Sudeste & SP & $\begin{array}{l}\text { Informação } \\
\text { não } \\
\text { disponível }\end{array}$ & Comissão & $\begin{array}{l}\text { Medidas } \\
\text { Cautelares }\end{array}$ & $\begin{array}{l}\text { Informação não } \\
\text { disponível }\end{array}$ & Caso Benedito Mariano & $27 / 04 / 2000$ & $27 / 04 / 2000$ \\
\hline
\end{tabular}




\begin{tabular}{|c|c|c|c|c|c|c|c|c|}
\hline Região & UF & $\begin{array}{c}\text { Número do } \\
\text { Processo }\end{array}$ & Órgão & Fase & Especificação da fase & Nome do Caso & $\begin{array}{c}\text { Data de } \\
\text { Início do } \\
\text { Trâmite }\end{array}$ & $\begin{array}{c}\text { Data da } \\
\text { Alegada } \\
\text { Violação }\end{array}$ \\
\hline Norte & $\mathrm{AM}$ & $\begin{array}{c}\text { Informação } \\
\text { não } \\
\text { disponível }\end{array}$ & Comissão & $\begin{array}{l}\text { Medidas } \\
\text { Cautelares }\end{array}$ & $\begin{array}{l}\text { Informação não } \\
\text { disponível }\end{array}$ & Caso Catherine Halvey & 09/03/2000 & $09 / 03 / 2000$ \\
\hline Sudeste & ES & $\begin{array}{c}\text { Informação } \\
\text { não } \\
\text { disponível }\end{array}$ & Comissão & $\begin{array}{l}\text { Medidas } \\
\text { Cautelares }\end{array}$ & $\begin{array}{l}\text { Informação não } \\
\text { disponível }\end{array}$ & Caso Joaquim Marcelo Denadai & 24/06/1999 & $24 / 06 / 1999$ \\
\hline Norte & PA & $\begin{array}{c}\text { Informação } \\
\text { não } \\
\text { disponível }\end{array}$ & Comissão & $\begin{array}{l}\text { Medidas } \\
\text { Cautelares }\end{array}$ & $\begin{array}{l}\text { Informação não } \\
\text { disponível }\end{array}$ & Caso Luzia Canuto & 20/03/1998 & 20/03/1998 \\
\hline Norte & PA & $\begin{array}{c}\text { Informação } \\
\text { não } \\
\text { disponível }\end{array}$ & Comissão & $\begin{array}{l}\text { Medidas } \\
\text { Cautelares }\end{array}$ & $\begin{array}{l}\text { Informação não } \\
\text { disponível }\end{array}$ & $2^{\circ}$ Caso Padre Ricardo Rezende & 01/10/1998 & 01/10/1998 \\
\hline Sudeste & SP & $\begin{array}{l}\text { CASO } \\
12.002 \\
\end{array}$ & Comissão & $\begin{array}{c}\text { Medidas } \\
\text { Cautelares } \\
\end{array}$ & $\begin{array}{c}\text { Informação não } \\
\text { disponível }\end{array}$ & Maria Emilia de Marchi e outros & $16 / 12 / 1998$ & $16 / 12 / 1998$ \\
\hline Norte & PA & $\begin{array}{c}\text { Informação } \\
\text { não } \\
\text { disponível }\end{array}$ & Comissão & $\begin{array}{l}\text { Medidas } \\
\text { Cautelares }\end{array}$ & $\begin{array}{l}\text { Informação não } \\
\text { disponível }\end{array}$ & $\begin{array}{c}1^{\circ} \text { Caso Padre Ricardo Rezende e } \\
\text { outros }\end{array}$ & 01/02/1995 & $01 / 02 / 1995$ \\
\hline Sudeste & ES & $\begin{array}{c}\text { Informação } \\
\text { não } \\
\text { disponível }\end{array}$ & Comissão & $\begin{array}{l}\text { Medidas } \\
\text { Cautelares }\end{array}$ & $\begin{array}{l}\text { Informação não } \\
\text { disponível }\end{array}$ & $\begin{array}{l}\text { Caso do advogado Osmar Barcelos } \\
\text { do Nascimento }\end{array}$ & 20/05/1996 & $20 / 05 / 1996$ \\
\hline Sudeste & $\mathrm{RJ}$ & $\begin{array}{c}\text { Informação } \\
\text { não } \\
\text { disponível }\end{array}$ & Comissão & $\begin{array}{l}\text { Medidas } \\
\text { Cautelares }\end{array}$ & $\begin{array}{l}\text { Informação não } \\
\text { disponível }\end{array}$ & $\begin{array}{c}\text { Caso dos menores internos do } \\
\text { instituto padre Severino, da escola } \\
\text { João Luis Alves e da escola Santos } \\
\text { Dumont } \\
\end{array}$ & 20/05/1996 & 20/05/1996 \\
\hline Nordeste & $\mathrm{R} \mathrm{N}$ & $\begin{array}{c}\text { Informação } \\
\text { não } \\
\text { disponível } \\
\end{array}$ & Comissão & $\begin{array}{l}\text { Medidas } \\
\text { Cautelares }\end{array}$ & $\begin{array}{l}\text { Informação não } \\
\text { disponível }\end{array}$ & $\begin{array}{c}\text { Caso ameaçados pelos 'Meninos de } \\
\text { Ouro' }\end{array}$ & $19 / 12 / 1996$ & $19 / 12 / 1996$ \\
\hline Sudeste & ES & $\begin{array}{c}\text { Informação } \\
\text { não } \\
\text { disponível }\end{array}$ & Corte & $\begin{array}{l}\text { Medidas } \\
\text { Provisionais }\end{array}$ & $\begin{array}{l}\text { Informação não } \\
\text { disponível }\end{array}$ & $\begin{array}{l}\text { Caso da Unidade de Internação } \\
\text { Socioeducativa }\end{array}$ & $30 / 12 / 2010$ & $30 / 12 / 2010$ \\
\hline
\end{tabular}




\begin{tabular}{|c|c|c|c|c|c|c|c|c|}
\hline Região & $\mathbf{U F}$ & $\begin{array}{l}\text { Número do } \\
\text { Processo }\end{array}$ & Órgão & Fase & Especificação da fase & Nome do Caso & $\begin{array}{l}\text { Data de } \\
\text { Início do } \\
\text { Trâmite } \\
\end{array}$ & $\begin{array}{l}\text { Data da } \\
\text { Alegada } \\
\text { Violação }\end{array}$ \\
\hline $\begin{array}{l}\text { Centro- } \\
\text { oeste }\end{array}$ & To & $\begin{array}{c}\text { Informação } \\
\text { não } \\
\text { disponível }\end{array}$ & Corte & $\begin{array}{l}\text { Medidas } \\
\text { Provisionais }\end{array}$ & $\begin{array}{l}\text { Informação não } \\
\text { disponível }\end{array}$ & Caso Julia Gomes Lund e outros & $15 / 07 / 2009$ & $15 / 07 / 2009$ \\
\hline Sudeste & SP & $\begin{array}{c}\text { Informação } \\
\text { não } \\
\text { disponível }\end{array}$ & Corte & $\begin{array}{l}\text { Medidas } \\
\text { Provisionais }\end{array}$ & $\begin{array}{l}\text { Informação não } \\
\text { disponível }\end{array}$ & $\begin{array}{l}\text { Caso dos detentos da penitenciária } \\
\text { de Araraquara }\end{array}$ & $28 / 072006$ & 28/072006 \\
\hline Norte & RO & $\begin{array}{c}\text { Informação } \\
\text { não } \\
\text { disponível }\end{array}$ & Corte & $\begin{array}{l}\text { Medidas } \\
\text { Provisionais }\end{array}$ & $\begin{array}{l}\text { Informação não } \\
\text { disponível }\end{array}$ & $\begin{array}{l}\text { Caso dos internos do cárcere de } \\
\text { Urso Branco (Complexo de Curado) }\end{array}$ & $18 / 06 / 2002$ & $18 / 06 / 2002$ \\
\hline Nordeste & MA & $\begin{array}{c}\text { Informação } \\
\text { não } \\
\text { disponível }\end{array}$ & Corte & $\begin{array}{l}\text { Medidas } \\
\text { Provisionais }\end{array}$ & $\begin{array}{l}\text { Informação não } \\
\text { disponível }\end{array}$ & $\begin{array}{c}\text { Caso do Complexo Penitenciário de } \\
\text { Pedrinhas }\end{array}$ & $23 / 09 / 2014$ & 23/09/2014 \\
\hline $\begin{array}{l}\text { Centro- } \\
\text { Oeste }\end{array}$ & TO & $\begin{array}{c}\text { Informação } \\
\text { não } \\
\text { disponível }\end{array}$ & Corte & $\begin{array}{l}\text { Cumprimento de } \\
\text { Resoluções da } \\
\text { Corte }\end{array}$ & Resoluções da Corte & $\begin{array}{l}\text { Caso Julia Gomes Lund e outros } \\
\text { (Guerrilha do Araguaia) vs. Brasil }\end{array}$ & 07/08/1995 & $\begin{array}{l}\text { 01/01/1972 até } \\
\text { o presente }\end{array}$ \\
\hline Sul & PR & $\begin{array}{c}\text { Informação } \\
\text { não } \\
\text { disponível }\end{array}$ & Corte & $\begin{array}{l}\text { Cumprimento de } \\
\text { Resoluções da } \\
\text { Corte }\end{array}$ & Resoluções da Corte & Caso Garibaldi vs. Brasil & 06/05/2003 & 27/11/1998 \\
\hline Nordeste & $\mathrm{CE}$ & $\begin{array}{c}\text { Informação } \\
\text { não } \\
\text { disponível } \\
\end{array}$ & Corte & $\begin{array}{l}\text { Cumprimento de } \\
\text { Resoluções da } \\
\text { Corte }\end{array}$ & Resoluções da Corte & $\begin{array}{c}\text { Caso Damião Ximenes Lopes vs. } \\
\text { Brasil }\end{array}$ & 22/11/1999 & 01/10/1999 \\
\hline Sul & PR & $\begin{array}{c}\text { Informação } \\
\text { não } \\
\text { disponível } \\
\end{array}$ & Corte & $\begin{array}{l}\text { Cumprimento de } \\
\text { Resoluções da } \\
\text { Corte }\end{array}$ & Resoluções da Corte & $\begin{array}{l}\text { Caso Arley José Escher e outros vs. } \\
\text { Brasil }\end{array}$ & $26 / 12 / 2000$ & 01/04/1999 \\
\hline Nordeste & $\mathrm{RN}$ & $\begin{array}{c}\text { Informação } \\
\text { não } \\
\text { disponível }\end{array}$ & Corte & Arquivada & Arquivada & $\begin{array}{l}\text { Caso Nogueira de Carvalho e outro } \\
\text { vs. Brasil }\end{array}$ & $11 / 12 / 1997$ & 20/10/1996 \\
\hline Nordeste & PB & P-1170-09 & Comissão & Admissibilidade & $\begin{array}{l}\text { Informação não } \\
\text { disponível }\end{array}$ & Almir Muniz da Silva & $18 / 09 / 2009$ & $\begin{array}{c}\text { Informação } \\
\text { não disponível }\end{array}$ \\
\hline
\end{tabular}




\begin{tabular}{|c|c|c|c|c|c|c|c|c|}
\hline Região & UF & $\begin{array}{l}\text { Número do } \\
\text { Processo }\end{array}$ & Órgão & Fase & Especificação da fase & Nome do Caso & $\begin{array}{l}\text { Data de } \\
\text { Início do } \\
\text { Trâmite }\end{array}$ & $\begin{array}{l}\text { Data da } \\
\text { Alegada } \\
\text { Violação }\end{array}$ \\
\hline Sudeste & SP & P-23-10 & Comissão & Admissibilidade & $\begin{array}{l}\text { Informação não } \\
\text { disponível }\end{array}$ & Almir Rodrigues Ferreira & 06/01/2010 & $\begin{array}{c}\text { Informação } \\
\text { não disponível }\end{array}$ \\
\hline Norte & RO & P-1349-09 & Comissão & Admissibilidade & $\begin{array}{l}\text { Informação não } \\
\text { disponível }\end{array}$ & $\begin{array}{c}\text { Apenados do Sistema Prisional de } \\
\text { Arniqueiras }\end{array}$ & $27 / 10 / 2009$ & $\begin{array}{l}\text { Informação } \\
\text { não disponível }\end{array}$ \\
\hline $\begin{array}{l}\text { Centro- } \\
\text { Oeste }\end{array}$ & MS & P-1056-20 & Comissão & Admissibilidade & $\begin{array}{l}\text { Informação não } \\
\text { disponível }\end{array}$ & $\begin{array}{l}\text { Brigido Ibanhes e Elisangela dos } \\
\text { Santos de Souza Ibanhes }\end{array}$ & $22 / 07 / 2010$ & $\begin{array}{c}\text { Informação } \\
\text { não disponível }\end{array}$ \\
\hline Sudeste & SP & P-187-09 & Comissão & Admissibilidade & $\begin{array}{l}\text { Informação não } \\
\text { disponível }\end{array}$ & $\begin{array}{c}\text { Carlos Eduardo de Oliveira Preti e } \\
\text { outros }\end{array}$ & 23/02/2009 & $\begin{array}{c}\text { Informação } \\
\text { não disponível }\end{array}$ \\
\hline Sudeste & SP & P-690-11 & Comissão & Admissibilidade & $\begin{array}{l}\text { Informação não } \\
\text { disponível }\end{array}$ & Cho Bong Heang & $19 / 02 / 2011$ & $\begin{array}{c}\text { Informação } \\
\text { não disponível }\end{array}$ \\
\hline Sudeste & SP & P-60-09 & Comissão & Admissibilidade & $\begin{array}{l}\text { Informação não } \\
\text { disponível }\end{array}$ & Claudio Bento de Oliveira & 20/01/2009 & $\begin{array}{c}\text { Informação } \\
\text { não disponível }\end{array}$ \\
\hline Nordeste & MA & P-1204-10 & Comissão & Admissibilidade & $\begin{array}{l}\text { Informação não } \\
\text { disponível }\end{array}$ & $\begin{array}{c}\text { Comunidade Quilombola de Saco } \\
\text { das Almas }\end{array}$ & $28 / 06 / 2010$ & $\begin{array}{l}\text { Informação } \\
\text { não disponível }\end{array}$ \\
\hline $\begin{array}{l}\text { Centro- } \\
\text { Oeste }\end{array}$ & GO & P-1222-09 & Comissão & Admissibilidade & $\begin{array}{l}\text { Informação não } \\
\text { disponível }\end{array}$ & Daliana Kristel Gonçalves Camargo & $30 / 09 / 2009$ & $\begin{array}{c}\text { Informação } \\
\text { não disponível }\end{array}$ \\
\hline Sudeste & SP & P-1085-11 & Comissão & Admissibilidade & $\begin{array}{c}\text { Informação não } \\
\text { disponível }\end{array}$ & Francisco Rocha & $17 / 08 / 2011$ & $\begin{array}{c}\text { Informação } \\
\text { não disponível }\end{array}$ \\
\hline Nordeste & $\mathrm{CE}$ & P-1411-07 & Comissão & Admissibilidade & $\begin{array}{l}\text { Informação não } \\
\text { disponível }\end{array}$ & Francisco de Souza Geraldo & $18 / 12 / 2007$ & $\begin{array}{l}\text { Informação } \\
\text { não disponível }\end{array}$ \\
\hline
\end{tabular}




\begin{tabular}{|c|c|c|c|c|c|c|c|c|}
\hline Região & UF & $\begin{array}{l}\text { Número do } \\
\text { Processo }\end{array}$ & Órgão & Fase & Especificação da fase & Nome do Caso & $\begin{array}{l}\text { Data de } \\
\text { Início do } \\
\text { Trâmite }\end{array}$ & $\begin{array}{l}\text { Data da } \\
\text { Alegada } \\
\text { Violação }\end{array}$ \\
\hline Sudeste & SP & P-1174-09 & Comissão & Admissibilidade & $\begin{array}{l}\text { Informação não } \\
\text { disponível }\end{array}$ & José Rafael Brezer & $17 / 09 / 2009$ & $\begin{array}{l}\text { Informação } \\
\text { não disponível }\end{array}$ \\
\hline Sudeste & SP & P-362-09 & Comissão & Admissibilidade & $\begin{array}{l}\text { Informação não } \\
\text { disponível }\end{array}$ & Luiza Melinho & 26/03/2014 & $\begin{array}{l}\text { Informação } \\
\text { não disponível }\end{array}$ \\
\hline Sudeste & SP & P-858-09 & Comissão & Admissibilidade & $\begin{array}{l}\text { Informação não } \\
\text { disponível }\end{array}$ & Luiz José da Cunha e Família & $14 / 07 / 2009$ & $\begin{array}{l}\text { Informação } \\
\text { não disponível }\end{array}$ \\
\hline Norte & $\mathrm{AM}$ & P-90-09 & Comissão & Admissibilidade & $\begin{array}{l}\text { Informação não } \\
\text { disponível }\end{array}$ & Luiz Otávio Monteiro & 29/01/2009 & $\begin{array}{l}\text { Informação } \\
\text { não disponível }\end{array}$ \\
\hline Sudeste & MG & P-974-09 & Comissão & Admissibilidade & $\begin{array}{l}\text { Informação não } \\
\text { disponível }\end{array}$ & Paulo Cézar de Oliveira & 05/08/2009 & $\begin{array}{l}\text { Informação } \\
\text { não disponível }\end{array}$ \\
\hline Sudeste & RJ & P-1116-07 & Comissão & Admissibilidade & $\begin{array}{l}\text { Informação não } \\
\text { disponível }\end{array}$ & $\begin{array}{l}\text { Paulo Igor do Nascimento Filho, } \\
\text { Rafael Carvalho da Costa e outros }\end{array}$ & $27 / 08 / 2007$ & $\begin{array}{l}\text { Informação } \\
\text { não disponível }\end{array}$ \\
\hline Sul & RS & P-81-13 & Comissão & Admissibilidade & $\begin{array}{l}\text { Informação não } \\
\text { disponível }\end{array}$ & $\begin{array}{l}\text { Pessoas Privadas de Liberdade no } \\
\text { Presídio Central de Porto Alegre }\end{array}$ & $11 / 01 / 2013$ & $\begin{array}{l}\text { Informação } \\
\text { não disponível }\end{array}$ \\
\hline Sudeste & SP & & Comissão & Admissibilidade & $\begin{array}{l}\text { Informação não } \\
\text { disponível }\end{array}$ & $\begin{array}{l}\text { Wolf Gruenberg e Betty Guendler } \\
\text { Gruenberg }\end{array}$ & 06/08/2012 & $\begin{array}{c}\text { Informação } \\
\text { não disponível }\end{array}$ \\
\hline \multirow[t]{2}{*}{ Norte } & PA & 12.398 & Comissão & $\begin{array}{l}\text { Análise de } \\
\text { Mérito }\end{array}$ & $\begin{array}{l}\text { Informação não } \\
\text { disponível }\end{array}$ & $\begin{array}{l}\text { Max Cley Mendes, Marciley } \\
\text { Roseval Melo e Luis Fábio } \\
\text { Coutinho da Silva }\end{array}$ & 17/09/2001 & $\begin{array}{l}\text { Informação } \\
\text { não disponível }\end{array}$ \\
\hline & & MC-233-05 & Comissão & $\begin{array}{l}\text { Medidas } \\
\text { Cautelares }\end{array}$ & Inativa & Airton de Lucena Dants & $19 / 10 / 2005$ & $\begin{array}{c}\text { Informação } \\
\text { não disponível }\end{array}$ \\
\hline
\end{tabular}




\begin{tabular}{|c|c|c|c|c|c|c|c|c|}
\hline Região & UF & $\begin{array}{c}\text { Número do } \\
\text { Processo }\end{array}$ & Órgão & Fase & Especificação da fase & Nome do Caso & $\begin{array}{c}\text { Data de } \\
\text { Iní́io do } \\
\text { Trâmite }\end{array}$ & $\begin{array}{c}\text { Data da } \\
\text { Alegada } \\
\text { Violação }\end{array}$ \\
\hline Norte & RO & MC-250-06 & Comissão & $\begin{array}{c}\text { Medidas } \\
\text { Cautelares }\end{array}$ & Inativa & Almir Suruí, sua família e seu povo & $12 / 10 / 2006$ & $\begin{array}{c}\text { Informação } \\
\text { não disponível }\end{array}$ \\
\hline Sudeste & MG & MC-314-14 & Comissão & $\begin{array}{c}\text { Medidas } \\
\text { Cautelares }\end{array}$ & Ativa & $\begin{array}{c}\text { Comunidades Esperança, Vitória e } \\
\text { Rosa Leão - BH }\end{array}$ & $17 / 09 / 2014$ & $\begin{array}{c}\text { Informação } \\
\text { não disponível }\end{array}$ \\
\hline Nordeste & PE & $\begin{array}{c}\text { MC-1038- } \\
04\end{array}$ & Comissão & $\begin{array}{c}\text { Medidas } \\
\text { Cautelares }\end{array}$ & Inativa & $\begin{array}{c}\text { Dominici Sávio Ramos Coelho } \\
\text { Mororó }\end{array}$ & $16 / 11 / 2004$ & $\begin{array}{c}\text { Informação } \\
\text { não disponível }\end{array}$ \\
\hline Sudeste & SP & MC-251-10 & Comissão & $\begin{array}{c}\text { Medidas } \\
\text { Cautelares }\end{array}$ & Inativa & $\begin{array}{c}\text { Eduardo Nuno de Freitas Pereira } \\
10 / 05 / 2010\end{array}$ & $\begin{array}{c}\text { Informação } \\
\text { não disponível }\end{array}$ \\
\hline Sul & PR & MC-366-14 & Comissão & $\begin{array}{c}\text { Medidas } \\
\text { Cautelares }\end{array}$ & Ativa & $\begin{array}{c}\text { Presos, agentes e funcionários das } \\
\text { unidades de tratamento penal do } \\
\text { Paraná }\end{array}$ & $\begin{array}{c}11 / 09 / 2014 \\
\text { Informação } \\
\text { não disponível }\end{array}$ \\
\hline
\end{tabular}




\begin{tabular}{|c|c|c|c|c|}
\hline $\begin{array}{l}\text { Número do } \\
\text { Processo }\end{array}$ & Peticionários & $\begin{array}{l}\text { Peticionários } \\
\text { Classificados }\end{array}$ & Artigos Invocados & Tema das violações \\
\hline 12.970 & Sociedad Interamericana de Prensa & ONGs internacionais & CADH: $4,5,8,13$ e 25 & $\begin{array}{l}\text { Violência contra defensores de } \\
\text { Direitos Humanos } \\
\text { Prestação de Justiça }\end{array}$ \\
\hline 12.907 & $\begin{array}{c}\text { THEMIS - Assesoria Jurídica e Estudos de Gênero, } \\
\text { Católicas pelo Direito de Decidir, Comitê Latino } \\
\text { Americano de Defesa dos Direitos da Mulher - } \\
\text { CLADEM/SP, y por Justiça Global/RJ }\end{array}$ & ONGs internacionais & CADH: $5,7,8.1,11,19,24$ e 25 & $\begin{array}{l}\text { Violência contra mulheres } \\
\text { Violência contra menores }\end{array}$ \\
\hline P-1017-08 & Defensoria Pública do Estado do Rio de Janeiro & $\begin{array}{l}\text { Ombudsman } \\
\text { (ouvidorias) e } \\
\text { Defensorias }\end{array}$ & CADH: $1^{\circ}, 2^{\circ}, 5^{\circ}, 8^{\circ}, 25$. & $\begin{array}{l}\text { Violência institucional contra } \\
\text { privados de liberdade (sistema } \\
\text { prisional e socioeducativo) }\end{array}$ \\
\hline P-28-06 & Ailton Vieira & Indivíduos & Informação não disponível & Crimes do período da ditadura \\
\hline P-15-08 & Amaro Rosa de Barros & Indivíduos & Informação não disponível & Prestação de Justiça \\
\hline P-384-07 & Sr. Antonio Reinaldo Peixoto Pereira & Indivíduos & $\begin{array}{c}\text { CADH: } 24 \text { e } 25 . \\
\text { Protocolo Adicional à Convenção } \\
\text { Americana sobre Direitos Humanos } \\
\text { em Matéria de Direitos Econômicos, } \\
\text { Sociais e Culturais - Pacto San } \\
\text { Salvador - arts. } 6 \text { e } 9 .\end{array}$ & Prestação de Justiça \\
\hline
\end{tabular}




\begin{tabular}{|c|c|c|c|c|}
\hline $\begin{array}{l}\text { Número do } \\
\text { Processo }\end{array}$ & Peticionários & $\begin{array}{l}\text { Peticionários } \\
\text { Classificados }\end{array}$ & Artigos Invocados & Tema das violações \\
\hline P-145-06 & $\begin{array}{l}\text { Organização de Direitos Humanos PROJETO } \\
\text { LEGAL }\end{array}$ & ONGs nacionais & CADH: $4,5,11$ e 25 & Violência policial \\
\hline P-271-09 & $\begin{array}{l}\text { Sergio Constantino Wachelski, Bernardino } \\
\text { Cosobeck da Costa e Martonio Ribeiro Silva }\end{array}$ & Indivíduos & CADH: 4 e 5 & $\begin{array}{c}\text { Violência institucional contra } \\
\text { privados de liberdade (sistema } \\
\text { prisional e socioeducativo)Prestação } \\
\text { de Justiça }\end{array}$ \\
\hline P-221-12 & Cláudio Rogério Rodrigues da Silva & Indivíduos & $\begin{array}{l}\text { Declaração: II, V, XIV, XVII, } \\
\text { XVIII, XXIV, XXVI; } \\
\text { CADH: } 1,5,8,11,14,24,25,\end{array}$ & $\begin{array}{c}\text { Racismo } \\
\text { Prestação de Justiça } \\
\end{array}$ \\
\hline P-607-06 & $\begin{array}{c}\text { Organização de Direitos Humanos PROJETO } \\
\text { LEGAL }\end{array}$ & ONGs nacionais & CADH: 25 & $\begin{array}{c}\text { Violência institucional contra } \\
\text { privados de liberdade (sistema } \\
\text { prisional e socioeducativo) } \\
\text { Tortura } \\
\end{array}$ \\
\hline P-1449-06 & Projeto Legal & ONGs nacionais & CADH: $4,5,11$, e 25 . & $\begin{array}{l}\text { Violência policial } \\
\text { Prestação de Justiça }\end{array}$ \\
\hline$P-1608-07$ & Pai de Débora & Indivíduos & Não foram citados artigos & Prestação de Justiça \\
\hline P-1122-07 & Seccionária de Mato Grosso do Sul da OAB & $\begin{array}{l}\text { Ombudsman } \\
\text { (ouvidorias) e } \\
\text { Defensorias }\end{array}$ & CADH: $4,5,8$ e 25 & Prestação de Justiça \\
\hline P-673-11 & Centro pela Justiça e o Direito Internacional (CEJIL) & ONGs internacionais & $\begin{array}{c}\text { CADH: } 5,7,8,11,13,24 \text { e } 25 \\
\text { Covenção contra a torutra: } 1,2,6 \text { e } 8\end{array}$ & $\begin{array}{l}\text { Racismo } \\
\text { Prestação de Justiça } \\
\text { Tortura }\end{array}$ \\
\hline P-1140-04 & $\begin{array}{c}\text { Sra. Rita de Cássaia da Rosa e Sra. Clélia de } \\
\text { Lourdes Goldenberg, através da representação de } \\
\text { Felipe Néri da Silveira }\end{array}$ & Indivíduos & CADH: 8,25 e 28 & Prestação de Justiça \\
\hline
\end{tabular}




\begin{tabular}{|c|c|c|c|c|}
\hline $\begin{array}{l}\text { Número do } \\
\text { Processo }\end{array}$ & Peticionários & $\begin{array}{l}\text { Peticionários } \\
\text { Classificados }\end{array}$ & Artigos Invocados & Tema das violações \\
\hline P - $1277-07$ & Socrates Spyros Patseas (advogado) & Indivíduos & CADH: $4,5,8,19$ e 25 & $\begin{array}{l}\text { Violência institucional contra } \\
\text { privados de liberdade (sistema } \\
\text { prisional e socioeducativo) }\end{array}$ \\
\hline$P-905-08$ & Roosevelt de Souza Bormann (advogado) & Indivíduos & Informação Não Disponível & $\begin{array}{l}\text { Violência policial } \\
\text { Tortura }\end{array}$ \\
\hline P-1185-08 & $\begin{array}{l}\text { Conectas Direitos Humanos } \\
\text { Sonia Kodaira }\end{array}$ & $\begin{array}{l}\text { Indivíduos } \\
\text { ONGs nacionais }\end{array}$ & CADH: $1.1,4$ e 25 & $\begin{array}{c}\text { Violência policial } \\
\text { Prestação de Justiça } \\
\end{array}$ \\
\hline P-176-08 & Sra. Janaira de Fatima Magalhães & Indivíduos & $\begin{array}{c}\text { Não são citados possíveis artigos } \\
\text { violados }\end{array}$ & Violência contra menores \\
\hline P-1228-08 & Informação não disponível & $\begin{array}{c}\text { Informação não } \\
\text { disponível }\end{array}$ & Informação não disponível & Prestação de Justiça \\
\hline P-1643-07 & Jacqueline Simone de Souza e Silva Ferreira & Indivíduos & CADH: 8 e 25. & Prestação de Justiça \\
\hline P-1178-09 & SOS Direitos Humanos & ONGs nacionais & $\begin{array}{c}\text { CADH: } 5^{\circ}, 7^{\circ}, 8^{\circ}, 11,19 ; \\
\text { Convenção Internacional dos } \\
\text { Direitos da Criança: } 34,36,37 \text { e } 40 \text {; } \\
\text { Convenção de Belém do Pará: } 1^{\circ}, 2^{\circ} \text {, } \\
3^{\circ}, 4^{\circ}, 5^{\circ}, 7^{\circ}, 8^{\circ} \text { e } 10^{\circ} \\
\end{array}$ & $\begin{array}{c}\text { Violência contra mulheres } \\
\text { Violência institucional contra } \\
\text { privados de liberdade (sistema } \\
\text { prisional e socioeducativo) } \\
\text { Violência contra menores } \\
\end{array}$ \\
\hline P-1453-06 & $\begin{array}{c}\text { Organização de Direitos Humanos PROJETO } \\
\text { LEGAL }\end{array}$ & ONGs nacionais & CADH: $4,5,11$ e 25 & Violência policial \\
\hline P-1246-08 & Informação não disponível & $\begin{array}{l}\text { Informação não } \\
\text { disponível }\end{array}$ & Informação não disponível & $\begin{array}{c}\text { Violência institucional contra } \\
\text { privados de liberdade } \\
\text { Tortura }\end{array}$ \\
\hline
\end{tabular}




\begin{tabular}{|c|c|c|c|c|}
\hline $\begin{array}{l}\text { Número do } \\
\text { Processo }\end{array}$ & Peticionários & $\begin{array}{l}\text { Peticionários } \\
\text { Classificados }\end{array}$ & Artigos Invocados & Tema das violações \\
\hline P-32-07 & $\begin{array}{l}\text { Organização de Direitos Humanos PROJETO } \\
\text { LEGAL }\end{array}$ & ONGs nacionais & CADH: 25 & Violência policial \\
\hline P-1247-08 & $\begin{array}{c}\text { Ação dos Cristãos para a Abolição da Tortura } \\
\text { (ACAT-BRASIL) }\end{array}$ & ONGs nacionais & Informação não disponível & $\begin{array}{l}\text { Violência institucional contra } \\
\text { privados de liberdade (sistema } \\
\text { prisional e socioeducativo) } \\
\text { Tortura }\end{array}$ \\
\hline P-1268-09 & Informação não disponível & $\begin{array}{l}\text { Informação não } \\
\text { disponível }\end{array}$ & Informação não disponível & $\begin{array}{l}\text { Violência institucional contra } \\
\text { privados de liberdade (sistema } \\
\text { prisional e socioeducativo) }\end{array}$ \\
\hline P-1344-08 & Sociedade Interamericana de Imprensa (SIP) & ONGs internacionais & CADH: $4,8,13,25$ & $\begin{array}{c}\text { Violência contra defensores de } \\
\text { Direitos Humanos }\end{array}$ \\
\hline 12.753 & $\begin{array}{c}\text { Centro pela Justiça e pelo Direito Internacional } \\
\text { (CEJIL) } \\
\text { Sociedade Paraense de Defesa dos Direitos } \\
\text { Humanos } \\
\text { Comissão Pastoral da Terra (CPT) } \\
\end{array}$ & $\begin{array}{l}\text { ONGs nacionais em } \\
\text { parceria com ONGs } \\
\text { internacionais }\end{array}$ & $\begin{array}{c}\text { CADH: } 4,5,7,8 \text { e } 25 . \text { Convenção } \\
\text { Interamericana para Prevenir e } \\
\text { Erradicar a Tortura: arts. } 1,2,3,4,5, \\
6 \text { e } 8\end{array}$ & $\begin{array}{l}\text { Violência no campo } \\
\text { Prestação de Justiça }\end{array}$ \\
\hline 12.615 & $\begin{array}{l}\text { Defensores Públicos em exercício do Núcleo de } \\
\text { Defesa dos Direitos Humanos (NUDEH) } \\
\text { Coordenadoria de Defesa dos Direitos da Criança e } \\
\text { do Adolescente da Defensoria Pública (CDEDICA) }\end{array}$ & $\begin{array}{l}\text { Ombudsman } \\
\text { (ouvidorias) e } \\
\text { Defensorias }\end{array}$ & $\begin{array}{c}\text { CADH: } 1.1,5,8.1,19 \text { e } 25 ; \\
\text { Convenção Interamericana para } \\
\text { Prevenir e Punir a Tortura: arts. } 6,7 \\
\text { e } 8 .\end{array}$ & $\begin{array}{l}\text { Violência institucional contra } \\
\text { privados de liberdade (sistema } \\
\text { prisional e socioeducativo) } \\
\text { Violência contra menores } \\
\text { Tortura } \\
\end{array}$ \\
\hline 12.727 & $\begin{array}{c}\text { Justiça Global } \\
\text { Movimento dos Trabalhadores Rurais Sem Terra } \\
\text { (MST) } \\
\text { Comissão Pastoral da Terra (CPT) } \\
\text { Centro de Justiça Global e Terra de Direitos }\end{array}$ & ONGs nacionais & CADH: $1.1,4,5,8,15,22$ e 25 . & $\begin{array}{l}\text { Violência no campo } \\
\text { Violência policial } \\
\text { Prestação de Justiça }\end{array}$ \\
\hline
\end{tabular}




\begin{tabular}{|c|c|c|c|c|}
\hline 12.604 & $\begin{array}{l}\text { Nelson Vicente Portela Pellegrino, Helio Pereira } \\
\text { Bicudo e Cláudio Grossman }\end{array}$ & Indivíduos & CADH: $4,8.1,23$ e 25 & Violência policial \\
\hline N.Processo & Peticionários & $\begin{array}{l}\text { Peticionários } \\
\text { Classificados }\end{array}$ & Artigos Invocados & Tema das violações \\
\hline 12.213 & Sociedade Interamericana de Imprensa (SIP) & ONGs internacionais & CADH: $1.1,4,8,13$ e 25 . & $\begin{array}{l}\text { Violência contra defensores de } \\
\text { Direitos Humanos } \\
\text { Prestação de Justiça }\end{array}$ \\
\hline 12.837 & Clélia Lourdes Goldenberg e Rita de Cássia Rosa & Indivíduos & CADH: $1.1,2,8,25$ e 28. & Prestação de Justiça \\
\hline 12.242 & $\begin{array}{c}\text { Projeto Legal } \\
\text { Associação Mães de Cabo Frio }\end{array}$ & ONGs nacionais & CADH: $1.1,4,8,19$ e 25 . & Prestação de Justiça \\
\hline 12.569 & $\begin{array}{c}\text { Centro de Justiça Global } \\
\text { representantes das Comunidades Samucangaua, } \\
\text { Iririzal, Ladeira, Só Assim, Santa Maria, Canelatiua, } \\
\text { Itapera e Mamuninha } \\
\text { Centro de Cultura Negra do Maranhão (CCN) } \\
\text { Associação das Comunidades Negras Rurais } \\
\text { Quilombolas do Maranhão (ACONERUQ) } \\
\text { Federação dos Trabalhadores na Agricultura do } \\
\text { Estado do Maranhão (FETAEMA) } \\
\text { Global Exchange } \\
\end{array}$ & $\begin{array}{c}\text { Indivíduos } \\
\text { ONGs nacionais em } \\
\text { parceria com ONGs } \\
\text { internacionais }\end{array}$ & $\begin{array}{c}\text { Declaração: VI, VIII, XII, XIII, } \\
\text { XIV, XVIII, XXII e XXIII } \\
\text { CADH: } 1.1,2,8,16,17,21,24 \text { e } 25\end{array}$ & $\begin{array}{l}\text { Violência no campo } \\
\text { Prestação de Justiça }\end{array}$ \\
\hline 12.328 & Centro pela Justiça e o Direito Internacional (CEJIL) & ONGs internacionais & $\begin{array}{l}\text { CADH: } 1.1,4,5,7,8,25 \text { e } 19 ; \\
\text { Protocolo de São Salvador: } 13\end{array}$ & $\begin{array}{l}\text { Violência institucional contra } \\
\text { privados de liberdade (sistema } \\
\text { prisional e socioeducativo) } \\
\text { Violência contra menores } \\
\text { Tortura }\end{array}$ \\
\hline 11.702 & Centro pela Justiça e o Direito Internacional (CEJIL) & ONGs internacionais & CADH: $1.1,4,5,7,8,19$ e 25 & $\begin{array}{l}\text { Violência contra menores } \\
\text { Violência institucional contra } \\
\text { privados de liberdade }\end{array}$ \\
\hline
\end{tabular}




\begin{tabular}{|c|c|c|c|c|}
\hline N.Processo & Peticionários & $\begin{array}{l}\text { Peticionários } \\
\text { Classificados }\end{array}$ & Artigos Invocados & Tema das violações \\
\hline 12.569 & $\begin{array}{l}\text { Daniel Gomes dos Santos } \\
\text { Vilmar Soares da Silva }\end{array}$ & Indivíduos & CADH: 8 e 25 & $\begin{array}{l}\text { Violência policial } \\
\text { Prestação de Justiça } \\
\text { Tortura }\end{array}$ \\
\hline 12.428 & $\begin{array}{c}\text { Justiça Global } \\
\text { Movimento } 11 \text { de Dezembro }\end{array}$ & ONGs nacionais & $\begin{array}{l}\text { Declaração: art. XVI } \\
\text { CADH: } 4,5,18,25\end{array}$ & Prestação de Justiça \\
\hline 12.378 & $\begin{array}{c}\text { Justiça Global } \\
\text { THEMIS - Assessoria Jurídica e Estudos de Gênero } \\
\text { Comissão de Cidadania e Direitos Humanos da } \\
\text { Assembléia Legislativa do Rio Grande do Sul } \\
\text { Subcomissão da Criança e do Adolescente da } \\
\text { Assembléia Legislativa do Rio Grande do Sul } \\
\text { Instituto Amigos de Luca }\end{array}$ & $\begin{array}{l}\text { ONGs nacionais } \\
\text { Ombudsman } \\
\text { (ouvidorias) e } \\
\text { Defensorias }\end{array}$ & CADH: $1.1,8,17,19$ e 24 e 25.1 & $\begin{array}{l}\text { Violência contra mulheres } \\
\text { Prestação de Justiça }\end{array}$ \\
\hline $\begin{array}{c}12.857(\mathrm{P}- \\
302-07)\end{array}$ & $\begin{array}{l}\text { Sra. Joana D’Arc Mendes (auxiliada pelo Núcleo de } \\
\text { Defesa de Direitos Humanos da Defensoría Pública } \\
\text { Geral do Estado do RJ - NUDE - RJ) }\end{array}$ & $\begin{array}{l}\text { Indivíduos } \\
\text { Ombudsman } \\
\text { (ouvidorias) e } \\
\text { Defensorias } \\
\end{array}$ & CADH: $4,5,24$ e 25 & Violência policial \\
\hline 12.726 & $\begin{array}{l}\text { Justiça Global } \\
\text { Sociedade Maranhense de Direitos Humanos e pelo } \\
\text { Centro de Justiça Global }\end{array}$ & $\begin{array}{l}\text { ONGs nacionais em } \\
\text { parceria com ONGs } \\
\text { internacionais }\end{array}$ & $\begin{array}{l}\text { Declaração: arts. I e XVIII } \\
\text { CADH: } 4 \text { e } 25\end{array}$ & $\begin{array}{l}\text { Violência no campo } \\
\text { Prestação de Justiça }\end{array}$ \\
\hline 12.675 & $\begin{array}{c}\text { Centro pela Justiça e o Direito Internacional (CEJIL) } \\
\text { Comissão Pastoral da Terra (CPT) }\end{array}$ & $\begin{array}{l}\text { ONGs nacionais em } \\
\text { parceria com ONGs } \\
\text { internacionais }\end{array}$ & $\begin{array}{l}\text { Declaração: arts. I, XVIII e XXII. } \\
\text { CADH:1.1, } 8 \text { e } 25 .\end{array}$ & $\begin{array}{c}\text { Violência no campo } \\
\text { Violência contra defensores de } \\
\text { Direitos Humanos } \\
\text { Prestação de Justiça }\end{array}$ \\
\hline 12.503 & Gerson Miluisk de Carvalho & Indivíduos & $\begin{array}{l}\text { CADH: } .5,8 \text { e } 25 \text { Convenção Contra } \\
\text { a Tortura: } 4.1 \text { e } 2.9\end{array}$ & $\begin{array}{l}\text { Violência policial } \\
\text { Tortura }\end{array}$ \\
\hline 12.838 & Centro pela Justiça e o Direito Internacional (CEJIL) & ONGs internacionais & CADH: $1.1,5,7,8$ e 25 . & Violência policial \\
\hline
\end{tabular}




\begin{tabular}{|c|c|c|c|c|}
\hline $\begin{array}{l}\text { Número do } \\
\text { Processo }\end{array}$ & Peticionários & $\begin{array}{l}\text { Peticionários } \\
\text { Classificados }\end{array}$ & Artigos Invocados & Tema das violações \\
\hline $\begin{array}{c}12.806(P- \\
702-03)\end{array}$ & Sociedade Interamericana de Imprensa (SIP) & ONGs internacionais & CADH: $4,8,13$ e 25 & $\begin{array}{c}\text { Violência contra defensores de } \\
\text { Direitos Humanos }\end{array}$ \\
\hline 12.750 & Fundação Interamericana de Direitos Humanos & ONGs internacionais & CADH: $1,4,5,25$ e 26 & $\begin{array}{l}\text { Violência policial } \\
\text { Prestação de Justiça }\end{array}$ \\
\hline 12.878 & Sr. Fábio Demeneche & Indivíduos & CADH: $1.1,4,5,8.1$ e 25 . & Prestação de Justiça \\
\hline 11.793 & $\begin{array}{l}\text { Antonio Careli } \\
\text { Maria de Almeirda Careli }\end{array}$ & Indivíduos & CADH: $4,5,8,10,11$ e 25 & $\begin{array}{l}\text { Violência policial } \\
\text { Prestação de Justiça }\end{array}$ \\
\hline 12.425 & Justiça Global & ONGs internacionais & & \\
\hline 12.479 & $\begin{array}{c}\text { Associação Conectas Direitos Humanos } \\
\text { Instituto Pro Bono } \\
\text { Conselho Comunitário Penitenciário de Guarujá e } \\
\text { Vicente de Carvalho }\end{array}$ & ONGs nacionais & CADH: $1.1,4,8.1$ e 25 . & $\begin{array}{l}\text { Violência policial } \\
\text { Prestação de Justiça }\end{array}$ \\
\hline 12.746 & $\begin{array}{l}\text { Rogério Nunes de Oliveira e João Paulo de Aguiar } \\
\text { Sampaio Souza }\end{array}$ & Indivíduos & CADH: 2,3 e 6. & $\begin{array}{c}\text { Violência policial } \\
\text { Violência institucional contra } \\
\text { privados de liberdade (sistema } \\
\text { prisional e socioeducativo) } \\
\text { Tortura } \\
\end{array}$ \\
\hline 12.877 & José Laurindo Soares & Indivíduos & CADH: $1.1,2,5,8.1$ e 25 . & Prestação de Justiça \\
\hline 12.707 & DHInternacional & ONGs nacionais & CADH: $1.1,2,4,8,24,25$ & $\begin{array}{l}\text { Violência policial } \\
\text { Prestação de Justiça }\end{array}$ \\
\hline
\end{tabular}




\begin{tabular}{|c|c|c|c|c|}
\hline $\begin{array}{l}\text { Número do } \\
\text { Processo }\end{array}$ & Peticionários & $\begin{array}{l}\text { Peticionários } \\
\text { Classificados }\end{array}$ & Artigos Invocados & Tema das violações \\
\hline 12.859 & Projeto Legal & ONGs nacionais & CADH: $1.1,2,3,4,5,7,8,16$ e 25 . & Violência policial \\
\hline 12.616 & $\begin{array}{c}\text { Conectas Direitos Humanos } \\
\text { Teresa de Jesús Brambilla } \\
\text { Associação de Mães e Amigos de Crianças e } \\
\text { Adolescentes em Risco (AMAR) }\end{array}$ & ONGs nacionais & CADH: $1.1,4,8.1,19$ e 25 & $\begin{array}{l}\text { Violência institucional contra } \\
\text { privados de liberdade (sistema } \\
\text { prisional e socioeducativo) } \\
\text { Violência contra menores }\end{array}$ \\
\hline 12.327 & $\begin{array}{c}\text { Movimento Nacional de Direitos Humanos } \\
\text { Sociedade Paraense de Defesa dos Direitos } \\
\text { Humanos }\end{array}$ & ONGs nacionais & CADH: 5,8 e 25 & $\begin{array}{l}\text { Violência no campo } \\
\text { Prestação de Justiça }\end{array}$ \\
\hline 12.570 & Justiça Global, CPT, Dignitatis & $\begin{array}{l}\text { ONGs nacionais em } \\
\text { parceria com ONGs } \\
\text { internacionais }\end{array}$ & CADH: $4,5,8$ e 25 & Violência no campo \\
\hline 12.263 & $\begin{array}{l}\text { Movimento Nacional de Direitos Humanos (MNDH) } \\
\text { Gabinete de Assessoria Jurídica às Organizações } \\
\text { Governamentais (GAJOP) } \\
\text { Centro pela Justiça e o Direito Internacional (CEJIL) }\end{array}$ & $\begin{array}{l}\text { ONGs nacionais em } \\
\text { parceria com ONGs } \\
\text { internacionais } \\
\text { Ombudsman } \\
\text { (ouvidorias) e } \\
\text { Defensorias } \\
\end{array}$ & $\begin{array}{l}\text { CADH: } 1.1,4,8.1,24 \text { e } 25 \\
\text { Convenção de Belém do Pará: } 7 \text {. }\end{array}$ & $\begin{array}{l}\text { Violência contra mulheres } \\
\text { Prestação de Justiça }\end{array}$ \\
\hline 12.752 & $\begin{array}{l}\text { Centro de Estudos e Defesa da Cidadania, Direitos } \\
\text { Humanos e Segurança Pública (CEDESP) }\end{array}$ & ONGs nacionais & CADH: $1.1,4,5,8.1$ e 25.1 & $\begin{array}{l}\text { Violência policial } \\
\text { Prestação de Justiça }\end{array}$ \\
\hline 12.858 & Sra. Nancy Victor da Silva & Indivíduos & CADH: 4,8 e 25 & $\begin{array}{l}\text { Violência institucional contra } \\
\text { privados de liberdade (sistem } \\
\text { a prisional e socioeducativo) }\end{array}$ \\
\hline
\end{tabular}




\begin{tabular}{|c|c|c|c|c|}
\hline $\begin{array}{l}\text { Número do } \\
\text { Processo }\end{array}$ & Peticionários & $\begin{array}{l}\text { Peticionários } \\
\text { Classificados }\end{array}$ & Artigos Invocados & Tema das violações \\
\hline 12.332 & $\begin{array}{c}\text { Centro pela Justiça e o Direito Internacional (CEJIL) } \\
\text { Movimento Nacional de Direitos Humanos (MNDH) } \\
\text { Gabinete da Assessoria Jurídica às Organizações } \\
\text { Populares (GAJOP) } \\
\text { Comissão Pastoral da Terra (CPT) } \\
\text { Fundação de Defesa dos Direitos Humanos } \\
\text { Margarida Maria Alves (FDDH-MMA) } \\
\end{array}$ & $\begin{array}{l}\text { ONGs nacionais em } \\
\text { parceria com ONGs } \\
\text { internacionais }\end{array}$ & $\begin{array}{l}\text { Declaração: I e XII; } \\
\text { CADH: } 1.1,8 \text { e } 25 \text {. }\end{array}$ & $\begin{array}{l}\text { Violência no campo } \\
\text { Violência contra mulheres } \\
\text { Prestação de Justiça }\end{array}$ \\
\hline 12.835 & Sra. Cecilia Adriana Hernández Norabuena & Indivíduos & $\begin{array}{c}\text { CADH: } 25.2 \text { e } 33 \text {. } \\
\text { Regulamento da Convenção } \\
\text { Americana: artigos } 23 \text { em diante. }\end{array}$ & $\begin{array}{c}\text { Violência policial } \\
\text { Violência institucional contra } \\
\text { privados de liberdade (sistema } \\
\text { prisional e socioeducativo) } \\
\text { Tortura } \\
\end{array}$ \\
\hline 12.970 & Sociedade Interamericana de Imprensa (SIP) & ONGs internacionais & CADH: $4,8,13$ e 25 & $\begin{array}{l}\text { Violência contra defensores de } \\
\text { Direitos Humanos } \\
\text { Prestação de Justiça }\end{array}$ \\
\hline 12.876 & $\begin{array}{l}\text { Instituto Barão de Mauá. Aurélio Alexandre } \\
\text { Esteimber Pereira Okaida, advogado representando } \\
\text { todas as supostas vítimas }\end{array}$ & $\begin{array}{l}\text { Indivíduos } \\
\text { ONGs nacionais }\end{array}$ & CADH: $4,5.1,8,13,21$ e 25 & $\begin{array}{c}\text { Outros } \\
\text { Prestação de Justiça }\end{array}$ \\
\hline 12.751 & Fundação Interamericana de Direitos Humanos & ONGs internacionais & $\begin{array}{c}\text { CADH: } 1.1,4.1,5.1,5.2,7.1,8.2 \mathrm{e} \\
24\end{array}$ & $\begin{array}{l}\text { Violência policial } \\
\text { Prestação de Justiça }\end{array}$ \\
\hline 12.571 & Instituto da Mulher Negra (Geledés) & ONGs nacionais & CADH: $1,8,24$ e 25 . & $\begin{array}{l}\text { Violência contra mulheres } \\
\text { Racismo } \\
\text { Prestação de Justiça }\end{array}$ \\
\hline 11.414 & $\begin{array}{l}\text { Centro de Direitos Humanos da Arquidiocese de São } \\
\text { Paulo }\end{array}$ & ONGs nacionais & $\begin{array}{l}\text { Declaração: XVIII e XIX } \\
\text { CADH: } 8.1 \text { e } 25.1\end{array}$ & $\begin{array}{l}\text { Violência policial urbana } \\
\text { Homicídio }\end{array}$ \\
\hline
\end{tabular}




\begin{tabular}{|c|c|c|c|c|}
\hline N.Processo & Peticionários & $\begin{array}{l}\text { Peticionários } \\
\text { Classificados }\end{array}$ & Artigos Invocados & Tema das violações \\
\hline $\begin{array}{c}12.875 \\
(\mathrm{P}-133007)\end{array}$ & $\begin{array}{l}\text { Rede Social de Justiça } \\
\text { Comissão Pastoral da Terra }\end{array}$ & ONGs nacionais & CADH: $4,5,8,19$ e 25 & Prestação de Justiça \\
\hline 12.836 & Sr. Pedro Stábile Neto & Indivíduos & $\begin{array}{l}\text { Declaração Americana: XI, XIV, } \\
\text { XVIII. CADH: } 1.1,2,8,11 \text { e } 25 .\end{array}$ & Violência no campo \\
\hline 12.654 & $\begin{array}{c}\text { Associação Conectas Direitos Humanos } \\
\text { Instituto Pro Bono } \\
\text { Conselho Comunitário Penitenciário de Guarujá e } \\
\text { Vicente de Carvalho }\end{array}$ & ONGs nacionais & $\begin{array}{c}\text { CADH: 1.1, 4, 5, } 19 \text { e } 25 . \\
\text { Convenção de Belém do Pará: art. } 7 .\end{array}$ & $\begin{array}{c}\text { Violência institucional contra } \\
\text { privados de liberdade (sistema } \\
\text { prisional e socioeducativo) } \\
\text { Tortura } \\
\end{array}$ \\
\hline 12.613 & $\begin{array}{c}\text { Justiça Global } \\
\text { Associação Pela Reforma Prisional (ARP) } \\
\text { Grupo Tortura Nunca Mais do Rio de Janeiro } \\
\text { Associação dos Defensores Públicos do Estado do } \\
\text { Rio de Janeiro (APDERJ) } \\
\text { Laboratório de Análise de Violência da } \\
\text { Universidade do Estado do Rio de Janeiro } \\
\end{array}$ & $\begin{array}{l}\text { ONGs nacionais } \\
\text { Ombudsman } \\
\text { (ouvidorias) e } \\
\text { Defensorias } \\
\text { Universidades }\end{array}$ & CADH:1.1, 2, 5, 8.1 e 25. & $\begin{array}{l}\text { Violência institucional contra } \\
\text { privados de liberdade (sistema } \\
\text { prisional e socioeducativo) }\end{array}$ \\
\hline 12.568 & $\begin{array}{c}\text { Justiça Global } \\
\text { Comissão de Justiça e Paz da Arquidiocese de Porto } \\
\text { Velho }\end{array}$ & $\begin{array}{l}\text { ONGs nacionais em } \\
\text { parceria com ONGs } \\
\text { internacionais }\end{array}$ & CADH: $1.1,2,4,5,8$ e 25.1 & $\begin{array}{l}\text { Violência institucional contra } \\
\text { privados de liberdade (sistema } \\
\text { prisional e socioeducativo) }\end{array}$ \\
\hline 12.728 & $\begin{array}{c}\text { Movimento Nacional de Direitos Humanos/Regional } \\
\text { Nordeste } \\
\text { Gabinete de Assessoria Jurídica às Organizações } \\
\text { Populares (GAJOP) } \\
\text { Conselho Indigenista Missionário (CIMI) }\end{array}$ & ONGs nacionais & CADH: $1.1,2,8,21$ e 25 & $\begin{array}{l}\text { Violência contra Indígenas } \\
\text { Prestação de Justiça }\end{array}$ \\
\hline 12.781 & $\begin{array}{c}\text { Conselho Indígena de Roraima - CIR } \\
\text { Rainforest Foundation US }\end{array}$ & $\begin{array}{l}\text { ONGs nacionais em } \\
\text { parceria com ONGs } \\
\text { internacionais }\end{array}$ & $\begin{array}{l}\text { Declaração: I, II, III, VIII, IX, XVIII } \\
\text { e XXIII; } \\
\begin{array}{c}\text { CADH: } 1.1,2,4,5,8,12,21,22,24 \\
\text { e } 25 .\end{array}\end{array}$ & $\begin{array}{l}\text { Violência contra Indígenas } \\
\text { Prestação de Justiça }\end{array}$ \\
\hline 12.461 & Rafael Lozano & Indivíduos & $\begin{array}{l}\text { O peticionário não indicou qual } \\
\text { direito da Convenção Americana } \\
\text { teria sido violado. }\end{array}$ & Prestação de Justiça \\
\hline
\end{tabular}




\begin{tabular}{|c|c|c|c|c|}
\hline N.Processo & Peticionários & $\begin{array}{l}\text { Peticionários } \\
\text { Classificados }\end{array}$ & Artigos Invocados & Tema das violações \\
\hline 12.778 & Projeto Legal & ONGs nacionais & CADH: $4,5,11$ e 25 & $\begin{array}{l}\text { Violência policial } \\
\text { Prestação de Justiça }\end{array}$ \\
\hline 12.198 & Projeto Legal & ONGs nacionais & CADH: $1,4,8,17,19$ e 25 & $\begin{array}{l}\text { Violência contra menores } \\
\text { Prestação de Justiça }\end{array}$ \\
\hline 12.309 & Sociedade Interamericana de Imprensa (SIP) & ONGs internacionais & CADH: $4,8,13$ e 25 . & $\begin{array}{l}\text { Violência contra jornalista } \\
\text { Impunidade }\end{array}$ \\
\hline 12.783 & $\begin{array}{c}\text { Sra. Raquel Sundermann } \\
\text { Sindicato dos Trabalhadores da Universidade } \\
\text { Federal de São Carlos } \\
\text { Federação dos Sindicatos de Trabalhadores das } \\
\text { Universidades Brasileiras } \\
\end{array}$ & $\begin{array}{l}\text { Indivíduos } \\
\text { Universidades }\end{array}$ & $\begin{array}{l}\text { Regulamento da Convenção } \\
\text { Americana: } 1.1,4 \text { e } 25 \text {. }\end{array}$ & $\begin{array}{l}\text { Violência no campo } \\
\text { Prestação de Justiça }\end{array}$ \\
\hline 12.725 & THEMIS - Assessoria Jurídica e Estudos de Gênero & ONGs nacionais & $\begin{array}{c}\text { Convenção de Belém do Pará: 1, 2, } \\
\text { 3, } 4 \text { e } 7 \\
\text { CADH: } 8.1,19,24,25 \\
\end{array}$ & $\begin{array}{l}\text { Violência contra mulheres } \\
\text { Prestação de Justiça }\end{array}$ \\
\hline 12.782 & Projeto Legal & ONGs nacionais & CADH: Arts. $4,5,11$ e 25 & $\begin{array}{l}\text { Violência policial } \\
\text { Prestação de Justiça }\end{array}$ \\
\hline 12.879 & $\begin{array}{l}\text { CEJIL, Fundação Interamericana de Defesa, Centro } \\
\text { Santo Dias de Direitos Humanos na Arquidiocese de } \\
\text { São Paulo, Grupo Tortura Nunca Mais }\end{array}$ & $\begin{array}{l}\text { ONGs nacionais em } \\
\text { parceria com ONGs } \\
\text { internacionais }\end{array}$ & $\begin{array}{c}\text { Declaração: I, XVIII, XXV, XXVI. } \\
\text { CADH: } 1,2,5,8 \text { e } 25 \text {. Convenção } \\
\text { Interamericana para previnir e punir } \\
\text { a tortura: art. } 1,6 \text { e } 8 .\end{array}$ & $\begin{array}{c}\text { Violência policial } \\
\text { Violência institucional contra } \\
\text { privados de liberdade (sistema } \\
\text { prisional e socioeducativo) } \\
\text { Prestação de Justiça } \\
\text { Crimes do período da ditadura } \\
\text { Tortura } \\
\end{array}$ \\
\hline 12.212 & Sociedade Interamericana de Imprensa (SIP) & ONGs nacionais & CADH: $4,8,13$ e 25 & $\begin{array}{c}\text { Violência contra defensores de DH } \\
\text { Prestação de Justiça }\end{array}$ \\
\hline
\end{tabular}




\begin{tabular}{|c|c|c|c|c|}
\hline N.Processo & Peticionários & $\begin{array}{l}\text { Peticionários } \\
\text { Classificados }\end{array}$ & Artigos Invocados & Tema das violações \\
\hline 11.286 & $\begin{array}{l}\text { Centro Santos Dias de Direitos Humanos da } \\
\text { Arquidiocese de São Paulo }\end{array}$ & ONGs nacionais & $\begin{array}{l}\text { Declaração: I, XVIII e XIX } \\
\text { CADH: } 1.1,8 \text { e } 25\end{array}$ & Violência policial \\
\hline 12.019 & $\begin{array}{c}\text { Centro pela Justiça e o Direito Internacional (CEJIL) } \\
\text { Centro de Defesa e Promoção dos Direitos Humanos } \\
\text { da Arquidiocese de Fortaleza } \\
\text { Centro de Defesa da Vida Herbert de Sousa } \\
\text { Antônio Ferreira Braga }\end{array}$ & $\begin{array}{l}\text { ONGs nacionais em } \\
\text { parceria com ONGs } \\
\text { internacionais }\end{array}$ & $\begin{array}{c}\text { Declaração: I, II, V, IX, XV e } \\
\text { XXIII; } \\
\text { CADH: } 4,5,7 \text { e } 11 . \\
\text { Convenção Interamericana para } \\
\text { Prevenir e Punir a Tortura: } 1 \text { e } 6 .\end{array}$ & $\begin{array}{l}\text { Violência policial } \\
\text { Tortura } \\
\text { Prestação de Justiça }\end{array}$ \\
\hline 11.556 & $\begin{array}{c}\text { Centro pela Justiça e o Direito Internacional (CEJIL) } \\
\text { Centro de Defesa e Promoção dos Direitos Humanos } \\
\text { da Arquidiocese de Porto Velho } \\
\text { Comissão Teotônio Vilela de Direitos Humanos } \\
\text { Movimento dos Trabalhadores Rurais Sem Terra } \\
\text { (MST) } \\
\text { Human Rights Watch/Américas } \\
\end{array}$ & $\begin{array}{l}\text { ONGs nacionais em } \\
\text { parceria com ONGs } \\
\text { internacionais }\end{array}$ & $\begin{array}{c}\text { CADH: } 1.1,4,5,8 \text { e } 25 . \\
\text { Convenção Interamericana para } \\
\text { Prevenir e Punir a Tortura: arts. } 1,6 \\
\text { e } 8 .\end{array}$ & $\begin{array}{l}\text { Violência no campo } \\
\text { Tortura } \\
\text { Prestação de Justiça }\end{array}$ \\
\hline 11.517 & $\begin{array}{c}\text { Centro pela Justiça e o Direito Internacional (CEJIL) } \\
\text { Human Rights Watch/Americas } \\
\end{array}$ & ONGs internacionais & CADH: 4,8 , e 25. & $\begin{array}{l}\text { Violência no campo } \\
\text { Prestação de Justiça }\end{array}$ \\
\hline 11.566 & $\begin{array}{c}\text { Centro pela Justiça e o Direito Internacional (CEJIL) } \\
\text { Human Rights Watch/Americas }\end{array}$ & ONGs internacionais & CADH: 4,8 e 25 & $\begin{array}{l}\text { Violência policial } \\
\text { Violência contra menores } \\
\text { Prestação de Justiça }\end{array}$ \\
\hline 12.066 & $\begin{array}{l}\text { CEJIL } \\
\text { CPT }\end{array}$ & $\begin{array}{l}\text { ONGs nacionais em } \\
\text { parceria com ONGs } \\
\text { internacionais }\end{array}$ & $\begin{array}{l}\text { Declaração Americana: I, XIV e } \\
\text { XXV. CADH:. 6, 8, } 25 .\end{array}$ & $\begin{array}{l}\text { Violência no campo } \\
\text { Trabalho Escravo } \\
\text { Prestação de Justiça }\end{array}$ \\
\hline 11.634 & $\begin{array}{l}\text { Centro pela Justiça e o Direito Internacional (CEJIL) } \\
\text { Centro de Defesa Dom Luciano Mendes da } \\
\text { Associação Beneficiente São Martinho }\end{array}$ & $\begin{array}{l}\text { ONGs nacionais em } \\
\text { parceria com ONGs } \\
\text { internacionais }\end{array}$ & CADH: $4,8,19$ e 25. & $\begin{array}{l}\text { Violência policial } \\
\text { Violência contra menores }\end{array}$ \\
\hline 11.287 & Centro pela Justiça e o Direito Internacional (CEJIL) & ONGs internacionais & CADH: 8 e 25. & Violência no campo \\
\hline
\end{tabular}




\begin{tabular}{|c|c|c|c|c|}
\hline $\begin{array}{l}\text { Número do } \\
\text { Processo }\end{array}$ & Peticionários & $\begin{array}{l}\text { Peticionários } \\
\text { Classificados }\end{array}$ & Artigos Invocados & Tema das violações \\
\hline 11.289 & $\begin{array}{c}\text { Centro pela Justiça e o Direito Internacional (CEJIL) } \\
\text { Human Rights Watch/Americas }\end{array}$ & ONGs internacionais & $\begin{array}{l}\text { Declaração: I, XIV e XXV. } \\
\text { CADH: } 1.1,6,8 \text { e } 25 .\end{array}$ & $\begin{array}{l}\text { Violência no campo } \\
\text { Trabalho Escravo } \\
\text { Prestação de Justiça }\end{array}$ \\
\hline 12.426 & $\begin{array}{c}\text { Centro de Defensa de los Derechos del Niño y del } \\
\text { Adolescente Padre Marcos Passerini y Centro de } \\
\text { Justicia Global (CJG) }\end{array}$ & ONGs nacionais & $\begin{array}{c}\text { Declaração: } 1,6,7 \text { e } 18 . \text { CADH: } 4 \text {, } \\
\text { 8, } 19 \text { e } 25\end{array}$ & $\begin{array}{c}\text { Violência contra menores } \\
\text { Prestação de Justiça }\end{array}$ \\
\hline 12.308 & Sociedade Interamericana de Imprensa (SIP) & ONGs nacionais & CADH: $1.1,4,8,13$ e 25 . & $\begin{array}{l}\text { Violência policial } \\
\text { Prestação de Justiça }\end{array}$ \\
\hline 12.051 & $\begin{array}{l}\text { Centro pela Justiça e o Direito Internacional (CEJIL) } \\
\text { Comitê Latino-Americano de Defesa dos Direitos da } \\
\text { Mulher (CLADEM) }\end{array}$ & ONGs internacionais & $\begin{array}{c}\text { Declaração: arts. II e XVIII } \\
\text { CADH: } 1.1,8,24 \text { e } 25 . \\
\text { Convenção de Belém do Pará: } 7 \text { e } \\
12 . \\
\end{array}$ & $\begin{array}{l}\text { Violência contra mulheres } \\
\text { Prestação de Justiça }\end{array}$ \\
\hline 11.405 & Centro pela Justiça e o Direito Internacional (CEJIL) & ONGs internacionais & CADH: $4,5,8$ e 25 & $\begin{array}{c}\text { Violência policial } \\
\text { Violência contra defensores de } \\
\text { Direitos Humanos }\end{array}$ \\
\hline 11.516 & Centro pela Justiça e o Direito Internacional (CEJIL) & ONGs internacionais & $\begin{array}{l}\text { Declaração: arts. I, XVIII e XXV } \\
\text { CADH: } 1.1,8 \text { e } 25 .\end{array}$ & Violência contra Indígenas \\
\hline 10.301 & Centro pela Justiça e o Direito Internacional (CEJIL) & ONGs internacionais & $\begin{array}{l}\text { Declaração: I e XVIII } \\
\text { CADH: } 1,8 \text { e } 25\end{array}$ & $\begin{array}{l}\text { Violência institucional contra } \\
\text { privados de liberdade (sistema } \\
\text { prisional e socioeducativo) }\end{array}$ \\
\hline 12.310 & $\begin{array}{c}\text { Movimento dos Trabalhadores Rurais Sem Terra } \\
\text { (MST) } \\
\text { Comissão Pastoral da Terra (CPT) } \\
\text { Rede Nacional Autônoma de Advogados e } \\
\text { Advogadas Populares (RENAAP) } \\
\text { Centro de Justiça Global (CJG) } \\
\text { International Human Rights Law Group }\end{array}$ & $\begin{array}{l}\text { ONGs nacionais em } \\
\text { parceria com ONGs } \\
\text { internacionais }\end{array}$ & CADH: $1.1,4,8$ e 25 . & $\begin{array}{l}\text { Violência no campo } \\
\text { Violência policial } \\
\text { Prestação de Justiça }\end{array}$ \\
\hline
\end{tabular}




\begin{tabular}{|c|c|c|c|c|}
\hline N.Processo & Peticionários & $\begin{array}{l}\text { Peticionários } \\
\text { Classificados }\end{array}$ & Artigos Invocados & Tema das violações \\
\hline 12.001 & $\begin{array}{c}\text { Centro pela Justiça e o Direito Internacional (CEJIL) } \\
\text { Subcomissão do Negro da Comissão de Direitos } \\
\text { Humanos da Ordem dos Advogados do Brasil } \\
\text { (OAB/SP) } \\
\text { Instituto do Negro Padre Batista } \\
\end{array}$ & $\begin{array}{l}\text { ONGs nacionais em } \\
\text { parceria com ONGs } \\
\text { internacionais }\end{array}$ & CADH: $1.1,8.1,24$ e 25. & $\begin{array}{l}\text { Racismo } \\
\text { Prestação de Justiça }\end{array}$ \\
\hline 12.440 & $\begin{array}{l}\text { Justiça Global } \\
\text { Núcleo de Estudos Negros }\end{array}$ & ONGs nacionais & CADH: $1.1,4,5,8,24$ e 25. & $\begin{array}{l}\text { Violência policial } \\
\text { Racismo } \\
\text { Prestação de Justiça }\end{array}$ \\
\hline 11.291 & $\begin{array}{l}\text { Americas Watch, CEJIL y la Comisión Teotonio } \\
\text { Vilela }\end{array}$ & $\begin{array}{l}\text { ONGs nacionais em } \\
\text { parceria com ONGs } \\
\text { internacionais }\end{array}$ & CADH: $4,5,8,25$ e 1.1 & $\begin{array}{l}\text { Violência policial } \\
\text { Prestação de Justiça }\end{array}$ \\
\hline 11.598 & $\begin{array}{l}\text { Centro de Defensa y Garantía de los Derechos } \\
\text { Humanos/proyecto legal del Instituto Brasileño de } \\
\text { Innovaciones en Salud Social (I.B.I.S.S.) }\end{array}$ & ONGs nacionais & Declaração: 4 e 18 / CADH: 8, 25, 1 & $\begin{array}{l}\text { Violência policial } \\
\text { Prestação de Justiça }\end{array}$ \\
\hline 11.599 & $\begin{array}{c}\text { Centro de Defensa y Garantía de los Derechos } \\
\text { Humanos/Proyecto Legal del Instituto Brasileño de } \\
\text { Innovaciones en Salud Social (IBISS) }\end{array}$ & ONGs nacionais & CADH: $4,8,19,22$ e 25. & $\begin{array}{l}\text { Violência policial } \\
\text { Prestação de Justiça }\end{array}$ \\
\hline 12.852 & Sr. Alejandro Daniel Esteve & Indivíduos & CADH: $1,8.1,17,19$ e 25 & $\begin{array}{l}\text { Violência contra menores } \\
\text { Prestação de Justiça }\end{array}$ \\
\hline 12.694 & Armand Lerco e Alain Rouland & Indivíduos & CADH: $1.1,5,8,21$ e 25. & $\begin{array}{l}\text { Violência no campo } \\
\text { Prestação de Justiça }\end{array}$ \\
\hline P-11993 & Projeto legal & ONGs nacionais & CADH: $4,5,8,24,25$ e 1 & Violência contra menores \\
\hline 12.567 & $\begin{array}{c}\text { Centro pela Justiça e o Direito Internacional (CEJIL) } \\
\text { Conselho Indígena de Roraima (CIR) } \\
\text { Comissão de Direitos Humanos da Diocese de } \\
\text { Roraima } \\
\text { Conselho Indigenista Missionário (CIMI) } \\
\end{array}$ & $\begin{array}{l}\text { ONGs nacionais em } \\
\text { parceria com ONGs } \\
\text { internacionais }\end{array}$ & $\begin{array}{l}\text { CADH: } 5,21,22,24,8,25 \text { e } 1.1 \\
\text { Protocolo San Salvador: } 13,3 \text { e } 1\end{array}$ & $\begin{array}{l}\text { Violência contra defensores de } \\
\text { Direitos Humanos } \\
\text { Violência contra Indígenas } \\
\text { Prestação de Justiça } \\
\end{array}$ \\
\hline
\end{tabular}




\begin{tabular}{|c|c|c|c|c|}
\hline N.Processo & Peticionários & $\begin{array}{l}\text { Peticionários } \\
\text { Classificados }\end{array}$ & Artigos Invocados & Tema das violações \\
\hline 11.285 & Centro pela Justiça e o Direito Internacional (CEJIL) & ONGs internacionais & $\begin{array}{l}\text { Declaraçãa: I } \\
\text { CADH: } 8 \text { e } 25 .\end{array}$ & Violência policial \\
\hline 11.820 & $\begin{array}{l}\text { Centro pela Justiça e o Direito Internacional (CEJIL) } \\
\text { Movimento dos Trabalhadores sem Terra (MST) }\end{array}$ & $\begin{array}{l}\text { ONGs nacionais em } \\
\text { parceria com ONGs } \\
\text { internacionais }\end{array}$ & CADH: $4,5,8,25,2$ e 1.1 & Violência no campo \\
\hline 12.277 & $\begin{array}{c}\text { Sociedade Paraense de Defesa dos Direitos } \\
\text { Humanos (SDDH), o Centro pela Justiça e o Direito } \\
\text { Internacional (CEJIL), a Comissão Pastoral da Terra } \\
\text { (CPT) e o Movimento Nacional de Direitos } \\
\text { Humanos (MNDH) }\end{array}$ & $\begin{array}{l}\text { ONGs nacionais em } \\
\text { parceria com ONGs } \\
\text { internacionais }\end{array}$ & CADH: $1,4,5,8$ e 25 & $\begin{array}{l}\text { Violência no campo } \\
\text { Prestação de Justiça }\end{array}$ \\
\hline 12673 & \begin{tabular}{|c|} 
Justiça Global \\
CPT/Marabá \\
Terra de Direitos \\
Sindicato dos Trabalhadores de Rondon do Pará \\
\end{tabular} & $\begin{array}{l}\text { ONGs nacionais em } \\
\text { parceria com ONGs } \\
\text { internacionais }\end{array}$ & CADH: $4,5,7,8$ e 25 . & $\begin{array}{l}\text { Violência no campo } \\
\text { Prestação de Justiça }\end{array}$ \\
\hline 12.200 & $\begin{array}{c}\text { Centro pela Justiça e o Direito Internacional (CEJIL) } \\
\text { Comissão Pastoral da Terra }\end{array}$ & $\begin{array}{l}\text { ONGs nacionais em } \\
\text { parceria com ONGs } \\
\text { internacionais }\end{array}$ & $\begin{array}{l}\text { Declaração: I, IX e XVIII; } \\
\text { CADH: } 1.1,8.1 \text { e } 25 \text {. }\end{array}$ & $\begin{array}{l}\text { Violência no campo } \\
\text { Prestação de Justiça }\end{array}$ \\
\hline 12674 & Joss Opie representando a familia da viitima & Indivíduos & $\begin{array}{c}\text { Declaração: I e XVIII; } \\
\text { CADH: } 1.1,8.1 \text { e } 25 \text {; Convenção } \\
\text { Interamericana para Prevenir e Punir } \\
\text { a Tortura: } 1,6,8 \text { e } 9 .\end{array}$ & Tortura \\
\hline 11.290 & Centro pela Justiça e o Direito Internacional (CEJIL) & ONGs internacionais & $\begin{array}{l}\text { Declaração: I } \\
\text { CADH: } 8 \text { e } 25 .\end{array}$ & Violência policial \\
\hline 12.708 & $\begin{array}{c}\text { Augusta Tomázia Inácia } \\
\text { Elcio Pacheco } \\
\text { Dionara Amparo dos Anjos }\end{array}$ & Indivíduos & $\begin{array}{l}\text { Declaração: I e XVIII } \\
\text { CADH:1.1 e } 25\end{array}$ & $\begin{array}{l}\text { Violência policial } \\
\text { Tortura }\end{array}$ \\
\hline P-12008 & Informação não disponível & $\begin{array}{l}\text { Informação não } \\
\text { disponível }\end{array}$ & CADH: $4,5,8,24,25$ e 1 & $\begin{array}{c}\text { Violência policial } \\
\text { Violência contra menore }\end{array}$ \\
\hline
\end{tabular}




\begin{tabular}{|c|c|c|c|c|}
\hline N.Processo & Peticionários & $\begin{array}{l}\text { Peticionários } \\
\text { Classificados }\end{array}$ & Artigos Invocados & Tema das violações \\
\hline 11.994 & Centro pela Justiça e o Direito Internacional (CEJIL) & ONGs internacionais & CADH: $4,5,7,8$ e 25 e 1.1 & $\begin{array}{c}\text { Violência policial } \\
\text { Violência contra menores }\end{array}$ \\
\hline MC-372-02 & $\begin{array}{c}\text { Movimento Nacional de Direitos Humanos/Regional } \\
\text { Nordeste } \\
\text { Gabinete de Assessoria Jurídica às Organizações } \\
\text { Populares (GAJOP) } \\
\text { Conselho Indigenista Missionário (CIMI) } \\
\end{array}$ & ONGs nacionais & $\begin{array}{c}\text { Direito À Vida, À Integridade } \\
\text { Pessoal, À } \\
\text { Propriedade E À Garantia Judicial. }\end{array}$ & $\begin{array}{l}\text { Violência contra defensores de } \\
\text { Direitos Humanos } \\
\text { Violência contra Indígenas }\end{array}$ \\
\hline MC-387-02 & DHInternacional & ONGs internacionais & $\begin{array}{c}\text { Denúncia Sobre Ameaças Sofridas } \\
\text { Por } \\
\text { Mãe De Vítima De Violência } \\
\text { Policial. } \\
\end{array}$ & Violência policial \\
\hline MC-818-04 & $\begin{array}{c}\text { Conselho Indígena de Roraima - CIR } \\
\text { Rainforest Foundation US }\end{array}$ & $\begin{array}{l}\text { ONGs nacionais em } \\
\text { parceria com ONGs } \\
\text { internacionais }\end{array}$ & $\begin{array}{c}\text { Direito À Vida, À Integridade } \\
\text { Pessoal, À } \\
\text { Propriedade E À Garantia Judicial. }\end{array}$ & Violência contra Indígenas \\
\hline MC-14-06 & $\begin{array}{c}\text { Centro de Defesa dos Direitos Humanos da Criança } \\
\text { e do Adolescente - CEDECA/DF }\end{array}$ & ONGs nacionais & $\begin{array}{c}\text { Direito À Vida, À Integridade } \\
\text { Pessoal, À } \\
\text { Proteção Judicial E Direitos Das } \\
\text { Crianças } \\
\text { E Adolescentes. }\end{array}$ & $\begin{array}{l}\text { Violência institucional contra } \\
\text { privados de liberdade (sistema } \\
\text { prisional e socioeducativo) } \\
\text { Violência contra menores }\end{array}$ \\
\hline MC-382-10 & $\begin{array}{c}\text { Movimento Xingu Vivo para Sempre } \\
\text { Coordenação das Organizações Indígenas da } \\
\text { Amazônia Brasileira } \\
\text { Prelazia do Xingu Conselho Indigenista Missionário } \\
\text { Sociedade Paraense de Direitos Humanos } \\
\text { Justiça Global Asociacion Interamericana para la } \\
\text { Defensa del Ambiente }\end{array}$ & $\begin{array}{l}\text { ONGs nacionais em } \\
\text { parceria com ONGs } \\
\text { internacionais }\end{array}$ & $\begin{array}{l}\text { Direito À Vida, À Integridade } \\
\text { Pessoal, À Informação E À } \\
\text { Participação Política. }\end{array}$ & Violência contra Indígenas \\
\hline MC-199-11 & $\begin{array}{c}\text { Pastoral Carcerária de Pernambuco; Serviço } \\
\text { Ecumênico de Militância nas Prisões (SEMPRI); } \\
\text { Pastoral Carcerária Nacional; a Justiça Global e a } \\
\text { Clínica Internacional de Direitos Humanos da } \\
\text { Universidade de Harvard }\end{array}$ & $\begin{array}{l}\text { ONGs nacionais em } \\
\text { parceria com ONGs } \\
\text { internacionais } \\
\text { Universidades } \\
\end{array}$ & $\begin{array}{l}\text { Direito À Vida, À Integridade } \\
\text { Pessoal, À Saúde, À Garantia } \\
\text { Judicial E À Proteção Judicial. }\end{array}$ & $\begin{array}{l}\text { Violência institucional contra } \\
\text { privados de liberdade (sistema } \\
\text { prisional e socioeducativo) }\end{array}$ \\
\hline
\end{tabular}




\begin{tabular}{|c|c|c|c|c|}
\hline N.Processo & Peticionários & $\begin{array}{l}\text { Peticionários } \\
\text { Classificados }\end{array}$ & Artigos Invocados & Tema das violações \\
\hline MC-339-11 & Survival International & ONGs internacionais & $\begin{array}{c}\text { Direito À Vida, À Integridade } \\
\text { Pessoal, À } \\
\text { Propriedade E À Garantia Judicial. }\end{array}$ & Violência contra Indígenas \\
\hline MC-5-12 & $\begin{array}{c}\text { Conselho Indigenista Missionário, Justiça Global, } \\
\text { Food First Information and Action Network, } \\
\text { Comissão Regional de Justiça e Paz de Mato Grosso } \\
\text { do Sul e Comitê Nacional de Defesa dos Povos } \\
\text { Indígenas de Mato Grosso do Sul. }\end{array}$ & $\begin{array}{l}\text { ONGs nacionais em } \\
\text { parceria com ONGs } \\
\text { internacionais }\end{array}$ & $\begin{array}{c}\text { Direito À Vida, À Integridade } \\
\text { Pessoal, À } \\
\text { Propriedade E À Garantia Judicial. }\end{array}$ & Violência contra Indígenas \\
\hline$M C-8-13$ & $\begin{array}{l}\text { AJURIS; AMPRGS; ADPERGS; IBAPE; ITEC; } \\
\text { Themis Assessoria Jurídica e Estudos de Gênero. }\end{array}$ & $\begin{array}{l}\text { ONGs nacionais em } \\
\text { parceria com ONGs } \\
\text { internacionais }\end{array}$ & $\begin{array}{c}\text { Direito À Vida, À Integridade } \\
\text { Pessoal, Ầ Saúde, Proteção Judicial. }\end{array}$ & $\begin{array}{c}\text { Violência institucional contra } \\
\text { privados de liberdade (sistema } \\
\text { prisional e socioeducativo) }\end{array}$ \\
\hline MC-145-13 & $\begin{array}{l}\text { Conselho Indigenista Missionário (CIMI); Survival } \\
\text { International USA. }\end{array}$ & $\begin{array}{l}\text { ONGs nacionais em } \\
\text { parceria com ONGs } \\
\text { internacionais }\end{array}$ & $\begin{array}{c}\text { Direito À Vida, À Integridade } \\
\text { Pessoal, À } \\
\text { Propriedade E À Garantia Judicial. }\end{array}$ & Violência contra Indígenas \\
\hline MC-367-13 & $\begin{array}{l}\text { Sociedade Maranhense de Direitos Humanos } \\
\text { (SMDH) } \\
\text { Ordem dos Advogados do Brasil - Seção Maranhão } \\
\text { (OAB/MA) }\end{array}$ & $\begin{array}{l}\text { ONGs nacionais } \\
\text { Ombudsman } \\
\text { (ouvidorias) e } \\
\text { Defensorias }\end{array}$ & $\begin{array}{l}\text { Direito À Vida, À Integridade } \\
\text { Pessoal, Ầ Saúde, Proteção Judicial. }\end{array}$ & $\begin{array}{l}\text { Violência policial } \\
\text { Violência institucional contra } \\
\text { privados de liberdade (sistema } \\
\text { prisional e socioeducativo) }\end{array}$ \\
\hline MC-363-13 & Lairsson Rodrigues Bueno & Indivíduos & $\begin{array}{l}\text { Direito À Vida, À Integridade } \\
\text { Pessoal E À Proteção Judicial. }\end{array}$ & Violência policial \\
\hline MC-438-13 & $\begin{array}{c}\text { Grupo de Promoção e Proteção } \\
\text { dos Direitos Humanos da Defensoria Pública do } \\
\text { Estado de Roraima }\end{array}$ & $\begin{array}{l}\text { Ombudsman } \\
\text { (ouvidorias) e } \\
\text { Defensorias }\end{array}$ & $\begin{array}{c}\text { Direito À Vida, À Integridade } \\
\text { Pessoal, À Saúde, Proteção Judicial. }\end{array}$ & $\begin{array}{c}\text { Violência institucional contra } \\
\text { privados de liberdade (sistema } \\
\text { prisional e socioeducativo) }\end{array}$ \\
\hline MC-346-08 & $\begin{array}{l}\text { Organização de Direitos Humanos Projeto Legal - } \\
\text { ODHPL }\end{array}$ & ONGs nacionais & $\begin{array}{c}\text { Direito À Vida, À Integridade } \\
\text { Pessoal, Ầ Saúde, Proteção Judicial. }\end{array}$ & $\begin{array}{l}\text { Violência institucional contra } \\
\text { privados de liberdade (sistema } \\
\text { prisional e socioeducativo) } \\
\text { Violência contra menores } \\
\text { Tortura }\end{array}$ \\
\hline
\end{tabular}




\begin{tabular}{|c|c|c|c|c|}
\hline N.Processo & Peticionários & $\begin{array}{l}\text { Peticionários } \\
\text { Classificados }\end{array}$ & Artigos Invocados & Tema das violações \\
\hline MC-95-09 & Sérgio Constantino Wacheleski & Indivíduos & $\begin{array}{c}\text { Direito À Vida, À Integridade } \\
\text { Pessoal E À } \\
\text { Proteção Judicial. }\end{array}$ & Prestação de Justiça \\
\hline MC-114-10 & Não Informado & Não Informado & $\begin{array}{l}\text { Direito À Vida, À Integridade } \\
\text { Pessoal, Ầ Saúde. }\end{array}$ & $\begin{array}{l}\text { Violência institucional contra } \\
\text { privados de liberdade (sistema } \\
\text { prisional e socioeducativo) }\end{array}$ \\
\hline MC 351/02 & Justiça Global & ONGs internacionais & $\begin{array}{c}\text { Direito À Vida, À Integridade } \\
\text { Pessoal E À } \\
\text { Proteção Judicial. }\end{array}$ & $\begin{array}{c}\text { Violência contra defensores de } \\
\text { Direitos Humanos }\end{array}$ \\
\hline MC 224/09 & Não Informado & Não Informado & $\begin{array}{c}\text { Direito À Vida E À Integridade } \\
\text { Pessoal. }\end{array}$ & $\begin{array}{c}\text { Violência institucional contra } \\
\text { privados de liberdade (sistema } \\
\text { prisional e socioeducativo) } \\
\text { Violência contra menores } \\
\text { Tortura } \\
\end{array}$ \\
\hline MC 236/08 & Não Informado & Não Informado & $\begin{array}{c}\text { Direito À Vida, À Integridade } \\
\text { Pessoal, À } \\
\text { Saúde. }\end{array}$ & $\begin{array}{l}\text { Violência institucional contra } \\
\text { privados de liberdade (sistema } \\
\text { prisional e socioeducativo) }\end{array}$ \\
\hline $\begin{array}{l}\text { Informação } \\
\text { não } \\
\text { disponível }\end{array}$ & Não Informado & Não Informado & $\begin{array}{c}\text { Direito À Vida, À Integridade } \\
\text { Pessoal, À } \\
\text { Proteção Judicial E Direitos Das } \\
\text { Crianças } \\
\text { E Adolescentes. }\end{array}$ & $\begin{array}{l}\text { Violência institucional contra } \\
\text { privados de liberdade (sistema } \\
\text { prisional e socioeducativo) }\end{array}$ \\
\hline $\begin{array}{l}\text { Informação } \\
\text { não } \\
\text { disponível }\end{array}$ & Não Informado & Não Informado & $\begin{array}{c}\text { Direito À Vida E À Integridade } \\
\text { Pessoal. }\end{array}$ & $\begin{array}{c}\text { Violência contra defensores de } \\
\text { Direitos Humanos }\end{array}$ \\
\hline MC 130/06 & Não Informado & Não Informado & $\begin{array}{l}\text { Direito À Vida E À Integridade } \\
\text { Pessoal. }\end{array}$ & $\begin{array}{l}\text { Violência policial } \\
\text { Violência institucional contra } \\
\text { privados de liberdade Tortura }\end{array}$ \\
\hline
\end{tabular}




\begin{tabular}{|c|c|c|c|c|}
\hline N.Processo & Peticionários & $\begin{array}{l}\text { Peticionários } \\
\text { Classificados }\end{array}$ & Artigos Invocados & Tema das violações \\
\hline MC 852/04 & Não Informado & Não Informado & $\begin{array}{l}\text { Direito À Vida, À Integridade } \\
\text { Pessoal, Â Saúde. }\end{array}$ & $\begin{array}{l}\text { Violência institucional contra } \\
\text { privados de liberdade } \\
\text { Violência contra menores }\end{array}$ \\
\hline $\begin{array}{l}\text { Informação } \\
\text { não } \\
\text { disponível }\end{array}$ & Não Informado & Não Informado & $\begin{array}{l}\text { Direito À Vida E À Integridade } \\
\text { Pessoal. }\end{array}$ & Violência contra defensores de DH \\
\hline $\begin{array}{l}\text { Informação } \\
\text { não } \\
\text { disponível }\end{array}$ & Não Informado & Não Informado & $\begin{array}{l}\text { Direito À Vida E À Integridade } \\
\text { Pessoal. }\end{array}$ & $\begin{array}{c}\text { Violência contra defensores de } \\
\text { Direitos Humanos }\end{array}$ \\
\hline $\begin{array}{l}\text { Informação } \\
\text { não } \\
\text { disponível }\end{array}$ & Não Informado & Não Informado & $\begin{array}{l}\text { Direito À Vida, Integridade Pessoal, } \\
\text { Às } \\
\text { Garantias Judiciais E À Proteção } \\
\text { Judicial. }\end{array}$ & $\begin{array}{l}\text { Violência institucional contra } \\
\text { privados de liberdade (sistema } \\
\text { prisional e socioeducativo) }\end{array}$ \\
\hline $\begin{array}{l}\text { Informação } \\
\text { não } \\
\text { disponível }\end{array}$ & Não Informado & Não Informado & $\begin{array}{c}\text { Direito À Vida, À Integridade } \\
\text { Pessoal E À } \\
\text { Proteção Judicial. }\end{array}$ & $\begin{array}{c}\text { Violência contra defensores de } \\
\text { Direitos Humanos }\end{array}$ \\
\hline $\begin{array}{l}\text { Informação } \\
\text { não } \\
\text { disponível }\end{array}$ & Não Informado & Não Informado & $\begin{array}{l}\text { Direito À Vida E À Integridade } \\
\text { Pessoal. }\end{array}$ & Outros \\
\hline MC 351/02 & Não Informado & Não Informado & $\begin{array}{l}\text { Direito À Vida, À Integridade } \\
\text { Pessoal E À Proteção Judicial. }\end{array}$ & Outros \\
\hline $\begin{array}{l}\text { Informação } \\
\text { não }\end{array}$ & Não Informado & Não Informado & $\begin{array}{l}\text { Direito À Vida, À Integridade } \\
\text { Pessoal E À Proteção Judicial. }\end{array}$ & Outros \\
\hline
\end{tabular}




\begin{tabular}{|c|c|c|c|c|}
\hline disponível & & & & \\
\hline N. Processo & Peticionários & $\begin{array}{l}\text { Peticionários } \\
\text { Classificados }\end{array}$ & Artigos Invocados & Tema das violações \\
\hline $\begin{array}{l}\text { Informação } \\
\text { não } \\
\text { disponível }\end{array}$ & Não Informado & Não Informado & $\begin{array}{c}\text { Direito À Vida, À Integridade } \\
\text { Pessoal E À } \\
\text { Proteção Judicial. }\end{array}$ & Outros \\
\hline $\begin{array}{l}\text { Informação } \\
\text { não } \\
\text { disponível }\end{array}$ & Não Informado & Não Informado & $\begin{array}{c}\text { Direito À Vida, À Integridade } \\
\text { Pessoal E À } \\
\text { Proteção Judicial. }\end{array}$ & $\begin{array}{c}\text { Violência contra defensores de } \\
\text { Direitos Humanos }\end{array}$ \\
\hline $\begin{array}{l}\text { Informação } \\
\text { não } \\
\text { disponível }\end{array}$ & Não Informado & Não Informado & $\begin{array}{c}\text { Direito À Vida, À Integridade } \\
\text { Pessoal E À } \\
\text { Proteção Judicial. }\end{array}$ & $\begin{array}{c}\text { Violência contra defensores de } \\
\text { Direitos Humanos }\end{array}$ \\
\hline $\begin{array}{l}\text { Informação } \\
\text { não } \\
\text { disponível }\end{array}$ & Não Informado & Não Informado & $\begin{array}{c}\text { Direito À Vida, À Integridade } \\
\text { Pessoal E À } \\
\text { Proteção Judicial. }\end{array}$ & $\begin{array}{c}\text { Violência no campo } \\
\text { Violência contra defensores de } \\
\text { Direitos Humanos }\end{array}$ \\
\hline $\begin{array}{l}\text { Informação } \\
\text { não } \\
\text { disponível }\end{array}$ & Não Informado & Não Informado & $\begin{array}{c}\text { Direito À Vida, Integridade Pessoal, } \\
\text { À } \\
\text { Garantia Judicial E À Proteção } \\
\text { Judicial. }\end{array}$ & $\begin{array}{c}\text { Violência no campo } \\
\text { Violência contra defensores de } \\
\text { Direitos Humanos }\end{array}$ \\
\hline CASO 12.002 & Não Informado & Não Informado & $\begin{array}{c}\text { Direito À Vida, À Integridade } \\
\text { Pessoal E À } \\
\text { Proteção Judicial. }\end{array}$ & $\begin{array}{c}\text { Violência institucional contra } \\
\text { privados de liberdade (sistema } \\
\text { prisional e socioeducativo) }\end{array}$ \\
\hline $\begin{array}{l}\text { Informação } \\
\text { não } \\
\text { disponível }\end{array}$ & Não Informado & Não Informado & $\begin{array}{c}\text { Direito À Vida, À Integridade } \\
\text { Pessoal E À } \\
\text { Proteção Judicial. }\end{array}$ & $\begin{array}{c}\text { Violência contra defensores de } \\
\text { Direitos Humanos }\end{array}$ \\
\hline
\end{tabular}




\begin{tabular}{|c|c|c|c|c|}
\hline N. Processo & Peticionários & $\begin{array}{l}\text { Peticionários } \\
\text { Classificados }\end{array}$ & Artigos Invocados & Tema das violações \\
\hline $\begin{array}{l}\text { Informação } \\
\text { não } \\
\text { disponível }\end{array}$ & Não Informado & Não Informado & $\begin{array}{c}\text { Direito À Vida, À Integridade } \\
\text { Pessoal E À } \\
\text { Proteção Judicial. }\end{array}$ & $\begin{array}{l}\text { Violência contra defensores de } \\
\text { Direitos Humanos }\end{array}$ \\
\hline $\begin{array}{l}\text { Informação } \\
\text { não } \\
\text { disponível }\end{array}$ & Não Informado & Não Informado & $\begin{array}{c}\text { Direito À Vida, À Integridade } \\
\text { Pessoal E À } \\
\text { Proteção Judicial. }\end{array}$ & $\begin{array}{l}\text { Violência institucional contra } \\
\text { privados de liberdade (sistema } \\
\text { prisional e socioeducativo) }\end{array}$ \\
\hline $\begin{array}{l}\text { Informação } \\
\text { não } \\
\text { disponível }\end{array}$ & Não Informado & Não Informado & $\begin{array}{c}\text { Direito À Vida, À Integridade } \\
\text { Pessoal E À } \\
\text { Proteção Judicial. }\end{array}$ & $\begin{array}{l}\text { Violência contra defensores de } \\
\text { Direitos Humanos }\end{array}$ \\
\hline $\begin{array}{l}\text { Informação } \\
\text { não } \\
\text { disponível }\end{array}$ & $\begin{array}{c}\text { Centro de Defesa de Direitos Humanos da Serra do } \\
\text { estado do Espírito } \\
\text { Santo y Justiça Global }\end{array}$ & $\begin{array}{l}\text { ONGs nacionais em } \\
\text { parceria com ONGs } \\
\text { internacionais }\end{array}$ & $\begin{array}{l}\text { Direito À Vida E À Integridade } \\
\text { Pessoal. }\end{array}$ & $\begin{array}{c}\text { Violência institucional contra } \\
\text { privados de liberdade (sistema } \\
\text { prisional e socioeducativo) } \\
\text { Violência contra menores } \\
\text { Tortura } \\
\end{array}$ \\
\hline $\begin{array}{l}\text { Informação } \\
\text { não } \\
\text { disponível }\end{array}$ & $\begin{array}{c}\text { Centro por la } \\
\text { Justicia y el Derecho Internacional, } \\
\text { Grupo Tortura Nunca Más e Comisión de } \\
\text { Familiares de Muertos y Desaparecidos Políticos }\end{array}$ & $\begin{array}{l}\text { ONGs nacionais em } \\
\text { parceria com ONGs } \\
\text { internacionais }\end{array}$ & $\begin{array}{c}\text { Direito À Vida, À Integridade } \\
\text { Pessoal, À } \\
\text { Liberdade, Ao Trabalho E A Uma } \\
\text { Justa } \\
\text { Remuneração, Às Garantias } \\
\text { Judiciais E À } \\
\text { Proteção Judicial. }\end{array}$ & Crimes do período da ditadura \\
\hline $\begin{array}{l}\text { Informação } \\
\text { não } \\
\text { disponível }\end{array}$ & $\begin{array}{c}\text { Fundação Interamericana de Defesa dos Direitos } \\
\text { Humanos, Justiça Global, Movimento Nacional de } \\
\text { Direitos Humanos, Pastoral Carcerária, Ação dos } \\
\text { Cristãos para Abolição da Torura e Grupo Tortura } \\
\text { Nunca Mais }\end{array}$ & $\begin{array}{l}\text { ONGs nacionais em } \\
\text { parceria com ONGs } \\
\text { internacionais }\end{array}$ & $\begin{array}{c}\text { Direito À Vida E À Integridade } \\
\text { Pessoal. }\end{array}$ & $\begin{array}{l}\text { Violência institucional contra } \\
\text { privados de liberdade (sistema } \\
\text { prisional e socioeducativo) }\end{array}$ \\
\hline
\end{tabular}




\begin{tabular}{|c|c|c|c|c|}
\hline N. & Peticionários & $\begin{array}{l}\text { Peticionários } \\
\text { Classificados }\end{array}$ & Artigos Invocados & Tema das violações \\
\hline $\begin{array}{l}\text { Informação } \\
\text { não } \\
\text { disponível }\end{array}$ & Não Informado & Não Informado & $\begin{array}{c}\text { Direito À Vida, Integridade Pessoal, } \\
\text { Às } \\
\text { Garantias Judiciais E À Proteção } \\
\text { Judicial. }\end{array}$ & $\begin{array}{l}\text { Violência institucional contra } \\
\text { privados de liberdade (sistema } \\
\text { prisional e socioeducativo) }\end{array}$ \\
\hline $\begin{array}{l}\text { Informação } \\
\text { não } \\
\text { disponível }\end{array}$ & $\begin{array}{l}\text { Sociedade Maranhense de Direitos Humanos } \\
\text { (SMDH) } \\
\text { Ordem dos Advogados do Brasil - Seção Maranhão } \\
\text { (OAB/MA) }\end{array}$ & $\begin{array}{l}\text { ONGs nacionais } \\
\text { Ombudsman } \\
\text { (ouvidorias) e } \\
\text { Defensorias }\end{array}$ & $\begin{array}{c}\text { Direito À Vida, Integridade Pessoal, } \\
\text { Às } \\
\text { Garantias Judiciais E À Proteção } \\
\text { Judicial. }\end{array}$ & $\begin{array}{l}\text { Violência institucional contra } \\
\text { privados de liberdade (sistema } \\
\text { prisional e socioeducativo) }\end{array}$ \\
\hline $\begin{array}{l}\text { Informação } \\
\text { não } \\
\text { disponível }\end{array}$ & \begin{tabular}{|c|} 
Grupo Tortura Nunca Más de Río de Janeiro; \\
Comisión de Familiares de Muertos y Desaparecidos \\
Políticos del Instituto de Estudios de la Violencia del \\
Estado; Centro por la Justicia y el Derecho \\
Internacional (CEJIL) \\
\end{tabular} & $\begin{array}{l}\text { ONGs nacionais em } \\
\text { parceria com ONGs } \\
\text { internacionais }\end{array}$ & CADH: $1,2,3,5,7,8,9,13$ e 25 & Crimes do período da ditadura \\
\hline $\begin{array}{l}\text { Informação } \\
\text { não } \\
\text { disponível }\end{array}$ & $\begin{array}{c}\text { Comissão Pastoral da Terra (CPT); Justiça Global } \\
\text { Movimento dos Trabalhadores Rurais Sem Terra; } \\
\text { Rede Nacional de Advogados e Advogadas } \\
\text { Populares Terra de Direitos }\end{array}$ & ONGs nacionais & CADH: $1,2,8,11,16$ e 25 & $\begin{array}{l}\text { Violência no campo } \\
\text { Prestação de Justiça }\end{array}$ \\
\hline $\begin{array}{l}\text { Informação } \\
\text { não } \\
\text { disponível }\end{array}$ & Centro por la Justicia Global & ONGs internacionais & CADH: $1,4,5,8$ e 25 & $\begin{array}{l}\text { Prestação de Justiça } \\
\text { Tortura }\end{array}$ \\
\hline $\begin{array}{l}\text { Informação } \\
\text { não } \\
\text { disponível }\end{array}$ & $\begin{array}{c}\text { Rede Nacional de Advogados Autonomos Populares } \\
\text { (RENAAP) y Centro de Justiça } \\
\text { Global (CJG) }\end{array}$ & $\begin{array}{l}\text { ONGs nacionais em } \\
\text { parceria com ONGs } \\
\text { internacionais }\end{array}$ & CADH: $1,2,8,11,16,25$ e 28 & $\begin{array}{l}\text { Violência policial } \\
\text { Prestação de Justiça }\end{array}$ \\
\hline $\begin{array}{l}\text { Informação } \\
\text { não } \\
\text { disponível }\end{array}$ & $\begin{array}{l}\text { Centro de Derechos Humanos y Memoria Popular } \\
\text { (CDHMP), Holocaust Human Rights Project y el } \\
\text { Group of International Human Rights Law Students }\end{array}$ & $\begin{array}{l}\text { ONGs nacionais em } \\
\text { parceria com ONGs } \\
\text { internacionais } \\
\text { Universidades }\end{array}$ & CADH: $1,4,8$ e 25 & Prestação de Justiça \\
\hline
\end{tabular}




\begin{tabular}{|c|c|c|c|c|}
\hline $\begin{array}{l}\text { Número do } \\
\text { Processo }\end{array}$ & Peticionários & $\begin{array}{l}\text { Peticionários } \\
\text { Classificados }\end{array}$ & Artigos Invocados & Tema das violações \\
\hline P-1170-09 & Informação não disponível & $\begin{array}{c}\text { Informação não } \\
\text { disponível }\end{array}$ & Informação não disponível & Informação não disponível \\
\hline P-23-10 & Informação não disponível & $\begin{array}{l}\text { Informação não } \\
\text { disponível }\end{array}$ & Informação não disponível & Informação não disponível \\
\hline P-1349-09 & Informação não disponível & $\begin{array}{c}\text { Informação não } \\
\text { disponível }\end{array}$ & Informação não disponível & Informação não disponível \\
\hline P-1056-20 & Informação não disponível & $\begin{array}{l}\text { Informação não } \\
\text { disponível }\end{array}$ & Informação não disponível & Informação não disponível \\
\hline P-187-09 & Informação não disponível & $\begin{array}{c}\text { Informação não } \\
\text { disponível }\end{array}$ & Informação não disponível & Informação não disponível \\
\hline P-690-11 & Informação não disponível & $\begin{array}{c}\text { Informação não } \\
\text { disponível }\end{array}$ & Informação não disponível & Informação não disponível \\
\hline P-60-09 & Informação não disponível & $\begin{array}{c}\text { Informação não } \\
\text { disponível }\end{array}$ & Informação não disponível & Informação não disponível \\
\hline P-1204-10 & Informação não disponível & $\begin{array}{c}\text { Informação não } \\
\text { disponível }\end{array}$ & Informação não disponível & Informação não disponível \\
\hline P-1222-09 & Informação não disponível & $\begin{array}{c}\text { Informação não } \\
\text { disponível }\end{array}$ & Informação não disponível & Informação não disponível \\
\hline
\end{tabular}




\begin{tabular}{|c|c|c|c|c|}
\hline $\begin{array}{l}\text { Número do } \\
\text { Processo }\end{array}$ & Peticionários & $\begin{array}{l}\text { Peticionários } \\
\text { Classificados }\end{array}$ & Artigos Invocados & Tema das violações \\
\hline P-1085-11 & Informação não disponível & $\begin{array}{l}\text { Informação não } \\
\text { disponível }\end{array}$ & Informação não disponível & Informação não disponível \\
\hline P-1411-07 & Informação não disponível & $\begin{array}{c}\text { Informação não } \\
\text { disponível }\end{array}$ & Informação não disponível & Informação não disponível \\
\hline P-1174-09 & Informação não disponível & $\begin{array}{c}\text { Informação não } \\
\text { disponível }\end{array}$ & Informação não disponível & Informação não disponível \\
\hline P-362-09 & Informação não disponível & $\begin{array}{c}\text { Informação não } \\
\text { disponível }\end{array}$ & Informação não disponível & Informação não disponível \\
\hline P-858-09 & Informação não disponível & $\begin{array}{l}\text { Informação não } \\
\text { disponível }\end{array}$ & Informação não disponível & Informação não disponível \\
\hline P-90-09 & Informação não disponível & $\begin{array}{c}\text { Informação não } \\
\text { disponível }\end{array}$ & Informação não disponível & Informação não disponível \\
\hline P-974-09 & Informação não disponível & $\begin{array}{c}\text { Informação não } \\
\text { disponível }\end{array}$ & Informação não disponível & Informação não disponível \\
\hline P-1116-07 & Informação não disponível & $\begin{array}{c}\text { Informação não } \\
\text { disponível }\end{array}$ & Informação não disponível & Informação não disponível \\
\hline P-81-13 & Informação não disponível & $\begin{array}{l}\text { Informação não } \\
\text { disponível }\end{array}$ & Informação não disponível & Informação não disponível \\
\hline
\end{tabular}




\begin{tabular}{|c|c|c|c|c|}
\hline $\begin{array}{l}\text { Número do } \\
\text { Processo }\end{array}$ & Peticionários & $\begin{array}{l}\text { Peticionários } \\
\text { Classificados }\end{array}$ & Artigos Invocados & Tema das violações \\
\hline & Informação não disponível & $\begin{array}{c}\text { Informação não } \\
\text { disponível }\end{array}$ & Informação não disponível & Informação não disponível \\
\hline 12.398 & Informação não disponível & $\begin{array}{c}\text { Informação não } \\
\text { disponível }\end{array}$ & Informação não disponível & Informação não disponível \\
\hline MC-233-05 & Informação não disponível & $\begin{array}{l}\text { Informação não } \\
\text { disponível }\end{array}$ & Informação não disponível & Informação não disponível \\
\hline MC-250-06 & Informação não disponível & $\begin{array}{l}\text { Informação não } \\
\text { disponível }\end{array}$ & Informação não disponível & Informação não disponível \\
\hline MC-314-14 & Informação não disponível & $\begin{array}{l}\text { Informação não } \\
\text { disponível }\end{array}$ & Informação não disponível & Informação não disponível \\
\hline MC-1038-04 & Informação não disponível & $\begin{array}{l}\text { Informação não } \\
\text { disponível }\end{array}$ & Informação não disponível & Informação não disponível \\
\hline MC-251-10 & Informação não disponível & $\begin{array}{c}\text { Informação não } \\
\text { disponível }\end{array}$ & Informação não disponível & Informação não disponível \\
\hline MC-366-14 & Informação não disponível & $\begin{array}{l}\text { Informação não } \\
\text { disponível }\end{array}$ & Informação não disponível & Informação não disponível \\
\hline
\end{tabular}




\section{Apêndice C - Tabela consolidada com os Resultados Específicos}

\begin{tabular}{|c|c|}
\hline Região & Nordeste \\
\hline UF & BA \\
\hline N. Processo & 12.308 \\
\hline Órgão & Comissão \\
\hline Fase & Cumprimento de Recomendações \\
\hline $\begin{array}{l}\text { Tipos de } \\
\text { decisão }\end{array}$ & Recomendações da CmDH \\
\hline Nome do Caso & Manoel Leal de Oliveira \\
\hline $\begin{array}{c}\text { Data de Início } \\
\text { do Trâmite } \\
\text { nNome do } \\
\text { Casoa CmDH }\end{array}$ & $22 / 05 / 2000$ \\
\hline $\begin{array}{l}\text { Data da } \\
\text { Alegada } \\
\text { Violação }\end{array}$ & $14 / 01 / 1998$ \\
\hline $\begin{array}{c}\text { Data do } \\
\text { veredito da } \\
\text { CmDH }\end{array}$ & $17 / 03 / 2010$ \\
\hline $\begin{array}{l}\text { Data de envio à } \\
\text { CrDH }\end{array}$ & Não se aplica \\
\hline $\begin{array}{c}\text { Data da } \\
\text { sentença da } \\
\text { CORTE }\end{array}$ & Não se aplica \\
\hline $\begin{array}{l}\text { Número dos } \\
\text { Informes }\end{array}$ & N. $37 / 10$ E N. $72 / 06$ \\
\hline Peticionários & Sociedade Interamericana de Imprensa (SIP) \\
\hline $\begin{array}{l}\text { Peticionários } \\
\text { classificados }\end{array}$ & ONGs nacionais \\
\hline $\begin{array}{l}\text { Artigos } \\
\text { Invocados }\end{array}$ & CADH: $1.1,4,8,13$ e 25 . \\
\hline $\begin{array}{l}\text { Resumo dos } \\
\text { fatos }\end{array}$ & $\begin{array}{c}\text { Denúncia sobre assassinato de jornalista após publicação de escândalo de corrupção no jornal de } \\
\text { que era editor }\end{array}$ \\
\hline
\end{tabular}




\begin{tabular}{|c|c|c|c|c|c|}
\hline $\begin{array}{l}\text { Tema das } \\
\text { violações }\end{array}$ & \multicolumn{5}{|c|}{$\begin{array}{l}\text { Violência policial } \\
\text { Prestação de Justiça }\end{array}$} \\
\hline $\begin{array}{l}\text { Resoluções, } \\
\text { recom. MP e } \\
\text { MC }\end{array}$ & $\begin{array}{l}\text { 1. Reconozca } \\
\text { públicamente } \\
\text { su } \\
\text { responsabilidad } \\
\text { internacional } \\
\text { por las } \\
\text { violaciones de } \\
\text { los derechos } \\
\text { humanos } \\
\text { determinadas } \\
\text { por la CIDH en } \\
\text { este informe. }\end{array}$ & $\begin{array}{l}\text { 2. Realice una } \\
\text { investigación } \\
\text { completa, } \\
\text { imparcial y } \\
\text { efectiva de los } \\
\text { hechos, de forma } \\
\text { de determinar y } \\
\text { sancionar a todos } \\
\text { los autores } \\
\text { materiales e } \\
\text { intelectuales del } \\
\text { asesinato de } \\
\text { Manoel Leal de } \\
\text { Oliveira. }\end{array}$ & $\begin{array}{l}\text { 3. Realice una } \\
\text { investigación } \\
\text { completa, } \\
\text { imparcial y } \\
\text { efectiva de las } \\
\text { irregularidades } \\
\text { ocurridas a lo } \\
\text { largo de la } \\
\text { investigación } \\
\text { policial del } \\
\text { homicidio de } \\
\text { Manoel Leal de } \\
\text { Oliveira, } \\
\text { incluidos los } \\
\text { actos que } \\
\text { procuraron } \\
\text { dificultar la } \\
\text { identificación de } \\
\text { sus autores } \\
\text { materiales e } \\
\text { intelectuales. }\end{array}$ & $\begin{array}{l}\text { 4. Indemnice a la } \\
\text { familia de Manoel } \\
\text { Leal de Oliveira } \\
\text { por los daños } \\
\text { sufridos. Dicha } \\
\text { indemnización } \\
\text { debe ser calculada } \\
\text { conforme a los } \\
\text { parámetros } \\
\text { internacionales y } \\
\text { debe ser por un } \\
\text { monto suficiente } \\
\text { para resarcir, tanto } \\
\text { los daños } \\
\text { materiales, como } \\
\text { los daños morales } \\
\text { sufridos por los } \\
\text { familiares de la } \\
\text { víctima. }\end{array}$ & $\begin{array}{l}\text { 5. Adopte, de } \\
\text { forma prioritaria, } \\
\text { una política global } \\
\text { de protección del } \\
\text { trabajo de los } \\
\text { periodistas y } \\
\text { centralice, como } \\
\text { política pública, el } \\
\text { combate a la } \\
\text { impunidad en } \\
\text { relación con el } \\
\text { asesinato, la } \\
\text { agresión y la } \\
\text { amenaza a } \\
\text { periodistas, a } \\
\text { través de } \\
\text { investigaciones } \\
\text { exhaustivas e } \\
\text { independientes de } \\
\text { tales hechos, y } \\
\text { sancione a sus } \\
\text { autores materiales } \\
\text { e intelectuales. }\end{array}$ \\
\hline $\begin{array}{l}\text { Tipos das } \\
\text { resoluções e } \\
\text { recom. }\end{array}$ & $\begin{array}{l}\text { Reparação } \\
\text { simbólica }\end{array}$ & $\begin{array}{l}\text { Investigação e } \\
\text { sanção sem } \\
\text { reforma legal }\end{array}$ & $\begin{array}{c}\text { Investigação e } \\
\text { sanção sem } \\
\text { reforma legal }\end{array}$ & $\begin{array}{c}\text { Reparação } \\
\text { econômica } \\
\text { monetária }\end{array}$ & $\begin{array}{c}\text { Prevenção por } \\
\text { meio da } \\
\text { conscientização da } \\
\text { população }\end{array}$ \\
\hline $\begin{array}{l}\text { Objetos das as } \\
\text { resoluções e } \\
\text { recomendações }\end{array}$ & $\begin{array}{c}\text { Recompensação } \\
\text { de pessoas ou } \\
\text { grupos }\end{array}$ & $\begin{array}{c}\text { Investigação e } \\
\text { responsabilização } \\
\text { de violações de } \\
\text { direitos humanos }\end{array}$ & $\begin{array}{c}\text { Investigação e } \\
\text { responsabilização } \\
\text { de violações de } \\
\text { direitos humanos }\end{array}$ & $\begin{array}{c}\text { Recompensação } \\
\text { de pessoas ou } \\
\text { grupos }\end{array}$ & $\begin{array}{c}\text { Prevenção de } \\
\text { futuras violações } \\
\text { de direitos }\end{array}$ \\
\hline Compliance & $\begin{array}{l}\text { Cumpriu } \\
\text { totalmente }\end{array}$ & Não cumpriu & Não cumpriu & $\begin{array}{l}\text { Cumpriu } \\
\text { totalmente }\end{array}$ & $\begin{array}{c}\text { Cumpriu } \\
\text { parcialmente }\end{array}$ \\
\hline $\begin{array}{c}\text { Data de } \\
\text { quando corte } \\
\text { informou que } \\
\text { cumpriu }\end{array}$ & $06 / 06 / 2012$ & $07 / 05 / 2015$ & $07 / 05 / 2015$ & $06 / 06 / 2012$ & $17 / 10 / 2014$ \\
\hline
\end{tabular}

\begin{tabular}{|c|c|}
\hline Região & Sul \\
\hline UF & PR \\
\hline N. Processo & 12.310 \\
\hline Órgão & Comissão \\
\hline Fase & Cumprimento de Recomendações \\
\hline Tipos de decisão & Recomendações da CmDH \\
\hline
\end{tabular}




\begin{tabular}{|c|c|c|c|c|c|}
\hline Nome do Caso & \multicolumn{5}{|c|}{ Sebastião Camargo Filho } \\
\hline $\begin{array}{l}\text { Data de Início } \\
\text { do Trâmite } \\
\text { nome do Casoa } \\
\text { CmDH }\end{array}$ & \multicolumn{5}{|c|}{$30 / 06 / 2000$} \\
\hline $\begin{array}{l}\text { Data da Alegada } \\
\text { Violação }\end{array}$ & \multicolumn{5}{|c|}{ 07/02/1998 } \\
\hline $\begin{array}{l}\text { Data do veredito } \\
\text { da CmDH }\end{array}$ & \multicolumn{5}{|c|}{$19 / 03 / 2009$} \\
\hline $\begin{array}{c}\text { Data de envio à } \\
\text { CrDH }\end{array}$ & \multicolumn{5}{|c|}{ Não se aplica } \\
\hline $\begin{array}{l}\text { Data da } \\
\text { sentença da } \\
\text { CORTE }\end{array}$ & \multicolumn{5}{|c|}{ Não se aplica } \\
\hline $\begin{array}{l}\text { Número dos } \\
\text { Informes }\end{array}$ & \multicolumn{5}{|c|}{ N. $33 / 08 \mathrm{E} \mathrm{N}^{\circ} 25 / 09$} \\
\hline Peticionários & \multicolumn{5}{|c|}{$\begin{array}{l}\text { Movimento dos Trabalhadores Rurais Sem Terra (MST)Comissão Pastoral da Terra (CPT)Rede } \\
\text { Nacional Autônoma de Advogados e Advogadas Populares (RENAAP)Centro de Justiça Global } \\
\text { (CJG) International Human Rights Law Group }\end{array}$} \\
\hline $\begin{array}{l}\text { Peticionários } \\
\text { classificados }\end{array}$ & \multicolumn{5}{|c|}{ ONGs nacionais em parceria com ONGs internacionais } \\
\hline $\begin{array}{c}\text { Artigos } \\
\text { Invocados }\end{array}$ & \multicolumn{5}{|c|}{ CADH: $1.1,4,8$ e 25 . } \\
\hline $\begin{array}{l}\text { Resumo dos } \\
\text { fatos }\end{array}$ & \multicolumn{5}{|c|}{$\begin{array}{l}\text { Denúncia sobre assassinato de membro do movimento dos trabalhadores rurais sem terra no } \\
\text { Paraná sem investigação e indenização }\end{array}$} \\
\hline $\begin{array}{l}\text { Tema das } \\
\text { violações }\end{array}$ & \multicolumn{5}{|c|}{$\begin{array}{l}\text { Violência no campo } \\
\text { Violência policial } \\
\text { Prestação de Justiça }\end{array}$} \\
\hline $\begin{array}{l}\text { Resoluções, } \\
\text { recom. MP e } \\
\text { MC }\end{array}$ & $\begin{array}{l}\text { 1. Realización de } \\
\text { una investigación } \\
\text { completa, } \\
\text { imparcial y } \\
\text { efectiva de los } \\
\text { hechos, con el } \\
\text { objeto de } \\
\text { establecer y } \\
\text { sancionar la } \\
\text { responsabilidad } \\
\text { material e } \\
\text { intelectual del } \\
\text { asesinato de } \\
\text { Sebastião } \\
\text { Camargo Filho }\end{array}$ & $\begin{array}{c}\text { 2. Plena } \\
\text { reparación a los } \\
\text { familiares de } \\
\text { Sebastião } \\
\text { Camargo Filho, } \\
\text { incluyendo } \\
\text { tanto el aspecto } \\
\text { moral como el } \\
\text { material, por las } \\
\text { violaciones de } \\
\text { derechos } \\
\text { humanos } \\
\text { determinadas } \\
\text { en el informe }\end{array}$ & $\begin{array}{l}\text { 3. Adopción } \\
\text { con carácter } \\
\text { prioritario de } \\
\text { una política } \\
\text { global de } \\
\text { erradicación de } \\
\text { la violencia } \\
\text { rural, que } \\
\text { contemple } \\
\text { medidas de } \\
\text { prevención y } \\
\text { protección de } \\
\text { comunidades } \\
\text { en riesgo y el } \\
\text { fortalecimiento } \\
\text { de las medidas } \\
\text { de protección } \\
\text { destinadas a } \\
\text { líderes de } \\
\text { movimientos } \\
\text { que trabajan } \\
\text { por la } \\
\text { distribución } \\
\text { equitativa de la } \\
\text { propiedad rural }\end{array}$ & $\begin{array}{l}\text { 4. Adopción de } \\
\text { medidas } \\
\text { efectivas } \\
\text { destinadas a } \\
\text { desmantelar los } \\
\text { grupos armados } \\
\text { ilegales que } \\
\text { actúan en los } \\
\text { conflictos } \\
\text { relacionados con } \\
\text { la distribución de } \\
\text { la tierra }\end{array}$ & $\begin{array}{l}\text { 5. Adopción de una } \\
\text { política pública de } \\
\text { lucha contra la } \\
\text { impunidad de las } \\
\text { violaciones a los } \\
\text { derechos humanos } \\
\text { de las personas } \\
\text { involucradas en } \\
\text { conflictos agrarios y } \\
\text { que luchan por una } \\
\text { distribución } \\
\text { equitativa de la } \\
\text { tierra }\end{array}$ \\
\hline
\end{tabular}




\begin{tabular}{|c|c|c|c|c|c|}
\hline $\begin{array}{c}\text { Tipos das } \\
\text { resoluções e } \\
\text { recom. }\end{array}$ & $\begin{array}{c}\text { Investigação e } \\
\text { sanção sem } \\
\text { reforma legal }\end{array}$ & $\begin{array}{c}\text { Reparação } \\
\text { econômica } \\
\text { monetária }\end{array}$ & $\begin{array}{c}\text { Prevenção por } \\
\text { meio do } \\
\text { fortalecimento, } \\
\text { criação, ou } \\
\text { reforma de } \\
\text { instituições } \\
\text { públicas }\end{array}$ & $\begin{array}{c}\text { Investigação e } \\
\text { sanção sem } \\
\text { reforma legal }\end{array}$ & $\begin{array}{c}\text { Prevenção sem } \\
\text { especificar medidas }\end{array}$ \\
\hline $\begin{array}{c}\text { Objetos das as } \\
\text { resoluções e } \\
\text { recomendações }\end{array}$ & $\begin{array}{c}\text { Investigação e } \\
\text { responsabilização } \\
\text { de violações de } \\
\text { direitos humanos }\end{array}$ & $\begin{array}{c}\text { Recompensação } \\
\text { de pessoas ou } \\
\text { grupos }\end{array}$ & $\begin{array}{c}\text { Prevenção de } \\
\text { futuras } \\
\text { violações de } \\
\text { direitos }\end{array}$ & $\begin{array}{c}\text { Investigação e } \\
\text { responsabilização } \\
\text { de violações de } \\
\text { direitos humanos }\end{array}$ & $\begin{array}{c}\text { Prevenção de } \\
\text { futuras violações de } \\
\text { direitos }\end{array}$ \\
\hline $\begin{array}{c}\text { Cumpriu } \\
\text { Compliance }\end{array}$ & Naro cumpriu & $\begin{array}{c}\text { Cumpriu } \\
\text { parcialmente }\end{array}$ & Não cumpriu & Não cumpriu \\
\hline $\begin{array}{c}\text { Data de quando } \\
\text { corte informou } \\
\text { que cumpriu }\end{array}$ & $07 / 05 / 2015$ & $07 / 05 / 2015$ & $07 / 05 / 2015$ & $07 / 05 / 2015$ & $07 / 05 / 2015$ \\
\hline
\end{tabular}

\begin{tabular}{|c|c|}
\hline Região & Sudeste \\
\hline UF & RJ \\
\hline N. Processo & 12.440 \\
\hline Órgão & Comissão \\
\hline Fase & Cumprimento de Recomendações \\
\hline Tipos de decisão & Recomendações da $\mathrm{CmDH}$ \\
\hline \multicolumn{2}{|r|}{ Wallace de Almeida } \\
\hline \multicolumn{2}{|l|}{$\begin{array}{c}\text { Data de Início do } \\
\text { Trâmite nNome do } \\
\text { Casoa CmDH }\end{array}$} \\
\hline $\begin{array}{l}\text { Data da Alegada } \\
\text { Violação }\end{array}$ & $14 / 09 / 1998$ \\
\hline $\begin{array}{c}\text { Data do veredito da } \\
\mathrm{CmDH}\end{array}$ & $20 / 03 / 2009$ \\
\hline $\begin{array}{c}\text { Data de envio à } \\
\text { CrDH }\end{array}$ & Não se aplica \\
\hline $\begin{array}{c}\text { Data da sentença da } \\
\text { CORTE }\end{array}$ & Não se aplica \\
\hline $\begin{array}{l}\text { Número dos } \\
\text { Informes }\end{array}$ & N. 34/08 E N. 26/09 \\
\hline \multicolumn{2}{|r|}{ Justiça GlobalNúcleo de Estudos Negros } \\
\hline $\begin{array}{l}\text { Peticionários } \\
\text { classificados }\end{array}$ & ONGs nacionais \\
\hline Artigos Invocados & CADH: $1.1,4,5,8,24$ e 25 . \\
\hline
\end{tabular}




\begin{tabular}{|c|c|c|c|c|}
\hline Resumo dos fatos & \multicolumn{4}{|c|}{$\begin{array}{c}\text { Denúncia sobre assassinato da vítima em razão de abuso em operação policial, inclusive com } \\
\text { indícios de discriminação racial }\end{array}$} \\
\hline & \multicolumn{4}{|c|}{$\begin{array}{c}\text { Violência policial } \\
\text { Racismo } \\
\text { Prestação de Justiça }\end{array}$} \\
\hline $\begin{array}{l}\text { Resoluções, recom. } \\
\text { MP e MC }\end{array}$ & $\begin{array}{l}\text { 1. Realización de una } \\
\text { investigación completa, } \\
\text { imparcial y efectiva de } \\
\text { los hechos, por órganos } \\
\text { judiciales } \\
\text { independientes del } \\
\text { fuero policial } \\
\text { civil/militar, con el } \\
\text { objeto de establecer y } \\
\text { sancionar la } \\
\text { responsabilidad } \\
\text { respecto a los hechos } \\
\text { relacionados con el } \\
\text { asesinato de Wallace de } \\
\text { Almeida, y los } \\
\text { impedimentos que } \\
\text { vedaron se lleve a cabo } \\
\text { tanto una investigación } \\
\text { como un juzgamiento } \\
\text { efectivo }\end{array}$ & $\begin{array}{l}\text { 2. Plena } \\
\text { reparación a los } \\
\text { familiares de } \\
\text { Wallace de } \\
\text { Almeida, } \\
\text { incluyendo } \\
\text { tanto el aspecto } \\
\text { moral como el } \\
\text { material, por las } \\
\text { violaciones de } \\
\text { derechos } \\
\text { humanos } \\
\text { determinadas } \\
\text { en el presente } \\
\text { informe }\end{array}$ & $\begin{array}{l}\text { 3. Adopción e } \\
\text { instrumentalización } \\
\text { de las medidas } \\
\text { necesarias para una } \\
\text { efectiva } \\
\text { implementación } \\
\text { del artículo } 10 \text { del } \\
\text { Código Procesal } \\
\text { Penal Brasileño }\end{array}$ & $\begin{array}{l}\text { 4. Adopción e } \\
\text { instrumentalización de } \\
\text { medidas adecuadas } \\
\text { dirigidas a los } \\
\text { funcionarios de justicia y } \\
\text { de la policía, a fin de } \\
\text { evitar acciones que } \\
\text { impliquen discriminación } \\
\text { racial en los operativos } \\
\text { policiales, en las } \\
\text { investigaciones, en el } \\
\text { proceso o en la condena } \\
\text { penal }\end{array}$ \\
\hline $\begin{array}{l}\text { Tipos das } \\
\text { resoluções e recom. }\end{array}$ & $\begin{array}{l}\text { Investigação e sanção } \\
\text { com reforma legal }\end{array}$ & $\begin{array}{l}\text { Reparação } \\
\text { econômica } \\
\text { monetária }\end{array}$ & $\begin{array}{l}\text { Prevenção por } \\
\text { meio de reformas } \\
\text { jurídicas }\end{array}$ & $\begin{array}{l}\text { Prevenção por meio da } \\
\text { formação de agentes } \\
\text { públicos }\end{array}$ \\
\hline $\begin{array}{l}\text { Objetos das as } \\
\text { resoluções e } \\
\text { recomendações }\end{array}$ & $\begin{array}{l}\text { Investigação e } \\
\text { responsabilização de } \\
\text { violações de direitos } \\
\text { humanos }\end{array}$ & $\begin{array}{l}\text { Recompensação } \\
\text { de pessoas ou } \\
\text { grupos }\end{array}$ & $\begin{array}{l}\text { Prevenção de } \\
\text { futuras violações } \\
\text { de direitos }\end{array}$ & $\begin{array}{l}\text { Prevenção de futuras } \\
\text { violações de direitos }\end{array}$ \\
\hline Compliance & Não cumpriu & $\begin{array}{c}\text { Cumpriu } \\
\text { parcialmente }\end{array}$ & Não cumpriu & Não cumpriu \\
\hline $\begin{array}{l}\text { Data de quando } \\
\text { corte informou que } \\
\text { cumpriu }\end{array}$ & $07 / 05 / 2015$ & $07 / 05 / 2015$ & $07 / 05 / 2015$ & $07 / 05 / 2015$ \\
\hline
\end{tabular}

\begin{tabular}{|c|c|}
\hline Região & Nordeste \\
\hline UF & CE \\
\hline N. Processo & 12.019 \\
\hline Órgão & Comissão \\
\hline Fase & Cumprimento de Recomendações \\
\hline Tipos de decisão & Recomendações da CmDH \\
\hline
\end{tabular}




\begin{tabular}{|c|c|}
\hline Nome do Caso & Antônio Ferreira Braga \\
\hline $\begin{array}{l}\text { Data de Início do } \\
\text { Trâmite nNome do } \\
\text { Casoa CmDH }\end{array}$ & 11/06/1998 \\
\hline $\begin{array}{l}\text { Data da Alegada } \\
\text { Violação }\end{array}$ & $11 / 03 / 1993$ \\
\hline $\begin{array}{c}\text { Data do veredito da } \\
\text { CmDH }\end{array}$ & $18 / 07 / 2008$ \\
\hline $\begin{array}{c}\text { Data de envio à } \\
\text { CrDH }\end{array}$ & Não se aplica \\
\hline $\begin{array}{l}\text { Data da sentença } \\
\text { da CORTE }\end{array}$ & Não se aplica \\
\hline $\begin{array}{l}\text { Número dos } \\
\text { Informes }\end{array}$ & N. $84 / 07$ E N. $35 / 08$ \\
\hline Peticionários & $\begin{array}{c}\text { Centro pela Justiça e o Direito Internacional (CEJIL)Centro de Defesa e Promoção dos } \\
\text { Direitos Humanos da Arquidiocese de FortalezaCentro de Defesa da Vida Herbert de } \\
\text { SousaAntônio Ferreira Braga }\end{array}$ \\
\hline $\begin{array}{l}\text { Peticionários } \\
\text { classificados }\end{array}$ & ONGs nacionais em parceria com ONGs internacionais \\
\hline Artigos Invocados & $\begin{array}{c}\text { Declaração: I, II, V, IX, XV e XXIII; } \\
\text { CADH: 4, 5, 7 e 11. } \\
\text { Convenção Interamericana para Prevenir e Punir a Tortura: } 1 \text { e } 6 .\end{array}$ \\
\hline Resumo dos fatos & Denúncia sobre detenção ilegalmente feita pela polícia civil, inclusive com tortura da vítima \\
\hline Tema das violações & $\begin{array}{l}\text { Violência policial } \\
\text { Tortura } \\
\text { Prestação de Justiça }\end{array}$ \\
\hline
\end{tabular}




\begin{tabular}{|c|c|c|c|c|}
\hline $\begin{array}{c}\text { Resoluções, recom. } \\
\text { MP e MC }\end{array}$ & $\begin{array}{l}\text { 1. En relación con la } \\
\text { adopción de las } \\
\text { medidas necesarias a } \\
\text { fin de que se dé } \\
\text { efecto legal a la } \\
\text { obligación de } \\
\text { investigar y sancionar } \\
\text { efectivamente a los } \\
\text { autores de la } \\
\text { detención ilegal y las } \\
\text { torturas infligidas a } \\
\text { Antônio Ferreira } \\
\text { Braga, y evitar que la } \\
\text { prescripción se } \\
\text { invoque con respecto } \\
\text { a delitos como la } \\
\text { tortura }\end{array}$ & $\begin{array}{l}\text { 2. En relación con } \\
\text { la investigación } \\
\text { civil y } \\
\text { administrativa de } \\
\text { las autoridades que } \\
\text { podrían haber } \\
\text { actuado de manera } \\
\text { negligente, } \\
\text { resultando en un } \\
\text { retraso irrazonable } \\
\text { del proceso penal } \\
\text { referente a este caso }\end{array}$ & $\begin{array}{l}\text { 3. En relación con } \\
\text { la reparación } \\
\text { adecuada para } \\
\text { Antônio Ferreira } \\
\text { Braga }\end{array}$ & $\begin{array}{l}\text { 4. En relación con la } \\
\text { capacitación de los } \\
\text { oficiales de la policía } \\
\text { civil sobre derechos } \\
\text { fundamentales, } \\
\text { especialmente en lo } \\
\text { que se refiere al trato } \\
\text { humano y la } \\
\text { prohibición de la } \\
\text { tortura }\end{array}$ \\
\hline $\begin{array}{c}\text { Tipos das resoluções } \\
\text { e recom. }\end{array}$ & $\begin{array}{c}\text { Investigação e } \\
\text { sanção com reforma } \\
\text { legal }\end{array}$ & $\begin{array}{c}\text { Investigação e } \\
\text { sanção sem reforma } \\
\text { legal }\end{array}$ & $\begin{array}{l}\text { Reparação } \\
\text { econômica } \\
\text { monetária }\end{array}$ & $\begin{array}{l}\text { Prevenção por meio da } \\
\text { formação de agentes } \\
\text { públicos }\end{array}$ \\
\hline $\begin{array}{l}\text { Objetos das as } \\
\text { resoluções e } \\
\text { recomendações }\end{array}$ & $\begin{array}{c}\text { Investigação e } \\
\text { responsabilização de } \\
\text { violações de direitos } \\
\text { humanos }\end{array}$ & $\begin{array}{c}\text { Investigação e } \\
\text { responsabilização } \\
\text { de violações de } \\
\text { direitos humanos }\end{array}$ & $\begin{array}{l}\text { Recompensação de } \\
\text { pessoas ou grupos }\end{array}$ & $\begin{array}{l}\text { Prevenção de futuras } \\
\text { violações de direitos }\end{array}$ \\
\hline Compliance & Não cumpriu & Não cumpriu & Não cumpriu & Não cumpriu \\
\hline $\begin{array}{c}\text { Data de quando } \\
\text { corte informou que } \\
\text { cumpriu }\end{array}$ & $07 / 05 / 2015$ & $07 / 05 / 2015$ & $07 / 05 / 2015$ & 07/05/2015 \\
\hline
\end{tabular}

\begin{tabular}{|c|c|}
\hline Região & Sudeste \\
\hline UF & SP \\
\hline Órgão & 12.001 \\
\hline Fase & Comissão \\
\hline Tipos de decisão & Cumprimento de Recomendações \\
\hline Nome do Caso & Simone André Diniz \\
\hline $\begin{array}{c}\text { Data de Início do } \\
\text { Câmite nNome do } \\
\text { Casoa CmDH }\end{array}$ & $0710 / 1997$ \\
\hline $\begin{array}{c}\text { Data da Alegada } \\
\text { Violação }\end{array}$ & \\
\hline $\begin{array}{c}\text { Data do veredito da } \\
\text { CmDH }\end{array}$ & $02 / 03 / 1997$ \\
\hline $\begin{array}{c}\text { Data de envio à } \\
\text { CrDH }\end{array}$ & $21 / 10 / 2006$ \\
\hline
\end{tabular}




\begin{tabular}{|c|c|c|c|c|c|c|}
\hline $\begin{array}{c}\text { Data da sentença da } \\
\text { CORTE }\end{array}$ & \multicolumn{6}{|c|}{ Não se aplica } \\
\hline $\begin{array}{l}\text { Número dos } \\
\text { Informes }\end{array}$ & \multicolumn{6}{|c|}{ N. 83/04 E N. 66/06 } \\
\hline Peticionários & \multicolumn{6}{|c|}{$\begin{array}{c}\text { Centro pela Justiça e o Direito Internacional (CEJIL)Subcomissão do Negro da Comissão de } \\
\text { Direitos Humanos da Ordem dos Advogados do Brasil (OAB/SP)Instituto do Negro Padre } \\
\text { Batista }\end{array}$} \\
\hline $\begin{array}{l}\text { Peticionários } \\
\text { classificados }\end{array}$ & \multicolumn{6}{|c|}{ ONGs nacionais em parceria com ONGs internacionais } \\
\hline Artigos Invocados & \multicolumn{6}{|c|}{ CADH: $1.1,8.1,24$ e 25 . } \\
\hline Resumo dos fatos & \multicolumn{6}{|c|}{$\begin{array}{c}\text { Denúncia Sobre Discriminação Racial Sofrida Por Empregada Doméstica Que Não Foi } \\
\text { Contratada Por Ser Negra }\end{array}$} \\
\hline Tema das violações & \multicolumn{6}{|c|}{$\begin{array}{c}\text { Racismo } \\
\text { Prestação de Justiça }\end{array}$} \\
\hline $\begin{array}{c}\text { Resoluções, recom. } \\
\text { MP e MC }\end{array}$ & $\begin{array}{l}\text { 1.Reparar } \\
\text { plenament } \\
\text { e a la } \\
\text { víctima } \\
\text { Simone } \\
\text { André } \\
\text { Diniz, } \\
\text { consideran } \\
\text { do tanto el } \\
\text { aspecto } \\
\text { moral } \\
\text { como el } \\
\text { aspecto } \\
\text { material, } \\
\text { por las } \\
\text { violaciones } \\
\text { de los } \\
\text { derechos } \\
\text { humanos } \\
\text { determinad } \\
\text { as en el } \\
\text { informe de } \\
\text { méritos, en } \\
\text { especial }\end{array}$ & $\begin{array}{l}2 . \text { Recono } \\
\text { cer } \\
\text { públicame } \\
\text { nte la } \\
\text { responsab } \\
\text { ilidad } \\
\text { internacio } \\
\text { nal por la } \\
\text { violación } \\
\text { de los } \\
\text { derechos } \\
\text { humanos } \\
\text { de } \\
\text { Simone } \\
\text { André } \\
\text { Diniz }\end{array}$ & $\begin{array}{l}\text { 3.Conceder } \\
\text { apoyo } \\
\text { financiero a la } \\
\text { víctima para } \\
\text { que pueda } \\
\text { iniciar y } \\
\text { concluir un } \\
\text { curso superior }\end{array}$ & $\begin{array}{l}\text { 4.Establecer } \\
\text { un valor } \\
\text { pecuniario } \\
\text { que se pagará } \\
\text { a la víctima a } \\
\text { título de } \\
\text { indemnizació } \\
\text { n por daños } \\
\text { morales }\end{array}$ & $\begin{array}{l}\text { 5.Realizar las } \\
\text { modificacion } \\
\text { es } \\
\text { legislativas y } \\
\text { administrativ } \\
\text { as necesarias } \\
\text { para que la } \\
\text { legislación } \\
\text { contra el } \\
\text { racismo sea } \\
\text { efectiva, con } \\
\text { el fin de } \\
\text { sanear los } \\
\text { obstáculos } \\
\text { demostrados } \\
\text { en los } \\
\text { párrafos } 78 \text { y } \\
94 \text { del } \\
\text { presente } \\
\text { informe }\end{array}$ & $\begin{array}{l}\text { 6.Realizar una } \\
\text { investigación } \\
\text { completa, } \\
\text { imparcial e } \\
\text { efectiva de los } \\
\text { hechos, con el } \\
\text { objetivo de } \\
\text { establecer y } \\
\text { sancionar la } \\
\text { responsabilidad } \\
\text { respecto de los } \\
\text { hechos } \\
\text { relacionados } \\
\text { con la } \\
\text { discriminación } \\
\text { racial sufrida } \\
\text { por Simone } \\
\text { André Diniz }\end{array}$ \\
\hline $\begin{array}{c}\text { Tipos das resoluções } \\
\text { e recom. }\end{array}$ & $\begin{array}{l}\text { Reparação } \\
\text { econômica } \\
\text { monetária }\end{array}$ & $\begin{array}{l}\text { Reparaçã } \\
\text { o } \\
\text { simbólica }\end{array}$ & $\begin{array}{l}\text { Reparação } \\
\text { econômica } \\
\text { monetária }\end{array}$ & $\begin{array}{l}\text { Reparação } \\
\text { econômica } \\
\text { monetária }\end{array}$ & $\begin{array}{l}\text { Prevenção } \\
\text { por meio de } \\
\text { reformas } \\
\text { jurídicas }\end{array}$ & $\begin{array}{l}\text { Investigação e } \\
\text { sanção com } \\
\text { reforma legal }\end{array}$ \\
\hline
\end{tabular}




\begin{tabular}{|c|c|c|c|c|c|c|}
\hline $\begin{array}{c}\text { Objetos das as } \\
\text { resoluções e } \\
\text { recomendações }\end{array}$ & $\begin{array}{c}\text { Recompen } \\
\text { sação de } \\
\text { pessoas ou } \\
\text { grupos }\end{array}$ & $\begin{array}{c}\text { Recompe } \\
\text { nsação de } \\
\text { pessoas } \\
\text { ou grupos }\end{array}$ & $\begin{array}{c}\text { Recompensaç } \\
\text { ão de pessoas } \\
\text { ou grupos }\end{array}$ & $\begin{array}{c}\text { Recompensaç } \\
\text { ão de pessoas } \\
\text { ou grupos }\end{array}$ & $\begin{array}{c}\text { Prevenção de } \\
\text { futuras } \\
\text { violações de } \\
\text { direitos }\end{array}$ & $\begin{array}{c}\text { Investigação e } \\
\text { responsabilizaç } \\
\text { ão de violações } \\
\text { de direitos } \\
\text { humanos }\end{array}$ \\
\hline $\begin{array}{c}\text { Cumpriu } \\
\text { totalmente }\end{array}$ & $\begin{array}{c}\text { Cumpriu } \\
\text { totalment } \\
\text { e }\end{array}$ & Não cumpriu & $\begin{array}{c}\text { Cumpriu } \\
\text { totalmente }\end{array}$ & $\begin{array}{c}\text { Cumpriu } \\
\text { parcialmente }\end{array}$ & Não cumpriu \\
$\begin{array}{c}\text { Data de quando } \\
\text { corte informou que } \\
\text { cumpriu }\end{array}$ & $08 / 06 / 2010$ & $\begin{array}{c}08 / 06 / 201 \\
0\end{array}$ & $07 / 05 / 2015$ & $08 / 06 / 2010$ & $06 / 06 / 2013$ & $07 / 05 / 2015$ \\
\end{tabular}

\begin{tabular}{|c|c|}
\hline Região & Norte \\
\hline $\mathbf{U F}$ & RO \\
\hline N. Processo & 11.556 \\
\hline Órgão & Comissão \\
\hline Fase & Cumprimento de Recomendações \\
\hline Tipos de decisão & Recomendações da CmDH \\
\hline Nome do Caso & Massacre de Corumbiara \\
\hline $\begin{array}{l}\text { Data de Início do } \\
\text { Trâmite nNome do } \\
\text { Casoa CmDH }\end{array}$ & 06/10/1995 \\
\hline $\begin{array}{l}\text { Data da Alegada } \\
\text { Violação }\end{array}$ & 15/07/1995 \\
\hline $\begin{array}{c}\text { Data do veredito da } \\
\text { CmDH }\end{array}$ & $11 / 03 / 2004$ \\
\hline $\begin{array}{c}\text { Data de envio à } \\
\text { CrDH }\end{array}$ & Não se aplica \\
\hline $\begin{array}{l}\text { Data da sentença da } \\
\text { CORTE }\end{array}$ & Não se aplica \\
\hline $\begin{array}{l}\text { Número dos } \\
\text { Informes }\end{array}$ & N. 22/03 E N. 32/04 \\
\hline Peticionários & $\begin{array}{c}\text { Centro pela Justiça e o Direito Internacional (CEJIL)Centro de Defesa e Promoção dos } \\
\text { Direitos Humanos da Arquidiocese de Porto VelhoComissão Teotônio Vilela de Direitos } \\
\text { HumanosMovimento dos Trabalhadores Rurais Sem Terra (MST)Human Rights } \\
\text { Watch/Américas }\end{array}$ \\
\hline
\end{tabular}




\begin{tabular}{|c|c|c|c|c|}
\hline $\begin{array}{l}\text { Peticionários } \\
\text { classificados }\end{array}$ & \multicolumn{4}{|c|}{ ONGs nacionais em parceria com ONGs internacionais } \\
\hline Artigos Invocados & \multicolumn{4}{|c|}{$\begin{array}{l}\text { CADH: } 1.1,4,5,8 \text { e } 25 . \\
\text { Convenção Interamericana para Prevenir e Punir a Tortura: arts. } 1,6 \text { e } 8 .\end{array}$} \\
\hline Resumo dos fatos & \multicolumn{4}{|c|}{$\begin{array}{c}\text { Denúncia sobre mortes de trabalhadores rurais em ação da polícia para reintegração de posse } \\
\text { de terreno }\end{array}$} \\
\hline Tema das violações & \multicolumn{4}{|c|}{$\begin{array}{l}\text { Violência no campo } \\
\text { Tortura } \\
\text { Prestação de Justiça }\end{array}$} \\
\hline $\begin{array}{l}\text { Resoluções, recom. } \\
\text { MP e MC }\end{array}$ & $\begin{array}{l}\text { 1.Realizar una } \\
\text { investigación } \\
\text { completa, imparcial } \\
\text { y efectiva de los } \\
\text { hechos por órganos } \\
\text { que no sean } \\
\text { militares, que } \\
\text { determine y } \\
\text { sancione la } \\
\text { responsabilidad de } \\
\text { todos los autores } \\
\text { materiales e } \\
\text { intelectuales, tanto } \\
\text { militares como } \\
\text { civiles, respecto a } \\
\text { las muertes, } \\
\text { lesiones personales } \\
\text { y demás hechos } \\
\text { ocurridos en la } \\
\text { hacienda Santa } \\
\text { Elina el } 9 \text { de agosto } \\
\text { de } 1995\end{array}$ & $\begin{array}{l}\text { 2.Reparar } \\
\text { adecuadamente } \\
\text { a las víctimas } \\
\text { especificadas en } \\
\text { este informe, o a } \\
\text { sus familiares, } \\
\text { de ser el caso, } \\
\text { por las } \\
\text { violaciones de } \\
\text { derechos } \\
\text { humanos } \\
\text { determinadas en } \\
\text { el presente } \\
\text { informe }\end{array}$ & $\begin{array}{l}\text { 3.Adoptar las } \\
\text { medidas } \\
\text { necesarias para } \\
\text { tratar de evitar } \\
\text { que se produzcan } \\
\text { hechos similares } \\
\text { en el futuro. }\end{array}$ & $\begin{array}{l}\text { 4.Modificar el artículo } 9 \text { del } \\
\text { Código Penal Militar, el } \\
\text { artículo } 82 \text { del Código de } \\
\text { Procedimiento Penal Militar y } \\
\text { cualquier otra norma interna } \\
\text { que requiera modificarse a los } \\
\text { efectos de abolir la } \\
\text { competencia de la policía } \\
\text { militar para investigar } \\
\text { violaciones a derechos } \\
\text { humanos cometidas por } \\
\text { policías militares, y transferir } \\
\text { dicha competencia a la policía } \\
\text { civil }\end{array}$ \\
\hline $\begin{array}{l}\text { Tipos das resoluções } \\
\text { e recom. }\end{array}$ & $\begin{array}{l}\text { Investigação e } \\
\text { sanção sem } \\
\text { reforma legal }\end{array}$ & $\begin{array}{l}\text { Reparação } \\
\text { econômica } \\
\text { monetária }\end{array}$ & $\begin{array}{l}\text { Prevenção sem } \\
\text { especificar } \\
\text { medidas }\end{array}$ & $\begin{array}{l}\text { Prevenção por meio de } \\
\text { reformas jurídicas }\end{array}$ \\
\hline $\begin{array}{l}\text { Objetos das as } \\
\text { resoluções e } \\
\text { recomendações }\end{array}$ & $\begin{array}{l}\text { Investigação e } \\
\text { responsabilização } \\
\text { de violações de } \\
\text { direitos humanos }\end{array}$ & $\begin{array}{c}\text { Recompensação } \\
\text { de pessoas ou } \\
\text { grupos }\end{array}$ & $\begin{array}{c}\text { Prevenção de } \\
\text { futuras violações } \\
\text { de direitos }\end{array}$ & $\begin{array}{l}\text { Prevenção de futuras } \\
\text { violações de direitos }\end{array}$ \\
\hline Compliance & $\begin{array}{l}\text { Cumpriu } \\
\text { totalmente }\end{array}$ & Não cumpriu & $\begin{array}{c}\text { Cumpriu } \\
\text { parcialmente }\end{array}$ & Não cumpriu \\
\hline $\begin{array}{c}\text { Data de quando } \\
\text { corte informou que } \\
\text { cumpriu }\end{array}$ & $07 / 03 / 2011$ & $07 / 05 / 2015$ & $07 / 03 / 2011$ & $07 / 05 / 2015$ \\
\hline
\end{tabular}




\begin{tabular}{|c|c|}
\hline Região & Sudeste \\
\hline UF & RJ \\
\hline N. Processo & 11.634 \\
\hline Órgão & Comissão \\
\hline Fase & Cumprimento de Recomendações \\
\hline Tipos de decisão & Recomendações da CmDH \\
\hline Nome do Caso & Jaílton Néri da Fonseca \\
\hline $\begin{array}{l}\text { Data de Início do } \\
\text { Trâmite nNome do } \\
\text { Casoa CmDH }\end{array}$ & 07/12/1995 \\
\hline $\begin{array}{l}\text { Data da Alegada } \\
\text { Violação }\end{array}$ & $22 / 12 / 1992$ \\
\hline $\begin{array}{l}\text { Data do veredito da } \\
\text { CmDH }\end{array}$ & $11 / 03 / 2004$ \\
\hline $\begin{array}{l}\text { Data de envio à } \\
\text { CrDH }\end{array}$ & Não se aplica \\
\hline $\begin{array}{l}\text { Data da sentença da } \\
\text { CORTE }\end{array}$ & Não se aplica \\
\hline $\begin{array}{l}\text { Número dos } \\
\text { Informes }\end{array}$ & N. 23/03 E N. 33/04 \\
\hline Peticionários & $\begin{array}{l}\text { Centro pela Justiça e o Direito Internacional (CEJIL)Centro de Defesa Dom Luciano Mendes } \\
\text { da Associação Beneficiente São Martinho }\end{array}$ \\
\hline $\begin{array}{l}\text { Peticionários } \\
\text { classificados }\end{array}$ & ONGs nacionais em parceria com ONGs internacionais \\
\hline Artigos Invocados & CADH: $4,8,19$ e 25. \\
\hline Resumo dos fatos & Denúncia sobre execução sumária de menor por forças policiais em favela do rio de janeiro \\
\hline Tema das violações & $\begin{array}{l}\text { Violência policial } \\
\text { Violência contra menores }\end{array}$ \\
\hline
\end{tabular}




\begin{tabular}{|c|c|c|c|c|c|c|}
\hline $\begin{array}{c}\text { Resoluções, recom. } \\
\text { MP e MC }\end{array}$ & $\begin{array}{l}\text { 1.Reparar } \\
\text { plenament } \\
\text { e a los } \\
\text { familiares } \\
\text { de Jailton } \\
\text { Neri da } \\
\text { Fonseca, } \\
\text { incluyendo } \\
\text { tanto el } \\
\text { aspecto } \\
\text { moral } \\
\text { como el } \\
\text { material, } \\
\text { por las } \\
\text { violaciones } \\
\text { de } \\
\text { derechos } \\
\text { humanos } \\
\text { determinad } \\
\text { as en el } \\
\text { presente } \\
\text { informe, y } \\
\text { en } \\
\text { particular }\end{array}$ & $\begin{array}{l}\text { 2.Realizar } \\
\text { una } \\
\text { investigació } \\
\text { n completa, } \\
\text { imparcial y } \\
\text { efectiva de } \\
\text { los hechos, } \\
\text { por órganos } \\
\text { que no sean } \\
\text { militares, } \\
\text { con el objeto } \\
\text { de establecer } \\
\text { y sancionar } \\
\text { la } \\
\text { responsabili } \\
\text { dad respecto } \\
\text { a los hechos } \\
\text { relacionados } \\
\text { con la } \\
\text { detención y } \\
\text { asesinato de } \\
\text { Jailton Neri } \\
\text { da Fonseca }\end{array}$ & $\begin{array}{l}\text { 3.Indemniza } \\
\text { r a los } \\
\text { familiares de } \\
\text { Jailton Neri } \\
\text { da Fonseca } \\
\text { tanto por los } \\
\text { daños } \\
\text { materiales } \\
\text { como los } \\
\text { daños } \\
\text { morales } \\
\text { sufridos con } \\
\text { ocasión a su } \\
\text { asesinato. } \\
\text { Dicha } \\
\text { reparación a } \\
\text { ser pagada } \\
\text { por el Estado } \\
\text { brasileño, } \\
\text { debe ser } \\
\text { calculada } \\
\text { conforme a } \\
\text { los } \\
\text { parámetros } \\
\text { internacional } \\
\text { es, y debe } \\
\text { ser por un } \\
\text { monto } \\
\text { suficiente } \\
\text { para resarcir } \\
\text { tanto los } \\
\text { daños } \\
\text { materiales } \\
\text { como los } \\
\text { daños } \\
\text { morales } \\
\text { sufridos por } \\
\text { los } \\
\text { familiares de } \\
\text { Jailton Neri } \\
\text { da Fonseca } \\
\text { con ocasión } \\
\text { de su } \\
\text { asesinato y } \\
\text { demás } \\
\text { violaciones a } \\
\text { sus derechos } \\
\text { humanos a } \\
\text { que se } \\
\text { refiere este } \\
\text { informe }\end{array}$ & $\begin{array}{l}\text { 4.Modificar } \\
\text { el artículo } 9 \\
\text { del Código } \\
\text { Penal } \\
\text { Militar, el } \\
\text { artículo } 82 \\
\text { del Código } \\
\text { de } \\
\text { Procedimien } \\
\text { to Penal } \\
\text { Militar y } \\
\text { cualquier } \\
\text { otra norma } \\
\text { interna que } \\
\text { requiera } \\
\text { modificarse } \\
\text { a los efectos } \\
\text { de abolir la } \\
\text { competencia } \\
\text { de la policía } \\
\text { militar para } \\
\text { investigar } \\
\text { violaciones a } \\
\text { derechos } \\
\text { humanos } \\
\text { cometidas } \\
\text { por policías } \\
\text { militares, y } \\
\text { transferir } \\
\text { dicha } \\
\text { competencia } \\
\text { a la policía } \\
\text { civil }\end{array}$ & $\begin{array}{l}\text { 5.Adoptar e } \\
\text { instrumentar } \\
\text { medidas de } \\
\text { educación de } \\
\text { los } \\
\text { funcionarios } \\
\text { de justicia y } \\
\text { de la policía, } \\
\text { al fin de evitar } \\
\text { acciones que } \\
\text { implique en } \\
\text { discriminación } \\
\text { racial en los } \\
\text { operativos } \\
\text { policiales, en } \\
\text { las } \\
\text { investigacione } \\
\text { s, en el } \\
\text { proceso o en } \\
\text { la condena } \\
\text { penal }\end{array}$ & $\begin{array}{l}\text { 6.Adoptar e } \\
\text { instrumentar } \\
\text { acciones } \\
\text { inmediatas } \\
\text { para asegurar } \\
\text { el } \\
\text { cumplimiento } \\
\text { de los } \\
\text { derechos } \\
\text { establecidos } \\
\text { en la } \\
\text { Convención } \\
\text { Americana, en } \\
\text { la Convención } \\
\text { sobre los } \\
\text { Derechos del } \\
\text { Niño y en las } \\
\text { demás normas } \\
\text { nacionales e } \\
\text { internacionale } \\
\text { s } \\
\text { concernientes } \\
\text { al tema, de } \\
\text { manera que se } \\
\text { haga efectivo } \\
\text { el derecho a } \\
\text { protección } \\
\text { especial de la } \\
\text { niñez en Brasil }\end{array}$ \\
\hline $\begin{array}{c}\text { Tipos das resoluções } \\
\text { e recom. }\end{array}$ & $\begin{array}{l}\text { Reparação } \\
\text { econômica } \\
\text { monetária }\end{array}$ & $\begin{array}{l}\text { Investigação } \\
\text { e sanção sem } \\
\text { reforma } \\
\text { legal }\end{array}$ & $\begin{array}{l}\text { Reparação } \\
\text { econômica } \\
\text { monetária }\end{array}$ & $\begin{array}{l}\text { Prevenção } \\
\text { por meio de } \\
\text { reformas } \\
\text { jurídicas }\end{array}$ & $\begin{array}{l}\text { Prevenção por } \\
\text { meio da } \\
\text { formação de } \\
\text { agentes } \\
\text { públicos }\end{array}$ & $\begin{array}{l}\text { Prevenção por } \\
\text { meio da } \\
\text { conscientizaçã } \\
\text { o da } \\
\text { população }\end{array}$ \\
\hline
\end{tabular}




\begin{tabular}{|c|c|c|c|c|c|c|}
\hline $\begin{array}{c}\text { Objetos das as } \\
\text { resoluções e } \\
\text { recomendações }\end{array}$ & $\begin{array}{c}\text { Recompen } \\
\text { sação de } \\
\text { pessoas ou } \\
\text { grupos }\end{array}$ & $\begin{array}{c}\text { Investigação } \\
\text { responsabiliz } \\
\text { ação de } \\
\text { violações de } \\
\text { direitos } \\
\text { humanos } \\
\text { ção de } \\
\text { pessoas ou } \\
\text { grupos }\end{array}$ & $\begin{array}{c}\text { Recompensa } \\
\text { de futuras } \\
\text { violações de } \\
\text { direitos }\end{array}$ & $\begin{array}{c}\text { Prevenção de } \\
\text { futuras } \\
\text { violações de } \\
\text { direitos }\end{array}$ & $\begin{array}{c}\text { Prevenção de } \\
\text { futuras } \\
\text { violações de } \\
\text { direitos }\end{array}$ \\
\hline $\begin{array}{c}\text { Compliance } \\
\text { Data de quando } \\
\text { corte informou que } \\
\text { cumpriu }\end{array}$ & $08 / 06 / 2010$ & $07 / 05 / 2015$ & $08 / 06 / 2010$ & $07 / 05 / 2015$ & $07 / 05 / 2015$ & $07 / 05 / 2015$ \\
\hline
\end{tabular}

\begin{tabular}{|c|c|}
\hline Região & Sudeste \\
\hline UF & SP \\
\hline N. Processo & 10.301 \\
\hline Órgão & Comissão \\
\hline Fase & Cumprimento de Recomendações \\
\hline Nome do Caso & Recomendações da CmDH \\
\hline $\begin{array}{c}\text { Data de Início do } \\
\text { Trâmite nNome do } \\
\text { Casoa CmDH }\end{array}$ & Parque São Lucas \\
\hline $\begin{array}{c}\text { Data da Alegada } \\
\text { Violação }\end{array}$ & $08 / 02 / 1989$ \\
\hline $\begin{array}{c}\text { Data do veredito da } \\
\text { CmDH }\end{array}$ & $05 / 02 / 1989$ \\
\hline $\begin{array}{c}\text { Data de envio à } \\
\text { CrDH }\end{array}$ & \\
\hline $\begin{array}{c}\text { Peticionários } \\
\text { Data da sentença da } \\
\text { CORTE }\end{array}$ & Centro pela Justiça e o Direito Internacional (CEJIL) \\
\hline Número dos & \\
\hline
\end{tabular}




\begin{tabular}{|c|c|c|c|c|}
\hline Peticionários & \multicolumn{4}{|c|}{ ONGs internacionais } \\
\hline Artigos Invocados & \multicolumn{4}{|c|}{$\begin{array}{l}\text { Declaração: I e XVIII } \\
\text { CADH: } 1,8 \text { e } 25\end{array}$} \\
\hline Resumo dos fatos & \multicolumn{4}{|c|}{ Denúncia sobre tortura de presos no distrito policial parque são lucas, em São Paulo } \\
\hline Tema das violações & \multicolumn{4}{|c|}{ Violência institucional contra privados de liberdade (sistema prisional e socioeducativo) } \\
\hline $\begin{array}{c}\text { Resoluções, recom. } \\
\text { MP e MC }\end{array}$ & $\begin{array}{l}\text { 1. Transferencia } \\
\text { a la Justicia } \\
\text { Ordinaria del } \\
\text { juzgamiento de } \\
\text { delitos comunes } \\
\text { cometidos por } \\
\text { policías } \\
\text { militares }\end{array}$ & $\begin{array}{l}\text { 2. Que se } \\
\text { desactiven las } \\
\text { celdas de } \\
\text { aislamiento ("celas } \\
\text { fortes"). }\end{array}$ & $\begin{array}{l}\text { 3.Castigo de los policías } \\
\text { civiles y militares } \\
\text { involucrados }\end{array}$ & $\begin{array}{l}\text { 4.Pago de } \\
\text { indemnizaciones } \\
\text { compensatorias } \\
\text { adecuadas a los } \\
\text { familiares de las } \\
\text { víctimas }\end{array}$ \\
\hline $\begin{array}{c}\text { Tipos das resoluções } \\
\text { e recom. }\end{array}$ & $\begin{array}{l}\text { Prevenção por } \\
\text { meio de } \\
\text { reformas } \\
\text { jurídicas }\end{array}$ & Outros & $\begin{array}{l}\text { Investigação e sanção } \\
\text { sem reforma legal }\end{array}$ & $\begin{array}{c}\text { Reparação econômica } \\
\text { monetária }\end{array}$ \\
\hline $\begin{array}{l}\text { Objetos das as } \\
\text { resoluções e } \\
\text { recomendações }\end{array}$ & $\begin{array}{l}\text { Prevenção de } \\
\text { futuras } \\
\text { violações de } \\
\text { direitos }\end{array}$ & $\begin{array}{l}\text { Proteção de vítimas } \\
\text { e testemunhas e } \\
\text { outros }\end{array}$ & $\begin{array}{c}\text { Investigação e } \\
\text { responsabilização de } \\
\text { violações de direitos } \\
\text { humanos }\end{array}$ & $\begin{array}{l}\text { Recompensação de } \\
\text { pessoas ou grupos }\end{array}$ \\
\hline Compliance & Não cumpriu & $\begin{array}{c}\text { Cumpriu } \\
\text { parcialmente }\end{array}$ & Não cumpriu & Cumpriu parcialmente \\
\hline $\begin{array}{c}\text { Data de quando } \\
\text { corte informou que } \\
\text { cumpriu }\end{array}$ & $07 / 05 / 2015$ & $07 / 03 / 2011$ & $07 / 05 / 2015$ & $07 / 03 / 2011$ \\
\hline
\end{tabular}

\begin{tabular}{|c|c|}
\hline Região & Sul \\
\hline UF & PR \\
\hline N. Processo & 11.517 \\
\hline Órgão & Comissão \\
\hline Fase & Cumprimento de Recomendações \\
\hline
\end{tabular}




\begin{tabular}{|c|c|}
\hline Tipos de decisão & Recomendações da CmDH \\
\hline Nome do Caso & Diniz Bento da Silva (Teixeirinha) \\
\hline $\begin{array}{l}\text { Data de Início do } \\
\text { Trâmite nNome do } \\
\text { Casoa CmDH }\end{array}$ & $05 / 07 / 1995$ \\
\hline $\begin{array}{l}\text { Data da Alegada } \\
\text { Violação }\end{array}$ & $08 / 03 / 1993$ \\
\hline $\begin{array}{l}\text { Data do veredito da } \\
\text { CmDH }\end{array}$ & $28 / 02 / 2002$ \\
\hline $\begin{array}{l}\text { Data de envio à } \\
\text { CrDH }\end{array}$ & Não se aplica \\
\hline $\begin{array}{l}\text { Data da sentença da } \\
\text { CORTE }\end{array}$ & Não se aplica \\
\hline $\begin{array}{l}\text { Número dos } \\
\text { Informes }\end{array}$ & N. 111/01 E N. 23/02 \\
\hline Peticionários & Centro pela Justiça e o Direito Internacional (CEJIL)Human Rights Watch/Americas \\
\hline $\begin{array}{l}\text { Peticionários } \\
\text { classificados }\end{array}$ & ONGs internacionais \\
\hline Artigos Invocados & CADH: 4,8 , e 25 . \\
\hline Resumo dos fatos & $\begin{array}{l}\text { Denúncia sobre execução sumária de membro do movimento dos trabalhadores rurais sem } \\
\text { terra por forças policiais }\end{array}$ \\
\hline Tema das violações & $\begin{array}{l}\text { Violência no campo } \\
\text { Prestação de Justiça }\end{array}$ \\
\hline
\end{tabular}




\begin{tabular}{|c|c|c|c|}
\hline $\begin{array}{l}\text { Resoluções, recom. } \\
\text { MP e MC }\end{array}$ & $\begin{array}{l}\text { 1. Realizar una investigación } \\
\text { seria, imparcial y efectiva por } \\
\text { medio de la justicia común, a } \\
\text { fin de juzgar y castigar a los } \\
\text { responsables de la muerte de } \\
\text { Diniz Bento da Silva; castigar } \\
\text { a los responsables por las } \\
\text { irregularidades comprobadas } \\
\text { en la investigación de la } \\
\text { Policía Militar, así como a los } \\
\text { responsables de la demora } \\
\text { injustificada en la realización } \\
\text { de la investigación civil, de } \\
\text { acuerdo con la legislación } \\
\text { brasileña. }\end{array}$ & $\begin{array}{l}\text { 2. Adoptar las } \\
\text { medidas necesarias } \\
\text { para que los } \\
\text { familiares de la } \\
\text { víctima reciban } \\
\text { adecuada reparación } \\
\text { por las violaciones } \\
\text { de derechos aquí } \\
\text { establecidas }\end{array}$ & $\begin{array}{l}\text { 3. Adoptar las medidas necesarias } \\
\text { para evitar la repetición de hechos } \\
\text { semejantes, en especial formas de } \\
\text { prevenir la confrontación con } \\
\text { trabajadores rurales en los conflictos } \\
\text { sobre tierras, negociación y solución } \\
\text { pacífica de esos conflictos }\end{array}$ \\
\hline $\begin{array}{l}\text { Tipos das resoluções } \\
\text { e recom. }\end{array}$ & $\begin{array}{l}\text { Investigação e sanção com } \\
\text { reforma legal }\end{array}$ & $\begin{array}{l}\text { Reparação } \\
\text { econômica } \\
\text { monetária }\end{array}$ & Prevenção sem especificar medidas \\
\hline $\begin{array}{l}\text { Objetos das as } \\
\text { resoluções e } \\
\text { recomendações }\end{array}$ & $\begin{array}{c}\text { Investigação e } \\
\text { responsabilização de violações } \\
\text { de direitos humanos }\end{array}$ & $\begin{array}{l}\text { Recompensação de } \\
\text { pessoas ou grupos }\end{array}$ & $\begin{array}{l}\text { Prevenção de futuras violações de } \\
\text { direitos }\end{array}$ \\
\hline Compliance & Não cumpriu & $\begin{array}{l}\text { Cumpriu } \\
\text { parcialmente }\end{array}$ & Cumpriu parcialmente \\
\hline $\begin{array}{c}\text { Data de quando } \\
\text { corte informou que } \\
\text { cumpriu }\end{array}$ & $07 / 05 / 2015$ & $06 / 06 / 2013$ & $06 / 06 / 2013$ \\
\hline
\end{tabular}

\begin{tabular}{|c|c|}
\hline Região & Nordeste \\
\hline UF & CE \\
\hline N. Processo & 12.051 \\
\hline Órgão & Comissão \\
\hline Fase & Cumprimento de Recomendações \\
\hline Tipos de decisão & Recomendações da CmDH \\
\hline Nome do Caso & Maria da Penha Fernandes \\
\hline $\begin{array}{c}\text { Data de Início do } \\
\text { Trâmite nNome do } \\
\text { Casoa CmDH }\end{array}$ & $20 / 08 / 1998$ \\
\hline $\begin{array}{c}\text { Data da Alegada } \\
\text { Violação }\end{array}$ & $29 / 05 / 1983$ \\
\hline $\begin{array}{c}\text { Data do veredito da } \\
\text { CmDH }\end{array}$ & $16 / 04 / 2001$ \\
\hline $\begin{array}{c}\text { Data de envio à } \\
\text { CrDH }\end{array}$ & Não se aplica \\
\hline
\end{tabular}




\begin{tabular}{|c|c|c|c|c|c|c|}
\hline \multicolumn{2}{|c|}{$\begin{array}{c}\text { Data da sentença da } \\
\text { CORTE }\end{array}$} & \multicolumn{5}{|c|}{ Não se aplica } \\
\hline \multicolumn{2}{|c|}{$\begin{array}{l}\text { Número dos } \\
\text { Informes } \\
\end{array}$} & \multicolumn{5}{|c|}{ N.105/00 E N. 54/01 } \\
\hline \multicolumn{2}{|c|}{ Peticionários } & \multicolumn{5}{|c|}{$\begin{array}{c}\text { Centro pela Justiça e o Direito Internacional (CEJIL)Comitê Latino-Americano de Defesa dos } \\
\text { Direitos da Mulher (CLADEM) }\end{array}$} \\
\hline \multicolumn{2}{|c|}{$\begin{array}{l}\text { Peticionários } \\
\text { classificados }\end{array}$} & \multicolumn{5}{|c|}{ ONGs internacionais } \\
\hline \multicolumn{2}{|c|}{ Artigos Invocados } & \multicolumn{5}{|c|}{$\begin{array}{c}\text { Declaração: arts. II e XVIII } \\
\text { CADH: } 1.1,8,24 \text { e } 25 . \\
\text { Convenção de Belém do Pará: } 7 \text { e } 12 .\end{array}$} \\
\hline \multicolumn{2}{|c|}{ Resumo dos fatos } & \multicolumn{5}{|c|}{$\begin{array}{c}\text { Denúncia sobre caso de violência doméstica com demora e negligência no processamento da } \\
\text { ação criminal }\end{array}$} \\
\hline \multicolumn{2}{|c|}{ Tema das violações } & \multicolumn{5}{|c|}{$\begin{array}{l}\text { Violência contra mulheres } \\
\text { Prestação de Justiça }\end{array}$} \\
\hline $\begin{array}{l}\text { Resoluçõe } \\
\text { S, recom. } \\
\text { MP e MC }\end{array}$ & $\begin{array}{l}1 . \\
\text { Completar } \\
\text { rápida y } \\
\text { efectivame } \\
\text { te el } \\
\text { procesamie } \\
\text { nto penal } \\
\text { del } \\
\text { responsabl } \\
\text { de la } \\
\text { agresión y } \\
\text { tentativa de } \\
\text { homicidio } \\
\text { en perjuici } \\
\text { de la señor } \\
\text { Maria da } \\
\text { Penha } \\
\text { Fernandes } \\
\text { Maia. }\end{array}$ & & $\begin{array}{l}\text { 2. Llevar } \\
\text { igualmente a } \\
\text { cabo una } \\
\text { investigación } \\
\text { seria, imparcial y } \\
\text { exhaustiva para } \\
\text { determinar la } \\
\text { responsabilidad } \\
\text { por } \\
\text { irregularidades o } \\
\text { retardos } \\
\text { injustificados } \\
\text { que impidieron } \\
\text { el procesamiento } \\
\text { rápido y efectivo } \\
\text { del responsable; } \\
\text { y tomar las } \\
\text { medidas } \\
\text { administrativas, } \\
\text { legislativas y } \\
\text { judiciales } \\
\text { correspondientes }\end{array}$ & $\begin{array}{l}\text { 3. Adoptar, sin } \\
\text { perjuicio de las } \\
\text { eventuales acciones } \\
\text { contra el } \\
\text { responsable civil de } \\
\text { la agresión, } \\
\text { medidas necesarias } \\
\text { para que el Estado } \\
\text { asigne a la víctima } \\
\text { adecuada } \\
\text { reparación } \\
\text { simbólica y } \\
\text { material por las } \\
\text { violaciones aquí } \\
\text { establecidas, en } \\
\text { particular su falla } \\
\text { en ofrecer un } \\
\text { recurso rápido y } \\
\text { efectivo; por } \\
\text { mantener el caso en } \\
\text { la impunidad por } \\
\text { más de quince años; } \\
\text { y por evitar con ese } \\
\text { retraso la } \\
\text { posibilidad } \\
\text { oportuna de acción } \\
\text { de reparación e } \\
\text { indemnización } \\
\text { civil. }\end{array}$ & $\begin{array}{l}\text { 4. Continuar y } \\
\text { profundizar el } \\
\text { proceso de reformas } \\
\text { que eviten la } \\
\text { tolerancia estatal y } \\
\text { el tratamiento } \\
\text { discriminatorio } \\
\text { respecto a la } \\
\text { violencia doméstica } \\
\text { contra las mujeres } \\
\text { en Brasil. En } \\
\text { particular la } \\
\text { Comisión } \\
\text { recomienda: }\end{array}$ & $\begin{array}{l}\text { 4.a. Medidas de } \\
\text { capacitación y } \\
\text { sensibilización de los } \\
\text { funcionarios judiciales } \\
\text { y policiales } \\
\text { especializados para que } \\
\text { comprendan la } \\
\text { importancia de no } \\
\text { tolerar la violencia } \\
\text { doméstica; }\end{array}$ \\
\hline $\begin{array}{l}\text { Tipos das } \\
\text { resoluções } \\
\text { e recom. }\end{array}$ & $\begin{array}{c}\text { Investigaç } \\
\text { o e sançãc } \\
\text { sem } \\
\text { reforma } \\
\text { legal }\end{array}$ & & $\begin{array}{l}\text { Investigação e } \\
\text { sanção com } \\
\text { reforma legal }\end{array}$ & $\begin{array}{c}\text { Investigação e } \\
\text { sanção com reforma } \\
\text { legal }\end{array}$ & $\begin{array}{l}\text { Prevenção por meio } \\
\text { de reformas } \\
\text { jurídicas }\end{array}$ & $\begin{array}{l}\text { Prevenção por meio da } \\
\text { formação de agentes } \\
\text { públicos }\end{array}$ \\
\hline $\begin{array}{l}\text { Objetos } \\
\text { das as } \\
\text { resoluções } \\
\text { e } \\
\text { recomend } \\
\text { ações }\end{array}$ & $\begin{array}{c}\text { Investigaç } \\
\text { o e } \\
\text { responsabi } \\
\text { zação de } \\
\text { violações } \\
\text { direitos } \\
\text { humanos }\end{array}$ & & $\begin{array}{l}\text { Investigação e } \\
\text { responsabilizaçã } \\
\text { o de violações de } \\
\text { direitos humanos }\end{array}$ & $\begin{array}{l}\text { Investigação e } \\
\text { responsabilização } \\
\text { de violações de } \\
\text { direitos humanos }\end{array}$ & $\begin{array}{l}\text { Prevenção de } \\
\text { futuras violações de } \\
\text { direitos }\end{array}$ & $\begin{array}{l}\text { Prevenção de futuras } \\
\text { violações de direitos }\end{array}$ \\
\hline
\end{tabular}




\begin{tabular}{|c|c|c|c|c|c|c|}
\hline $\begin{array}{c}\text { Complian } \\
\text { ce }\end{array}$ & $\begin{array}{l}\text { Não } \\
\text { cumpriu }\end{array}$ & \multicolumn{2}{|c|}{$\begin{array}{c}\text { Cumpriu } \\
\text { parcialmente }\end{array}$} & & $\begin{array}{c}\text { Cumpriu } \\
\text { parcialmente }\end{array}$ & Cumpriu parcialmente \\
\hline $\begin{array}{l}\text { Data de } \\
\text { quando } \\
\text { corte } \\
\text { informou } \\
\text { que } \\
\text { cumpriu }\end{array}$ & $07 / 05 / 2015$ & \multicolumn{2}{|c|}{$07 / 05 / 2015$} & $07 / 05 / 2015$ & $07 / 05 / 2015$ & $07 / 05 / 2015$ \\
\hline $\begin{array}{l}\text { Resoluções, } \\
\text { recom. MP e } \\
\text { MC }\end{array}$ & \multicolumn{2}{|c|}{$\begin{array}{l}\text { 4.c. El } \\
\text { establecimiento de } \\
\text { formas alternativas a } \\
\text { las judiciales, } \\
\text { rápidas y efectivas } \\
\text { de solución de } \\
\text { conflicto } \\
\text { intrafamiliar, así } \\
\text { como de } \\
\text { sensibilización } \\
\text { respecto a su } \\
\text { gravedad y las } \\
\text { consecuencias } \\
\text { penales que genera; }\end{array}$} & \multicolumn{2}{|c|}{$\begin{array}{l}\text { 4.d. Multiplicar el } \\
\text { número de delegaciones } \\
\text { especiales de policía para } \\
\text { los derechos de la mujer } \\
\text { y dotarlas con los } \\
\text { recursos especiales } \\
\text { necesarios para la } \\
\text { efectiva tramitación e } \\
\text { investigación de todas las } \\
\text { denuncias de violencia } \\
\text { doméstica, así como de } \\
\text { recursos y apoyo al } \\
\text { Ministerio Público en la } \\
\text { preparación de sus } \\
\text { informes judiciales; }\end{array}$} & $\begin{array}{l}\text { 4.e. Incluir en sus } \\
\text { planes pedagógicos } \\
\text { unidades } \\
\text { curriculares } \\
\text { destinadas a la } \\
\text { comprensión de la } \\
\text { importancia del } \\
\text { respeto a la mujer y } \\
\text { a sus derechos } \\
\text { reconocidos en la } \\
\text { Convención de } \\
\text { Belém do Pará, así } \\
\text { como al manejo de } \\
\text { los conflictos } \\
\text { intrafamiliares, }\end{array}$ & $\begin{array}{l}\text { 4.f. Informar a la Comisión } \\
\text { Interamericana de } \\
\text { Derechos Humanos dentro } \\
\text { del plazo de sesenta días } \\
\text { contados a partir de la } \\
\text { transmisión del presente } \\
\text { Informe al Estado, con un } \\
\text { informe de cumplimiento } \\
\text { de estas recomendaciones } \\
\text { a los efectos previstos en el } \\
\text { artículo 51(1) de la } \\
\text { Convención Americana. }\end{array}$ \\
\hline $\begin{array}{l}\text { Tipos das } \\
\text { resoluções e } \\
\text { recom. }\end{array}$ & \multicolumn{2}{|c|}{ Outros } & \multicolumn{2}{|c|}{$\begin{array}{l}\text { Prevenção por meio do } \\
\text { fortalecimento, criação, } \\
\text { ou reforma de } \\
\text { instituições públicas }\end{array}$} & $\begin{array}{l}\text { Prevenção por meio } \\
\text { da formação de } \\
\text { agentes públicos }\end{array}$ & Outros \\
\hline $\begin{array}{l}\text { Objetos das } \\
\text { as resoluções } \\
\text { e } \\
\text { recomendaçõ } \\
\text { es }\end{array}$ & \multicolumn{2}{|c|}{$\begin{array}{c}\text { Proteção de vítimas } \\
\text { e testemunhas e } \\
\text { outros }\end{array}$} & \multicolumn{2}{|c|}{$\begin{array}{l}\text { Prevenção de futuras } \\
\text { violações de direitos }\end{array}$} & $\begin{array}{c}\text { Prevenção de } \\
\text { futuras violações de } \\
\text { direitos }\end{array}$ & $\begin{array}{l}\text { Proteção de vítimas e } \\
\text { testemunhas e outros }\end{array}$ \\
\hline Compliance & \multicolumn{2}{|c|}{$\begin{array}{c}\text { Cumpriu } \\
\text { parcialmente }\end{array}$} & \multicolumn{2}{|c|}{ Cumpriu parcialmente } & $\begin{array}{c}\text { Cumpriu } \\
\text { parcialmente }\end{array}$ & Cumpriu parcialmente \\
\hline $\begin{array}{c}\text { Data de } \\
\text { quando corte } \\
\text { informou } \\
\text { que cumpriu }\end{array}$ & \multicolumn{2}{|c|}{$07 / 05 / 2015$} & & $5 / 2015$ & $07 / 05 / 2015$ & $07 / 05 / 2015$ \\
\hline
\end{tabular}

\begin{tabular}{|c|c|}
\hline Região & Sudeste \\
\hline UF & SP \\
\hline N. Processo & 11.286 \\
\hline Órgão & Comissão \\
\hline Fase & Cumprimento de Recomendações \\
\hline Tipos de decisão & Recomendações da CmDH \\
\hline Nome do Caso & Aluísio Cavalcanti e outros \\
\hline
\end{tabular}




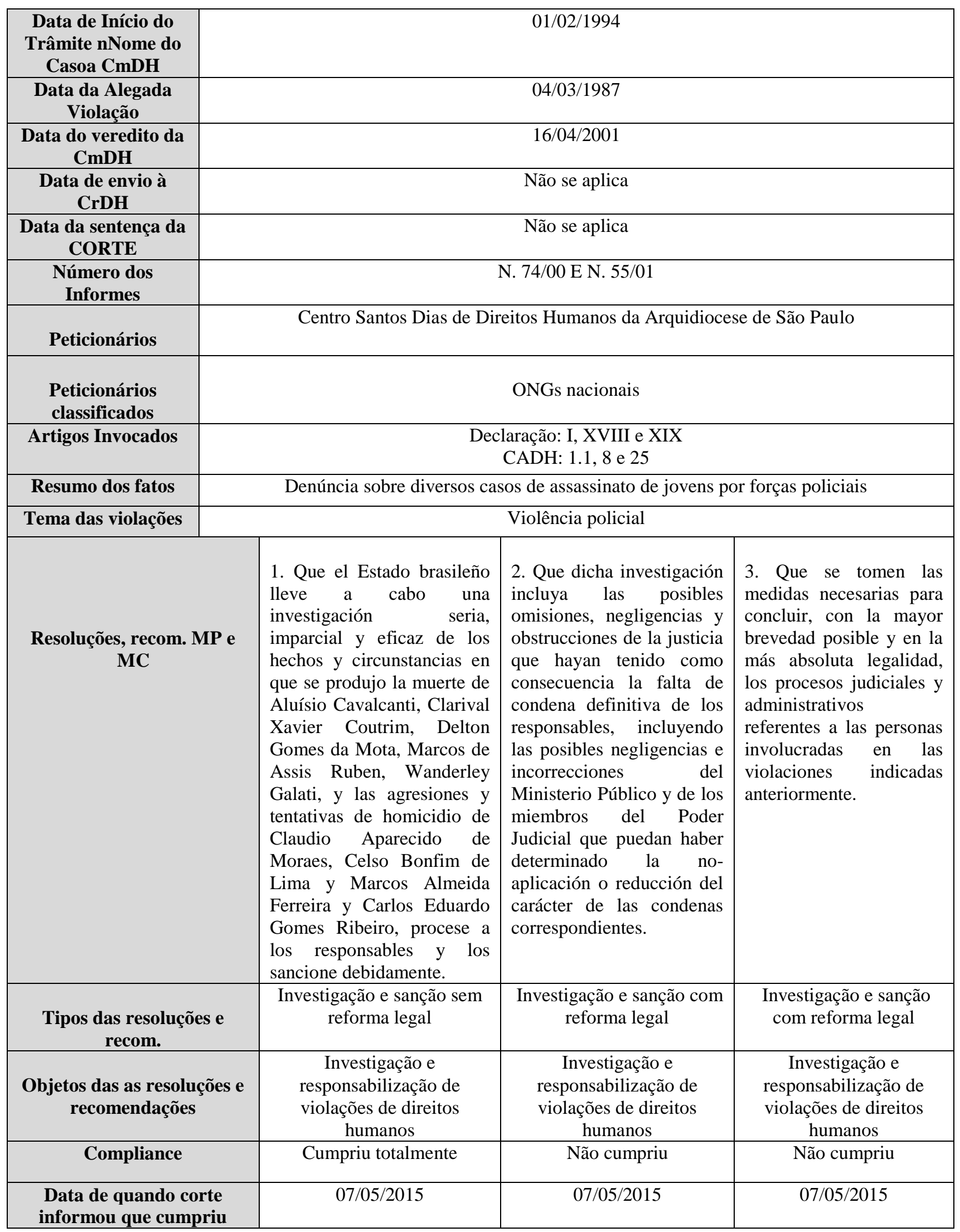




\begin{tabular}{|c|c|c|c|c|}
\hline $\begin{array}{c}\text { Resol } \\
\text { uções } \\
\text {, } \\
\text { reco } \\
\text { m. } \\
\text { MP e } \\
\text { MC }\end{array}$ & $\begin{array}{l}\text { 4. Que el Estado } \\
\text { brasileño repare } \\
\text { las consecuencias } \\
\text { de las violaciones } \\
\text { de los derechos de } \\
\text { las víctimas y sus } \\
\text { familiares o a } \\
\text { quienes tengan } \\
\text { derecho, por los } \\
\text { daños sufridos } \\
\text { mencionados en } \\
\text { este informe. }\end{array}$ & $\begin{array}{l}\text { 5. Que se tomen las } \\
\text { medidas necesarias para } \\
\text { abolir la competencia de la } \\
\text { Justicia Militar sobre delitos } \\
\text { cometidos por policías } \\
\text { contra civiles, tal como lo } \\
\text { proponía el proyecto } \\
\text { original presentado } \\
\text { oportunamente para la } \\
\text { revocación del literal f) del } \\
\text { artículo } 9 \text { del Código Penal } \\
\text { Militar, y se apruebe en } \\
\text { cambio el párrafo único allí } \\
\text { propuesto }\end{array}$ & $\begin{array}{l}\text { 6. Que el Estado brasileño } \\
\text { tome medidas para que se } \\
\text { establezca un sistema de } \\
\text { supervisión externa e } \\
\text { interna de la Policía } \\
\text { Militar de Río de Janeiro, } \\
\text { independiente, imparcial y } \\
\text { efectivo. }\end{array}$ & $\begin{array}{l}\text { 7. Que el Estado } \\
\text { brasileño presente a la } \\
\text { Comisión dentro de los } \\
\text { sesenta días de } \\
\text { transmisión del presente, } \\
\text { un informe sobre } \\
\text { cumplimiento de } \\
\text { recomendaciones con el } \\
\text { objeto de aplicar lo } \\
\text { dispuesto en el artículo } \\
\text { 51(1) de la Convención } \\
\text { Americana. }\end{array}$ \\
\hline \multicolumn{2}{|c|}{$\begin{array}{c}\text { Reparação econômica } \\
\text { monetária }\end{array}$} & $\begin{array}{l}\text { Prevenção por meio de } \\
\text { reformas jurídicas }\end{array}$ & $\begin{array}{l}\text { Prevenção por meio do } \\
\text { fortalecimento, criação, ou } \\
\text { reforma de instituições } \\
\text { públicas }\end{array}$ & Outros \\
\hline \multicolumn{2}{|c|}{$\begin{array}{c}\text { Recompensação de pessoas } \\
\text { ou grupos }\end{array}$} & $\begin{array}{l}\text { Prevenção de futuras } \\
\text { violações de direitos }\end{array}$ & $\begin{array}{l}\text { Prevenção de futuras } \\
\text { violações de direitos }\end{array}$ & $\begin{array}{l}\text { Proteção de vítimas e } \\
\text { testemunhas e outros }\end{array}$ \\
\hline \multicolumn{2}{|r|}{ Não cumpriu } & Não cumpriu & Não cumpriu & Não cumpriu \\
\hline \multicolumn{2}{|r|}{$07 / 05 / 2015$} & $07 / 05 / 2015$ & $07 / 05 / 2015$ & $07 / 05 / 2015$ \\
\hline
\end{tabular}

\begin{tabular}{|c|c|}
\hline Região & Sudeste \\
\hline $\mathbf{U F}$ & $\mathrm{SP}$ \\
\hline N. Processo & 11.291 \\
\hline Órgão & Comissão \\
\hline Fase & Cumprimento de Recomendações \\
\hline Tipos de decisão & Recomendações da CmDH \\
\hline Nome do Caso & Carandirú \\
\hline $\begin{array}{l}\text { Data de Início do } \\
\text { Trâmite nNome do } \\
\text { Casoa CmDH }\end{array}$ & $22 / 02 / 1994$ \\
\hline $\begin{array}{c}\text { Data da Alegada } \\
\text { Violação }\end{array}$ & $02 / 10 / 1992$ \\
\hline $\begin{array}{c}\text { Data do veredito da } \\
\mathrm{CmDH}\end{array}$ & $13 / 04 / 2000$ \\
\hline Data de envio à CrDH & Não se aplica \\
\hline $\begin{array}{c}\text { Data da sentença da } \\
\text { CORTE }\end{array}$ & Não se aplica \\
\hline Número dos Informes & N. 120/99 E N. 34/00 \\
\hline Peticionários & Americas Watch, CEJIL y la Comisión Teotonio Vilela \\
\hline $\begin{array}{l}\text { Peticionários } \\
\text { classificados }\end{array}$ & ONGs nacionais em parceria com ONGs internacionais \\
\hline
\end{tabular}




\begin{tabular}{|c|c|c|c|}
\hline Artigos Invocados & \multicolumn{3}{|c|}{ CADH: $4,5,8,25$ e 1.1} \\
\hline Resumo dos fatos & \multicolumn{3}{|c|}{$\begin{array}{l}\text { Denúncia sobre o massacre promovido por forças policiais ao invadirem o presídio do } \\
\text { carandiru para debelar uma rebelião }\end{array}$} \\
\hline Tema das violações & \multicolumn{3}{|c|}{$\begin{array}{l}\text { Violência policial } \\
\text { Prestação de Justiça }\end{array}$} \\
\hline $\begin{array}{l}\text { Resoluções, recom. } \\
\text { MP e MC }\end{array}$ & $\begin{array}{l}\text { 2. Adotar as medidas } \\
\text { necessárias para que as } \\
\text { vítimas dessas violações } \\
\text { que foram identificadas e } \\
\text { suas famílias recebam } \\
\text { adequada e oportuna } \\
\text { indenização pelas } \\
\text { violações definidas nas } \\
\text { conclusões deste relatório, } \\
\text { assim como para que } \\
\text { sejam identificadas as } \\
\text { demais vítimas. }\end{array}$ & $\begin{array}{l}\text { 3. Desenvolver políticas e estratégias } \\
\text { destinadas a descongestionar a } \\
\text { população das casas de detenção, } \\
\text { estabelecer programas de reabilitação } \\
\text { e reinserção social acordes com as } \\
\text { normas nacionais e internacionais e } \\
\text { prevenir surtos de violência nesses } \\
\text { estabelecimentos. Desenvolver, } \\
\text { ademais, para o pessoal carcerário e } \\
\text { policial, políticas, estratégias e } \\
\text { treinamento especial orientados para } \\
\text { a negociação e a solução pacífica de } \\
\text { conflitos, assim como técnicas de } \\
\text { reinstauração da ordem que permitam } \\
\text { a subjugação de eventuais motins } \\
\text { com o mínimo de risco para a vida e } \\
\text { a integridade pessoal dos internos e } \\
\text { das forças policiais. }\end{array}$ & $\begin{array}{l}\text { 4. Adotar as medidas } \\
\text { necessárias para o } \\
\text { cumprimento, no } \\
\text { presente caso, das } \\
\text { disposições do artigo } \\
28 \text { da Convenção } \\
\text { (Cláusula federal) } \\
\text { relativas às matérias } \\
\text { que correspondem à } \\
\text { competência das } \\
\text { entidades componentes } \\
\text { da federação, neste } \\
\text { caso o Estado de São } \\
\text { Paulo. }\end{array}$ \\
\hline $\begin{array}{l}\text { Tipos das resoluções } \\
\text { e recom. }\end{array}$ & $\begin{array}{l}\text { Reparação econômica } \\
\text { monetária }\end{array}$ & $\begin{array}{l}\text { Prevenção por meio da formação de } \\
\text { agentes públicos }\end{array}$ & Outros \\
\hline $\begin{array}{c}\text { Objetos das as } \\
\text { resoluções e } \\
\text { recomendações } \\
\end{array}$ & $\begin{array}{l}\text { Recompensação de } \\
\text { pessoas ou grupos }\end{array}$ & $\begin{array}{l}\text { Prevenção de futuras violações de } \\
\text { direitos }\end{array}$ & $\begin{array}{l}\text { Proteção de vítimas e } \\
\text { testemunhas e outros }\end{array}$ \\
\hline Compliance & Não cumpriu & Não cumpriu & Não cumpriu \\
\hline $\begin{array}{c}\text { Data de quando } \\
\text { corte informou que } \\
\text { cumpriu }\end{array}$ & $18 / 02 / 2014$ & $18 / 02 / 2014$ & $18 / 02 / 2014$ \\
\hline
\end{tabular}

\begin{tabular}{|c|c|}
\hline Região & Sudeste \\
\hline UF & RJ \\
\hline N. Processo & Comissão \\
\hline Órgão & Cumprimento de Recomendações \\
\hline Fase & Recomendações da CmDH \\
\hline Tipos de decisão & Alonso Eugénio da Silva \\
\hline Nome do Caso & $07 / 12 / 1995$ \\
\hline $\begin{array}{l}\text { Data de Início do } \\
\text { Casoa Cmite nNome do }\end{array}$ & $08 / 03 / 1992$ \\
\hline $\begin{array}{c}\text { Data da Alegada } \\
\text { Violação }\end{array}$ & $24 / 02 / 2000$ \\
\hline $\begin{array}{c}\text { Data do veredito da } \\
\text { CmDH }\end{array}$ & Não se aplica \\
\hline $\begin{array}{c}\text { Data de envio à } \\
\text { CrDH }\end{array}$ & Não se aplica \\
\hline $\begin{array}{c}\text { Data da sentença da } \\
\text { CORTE }\end{array}$ & \\
\hline
\end{tabular}




\begin{tabular}{|c|c|c|}
\hline $\begin{array}{l}\text { Número dos } \\
\text { Informes }\end{array}$ & \multicolumn{2}{|l|}{ N. 22/99 E N. 09/00 } \\
\hline Peticionários & \multicolumn{2}{|c|}{$\begin{array}{l}\text { Centro de Defensa y Garantía de los Derechos Humanos/proyecto legal del Instituto Brasileño } \\
\text { de Innovaciones en Salud Social (I.B.I.S.S.) }\end{array}$} \\
\hline $\begin{array}{l}\text { Peticionários } \\
\text { classificados }\end{array}$ & \multicolumn{2}{|l|}{ ONGs nacionais } \\
\hline Artigos Invocados & \multicolumn{2}{|l|}{$\begin{array}{c}\text { Declaração: VI e XVIII } \\
\text { CADH: } 1.1,8 \text { e } 25\end{array}$} \\
\hline Resumo dos fatos & \multicolumn{2}{|c|}{ Denúncia sobre homicídio de menor por policial militar durante detenção por suposto assalto. } \\
\hline Tema das violações & \multicolumn{2}{|l|}{$\begin{array}{c}\text { Violência policial } \\
\text { Prestação de Justiça } \\
\end{array}$} \\
\hline $\begin{array}{l}\text { Resoluções, recom. } \\
\text { MP e MC }\end{array}$ & $\begin{array}{l}\text { 1. Llevar a cabo una investigación completa, imparcial y } \\
\text { efectiva para determinar las circunstancias en que } \\
\text { ocurrió la muerte del menor Alonso Eugenio de Silva y } \\
\text { sobre las irregularidades en la investigación policial } \\
\text { subsiguiente y la actuación del Ministerio público y } \\
\text { funcionarios judiciales, para sancionar a todos los } \\
\text { responsables con arreglo a la legislación vigente. }\end{array}$ & $\begin{array}{l}\text { 2. Adoptar las medidas necesarias } \\
\text { para que los familiares de la } \\
\text { víctima reciban adecuada y } \\
\text { oportuna reparación por las } \\
\text { violaciones aquí establecidas. }\end{array}$ \\
\hline $\begin{array}{l}\text { Tipos das resoluções } \\
\text { e recom. }\end{array}$ & Investigação e sanção sem reforma legal & Reparação econômica monetária \\
\hline $\begin{array}{l}\text { Objetos das as } \\
\text { resoluções e } \\
\text { recomendações }\end{array}$ & $\begin{array}{l}\text { Investigação e responsabilização de violações de direitos } \\
\text { humanos }\end{array}$ & $\begin{array}{l}\text { Recompensação de pessoas ou } \\
\text { grupos }\end{array}$ \\
\hline Compliance & Informação não disponível & Informação não disponível \\
\hline $\begin{array}{c}\text { Data de quando } \\
\text { corte informou que } \\
\text { cumpriu }\end{array}$ & Informação não disponível & Informação não disponível \\
\hline
\end{tabular}

\begin{tabular}{|c|c|}
\hline Região & Sudeste \\
\hline UF & RJ \\
\hline N. Processo & Comissão \\
\hline Fase & Cumprimento de Recomendações \\
\hline Tipos de decisão & Recomendações da CmDH \\
\hline Nome do Caso & Marcos Aurelio de Oliveira \\
\hline $\begin{array}{l}\text { Data de Início do } \\
\text { Trâmite nNome do }\end{array}$ & $07 / 12 / 1995$ \\
\hline $\begin{array}{c}\text { Data da Alegada } \\
\text { Violação }\end{array}$ & $25 / 09 / 1993$ \\
\hline $\begin{array}{c}\text { Data do veredito da } \\
\text { CmDH }\end{array}$ & $24 / 02 / 2000$ \\
\hline $\begin{array}{c}\text { Data de envio à } \\
\text { CrDH }\end{array}$ & Não se aplica \\
\hline $\begin{array}{c}\text { Data da sentença da } \\
\text { CORTE }\end{array}$ & Não se aplica \\
\hline
\end{tabular}




\begin{tabular}{|c|c|c|c|}
\hline Número dos & \multicolumn{3}{|c|}{ N. $23 / 99$ E N. $10 / 00$} \\
\hline Peticionários & \multicolumn{3}{|c|}{$\begin{array}{l}\text { Centro de Defensa y Garantía de los Derechos Humanos/Proyecto Legal del Instituto Brasileño } \\
\text { de Innovaciones en Salud Social (IBISS) }\end{array}$} \\
\hline $\begin{array}{l}\text { Peticionários } \\
\text { classificados }\end{array}$ & \multicolumn{3}{|c|}{ ONGs nacionais } \\
\hline Artigos Invocados & \multicolumn{3}{|c|}{ CADH: $4,8,19,22$ e 25.} \\
\hline Resumo dos fatos & \multicolumn{3}{|c|}{ Denúncia sobre execução sumária de criança de rua por policial civil } \\
\hline Tema das violações & \multicolumn{3}{|c|}{$\begin{array}{l}\text { Violência policial } \\
\text { Prestação de Justiça }\end{array}$} \\
\hline $\begin{array}{l}\text { Resoluções, recom. } \\
\text { MP e MC }\end{array}$ & $\begin{array}{l}\text { 1. Completar una investigación } \\
\text { imparcial y efectiva ante la } \\
\text { jurisdicción ordinaria con el fin de } \\
\text { juzgar y sancionar a los } \\
\text { responsables. }\end{array}$ & $\begin{array}{l}\text { 2. Esclarecer las } \\
\text { circunstancias de la } \\
\text { desaparición así como el } \\
\text { destino de los restos de la } \\
\text { víctima y devolverlos a sus } \\
\text { familiares. }\end{array}$ & $\begin{array}{l}\text { 3. Adoptar las medidas } \\
\text { necesarias para que los } \\
\text { familiares de la víctima } \\
\text { reciban adecuada y } \\
\text { oportuna reparación por } \\
\text { las violaciones aquí } \\
\text { establecidas. }\end{array}$ \\
\hline $\begin{array}{l}\text { Tipos das resoluções } \\
\text { e recom. }\end{array}$ & $\begin{array}{l}\text { Investigação e sanção sem } \\
\text { reforma legal }\end{array}$ & Reparação simbólica & $\begin{array}{l}\text { Reparação econômica } \\
\text { monetária }\end{array}$ \\
\hline $\begin{array}{l}\text { Objetos das as } \\
\text { resoluções e } \\
\text { recomendações }\end{array}$ & $\begin{array}{l}\text { Investigação e responsabilização } \\
\text { de violações de direitos humanos }\end{array}$ & $\begin{array}{l}\text { Recompensação de pessoas } \\
\text { ou grupos }\end{array}$ & $\begin{array}{l}\text { Recompensação de } \\
\text { pessoas ou grupos }\end{array}$ \\
\hline Compliance & Informação não disponível & Informação não disponível & $\begin{array}{c}\text { Informação não } \\
\text { disponível }\end{array}$ \\
\hline $\begin{array}{l}\text { Data de quando } \\
\text { corte informou que } \\
\text { cumpriu }\end{array}$ & Informação não disponível & Informação não disponível & $\begin{array}{l}\text { Informação não } \\
\text { disponível }\end{array}$ \\
\hline
\end{tabular}

\begin{tabular}{|c|c|}
\hline Região & Norte \\
\hline UF & 11.516 \\
\hline N. Processo & Comissão \\
\hline Órgão & Cumprimento de Recomendações \\
\hline Fase & Recomendações da CmDH \\
\hline Tipos de decisão & Ovelário Tames \\
\hline $\begin{array}{l}\text { Nome do Caso } \\
\text { Trâmite nNome do } \\
\text { Casoa CmDH }\end{array}$ & $01 / 06 / 1995$ \\
& \\
\hline
\end{tabular}




\begin{tabular}{|c|c|c|c|c|}
\hline $\begin{array}{l}\text { Data da Alegada } \\
\text { Violação }\end{array}$ & \multicolumn{4}{|c|}{$23 / 10 / 1988$} \\
\hline $\begin{array}{l}\text { Data do veredito da } \\
\text { CmDH }\end{array}$ & \multicolumn{4}{|c|}{ 13/04/1999 } \\
\hline $\begin{array}{l}\text { Data de envio à } \\
\text { CrDH }\end{array}$ & \multicolumn{4}{|c|}{ Não se aplica } \\
\hline $\begin{array}{l}\text { Data da sentença da } \\
\text { CORTE }\end{array}$ & \multicolumn{4}{|c|}{ Não se aplica } \\
\hline $\begin{array}{l}\text { Número dos } \\
\text { Informes }\end{array}$ & \multicolumn{4}{|c|}{ N. $80 / 98$ E N. $60 / 99$} \\
\hline Peticionários & \multicolumn{4}{|c|}{ Centro pela Justiça e o Direito Internacional (CEJIL) } \\
\hline $\begin{array}{l}\text { Peticionários } \\
\text { classificados }\end{array}$ & \multicolumn{4}{|c|}{ ONGs internacionais } \\
\hline Artigos Invocados & \multicolumn{4}{|c|}{$\begin{array}{c}\text { Declaração: I, XVIII e XXV } \\
\text { CADH: } 1.1,8 \text { e } 25 .\end{array}$} \\
\hline Resumo dos fatos & \multicolumn{4}{|c|}{$\begin{array}{c}\text { Denúncia sobre detenção arbitrária da vítima, que foi morta depois de torturada por agentes de } \\
\text { segurança }\end{array}$} \\
\hline Tema das violações & \multicolumn{4}{|c|}{ Violência contra Indígenas } \\
\hline $\begin{array}{l}\text { Resoluções, recom. } \\
\text { MP e MC }\end{array}$ & $\begin{array}{l}\text { 1. Que el } \\
\text { Estado } \\
\text { brasileño } \\
\text { lleve a cabo } \\
\text { una } \\
\text { investigació } \\
\text { n seria, } \\
\text { imparcial y } \\
\text { eficaz de los } \\
\text { hechos y } \\
\text { circunstancia } \\
\text { s en que se } \\
\text { produjo la } \\
\text { muerte de } \\
\text { Ovelário } \\
\text { Tames, } \\
\text { procese a los } \\
\text { responsables } \\
\text { y los } \\
\text { sancione } \\
\text { debidamente } \\
\text {. }\end{array}$ & $\begin{array}{l}\text { 2. Que dicha } \\
\text { investigación incluya } \\
\text { las posibles } \\
\text { omisiones, } \\
\text { negligencias y } \\
\text { obstrucciones de la } \\
\text { justicia que hayan } \\
\text { tenido como } \\
\text { consecuencia la falta } \\
\text { de condena definitiva } \\
\text { de los responsables, } \\
\text { incluyendo las } \\
\text { posibles negligencias } \\
\text { e incorrecciones del } \\
\text { Ministerio Público y } \\
\text { de los jueces que } \\
\text { puedan haber } \\
\text { determinado la no } \\
\text { aplicación o } \\
\text { reducción del carácter } \\
\text { de la mencionada } \\
\text { condena }\end{array}$ & $\begin{array}{l}\text { 3. Que se tomen las } \\
\text { medidas necesarias } \\
\text { para concluir, a la } \\
\text { mayor brevedad } \\
\text { posible y en la más } \\
\text { absoluta legalidad, } \\
\text { los procesos } \\
\text { judiciales y } \\
\text { administrativos } \\
\text { referentes a todas } \\
\text { las personas } \\
\text { involucradas en las } \\
\text { violaciones } \\
\text { indicadas en las } \\
\text { conclusiones } \\
\text { anteriormente } \\
\text { descritas }\end{array}$ & $\begin{array}{l}\text { 4. Que el Estado brasileño } \\
\text { repare las consecuencias de las } \\
\text { violaciones de los derechos a los } \\
\text { familiares o a quienes tengan } \\
\text { derecho, que hayan sufrido } \\
\text { perjuicios a raíz de las } \\
\text { violaciones de los derechos } \\
\text { antes mencionadas, reparación } \\
\text { que debe basarse en el concepto } \\
\text { de familia establecido por la } \\
\text { Corte Interamericana de } \\
\text { Derechos Humanos }\end{array}$ \\
\hline
\end{tabular}




\begin{tabular}{|c|c|c|c|c|}
\hline $\begin{array}{c}\text { Tipos das resoluções } \\
\text { e recom. }\end{array}$ & $\begin{array}{l}\text { Investigação } \\
\text { e sanção sem } \\
\text { reforma } \\
\text { legal }\end{array}$ & $\begin{array}{c}\text { Investigação e } \\
\text { sanção com reforma } \\
\text { legal }\end{array}$ & $\begin{array}{c}\text { Investigação e } \\
\text { sanção sem reforma } \\
\text { legal }\end{array}$ & Reparação econômica monetária \\
\hline $\begin{array}{l}\text { Objetos das as } \\
\text { resoluções e } \\
\text { recomendações }\end{array}$ & $\begin{array}{c}\text { Investigação } \\
\text { e } \\
\text { responsabiliz } \\
\text { ação de } \\
\text { violações de } \\
\text { direitos } \\
\text { humanos }\end{array}$ & $\begin{array}{c}\text { Investigação e } \\
\text { responsabilização de } \\
\text { violações de direitos } \\
\text { humanos }\end{array}$ & $\begin{array}{l}\text { Investigação e } \\
\text { responsabilização } \\
\text { de violações de } \\
\text { direitos humanos }\end{array}$ & $\begin{array}{c}\text { Recompensação de pessoas ou } \\
\text { grupos }\end{array}$ \\
\hline Compliance & $\begin{array}{l}\text { Informação } \\
\text { não } \\
\text { disponível }\end{array}$ & $\begin{array}{l}\text { Informação não } \\
\text { disponível }\end{array}$ & $\begin{array}{l}\text { Informação não } \\
\text { disponível }\end{array}$ & Informação não disponível \\
\hline $\begin{array}{c}\text { Data de quando } \\
\text { corte informou que } \\
\text { cumpriu }\end{array}$ & $\begin{array}{l}\text { Informação } \\
\text { não } \\
\text { disponível }\end{array}$ & $\begin{array}{l}\text { Informação não } \\
\text { disponível }\end{array}$ & $\begin{array}{l}\text { Informação não } \\
\text { disponível }\end{array}$ & Informação não disponível \\
\hline
\end{tabular}

\begin{tabular}{|c|c|}
\hline Região & Norte \\
\hline $\mathbf{U F}$ & PA \\
\hline N. Processo & 11.405 \\
\hline Órgão & Comissão \\
\hline Fase & Cumprimento de Recomendações \\
\hline Tipos de decisão & Recomendações da CmDH \\
\hline Nome do Caso & Newton Coutinho Mendes e outros \\
\hline $\begin{array}{l}\text { Data de Início do } \\
\text { Trâmite nNome do } \\
\text { Casoa CmDH }\end{array}$ & $18 / 11 / 1994$ \\
\hline $\begin{array}{c}\text { Data da Alegada } \\
\text { Violação }\end{array}$ & 01/04/1994 \\
\hline $\begin{array}{c}\text { Data do veredito da } \\
\text { CmDH }\end{array}$ & $13 / 04 / 1999$ \\
\hline $\begin{array}{c}\text { Data de envio à } \\
\text { CrDH }\end{array}$ & Não se aplica \\
\hline $\begin{array}{c}\text { Data da sentença da } \\
\text { CORTE }\end{array}$ & Não se aplica \\
\hline $\begin{array}{l}\text { Número dos } \\
\text { Informes }\end{array}$ & N. 79/98 E N. 59/99 \\
\hline Peticionários & Centro pela Justiça e o Direito Internacional (CEJIL) \\
\hline $\begin{array}{l}\text { Peticionários } \\
\text { classificados }\end{array}$ & ONGs internacionais \\
\hline
\end{tabular}




\begin{tabular}{|c|c|c|c|}
\hline Artigos Invocados & \multicolumn{3}{|c|}{ CADH: $4,5,8$ e 25} \\
\hline Resumo dos fatos & \multicolumn{3}{|c|}{$\begin{array}{l}\text { Denúncia sobre mortes e ameaças de morte sofridas por defensores de direitos humanos e } \\
\text { pessoas ligadas à ocupação de terras em razão de grupo de extermínio formado por proprietários }\end{array}$} \\
\hline Tema das violações & \multicolumn{3}{|c|}{$\begin{array}{l}\text { Violência policial } \\
\text { Violência contra defensores de Direitos Humanos }\end{array}$} \\
\hline $\begin{array}{l}\text { Resoluções, recom. } \\
\text { MP e MC }\end{array}$ & $\begin{array}{l}\text { 1. Que tome las medidas para } \\
\text { que las autoridades } \\
\text { competentes pongan en marcha } \\
\text { los mecanismos y garantías } \\
\text { necesarias para realizar una } \\
\text { investigación independiente, } \\
\text { completa, seria e imparcial de } \\
\text { los hechos que se vienen } \\
\text { desarrollando en la zona sur } \\
\text { del Estado de Pará, en } \\
\text { perjuicio de las víctimas } \\
\text { mencionadas en este informe, } \\
\text { con el objeto de identificar y } \\
\text { sancionar a todas las personas } \\
\text { que resulten individualizadas } \\
\text { como responsables de las } \\
\text { violaciones a los derechos } \\
\text { humanos mencionadas en las } \\
\text { conclusiones expuestas supra } \\
\text { VIII. }\end{array}$ & $\begin{array}{l}\text { 2. Que en cumplimiento de sus } \\
\text { obligaciones previstas en los } \\
\text { artículos } 2,8 \text { y } 25 \text { de la } \\
\text { Convención Americana, adopte } \\
\text { las medidas necesarias con } \\
\text { arreglo a sus procedimientos } \\
\text { constitucionales, a fin de hacer } \\
\text { plenamente efectivos, en lo } \\
\text { sucesivo, los derechos a la vida, } \\
\text { a la integridad personal, y a las } \\
\text { garantías y protección judicial } \\
\text { para todos los habitantes de la } \\
\text { zona sur del Estado de Pará, y } \\
\text { en particular para los } \\
\text { trabajadores rurales, sus } \\
\text { representantes y los defensores } \\
\text { de derechos humanos. }\end{array}$ & $\begin{array}{l}\text { 3. Que en virtud de las } \\
\text { violaciones de la } \\
\text { Convención Americana } \\
\text { arriba expuestas, adopte } \\
\text { las medidas más } \\
\text { apropiadas para reparar a } \\
\text { las víctimas o sus } \\
\text { familiares por el daño } \\
\text { sufrido por las personas } \\
\text { identificadas en este } \\
\text { informe }\end{array}$ \\
\hline $\begin{array}{l}\text { Tipos das } \\
\text { resoluções e recom. }\end{array}$ & $\begin{array}{l}\text { Investigação e sanção sem } \\
\text { reforma legal }\end{array}$ & $\begin{array}{l}\text { Prevenção sem especificar } \\
\text { medidas }\end{array}$ & Outros \\
\hline $\begin{array}{l}\text { Objetos das as } \\
\text { resoluções e } \\
\text { recomendações }\end{array}$ & $\begin{array}{c}\text { Investigação e } \\
\text { responsabilização de violações } \\
\text { de direitos humanos }\end{array}$ & $\begin{array}{l}\text { Prevenção de futuras violações } \\
\text { de direitos }\end{array}$ & $\begin{array}{l}\text { Proteção de vítimas e } \\
\text { testemunhas e outros }\end{array}$ \\
\hline Compliance & Informação não disponível & Informação não disponível & Informação não disponível \\
\hline $\begin{array}{l}\text { Data de quando } \\
\text { corte informou que } \\
\text { cumpriu }\end{array}$ & Informação não disponível & Informação não disponível & Informação não disponível \\
\hline
\end{tabular}

\begin{tabular}{|c|c|}
\hline Região & Norte \\
\hline UF & PA \\
\hline N. Processo & Comissão \\
\hline Órgão & Cumprimento de Recomendações \\
\hline Fase & Recomendações da CmDH \\
\hline Tipos de decisão & João Canuto de Oliveira \\
\hline Nome do Caso & $27 / 05 / 1994$ \\
\hline $\begin{array}{l}\text { Data de Início do } \\
\text { Casoa CmDHe nNome do }\end{array}$ & $18 / 12 / 1985$ \\
\hline $\begin{array}{c}\text { Data da Alegada } \\
\text { Violação }\end{array}$ & \\
\hline
\end{tabular}




\begin{tabular}{|c|c|c|c|}
\hline $\begin{array}{c}\text { Data do veredito da } \\
\text { CmDH }\end{array}$ & \multicolumn{3}{|c|}{$07 / 04 / 1998$} \\
\hline $\begin{array}{c}\text { Data de envio à } \\
\text { CrDH }\end{array}$ & \multicolumn{3}{|c|}{ Não se aplica } \\
\hline $\begin{array}{l}\text { Data da sentença da } \\
\text { CORTE }\end{array}$ & \multicolumn{3}{|c|}{ Não se aplica } \\
\hline $\begin{array}{l}\text { Número dos } \\
\text { Informes }\end{array}$ & \multicolumn{3}{|c|}{ N. $24 / 98$} \\
\hline Peticionários & \multicolumn{3}{|c|}{ Centro pela Justiça e o Direito Internacional (CEJIL) } \\
\hline $\begin{array}{l}\text { Peticionários } \\
\text { classificados }\end{array}$ & \multicolumn{3}{|c|}{ ONGs internacionais } \\
\hline Artigos Invocados & \multicolumn{3}{|c|}{ CADH: 8 e 25} \\
\hline Resumo dos fatos & \multicolumn{3}{|c|}{$\begin{array}{c}\text { Denúncia sobre a falta de investigação e punição dos responsáveis pelo homicídio delíder de } \\
\text { trabalhadores rurais no Pará }\end{array}$} \\
\hline Tema das violações & \multicolumn{3}{|c|}{ Violência no campo } \\
\hline $\begin{array}{l}\text { Resoluções, recom. } \\
\text { MP e MC }\end{array}$ & $\begin{array}{l}\text { 1. Al Estado brasileño que sus } \\
\text { órganos correspondientes } \\
\text { impulsen, con la debida } \\
\text { diligencia, el proceso penal, y } \\
\text { que sus órganos } \\
\text { jurisdiccionales competentes } \\
\text { juzguen de manera pronta e } \\
\text { imparcial, sancionando en su } \\
\text { oportunidad y de acuerdo a la } \\
\text { gravedad del delito cometido y } \\
\text { las leyes aplicables, a aquellos } \\
\text { individuos involucrados en el } \\
\text { asesinato de João Canuto }\end{array}$ & $\begin{array}{l}\text { 2. Al Estado brasileño que } \\
\text { indemnice mediante el } \\
\text { pago de una suma } \\
\text { compensatoria a los } \\
\text { familiares de la víctima, el } \\
\text { daño causado como } \\
\text { consecuencia de las } \\
\text { actividades ilícitas y } \\
\text { negligencia en la actuación } \\
\text { y ejercicio del poder } \\
\text { público por parte del } \\
\text { Estado y sus agentes en } \\
\text { este caso }\end{array}$ & $\begin{array}{l}\text { 3. Al Estado brasileño que, de } \\
\text { acuerdo con el artículo } 28.2 \text { de } \\
\text { la Convención, tome de } \\
\text { inmediato las medidas } \\
\text { pertinentes, conforme a su } \\
\text { constitución y sus leyes, a fin de } \\
\text { que las autoridades competentes } \\
\text { del Estado de Pará puedan } \\
\text { adoptar las disposiciones del } \\
\text { caso para el cumplimiento de } \\
\text { los compromisos establecidos } \\
\text { en la Convención Americana } \\
\text { sobre Derechos Humanos }\end{array}$ \\
\hline $\begin{array}{l}\text { Tipos das resoluções } \\
\text { e recom. }\end{array}$ & $\begin{array}{l}\text { Investigação e sanção sem } \\
\text { reforma legal }\end{array}$ & $\begin{array}{l}\text { Reparação econômica } \\
\text { monetária }\end{array}$ & $\begin{array}{l}\text { Prevenção por meio de reformas } \\
\text { jurídicas }\end{array}$ \\
\hline $\begin{array}{l}\text { Objetos das as } \\
\text { resoluções e } \\
\text { recomendações } \\
\end{array}$ & $\begin{array}{c}\text { Investigação e } \\
\text { responsabilização de violações } \\
\text { de direitos humanos } \\
\end{array}$ & $\begin{array}{l}\text { Recompensação de } \\
\text { pessoas ou grupos }\end{array}$ & $\begin{array}{l}\text { Prevenção de futuras violações } \\
\text { de direitos }\end{array}$ \\
\hline Compliance & Cumpriu totalmente & Cumpriu totalmente & Cumpriu totalmente \\
\hline $\begin{array}{l}\text { Data de quando } \\
\text { corte informou que } \\
\text { cumpriu }\end{array}$ & $13 / 04 / 2000$ & $13 / 04 / 2000$ & $13 / 04 / 2000$ \\
\hline
\end{tabular}

\begin{tabular}{|c|c|}
\hline Região & Sudeste \\
\hline UF & RJ \\
\hline N. Processo & 11.566 \\
\hline Órgão & Corte \\
\hline Fase & Etapa de Fundo \\
\hline Tipos de decisão & Recomendações da CmDH \\
\hline Nome do Caso & Favela Nova Brasília (Evandro Oliveira e outros) \\
\hline
\end{tabular}




\begin{tabular}{|c|c|c|c|c|}
\hline $\begin{array}{l}\text { Data de Início do } \\
\text { Trâmite nNome do } \\
\text { Casoa CmDH }\end{array}$ & \multicolumn{4}{|c|}{$18 / 04 / 2000$} \\
\hline $\begin{array}{c}\text { Data da Alegada } \\
\text { Violação }\end{array}$ & \multicolumn{4}{|c|}{$18 / 10 / 1994$} \\
\hline $\begin{array}{c}\text { Data do veredito da } \\
\mathrm{CmDH}\end{array}$ & \multicolumn{4}{|c|}{$31 / 10 / 2011$} \\
\hline $\begin{array}{c}\text { Data de envio à } \\
\text { CrDH }\end{array}$ & \multicolumn{4}{|c|}{$19 / 05 / 2015$} \\
\hline $\begin{array}{c}\text { Data da sentença da } \\
\text { CORTE }\end{array}$ & \multicolumn{4}{|c|}{ Não se aplica } \\
\hline $\begin{array}{l}\text { Número dos } \\
\text { Informes }\end{array}$ & \multicolumn{4}{|c|}{ N. $141 / 11$ E N. $78 / 98$} \\
\hline Peticionários & \multicolumn{4}{|c|}{ Centro pela Justiça e o Direito Internacional (CEJIL)Human Rights Watch/Americas } \\
\hline $\begin{array}{l}\text { Peticionários } \\
\text { classificados }\end{array}$ & \multicolumn{4}{|c|}{ ONGs internacionais } \\
\hline Artigos Invocados & \multicolumn{4}{|c|}{ CADH: 4,8 e 25} \\
\hline Resumo dos fatos & \multicolumn{4}{|c|}{$\begin{array}{l}\text { Denúncia sobre execuções extrajudiciais de } 26 \text { pessoas - incluindo seis crianças - no âmbito } \\
\text { das incursões policiais feitas pela Polícia Civil do Rio de Janeiro na Favela Nova Brasília. Estas } \\
\text { mortes foram justificadas pelas autoridades policiais mediante o levantamento de "atas de } \\
\text { resistência à prisão". }\end{array}$} \\
\hline Tema das violações & \multicolumn{4}{|c|}{$\begin{array}{l}\text { Violência policial } \\
\text { Violência contra menores } \\
\text { Prestação de Justiça }\end{array}$} \\
\hline $\begin{array}{l}\text { Resoluções, recom. } \\
\text { MP e MC }\end{array}$ & $\begin{array}{l}\text { 1.Faça uma investigação } \\
\text { exaustiva, imparcial e } \\
\text { eficaz das violações } \\
\text { descritas no relatório, em } \\
\text { um prazo razoável, por } \\
\text { parte de autoridades } \\
\text { judiciais independentes } \\
\text { da polícia, com vistas a } \\
\text { determinar a verdade e } \\
\text { punir os responsáveis. A } \\
\text { investigação deve levar } \\
\text { em conta os vínculos } \\
\text { existentes entre as } \\
\text { violações de direitos } \\
\text { humanos descritas no } \\
\text { relatório e o padrão de } \\
\text { uso excessivo da força } \\
\text { letal por parte da polícia. } \\
\text { Devem também ser } \\
\text { consideradas as possíveis } \\
\text { omissões, atrasos, } \\
\text { negligências e obstruções } \\
\text { na justiça provocadas por } \\
\text { agentes do Estado }\end{array}$ & $\begin{array}{l}\text { 2. Adote todas as } \\
\text { medidas } \\
\text { necessárias para } \\
\text { garantir uma } \\
\text { compensação } \\
\text { adequada e } \\
\text { completa tanto } \\
\text { pelos danos } \\
\text { morais como } \\
\text { pelos danos } \\
\text { materiais gerados } \\
\text { pelas violações } \\
\text { que a Corte } \\
\text { estabelecer em } \\
\text { sua Sentença }\end{array}$ & $\begin{array}{l}\text { 3. Elimine } \\
\text { imediatamente a } \\
\text { prática de } \\
\text { registrar } \\
\text { automaticament } \\
\text { e as mortes } \\
\text { perpetradas pela } \\
\text { polícia como } \\
\text { "resistência à } \\
\text { prisão". }\end{array}$ & $\begin{array}{l}\text { 4. Erradique a impunidade } \\
\text { da violência policial em } \\
\text { geral, adaptando suas leis } \\
\text { internas, regulamentações } \\
\text { administrativas, } \\
\text { procedimentos e planos } \\
\text { operacionais das } \\
\text { instituições com } \\
\text { competência em políticas } \\
\text { de segurança do cidadão, a } \\
\text { fim de garantir que sejam } \\
\text { capazes de prevenir, } \\
\text { investigar e punir qualquer } \\
\text { violação de direitos } \\
\text { humanos resultante dos } \\
\text { atos de violência } \\
\text { cometidos por agentes do } \\
\text { Estado. }\end{array}$ \\
\hline $\begin{array}{c}\text { Tipos das resoluções } \\
\text { e recom. }\end{array}$ & $\begin{array}{l}\text { Investigação e sanção } \\
\text { com reforma legal }\end{array}$ & $\begin{array}{l}\text { Reparação } \\
\text { econômica } \\
\text { monetária }\end{array}$ & Outros & $\begin{array}{l}\text { Prevenção por meio de } \\
\text { reformas jurídicas }\end{array}$ \\
\hline $\begin{array}{l}\text { Objetos das as } \\
\text { resoluções e }\end{array}$ & $\begin{array}{c}\text { Investigação e } \\
\text { responsabilização de }\end{array}$ & $\begin{array}{l}\text { Recompensação } \\
\text { de pessoas ou }\end{array}$ & $\begin{array}{l}\text { Proteção de } \\
\text { vítimas e }\end{array}$ & $\begin{array}{l}\text { Prevenção de futuras } \\
\text { violações de direitos }\end{array}$ \\
\hline
\end{tabular}




\begin{tabular}{|c|c|c|c|c|}
\hline recomendações & $\begin{array}{c}\text { violações de direitos } \\
\text { humanos }\end{array}$ & grupos & $\begin{array}{l}\text { testemunhas e } \\
\text { outros }\end{array}$ & \\
\hline Compliance & Não cumpriu & Não cumpriu & Não cumpriu & Não cumpriu \\
\hline $\begin{array}{l}\text { Data de quando } \\
\text { corte informou que } \\
\text { cumpriu }\end{array}$ & $19 / 05 / 2015$ & $19 / 05 / 2015$ & $19 / 05 / 2015$ & $19 / 05 / 2015$ \\
\hline $\begin{array}{c}\text { Resoluções, recom. } \\
\text { MP e MC }\end{array}$ & $\begin{array}{l}\text { 5. Estabeleça sistemas de } \\
\text { controle e prestação de } \\
\text { contas internos e } \\
\text { externos para tornar } \\
\text { efetivo o dever de } \\
\text { investigar, com uma } \\
\text { perspectiva de gênero e } \\
\text { étnicorracial, todos os } \\
\text { casos em que os agentes } \\
\text { da ordem utilizam a } \\
\text { força letal e/ou a } \\
\text { violência sexual, bem } \\
\text { como fortaleça a } \\
\text { capacidade institucional } \\
\text { de órgãos independentes } \\
\text { de supervisão, inclusive } \\
\text { os órgãos forenses, para } \\
\text { enfrentar o padrão de } \\
\text { impunidade dos casos de } \\
\text { execuções extrajudiciais } \\
\text { por parte da polícia }\end{array}$ & $\begin{array}{l}\text { 6. Implemente } \\
\text { planos para } \\
\text { modernizar e } \\
\text { profissionalizar as } \\
\text { forças policiais, } \\
\text { assegurando a } \\
\text { prestação de } \\
\text { contas por abusos } \\
\text { do passado } \\
\text { mediante a } \\
\text { expulsão de } \\
\text { conhecidos } \\
\text { perpetradores dos } \\
\text { órgãos de } \\
\text { segurança do } \\
\text { Estado, bem como } \\
\text { de outros cargos } \\
\text { de autoridade e } \\
\text { fazendo ajustes } \\
\text { em sua filosofia } \\
\text { institucional para } \\
\text { cumprir os } \\
\text { padrões e } \\
\text { princípios } \\
\text { internacionais de } \\
\text { direitos humanos } \\
\text { relativos à } \\
\text { segurança do } \\
\text { cidadão } \\
\end{array}$ & $\begin{array}{l}\text { 7. Capacite } \\
\text { adequadamente } \\
\text { o pessoal } \\
\text { policial no } \\
\text { modo de tratar } \\
\text { de maneira } \\
\text { eficaz e } \\
\text { eficiente as } \\
\text { pessoas } \\
\text { provenientes } \\
\text { dos setores mais } \\
\text { vulneráveis da } \\
\text { sociedade, } \\
\text { incluindo } \\
\text { crianças, } \\
\text { mulheres e } \\
\text { moradores de } \\
\text { favelas, visando } \\
\text { a superar o } \\
\text { estigma de que } \\
\text { todos os pobres } \\
\text { são criminosos. }\end{array}$ & $\begin{array}{l}\text { 8. Regule legalmente, tanto } \\
\text { no aspecto formal como } \\
\text { material, os procedimentos } \\
\text { policiais que envolvam o } \\
\text { uso legítimo da força, } \\
\text { estipulando expressamente } \\
\text { que só se pode recorrer a } \\
\text { este extremo como último } \\
\text { recurso e que o uso da } \\
\text { força deve estar inspirado } \\
\text { nos princípios de } \\
\text { excepcionalidade, } \\
\text { necessidade e } \\
\text { proporcionalidade. A este } \\
\text { respeito, o Estado deve } \\
\text { levar em conta, entre } \\
\text { outros, os Princípios } \\
\text { Básicos das Nações Unidas } \\
\text { sobre o Emprego da Força } \\
\text { e de Armas de Fogo pelos } \\
\text { Funcionários Encarregados } \\
\text { de Fazer Cumprir a Lei e } \\
\text { os Princípios das Nações } \\
\text { Unidas Relativos a uma } \\
\text { Eficaz Prevenção e } \\
\text { Investigação das } \\
\text { Execuções Extralegais, } \\
\text { Arbitrárias ou Sumárias }\end{array}$ \\
\hline $\begin{array}{c}\text { Tipos das resoluções } \\
\text { e recom. }\end{array}$ & $\begin{array}{l}\text { Prevenção por meio de } \\
\text { reformas jurídicas }\end{array}$ & $\begin{array}{l}\text { Prevenção por } \\
\text { meio da formação } \\
\text { de agentes } \\
\text { públicos }\end{array}$ & $\begin{array}{c}\text { Prevenção por } \\
\text { meio da } \\
\text { formação de } \\
\text { agentes públicos }\end{array}$ & $\begin{array}{l}\text { Prevenção por meio de } \\
\text { reformas jurídicas }\end{array}$ \\
\hline $\begin{array}{l}\text { Objetos das as } \\
\text { resoluções e } \\
\text { recomendações }\end{array}$ & $\begin{array}{l}\text { Prevenção de futuras } \\
\text { violações de direitos }\end{array}$ & $\begin{array}{c}\text { Prevenção de } \\
\text { futuras violações } \\
\text { de direitos }\end{array}$ & $\begin{array}{l}\text { Prevenção de } \\
\text { futuras } \\
\text { violações de } \\
\text { direitos }\end{array}$ & $\begin{array}{l}\text { Prevenção de futuras } \\
\text { violações de direitos }\end{array}$ \\
\hline Compliance & Não cumpriu & Não cumpriu & Não cumpriu & Não cumpriu \\
\hline $\begin{array}{c}\text { Data de quando } \\
\text { corte informou que } \\
\text { cumpriu }\end{array}$ & $19 / 05 / 2015$ & $19 / 05 / 2015$ & $19 / 05 / 2015$ & $19 / 05 / 2015$ \\
\hline
\end{tabular}

\begin{tabular}{|c|c|}
\hline Região & Norte \\
\hline UF & PA \\
\hline N. Processo & 12.066 \\
\hline Órgão & Corte \\
\hline Fase & Etapa de Fundo \\
\hline
\end{tabular}




\begin{tabular}{|c|c|c|c|c|}
\hline Tipos de decisão & \multicolumn{4}{|c|}{ Recomendações da $\mathrm{CmDH}$} \\
\hline Nome do Caso & \multicolumn{4}{|c|}{ Fazenda Brasil Verde } \\
\hline $\begin{array}{l}\text { Data de Início do } \\
\text { Trâmite nNome do } \\
\text { Casoa CmDH }\end{array}$ & \multicolumn{4}{|c|}{$12 / 11 / 1998$} \\
\hline $\begin{array}{l}\text { Data da Alegada } \\
\text { Violação }\end{array}$ & \multicolumn{4}{|c|}{$21 / 12 / 1988$} \\
\hline $\begin{array}{c}\text { Data do veredito da } \\
\mathrm{CmDH}\end{array}$ & \multicolumn{4}{|c|}{$03 / 11 / 2011$} \\
\hline $\begin{array}{c}\text { Data de envio à } \\
\text { CrDH }\end{array}$ & \multicolumn{4}{|c|}{$06 / 03 / 2015$} \\
\hline $\begin{array}{l}\text { Data da sentença da } \\
\text { CORTE }\end{array}$ & \multicolumn{4}{|c|}{ Não se aplica } \\
\hline $\begin{array}{l}\text { Número dos } \\
\text { Informes }\end{array}$ & \multicolumn{4}{|c|}{ N. $169 / 11$} \\
\hline Peticionários & \multicolumn{4}{|c|}{ CEJILCPT } \\
\hline $\begin{array}{l}\text { Peticionários } \\
\text { classificados }\end{array}$ & \multicolumn{4}{|c|}{ ONGs nacionais em parceria com ONGs internacionais } \\
\hline Artigos Invocados & \multicolumn{4}{|c|}{$\begin{array}{l}\text { Declaração: I, XVI e XXV } \\
\text { CADH: } 6,8 \text { e } 25 .\end{array}$} \\
\hline Resumo dos fatos & \multicolumn{4}{|c|}{$\begin{array}{l}\text { Denúncia sobre a situação de trabalho escravo de milhares de trabalhadores em fazenda no } \\
\text { Pará, desaparecimento de menores e denegação de justiça pelo Estado }\end{array}$} \\
\hline Tema das violações & \multicolumn{4}{|c|}{$\begin{array}{l}\text { Violência no campo } \\
\text { Trabalho Escravo } \\
\text { Prestação de Justiça }\end{array}$} \\
\hline $\begin{array}{l}\text { Resoluções, recom. } \\
\text { MP e MC }\end{array}$ & $\begin{array}{l}\text { 1. Reparar } \\
\text { adecuadamente } \\
\text { las violaciones de } \\
\text { derechos humanos } \\
\text { tanto en el aspecto } \\
\text { material como } \\
\text { moral. En } \\
\text { especial, el Estado } \\
\text { debe asegurar que } \\
\text { se restituya a las } \\
\text { víctimas los } \\
\text { salarios debidos } \\
\text { por el trabajo } \\
\text { realizado, así } \\
\text { como las sumas } \\
\text { de dinero } \\
\text { ilegalmente } \\
\text { sustraídas de } \\
\text { ellos. De ser } \\
\text { necesario, dicha } \\
\text { restitución podrá } \\
\text { hacerse de las } \\
\text { ganancias ilegales } \\
\text { de los dueños de } \\
\text { las fazendas. }\end{array}$ & $\begin{array}{l}\text { 2.Llevar a cabo una } \\
\text { investigación de los } \\
\text { hechos relacionados } \\
\text { con las violaciones de } \\
\text { derechos humanos } \\
\text { declaradas en el } \\
\text { informe en relación } \\
\text { con el trabajo esclavo } \\
\text { y conducir las } \\
\text { investigaciones de } \\
\text { manera imparcial, } \\
\text { efectiva y dentro de } \\
\text { un plazo razonable } \\
\text { con el objeto de } \\
\text { esclarecer los hechos } \\
\text { en forma completa, } \\
\text { identificar a los } \\
\text { responsables e } \\
\text { imponer las sanciones } \\
\text { que correspondan. }\end{array}$ & $\begin{array}{l}\text { 3.Llevar a cabo } \\
\text { una investigación } \\
\text { de los hechos } \\
\text { relacionados con } \\
\text { la desaparición de } \\
\text { Iron Canuto da } \\
\text { Silva y Luis } \\
\text { Ferreira da Cruz y } \\
\text { conducir las } \\
\text { investigaciones de } \\
\text { manera imparcial, } \\
\text { efectiva y dentro } \\
\text { de un plazo } \\
\text { razonable con el } \\
\text { objeto de } \\
\text { esclarecer los } \\
\text { hechos en forma } \\
\text { completa, } \\
\text { identificar a los } \\
\text { responsables e } \\
\text { imponer las } \\
\text { sanciones que } \\
\text { correspondan. }\end{array}$ & $\begin{array}{l}\text { 4.Disponer las medidas } \\
\text { administrativas, } \\
\text { disciplinarias o penales } \\
\text { correspondientes frente a las } \\
\text { acciones u omisiones de los } \\
\text { funcionarios estatales que } \\
\text { contribuyeron a la } \\
\text { denegación de justicia e } \\
\text { impunidad en la que se } \\
\text { encuentran los hechos del } \\
\text { caso. En ese sentido, se debe } \\
\text { poner especial énfasis en que } \\
\text { se abrieron procesos } \\
\text { administrativos y no penales } \\
\text { para la investigación de } \\
\text { desapariciones; que se } \\
\text { abrieron procesos } \\
\text { administrativos y laborales } \\
\text { para la investigación de } \\
\text { trabajo esclavo, y que la } \\
\text { única investigación penal } \\
\text { abierta en relación con dicho } \\
\text { delito prescribió. }\end{array}$ \\
\hline
\end{tabular}




\begin{tabular}{|c|c|c|c|c|c|c|c|}
\hline $\begin{array}{c}\text { Tipos das resoluções } \\
\text { e recom. }\end{array}$ & $\begin{array}{l}\text { Reparação } \\
\text { econômica } \\
\text { monetária }\end{array}$ & \multicolumn{2}{|c|}{$\begin{array}{c}\text { Investigação e sanção } \\
\text { sem reforma legal }\end{array}$} & \multicolumn{2}{|c|}{$\begin{array}{l}\text { Investigação e } \\
\text { sanção sem } \\
\text { reforma legal }\end{array}$} & \multicolumn{2}{|c|}{$\begin{array}{l}\text { Investigação e sanção com } \\
\text { reforma legal }\end{array}$} \\
\hline $\begin{array}{l}\text { Objetos das as } \\
\text { resoluções e } \\
\text { recomendações }\end{array}$ & $\begin{array}{l}\text { Recompensação } \\
\text { de pessoas ou } \\
\text { grupos }\end{array}$ & \multicolumn{2}{|c|}{$\begin{array}{c}\text { Investigação e } \\
\text { responsabilização de } \\
\text { violações de direitos } \\
\text { humanos }\end{array}$} & \multicolumn{2}{|c|}{$\begin{array}{c}\text { Investigação e } \\
\text { responsabilização } \\
\text { de violações de } \\
\text { direitos humanos }\end{array}$} & \multicolumn{2}{|c|}{$\begin{array}{c}\text { Investigação e } \\
\text { responsabilização de } \\
\text { violações de direitos } \\
\text { humanos }\end{array}$} \\
\hline Compliance & Não cumpriu & \multicolumn{2}{|c|}{ Não cumpriu } & \multicolumn{2}{|c|}{ Não cumpriu } & & Não cumpriu \\
\hline $\begin{array}{c}\text { Data de quando } \\
\text { corte informou que } \\
\text { cumpriu }\end{array}$ & $06 / 03 / 2015$ & \multicolumn{2}{|c|}{$06 / 03 / 2015$} & \multicolumn{2}{|c|}{$06 / 03 / 2015$} & & $06 / 03 / 2015$ \\
\hline $\begin{array}{c}\text { Resoluções, recom. } \\
\text { MP e MC }\end{array}$ & $\begin{array}{l}\text { 5.Establecer } \\
\text { un mecanismo } \\
\text { que facilite la } \\
\text { localización } \\
\text { de las víctimas } \\
\text { de trabajo } \\
\text { esclavo así } \\
\text { como de Iron } \\
\text { Canuto da } \\
\text { Silva, Luis } \\
\text { Ferreira da } \\
\text { Cruz, Adailton } \\
\text { Martins dos } \\
\text { Reis, José } \\
\text { Soriano Da } \\
\text { Costa, así } \\
\text { como de los } \\
\text { familiares de } \\
\text { los dos } \\
\text { primeros, José } \\
\text { Teodoro da } \\
\text { Silva y Miguel } \\
\text { Ferreira da } \\
\text { Cruz, con el } \\
\text { fin de } \\
\text { repararlos. }\end{array}$ & $\begin{array}{l}\text { 6.Continuar } \\
\text { implementand } \\
\text { o políticas } \\
\text { públicas, así } \\
\text { como medidas } \\
\text { legislativas y } \\
\text { de otra índole } \\
\text { de } \\
\text { erradicación } \\
\text { del trabajo } \\
\text { esclavo. En } \\
\text { especial, el } \\
\text { Estado debe } \\
\text { monitorear la } \\
\text { aplicación y } \\
\text { sanción de } \\
\text { personas } \\
\text { responsables } \\
\text { de trabajo } \\
\text { esclavo, en } \\
\text { todos los } \\
\text { niveles. }\end{array}$ & $\begin{array}{l}\text { 7.Fortale } \\
\text { sistema 1 } \\
\text { crear } \\
\text { mecanis } \\
\text { coordina } \\
\text { entre la } \\
\text { jurisdicc } \\
\text { penal y 1 } \\
\text { jurisdicc } \\
\text { laboral p } \\
\text { superar 1 } \\
\text { vacíos q } \\
\text { generan } \\
\text { investiga } \\
\text { procesan } \\
\text { sanción } \\
\text { personas } \\
\text { responsa } \\
\text { los delitc } \\
\text { servidun } \\
\text { trabajo f }\end{array}$ & $\begin{array}{l}\text { er el } \\
\text { gal y } \\
\text { os de } \\
\text { ión } \\
\text { on } \\
\text { fn } \\
\text { ra } \\
\text { s } \\
\text { e se } \\
\text { nla } \\
\text { ión, } \\
\text { ento y } \\
\text { e las } \\
\text { les de } \\
\text { de } \\
\text { re y } \\
\text { zzoso. }\end{array}$ & $\begin{array}{l}\text { 8. Velar p } \\
\text { estricto } \\
\text { cumplimi } \\
\text { las leyes } 1 \\
\text { relativas a } \\
\text { jornadas } 1 \\
\text { y el pago } \\
\text { igualdad a } \\
\text { demás } \\
\text { trabajador } \\
\text { asalariado }\end{array}$ & $\begin{array}{l}\text { el } \\
\text { o de } \\
\text { orales } \\
\text { s } \\
\text { orales } \\
\text { los }\end{array}$ & $\begin{array}{l}\text { 9.Adoptar las } \\
\text { medidas necesarias } \\
\text { para erradicar todo } \\
\text { tipo de } \\
\text { discriminación } \\
\text { racial, } \\
\text { particularmente } \\
\text { llevar a cabo } \\
\text { campañas de } \\
\text { promoción para } \\
\text { concientizar a la } \\
\text { población nacional } \\
\text { y funcionarios del } \\
\text { Estado -incluidos } \\
\text { los operadores de } \\
\text { justicia- sobre la } \\
\text { discriminación y el } \\
\text { sometimiento a } \\
\text { servidumbre y } \\
\text { trabajo forzoso }\end{array}$ \\
\hline
\end{tabular}




\begin{tabular}{|c|c|c|c|c|c|}
\hline $\begin{array}{c}\text { Tipos das resoluções } \\
\text { e recom. }\end{array}$ & $\begin{array}{l}\text { Proteção de } \\
\text { vítimas e } \\
\text { testemunhas }\end{array}$ & Outros & $\begin{array}{l}\text { Prevenção por } \\
\text { meio do } \\
\text { fortalecimento, } \\
\text { criação, ou } \\
\text { reforma de } \\
\text { instituições } \\
\text { públicas }\end{array}$ & $\begin{array}{l}\text { Prevenção por } \\
\text { meio do } \\
\text { fortalecimento, } \\
\text { criação, ou } \\
\text { reforma de } \\
\text { instituições } \\
\text { públicas }\end{array}$ & $\begin{array}{c}\text { Investigação e } \\
\text { sanção sem reforma } \\
\text { legal }\end{array}$ \\
\hline $\begin{array}{l}\text { Objetos das as } \\
\text { resoluções e } \\
\text { recomendações }\end{array}$ & $\begin{array}{l}\text { Proteção de } \\
\text { vítimas e } \\
\text { testemunhas e } \\
\text { outros }\end{array}$ & $\begin{array}{l}\text { Proteção de } \\
\text { vítimas e } \\
\text { testemunhas e } \\
\text { outros }\end{array}$ & $\begin{array}{l}\text { Prevenção de } \\
\text { futuras } \\
\text { violações de } \\
\text { direitos }\end{array}$ & $\begin{array}{c}\text { Prevenção de } \\
\text { futuras violações } \\
\text { de direitos }\end{array}$ & $\begin{array}{l}\text { Investigação e } \\
\text { responsabilização } \\
\text { de violações de } \\
\text { direitos humanos }\end{array}$ \\
\hline Compliance & Não cumpriu & Não cumpriu & Não cumpriu & Não cumpriu & Não cumpriu \\
\hline $\begin{array}{l}\text { Data de quando } \\
\text { corte informou que } \\
\text { cumpriu }\end{array}$ & $06 / 03 / 2015$ & $06 / 03 / 2015$ & $06 / 03 / 2015$ & $06 / 03 / 2015$ & $06 / 03 / 2015$ \\
\hline
\end{tabular}

\begin{tabular}{|c|c|}
\hline Região & Norte \\
\hline UF & PA \\
\hline N. Processo & 11.289 \\
\hline Órgão & Comissão \\
\hline Fase & Solução Amistosa \\
\hline Tipos de decisão & Cumprimento de Acordo de Solução Amistosa \\
\hline Nome do Caso & José Pereira e outros \\
\hline $\begin{array}{l}\text { Data de Início do } \\
\text { Trâmite nNome do } \\
\text { Casoa CmDH }\end{array}$ & $16 / 11 / 1994$ \\
\hline $\begin{array}{l}\text { Data da Alegada } \\
\text { Violação }\end{array}$ & $01 / 09 / 1989$ \\
\hline $\begin{array}{l}\text { Data do veredito da } \\
\text { CmDH }\end{array}$ & $02 / 10 / 2003$ \\
\hline $\begin{array}{c}\text { Data de envio à } \\
\text { CrDH }\end{array}$ & Não se aplica \\
\hline $\begin{array}{l}\text { Data da sentença da } \\
\text { CORTE }\end{array}$ & Não se aplica \\
\hline $\begin{array}{l}\text { Número dos } \\
\text { Informes }\end{array}$ & N. $95 / 93$ \\
\hline Peticionários & Centro pela Justiça e o Direito Internacional (CEJIL)Human Rights Watch/Americas \\
\hline $\begin{array}{l}\begin{array}{l}\text { Peticionários } \\
\text { classificados }\end{array} \\
\end{array}$ & ONGs internacionais \\
\hline Artigos Invocados & $\begin{array}{c}\text { Declaração: I, XIV e XXV. } \\
\text { CADH: } 1.1,6,8 \text { e } 25 . \\
\end{array}$ \\
\hline Resumo dos fatos & $\begin{array}{c}\text { Denúncia sobre redução de trabalhadores a condições análogas à escravidão e de demora na } \\
\text { tomada de providências. }\end{array}$ \\
\hline
\end{tabular}




\begin{tabular}{|c|c|c|c|c|c|c|c|}
\hline Tema das violações & \multicolumn{7}{|c|}{$\begin{array}{l}\text { Violência no campo } \\
\text { Trabalho Escravo } \\
\text { Prestação de Justiça }\end{array}$} \\
\hline $\begin{array}{l}\text { Resoluções, } \\
\text { recom. MP e MC }\end{array}$ & $\begin{array}{l}\text { 1. A fim de } \\
\text { melhorar a } \\
\text { Legislação } \\
\text { Nacional, } \\
\text { que tem } \\
\text { como } \\
\text { objetivo } \\
\text { proibir a } \\
\text { prática do } \\
\text { trabalho } \\
\text { escravo no } \\
\text { país, o } \\
\text { Estado } \\
\text { brasileiro } \\
\text { compromete- } \\
\text { se a } \\
\text { implementar } \\
\text { as ações e as } \\
\text { propostas de } \\
\text { mudanças } \\
\text { legislativas } \\
\text { contidas no } \\
\text { Plano } \\
\text { Nacional } \\
\text { para a } \\
\text { Erradicação } \\
\text { do Trabalho } \\
\text { Escravo, } \\
\text { elaborado } \\
\text { pela } \\
\text { Comissão } \\
\text { Especial do } \\
\text { Conselho de } \\
\text { Defesa dos } \\
\text { Direitos da } \\
\text { Pessoa } \\
\text { Humana, e } \\
\text { iniciado pelo } \\
\text { Governo } \\
\text { brasileiro em } \\
\text { 11 de março } \\
\text { de 2003. } \\
\end{array}$ & $\begin{array}{l}\text { 2. O Estado } \\
\text { brasileiro } \\
\text { compromete-se a } \\
\text { efetuar todos os } \\
\text { esforços para a } \\
\text { aprovação } \\
\text { legislativa (i) do } \\
\text { Projeto de Lei No } \\
\text { 2130-A, de } 1996 \\
\text { que inclui, entre as } \\
\text { infrações contra a } \\
\text { ordem econômica, a } \\
\text { utilização de } \\
\text { mecanismos } \\
\text { "ilegítimos da } \\
\text { redução dos custos } \\
\text { de produção como } \\
\text { o não pagamento } \\
\text { dos impostos } \\
\text { trabalhistas e } \\
\text { sociais, exploração } \\
\text { do trabalho infantil, } \\
\text { escravo o semi- } \\
\text { escravo"; e (ii) o } \\
\text { Substitutivo } \\
\text { apresentado pela } \\
\text { Deputada Zulaiê } \\
\text { Cobra ao projeto } \\
\text { de Lei No 5.693 do } \\
\text { Deputado Nelson } \\
\text { Pellegrino, que } \\
\text { modifica o artigo } \\
\text { 149 do Código } \\
\text { Penal Brasileiro. }\end{array}$ & $\begin{array}{l}3 . \text { o } \\
\text { Estado } \\
\text { brasileiro } \\
\text { comprom } \\
\text { ete-se a } \\
\text { defender } \\
\text { a } \\
\text { determin } \\
\text { ação da } \\
\text { competê } \\
\text { ncia } \\
\text { federal } \\
\text { para o } \\
\text { julgamen } \\
\text { to do } \\
\text { crime de } \\
\text { redução } \\
\text { análoga à } \\
\text { de } \\
\text { escravo, } \\
\text { com o } \\
\text { objetivo } \\
\text { de evitar } \\
\text { a } \\
\text { impunida } \\
\text { de. }\end{array}$ & $\begin{array}{l}\text { 4. } \\
\text { Consideran } \\
\text { do que as } \\
\text { propostas } \\
\text { legislativas } \\
\text { demandarã } \\
\text { o um } \\
\text { tempo } \\
\text { consideráv } \\
\text { el para } \\
\text { serem } \\
\text { implement } \\
\text { adas na } \\
\text { medida } \\
\text { que } \\
\text { dependem } \\
\text { da atuação } \\
\text { do } \\
\text { Congresso } \\
\text { Nacional, e } \\
\text { que a } \\
\text { gravidade } \\
\text { do } \\
\text { problema } \\
\text { da prática } \\
\text { do trabalho } \\
\text { escravo } \\
\text { requer a } \\
\text { tomada de } \\
\text { medidas } \\
\text { imediatas, } \\
\text { o Estado } \\
\text { compromet } \\
\text { e-se desde } \\
\text { já a: }\end{array}$ & $\begin{array}{l}\text { 4.1. (i) } \\
\text { fortalec } \\
\text { er o } \\
\text { Ministé } \\
\text { rio } \\
\text { Público } \\
\text { do } \\
\text { Trabalh } \\
\text { o; }\end{array}$ & $\begin{array}{l}\text { 4.2. (ii) velar } \\
\text { pelo } \\
\text { cumprimento } \\
\text { imediato da } \\
\text { legislação } \\
\text { existente, por } \\
\text { meio de } \\
\text { cobranças de } \\
\text { multas } \\
\text { administrativa } \\
\text { s e judiciais, } \\
\text { da } \\
\text { investigação e } \\
\text { a apresentação } \\
\text { de denúncias } \\
\text { contra os } \\
\text { autores da } \\
\text { prática de } \\
\text { trabalho } \\
\text { escravo; }\end{array}$ & $\begin{array}{l}4.3 . \\
\text { (iii) } \\
\text { fortal } \\
\text { ecer o } \\
\text { Grup } \\
\text { o } \\
\text { Móvil } \\
\text { do } \\
\text { MTE; }\end{array}$ \\
\hline $\begin{array}{l}\text { Tipos das } \\
\text { resoluções e } \\
\text { recom. }\end{array}$ & $\begin{array}{l}\text { Prevenção } \\
\text { por meio de } \\
\text { reformas } \\
\text { jurídicas }\end{array}$ & $\begin{array}{c}\text { Prevenção por meio } \\
\text { de reformas } \\
\text { jurídicas }\end{array}$ & $\begin{array}{l}\text { Prevençã } \\
\text { o por } \\
\text { meio de } \\
\text { reformas } \\
\text { jurídicas }\end{array}$ & $\begin{array}{c}\text { Prevenção } \\
\text { por meio } \\
\text { do } \\
\text { fortalecime } \\
\text { nto, } \\
\text { criação, ou } \\
\text { reforma de } \\
\text { instituições } \\
\text { públicas }\end{array}$ & $\begin{array}{c}\text { Preven } \\
\text { ção por } \\
\text { meio } \\
\text { do } \\
\text { fortalec } \\
\text { imento, } \\
\text { criação, } \\
\text { ou } \\
\text { reforma } \\
\text { de } \\
\text { institui } \\
\text { ções } \\
\end{array}$ & $\begin{array}{l}\text { Investigação e } \\
\text { sanção sem } \\
\text { reforma legal }\end{array}$ & $\begin{array}{c}\text { Preve } \\
\text { nção } \\
\text { por } \\
\text { meio } \\
\text { da } \\
\text { consc } \\
\text { ientiz } \\
\text { ação } \\
\text { da } \\
\text { popul } \\
\text { ação }\end{array}$ \\
\hline
\end{tabular}




\begin{tabular}{|c|c|c|c|c|c|c|c|c|c|}
\hline & & & & & & $\begin{array}{c}\text { pública } \\
\text { S }\end{array}$ & & & \\
\hline \multicolumn{2}{|c|}{$\begin{array}{l}\text { Objetos das as } \\
\text { resoluções e } \\
\text { recomendações }\end{array}$} & $\begin{array}{l}\text { Prevenção de } \\
\text { futuras } \\
\text { violações de } \\
\text { direitos }\end{array}$ & $\begin{array}{c}\text { Prevenção de } \\
\text { futuras violações de } \\
\text { direitos }\end{array}$ & $\begin{array}{l}\text { Prevençã } \\
\text { o de } \\
\text { futuras } \\
\text { violações } \\
\text { de } \\
\text { direitos }\end{array}$ & $\begin{array}{l}\text { Prevenção } \\
\text { de futuras } \\
\text { violações } \\
\text { de direitos }\end{array}$ & $\begin{array}{l}\text { Preven } \\
\text { ção de } \\
\text { futuras } \\
\text { violaçõ } \\
\text { es de } \\
\text { direitos }\end{array}$ & \multicolumn{2}{|c|}{$\begin{array}{l}\text { Investigação e } \\
\text { responsabiliza } \\
\text { ção de } \\
\text { violações de } \\
\text { direitos } \\
\text { humanos }\end{array}$} & $\begin{array}{c}\text { Preve } \\
\text { nção } \\
\text { de } \\
\text { futura } \\
\text { s } \\
\text { violaç } \\
\text { ões } \\
\text { de } \\
\text { direit } \\
\text { os }\end{array}$ \\
\hline \multicolumn{2}{|c|}{ Compliance } & $\begin{array}{c}\text { Cumpriu } \\
\text { parcialmente }\end{array}$ & $\begin{array}{c}\text { Cumpriu } \\
\text { parcialmente }\end{array}$ & $\begin{array}{c}\text { Não } \\
\text { cumpriu }\end{array}$ & $\begin{array}{l}\text { Cumpriu } \\
\text { parcialmen } \\
\text { te }\end{array}$ & $\begin{array}{c}\text { Cumpri } \\
\text { u } \\
\text { parcial } \\
\text { mente }\end{array}$ & \multicolumn{2}{|c|}{$\begin{array}{c}\text { Cumpriu } \\
\text { parcialmente }\end{array}$} & $\begin{array}{c}\text { Cump } \\
\text { riu } \\
\text { parcia } \\
\text { lment } \\
\text { e }\end{array}$ \\
\hline \multicolumn{2}{|c|}{$\begin{array}{l}\text { Data de quando } \\
\text { corte informou } \\
\text { que cumpriu }\end{array}$} & $07 / 05 / 2015$ & $07 / 05 / 2015$ & $\begin{array}{c}07 / 05 / 20 \\
15\end{array}$ & $17 / 10 / 2014$ & $\begin{array}{c}17 / 10 / 2 \\
014\end{array}$ & \multicolumn{2}{|c|}{$17 / 10 / 2014$} & $\begin{array}{l}17 / 10 \\
/ 2014\end{array}$ \\
\hline $\begin{array}{l}\text { Reso } \\
\text { luçõ } \\
\text { es, } \\
\text { reco } \\
\text { m. } \\
\text { MP } \\
\text { e } \\
\text { MC }\end{array}$ & $\begin{array}{l}\text { 4.4. (iv) } \\
\text { realizar } \\
\text { gestões } \\
\text { junto ao } \\
\text { Poder } \\
\text { Judiciário e } \\
\text { a suas } \\
\text { entidades } \\
\text { representati } \\
\text { vas, no } \\
\text { sentido de } \\
\text { garantir o } \\
\text { castigo dos } \\
\text { autores dos } \\
\text { crimes de } \\
\text { trabalho } \\
\text { escravo }\end{array}$ & $\begin{array}{l}\text { 5. O } \\
\text { Governo } \\
\text { compromete } \\
\text {-se a } \\
\text { revogar, até } \\
\text { o fim do } \\
\text { ano, por } \\
\text { meio de atos } \\
\text { administrativ } \\
\text { os que lhe } \\
\text { corresponda } \\
\text { m, o } \\
\text { Término de } \\
\text { Cooperação } \\
\text { assinado em } \\
\text { fevereiro de } \\
\text { 2001 entre } \\
\text { os } \\
\text { proprietários } \\
\text { de fazendas } \\
\text { e } \\
\text { autoridades } \\
\text { do } \\
\text { Ministério } \\
\text { de Trabalho } \\
\text { e do } \\
\text { Ministério }\end{array}$ & $\begin{array}{l}\text { 6. O Estado } \\
\text { brasileiro } \\
\text { compromete-se a } \\
\text { fortalecer } \\
\text { gradativamente a } \\
\text { Divisão de } \\
\text { Repressão ao } \\
\text { Trabalho Escravo e } \\
\text { de Segurança dos } \\
\text { Dignatários- } \\
\text { DTESD, criada no } \\
\text { âmbito do } \\
\text { Departamento da } \\
\text { Policía Federal por } \\
\text { meio da Portaria- } \\
\text { MJ No } 1.016, \text { de } 4 \\
\text { de setembro de } \\
\text { 2002, de maneira a } \\
\text { dotar a Divisão com } \\
\text { fundos e recursos } \\
\text { humanos adequados } \\
\text { para o bom } \\
\text { cumprimento das } \\
\text { funções da Polícia } \\
\text { Federal nas ações } \\
\text { de fiscalização de } \\
\text { denúncias de }\end{array}$ & $\begin{array}{l}\text { 7. O } \\
\text { Estado } \\
\text { brasileiro } \\
\text { comprom } \\
\text { ete-se a } \\
\text { diligenci } \\
\text { ar junto } \\
\text { ao } \\
\text { Ministéri } \\
\text { o Público } \\
\text { Federal, } \\
\text { com o } \\
\text { objetivo } \\
\text { de } \\
\text { ressaltar } \\
\text { a } \\
\text { importân } \\
\text { cia da } \\
\text { participa } \\
\text { ção e } \\
\text { acompan } \\
\text { hamento } \\
\text { das ações } \\
\text { de } \\
\text { fiscalizaç } \\
\text { ão de } \\
\text { trabalho }\end{array}$ & \multicolumn{3}{|c|}{$\begin{array}{l}\text { 8. O Estado brasileiro } \\
\text { realizará uma campanha } \\
\text { nacional de sensibilização } \\
\text { contra a prática do trabalho } \\
\text { escravo, prevista para } \\
\text { outubro de 2003, e com } \\
\text { um enfoque particular no } \\
\text { Estado do Pará. Nessa } \\
\text { oportunidade, mediante a } \\
\text { presença dos peticionários } \\
\text { dar-se-á publicidade aos } \\
\text { termos deste Acordo de } \\
\text { Solução Amistosa. A } \\
\text { campanha estará baseada } \\
\text { num plano de comunicação } \\
\text { que contemplará a } \\
\text { elaboração de material } \\
\text { informativo dirigido aos } \\
\text { trabalhadores, a inserção } \\
\text { do tema na mídia pela } \\
\text { imprensa e através de } \\
\text { difusão de curtas } \\
\text { publicitários. Também } \\
\text { estão previstas visitas de } \\
\text { autoridades nas áreas de } \\
\text { enfoque }\end{array}$} & \multicolumn{2}{|c|}{$\begin{array}{l}\text { 9. O Estado } \\
\text { brasileiro } \\
\text { compromete-se a } \\
\text { avaliar a } \\
\text { possibilidade de } \\
\text { realização de } \\
\text { seminários sobre } \\
\text { a erradicação do } \\
\text { trabalho escravo } \\
\text { no Estado do } \\
\text { Pará, até o } \\
\text { primeiro semestre } \\
\text { de 2004, com a } \\
\text { presença do } \\
\text { Ministério } \\
\text { Público Federal, } \\
\text { estendendo o } \\
\text { convite para a } \\
\text { participação dos } \\
\text { peticionários }\end{array}$} \\
\hline
\end{tabular}




\begin{tabular}{|c|c|c|c|c|c|c|}
\hline & & $\begin{array}{l}\text { Público do } \\
\text { Trabalho, e } \\
\text { que foi } \\
\text { denunciado } \\
\text { no presente } \\
\text { processo em } \\
28 \text { de } \\
\text { fevereiro de } \\
2001\end{array}$ & \multicolumn{2}{|r|}{$\begin{array}{l}\text { escravo } \\
\text { pelos } \\
\text { Procurad } \\
\text { ores } \\
\text { Federais }\end{array}$} & & \\
\hline $\begin{array}{l}\text { Tipo } \\
\text { s das } \\
\text { resol } \\
\text { uçõe } \\
\text { s e } \\
\text { reco } \\
\text { m. }\end{array}$ & $\begin{array}{c}\text { Prevenção } \\
\text { por meio do } \\
\text { fortalecime } \\
\text { nto, criação, } \\
\text { ou reforma } \\
\text { de } \\
\text { instituições } \\
\text { públicas }\end{array}$ & $\begin{array}{l}\text { Prevenção } \\
\text { por meio de } \\
\text { reformas } \\
\text { jurídicas }\end{array}$ & $\begin{array}{l}\text { Prevenção } \\
\text { por meio } \\
\text { do } \\
\text { fortalecime } \\
\text { nto, } \\
\text { criação, ou } \\
\text { reforma de } \\
\text { instituições } \\
\text { públicas }\end{array}$ & $\begin{array}{l}\text { Prevenção por } \\
\text { meio do } \\
\text { fortalecimento, } \\
\text { criação, ou } \\
\text { reforma de } \\
\text { instituições } \\
\text { públicas }\end{array}$ & $\begin{array}{l}\text { Prevenção por meio da } \\
\text { conscientização da } \\
\text { população }\end{array}$ & $\begin{array}{l}\text { Prevenção por } \\
\text { meio da } \\
\text { conscientização } \\
\text { da população }\end{array}$ \\
\hline $\begin{array}{c}\text { Obj } \\
\text { etos } \\
\text { das } \\
\text { as } \\
\text { resol } \\
\text { uçõe } \\
\text { s e } \\
\text { reco } \\
\text { men } \\
\text { daçõ } \\
\text { es }\end{array}$ & $\begin{array}{c}\text { Prevenção } \\
\text { de futuras } \\
\text { violações } \\
\text { de direitos }\end{array}$ & $\begin{array}{c}\text { Prevenção } \\
\text { de futuras } \\
\text { violações de } \\
\text { direitos }\end{array}$ & $\begin{array}{l}\text { Prevenção } \\
\text { de futuras } \\
\text { violações } \\
\text { de direitos }\end{array}$ & $\begin{array}{c}\text { Prevenção de } \\
\text { futuras violações } \\
\text { de direitos }\end{array}$ & $\begin{array}{l}\text { Prevenção de futuras } \\
\text { violações de direitos }\end{array}$ & $\begin{array}{c}\text { Prevenção de } \\
\text { futuras violações } \\
\text { de direitos }\end{array}$ \\
\hline $\begin{array}{l}\text { Com } \\
\text { plia } \\
\text { nce }\end{array}$ & $\begin{array}{c}\text { Não } \\
\text { cumpriu }\end{array}$ & Não cumpriu & $\begin{array}{c}\text { Não } \\
\text { cumpriu }\end{array}$ & Não cumpriu & Não cumpriu & Não cumpriu \\
\hline $\begin{array}{c}\text { Data } \\
\text { de } \\
\text { qua } \\
\text { ndo } \\
\text { cort } \\
\text { e } \\
\text { info } \\
\text { rmo } \\
\text { u } \\
\text { que } \\
\text { cum } \\
\text { priu }\end{array}$ & $07 / 05 / 2015$ & $07 / 05 / 2015$ & $07 / 05 / 2015$ & $07 / 05 / 2015$ & $07 / 05 / 2015$ & $07 / 05 / 2015$ \\
\hline
\end{tabular}

\begin{tabular}{|c|c|}
\hline Região & Nordeste \\
\hline UF & MA \\
\hline N. Processo & 12.426 \\
\hline
\end{tabular}




\begin{tabular}{|c|c|}
\hline Órgão & Comissão \\
\hline Fase & Solução Amistosa \\
\hline Tipos de decisão & Cumprimento de Acordo de Solução Amistosa \\
\hline Nome do Caso & Meninos Emasculados do Maranhão \\
\hline $\begin{array}{l}\text { Data de Início do } \\
\text { Trâmite nNome do } \\
\text { Casoa CmDH }\end{array}$ & $27 / 07 / 2001$ \\
\hline $\begin{array}{l}\text { Data da Alegada } \\
\text { Violação }\end{array}$ & $01 / 09 / 1991$ \\
\hline $\begin{array}{l}\text { Data do veredito } \\
\text { da } \mathrm{CmDH}\end{array}$ & $15 / 03 / 2006$ \\
\hline $\begin{array}{l}\text { Data de envio à } \\
\text { CrDH }\end{array}$ & Não se aplica \\
\hline $\begin{array}{l}\text { Data da sentença } \\
\text { da CORTE }\end{array}$ & Não se aplica \\
\hline $\begin{array}{l}\text { Número dos } \\
\text { Informes }\end{array}$ & N.43/06 \\
\hline Peticionários & $\begin{array}{c}\text { Centro de Defensa de los Derechos del Niño y del Adolescente Padre Marcos Passerini y Centro de } \\
\text { Justicia Global (CJG) }\end{array}$ \\
\hline $\begin{array}{l}\text { Peticionários } \\
\text { classificados }\end{array}$ & ONGs nacionais \\
\hline Artigos Invocados & $\begin{array}{c}\text { Declaração: I, VI, VII e XVIII } \\
\text { CADH: } 4,8,19 \text { e } 25\end{array}$ \\
\hline Resumo dos fatos & $\begin{array}{c}\text { Denúncia sobre caso de violência doméstica com demora e negligência no processamento da ação } \\
\text { criminal. }\end{array}$ \\
\hline $\begin{array}{l}\text { Tema das } \\
\text { violações }\end{array}$ & $\begin{array}{l}\text { Violência contra menores } \\
\text { Prestação de Justiça }\end{array}$ \\
\hline
\end{tabular}




\begin{tabular}{|c|c|c|c|c|c|}
\hline $\begin{array}{c}\text { Resoluções, recom. } \\
\text { MP e MC }\end{array}$ & $\begin{array}{l}\text { 1. El Estado de } \\
\text { Marañón instalará } \\
\text { una placa en } \\
\text { homenaje } \\
\text { simbólico a los } \\
\text { niños-víctimas en } \\
\text { el Complejo } \\
\text { Integrado de } \\
\text { Protección al } \\
\text { Niño y al } \\
\text { Adolescente, que } \\
\text { se inaugurará en } \\
\text { el curso de una } \\
\text { ceremonia pública } \\
\text { de reconocimie. }\end{array}$ & $\begin{array}{l}\text { 2. La Unión } \\
\text { Federal, por } \\
\text { medio del } \\
\text { Ministerio de } \\
\text { las Ciudades, } \\
\text { y el Estado de } \\
\text { Marañón, por } \\
\text { medio de la } \\
\text { Secretaria de } \\
\text { las Ciudades, } \\
\text { incluirán a las } \\
\text { familias } \\
\text { beneficiarias, } \\
\text { en el plazo de } \\
\text { 12 (doce) } \\
\text { meses, en los } \\
\text { programas de } \\
\text { Viviendas de } \\
\text { Interés Social } \\
\text { cuya gestión } \\
\text { está a cargo } \\
\text { del Ministerio } \\
\text { de las } \\
\text { Ciudades, en } \\
\text { forma no } \\
\text { onerosa, en las } \\
\text { áreas en que } \\
\text { actualmente } \\
\text { residen }\end{array}$ & $\begin{array}{l}\text { 3. La Unión } \\
\text { Federal, por } \\
\text { medio del } \\
\text { Ministerio de } \\
\text { Desarrollo } \\
\text { Social, y el } \\
\text { Estado de } \\
\text { Marañón, por } \\
\text { medio de la } \\
\text { Secretaria de } \\
\text { Desarrollo } \\
\text { Social, } \\
\text { incluirán a las } \\
\text { familias } \\
\text { beneficiarias } \\
\text { en sus } \\
\text { respectivos } \\
\text { programas } \\
\text { sociales, } \\
\text { incluidos sus } \\
\text { programas de } \\
\text { transferencia } \\
\text { de renta, de } \\
\text { acuerdo con } \\
\text { los criterios de } \\
\text { elegibilidad } \\
\text { específicos de } \\
\text { cada } \\
\text { programa. }\end{array}$ & $\begin{array}{l}\text { 4. El Estado de } \\
\text { Marañón, } \\
\text { mediante } \\
\text { autorización } \\
\text { legislativa, } \\
\text { realizará el pago } \\
\text { de una pensión } \\
\text { especial } \\
\text { mensual, de } \\
\text { carácter } \\
\text { indemnizatorio, } \\
\text { por un valor de } \\
\text { R } \$ 500,00 \\
\text { (quinientos } \\
\text { reales), a cada } \\
\text { una de las } \\
\text { familias } \\
\text { beneficiarias, } \\
\text { por un plazo de } \\
15 \text { (quince) años }\end{array}$ & $\begin{array}{l}\text { 5. El cumplimiento } \\
\text { integral de las cláusulas } \\
\text { Nos. 8, } 9 \text { y } 10 \text { exime al } \\
\text { Estado brasileño -tanto } \\
\text { a la Unión Federal } \\
\text { como al Estado de } \\
\text { Marañón-de la } \\
\text { obligación de efectuar } \\
\text { cualquier otro } \\
\text { resarcimiento a las } \\
\text { familias beneficiarias } \\
\text { por el presente } \\
\text { Acuerdo. }\end{array}$ \\
\hline $\begin{array}{c}\text { Tipos das } \\
\text { resoluções e } \\
\text { recom. }\end{array}$ & $\begin{array}{l}\text { Reparação } \\
\text { simbólica }\end{array}$ & $\begin{array}{c}\text { Reparação } \\
\text { econômica } \\
\text { não monetária }\end{array}$ & $\begin{array}{c}\text { Reparação } \\
\text { econômica } \\
\text { não monetária }\end{array}$ & $\begin{array}{l}\text { Reparação } \\
\text { econômica } \\
\text { monetária }\end{array}$ & Outros \\
\hline $\begin{array}{l}\text { Objetos das as } \\
\text { resoluções e } \\
\text { recomendações }\end{array}$ & $\begin{array}{c}\text { Recompensação } \\
\text { de pessoas ou } \\
\text { grupos }\end{array}$ & $\begin{array}{c}\text { Recompensaçã } \\
\text { o de pessoas } \\
\text { ou grupos }\end{array}$ & $\begin{array}{c}\text { Recompensaçã } \\
\text { o de pessoas } \\
\text { ou grupos }\end{array}$ & $\begin{array}{c}\text { Recompensação } \\
\text { de pessoas ou } \\
\text { grupos }\end{array}$ & $\begin{array}{l}\text { Proteção de vítimas e } \\
\text { testemunhas e outros }\end{array}$ \\
\hline Compliance & $\begin{array}{l}\text { Cumpriu } \\
\text { totalmente }\end{array}$ & $\begin{array}{l}\text { Cumpriu } \\
\text { totalmente }\end{array}$ & $\begin{array}{l}\text { Cumpriu } \\
\text { totalmente }\end{array}$ & $\begin{array}{l}\text { Cumpriu } \\
\text { totalmente }\end{array}$ & Cumpriu totalmente \\
\hline $\begin{array}{l}\text { Data de quando } \\
\text { corte informou } \\
\text { que cumpriu }\end{array}$ & $25 / 02 / 2009$ & $25 / 02 / 2009$ & $25 / 02 / 2009$ & $25 / 02 / 2009$ & $25 / 02 / 2009$ \\
\hline $\begin{array}{c}\text { Resoluções, recom. } \\
\text { MP e MC }\end{array}$ & $\begin{array}{l}\text { 6. La Unión } \\
\text { Federal se } \\
\text { compromete a } \\
\text { incluir, también } \\
\text { en el año de 2006, } \\
\text { al Estado de } \\
\text { Marañón en el } \\
\text { Programa de } \\
\text { Acciones } \\
\text { Integradas } \\
\text { Referenciales de } \\
\text { Lucha contra la } \\
\text { Violencia Sexual } \\
\text { contra Niños y } \\
\text { Adolescentes en } \\
\text { el Territorio }\end{array}$ & $\begin{array}{c}\text { 7. El Estado } \\
\text { de Marañón se } \\
\text { compromete a } \\
\text { dar } \\
\text { continuidad a } \\
\text { la } \\
\text { implementació } \\
\text { n del Sistema } \\
\text { Estadual de } \\
\text { Lucha contra } \\
\text { la Violencia } \\
\text { Sexual contra } \\
\text { el Niño y el } \\
\text { Adolescente y } \\
\text { del Sistema } \\
\text { Interinstitucio }\end{array}$ & $\begin{array}{l}\text { 8. Con el } \\
\text { objetivo de } \\
\text { atender a } \\
\text { niños y } \\
\text { adolescentes } \\
\text { que sean } \\
\text { víctimas de } \\
\text { violencia } \\
\text { sexual, así } \\
\text { como a sus } \\
\text { familias, el } \\
\text { Estado de } \\
\text { Marañón, por } \\
\text { medio de la } \\
\text { Secretaria de } \\
\text { Desarrollo }\end{array}$ & $\begin{array}{l}\text { 9. Teniendo en } \\
\text { cuenta las } \\
\text { especiales } \\
\text { características } \\
\text { que presenta la } \\
\text { atención de los } \\
\text { casos de } \\
\text { violencia contra } \\
\text { niños y } \\
\text { adolescentes, el } \\
\text { Estado de } \\
\text { Marañón, por } \\
\text { medio de la } \\
\text { Secretaria de } \\
\text { Estado de } \\
\text { Seguridad }\end{array}$ & $\begin{array}{l}\text { 9.2.incluir el tema de la } \\
\text { violencia contra niños } \\
\text { y adolescentes en el } \\
\text { plan de estudios del } \\
\text { Curso de Formación de } \\
\text { Policías Civiles y } \\
\text { Militares que } \\
\text { concursen a partir de } \\
\text { entonces; }\end{array}$ \\
\hline
\end{tabular}




\begin{tabular}{|c|c|c|c|c|c|}
\hline & $\begin{array}{c}\text { Brasileño (PAIR), } \\
\text { coordinado por la } \\
\text { Secretaria } \\
\text { Especial de los } \\
\text { Derechos } \\
\text { Humanos de la } \\
\text { Presidencia de la } \\
\text { República; en } \\
\text { conjunto con el } \\
\text { Ministerio de } \\
\text { Desarrollo Social, } \\
\text { el Ministerio de } \\
\text { Salud, el } \\
\text { Ministerio de } \\
\text { Educación, el } \\
\text { Ministerio de } \\
\text { Deportes; el } \\
\text { Ministerio de } \\
\text { Justicia, el } \\
\text { Ministerio de } \\
\text { Turismo; y en } \\
\text { asociación de } \\
\text { esfuerzos con la } \\
\text { Organización } \\
\text { Internacional del } \\
\text { Trabajo (OIT), la } \\
\text { USAID y Partners } \\
\text { of the Americas } \\
\end{array}$ & $\begin{array}{c}\text { nal de } \\
\text { Acciones } \\
\text { Antidrogas - } \\
\text { SIAD en el } \\
\text { ámbito del } \\
\text { Estado de } \\
\text { Marañón, } \\
\text { conforme a lo } \\
\text { definido por } \\
\text { los respectivos } \\
\text { decretos } \\
\text { estaduales }\end{array}$ & $\begin{array}{c}\text { Social, se } \\
\text { compromete a } \\
\text { incluir en el } \\
\text { Programa } \\
\text { Centinela, en } \\
\text { el plazo de 06 } \\
\text { (seis) meses, a } \\
\text { los municipios } \\
\text { de São José de } \\
\text { Ribamar, Paço } \\
\text { do Lumiar y } \\
\text { Raposa }\end{array}$ & $\begin{array}{l}\text { Pública, se } \\
\text { compromete a: } \\
91 \text { realizar, } \\
\text { durante el plazo } \\
\text { mínimo de } 03 \\
\text { (tres) años, } \\
\text { cursos de } \\
\text { capacitación de } \\
\text { policías civiles } \\
\text { y militares para } \\
\text { la atención de } \\
\text { crímenes que } \\
\text { afecten a niños } \\
\text { y adolescentes }\end{array}$ & \\
\hline $\begin{array}{l}\text { Tipos das } \\
\text { resoluções e } \\
\text { recom. }\end{array}$ & $\begin{array}{c}\text { Prevenção por } \\
\text { meio do } \\
\text { fortalecimento, } \\
\text { criação, ou } \\
\text { reforma de } \\
\text { instituições } \\
\text { públicas }\end{array}$ & $\begin{array}{l}\text { Prevenção por } \\
\text { meio do } \\
\text { fortalecimento } \\
\text {, criação, ou } \\
\text { reforma de } \\
\text { instituições } \\
\text { públicas }\end{array}$ & $\begin{array}{l}\text { Prevenção por } \\
\text { meio da } \\
\text { formação de } \\
\text { agentes } \\
\text { públicos }\end{array}$ & $\begin{array}{l}\text { Prevenção por } \\
\text { meio da } \\
\text { conscientização } \\
\text { da população }\end{array}$ & $\begin{array}{l}\text { Prevenção por meio da } \\
\text { formação de agentes } \\
\text { públicos }\end{array}$ \\
\hline $\begin{array}{l}\text { Objetos das as } \\
\text { resoluções e } \\
\text { recomendações }\end{array}$ & $\begin{array}{c}\text { Prevenção de } \\
\text { futuras violações } \\
\text { de direitos }\end{array}$ & $\begin{array}{l}\text { Prevenção de } \\
\text { futuras } \\
\text { violações de } \\
\text { direitos }\end{array}$ & $\begin{array}{l}\text { Prevenção de } \\
\text { futuras } \\
\text { violações de } \\
\text { direitos }\end{array}$ & $\begin{array}{l}\text { Prevenção de } \\
\text { futuras } \\
\text { violações de } \\
\text { direitos }\end{array}$ & $\begin{array}{l}\text { Prevenção de futuras } \\
\text { violações de direitos }\end{array}$ \\
\hline Compliance & $\begin{array}{l}\text { Cumpriu } \\
\text { totalmente }\end{array}$ & $\begin{array}{l}\text { Cumpriu } \\
\text { totalmente }\end{array}$ & $\begin{array}{l}\text { Cumpriu } \\
\text { totalmente }\end{array}$ & $\begin{array}{l}\text { Cumpriu } \\
\text { totalmente }\end{array}$ & Cumpriu totalmente \\
\hline $\begin{array}{l}\text { Data de quando } \\
\text { corte informou } \\
\text { que cumpriu }\end{array}$ & $25 / 02 / 2009$ & $25 / 02 / 2009$ & $25 / 02 / 2009$ & $25 / 02 / 2009$ & $25 / 02 / 2009$ \\
\hline $\begin{array}{c}\text { Resoluções, recom. } \\
\text { MP e MC }\end{array}$ & $\begin{array}{l}\text { 9.3. reglamentar y } \\
\text { adoptar, en el } \\
\text { plazo de } 06 \text { (seis) } \\
\text { meses, } \\
\text { procedimientos } \\
\text { especiales de } \\
\text { atención de los } \\
\text { casos que afecten } \\
\text { a niños y } \\
\text { adolescentes } \\
\text { víctimas, en } \\
\text { forma de evitar } \\
\text { restricciones en la }\end{array}$ & $\begin{array}{l}\text { 9.4.reglamenta } \\
\text { r la derivación } \\
\text { de casos de } \\
\text { mayor } \\
\text { complejidad } \\
\text { que afecten a } \\
\text { niños y } \\
\text { adolescentes } \\
\text { registrados en } \\
\text { las } \\
\text { Delegaciones } \\
\text { de la } \\
\text { denominada } \\
\end{array}$ & $\begin{array}{l}\text { 9.5.reestructur } \\
\text { ar y equipar a } \\
\text { la Delegación } \\
\text { de Policía del } \\
\text { municipio de } \\
\text { Raposa-MA, } \\
\text { de modo de } \\
\text { propiciar la } \\
\text { adecuada } \\
\text { atención de los } \\
\text { casos que } \\
\text { afecten a niños } \\
\text { y adolescentes }\end{array}$ & $\begin{array}{l}\text { 9.6.inaugurar y } \\
\text { mantener en } \\
\text { funcionamiento, } \\
\text { con } \\
\text { profesionales } \\
\text { eficaces, el } \\
\text { Centro de } \\
\text { Pericias } \\
\text { Oficiales para } \\
\text { casos de } \\
\text { violencia sexual } \\
\text { perpetrada } \\
\text { contra niños y } \\
\end{array}$ & $\begin{array}{c}\text { 10.Con el fin de } \\
\text { mejorar la atención } \\
\text { escolar destinada a los } \\
\text { niños y adolescentes de } \\
\text { la Gran São Luís y a la } \\
\text { utilización del } \\
\text { ambiente escolar para } \\
\text { actividades deportivas } \\
\text { y culturales, el Estado } \\
\text { de Marañón, por medio } \\
\text { de la Secretaría de } \\
\text { Estado de la } \\
\text { Educación, se }\end{array}$ \\
\hline
\end{tabular}




\begin{tabular}{|c|c|c|c|c|c|}
\hline & $\begin{array}{l}\text { atención inicial a } \\
\text { las víctimas }\end{array}$ & $\begin{array}{c}\text { Región de la } \\
\text { Gran São Luís } \\
\text { a la } \\
\text { Delegación de } \\
\text { Protección del } \\
\text { Niño y del } \\
\text { Adolescente - } \\
\text { DPCA }\end{array}$ & víctimas & adolescentes & $\begin{array}{c}\text { compromete a: } \\
\text { 10.1.viabilizar, a partir } \\
\text { del mes de febrero de } \\
\text { 2006, actividades } \\
\text { deportivas y culturales } \\
\text { en los fines de semana } \\
\text { en todas las escuelas de } \\
\text { la red estadual de } \\
\text { enseñanza existentes en } \\
\text { los municipios de la } \\
\text { Región de la Gran São } \\
\text { Luís; }\end{array}$ \\
\hline $\begin{array}{l}\text { Tipos das } \\
\text { resoluções e } \\
\text { recom. }\end{array}$ & $\begin{array}{l}\text { Prevenção por } \\
\text { meio do } \\
\text { fortalecimento, } \\
\text { criação, ou } \\
\text { reforma de } \\
\text { instituições } \\
\text { públicas }\end{array}$ & $\begin{array}{l}\text { Prevenção por } \\
\text { meio de } \\
\text { reformas } \\
\text { jurídicas }\end{array}$ & $\begin{array}{l}\text { Prevenção por } \\
\text { meio do } \\
\text { fortalecimento } \\
\text {, criação, ou } \\
\text { reforma de } \\
\text { instituições } \\
\text { públicas }\end{array}$ & $\begin{array}{l}\text { Prevenção por } \\
\text { meio do } \\
\text { fortalecimento, } \\
\text { criação, ou } \\
\text { reforma de } \\
\text { instituições } \\
\text { públicas }\end{array}$ & $\begin{array}{l}\text { Prevenção por meio do } \\
\text { fortalecimento, criação, } \\
\text { ou reforma de } \\
\text { instituições públicas }\end{array}$ \\
\hline $\begin{array}{l}\text { Objetos das as } \\
\text { resoluções e } \\
\text { recomendações }\end{array}$ & $\begin{array}{c}\text { Prevenção de } \\
\text { futuras violações } \\
\text { de direitos }\end{array}$ & $\begin{array}{l}\text { Prevenção de } \\
\text { futuras } \\
\text { violaçõos de } \\
\text { direitos }\end{array}$ & $\begin{array}{l}\text { Prevenção de } \\
\text { futuras } \\
\text { violaçõos de } \\
\text { direitos }\end{array}$ & $\begin{array}{l}\text { Prevenção de } \\
\text { futuras } \\
\text { violações de } \\
\text { direitos }\end{array}$ & $\begin{array}{l}\text { Prevenção de futuras } \\
\text { violações de direitos }\end{array}$ \\
\hline Compliance & $\begin{array}{l}\text { Cumpriu } \\
\text { totalmente }\end{array}$ & $\begin{array}{l}\text { Cumpriu } \\
\text { totalmente }\end{array}$ & $\begin{array}{l}\text { Cumpriu } \\
\text { totalmente }\end{array}$ & $\begin{array}{l}\text { Cumpriu } \\
\text { totalmente }\end{array}$ & Cumpriu totalmente \\
\hline $\begin{array}{l}\text { Data de quando } \\
\text { corte informou } \\
\text { que cumpriu }\end{array}$ & $25 / 02 / 2009$ & $25 / 02 / 2009$ & $25 / 02 / 2009$ & $25 / 02 / 2009$ & $25 / 02 / 2009$ \\
\hline $\begin{array}{c}\text { Resoluções, recom. } \\
\text { MP e MC }\end{array}$ & $\begin{array}{l}\text { 10.2.articular, con } \\
\text { la Unión Nacional } \\
\text { de Dirigentes } \\
\text { Municipales de } \\
\text { Educación- } \\
\text { UNDIME, la } \\
\text { viabilización de } \\
\text { actividades } \\
\text { deportivas y } \\
\text { culturales en los } \\
\text { fines de semana } \\
\text { en las escuelas de } \\
\text { la red municipal } \\
\text { de enseñanza de } \\
\text { los municipios de } \\
\text { la Gran São Luís; }\end{array}$ & \multicolumn{2}{|c|}{$\begin{array}{l}\text { 10.3.construir, hasta el final del } \\
\text { año de 2006, una escuela de } \\
\text { enseñanza media con no menos } \\
06 \text { (seis) aulas, en la zona de la } \\
\text { Maiobinha, en Paço do Lumiar; }\end{array}$} & $\begin{array}{l}\text { 10.4.concluir, } \\
\text { en el plazo de } \\
06 \text { (seis) meses, } \\
\text { la construcción } \\
\text { de una escuela } \\
\text { de enseñanza } \\
\text { media, con } 15 \\
\text { salas, y una } \\
\text { escuela de } \\
\text { enseñanza } \\
\text { elemental, con } \\
12 \text { aulas, } \\
\text { localizadas en el } \\
\text { barrio Ciudad } \\
\text { Operária, en São } \\
\text { Luís. }\end{array}$ & $\begin{array}{l}\text { 11. Con el propósito de } \\
\text { incrementar la } \\
\text { asistencia jurídica que } \\
\text { dispensa la Defensoría } \\
\text { Pública, el Estado de } \\
\text { Marañón se } \\
\text { compromete asimismo } \\
\text { a reactivar, en el plazo } \\
\text { de } 06 \text { (seis) meses, el } \\
\text { núcleo de Paço do } \\
\text { Lumiar, con la } \\
\text { designación, por } \\
\text { concurso, de un } \\
\text { defensor público. }\end{array}$ \\
\hline
\end{tabular}




\begin{tabular}{|c|c|c|c|c|}
\hline $\begin{array}{l}\text { Tipos das } \\
\text { resoluções e } \\
\text { recom. }\end{array}$ & $\begin{array}{l}\text { Prevenção por } \\
\text { meio do } \\
\text { fortalecimento, } \\
\text { criação, ou } \\
\text { reforma de } \\
\text { instituições } \\
\text { públicas }\end{array}$ & $\begin{array}{l}\text { Prevenção por meio do } \\
\text { fortalecimento, criação, ou } \\
\text { reforma de instituições públicas }\end{array}$ & $\begin{array}{l}\text { Prevenção por } \\
\text { meio do } \\
\text { fortalecimento, } \\
\text { criação, ou } \\
\text { reforma de } \\
\text { instituições } \\
\text { públicas }\end{array}$ & $\begin{array}{l}\text { Prevenção por meio do } \\
\text { fortalecimento, criação, } \\
\text { ou reforma de } \\
\text { instituições públicas }\end{array}$ \\
\hline $\begin{array}{l}\text { Objetos das as } \\
\text { resoluções e } \\
\text { recomendações }\end{array}$ & $\begin{array}{c}\text { Prevenção de } \\
\text { futuras violações } \\
\text { de direitos }\end{array}$ & $\begin{array}{l}\text { Prevenção de futuras violações } \\
\text { de direitos }\end{array}$ & $\begin{array}{l}\text { Prevenção de } \\
\text { futuras } \\
\text { violações de } \\
\text { direitos }\end{array}$ & $\begin{array}{l}\text { Prevenção de futuras } \\
\text { violações de direitos }\end{array}$ \\
\hline Compliance & $\begin{array}{l}\text { Cumpriu } \\
\text { totalmente }\end{array}$ & Cumpriu totalmente & $\begin{array}{l}\text { Cumpriu } \\
\text { totalmente }\end{array}$ & Cumpriu totalmente \\
\hline $\begin{array}{l}\text { Data de quando } \\
\text { corte informou } \\
\text { que cumpriu }\end{array}$ & $25 / 02 / 2009$ & $25 / 02 / 2009$ & $25 / 02 / 2009$ & $25 / 02 / 2009$ \\
\hline
\end{tabular}

\begin{tabular}{|c|c|}
\hline Região & Centro-Oeste \\
\hline UF & TO \\
\hline \multicolumn{2}{|l|}{ N. Processo } \\
\hline Órgão & Corte \\
\hline Fase & Cumprimento de Sentença da Corte \\
\hline Tipos de decisão & Sentença da Corte \\
\hline Nome do Caso & Caso Julia Gomes Lund e outros (Guerrilha do Araguaia) vs. Brasil \\
\hline $\begin{array}{l}\text { Data de Início do } \\
\text { Trâmite nNome do } \\
\text { Casoa CmDH }\end{array}$ & 07/08/1995 \\
\hline $\begin{array}{l}\text { Data da Alegada } \\
\text { Violação }\end{array}$ & $01 / 01 / 1972$ \\
\hline $\begin{array}{l}\text { Data do veredito } \\
\text { da } \mathrm{CmDH}\end{array}$ & $31 / 10 / 2008$ \\
\hline $\begin{array}{c}\text { Data de envio à } \\
\text { CrDH }\end{array}$ & $26 / 03 / 2009$ \\
\hline $\begin{array}{l}\text { Data da sentença } \\
\text { da CORTE }\end{array}$ & $24 / 11 / 2010$ \\
\hline $\begin{array}{l}\text { Número dos } \\
\text { Informes }\end{array}$ & N.33/01 E N.91/08 \\
\hline
\end{tabular}




\begin{tabular}{|c|c|c|c|c|}
\hline Peticionários & \multicolumn{4}{|c|}{$\begin{array}{c}\text { Grupo Tortura Nunca Más de Río de Janeiro; Comisión de Familiares de Muertos y Desaparecidos } \\
\text { Políticos del Instituto de Estudios de la Violencia del Estado; Centro por la Justicia y el Derecho } \\
\text { Internacional (CEJIL) }\end{array}$} \\
\hline $\begin{array}{l}\text { Peticionários } \\
\text { classificados }\end{array}$ & \multicolumn{4}{|c|}{ ONGs nacionais em parceria com ONGs internacionais } \\
\hline Artigos Invocados & \multicolumn{4}{|c|}{ CADH: $1,2,3,5,7,8,9,13$ e 25} \\
\hline Resumo dos fatos & \multicolumn{4}{|c|}{$\begin{array}{l}\text { Denúncia sobre o desaparecimento forçado de militantes que participaram da "guerrilha do } \\
\text { araguaia", combatendo o regime ditatorial brasileiro, e falta de investigação sobre os fatos. }\end{array}$} \\
\hline $\begin{array}{l}\text { Tema das } \\
\text { violações }\end{array}$ & \multicolumn{4}{|c|}{ Crimes do período da ditadura } \\
\hline $\begin{array}{l}\text { Resoluções, recom. } \\
\text { MP e MC }\end{array}$ & $\begin{array}{l}\text { 1.La Sentencia de } \\
\text { Excepciones } \\
\text { Preliminares, } \\
\text { Fondo, } \\
\text { Reparaciones y } \\
\text { Costas } \\
\text { constituye per } \\
\text { se una forma de } \\
\text { reparación. }\end{array}$ & $\begin{array}{l}\text { 2.El Estado debe } \\
\text { conducir eficazmente, } \\
\text { ante la jurisdicción } \\
\text { ordinaria, } \\
\text { la investigación penal } \\
\text { de los hechos del } \\
\text { presente caso a fin de } \\
\text { esclarecerlos, determin } \\
\text { ar las correspondientes } \\
\text { responsabilidades } \\
\text { penales } \\
\text { aplicar efectivamente } \\
\text { las sanciones y } \\
\text { consecuencias que la } \\
\text { ley prevea. }\end{array}$ & \begin{tabular}{lr} 
3.El Estado debe \\
realizar todos & los \\
esfuerzos & para \\
determinar & el \\
paradero & de \\
las & víctimas \\
desaparecidas y, en \\
su caso, identificar \\
y entregar los \\
restos mortales a \\
\multicolumn{2}{l}{ sus familiares. }
\end{tabular} & $\begin{array}{l}\text { 4.El Estado debe brindar el } \\
\text { tratamiento médico y } \\
\text { psicológico o psiquiátrico } \\
\text { que requieran las víctimas } \\
\text { y, en su caso, pagar la suma } \\
\text { establecida. }\end{array}$ \\
\hline $\begin{array}{l}\text { Tipos das } \\
\text { resoluções e } \\
\text { recom. }\end{array}$ & $\begin{array}{l}\text { Reparação } \\
\text { simbólica }\end{array}$ & $\begin{array}{l}\text { Investigação e sanção } \\
\text { sem reforma legal }\end{array}$ & Outros & $\begin{array}{l}\text { Reparação econômica não } \\
\text { monetária }\end{array}$ \\
\hline $\begin{array}{l}\text { Objetos das as } \\
\text { resoluções e } \\
\text { recomendações }\end{array}$ & $\begin{array}{l}\text { Recompensação } \\
\text { de pessoas ou } \\
\text { grupos }\end{array}$ & $\begin{array}{l}\text { Investigação e } \\
\text { responsabilização de } \\
\text { violações de direitos } \\
\text { humanos }\end{array}$ & $\begin{array}{l}\text { Proteção de vítimas } \\
\text { e testemunhas e } \\
\text { outros }\end{array}$ & $\begin{array}{l}\text { Recompensação de pessoas } \\
\text { ou grupos }\end{array}$ \\
\hline Compliance & $\begin{array}{l}\text { Cumpriu } \\
\text { totalmente }\end{array}$ & Não cumpriu & Não cumpriu & Não cumpriu \\
\hline $\begin{array}{l}\text { Data de quando } \\
\text { corte informou } \\
\text { que cumpriu }\end{array}$ & $24 / 11 / 2010$ & $17 / 10 / 2014$ & $17 / 10 / 2014$ & $17 / 10 / 2014$ \\
\hline $\begin{array}{l}\text { Resoluções, recom. } \\
\text { MP e MC }\end{array}$ & $\begin{array}{l}\text { 5.El Estado debe } \\
\text { publicar en un } \\
\text { plazo de seis } \\
\text { meses (i) el } \\
\text { resumen oficial } \\
\text { del Fallo emitido } \\
\text { por la Corte en un } \\
\text { diario de amplia } \\
\text { circulación } \\
\text { nacional; } \\
\text { (ii) íntegramente } \\
\text { la presente } \\
\text { Sentencia en un } \\
\text { sitio web } \\
\text { adecuado del } \\
\text { Estado, } \\
\text { tomando en } \\
\text { cuenta las } \\
\end{array}$ & $\begin{array}{l}\text { 6. El Estado debe } \\
\text { realizar un acto público } \\
\text { de reconocimiento de } \\
\text { responsabilidad } \\
\text { internacional por } \\
\text { los hechos del presente } \\
\text { caso. }\end{array}$ & $\begin{array}{c}\text { 7.El Estado debe } \\
\text { continuar con las } \\
\text { acciones } \\
\text { desarrolladas en } \\
\text { materia de } \\
\text { capacitación e } \\
\text { implementar, en un } \\
\text { plazo razonable, un } \\
\text { programa o curso } \\
\text { permanente } \\
\text { y obligatorio sobre } \\
\text { derechos humanos, } \\
\text { dirigido a todos los } \\
\text { niveles jerárquicos } \\
\text { de las Fuerzas } \\
\text { Armadas. }\end{array}$ & $\begin{array}{c}\text { 8. El Estado debe adoptar, } \\
\text { en un plazo razonable, las } \\
\text { medidas que sean } \\
\text { necesarias para tipificar el } \\
\text { delito de desaparición } \\
\text { forzada de personas de } \\
\text { conformidad con los } \\
\text { estándares interamericanos. } \\
\text { Mientras cumple con esta } \\
\text { medida, el Estado deberá } \\
\text { adoptar todas aquellas } \\
\text { acciones que garanticen el } \\
\text { efectivo enjuiciamiento y, } \\
\text { en su caso, sanción respecto } \\
\text { de los hechos constitutivos } \\
\text { de desaparición forzada a } \\
\text { través de los mecanismos } \\
\text { existentes en el }\end{array}$ \\
\hline
\end{tabular}




\begin{tabular}{|c|c|c|c|c|}
\hline & $\begin{array}{c}\text { características de } \\
\text { la publicación que } \\
\text { se ordena realizar, } \\
\text { la cual debe } \\
\text { permanecer } \\
\text { disponible } \\
\text { durante, al menos, } \\
\text { un año; (iii) esta } \\
\text { decisión } \\
\text { en formato de } \\
\text { libro; y (iv) la } \\
\text { Sentencia de } \\
\text { Excepciones } \\
\text { Preliminares, Fon } \\
\text { do, Reparaciones } \\
\text { y Costas en } \\
\text { formato de libro } \\
\text { Electrónico en un } \\
\text { sitio web } \\
\text { adecuado. }\end{array}$ & & & derecho interno. \\
\hline $\begin{array}{l}\text { Tipos das } \\
\text { resoluções e } \\
\text { recom. }\end{array}$ & $\begin{array}{c}\text { Reparação } \\
\text { simbólica }\end{array}$ & Reparação simbólica & $\begin{array}{c}\text { Prevenção por meio } \\
\text { da formação de } \\
\text { agentes públicos }\end{array}$ & $\begin{array}{l}\text { Prevenção por meio de } \\
\text { reformas jurídicas }\end{array}$ \\
\hline $\begin{array}{l}\text { Objetos das as } \\
\text { resoluções e } \\
\text { recomendações }\end{array}$ & $\begin{array}{l}\text { Recompensação } \\
\text { de pessoas ou } \\
\text { grupos }\end{array}$ & $\begin{array}{l}\text { Recompensação de } \\
\text { pessoas ou grupos }\end{array}$ & $\begin{array}{c}\text { Prevenção de } \\
\text { futuras violações de } \\
\text { direitos }\end{array}$ & $\begin{array}{l}\text { Prevenção de futuras } \\
\text { violações de direitos }\end{array}$ \\
\hline Compliance & $\begin{array}{l}\text { Cumpriu } \\
\text { totalmente }\end{array}$ & Não cumpriu & Não cumpriu & Não cumpriu \\
\hline $\begin{array}{l}\text { Data de quando } \\
\text { corte informou } \\
\text { que cumpriu }\end{array}$ & $17 / 10 / 2014$ & $17 / 10 / 2014$ & $17 / 10 / 2014$ & $17 / 10 / 2014$ \\
\hline $\begin{array}{c}\text { Resoluções, recom. } \\
\text { MP e MC }\end{array}$ & $\begin{array}{l}\text { 9.El Estado debe } \\
\text { continuar } \\
\text { desarrollando las } \\
\text { iniciativas de } \\
\text { búsqueda, sistem } \\
\text { atización y } \\
\text { publicación de } \\
\text { toda la } \\
\text { información sobre } \\
\text { la Guerrilha do } \\
\text { Araguaia, así } \\
\text { como de } \\
\text { la información } \\
\text { relativa a } \\
\text { violaciones de } \\
\text { derechos humanos } \\
\text { ocurridas durante } \\
\text { el régimen } \\
\text { militar. }\end{array}$ & $\begin{array}{l}\text { 10.El Estado debe } \\
\text { pagar (i) US\$ } 3.000 \text { a } \\
\text { favor de cada uno de } \\
\text { los familiares que } \\
\text { ha sido considerado } \\
\text { víctima conforme al } \\
\text { párrafo } 251 \text { de la } \\
\text { Sentencia } \\
\text { de Excepciones } \\
\text { Preliminares, Fondo, } \\
\text { Reparaciones y Costas; } \\
\text { (ii) US\$ } 45.000,00 \text { para } \\
\text { cada familiar directo y } \\
\text { US\$ } 15.000,00 \\
\text { para cada familiar no } \\
\text { directo, considerados } \\
\text { víctimas en el presente } \\
\text { caso e indicados en el } \\
\text { párrafo } 251 \text { de la } \\
\text { Sentencia de } \\
\text { Excepciones } \\
\text { Preliminares, Fondo, } \\
\text { Reparaciones y Costas; } \\
\text { (iii) US\$ 5.000,00 / } \\
\text { US\$ 5.000,00 / US\$ } \\
35.000,00 \text { a favor del }\end{array}$ & $\begin{array}{c}\text { 11. El Estado debe } \\
\text { realizar una } \\
\text { convocatoria en, al } \\
\text { menos, un } \\
\text { periódico de } \\
\text { circulación naciona } \\
\text { 1 y uno en la región } \\
\text { donde ocurrieron } \\
\text { los hechos del } \\
\text { presente caso, } \\
\text { o mediante otra } \\
\text { modalidad } \\
\text { adecuada, para que, } \\
\text { por un período de } \\
24 \text { meses contado a } \\
\text { partir de la } \\
\text { notificación de la } \\
\text { Sentencia de } \\
\text { Excepciones } \\
\text { Preliminares, Fond } \\
\text { o, Reparaciones y } \\
\text { Costas, } \\
\text { los familiares de } \\
\text { las personas } \\
\text { indicadas en el } \\
\text { párrafo } 119 \text { del }\end{array}$ & $\begin{array}{c}\text { 12.El Estado debe permitir } \\
\text { que, por un plazo de seis } \\
\text { meses contado a partir de } \\
\text { la notificación de la } \\
\text { Sentencia de Excepciones } \\
\text { Preliminares, } \\
\text { Fondo, Reparaciones y } \\
\text { Costas, los familiares de } \\
\text { los señores Francisco } \\
\text { Manoel Chaves, Pedro } \\
\text { Matias de Oliveira (“Pedro } \\
\text { Carretel"), Hélio Luiz } \\
\text { Navarro de Magalhães y } \\
\text { Pedro Alexandrino de } \\
\text { Oliveira Filho, } \\
\text { puedan presentarle, si así lo } \\
\text { desean, sus solicitudes de } \\
\text { indemnización utilizando los } \\
\text { criterios y mecanismos } \\
\text { establecidos en el derecho } \\
\text { interno por la Ley No. } \\
\text { 9.140/95. }\end{array}$ \\
\hline
\end{tabular}




\begin{tabular}{|c|c|c|c|c|}
\hline & & $\begin{array}{c}\text { Grupo Tortura Nunca } \\
\text { Mais, de la Comisión } \\
\text { de Familiares de } \\
\text { Muertos y } \\
\text { Desaparecidos de São } \\
\text { Paulo y del Centro por } \\
\text { la Justicia y el Derecho } \\
\text { Internacional, } \\
\text { respectivamente, } \\
\text { por concepto de costas } \\
\text { y gastos. }\end{array}$ & $\begin{array}{c}\text { fallo aporten } \\
\text { prueba fehaciente } \\
\text { que permita al } \\
\text { Estado } \\
\text { identificarlos y, en } \\
\text { su caso, } \\
\text { considerarlos vícti } \\
\text { mas en los términos } \\
\text { de la Ley No. } \\
\text { 9.140/95 y de esta } \\
\text { Sentencia. }\end{array}$ & \\
\hline $\begin{array}{l}\text { Tipos das } \\
\text { resoluções e } \\
\text { recom. }\end{array}$ & $\begin{array}{l}\text { Reparação } \\
\text { simbólica }\end{array}$ & $\begin{array}{c}\text { Reparação econômica } \\
\text { monetária }\end{array}$ & $\begin{array}{c}\text { Reparação } \\
\text { simbólica }\end{array}$ & Reparação simbólica \\
\hline $\begin{array}{l}\text { Objetos das as } \\
\text { resoluções e } \\
\text { recomendações }\end{array}$ & $\begin{array}{c}\text { Recompensação } \\
\text { de pessoas ou } \\
\text { grupos }\end{array}$ & $\begin{array}{l}\text { Recompensação de } \\
\text { pessoas ou grupos }\end{array}$ & $\begin{array}{l}\text { Recompensação de } \\
\text { pessoas ou grupos }\end{array}$ & $\begin{array}{c}\text { Recompensação de pessoas } \\
\text { ou grupos }\end{array}$ \\
\hline Compliance & $\begin{array}{l}\text { Parcialmente } \\
\text { cumprido }\end{array}$ & Parcialmente cumprido & $\begin{array}{l}\text { Parcialmente } \\
\text { cumprido }\end{array}$ & Cumpriu totalmente \\
\hline $\begin{array}{l}\text { Data de quando } \\
\text { corte informou } \\
\text { que cumpriu }\end{array}$ & $17 / 10 / 2014$ & $17 / 10 / 2014$ & $17 / 10 / 2014$ & $17 / 10 / 2014$ \\
\hline
\end{tabular}

\begin{tabular}{|c|c|}
\hline Região & Sul \\
\hline $\mathbf{U F}$ & PR \\
\hline N. Processo & Informação não disponível \\
\hline Órgão & Corte \\
\hline Fase & Cumprimento de Sentença da Corte \\
\hline Tipos de decisão & Sentença da Corte \\
\hline Nome do Caso & Caso Garibaldi vs. Brasil \\
\hline $\begin{array}{l}\text { Data de Início do } \\
\text { Trâmite nNome do } \\
\text { Casoa CmDH }\end{array}$ & $06 / 05 / 2003$ \\
\hline $\begin{array}{c}\text { Data da Alegada } \\
\text { Violação }\end{array}$ & $27 / 11 / 1998$ \\
\hline $\begin{array}{c}\text { Data do veredito } \\
\text { da } \mathrm{CmDH}\end{array}$ & $27 / 03 / 2007$ \\
\hline $\begin{array}{c}\text { Data de envio à } \\
\text { CrDH }\end{array}$ & $24 / 12 / 2007$ \\
\hline $\begin{array}{l}\text { Data da sentença } \\
\text { da CORTE }\end{array}$ & $23 / 09 / 2009$ \\
\hline $\begin{array}{c}\text { Número dos } \\
\text { Informes }\end{array}$ & N.13/07 \\
\hline Peticionários & $\begin{array}{c}\text { Comissão Pastoral da Terra (CPT); Justiça Global Movimento dos Trabalhadores Rurais Sem } \\
\text { Terra; Rede Nacional de Advogados e Advogadas Populares Terra de Direitos }\end{array}$ \\
\hline $\begin{array}{l}\text { Peticionários } \\
\text { classificados }\end{array}$ & ONGs nacionais \\
\hline Artigos Invocados & CADH: $1,2,8,11,16$ e 25 \\
\hline
\end{tabular}




\begin{tabular}{|c|c|c|c|c|c|}
\hline Resumo dos fatos & \multicolumn{5}{|c|}{$\begin{array}{l}\text { Denúncia sobre assassinato de membro do movimento dos trabalhadores rurais sem terra (mst) e de } \\
\text { falta de investigações. }\end{array}$} \\
\hline $\begin{array}{l}\text { Tema das } \\
\text { violações }\end{array}$ & \multicolumn{5}{|c|}{$\begin{aligned} \text { Violência no campo } \\
\text { Prestação de Justiça } \\
\end{aligned}$} \\
\hline $\begin{array}{l}\text { Resoluções, recom. } \\
\text { MP e MC }\end{array}$ & $\begin{array}{l}\text { 1.La } \\
\text { Sentencia } \\
\text { de } \\
\text { Excepcion } \\
\text { es } \\
\text { Preliminar } \\
\text { es, Fondo, } \\
\text { Reparacion } \\
\text { es y Costas } \\
\text { constituye } \\
\text { per se una } \\
\text { forma de } \\
\text { reparación }\end{array}$ & $\begin{array}{l}\text { 2.El Estado debe publicar } \\
\text { en el Diario Oficial, en } \\
\text { otro diario de amplia } \\
\text { circulación nacional y en } \\
\text { un periódico de amplia } \\
\text { circulación en el estado de } \\
\text { Paraná, por una sola vez, la } \\
\text { portada, los Capítulos I, VI } \\
\text { y VII, sin las notas al pie } \\
\text { de página, y la parte } \\
\text { resolutiva de la Sentencia } \\
\text { de Excepciones } \\
\text { Preliminares, Fondo, } \\
\text { Reparaciones y Costas, así } \\
\text { como debe publicar } \\
\text { íntegramente el Fallo, al } \\
\text { menos por un año, en una } \\
\text { página web oficial } \\
\text { adecuada del estado } \\
\text { federal y del estado de } \\
\text { Paraná, tomando en cuenta } \\
\text { las características de la } \\
\text { publicación que se ordena } \\
\text { realizar. Las publicaciones } \\
\text { en los periódicos y en } \\
\text { Internet deberán realizarse } \\
\text { en los plazos de seis y dos } \\
\text { meses, respectivamente, } \\
\text { contados a partir de la } \\
\text { notificación de la } \\
\text { Sentencia de Excepciones } \\
\text { Preliminares, Fondo, } \\
\text { Reparaciones y Costas. }\end{array}$ & $\begin{array}{l}\text { 3.El Estado debe } \\
\text { conducir } \\
\text { eficazmente y } \\
\text { dentro de un plazo } \\
\text { razonable la } \\
\text { Investigación y } \\
\text { cualquier proceso } \\
\text { que se llegare a } \\
\text { abrir, como } \\
\text { consecuencia de } \\
\text { ésta, para } \\
\text { identificar, juzgar y, } \\
\text { eventualmente, } \\
\text { sancionar a los } \\
\text { autores de la muerte } \\
\text { del señor Garibaldi. } \\
\text { Del mismo modo, } \\
\text { el Estado debe } \\
\text { investigar y, si es el } \\
\text { caso, sancionar las } \\
\text { eventuales faltas } \\
\text { funcionales en las } \\
\text { que podrían haber } \\
\text { incurrido los } \\
\text { funcionarios } \\
\text { públicos a cargo de } \\
\text { la Investigación. }\end{array}$ & $\begin{array}{l}\text { 4.El Estado } \\
\text { debe pagar a } \\
\text { Iracema } \\
\text { Garibaldi, } \\
\text { Darsônia } \\
\text { Garibaldi, } \\
\text { Vanderlei } \\
\text { Garibaldi, } \\
\text { Fernando } \\
\text { Garibaldi, } \\
\text { Itamar } \\
\text { Garibaldi, Itacir } \\
\text { Garibaldi y } \\
\text { Alexandre } \\
\text { Garibaldi, los } \\
\text { montos fijados } \\
\text { en los párrafos } \\
\text { 187 y 193 de la } \\
\text { Sentencia de } \\
\text { Excepciones } \\
\text { Preliminares, } \\
\text { Fondo, } \\
\text { Reparaciones y } \\
\text { Costas por } \\
\text { concepto de } \\
\text { daño material e } \\
\text { inmaterial, } \\
\text { dentro del plazo } \\
\text { de un año } \\
\text { contado a partir } \\
\text { de la } \\
\text { notificación de } \\
\text { la misma. }\end{array}$ & $\begin{array}{l}\text { 5.El Estado } \\
\text { debe pagar a } \\
\text { Iracema } \\
\text { Garibaldi el } \\
\text { monto fijado } \\
\text { en el párrafo } \\
199 \text { de la } \\
\text { Sentencia de } \\
\text { Excepciones } \\
\text { Preliminares } \\
\text {, Fondo, } \\
\text { Reparacione } \\
\text { s y Costas } \\
\text { por reintegro } \\
\text { de costas y } \\
\text { gastos, } \\
\text { dentro del } \\
\text { plazo de un } \\
\text { año contado } \\
\text { a partir de la } \\
\text { notificación } \\
\text { de la } \\
\text { misma. }\end{array}$ \\
\hline $\begin{array}{l}\text { Tipos das } \\
\text { resoluções e } \\
\text { recom. }\end{array}$ & $\begin{array}{l}\text { Reparação } \\
\text { simbólica }\end{array}$ & Reparação simbólica & $\begin{array}{c}\text { Investigação e } \\
\text { sanção sem reforma } \\
\text { legal }\end{array}$ & $\begin{array}{l}\text { Reparação } \\
\text { econômica } \\
\text { monetária }\end{array}$ & $\begin{array}{l}\text { Reparação } \\
\text { econômica } \\
\text { monetária }\end{array}$ \\
\hline $\begin{array}{l}\text { Objetos das as } \\
\text { resoluções e } \\
\text { recomendações }\end{array}$ & $\begin{array}{l}\text { Recompen } \\
\text { sação de } \\
\text { pessoas ou } \\
\text { grupos }\end{array}$ & $\begin{array}{l}\text { Recompensação de } \\
\text { pessoas ou grupos }\end{array}$ & $\begin{array}{l}\text { Investigação e } \\
\text { responsabilização } \\
\text { de violações de } \\
\text { direitos humanos }\end{array}$ & $\begin{array}{l}\text { Recompensação } \\
\text { de pessoas ou } \\
\text { grupos }\end{array}$ & $\begin{array}{l}\text { Recompensa } \\
\text { ção de } \\
\text { pessoas ou } \\
\text { grupos } \\
\end{array}$ \\
\hline Compliance & $\begin{array}{l}\text { Cumpriu } \\
\text { totalmente }\end{array}$ & Parcialmente cumprido & Cumpriu totalmente & $\begin{array}{l}\text { Cumpriu } \\
\text { totalmente }\end{array}$ & $\begin{array}{c}\text { Cumpriu } \\
\text { totalmente }\end{array}$ \\
\hline $\begin{array}{l}\text { Data de quando } \\
\text { corte informou } \\
\text { que cumpriu } \\
\end{array}$ & $23 / 09 / 2009$ & $20 / 02 / 2012$ & $20 / 02 / 2012$ & $20 / 02 / 2012$ & $20 / 02 / 2012$ \\
\hline
\end{tabular}

\begin{tabular}{|c|c|}
\hline Região & Nordeste \\
\hline UF & CE \\
\hline N. Processo & Informação não disponível \\
\hline Órgão & Corte \\
\hline Fase & Cumprimento de Sentença da Corte \\
\hline
\end{tabular}




\begin{tabular}{|c|c|c|c|c|}
\hline Tipos de decisão & \multicolumn{4}{|c|}{ Sentença da Corte } \\
\hline Nome do Caso & \multicolumn{4}{|c|}{ Caso Damião Ximenes Lopes vs. Brasil } \\
\hline $\begin{array}{l}\text { Data de Início do } \\
\text { Trâmite nNome do } \\
\text { Casoa CmDH }\end{array}$ & \multicolumn{4}{|c|}{$22 / 11 / 1999$} \\
\hline $\begin{array}{c}\text { Data da Alegada } \\
\text { Violação }\end{array}$ & \multicolumn{4}{|c|}{$01 / 10 / 1999$} \\
\hline $\begin{array}{l}\text { Data do veredito } \\
\text { da } \mathrm{CmDH}\end{array}$ & \multicolumn{4}{|c|}{$08 / 10 / 2003$} \\
\hline $\begin{array}{l}\text { Data de envio à } \\
\text { CrDH }\end{array}$ & \multicolumn{4}{|c|}{$01 / 10 / 2004$} \\
\hline $\begin{array}{l}\text { Data da sentença } \\
\text { da CORTE }\end{array}$ & \multicolumn{4}{|c|}{$30 / 11 / 2005$} \\
\hline $\begin{array}{c}\text { Número dos } \\
\text { Informes }\end{array}$ & \multicolumn{4}{|c|}{ N. 38/02 E N. 43/03 } \\
\hline Peticionários & \multicolumn{4}{|c|}{ CEJIL } \\
\hline $\begin{array}{l}\text { Peticionários } \\
\text { classificados }\end{array}$ & \multicolumn{4}{|c|}{ ONGs internacionais } \\
\hline Artigos Invocados & \multicolumn{4}{|c|}{ CADH: $1,4,5,8$ e 25} \\
\hline Resumo dos fatos & \multicolumn{4}{|c|}{$\begin{array}{l}\text { Denúncia sobre a morte de portador de deficiência mental internado em clínica, em razão de maus- } \\
\text { tratos e das condições do local, sem a devida investigação }\end{array}$} \\
\hline $\begin{array}{l}\text { Tema das } \\
\text { violações }\end{array}$ & \multicolumn{4}{|c|}{$\begin{array}{l}\text { Prestação de Justiça } \\
\text { Tortura }\end{array}$} \\
\hline $\begin{array}{l}\text { Resoluções, } \\
\text { recom. MP e MC }\end{array}$ & $\begin{array}{l}\text { 1. Que la } \\
\text { Sentencia de } \\
\text { Fondo, } \\
\text { Reparaciones y } \\
\text { Costas } \\
\text { constituye per } \\
\text { se una forma } \\
\text { de reparación }\end{array}$ & $\begin{array}{l}\text { 2. Que el Estado } \\
\text { debe garantizar, } \\
\text { en un plazo } \\
\text { razonable, que el } \\
\text { proceso interno } \\
\text { tendiente a } \\
\text { investigar y } \\
\text { sancionar a los } \\
\text { responsables de } \\
\text { los hechos de este } \\
\text { caso surta sus } \\
\text { debidos efectos. }\end{array}$ & $\begin{array}{l}\text { 3.Que el Estado debe } \\
\text { publicar, en el plazo } \\
\text { de seis meses, en el } \\
\text { Diario Oficial y en } \\
\text { otro diario de amplia } \\
\text { circulación nacional, } \\
\text { por una sola vez, el } \\
\text { Capítulo VII relativo } \\
\text { a los Hechos } \\
\text { Probados de la } \\
\text { Sentencia de Fondo, } \\
\text { Reparaciones y } \\
\text { Costas, sin las notas } \\
\text { al pie de página } \\
\text { correspondientes, así } \\
\text { como la parte } \\
\text { resolutiva del fallo. }\end{array}$ & $\begin{array}{l}\text { 4. Que el Estado debe continuar } \\
\text { desarrollando un programa de } \\
\text { formación y capacitación para el } \\
\text { personal médico, psiquiátrico, } \\
\text { psicológico, de enfermería, auxiliares } \\
\text { de enfermería y para todas aquellas } \\
\text { personas vinculadas con la atención } \\
\text { de salud mental, en particular, sobre } \\
\text { los principios que deben regir el trato } \\
\text { de las personas que padecen } \\
\text { discapacidades mentales, conforme a } \\
\text { los estándares internacionales en la } \\
\text { materia y aquellos establecidos en la } \\
\text { Sentencia de Fondo, Reparaciones y } \\
\text { Costas. }\end{array}$ \\
\hline $\begin{array}{l}\text { Tipos das } \\
\text { resoluções e } \\
\text { recom. }\end{array}$ & $\begin{array}{l}\text { Reparação } \\
\text { simbólica }\end{array}$ & $\begin{array}{l}\text { Investigação e } \\
\text { sanção sem } \\
\text { reforma legal }\end{array}$ & Reparação simbólica & $\begin{array}{l}\text { Prevenção por meio da formação de } \\
\text { agentes públicos }\end{array}$ \\
\hline $\begin{array}{l}\text { Objetos das as } \\
\text { resoluções e } \\
\text { recomendações }\end{array}$ & $\begin{array}{l}\text { Recompensaçã } \\
\text { o de pessoas } \\
\text { ou grupos }\end{array}$ & $\begin{array}{c}\text { Investigação e } \\
\text { responsabilização } \\
\text { de violações de } \\
\text { direitos humanos }\end{array}$ & $\begin{array}{l}\text { Recompensação de } \\
\text { pessoas ou grupos }\end{array}$ & $\begin{array}{l}\text { Prevenção de futuras violações de } \\
\text { direitos }\end{array}$ \\
\hline Compliance & $\begin{array}{l}\text { Cumpriu } \\
\text { totalmente }\end{array}$ & Não cumpriu & Cumpriu totalmente & Não cumpriu \\
\hline $\begin{array}{l}\text { Data de quando } \\
\text { corte informou } \\
\text { que cumpriu }\end{array}$ & $31 / 11 / 2005$ & $21 / 09 / 2009$ & $02 / 05 / 2008$ & $21 / 09 / 2009$ \\
\hline
\end{tabular}




\begin{tabular}{|c|c|c|c|}
\hline $\begin{array}{l}\text { Resoluções, } \\
\text { recom. MP e MC }\end{array}$ & $\begin{array}{l}\text { 5. Que el Estado debe } \\
\text { pagar en efectivo a las } \\
\text { señoras US } \$ 1.500,00 \text { a } \\
\text { Albertina Viana Lopes y } \\
\text { US } \$ 10.000,00 \text { a Irene } \\
\text { Ximenes Lopes Miranda, } \\
\text { en el plazo de un año, por } \\
\text { concepto de la } \\
\text { indemnización por daño } \\
\text { material. }\end{array}$ & $\begin{array}{l}\text { 6. Que el Estado debe pagar } \\
\text { en efectivo a las señoras } \\
\text { Albertina Viana Lopes e Irene } \\
\text { Ximenes Lopes Miranda, y los } \\
\text { señores Francisco Leopoldino } \\
\text { Lopes y Cosme Ximenes } \\
\text { Lopes, en el plazo de un año, } \\
\text { por concepto de la } \\
\text { indemnización por daño } \\
\text { inmaterial, la cantidad fijada } \\
\text { en el párrafo } 238 \text { de la } \\
\text { Sentencia de Fondo, } \\
\text { Reparaciones y Costas. }\end{array}$ & $\begin{array}{l}\text { 7. Que el Estado debe pagar en } \\
\text { efectivo, en el plazo de un año, por } \\
\text { concepto de costas y gastos } \\
\text { generados en el ámbito interno y en } \\
\text { el proceso internacional ante el } \\
\text { sistema interamericano de protección } \\
\text { de los derechos humanos, la cantidad } \\
\text { de US } \$ 10,000,00 \text {, la cual deberá ser } \\
\text { entregada a la señora Albertina Viana } \\
\text { Lopes. }\end{array}$ \\
\hline $\begin{array}{c}\text { Tipos das } \\
\text { resoluções e } \\
\text { recom. }\end{array}$ & $\begin{array}{c}\text { Reparação econômica } \\
\text { monetária }\end{array}$ & $\begin{array}{c}\text { Reparação econômica } \\
\text { monetária }\end{array}$ & Reparação econômica monetária \\
\hline $\begin{array}{l}\text { Objetos das as } \\
\text { resoluções e } \\
\text { recomendações }\end{array}$ & $\begin{array}{l}\text { Recompensação de } \\
\text { pessoas ou grupos }\end{array}$ & $\begin{array}{l}\text { Recompensação de pessoas } \\
\text { ou grupos }\end{array}$ & $\begin{array}{c}\text { Recompensação de pessoas ou } \\
\text { grupos }\end{array}$ \\
\hline Compliance & Cumpriu totalmente & Cumpriu totalmente & Cumpriu totalmente \\
\hline $\begin{array}{l}\text { Data de quando } \\
\text { corte informou } \\
\text { que cumpriu }\end{array}$ & $02 / 05 / 2008$ & $02 / 05 / 2008$ & $02 / 05 / 2008$ \\
\hline
\end{tabular}

\begin{tabular}{|c|c|}
\hline Região & Sul \\
\hline UF & PR \\
\hline N. Processo & Informação não disponível \\
\hline Órgão & Corte \\
\hline Fase & Cumprimento de Sentença da Corte \\
\hline Tipos de decisão & Sentença da Corte \\
\hline Nome do Caso & Caso Arley José Escher e outros vs. Brasil \\
\hline $\begin{array}{l}\text { Data de Início do } \\
\text { Trâmite nNome do } \\
\text { Casoa CmDH }\end{array}$ & $26 / 12 / 2000$ \\
\hline $\begin{array}{c}\text { Data da Alegada } \\
\text { Violação } \\
\end{array}$ & $01 / 04 / 1999$ \\
\hline $\begin{array}{l}\text { Data do veredito } \\
\text { da } \mathrm{CmDH}\end{array}$ & $08 / 03 / 2007$ \\
\hline $\begin{array}{c}\text { Data de envio à } \\
\text { CrDH }\end{array}$ & $20 / 11 / 2007$ \\
\hline $\begin{array}{c}\text { Data da sentença } \\
\text { da CORTE }\end{array}$ & $06 / 07 / 2009$ \\
\hline $\begin{array}{c}\text { Número dos } \\
\text { Informes }\end{array}$ & N. 18/06 E N.14/07 \\
\hline Peticionários & Rede Nacional de Advogados Autonomos Populares (RENAAP) y Centro de JustiçaGlobal (CJG) \\
\hline $\begin{array}{l}\text { Peticionários } \\
\text { classificados }\end{array}$ & ONGs nacionais em parceria com ONGs internacionais \\
\hline Artigos Invocados & CADH: $1,2,8,11,16,25$ e 28 \\
\hline
\end{tabular}




\begin{tabular}{|c|c|c|c|c|c|}
\hline Resumo dos fatos & \multicolumn{5}{|c|}{$\begin{array}{c}\text { Denúncia sobre grampos telefônicos feitos irregularmente pela polícia e autorizados pelo judiciário, } \\
\text { com posterior divulgação das gravações e dano à imagem das vítimas. }\end{array}$} \\
\hline $\begin{array}{l}\text { Tema das } \\
\text { violações }\end{array}$ & \multicolumn{5}{|c|}{$\begin{array}{l}\text { Violência policial } \\
\text { Prestação de Justiça }\end{array}$} \\
\hline $\begin{array}{c}\text { Resoluções, recom. } \\
\text { MP e MC }\end{array}$ & $\begin{array}{l}\text { 1.Esta } \\
\text { Sentencia } \\
\text { constituye } \\
\text { per se una } \\
\text { forma de } \\
\text { reparación. }\end{array}$ & $\begin{array}{l}\text { 2.El Estado debe } \\
\text { pagar a los señores } \\
\text { Arlei José Escher, } \\
\text { Dalton Luciano de } \\
\text { Vargas, Delfino } \\
\text { José Becker, Pedro } \\
\text { Alves Cabral y } \\
\text { Celso Aghinoni, el } \\
\text { monto fijado en el } \\
\text { párrafo } 235 \text { de la } \\
\text { presente Sentencia } \\
\text { por concepto de } \\
\text { daño inmaterial, } \\
\text { dentro del plazo de } \\
\text { un año contado a } \\
\text { partir de la } \\
\text { notificación de la } \\
\text { misma y conforme } \\
\text { las modalidades } \\
\text { especificadas en } \\
\text { los párrafos } 260 \text { a } \\
264 \text { de este Fallo. }\end{array}$ & $\begin{array}{l}\text { 3.El Estado debe publicar en } \\
\text { el Diario Oficial, en otro } \\
\text { diario de amplia circulación } \\
\text { nacional y en un periódico de } \\
\text { amplia circulación en el estado } \\
\text { de Paraná, por una sola vez, la } \\
\text { portada, los Capítulos I, VI a } \\
\text { XI, sin las notas al pie de } \\
\text { página, y la parte resolutiva de } \\
\text { la presente Sentencia, así } \\
\text { como debe publicar } \\
\text { íntegramente el presente Fallo } \\
\text { en una página web oficial del } \\
\text { Estado federal y del estado de } \\
\text { Paraná. Las publicaciones en } \\
\text { los periódicos y en Internet } \\
\text { deberán realizarse en los } \\
\text { plazos de seis y dos meses, } \\
\text { respectivamente, contados a } \\
\text { partir de la notificación de la } \\
\text { presente Sentencia, en los } \\
\text { términos del párrafo } 239 \text { de la } \\
\text { misma. }\end{array}$ & $\begin{array}{l}\text { 4.El } \\
\text { Estado } \\
\text { debe } \\
\text { investigar } \\
\text { los hechos } \\
\text { que } \\
\text { generaron } \\
\text { las } \\
\text { violaciones } \\
\text { del } \\
\text { presente } \\
\text { caso, en } \\
\text { los } \\
\text { términos } \\
\text { del párrafo } \\
247 \text { de la } \\
\text { presente } \\
\text { Sentencia. }\end{array}$ & $\begin{array}{l}\text { 5.El Estado } \\
\text { debe pagar el } \\
\text { monto fijado } \\
\text { en el párrafo } \\
259 \text { de la } \\
\text { presente } \\
\text { Sentencia por } \\
\text { reintegro de } \\
\text { costas y } \\
\text { gastos, dentro } \\
\text { del plazo de } \\
\text { un año } \\
\text { contado a } \\
\text { partir de la } \\
\text { notificación de } \\
\text { la misma y } \\
\text { conforme a las } \\
\text { modalidades } \\
\text { especificadas } \\
\text { en los párrafos } \\
\text { 260 a 264 de } \\
\text { este Fallo. }\end{array}$ \\
\hline $\begin{array}{l}\text { Tipos das } \\
\text { resoluções e } \\
\text { recom. }\end{array}$ & $\begin{array}{l}\text { Reparação } \\
\text { simbólica }\end{array}$ & $\begin{array}{l}\text { Reparação } \\
\text { econômica } \\
\text { monetária }\end{array}$ & Reparação simbólica & $\begin{array}{c}\text { Investigaçã } \\
\text { o e sanção } \\
\text { sem } \\
\text { reforma } \\
\text { legal } \\
\end{array}$ & $\begin{array}{l}\text { Reparação } \\
\text { econômica } \\
\text { monetária }\end{array}$ \\
\hline $\begin{array}{l}\text { Objetos das as } \\
\text { resoluções e } \\
\text { recomendações }\end{array}$ & $\begin{array}{l}\text { Recompens } \\
\text { ação de } \\
\text { pessoas ou } \\
\text { grupos }\end{array}$ & $\begin{array}{c}\text { Recompensação } \\
\text { de pessoas ou } \\
\text { grupos }\end{array}$ & $\begin{array}{l}\text { Recompensação de pessoas } \\
\text { ou grupos }\end{array}$ & $\begin{array}{c}\text { Investigaçã } \\
\text { o e } \\
\text { responsabil } \\
\text { ização de } \\
\text { violações } \\
\text { de direitos } \\
\text { humanos }\end{array}$ & $\begin{array}{c}\text { Recompensaçã } \\
\text { o de pessoas } \\
\text { ou grupos }\end{array}$ \\
\hline Compliance & $\begin{array}{l}\text { Cumpriu } \\
\text { totalmente }\end{array}$ & $\begin{array}{l}\text { Cumpriu } \\
\text { totalmente }\end{array}$ & Cumpriu totalmente & $\begin{array}{l}\text { Cumpriu } \\
\text { totalmente }\end{array}$ & $\begin{array}{l}\text { Cumpriu } \\
\text { totalmente }\end{array}$ \\
\hline $\begin{array}{l}\text { Data de quando } \\
\text { corte informou } \\
\text { que cumpriu }\end{array}$ & $06 / 07 / 2009$ & $19 / 06 / 2012$ & $19 / 06 / 2012$ & $19 / 06 / 2012$ & $19 / 06 / 2012$ \\
\hline
\end{tabular}

\begin{tabular}{|c|c|}
\hline Região & Nordeste \\
\hline UF & RN \\
\hline N. Processo & Corte \\
\hline Órgão & Arquivada \\
\hline Fase & Arquivada \\
\hline Tipos de decisão & Caso Nogueira de Carvalho e outro vs. Brasil \\
\hline Nome do Caso & \\
\hline
\end{tabular}




\begin{tabular}{|c|c|}
\hline $\begin{array}{l}\text { Data de Início do } \\
\text { Trâmite nNome do } \\
\text { Casoa CmDH }\end{array}$ & $11 / 12 / 1997$ \\
\hline $\begin{array}{c}\text { Data da Alegada } \\
\text { Violação }\end{array}$ & $20 / 10 / 1996$ \\
\hline $\begin{array}{l}\text { Data do veredito } \\
\text { da } \mathrm{CmDH}\end{array}$ & $10 / 03 / 2004$ \\
\hline $\begin{array}{l}\text { Data de envio à } \\
\text { CrDH }\end{array}$ & $13 / 01 / 2005$ \\
\hline $\begin{array}{l}\text { Data da sentença } \\
\text { da CORTE }\end{array}$ & $28 / 11 / 2006$ \\
\hline $\begin{array}{l}\text { Número dos } \\
\text { Informes }\end{array}$ & N. $61 / 00$ E N. 22/04 \\
\hline Peticionários & $\begin{array}{l}\text { Centro de Derechos Humanos y Memoria Popular (CDHMP), Holocaust Human Rights Project y el } \\
\text { Group of International Human Rights Law Students }\end{array}$ \\
\hline $\begin{array}{l}\text { Peticionários } \\
\text { classificados }\end{array}$ & $\begin{array}{l}\text { ONGs nacionais em parceria com ONGs internacionais } \\
\text { Universidades }\end{array}$ \\
\hline Artigos Invocados & CADH: $1,4,8$ e 25 \\
\hline Resumo dos fatos & Denúncia sobre assassinato não investigado. \\
\hline $\begin{array}{l}\text { Tema das } \\
\text { violações }\end{array}$ & Prestação de Justiça \\
\hline $\begin{array}{l}\text { Resoluções, recom. } \\
\text { MP e MC }\end{array}$ & Arquivada \\
\hline $\begin{array}{c}\text { Tipos das } \\
\text { resoluções e } \\
\text { recom. }\end{array}$ & Não se aplica \\
\hline $\begin{array}{l}\text { Objetos das as } \\
\text { resoluções e } \\
\text { recomendações }\end{array}$ & Não se aplica \\
\hline Compliance & Não se aplica \\
\hline $\begin{array}{l}\text { Data de quando } \\
\text { corte informou } \\
\text { que cumpriu }\end{array}$ & Não se aplica \\
\hline
\end{tabular}

